\title{
UC-NRLF
}

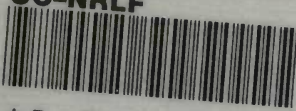

\$D $37 ? 24$ 


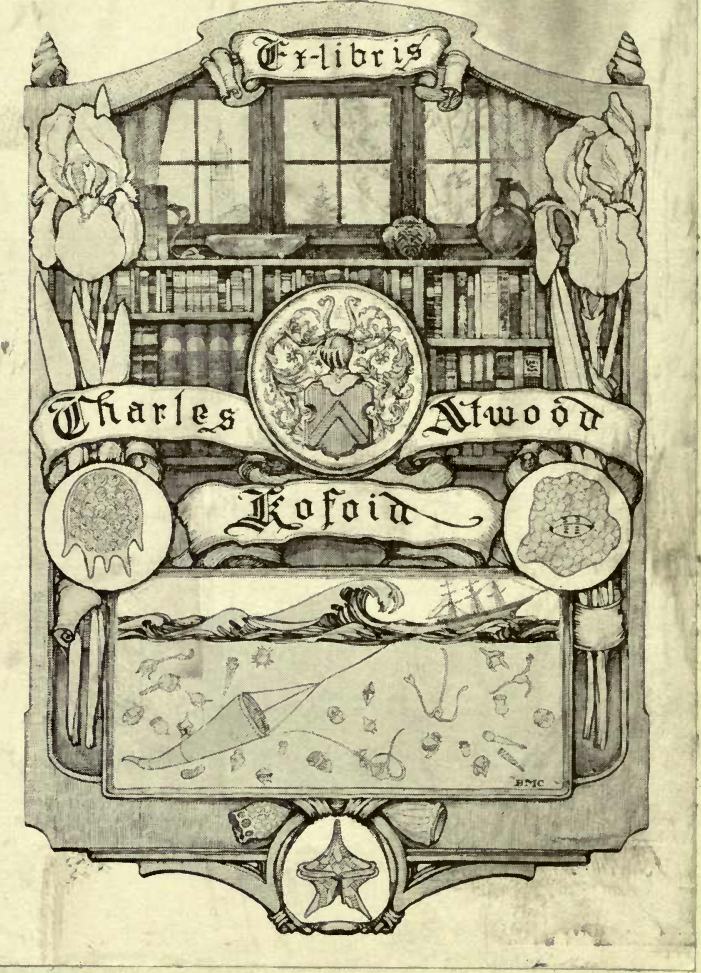





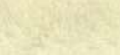





\section{FLOWERS OF THE FIELD.}





\section{FLOWERS OF THE FIELD.}

BY THE

\section{REV. C. A. JOHNS, B.A. F.L.S.}

AUTHOR OF BOTANICAL RAMBLES, THE FOREST TREES OF BRTTAN, BRITISH BIRDS IN THEIR HAUNTS, ETC. ETC.

PUBLISHED UNDER THE DIRECTION OF

THE COMMITTEE OF GENERAL LITERATURE AND EDUCATION; APPOINTED BY THE SOCIETY FOR PROMOTING CHRISTIAN KNOWLEDOR.

Xinth Zexition.

\section{ION DON:}

SOCIETY FOR PROMOTING CHRISTIAN KNOWLEDGE;

DEPOSITORIES :

77, GREAT QUEEN STREET, LINCOLN'S INN FIELDS;

4, Royal eXchange; 48, PICCADILLY; AND BY ALL BOOKSELLEIS. 
PRINTED

For the Society for Promoting Christian Knowledge AT THE CLARENDON PRESS, OX F O R. 


\section{$K-Q K 306$ \\ INTRODUCTION \\ J58 \\ 1860 \\ To \\ BRITISH BOTANY. Lib}

\section{CHAPTER I.}

EXPLANATION OF TERMS.

THough the highest claim of this volume is to introduce the lover of Nature to an acquaintance with the common British plants, the Author has given to his first Chapter the somewhat presuming title of an "Introduction to British Botany;" lest those into whose hands the work may fall should pass over the earlier part of it as a treatise or summary of contents so little connected with what follows, that the perusal of it may be omitted or deferred with safety. So far is this from being the case, that the reader who is unacquainted with the elements of botany will find the body of the work of little use, unless he carefully peruses the earlier pages, and makes himself thoroughly acquainted with the general plan.

The limits of a work of this kind will not allow any account of the internal structure of plants, or of the functions of their various organs. Nor, indeed, is such description necessary in a work which professes merely to teach the unscientific how to find out the names of the flowers they may happen to fall in with in the course of their country rambles. Such a knowledge of plants as this, it may be said, and said with truth, is not Botany ; nevertheless, it is a step towards Botany : for there can be no doubt that scientific treatises on this subject would often be studied with pleasure, if the 
reader were familiar with simply the outward appearance of the examples quoted: just as we take greater interest in accounts of astronomical discoveries, if we have seen and handled a telescope, than if we had merely had one described to us, no matter with what accuracy and minuteness. The reader, then, or, inasmuch as even the elementary knowledge of a science can only be attained by study, the student who wishes to make this volume practically useful in enabling him to find out the names of our common wild flowers, is recommended to read with care and attention the following pages, into which the Author has introduced nothing but what is essential to the proper understanding of the body of the work, and so to the attainment of his object.

Before a novice can commence the study of any science, he must make himself acquainted with the terms employed by writers on that science; he must not be frightened if things new to him should have strange names. Unmeaning and hard to be remembered they must appear to him at first, but this will be only as long as they remain mere sounds. When he has gained a knowledge of the things for which they stand, they will lose their formidable appearance, and, hard as they may still be to pronounce, they will very soon become familiar to the mind, if not to the tongue. In a scientific treatise on Botany, taken in its widest sense, these terms must of necessity be very numerous. Not so, however, with a popular description of the plants growing wild in a single country of limited extent; the Author, therefore, has endeavoured to keep technical terms as much as possible out of sight, in the hope that the lover of Nature may be beguiled into forming an acquaintance with the outward appearance of the plants of his neighbourhood, and eventually be induced to study their characters, or to extend his researches beyond the limits of his own country. He has, consequently, avoided the use of Latin words wherever English ones would do as well, and has often preferred 
to express by several words what might have been defined by one, because that one was probably strange to the reader. With respect to the organs of plants, he has not noticed the existence of any but those with which it is necessary that the student should be familiar before he refers to the body of the work for a description of any plant which he may have found; these, with their principal peculiarities, may be described at once. They are, Root, Stem, Leaf, Stipules, Bracts, Flower, Calyx, Conolla, Stamens, Pistils, Fruit, Seed, Receptacle, and Nectary.

The Root.-The most frequent form of the root is a tuft of fibres, each of which ends in a porous substance serving to absorb moisture from the soil. In many instances, however, the nourishment thus obtained, instead of being transmitted at once to that part of the plant which rises above the ground, is lodged in another organ, which, though partaking in some measure the properties of root and stem, is distinct from both. This too, with the fibres attached to it, is called a root, the fibres themselves being named rootlets. The principal forms of the root are :-

The Creeping Root, familiar examples of which are afforded by Couch-grass and Great Bindweed.

The Spindle-shaped Root; examples, Carrot and Parsnep.

A spindle-shaped root which ends abruptly, is termed premorse (bitten off), as in Premorse Scabious, p. 317.

The Tuberous Root consists of one or more roundish solid masses, having the power of producing rootlets and buds from several parts of its surface, as the Potatoe.

The Bulbous Root is a solid roundish mass, producing rootlets at the lower extremity, and a bud at the other; it consists either of fleshy scales, as in the White Lily, concentric circles, as in the Onion, or is of one uniform substance throughout, as in the Crocus. This last is sometimes called a corm. 
The Stem.- The stem is said to be simple when it bears leaves, or leaves and flowers only without branches; as in Grass of Parnassus, p. 82.

A compound stem is repeatedly and irregularly branched, as in Flax-seed, p. 110.

A stem is said to be forked when it divides into two branches of equal, or nearly equal size. The stem of Annual Knawel, p. 536, is repeatedly forked.

The term erect, when applied to the stem, has the same meaning as perpendicular.

An ascending stem is one which is horizontal when first it leaves the root, and then becomes erect. When several stems grow from one root, the central one is often erect, the rest ascending, as in the common Mallow.

A prostrate stem trails along the ground without ever becoming erect.

A creeping stem differs from the last by sending out roots from its joints. Some plants have erect stems with creeping scions, or shoots from the base, as the Creeping Buttercup, p. 12.

THE AxIL.-This name is given to the angle formed by a leaf where it leaves the stem. A bud or flower which springs from this angle, is termed axillary.

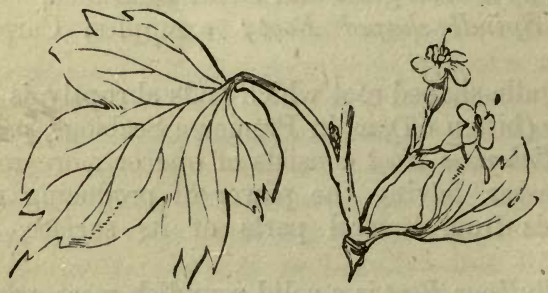

The Leaf.-Leaves which spring directly from the root are called radical; those which grow on the stem are either alternate, as in Balsam, p. 130; opposite, as in the Pink, p. 91 ; or whorled: the leaves of Woodruff, p. 308, grow in whorls. 
Leaves which have no stalks are termed sessile (sitting), as in Eryngo, p. 255.

A leaf which consists but of one piece is said to be simple, as in Marsh Marigold, p. 16; a ternate leaf consists of three leaflets on a common stalk, as in Medick, p. 150 ; a quinate, of five, as in Marsh Cinquefoil, p. 190. Other forms of the compound leaf are the pinnate, (from penna, a feather,) where a number of leaflets are ranged along the opposite sides of a common stalk, as in Saint-foin, p. 170.

A simple leaf is sometimes wavy at the edge, as in the Oak, p. $572 ; 3-, 5$-, or 7-lobed, as in the Mallows, pp. 112, 113; and these lobes are often deeply cut, as in Geranium, p. 125. A leaf of five or more narrow lobes united near the main stalk, is termed palmate, (from palma, the palm of the hand,) as in Hellebore, p. 18. The pedate leaf differs from the palmate, in having the two side lobes divided a second time at the edge nearest the stalk. A leaf which is lobed after the manner of a pinnate leaf, is termed pinnatifid, (from penna, a feather, and findo, to cleave.)

If a stalk is attached to a leaf at or near its centre, such a leaf is termed peltate, (from pelta, a buckler,) as in Cotylédon, p. 234.

A leaf through which a stalk passes is termed perfoliate, (from per, through, and folium, a leaf,) as in Hare's-ear, p. 267.

Two leaves united by their bases, and allowing the stem to pass through them, are termed connate, (from con, together, and nascor, to grow,) as in Chlora, p. 418.

The margin of the leaf is either entire, as in Soapwort, p. 93 ; crenate, as in Marsh Pennywort, p. 253 ; serrate (saw-edged), as in Rose, p. 201 ; toothed, as in Enchanter's Nightshade, p. 214; or fringed, as in Rock-rose, p. 74.

With respect to form, the varieties of leaves are very numerous, and the terms employed to define them not less so. Those which occur in this volume are :- 
Hair like, or capillary, as in Fennel, p. 271.

Linear, as in the Grasses and Pink, p. 91.

Strap-shaped, as in Corrigiola, p. 229.

Oblong, as in Rock-rose, p. 74.

Elliptical, oval, with both ends alike, as in the leaflets of Rose, p. 201.

Egg-shaped, oval, with the base broader than the extremity, as in Pear, p. 202.

Inversely egg-shaped, oval, with the base narrower than the extremity, as in Brookweed, p. 471.

Rounded, as in Pyrola, p. 403.

Heart-shaped, as in Violet, p. 77.

Inversely heart-shaped, as in the leaflets of Medick, p. 150.

Kidney-shaped, as in Ground Ivy, p. 497.

Arrow-shaped, as in Tower Mustard, p. 60.

Halbert-shaped, arrow-shaped, but with the barbs turned outwards.

Angular, as in Danish Scurvy-Grass.

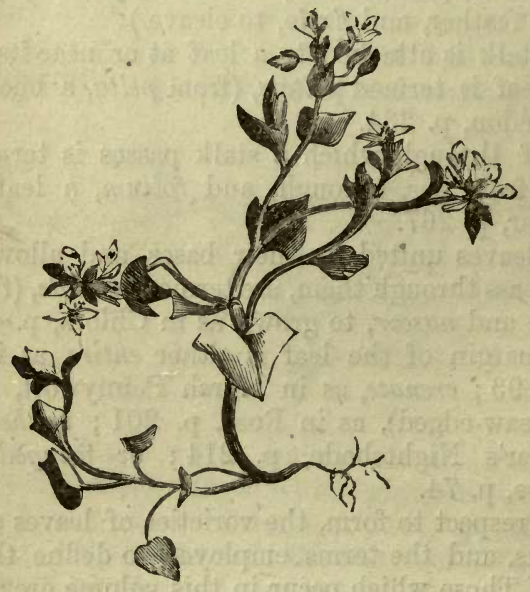

DANISH SCURVY GRASS. 
Sword-shaped, as in Iris, p. 596.

Stipules.-The base of the leaf-stalk is not unfrequently furnished with two sheathing wings; these are called stipules. The leaf of the Rose has oblong stipules at its base.

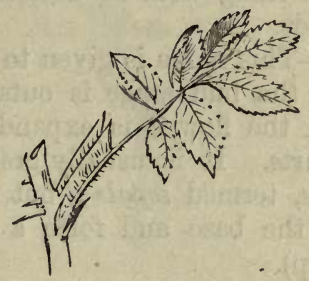

BraCTS.-Beneath the flower are frequently situated small leaves called bracts. Sometimes they are mere scales, as in the Broom-rape, p. 451 ; but more frequently they are only to be distinguished from true leaves by their smaller size, as in Evening Primrose, p. 213.

In the umbelliferous Tribe, p. 246, they often grow, several in a whorl, at the base of the general and partial umbels ; and in Compound Flowers, p. 319, they are yet more numerous at the base of the heads of flowers. When they grow in this form, they are termed an involucre, (from involvo, to wrap up, because they enclose the flowers before expansion.)

The Flower.-This, as it is the most ornamental, so it is the most important part of the plant, being rarely produced until the juices fit for its nourishment have been selected by the roots and matured by the leaves, and containing all the apparatus necessary for perfecting seeds. In flowering plants, besides the parts which are indispensable to the ripening of seeds, there are others which evidently serve as a protection, and others, again, the use of which is not known. The flower, however, generally, being essential to the continuance 
of the species, has been selected, as the part on which to found every arrangement of plants which ean lay claim to accuracy or utility. A thorough knowledge of its structure is therefore necessary before the student can proceed to discover the names of the commonest plants which are flung with so bountiful a hand over our hills and fields.

The CalyX.-This name is given to that part of the flower which in the bud stage is outside all the rest, and which when the flower is expanded encircles the more delicate parts. It is usually green, and consists of several leaves, termed sepals; but these sepals are often united at the base and form a cup, (hence the name calyx, a cup).

It is unnecessary here to describe the various forms of the calyx, which are very numerous. It may be remarked, however, that when the calyx is divided into two distinct lobes, one of which overhangs the other, it is termed gaping; in the Mallow tribe, p. 110, it is double; and in Compound Flowers, p. 319, the Valerian, p. 311, and Teazel Tribes, p. 314, it is at first a mere ring, but afterwards becomes a chaffy or feathery appendage to the seed, termed a pappus.

The Corolla. - Within the calyx is the corolla (little crown), a ring of delicate leaves called petals, usually
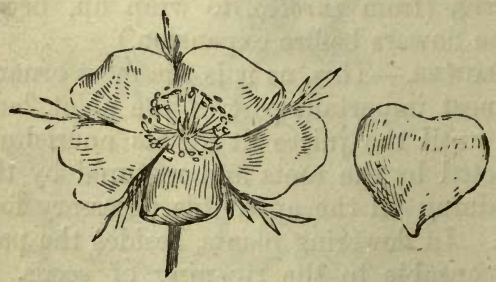

coloured - that is, not green - and often fragrant. The petals are either distinct, as in the Rose, in which the 
expanded part is termed the limb, the lower the claw; or united below, when the expanded part is termed the border, the lower the tube. The corolla more frequently

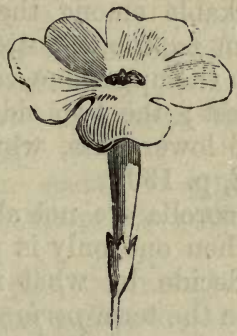

has as many petals or divisions as there are sepals ; and if these are all of the same size and shape, the corolla is said to be regular.

The most common forms of the regular corolla of one petal, are :-

Salver-shaped, as in Primrose, p. 512.

Funnel-shaped, as in Cowslip, p. 514.

Wheel-shaped, when the tube is no longer in proportion than the axle of a wheel, as in Speedwell, p. 471.

Bell-shaped, as in Campanula, p. 384.

Trumpet-shaped, as in Convolvulus, p. 425.

When the irregular corolla of one petal is divided into two lobes, one of which overhangs the other, it is termed labiate, or lipped, as in the Natural Family Labiatce, p. 474 ; if the lips are open, it is said to be gaping, as in Yellow Dead Nettle, p. 490 ; if closed, personate, (from persóna, a mask,) as in Toadflax, p. 459. In the Compound Flowers, p. 319, there are frequently two kinds of florets in one flower; those of the disk, or centre, being tubular, without an evident border; those of the ray, or margin, strap-shaped, as in the Daisy. 
Among regular flowers of many petals, the only form which it will be necessary to mention here is the cruciform, consisting of four petals placed cross-wise, as in the Cruciferous Tribe, p. 36.

The most remarkable among the irregular, is the papilionaceous, (from papílio, a butterfly,) consisting of five petals, of which the upper one, called the standard, is usually the largest; the two side ones are termed wings, and the two lower ones, which are often combined, form the keel, p. 139.

Both calyx and corolla are not always found in the same flower, and when one only is present, it is sometimes difficult to decide by what name it should be called. In this case the term perianth (from the Greek peri, around, and anthos, a flower) is a convenient one. Some flowers have neither calyx nor corolla, as Water Star-wort, p. 558. When the perianth is said to be double, it is to be understood that calyx and corolla are both present.

The Stamens.-Within the perianth, and frequently attached to it, is a row of delicate organs called stameris, of which the lower part is termed the fila-
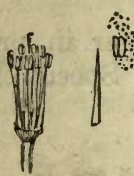
ment, the upper the anther. When the flament is slender throughout, it is said to be thread-like; but if it be thick at the base, and taper to a point, it is said to be awl-shaped. The anther varies in shape, but is most frequently oblong, and composed of two lobes and as many cells, which are filled with a fine dust, called pollen. If there be no filament, the anther is said to be sessile. In a majority of flowers the number of stamens equals that of the petals; a few plants have but one stamen : very often the number of stamens is some multiple of the petals, that is, there are twice or thrice, \&c. as many, and not a few flowers have from twenty to several hundred. Sometimes the filaments are united at the base into one or more sets, as in Hypericum, p. 117 ; 
sometimes they form a hollow tube, the anthers being distinct, or free, as in Mallow, p. 111; and sometimes the filaments are free, and the anthers are united into a ring, as in the Compound Flowers, p. 319 ; and Heath, p. 392.

The PistiL.-This is the central part of the flower, and in its commonest form is a delicate column composed of three parts, the ovary, the style, and the stigma.

The ovary, (from ovum, an egg,) sometimes called the germen, contains the rudiments of the

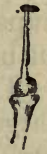
future seed.

The style, (from stylos, a column,) is to the pistil what the shaft is to a pillar, connecting the ovary with

The stigma, which is sometimes a mere viscid point, but more frequently an enlargement of the summit of the style, and is variously shaped, being globular, flat, lobed, \&c. If there be no style, the stigma is said to be sessile.

In the majority of flowers there is but one pistil ; but very often there is a single ovary, which bears several styles and stigmas. In this case the ovary usually consists of several cells, each of which, with its style and stigma, is.termed a carpel; and the same name is given to each of the ovaries in such flowers as Marsh Marigold, p. 16, where they are distinet; and in Blackberry, p. 193, where they are united.

Both calyx and corolla, it has been said above, may be absent. Not so with respect to stamens and pistils ; for, unless they are present, no seed can be perfected. It is not, however, essential that they should both be found in the same flower. Sometimes on the same plant flowers are to be found, some of which bear stamens only, others pistils only; and not unfrequently these organs grow, not only in separate flowers, but on different plants. In either case, those flowers alone which contain pistils produce seeds, and are therefore termed fertile; while those containing stamens only, are called 
barren. The external structure of barren and fertile flowers is often very dissimilar, as in Willow, p. 566 ; and Oak, p. 572. When the ovary is inserted above the base of the perianth, it is said to be superior, as in Crowfoot, p. 8 ; when below, inferior, as in Rose, p. 199. In like manner the perianth is said to be superior or inferior, according as it is inserted above or below the ovary.

The Fruit.-As the flower withers, the ovary enlarges and becomes the fruit, that is, the seed, with its case or covering, also called a pericarp, (from peri, around, and carpos, fruit). Among the various forms of fruit, the principal are-

The capsule, (from cápsula, a little box,) a dry case, either opening by valves, as in Pink, p. 91 ; by teeth, as in Lychnis, p. 95 ; by pores, as in Poppy, p. 28 ; or by splitting all round, as in Pimpernel, p. 516.

The silique and silicle, described at p. 36.

The pod, or legume, a long seed-vessel, differing from the silique in having no partition, and bearing the seeds in a single row, as in the Pea and Bean Tribe, p. 139.

The berry, a juicy or mealy fruit, bearing the seeds immersed in pulp, as in Elder, Currant, \&c.

The nut, a dry fruit, composed of a hard shell, containing a seed, as in Hazel, p. 573; and Gromwell, p. 432 .

The drupe, a nut enclosed in pulp, as the Plum and Cherry.

The cone, a collection of imbricated or overlapping scales, each of which covers two seeds, p. 575.

The SeED. - A seed is said to be dicotylédonous,

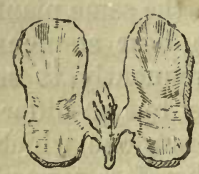
when it is composed of two lobes, or cotylédons, which enclose the plumule, or embryo of the future plant. As the seed germinates, the cotylédons either rise above the ground, as in Mustard, or remain buried, as in the garden Pea. Plants bearing seeds of this structure 
compose the first Natural Class, Dicotruénonous Plants or Exogens, p. 1. When the seed is not separable into two parts, it is termed monocotylédonous; and plants bearing such seeds compose the Second Natural Class, Monocotylédonous plants, or Endogens, p. 578 .

Receptacle.-This name is given to that part of the flower on which all the others rest. It is most conspicuous in the Compound Flowers, p. 319, where it is sometimes conical, as in Daisy, p. 375 ; chaffy, as in Cat's-ear, p. 334 ; bristly, as in Thistle, p. 348 ; or dotted as in Dandelion, p. 342 .

Nectary.-Any distinct organ in a flower which contains honey; for instance, the scale at the base of the petals in Crowfoot, p. 8 ; the spurs of the Columbine, p. $19, \&$ e.

INFLORESCENCE.-This term is used to denote the arrangement of flowers on the stem.

A flower-stalk springing directly from the root, and bearing no leaves, is termed a scape, as in Primrose, p. 513 .

When it is inserted in the angle between the main stem and a leaf, it is termed axillary, as in Balsam, p. 130 .

When it is at the extremity of the main stem, having no leaves beyond it, it is said to be terminal, as in Grass of Parnassus, p. 82.

A flower-stalk which bears but one flower, is said to be simple, as in Grass of Parnassus, p. 82.

A stalk bearing a number of sessile flowers, arranged one above another, is termed a spike, as in Plantain, p. 526.

When, instead of being sessile, the flowers are supported on simple stalks, the inflorescence is a cluster, as in Melilot, p. 151.

A panicle differs from a cluster in being branched, as in Spurrey, p. 231.

A corymb differs from a cluster in bearing the lower 
flowers on long stalks, while the upper are sessile, or nearly so, as in Stock, p. 67.

In a cyme the stalks are irregularly branched, but the flowers are nearly level, as in Elder, p. 297.

The umbel is a mode of inflorescence in which the flower-stalks spring from a common centre, and bear each a single flower, as in Ivy, p. 287. When the stalks bear, instead of a single flower, a second umbel, the inflorescence is a compound umbel, the primary division being termed a general umbel, the secondary a partial. This mode of inflorescence is common in the Umbelliferous Tribe, p. 246.

A head resembles a simple umbel, except that the flowers are all sessile, as in Scabious, p. 318.

A catkin rasembles a spike, except that the flowers are enclosed each within a scale-like bract, as in Hazel p. 573.

Other terms which are employed in the body of the work will be explained as they occur, or in the description which precedes the summary of each Natural Order. A glossary will also be found at the end of the volume, containing definitions of most of the commen terms in use. 


\section{CHAPTER II.}

\section{SYSTEMATIC BOTANY.}

Ir has been already stated that the only parts of a plant which are necessary to the production of seed are the stamens and pistils. On these organs, therefore, the learned Linnæus fixed, when framing his artificial arrangement of plants, as affording the readiest means of referring to the written characters of plants described in his works. ${ }^{1} \mathrm{He}$ nowhere claims the honour of having discovered their importance; on the contrary, he expressly alludes to a popular opinion that the fact was known to Thomas Millington, a naturalist of the preceding century. But whoever discovered the fact, it lay idle and unnoticed until Linnæus invented and perfected the system founded on the fact. This can be proved, both by the jealousy with which it was received by the naturalists of the day, whose favourite methods have disappeared before it, as well as by the acrimony with which the name and works of Linnæus are assailed by some modern botanists-men who, while they disparage the works of their great leader, find it impossible to quit the track that he has trodden out for them, from a conviction that truth lies in the path that he has prescribed, and nowhere else.

The first division of Vegetables, according to the system of Linnæus, is into TwENTY-Four Chasses, depending on the number, position, and relative.pro portion of the Stamens.

The first eleven Classes are characterised solely by the number of the stamens, and are thus named:-

(1) The number of species known to Linnæus, in 1753 , when he published his "Species Plantarum," amounted only to 7,300 . 
Class I. Monandria, one stamen.

II. Diandria, two stamens.

III. TRIANDRIa, three ditto.

IV. Tetrandria, four ditto.

V. Pentandria, five ditto.

VI. Hexandria, six ditto.

VII. Heptandria, seven ditto.

VIII. Octandria, eight ditto.

IX. EnNeandria, nine ditto.

$\mathrm{X}$. Decandria, ten ditto.

XI. Dodecandria, twelve to nineteen ditto.

The Twelfth and Thirteenth Classes are distinguished by the situation as well as number of the stamens.

Class XII. Icosandria, twenty stamens, or more, in-. serted on the calyx.

XIII. PolYandria, twenty stamens, or more, inserted on the receptacle.

The Fourteenth and Fifteenth Classes, by the number and relative proportion of the stamens.

Class XIV. Didynamia, four stamens, two longer than the others.

XV. Tetradynamia, six stamens, four long, and two short.

The Classes from the Sixteenth to the Nineteenth are distinguished by the combination of the stamens with each other, no account being taken of their number.

Class XVI. Monadelphia, stamens all united by their filaments.

XVII. Diadelphia, stamens combined by their filaments into two sets.

XVIII. Polyadelphia, stamens combined by their filaments into three or more sets.

- XIX. Syngenesia, stamens united by their anthers ; flowers compound.

in Class XX. Gynandria, the stamens are inserted on the pistil, and so combined with it as to form a central column.

The Twenty-first, Twenty-second, and Twenty-third 
Classes are distinguished by the stamens and pistils being in separate flowers.

Class XXI. Monceria, stamens and pistils in different flowers, but on the same plant.

XXII. Diøcia, stamens and pistils in different flowers and on separate plants.

XXIII. Polygamia, flowers of three kinds ; some having stamens only, some pistils only, and some both stamens and pistils.

XXIV. Cryptogamia, flowerless plants, or those in which stamens and pistils have not been detected, fructification being performed by other organs.

Each of the Classes is subdivided into two or more ORDERS. The ORDERS of the first Thirteen Classes depend on the number of the Pistils. Thus, any plant in either of the Classes from Monandria to Polyandria must be placed in one or other of the following ORDERS :- .

Order Monogynia, one pistil.

Digrnia, two pistils.

Trigynia, three ditto

Tetragynia, four ditto.

Pentagynia, five ditto.

Hexagrnia, six ditto.

Heptagynia, seven ditto.

Decagynia, ten ditto.

Dodecagrnia, twelve ditto.

Polygyinia, many ditto.

In the Fourteenth Class, Didynamia, there are two Orders.

Order I. Gymnospermia, ovaries four, one-seeded.

II. Angiospermia, ovary single, many-seeded.

In the Fifteenth Class, Tetradynamia, there are two Orders.

Order I. Siliculosa, fruit a silicle, or short pod without a partition.

II. Siliquosa, fruit a silique, or long pod without a partition. 
The Orders of the Sixteenth, Seventeenth, and Eighteenth Classes, Monadelphia, Diadelphia, and Polyadelphia, depend on the number of the stamens: thus, Class Monadelphia, Order Pentandria, includes plants having five stamens united by their filaments into one set; Class Diadelphia, Order Decandria, plants having ten stamens combined by their filaments into two sets ; and Class Polyadelphia, Order Polyandria, plants with more than twenty stamens combined by their filaments into three or more sets.

In the Nineteenth Class, Syngenesia, the Orders depend on the structure and arrangement of the florets; but as they are Orders nearly identical with the Groups into which the CoMpound Fuowers are distributed, their limits need not be assigned here.

In the Twentieth, Twenty-first, and Twenty-second Classes, Grnandria, Moncecia, and Diøcia, the Orders are determined by the number of the stamens. Plants, for example, having one stamen are in the Order MoNANDRIA ; those with two stamens, in the Order DIANDRIA, \&C.

The Twenty-third Class, Polygamia, contains only one British Order, namely, MonøcIa, in which there are three different kinds of flowers-those with stamens only, those with pistils only, and those with both stamens and pistils on the same plant.

As the limits of this volume exclude all mention of the plants in the extensive Class Cryptogamia, it is not necessary to enumerate the Orders into which it is divided. ${ }^{1}$

(1). The student is recommended to commit to memory the names, rather than the numbers of the Classes and Orders. While he does this he will find it useful to bear in mind that the names both of Classes and Orders are of Greek etymology, and that the prefixes are mostly numerals. Thus, mon signifies one ; di, two ; tri, three ; tetra, four ; pent, five ; hex, six ; hepta, seven ; oct, eight; enne, nine; dec, ten: dodec, twelve; icos, twenty; and poly, many. The root dynam signifies power or excess: thus, Didynamia means "the excess of two ;" Tetradynamia, "the excess of four." Adelphia signifies a brotherhood, as Monadelphia, "one brotherhood," or united set of stamens ; Syngenesia signifies " a growing together," in allusion to the combination of the anthers in that class. The termination oci denotes " a house- 
This arrangement brings together, for no other purpose than for convenience of reference, plants dissimilar in structure, habit, and properties. It is, therefore, an Artificial System; as such Linnæus proposed it, and such he always professed it to be. "I have never pretended that the method was natural," he says, in his letter to Haller. "A Natural System," he repeatedly remarks, in his other writings, "is the first and last object to be aimed at by botanists. ${ }^{1}$.... A perfect System of this kind should assemble plants allied in habit, mode of growth, properties, and uses." Of such a system he left a slight sketch; but the rich store of plants which has been laid open to modern botanists never came within his reach ; it is, therefore, not surprising that, being well aware of his defective materials, he never attempted to fill the sketch in. Make it as complete as he would, in a few years it would have been imperfect and useless. Not so, however, his Artificial System, which, still marked by the limits that he assigned, not only offers facilities for forming an acquaintance with the names of plants, but affords ready means of reference to any System in which plants are arranged according to their natural characters. It is not, therefore, too much to say that the Artificial System of Linnæus has served a double purpose. Before a Natural Method was arranged, it was the only one that was available; and now that it is

hold ;" so in the Class Monøcia, the stamens and pistils may be supposed to occupy separate apartments in one house. Polygamia signifies "many kinds of fructification :" Cryptogamia, "concealed. fructification." Andria denotes stamens; gynia, pistils : thus Triandria includes flowers with three stamens : Digynia, flowers with two pistils; and Gynandria, flowers with pistils and stamens united. In the two Orders of the Class Didynamia, the term Gymnospermia denotes "naked seed ;" the fruit being apparently destitute of a covering. Angiospermia implies that the seeds are enclosed in a "seedvessel." The terms siliculosa and Siliquosa are explained in the text.

(1) Methodi Naturalis fragmenta inquirenda sunt. Primum et ultimum hoe in Botanicis desideratum est. Plantæ omnes utrimque affinitatem monstrant uti territorium in mappâ geographicâ.-Lin. Phil. Bot. Aph. 77.

Methodus Naturalis est ultimus finis Botanicis.-Ibid. Aph. 163.

Naturalis Character ab omni Botanico teneatur oportet.-Ibid. Aph. 191. Classes, quo magis naturales, eo, eæteris paribus, præstantiores sunt. Adfines conveniunt habitu, nascendi modo, proprietatibus, viribus, usu. Summorum Botanicorum hodiernus labor in his sudat, et desudare decet; methodus Naturalis hinc ultimus finis Botanicis est et erit.-roid. Aph. 206. 
superseded, it is still eminently useful as an index, or a catalogue of the contents of its successor ; the secondary use being one which, perhaps, Linnæus himself scarcely contemplated.

It is not necessary here to give an account of the various Natural Systems which have been proposed. Suffice it to say, the one generally adopted in Britain is a modification of those of Jussieu and De Candolle. Here the whole Vegetable Kingdom is divided into three great CLASSES.

\section{Class I. DICOTYLEDONES.}

In this Class are placed such plants as produce seeds divisible into two lobes or cotyledons (p. 1). It is subdivided into Four Sub-classes, Thalamiflore, Calyciflore, COROLliflore, and Monochlamydee.

\section{Sub-class I. Thalamiflore.}

Flowers furnished with calyx and corolla; petals distinct, inserted into the receptacle, or thalamus; stamens springing from the base of the ovary.-This Sub-class contains Twenty-two British Orders. (Pp. 2-133.)

Sub-class II. Calyciflora.

Flowers furnished with calyx and corolla ; sepals distinct, or united; petals distinct; stamens inserted in the calyx, or close to its base.-This Sub-class contains Eighteen British Orders, numbered from XXIII. to XL. (Pp. 133-292.)

\section{Sub-class III. CoRolliflore.}

Flowers furnished with calyx and corolla; petals united, bearing the stamens. - In this Sub-class there are Twenty-seven British Orders, numbered from XLI. to LXVII. (Pp. 292-528.) 
Sub-class IV. MoNochlamypee. ${ }^{1}$

Perianth single, or none. This Sub-class contains Twelve British Orders, numbered from LXVIII. to LXXXI. (Pp. 528-577.)

\section{Class II. MONOCOTYLEDONES.}

Seeds with a single cotyledon (p. 570). It is subdivided into Two Sub-classes, Petaloidee and GluMACE $E$.

Sub-class I. Petaloidee.

Flowers with petals.-This Sub-class contains Seventeen British orders, numbered from LXXXII. to XCVIII. (P. 571 to the end.)

\section{Sub-class II. Glumacee.}

Flowers formed of chaffy scales, or glumes.-This Sub-class contains the Grasses and Sedges.

\section{Class III. ACOTYLEDONES.}

Flowerless plants. Here are placed the Ferns, Mosses, Liverworts, Lichens, Sea-weeds, and Fungi.

Each of the Natural Orders, or Tribes, alluded to above, consists of a number of plants which are more or less like one another in various respects, especially in the organs of fructification. The plants comprised in each Tribe are again distributed into genera, or families, each genus including all plants which resemble one another yet more closely in the essential characters of fructification. A species, or kind, is an assemblage of individual plants agreeing with each other in all essential points; and individuals which differ one from

(1) From the Greek monos, one, and chlamys, a mantle or covering; the plants of this Sub-class never having both calyx and corolla. 
another in minor points, such as an irregular formation of leaves or mode of growth, unusual colour of flowers, extraordinary number of petals, \&c., are termed varieties. These words are frequently used loosely in common conversation, but the habit cannot be too carefully avoided in botanical descriptions, as calculated to produce great confusion. Throughout these pages they will be employed exclusively with the meanings above assigned, which will be rendered clearer by the following examples :-The wild sweet-scented Violet is called by botanists Viola odoráta; the former name, Viola, indicating that it belongs to the genus so called, and being, therefore, termed its generic name. Besides the scented Violet, we have in England the Dog-Violet, the MarshViolet, the Pansy, and several others, all belonging to the same genus, and, therefore, described under the name Viola. But the Dog-Violet differs from the Sweet-scented, in having acute sepals, and leafy stems, whereas the latter has blunt sepals, and the leaves spring directly from the roots. The Dog-Violet is, therefore, a distinct species, Viola canina. The MarshViolet and Pansy differ also in important characters; they are, therefore, also considered distinct species, the fact being indicated by the addition of the specific or trivial ${ }^{1}$ names, palustris and tricolor, to the generic name Viola. The flowers of the scented Violet are sometimes white and sometimes blue; garden specimens are often tinged with pink, and still more frequently, double. These characters being either unimportant, or inconstant - for blue flowers generally have a great tendency to sport to white, and double flowers are not perpetuated by seed-the blue, white, pink, and double sweet Violets are not considered distinct species, but mere

(1) No little merit is due to Linnæus for inventing the specific or trivial name of plants. The method in use previous to his time was to attach to every plant some such title as the following: Gramen Xerampelinum, $M i$ liacea, protenuis ramosaque sparsa panicula, sive, Xerampelino congeñer, arvense, cestivum; gramen minutissimo semine. The name of this grass Linnæus expressed with accuracy and simplicity by the two words, Poa bulbosa. 
varieties. Now there are many plants which bear a close resemblance to a Violet in the structure of their flowers and seeds, but yet differ so far that they cannot be reduced under the same genus; they are therefore placed with it in the same Tribe, called VIOLACEe, all the genera in which differ in essential points from the genera which compose other Tribes, but agree with a vast number in having two-lobed seeds and leaves with netted veins, two of the characters of Dicotyledonous Plants. In this Class it is arranged with plants furnished with both calyx and corolla, and having their petals distinct and inserted with the stamens into the receptacle.

The plant of which we have been speaking belongs, then, to the-

\section{Class I. DICOTYLÉDONES. Sub-Class I. THÁLAMIFLOR Order or Tribe IX. VIOLACE. \\ Genus 1, Viola. \\ Species 2, odoráta. \\ Variety, blue, white, or double.}

In the Linnæan system the same plant is placed in the Class Pentandria, which comprises flowers having five stamens; and in the Order Monogrnia, which includes such of them as have one pistil.

In this work the British genera and species are arranged in their Natural Orders or Tribes; and a synopsis is also given of the genera only, as they stand in the Linnæan Classes and Orders. (P. xxviii. \&c.)

The student, it is presumed, wishes to determine the genus and species, or to find the name, of the plants which he meets with in his walks. Suppose him to have found a small shrubby plant with oblong leaves and large yellow flowers: in what part of this work must he look for a description which he may compare 
with the specimen in his hand? On examining a flower (he will do well to select one which is just expanded), he will discover a large number of stamens, evidently more than twenty, inserted in the receptacle, and he

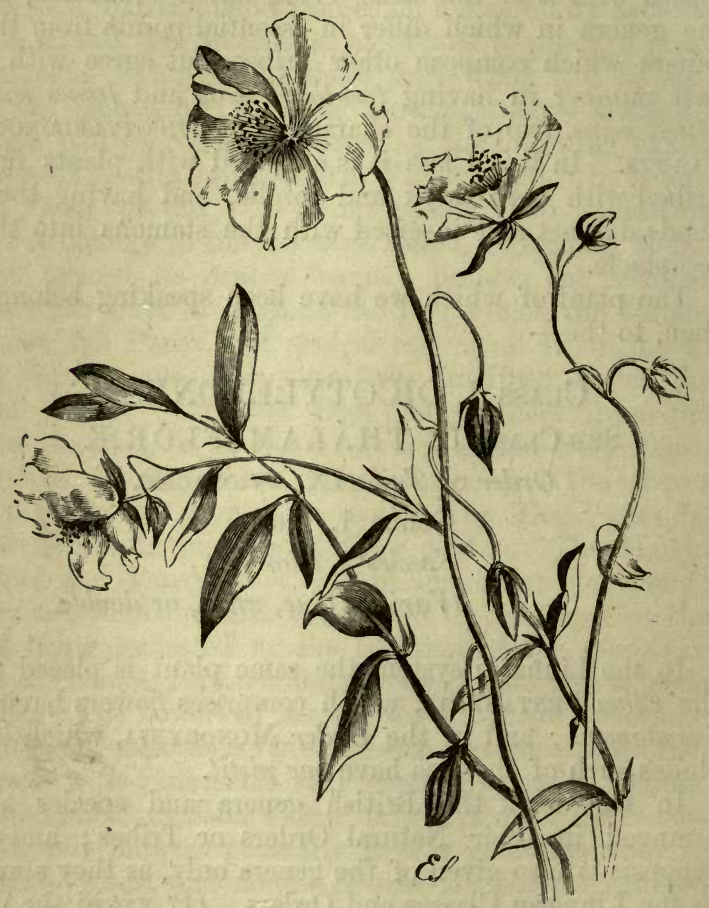

HFLIANTHFMUM VULGÁRE.

will have no doubt that it belongs to the Linnæan Class Polyandria. In the centre of the stamens he will detect a single pistil, and hence will conclude that it should be referred to the Order Monogrnia in that Class. He will, accordingly, turn to Class PoLr- 
ANDRIa, Order Monogynia (p. xlvii), and will proceed to read the characters of the genera there described, comparing such descriptions with his specimen. Opposite the first genus, Delphinium, he will find the characters, "Sepals 5, coloured, the upper one spurred." This is no description of his plant, so he passes on to 2. Papáver: "Sepals 2," \&c. He reads no further, but passes on to 6. Actcea: "Sepals 4." Neither will this do, for his plant has 5 sepals, of which the two outer are much smaller than the rest. The next, genus 7 . Heliánthemum, has "Sepals 5, the two outer smallest, or sometimes wanting; petals 5." To this genus, then, his plant belongs; - the short description which follows also suits his plant: "Small shrubs with oblong leaves, and showy, white or yellow flowers." $\mathrm{He}$ is then referred to the Rock-Rose Tribe (p. 74), where are - enumerated the leading characters of the Tribe and of all the British genera included in it. Being assured, by a perusal of these, that his plant belongs to the genus Helianthernum, he proceeds to ascertain its species, and finally satisties himself that he holds in his hand a specimen of a plant known among botanists by the name of Heliánthemum vulgáré (Common Rock-Rose).

To take another example. The plant of which it is desired to discover the name is an erect, herbaceous plant, with smooth leaves and long spiked clusters of green flowers. The number of stamens here is variable, so that there is some doubt whether it should be referred to the Class Dodecandria, including plants with from 12 to 20 stamens, or to the Class Polyandria, with more than 20. About the number of pistils, however, there can be no doubt-they are distinctly 3. Accordingly, if we turn to Class Dodecandria, Order Trigynia (p. xlvii.), we find only the genus "Reséda. Herbaceous or somewhat shrubby plants with furrowed stems, smooth leaves, and terminal spikes or clusters of greenish flowers." This description is accompanied by a reference to the Rocket-Tribe (p. 72). If, on the 
other hand, we refer to the Class Polyandria, we find the Order Pentagynia, including plants with from 2 to 6 pistils. Here, mention of Reséda occurs again, and other characters are given, equally descriptive of the plant in question, namely : "Flowers irregular; capsule

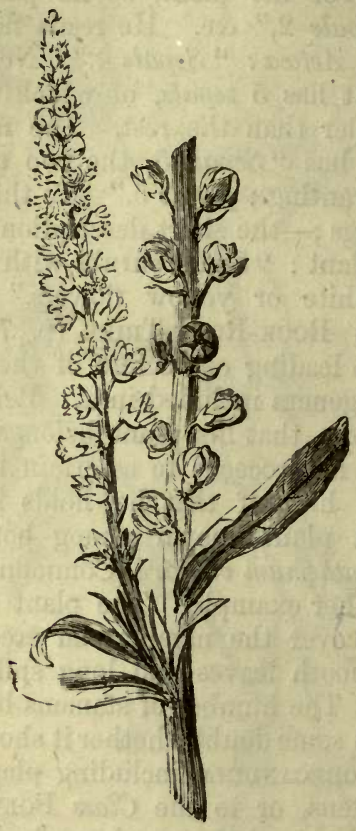

RESÉDA LITEOTA.

solitary, open at the top." We are again reterred to the Rocket Tribe (p. 72), where we find a fuller description of the tribe and genus, followed by such a description of the only two British species as assures us that our plant is $R$. Lutéola or Dyer's Rocket. 
One more example will suffice. The plant to be examined is a small herb with somewhat fleshy leaves and white flowers, with 6 stamens, four long and two short. Had they been all of equal length we should have had no hesitation in referring the plant to the Class Hexandria ; but as this is not the case, we turn to the Class Tetradynamia (p. xlix). Here we find that "all the plants in this class belong to the Cruciferous Tribe, p. 36." On turning to the reference, we learn that the division of this TrIBE corresponds with that of the Linncean Class, - namely, into plants bearing silicles and those bearing siliques. The plant in question bears a silicle, or pouch, and must be searched for in the group "+ Pouch 2-valved, with a central vertical partition." Thlaspi and Capsella are passed over, as having flat pouches; Hutchinsia and Teesdalia have a keeled pouch, the cells of which are 2-seeded; in Leprdium the valves of the pouch are keeled, and the cells 1-seeded; but in Cochlearia the pouch is globose, or nearly so, the valves are not flattened, and the seeds are numerous. Our plant, then, is a Cochlearia; and on turning to genus 6 (p. 46), we find that our specimen, which has an egg-shaped pouch and triangular leaves, is $C$. Dánica (Danish Scurvy-Grass). 


\section{LINN EAN ARRANGEMENT.}

\section{Class I. MONANDRIA. 1 Stamen. Order I. MONOGYNLA. 1 Pistil.}

1. Saliconnia. Calyx fleshy; petals 0 ; stigma 2-3 cleft. - Sea-side plants with jointed stems, inconspicuous flowers, and no true leaves. Goose-foot Tribe. P. 528.

2. Hippúris. Calyx minute; petals 0 ; stigma undivided.-Aquatic plants with whorled leaves, and inconspicuous axillary flowers. Mare's-TaIL TrIBE. P. 215.

3. Zostéra. Calyx 0 ; petals 0 ; stamens and pistils arranged alternately in 2 rows.-Marine plants, with long grass-like submersed leaves. POND-WEED TRIBE. P. 644 .

4. Cenirranthus. Calyx bearing a feathery appendage to the pericarp ; corolla of 1 petal spurred at the base. - Herbaceous plants with opposite leaves and small flowers. Valerian Tribe. P. 309.

5. Alchemilla. Calyx 8-cleft, bearing the stamens, which vary in number from 1 to 4 : petals 0 .- Herbaceous plants with stipuled leaves and small green flowers, Rose Tribe. P. 171.

Order II. DIGYNIA. 2 Pistils.

6. Callítriché. Small aquatic plants with opposite leaves, inconspicuous axillary flowers without petals, and 4-seeded fruit. WATER-STARWORT TRIBE. P. 558. 


\section{Class II. DIANDRIA. 2 Stamens.}

Order I. MoNogynia. 1 Pistil.

1. Ligustrum. Corolla 4-cleft, regular; fruit a berry.-A shrub with smooth leaves, and white panicled flowers. Olive Tribe. P. 407.

2. Verónica. Corolla unequally 4-cleft; fruit a 2-celled capsule.-Herbaceous plants with opposite leaves and blue or flesh-coloured flowers. FIG-WORT TRIBE. P. 453.

( Corolla 2-lipped and spurred;

3. Prnguícula. fruit a 1-celled capsule-Aquatic

4. Utricularia. or bog plants with delicate yellow, pink, or purple flowers. BuTtERWORT TRIBE. P. 506.

( Corolla gaping; fruit 4-lobed and

5. Lýcopus. 4-seeded. - Herbaceous plants with

6. Sílvis. $\quad$ square stems and opposite leaves. LABiate TRibe. P. 474.

7. Ciroan. Sepals 2 ; petals 2 .-Herbaceous plants with opposite leaves, and small pinkish white flowers. Willow-herb Tribe. P. 208.

8. Fráxinus. Calyx 0 ; corolla 0 ; fruit winged, 1-seeded.-A lofty tree. Olive Tribe. P. 407.

9. Lemna. Minute, stemless, aquatic, floating plants consisting entirely of a few simple roots and small leaves, embedded in which last, flowers are produced, but rarely. DUCK-WEEd TRIBE. P. 643.

Class III. TRIANDRIA. 3 Stamens.

Order I. MONOGYNIA. 1 Pistil.

1. Valeriana.
2. FÉdia. $\left\{\begin{array}{l}\text { Calyx crowning the fruit; corolla } \\ \text { 5-cleft. - Herbaceous plants with } \\ \text { opposite leaves and. small flowers. } \\ \text { VaLerian Tribe. P. } 309 .\end{array}\right.$ 
3. IRIS.

4. Crocus.

Perianth 6-cleft, superior.-Her-

5. Trichonéma. baceous plants with bulbous, or tuberous roots, sword-shaped, or grass-like leaves, and beautiful flowers. IrIs Tribe. P. 594.

6. Juncus. Perianth, 6-cleft, inferior-Mostly marsh plants with cylindrical stems and leaves, and brownish green flowers. Rush Tribe. P. 622.

* Many of the Sedge Tribe belong to this Class and Order; their inflorescence is in terminal spikes formed of chaffy scales, or glumes, with a flower at the base of each. Not described in this work.

\section{Order II. DIGYNIA. 2 Pistils.}

This Order contains only the Grass Tribe, the flowers of which consist of 2 chaffy valves or glumes arranged in small spikes (spikelets), each of which has a pair of glumes at the base, outside. For a description of this and the preceding tribe, see Miss Pratt's, "Grasses and Sedges."

\section{Order III. TRIGYNIA. 3 Pistils.}

7. Montia. Sepals 2 ; capsule 3 -valved.-A small aquatic plant, with opposite leaves and minute white flowers. Purslane Tribe. P. 226.

8. Holósteum. Sepals 5 ; capsule opening with 6 teeth.-A small plant with opposite leaves and white flowers which grow in umbels. CHICKWEED TRIBE. P. 87.

9. Polycarpon. - Sepals 5 ; capsule 3-valved.-A small plant with white flowers, bearing its lower leaves in whorls of 4. KNot-Grass Tribe. P. 228.

10. Tillat. Sepals 3 ; carpels 3.-A minute plant with fleshy leaves and greenish-white flowers. STONECrop Tribe. P. 232. 
CLass IV. TETRANDRIA. 4 Stamens equal in length. Order I. MONOGYNIA. 1 Pistil.

C Corolla of one petal; ovary in1. Dípsacus. ferior; fruit 1-seeded, crowned 2. SCABiósa. $\quad$ by the calyx.-Herbaceous plants 3. Krautia. with flowers in heads. Teazel TRIBE. P. 314.

4. RÚBIA.

5. Gálium.

6. Aspérula.

7. Sherardia.

8. Mentha.

9. Thymus.

10. Oríganum.

Corolla of one petal ; ovary in ferior; fruit 2-lobed and 2-seeded. -Herbaceous plants, all the British species of which have whorled leaves and small flowers.

Madder Tribe P. 302.

( Corolla of one petal; ovary superior, 4-lobed; fruit 4-seeded. -Herbaceous or shrubby plants with opposite aromatic leaves, and more or less irregular flowers. Labiate Tribe. P. 474.

11. Gentińna. superior; capsule 1-celled, 2-val-

12. Cicendia. ved, many-seeded.-Bitter herbs $-\{$ with opposite leaves, and blue or yellow flowers. Gentian Tribe. P. 412.

13. Plantágo. Corolla 4-cleft, the lobes reflexed; stamens very long; capsule 2-celled, bursting all round transversely.-Herbaceous plants with spiked flowers, which are remarkable for their very long stamens. Plantarn Tribe. P. 524.

14. Centúnculus. Stamens short; capsule 1-celled, bursting all round transversely.-A minute plant with alternate leaves and inconspicuous axillary flowers. Primrose Tribe. P. 510.

15. Eprmépium. Corolla of 4 petals with a scale at c 2 
the base of each within.-A mountainous plant remarkable for its thrice ternate leaves. BARBERRY TRIBE. P. 22.

16. Senebiéra. $\left\{\begin{array}{l}\text { Sepals } 4 \text {; petals } 4 \text {; fruit a si- } \\ \text { 17. Cardue or silicle.-Herbaceous plants } \\ \text { belonging to a tribe which usually } \\ \text { have six stamens, } 4 \text { long and } 2 \\ \text { short. Cruciform Flowers. P. } 36 .\end{array}\right.$

18. Connus. Calyx of 4 minute sepals; petals 4 ; fruit a berry-like drupe.-A shrub with opposite leaves and cymes of white flowers. Connel Tribe. P. 289.

19. Euónymus. Fruit an angular capsule opening with valves. - A shrub remarkable for its green branches and flowers, and bright rose-coloured capsules. SPINDLETREe TRIBE. P. 133.

20. Parietaria. Calyx 4-cleft; petals 0 ; stamens bursting with an elastic spring.-A branched herbaceous plant, with reddish stems and small clustered axillary Howers. Nettrle Tribe. P. 559.

21. Alchemilla. Calyx 8-cleft; petals $0 .-\mathrm{A}$ small tufted plant, with deeply cut leaves and minute greenish axillary flowers. Rose Tribe. P. 171.

22. Sanguisorba. Calyx 4-cleft, with 4 scales at the base; petals $0 .-\mathrm{A}$ slender herbaceous plant, with oblong heads of brownish-purple flowers. Rose TRIBE. P. 171 .

23. Isnardia. Calyx deeply 4-cleft; petals $0 .-\mathrm{A}$ very rare aquatic plant, with prostrate stems and small axillary flowers. Willow-HeRB TriBe. P. 208.

24. Thésium. Fruit a drupe crowned by the calyx. -A parasitic plant with branched herbaceous stems, narrow leaves, and terminal clusters of whitish flowers. Sandal-Wood Tribe. P. 546.

\section{ORder II. DIGYNIA. 2 Pistils.}

25. Gentiána. Capsule many-seeded.-Bitter herbs 
with opposite leaves and tubular flowers.'Gentias Tribe. P. 412.

26. Cúscuta. Capsule 4-seeded.-Leatless, parasitic plants, with red, tangled stems, and wax-like flowers. BindweEd Tribe. P. 423.

Order III. TETRAGYNIA. 4 Pistils.

$\int$ Sepals 4 ; petals 4 ; capsule many 27. Sagína. seeded, opening with valves or 28. Mønchia. \{teeth.-Minute plants with oppo29. Cerastium. site leaves and white flowers. Chickweed Tribe. P. 87.

30. Rabíola. Sepals 4, connected below; petals 4 ; capsule 8-valved, 8-celled.-A minute much branched plant, with smooth leaves and white flowers. FLAX Tribe. P. 107.

31. TrllaA. Sepals 4 ; petals 4 ; carpels 4 .-A minute plant with fleshy leaves and greenish white flowers. Stonecrop Tribe. P. 232.

32. Ilex. Corolla wheel-shaped; fruit a 4-seeded berry.-A hard-wooded tree or shrub with prickly leaves and scarlet berries. Holly Tribe. P. 405.

Perianth single of 4 leaves or 0 ; fruit of 4 nuts.-Submersed 33. Potamogéton. aquatics with long stems, mem34. Ruppia. $\{$ branous or floating, leathery leaves, and inconspicuous greenish flowers. Pond-WeEd TRIBE. P. 644 .

Class V. PENTANDRIA. 5 Stamens. Order I. MONOGYNIA. 1 Pistil.

* Perianth double; corolla of 1 petal; ovary 4-cleft, superior.

1. Echium. 2. Pulmonaria. 3. Lithosparmum. Mertensia. 5. Sýmphytum. 6. Borágo. 7. Lycop- 
sis. 8. ANchúsa 9. Mrosótis. 10. Asperúgo. 11. Crnoglossum. Ovary 4-lobed; fruit of 4 seeds.Herbaceous plants, mostly with rough leaves and salvershaped, funnel-shaped, wheel-shaped, or rarely irregular flowers of 1 petal. Borage Tribe. P. 427.

** Perianth double; corolla of 1 petal; ovary undivided, superior.

12. Prímula. 13. Hottonta. 14. CÝ́clamen. 15. Avagallis. 16. Lysimachia. 17. Glaux. 18. SámoLus. Stamens opposite the lobes of the corolla; capsule many-seeded.-Herbaceous plants with regular, generally showy flowers. GLaux has a coloured calyx and no corolla; in Sámolus, the ovary is half inferior. Primrose Tribe. P. 510.

19. Menranthes.
20. Villarsia.
21. Erythrea. $\left\{\begin{array}{l}\text { Stamens alternate with the } \\ \text { lobes of the corolla; capsule } \\ 2 \text {-valved.-Bitter herbs with } \\ \text { showy flowers. Gentian Tribe. } \\ \text { P. } 412 .\end{array}\right.$

22. Solánum. 23. Átropa. Fruit a berry. 24. Hyoscramus. Capsule euclosed in the calyx, and opening by a lid. 25. Datúra. Capsule 4-valved.-Herbaceous plants (except Solínum, which is somewhat shrubby) with showy flowers, and often an offensive odour, indicating dangerous narcotic properties. NIGHTSHADE TRIBE. P. 442.

26. Verbascum. Corolla irregular; stamens unequal in length: Herbaceous plants with large root-leaves, and tall stems bearing numerous yellow flowers. FIGWORT TRIBE. P. 453.

27. Convólvulus. 28. Calystégia. Corolla trumpetshaped, entire ; stigmas 2.-Mostly twining plants with large handsome flowers. BindweEd Tribe. P. 423.

29. Polemónium. Ovary 3-celled, 3-valved; stigmas 3.-An erect herbaceous plant with numerous blue or white flowers remarkable for their blue pollen. JACOB'sLADDER TRIBE. P. 421. 
30. Azálea. Corolla bell-shaped; stamens at the base of the corolla.-A low shrub with wiry branches and crowded leaves. Heath Tribe. P. 392.

31. VINCA. Corolla salver-shaped with oblique segments. - Somewhat shrubby plants with blue flowers, and bearing their seeds in 2 erect capsules, which do not burst. Periwinkle Tribe. P. 410.

*** Perianth double; corolla of 1 petal; ovary inferior.

32. JAsíoné. Flowers in heads; unthers united at the base.-An herbaceous plant with rough leaves and heads of blue flowers surrounded, like the Compound Flowers, by an involucre. Bell-Flower Tribe. P. 382.

33. Lobelia. Coralla 2-lipped, split to the base on the upper side; anthers united.-Herbaceous plants with showy flowers, of which the lower lip is deeply lobed. Lobelia Tribe. P. 388.

34. Campánula. $\left\{\begin{array}{l}\text { Corolla bell- or wheel-shaped; } \\ \text { style downy on its upper part.- } \\ \text { Herbaceous plants, mostly with } \\ \text { handsome blue flowers. BeLL- } \\ \text { FLower Tribe. P. 382. }\end{array}\right.$

36. LonıckrRa. Coroila with a long tube, gaping ; berry crowned by the calyx.-Mostly twining shrubs with fragrant flowers, which are either axillary or grow in heads. Woodbine Tribe. P. 295.

*** Perianth double; corolla of 4-5 petals; ovary superior.

37. Rhamnus. Stamens opposite the petals ; fruit a 2-4 seeded berry. - Small trees with greenish flowers and black berries. Buckthorn Tribe. P. 136.

38. Euónymus. Stamens alternate with the petals; fruit an angular capsule.-A shrub remarkable for its green branches and flowers, and bright rose-coloured capsules. SPindle-tree Tribe. P. 133. 
39. Impatiens. Sepals 2 , coloured; corolla irregular, spurred.-Succulent herbaceous plants, remarkable for the curious structure of their flowers and elastic capsules. Balsam Tribe. P. 129.

40. Víola. Sepals 5 ; corolla irregular, spurred.Herbaceous plants with blue, white, yellow, or variegated flowers, which are often fragrant. VIOLET TRIBE. P. 76 .

***** Perianth double; corolla of 5 petals; ovary inferior.

41. RiBes. Calyx 5-cleft, bearing the petals and stamens ; berry juicy.-Shrubs with green flowers and eatable fruit. Gooseberry and Currant Tribe. P. 239.

42. HÉDERA. Calyx of 5 teeth; petals and stamens inserted on the ovary; berry mealy.-An evergreen climbing shrub, bearing its green flowers in simple umbels. Ivy Tribe. P. 286.

\section{****** Perianth single.}

43. Glaux. Corolla bell-shaped, 5-lobed; capsule with about 5 seeds.-A sea-side plant, with succulent leaves and pink axillary flowers. Primrose Tribe. P. 510.

44. Illécebrum. Sepals 5, awl-shaped, white; seed 1.-A rare aquatic, with slender tangled stems, minute leaves, and whorled flowers. KNot-grass Tribe. P. 228.

45. Thesium. Perianth 4-5-cleft; fruit a drupe crowned by the calyx.-A parasitic plant, with branched herbaceous stems and terminal clusters of whitish flowers. Sandal-wood Tribe. P, 546.

\section{Order II. DIGYNIA. 2 Pistils.}

46. Hydrocótylé, to 79. MyrRhis. Petals 5 ; seeds 2, crowned by the calyx. - Herbaceous plants, mostly 
with hollow, jointed stems, compound leaves, and umbels of small flowers. UMBelliferous Tribe. P. 246.

80. Gentiána. Corolla of 1 petal ; capsule 1-celled. 2-valved, many-seeded.-Bitter herbs with opposite leaves and tubular flowers. Gentian Tribe. P. 412.

81. Cúscuta. Corolla of one petal ; capsule 4-seeded. -Leafless parasitic plants, with red tangled stems, and wax-like flowers. Bindweed Tribe. P. 423.

82. Herniaria. Sepals 5 ; petals or barren stamens 5 , alternate with the stamens.-A small, somewhat shrubby plant, with prostrate stems and numerous small green flowers. Knot-Grass Tribe. P. 228.

83. Scleranthus. Calyx 5-cleft, contracted at the mouth of the tube; petals 0 .-A low, repeatedly forked, herbaceous plant, with linear leaves and small green flowers. KNawel Tribe. P. 535.

84. Chevopodium. $\left\{\begin{array}{r}\text { Sepals } 5 \text {, sometimes combined } \\ \text { at the base; petals } 0 \text {; seed } 1 \text {, en- }\end{array}\right.$

85. SüDA. $\{$ closed by the calyx.-Herbaceous

86. BETA.

87. Sálsola. or somewhatshrubby plants, with fleshy leaves and green flowers. Goose-foot Tribe. P. 528.

88. Polígonum. Perianth single, coloured; seed 1 , enclosed in the perianth, not winged.-Herbaceous plants, with alternate leaves and sheathing stipules. Persicaria Tribe. P. 537.

89. Uluus. Perianth single, coloured; seed 1 , winged all round.-Lofty trees with purplish flowers, which appear before the rough leaves. ELM Tribe. P. 564.

\section{Order III. TRIGYNIA. 3 Pistils. * Perianth double.}

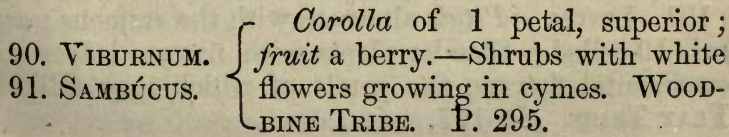


92. Támarix. Stigmas sessile, feathery; seeds tufted with down.-A shrub or small tree, with long, flexible branches, scale-like leaves, and rose-coloured flowers. Tamarisk Tribe. P. 222.

93. Corrigíola. Seed 1.-A small herbaceous plant, with prostrate stems, strap-shaped leaves, and tufted white flowers. Knot-grass Tribe. P. 228.

94. Spergularia. Petals entire; seeds in a capsule, not tufted with down.-Small plants with prostrate stems, narrow fleshy leaves, and pink flowers. KNoтgrass Tribe. P. 228.

95. Stellaria. $\begin{aligned} & \text { Petals } 2 \text { cleft, seeds in a capsule, } \\ & \text { not tufted with down. - Small her- } \\ & \text { baceous plants, with opposite leaves } \\ & \text { and white flowers. ChickweEd } \\ & \text { Tribe. P. } 87 . \\ & \text { ** Perianth single. }\end{aligned}$

97. Chenopodium. Seed 1.-Herbaceous or somewhat shrubby plants, with fleshy leaves and green flowers. Goose-foot Tribe. P. 528.

\section{Order IV. TETRAGYNIA. 4 Pistils.}

98. Parnassia.-An erect herbaceous plant, with handsome, solitary, cream-coloured flowers, beautifully veined. Sundew Tribe. P. 79.

\section{Order V. PENTAGYNIA. 5 Pistils.}
99. Státicé.
100. ARMÉrIa. Setals bearing the stamens.- flowers, remarkable for the mem- branaceous or chaffy character of the calyx. Thrift Trabe. P. 522.

101. Linum. Petals alternate with the stamens; oapsule 10-celled.-Slender plants with narrow leaves and ornamental flowers, the petals of which soon fall off. Flax Tribe. P. 107. 
102. Cerastium. Petals 2 cleft, capsule 1-celled, manyseeded.-Herbaceous plants with opposite leaves and white flowers. CHICKweEd Tribe. P. 87.

103. Spérgula. Petals entire, capsule 1-celled, manyseeded.-A small herbaceous plant, with whorled leaves and white flowers. KNot-grass Tribe. P. 228.

104. Sibbaldia. Petals and stamens inserted on the calyx.-A humble alpine plant, with ternate leaves and yellowish flowers, of which the stamens and pistils are very variable in number. Rose TriBe. P. 171.

\section{Order VI. HEXAGYNIA. 6 Pistils.}

105. Drósera.-Bog plants of humble growth, remarkable for having their leaves clothed with red, viscid hairs. Sun-dew Tribe. P. 79.

\section{Order VII. POLYGYNIA. Many Pistils.}

106. Mrosúnus.-A small plant with narrow leaves and minute flowers, the pistils of which are crowded on a common receptacle, so as to resemble a mouse's tail. Crowfoot Tribe. P. 2.

Class VI. HEXANDRIA. 6 Stamens of equal length.

$$
\begin{gathered}
\text { Order I. MONOGYNIA. } 1 \text { Pistil. } \\
\text { * Perianth double. }
\end{gathered}
$$

1. BéRBERIS.-Sepals 6, soon falling off; fruit a berry. - A thorny shrub with drooping clusters of yellow flowers. Barberry Tribe. P. 22.

2. Frankenia. Calyx 6-cleft.-A sea-side plant with prostrate, wiry stems, linear leaves, and axillary rose-coloured flowers. Sea-heath Tribe. P. 84. 
S Calyx in 12 divisions, 6 alternately 3. Peplis. $\{$ smaller.-Herbaceous marsh plants, 4. Lythrum. with opposite leaves and 4-cornered (stems. Loosestrife Tribe. P. 219. * Perianth single, superior.

5. Leucósum. $\int$ Plants with bulbous roots and 6. Galanthus. $\{$ showy flowers, which before expan7. Narcissus. $\{$ sion are enclosed in a sheath. AMACrylis Tribe. P. 598.

*** Perianth single, inferior.

8. Aspáragus. 9. Convallaria. 10. Polygonatum. 11. Agraphis. 12. Scilla. 13, Ornithógalum. 14. Alllium. 15. Gágea. 16. Túlipa. 17. FriTILLARIA. Perianth of 6 petals, or 6-cleft; anthers bursting inwards.-Herbaceous plants often with bulbous roots, bearing showy or (in AsPáRAGUs) small green flowers. Lily Tribe. P. 607.

18. Juncus.

19. Lúzula.

20. Narthécium.

Sepals or petals 6, chaffy; filaments downy.-Mostly marsh plants with pithy or jointed $\{$ leaves and greenish flowers; but NARTHÉcium has yellow flowers and sword-shaped leaves, and Lúzula hairy, grass-like leaves. Rush Tribe. P. 622.

21. Áconus. Flowers sessile on a long central column or spadix. - An aquatic plant, the sword-shaped leaves of which are fragrant when crushed. CuckooPINT TRIBE. P. 639.

22. Polýgonom. Perianth 5-cleft ; seed 1.-Herbaceous plants with alternate leaves and sheathing stipules. Persicaria Tribe. P. 537.

\section{Order II. DIGYNIA. 2 Pistils.}

23. OxÝRIA.-An alpine, herbaceous plant, with 
kidney-shaped, juicy leaves and greenish flowers: whole plant acid. Persicaria I'ribe. P. 537.

\section{Order III. TRIGYNIA. S Pistils.}

24. Romex. Seed 1, 3-cornered--Herbaceous plants with astringent leaves, which have sheathing stipules, reddish stems, and panicled, green flowers. Persicaria TRIBE. P. 537.

25. Tofieldia. Flowers with a 3-lobed bract at the base of each stalk. - A humble mountain-bog plant, with sword-shaped leaves and yellowish, spiked flowers. Meadow-saffron Tribe. P. 620.

26. Triglóchin. Sepals 6 ; carpels 3-6, 1-seeded. Sea-side or marsh plants, with linear fleshy leaves, and slender spikes of inconspicuous green flowers. ARrow-grass Tribe. P. 634.

27. Cólchicum. Perianth funnel-shaped, with a very long tube, coloured.-A bulbous-rooted plant, with broad leaves which wither before the flowers appear, and large, handsome, light-purple flowers. MEadowSAFFroN TRIBE. P. 620 .

28. Elatínte. Sepals 3 ; petals 3 ; capsule 3 -valved. -A minute aquatic plant, with rooting stems and opposite leaves. W WATER-WORT Tribe. P. 86.

\section{Orden IV. HEXAGYNIA. 6 Pistils.}

29. Actínocarpus. An herbaceous aquatic, remarkable for the star-like arrangement of its carpels. WATERplantain Tribe. P. 631.

ORder V. POLYGYNIA. Many Pistils.

30. Alisma. Herbaceous aquatics with smooth leaves and lilac flowers, each containing 3 sepals and 3 petals. Water-plantain Tribe. P. 631. 


\section{Class VII. HEPTANDRIA. 7 Stamens.}

\section{Order I. MONOGYNIA. 1 Pistil.}

1. Trientális. A northern herbaceous plant, with oblong, smouth leaves, and several terminal white flowers on slender stalks. Primrose Tribe. P. 510.

\section{Class VIII. OCTANDRIA. 8 Stamens. \\ Order I. MONOGYNIA. 1 Pistil. * Perianth double, inferior.}

1. Acer. Capsules 2, each furnished with a long wing.-Trees with lobed leaves and green flowers, which expand at the same time with the leaves. Maple Tribe. P. 121.

2. Chlona. Calyx 8-cleft; corolla 8-lobed.-An erect herbaceous plant, remarkable for the glaucous hue of its leaves, and for its yellow flowers, which expand only in fine weather. Gentian Tribe. P. 412.

3. Monótropa. Flowers in a cluster, the terminal one with 5 sepals, the lateral ones with $4 .-\mathrm{A}$ parasitie plant, consisting of a juicy stalk without leaves, and a drooping cluster of brownish flowers.-BIRD'S-NEST Tribe. P. 402.

4. ERÍ́ca.

5. Callúna.

6. Menziésia.

$\int$ Calyx of 4 sepals or 4-cleft; corolla of 1 petal, 4-cleft.-Shrubs $\{$ with evergreen, often rigid, opposite, or whorled leaves, and beautiful flowers. Неath Tribe. P. 392.

* Perianth double, superior.

7. Vaccínium. Corolla of 1 petal, 4-cleft.-Small shrubs with simple alternate leaves, and bell- or wheelshaped flowers. Cranberry Tribe. P. 389.

\footnotetext{
S Petals 4.-Herbaceous plants

8. ENothéra. $\{$ with purple or yellow flowers and

9. Epilóbium. $\{$ 4-valved capsules. Willow-Herb Tribe. P. 208.
} 
*** Perianth single.

10. DaPhNé. Corolla 4-cleft.-A shrub bearing leaves only near the summit of the stem, intermixed with drooping tufts of green flowers. Daphne Tribe. P. 544.

Order II. DIGYNIA. 2 Pistils.

11. Polýgonum. Perianth single, deeply 5-cleft; seed 1.-Herbaceous plants with alternate leaves and sheathing stipules. Persicaria Tribe. P. 537.

12. Sclerantuus. Perianth single; contracted at the mouth, 4-cleft; seed 1.-A humble herbaceous plant, with repeatedly forked stems, linear leaves, and small green flowers. KNawel Tribe. P. 535.

13. Chrysosplenium. Perianth single, capsule 2beaked, many seeded.-Herbaceous aquatic plants with juicy stems and leaves, and small greenish yellow flowers. Saxifrage Tribe. P. 241.

\section{ORdER III. TRIGYNIA. 3 Pistils.}

14. Polýgonum. Herbaceous plants with alternate leaves and sheathing stipules. Persicaria Tribe. P. 537.

\section{Order IV. TETRAGYNIA. 4 Pistils.}

15. PARIS. Sepals 8, 4 alternately smaller ; fruit a berry.-An herbaceous plant, with an erect stem, bearing 4 large leaves and a single, stalked, green flower.Herb-Paris Tribe. P. 606.

16. Anoxa. Flowers in a terminal head.-A delicate little plant, with a few bright green leaves and a round head of green flowers. IvY TRIBE. P. 286.

17. Eratíné. Sepals 5 ; petals 4, coloured; capsule 4-celled.-A minute aquatic plant, with rooting stems and opposite leaves. WATER-Wort Tribe. P. 86. 
18. Mønchia. Sepals 4; pelals 4, coloured; capsule 1-celled.-A humble herbaceous plant, with opposite linear leaves and solitary flowers. CHICkweEd TriBe. P. 87.

\section{Class IX. ENNEANDRIA. 9 Stamens.}

Order I. HEXAGYNIA. 6 Pistils.

1. Bútomus.-An aquatic plant with long, swordshaped leaves, and tall stalks bearing each an umbel of handsome rose-coloured flowers. Flowering-Rusi Tribe. P. 629.

Class X. DECANDRIA. 10 Stamens. Order I. MONOGYNIA. 1 Pistil. * Ovary superior.

1. Monótropa. Flowers in a cluster, the terminal one with 5 sepals, the lateral ones with $4 .-\mathrm{A}$ parasitic plant, consisting of a juicy stalk without leaves, and a drooping cluster of brownish flowers. BIRD'S-NEST Tribe. P. 402.

2. PÝrola. Sepals 5 ; corolla of 5 deep lobes or petals. Somewhat shrubby plants, with unbranched stems, simple, smooth, evergreen leaves, and large, often fragrant flowers. BIRD'S-NEST TRIBE. P. 402.

3. Menziesia. Calyx deeply 5-cleft; corolla of

4. AndrómedA. $\{1$ petal, egg-shaped.-Shrubs with

5. Árbutus. $\left\{\begin{array}{l}\text { evergreen leaves and drooping } \\ \text { flows }\end{array}\right.$ flowers. Heath Tribe. P. 392.

* *vary inferior.

6. VAccínium. Corolla of 1 petal.-Small shrubs with simple, alternate leaves, and bell- or wheel-shaped flowers. Cranberry Tribe. P. 389. 
DECANDRIA.

\section{Order II. DIGYNIA. 2 Pistils.}

* Perianth single.

7. Polýgonum. Perianth deeply 5-cleft; seed 1.Herbaceous plants with alternate leaves and sheathing stipules. Persicaria Tribe. P. 537.

8. Scleranthus. Perianth contracted at the mouth, 5-cleft; seed 1.-A humble herbaceous plant, with repeatedly forked stems, linear leaves, and small green flowers. KNAwEL TRIBE. P. 535.

9. Chrysosplenium. Capsule 2-beaked, many-seeded. -Herbaceous aquatic plants, with juicy stems and leaves, and small greenish yellow flowers. SAxIFRAGE Tribe. P. 241.

* Perianth double.

10. Saxífraga. Petals 5 ; capsule opening with valves or teeth.-Mostly alpine herbaceous plants, with tufted leaves and panicled large flowers. SAXIFRAGE TRIBE. P. 241.

11. Dianthus. $\left\{\begin{array}{l}\text { Petals } 5 \text {; capsule 1-celled, open- } \\ \text { ing with teeth.-Herbaceous plants } \\ \text { with glaucous, opposite leaves, and } \\ \text { terminal handsome flowers. Pink } \\ \text { Tribe. P. } 87 .\end{array}\right.$

\section{Order III. TRIGYNIA. 3 Pistils.}

13. Polygonum. Perianth single ; seed 1.-Herbaceous plants with alternate leaves and sheathing stipules. Persicaria Tribe. P. 537.

14. Siléné.

15. Stellaria.

- Sepals 5 ; petals 5 ; capsule many-

16. HONCKENYA. seeded.-Herbaceous plants with

17. Arenaria,

18. Malíchium.

19. Cherleria. opposite leaves and terminal flowers. Cherleria is often without petals. PINK and CHICKWEED TRIBES. P. 87. 
Order IV. PENTAGYNIA. 5 Pistils.

* Perianth inferior; carpels 5.

20. Sibbaldia. Petals and stamens inserted on the mouth of the calyx.-A humble alpine plant, with ternate leaves and yellowish flowers, of which the stamens and pistils are very variable in number. Rose TrIBE. P. 171.

21. Cotylédon. $\left\{\begin{array}{l}\text { Petals and stamens inserted in the } \\ \text { bottom of the calyx.-Herbaceous } \\ \text { plants, remarkable for their thick, } \\ \text { fleshy leaves. Stonecrop Tribe. } \\ \text { P. } 232 .\end{array}\right.$ * Perianth inferior ; capsule 1.

23. Oxalis. Sepals 5; petals 5 ; capsule 5-celled; seeds enclosed each in an elastic case.-Herbaceous plants with ternate leaves and delicate flowers. WOOD-SORREL TRIBE. P. 131.

24. Siléné. 25. Lychnis. 26. Agrostemma.

27. Stellaria. 28. Cerástium. Sepals 5 ; petals 5 ; capsule 1-celled.-Herbaceous plants with opposite leaves and terminal flowers. PINk and Chickween Tribes. P. 87.

\section{* Perianth superior.}

29. Adoxa. Flowers in a terminal head.-A delicate little plant, with a few bright green leaves, and a round head of green flowers. Ivy Tribe. P. 286.

Class XI. DODECANDRIA. 12 to 18 Stamens.

Order I. MONOGYNIA. I Pistil.

1. Ásarum. Perianth single, 3-cleft.-An herbaceous plant, with 2 shining leaves and a solitary, drooping, greenish flower. Brrthwort Tribe. P. 547.

LyThrum. Calyx with 12 divisions, alternately smaller; petals 5.-Herbaceous plants with 4-cornercd 
FOLY ANDRIA.

stems, opposite leaves, and purple flowers. Loosestrife TRIBE. P. 219.

\section{ORDER II. DIGYNIA. 2 Pistils.}

3. Agrimonia. A rough herbaceous plant, with pinnate leaves and spiked, yellow flowers. ROSE TRIBE. P. 171.

ORDER III. TRIGYNIA. 3 Pistils.

4. Reséda. Herbaceous or somewhat shrubhy plants with furrowed stems, smooth leaves, and terminal spikes or clusters of greenish flowers. Rocket Tribe. P. 72 .

ORder IV. TETRAGYNIA. 4 Pistils.

5. Tormentilla. Herbaceous plants, with slender stems, quinate leaves, and bright yellow flowers. Rose TRIBE. P. 171.

\section{ORDER V. DODECAGYNIA.}

6. Sempervívum. A succulent, herbaceous plant, with remarkably thick leaves, and a terminal cyme of dull purple flowers. Stonecrop Tribe. P. 232.

Class XII. ICOSANDRIA. 20 or more Stamens placed on the Calyx.

All the genera in this Class belong to the Natural Order Rosicez. Rose Tribe. P. 171.

Class XIII. POLYANDRIA. Many Stamens inserted in the Receptacle.

ORDER I. MONOGYNIA. 1 Pistil.

1. Delphínium. Sepals 5, coloured, the upper one spurred.-A slender, herbaceous plant with terminal d 2 
clusters of irregular, blue flowers. CRowfoot Tribe. P. 2.

2. Papáver.
3. Meconopsis.
4. Glaucium.
5. Chelidonidm. $\left\{\begin{array}{l}\text { Sepals } 2 \text {; petals } 4 \text { - - Herbaceous } \\ \text { plants with showy flowers, and } \\ \text { abounding in white or yellow } \\ \text { juice, which is narcotic. Poppy } \\ \text { Tribe. P. 27. }\end{array}\right.$

6. Actea. Sepals 4; petals 4.-An herbaceous plant with triangular stems, twice-ternate leaves, and terminal clusters of white flowers.-CROWfoot Tribe. P. 2.

7. Helínthemum. Sepals 5, the two outer smallest, or sometimes wanting; petals 5.-Small shrubs with oblong leaves and showy, white or yellow flowers. Rock-Rose Tribe. P. 74.

8. Tília. Sepals 5, equal; petals 5.-Lofty trees with heart-shaped leaves, and yellow flowers which grow several together from the middle of an oblong bract. Lime Tribe. P. 115.

9. Nrмpнжа. $\left\{\begin{array}{c}\text { Sepals and petals numerous.- } \\ \text { Aquatic plants with floating leaves }\end{array}\right.$ 10. Nuphar. $\left\{\begin{array}{l}\text { and large white or yellow flowers. } \\ \text { and }\end{array}\right.$ Water-lily Tribe. P. 25.

ORder II. PENTAGYNIA. 2-6 Pistils.

11. Reś́da. Flowers irregular ; capsule solitary, open at the top.-Herbaceous or somewhat shrubby plants with furrowed stems, smooth leaves, and terminal spikes or clusters of greenish flowers. Rocket TRIBE. P. 72.

All the remaining plants in this Order belong to the Crowfoot Tribe. P. 2.

Order III. POLYGYNIA. Many Pistils.

All the plants of this Order belong to the Crowfoot Tribe. P. 2. 
Class XIV. DIDYNAMIA. 4 Stamens, 2 longer than the other 2.

ORdER I. GYMNOSPERMIA. Ovaries 4, 1-seeded.

1. Verbéna. Corolla slightly irregular; Ovaries united.-An erect herbaceous plant, with a roughish stem, and terminal slender spikes of small lavender flowers. Vervain Tribe. P. 504.

All the remaining plants of this order belong to the Labiate Tribe. P. 474.

ORDER II. ANGIOSPERMIA. Ovary single, many-seeded.

2. Linnæa. Corolla bell-shaped, regular.-A beautiful northern plant with trailing stems, roundish leaves, and delicate pink flowers, which hang in pairs from the summit of a slender stalk. Woodbine Tribe. P. 295.

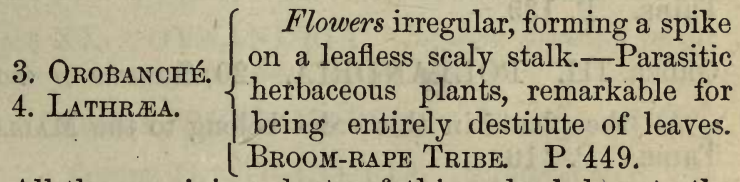

All the remaining plants of this order belong to the Figwort Tribe. P. 453.

Class XV. TETRADYNAMiIA. 6 Stamens, 4 long and 2 short.

All the plants in this class belong to the Cruciferous TRIBE. P. 36.

Class XVI. MONADELPHIA. Stamens united by their filaments into 1 set.

ORdfr I. PENTANDRIA. 5 Stamens.

1. ERóDIU.M. $\left\{\begin{array}{l}\text { Ovary of } 5 \text { carpels, placed round a } \\ \text { 2. GERÁNIUM. }\end{array}\left\{\begin{array}{l}\text { long awl-shaped beak.-Herbaceuus } \\ \text { plants with lobed or compound leaves } \\ \text { and purpleflowers. GERANIUM TriBe. } \\ \text { P. 123. }\end{array}\right.\right.$ 
3. Linum. Capsule 10-celled.-Herbaceous plants with slender stems, narrow leaves, and delicate flowers, Flax Tribe. P. 107.

\section{Order II. DECANDRIA. 10 Stamens.}

4. Gerínium. Ovary of 5 carpels, placed round a long awl-shaped beak.-Herbaceous plants with lobed or compound leaves and purple flowers. Geranium Tribe. P. 123.

2. Oxalis. Capsule 5-celled-Herbaceous plants with ternate leaves and delicate flowers. WOOD-SORREL T'RIBE. P. 131.

3. Ulex. 4. Genista. 5. Onónis. 6. Anthyllis. Flowers papilionaceous.-Shrubs or herbs, well distinguished by the peculiar form of their corolla, and by their 2-valved capsules or legumes. PEA aNd Bean Tribe. P. 139.

ORDER. III. POLYANDRIA. 20 Stameñs or more.

All the plants in this order belong to the MaLLow Tribe. P. 110.

Class XVII. DIADELPHIA. Stamens combined by their filaments into 2 sets.

Order I. HEXANDRIA. 6 Stamens.

Sepals 2 ; petals 4, unequal, one

1. Conýdalis. $\left\{\begin{array}{l}\text { of them swollen or spurred at the } \\ \text { base.-Herbaceous plants, often with }\end{array}\right.$

2. Fumária. $\{$ long climbing stems and clusters of small flowers. Fumitory Tribe. [P. 33 .

Order II. OCTANDRIA. 8 Stamens.

3. Polýgala. Sepals 5, the two inner large and petal-like : petals combined with the filaments. MILk. WORT Tribe. P. 83. 


\section{ORDER III. DECANDRIA. 10 Stamens.}

All the plants in this order have papilionaceous flowers, with the stamens combined into 2 sets of 9 and 1. Pea and Bean Tribe. P. 139.

Class XVIII. POLYADELPHIA. Stamens combined by their filaments into 3 or more sets.

All the plants in this class belong to the ST. JoHN'sWort Tribe. P. 117.

Class XIX. SYNGENESIA. Stamens united by their anthers into a tube; Flowers compound.

All the plants in this class belong to the Compound Flowers. P. 319.

Class XX. GYNANDRIA. Stamens growing in the pistil, and united with it.

Order I. MONANDRIA. 1 Stamen, and,

ORDER II. DIANDRIA. 2 Stamens.

All the plants in these two orders belong to the Orchideous Tribe. P. 582.

Oruer III. HEXANDRIA. 6 Stamens.

1. Aristolóchia. Perianth single, tubular, curved. -A climbing plant with heart-shaped leaves, and pale yellow flowers, the tube of which is swollen at the base and contracted near the mouth. Birthwort Tribe. P. 547.

Class XXI. MONCEIA. Stamens and Pistils in separate flowers on the same plant.

Order I. MONANDRIA. 1 Stamen.

1. Euphórbia. Several barren flowers, and 1 fertile, 
contained in a bract, or involucre of 1 leaf; ovary 3-lobed, 3-seeded.-Herbaceous plants abounding in acrid, milky juice, branched principally above, and bearing many green flowers. Spurge Tribe. P. 549.

2. Callítriché. Ovary 4-lobed; styles 2.-Small aquatic plants with opposite leaves, inconspicuous axillary flowers without petals, and 4 -seeded fruit. Water-starWort Tribe. P. 558 .

3. Zannichellia. Ovaries 4, styles 4.-A submersed aquatic plant with numerous slender stems, linear leaves, and inconspicuous green flowers. 4. Zostéra. Ovaries 4 ; style 1, 2-cleft.-A submersed marine plant, with long, grassy leaves, some of which are sheathing at the base, and contain barren and fertile flowers without petals, arranged alternately in 2 rows on a common stalk. Pond-Weed Tribe. P. 644.

5. Arum. Stamens and pistils arranged in separate rings round a common central column or spadix.-A curious herbaceous plant with large, glossy leaves, from among which rises a sheath containing a solid crimson column bearing a ring of stamens about the middle, and a row of pistils beneath. Cuckoo-PINT Tribe. P. 639 .

\section{ORDER II. DIANDRIA. 2 Stamens.}

6. Callítriché. Ovary 4-lobed; styles 2.-Aquatic plants with opposite leaves, inconspicuous, axillary flowers without petals, and 4 -seeded fruit. WATERSTARWORT Tribe. P. 558.

7. Lema. Ovary 1-celled; style 1; stigma 1.Minute, stemless, aquatic, floating plants, consisting entirely of a few thread-like roots and fleshy leaves, embedded in which last flowers are produced, but rarely. Duck Weed Tribe. P. 643.

8. Carex. Inflorescence in terminal spikes formed of chaffy scales or glumes, with a flower at the 
base of each. Sedge Tribe. Not described in this work. (See Miss Pratt's “Grasses and Sedges.”)

\section{ORDER III. TRIANDRIA. 3 Stamens.}

9. Tүрна. Inflorescence in a large terminal spike, the upper part of which contains stamens only, the lower pistils only. 10. Spargánium. Inflorescence in globular heads, of which the upper ones contain stamens only, the lower pistils only.-Aquatic plants with linear leaves growing on the margins of rivers and ponds. Reed-Mace Tribe. P. 635.

* Many of the Sedge Tribe belong to this order; their inflorescence is in terminal spikes, formed of chaffy scales or glumes, with a flower at the base of each. Not described in this work. (See Miss Pratt's "Grasses and Sedges.")

\section{ORDER IV. TETRANDRIA. 4 Stamens.}

11. Littorelda. Barren flower: sepals 4 ; petals 4 ; stamens very long. - Fertile flower: ovary 1-seeded; style very long.-An herbaceous marsh plant with fleshy, linear leaves, a stalked, barren flower, and sessile, fertile flowers. Plantain Tribe. P 524.

12. Aunus. Flowers in catkins, the scales of which are 3-cleft.-A tree with smooth jagged leaves and numerous small catkins. CAtKin-bearing Tribe. P. 565.

13. Mrríca. Flowers in catkins, the scales of which are entire.-A shrub, growing in boggy ground, welldistinguished by its resinous, aromatic catkins, which appear before the leaves. Catkin-bearing Tribe. P. 565 .

14. Buxus. Sepals 4 ; styles 3 ; capsule with 3 beaks. - A hard-wooded shrub, or small tree, with evergreen leaves and green axillary flowers. Spurge Tribe. P. 549 . 
15. Parietaria.

16. URTícA.

Flowers in spikes or clusters; calyx of the barren flower of 4 sepals, or 4-cleft ; seed 1.-Herbaceous plants with hairy or stinging leaves, and small, green flowers, which are remarkable for the elasticity of their stamens. Nettle Tribe. P. 559.

\section{ORDER V. PENTANDRIA. 5 Stamens.}

17. Átriplex. Herbaceous or somewhat shrubby plants, with fleshy, often angular and mealy leaves, and leafy compound spikes of greenish flowers, which, as well as the foliage, are not unfrequently tinged with red. Goose-foot Tribe - P. 528.

ORder VI. POLYANDRIA. More than 5 Stamens.

18. Mrriophyllum. Sepals 4 ; petals 4 ; stamens 8 ; mistils 4.-Submersed aquatics, with finely-divided leaves and small whorled or spiked flowers. MARE'staIl Tribe. P. 215.

19. Cerátophyllum. Sepals numerous; petals 0 ; stamens 18-20; pistil 1.-Submersed aquatics with finely divided, rigid, and whorled leaves. HonNworT Tribe. P. 218.

20. SagitTaria. Sepals 3 ; petals 3 -An herbaceous aquatic, remarkable for its large arrow-shaped leaves, and delicate lilac flowers. WATER-PLANTAIN Tribe. P. 631.

21. Potérium. Flowers in a round head, the upper fertile, the lower barren.-A slender herbaceous plant, with pinnate leaves, and round heads of greenish flowers, which are remarkable for their tufted pistils and long stamens. Rose Tribe. P. 171.

22. ARUM. Stamens and pistits arranged in separate rings round a common central column or spadix.- 
A curious herbaceous plant with large glossy leaves, from among which rises a sheath containing a solid crimson column, bearing a ring of stamens about the middle, and a row of pistils beneath. Cuckoo-pint Tribe. P. 639.

23. Quercus. 24. Fagus. 25. Castánea. 26. BÉtula. 27. Carpìnus. 28. Córylus. Barren flowers in a catkin or loose spike. - Trees, the fruit of which is a nut, wholly or in part enclosed in a tough case, with the exception of BÉtula, the small nut of which is winged. Catkin-Bearing Tribe. P. 565.

\section{Order VII. MONADELPHIA. Stamens united in 1 set.}

1. Pinus. Trees with resinous wood, and linear, often rigid leaves, and bearing their fruit in cones. FIRTRIBE. P. 574.

Class XXII. DICECIA. Stamens and Pistils in separate flowers and on different plants.

Order I. DIANDRIA. 2 Stamens.

1. SALIX. Inflorescence in catkins, the scales of which contain each a single flower; stigmas 2 ; seeds cottony. -Trees or shrubs with long, flexible branches and simple leaves. Catkin-bearing Tribe. P. 565.

ORDER II. TRIANDRIA. 3 Stamens.

2. Émpetrum. Perianth of several scales; filaments very long ; stigma 1 , rayed.-A small shrub with heathlike leaves, small flowers, and black berries. CrowBerry Tribe. P. 549.

3. Ruscus. Flowers solitary, from the centre of the leaf; sepals 6 ; petals $0 .-\mathrm{A}$ low shrub with green branches, stout leaves each of which terminates in a thorn, small green flowers, and scarlet berries. LiLY TRIBE. P. 607. 
4. Valeriána. Corolla of one petal, bearing the stamens ; seed 1, crowned by the calyx.-An herbaceous plant, with a simple stem, deeply-cut leaves, and a terminal corymb of light-pink flowers. Valerian Tribe. P. 309.

5. SAlix. Inflorescence in catkins, the scales of which contain each a single flower ; stigmas 2 ; seeds cottony.Trees or shrubs with long, flexible branches and simple leaves. Catkin-Bearing Tribe. P. 565.

\section{ORDER III. TETRANDRIA. 4 Stamens.}

6. Viscum. Petals 4, fleshy ; fruit a 1-seeded berry. A parasitic shrub with green branches, leathery leaves, and conspicuous white berries. Mistletoe Tribe. P. 292.

7. HippópHáË. Barren flower : perianth 2-cleft ;fertile flower : perianth 4-cleft ; fruiti one-seeded, berry. like.-A sea-side, thorny shrub, with silvery leaves and orange-coloured fruit. Oleaster TRIBE. P. 543.

8. Rнamnus. Calyx 4-cleft; petals 4.-A thorny shrub, with simple serrated leaves, numerous greenish flowers, and black berries. BuckthorN TrIBE. P. 136 .

9. Mrríca. Flowers in catkins.-A shrub, growing in boggy ground, well distinguished by its resinous, aromatic catkins, which appear before the leaves. Catkin-bearing Tribe. P. 565.

10. Untíca. Barren flower: sepals 4 ; petals 0 ;fertile flower: sepals 2 ; petals 0 : seed 1.-An erect, scarcely branched, herbaceous plant, with opposite, stinging leaves, and small green flowers, which are remarkable for the elasticity of their stamens. Nettle Tribe. P. 559 .

Order IV. PENTANDRIA. 5 Stamens.

11. Húmulus. Barren flower solitary; sepals 5; 
petals 0 ;-fertile flowers in large membranaceous eatkins.-A climbing plant with rough stems, lobed leaves, and handsome clusters of drooping catkins. NeTtLE Tribe. P. 559.

12. Ríbés. Calyx 5-cleft; sepals 5, inserted on the calyx; fruit a berry.-An alpine shrub with lobed leaves, erect clusters of green flowers, and red berries.Gooseberry and Currant Tribe. P. 239.

13. Bryónia. Calyx 5-toothed; sepals 5 ; filaments 3 ; anthers 5 ; fruit a berry.-A climbing plant with elegantly lobed, downy leaves, greenish flowers and scarlet berries. Gourd Tribe. P. 224.

14. SALIX. Inflorescence in catkins, the scales of which contain each a single flower.-A handsome shrub with long, flexible branches, glossy leaves, and seeds tufted with silky down. Catkin-Bearing Tribe. P. 565.

\section{ORdER V. HEXANDRIA. 6 Stamens.}

15. Tamus. Perianth single, in 6 equal segments; fruit a berry.-A climbing plant, with heart-shaped, glossy leaves, small green flowers, and scarlet berries. YAM TRIBE. P. 604 .

16. Rumex. Seed 1, 3-cornered, enclosed in the calyx.-Herbaceous plants with erect stems, acid leaves, and panicles of green flowers tinged with red. PersICÁRIA.Tribe. P. 537.

\section{ORDER VI. OCTANDRIA. 8 Stamens. -}

17. Pópulus. Inflorescence in catkins, the scales of which are jagged ; stamens 8-30.-Lofty trees remarkable for having the upper portion of the leaf-stalk flattened vertically. Catkin-bearing Tribe. P. 565,

18. Sedum. Sepals 4 ; petals $4 .-$ A mountain plant, with thick, fleshy leaves and yellow flowers, remarkable for the rose-like scent of its roots. STONECROP TRIBE. P. 232. 
Order VII. ENNEANDRIA. 9 Stamens.

19. Merctrílis. Sepals 3 ; petals 0 ; capsule '2lobed.-Herbaceous plants with roughish leaves, bearing small green flowers in loose spikes. Spurge TrIBE. P. 549 .

Order VIII. DECANDRIA. 10 Stamens.

20. Lychnis. Calyx 5-cleft; petals 5.-Herbaceous plants, with downy oblong leaves, and large brightpurple or white flowers. Pink Tribe. P. 87.

ORder IX. POLYANDRIA. Many Stamens.

21. Stratiótes. Sepals 3 ; petals $3 .-\mathrm{A}$ curious aquatic plant, with sword-shaped, prickly leaves, and large, white flowers, which grow from a 2-leaved sheath. Frog-Bit Tribe. P. 579.

22. Pópulus. Inflorescence in a catkin, the scales of which are jagged. - Lofty trees, remarkable for having the upper portion of the leaf-stalk flattened vertically. Catkin-bearing Tribe. P. 565.

\section{ORdER X. MONADELPHIA.}

Stamens urited by their filaments into 1 set.

23. Juníperus. Berry formed of the united scales of the catkin, 3-seeded.-A shrub with prickly, evergreen leaves, inconspicuous flowers, and purple berries. FIR Tribe. P. 574.

24. Taxus. Seed solitary, half invested with a fleshy cup.-A hard-wooded tree, with linear, evergreen leaves, and scarlet seed-vessels. Fir Tribe. P. 574. 


\section{ORDER XI. POLYADELPHIA.}

Stamens combined by their filaments into 3 sets.

25. Bryónia. Calyx 5-toothed; petals 5; filaments 5.-A climbing plant, with elegantly-lobed downy leaves, greenish flowers, and scarlet berries. Gourd Tribe. P. 224.

Class XXIII. POLYGaMIA. Flowers of 2 kinds ; some bearing Stamens and Pistils; some, Stamens only; and some, pistils only.

\section{Order I. MONCECIA.}

All three kinds of Flowers on the same plant.

1. Átriplex. Herbaceous, or somewhat shrubby plants, with fleshy, often angular and mealy leaves, and leafy, compound spikes of greenish flowers; which, as well as the foliage, are often tinged with red. GooseFOOT TRIBE. P. 528.

\section{Class XXIV. CRYPTOGAMIA.}

This Class, by far the most extensive in the Linnean ARRANGEMENT, comprises all plants in which the existence of stamens and pistils cannot be detected. Here are placed the Fersis, Mosses, Liverworts, Lichens, Fungr, and SEA-WEEDS, none of which are described in this work. 



\section{NATURAL ARRANGEMENT OF PLANTS.}

\section{Class I. DICOTYLEDONOUS oR EXOGENOUS PLANTS.}

THIs is the most extensive class in the vegetable kingdom, and derives its name from the fact that the seeds are composed of two, or more, lobes, called cotyledons, which enclose the plumule, or embryo of the future plant. As germination commences, the plumule lengthens downwards into a root, called in its early stage, a radicle: at the same time the upper extremity lengthens into a stem, which is composed of bark, woody fibre, spiral vessels, cellular tissue, and a central column of pith. The stem increases in diameter by deposits beneath the bark, but outside the existing fibre. Hence, the plants belonging to this class are called ExoGENous (increasing by additions on the outside). In all trees and shrubs of this class the wood is arranged in concentric layers, the hardest part being nearest the pith. The leaves are reticulated, or furnished with a network of veins. The flowers are furnished with stamens and 
pistils ; 5 or 4 , or some multiple of 5 or 4 , being the predominating number of the parts of fructification.

\section{SUB-CLASS I.}

\section{THALAMTFLORA.-ORD. I-XXII.}

Flowers furnished with calyx and corolla; petals distinct, inserted into the receptacle or thalamus; stamens springing from below the base of the ovary.

\section{Natural ORDER I.}

\section{RANUNCULAĆEA-The Crowfoot Tribe.}

Sepals generally 5 ; petals 5 or more, frequently irregular in form ; stamens indefinite in number, inserted on the receptacle; ovaries generally numerous ; fruit consisting of several one or many-seeded carpels ; in Actaca, a berry.-An extensive tribe of plants, inhabiting for the most part the temperate regions of the globe. All the British species are herbaceous, leaves generally much divided, and flowers showy; sepals and petals often running into one another, sometimes extended into spurs. Most of them possess acrid and poisonous properties if taken into the stomach, and not a few produce wounds if applied to the skin. Some species were formerly used in medicine, and the extract of Monkshood is still employed to relieve pain in affections of the nerves. The Hellebore was held in high repute among the ancients, as a specific for madness ; the garden-flower known by the familiar name of Christmas Rose belongs to this family. Ranúnculus sceleratus is one of the most generally diffused plants, being as common in America, and on the banks of the Ganges, as it is in our own marshes. 
* Carpels one-seeded.

1. Cuématrs (Traveller's Joy).-Sepals 4-6, resembling petals; corolla wanting; carpels terminated by a long feathery tail. (Name from the Greek, cléma, a vine-shoot.)

2. Thalictrum (Meadow Rue).-Sepals 4-5; corolla wanting ; carpels without tails. (Name from the Greek, thallo, to flourish.)

3. ANEMÓNE (Wind-flower).-Sepals and petals alike, $5-15$; involucre of 3 cut leaves, distant from the flower. (Name from the Greek, anemos, the wind, from the exposed place of growth.)

4. Adónis (Pheasant's Eye).-Sepals 5; petals 5-10, without a nectary at the base; carpels without tails. (Name from Adonis, a youth who was killed by a wild boar, and whose blood is fabled to have stained flowers.)

-5. Ranúnculus (Crowfoot, Buttercup, Lesser Celandine, \&c.)-Sepals 5 (rarely 3 ); petals 5 (rarely numerous), with a nectary at the base. (Name from the Latin, rana, a frog, an animal which frequents the kind of places where these plants grow.)

6. Mrosúrus (Mouse-tail).- Sepals 5, prolonged at the base into a spur; petals 5 ; carpels crowded into a lengthened spike. (Name, Greek for a mouse's tail.)

\section{* Carpels many-seeded.}

7. Troulius (Globe-flower).-Sepals about 15, resembling petals; petals 5 or more, small, narrow. (Name said to be derived from an old German word, signifying a globe.)

8. Caltha (Marsh Marigold).-Sepals and petals alike, 5 or more. (Name from the Greek, cálathus, a cup, which its flowers resemble.)

9. Hellíborts (Hellebore). - Sepals 5, petal-like, perB 2 
sistent; petals small, tubular; carpels 3-10. (Name from the Greek, helein, to injure, and bora, food.)

10. Aquilégia (Columbine).-Sepals 5, petal-like, soon falling off ; petals 5, tubular, gaping upwards, and terminating below in a curved, horn-shaped spur; carpels 5. (Name from the Latin, aquila, an eagle, to the claws of which its nectaries bear a fancied resemblance.)

11. Delphínium (Larkspur).-Sepals 5, petal-like, soon falling off, the upper one helmet-shaped, with a long spur at the base ; petals 4, the two upper on long stalks, and concealed in the spurred sepal ; carpel $3-5$. (Name from delphin, a dolphin, to which animal the upper sepal bears a fancied resemblance.)

12. Aconítum (Monk's-hood).-Sepals 5, petal-like; the upper one helmet-shaped but not spurred; nectaries 2 , stalked, tubular at the extremity, and concealed beneath the helmet-shaped sepal ; carpels $3-5$. (Name of uncertain origin.)

13. Астжа (Bane-berry).-Sepals 4, soon falling off; petals 4 ; fruit a many-seeded berry. (Name from the Greek, acté, the elder, from the similarity of the leaves of the two plants.)

14. Psónia (Peony).-Sepals 5, unequal; petals $5-10$; carpels $2-5$, with fleshy stigmas formed of two plates. (Name from Pceon, a Greek physician, who is said to have cured wounds with it.)

\section{Chématis.}

1. C. Vitalba (Traveller's Joy).-The only British species. A hedge-shrub, common where limestone or chalk enters largely into the composition of the soil, climbing other shrubs by the help of its twisting leaf stalks; well distinguished in summer by its numerous greenish-white flowers, and in autumn and winter rendered yet more conspicuous by its tufts of feathered seed-vessels, popularly known by the name of "Old Man's Beard." It received its name from "decking and 
CROWFOOT TRIBE.

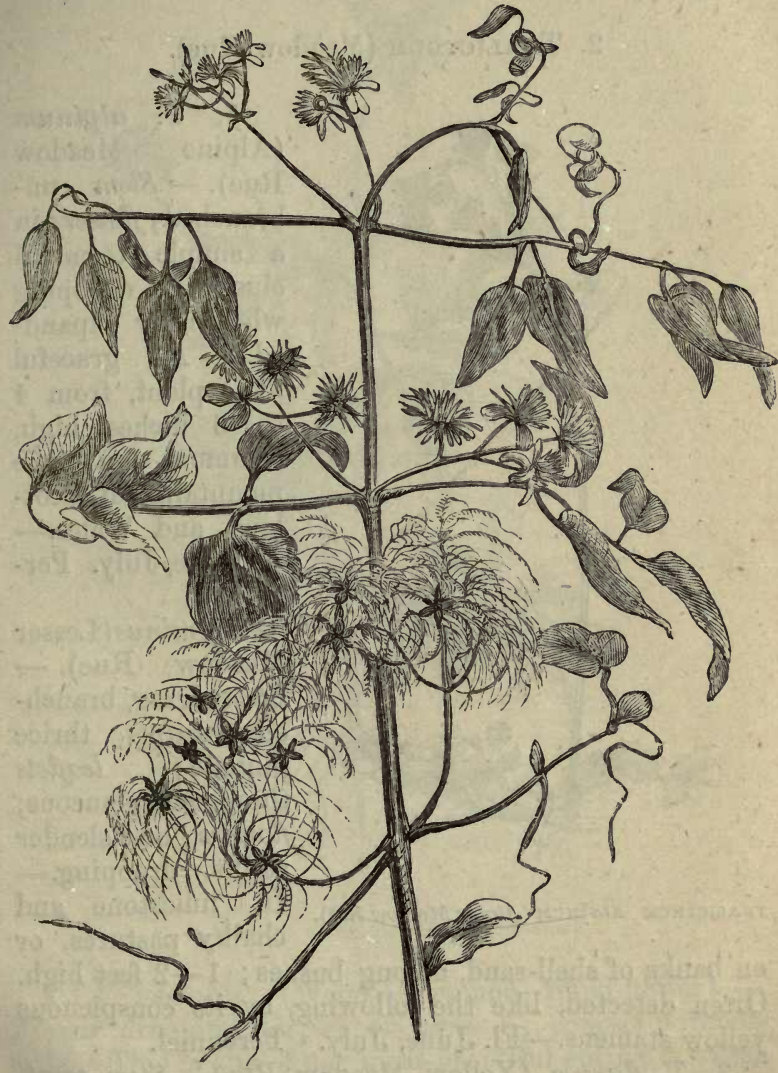

CLÉMATIS VITALBA (Traveller's Joy). 
adorning waies and hedges where people travel."Fl. May, June. Perennial.

2. Thalictrum (Meádow Rue).

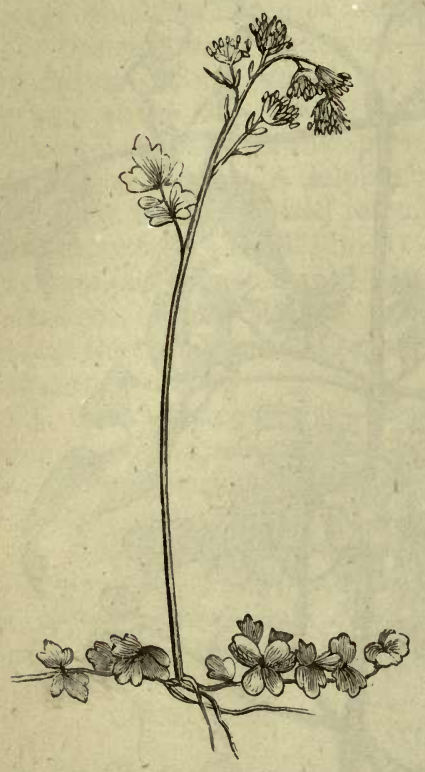

thalictrum alpinum (Alpine Meadow Rue).

1. T. alpínum (Alpine Meadow Rue). - Stem unbranched; flowers in a simple terminal cluster, drooping when fully expanded. - A graceful little plant, from 4 to 6 inches high, common on the mountains of Scotland and Wales.Fl. June, July. Perennial.

2. T. minus(Lesser Meadow Rue). Stem zigzag, branched; leaves thrice pinnate; leaflets three-cleft, glaucous; flowers on slender stalks, drooping.In limestone and chalky pastures, or on banks of shell-sand, among bushes ; $1-2$ feet high. Often detected, like the following, by its conspicuous yellow stamens.-Fl. June, July. Perennial.

3. T. flavum (Yellow Meadow Rue).-Stem erect, branched ; leaves twice pinnate; flowers crowded, erect. - Not uncommon about the banks of ditches and rivers; 4-4 feet high.-Fl. June, July. Perennial. 
3. Anemone (Wind-flower).

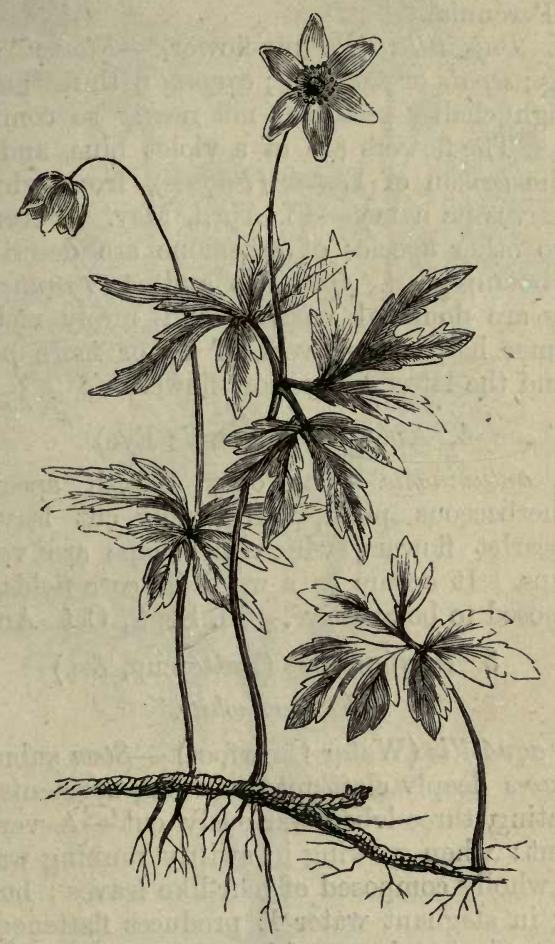

ANEMONe NeMorósa (Wood Anemone).

1. A. nemorósa (Wood Anemone, Wind-flower).Flower drooping; sepals or petals 6 ; carpels without tails.- This is one of our most beautiful spring flowers, adorning our upland woods at the season when primroses and violets are in perfection. The petals and sepals are generally white, but not unfrequently tinged 
with pink externally; more rarely they are of a delicate sky-blue, both within and without.-Fl. .MarchMay. Perennial.

2. A. Pulsatilla (Pasque-flower).-Flower slightly drooping; sepals or petals 6 ; carpels with feathery tails. - In high chalky pastures, not nearly so common as the last. The flowers are of a violet blue, and appear about the season of Easter (Pâques), from which the plant derives its name.-Fl. April, May. Perennial.

* Two other species of Anemone are described by British botanists, A. Apennína and A. ranunculoídes, but they are doubtful natives, and rarely met with. The former has blue flowers, of 12 or more petals or sepals, and the latter has yellow flowers.

\section{Adónis (Pheasant's Eye).}

1. A. autumnalis.-The only British species. A pretty herbaceous plant, with finely cut leaves and bright scarlet flowers; which in shape are very like buttercups. It occurs as a weed in corn-fields, but is not supposed to be a native.-Fl. Sept., Oct. Annual.

\section{Ranúnculus (Buttercup, \&c.) * Flowers white.}

1. R. aquátilis (Water Crowfoot).-Stem submersed; lower leaves deeply cleft into hair-like segments, upper ones floating, three-lobed, variously cut.-A very variable plant: when growing in swiftly running water the plant is wholly composed of hair-like leaves ; but when growing in stagnant water it produces flattened leaves as well, and abundance of large showy flowers. The foliage of this species is destitute of the acrid properties which exist in the rest of the genus.-Fl. MayJuly. Perennial.

2. $R$. hederáceus (Ivy-leaved Crowfoot).-Leaves all rounded and lobed; petals scarcely longer than the calyx ; stamens 5-10.- Smaller than the last, growing either in water, or close to the water's edge.-Fl. all the summer. Perennial. 

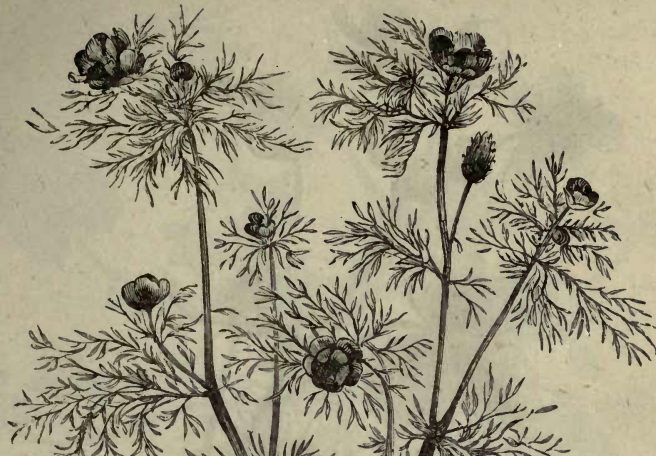

iT)
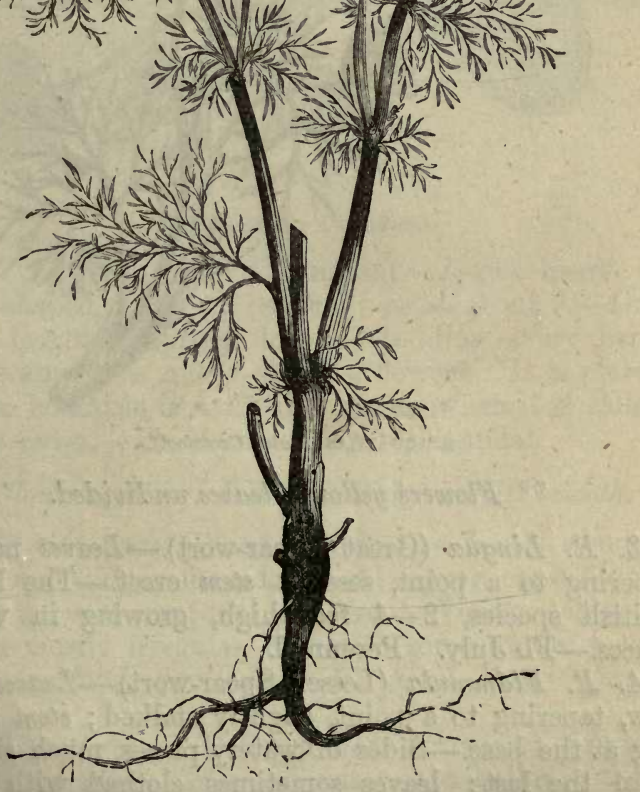

Adónis (Pheasant's Eye). 


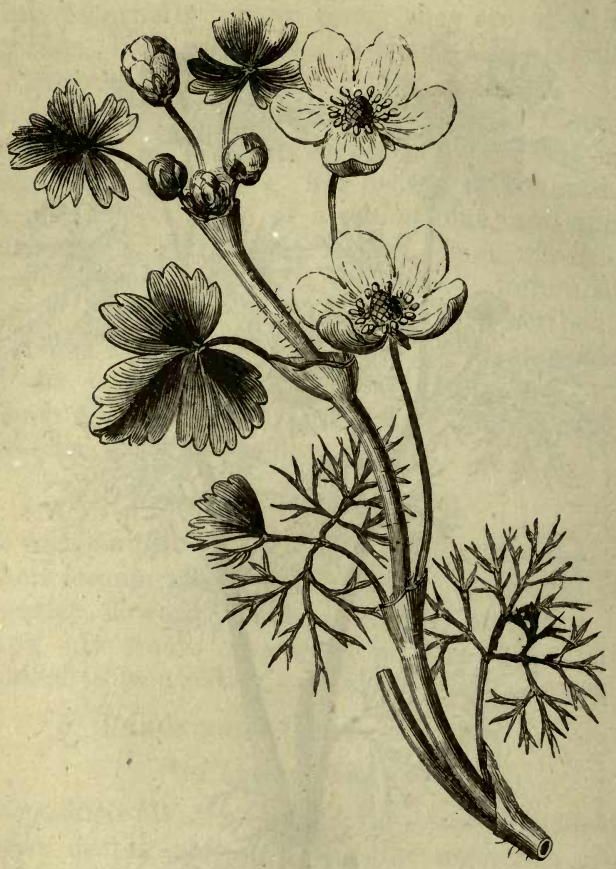

R. AQUATILIS (Water Crowfoot). .

** Flowers yellow; leaves undivided.

3. R. Lingua (Great Spear-wort).-Leaves narrow, tapering to a point, sessile: stem erect.-The largest British species, 2-4 feet high, growing in watery places.-Fl. July. Perennial.

4. R. Flámmula (Lesser Spear-wort).-Leaves narrow, tapering to a point, slightly stalked; stem creeping at the base.- Sides of watery places, much smaller than the last; leaves sometimes clothed with silky hairs.-Fl. June-August. Perennial. 
species, from 6 inches to 2 feet high, growing in watery places in most parts of the world. Leaves glossy; petals inconspicuous.-Fl. June-August. Annual.

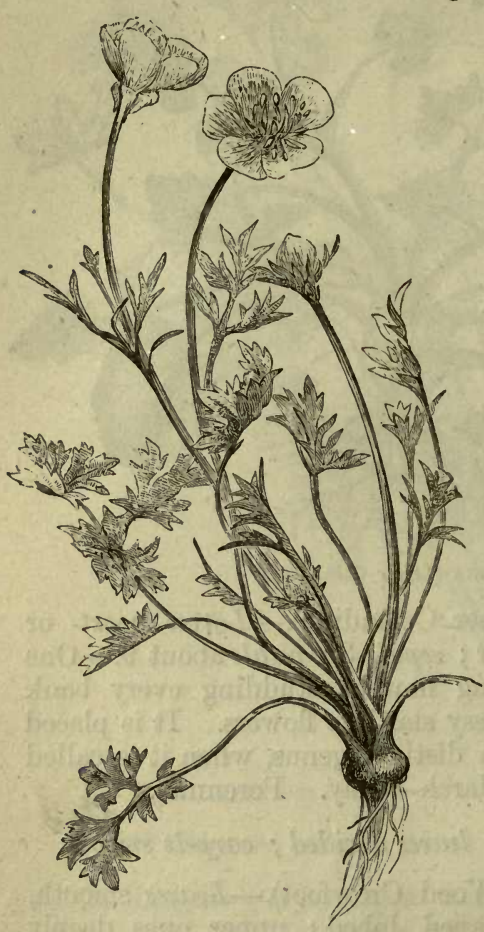

R. Bulbosus (Bulbous Buttercup).

8. R.bulbosus (Bulbous Buttercup). Calyx reflexed; flower-stalks channeled; root bulbous. - This is by children associated with the two following, under the name of Buttercups. Meadows.-Fl. May, June. Perennial.

9. R. repens (Creeping Buttercup). Calyx spreading; flower-stalks channeled ; root creeping. -Moist meadows and sides of ditches. A troublesome weed, increasing by creeping shoots, or scions, which take root wherever a leaf is produced.-Fl. June-August. Perennial.

10. R.acris (Meadow Crowfoot). - Calyx spreading; flowerstalks cylindrical, not furrowed; root composed of long fibres.-Meadows, common. Well distinguished from the preceding by the above characters, as well as by its slender stem, and by the narrower segments of its upper leaves.-Fl. June, July. Perennial. A double variety is common in gardens, under the name of Yellow Bachelor's Buttons. 
**** Flowers yellow; leaves divided; carpels not smooth.

11. R. hirsútus (Pale Hairy Buttercup).-Calyx reflexed; root fibrous; carpels margined, and rough with small warts.-Meadows and waste ground. Smaller than either of the last three, for stunted specimens of which it might be mistaken.-Fl. June-October. Annual. A double variety is sometimes found wild.

12. $R$. arvensis (Corn Crowfoot).-Calyx spreading; carpels large and prickly.-Corn-fields. Well distinguished by its deeply-cut smooth foliage, as well as by its prickly carpels. One of the most poisonous of the genus; yet its seeds are said to be the favourite food of partridges._Fl. June. Annual.

13. R. parviflorus (Small-flowered Crowfoot).-Stem prostrate, hairy; seeds covered with small hooked prickles.-Fields and waste places, not common. Well distinguished by its hairiness, prostrate mode of growth, and inconspicuous flowers which grow opposite the leaves.-Fl. May-August. Annual.

* Most of the plants in this genus are acrid, and are said to be injurious to cattle if mixed largely with their food. R. Flámmula and sceleratus are used in the Hebrides to raise blisters ; these are, however, of objectionable use, being likely to produce sores difficult to heal. $R$. aquátilis is by some botanists separated into several species. Another species, $R$. alpestris, which grows on the Clova mountains, has divided leaves and white flowers.

\section{Mrosúrus (Mouse-tail).}

1. M. minimus (Common Mouse-tail).-A small annual plant, 3-6 inches high, growing in gravelly or chalky cornfields in many parts of England, easily distinguished from every other British plant by the arrangement of its ripe carpels into the appearance of a mouse's tail.-Fl. May. Annual. 


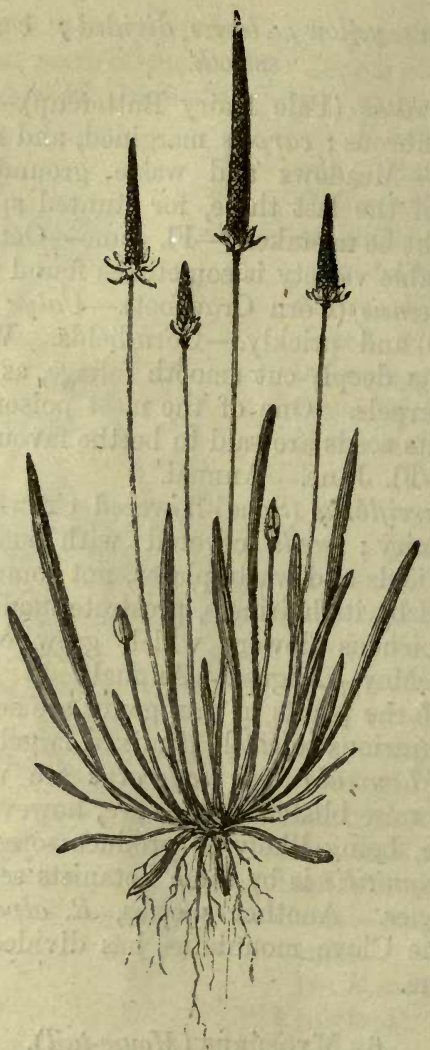

arostrus (Mouse-tail).

\section{Trollius (Globe Flower).}

1. Europoeus (Mountain Globe Flower).-A large and handsome plant, common in gardens, and growing wild in the mountainous parts of Scotland, Wales, and the north of England. The flowers are composed of 
about fifteen concave sepals, which converge into the form of a globe ; the petals are shorter and narrower than the sepals, and also curve inwards. By some

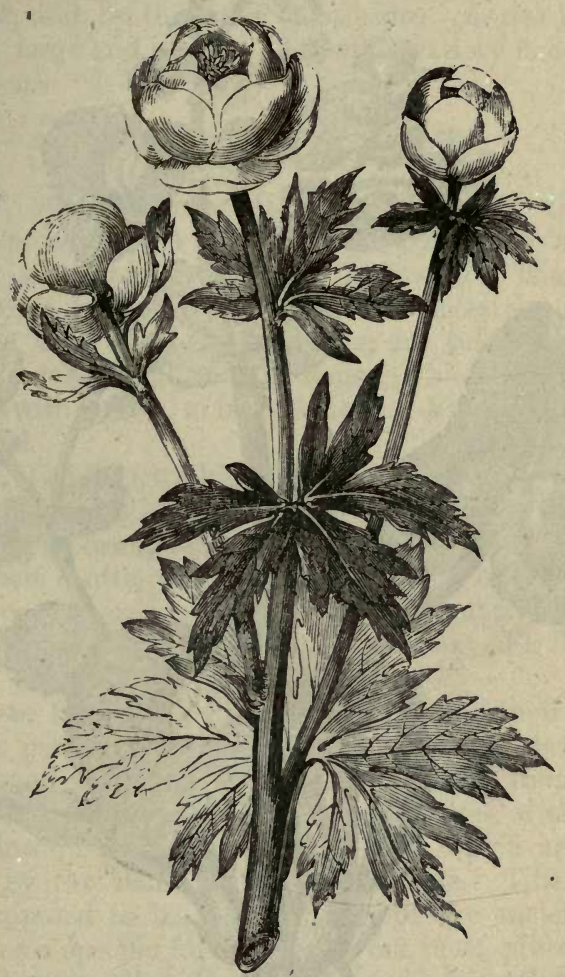

TROLLIUS (Globe Flower).

botanists the sepals are called petals, and the petals nectaries.-Fl. June, July. Perennial. 


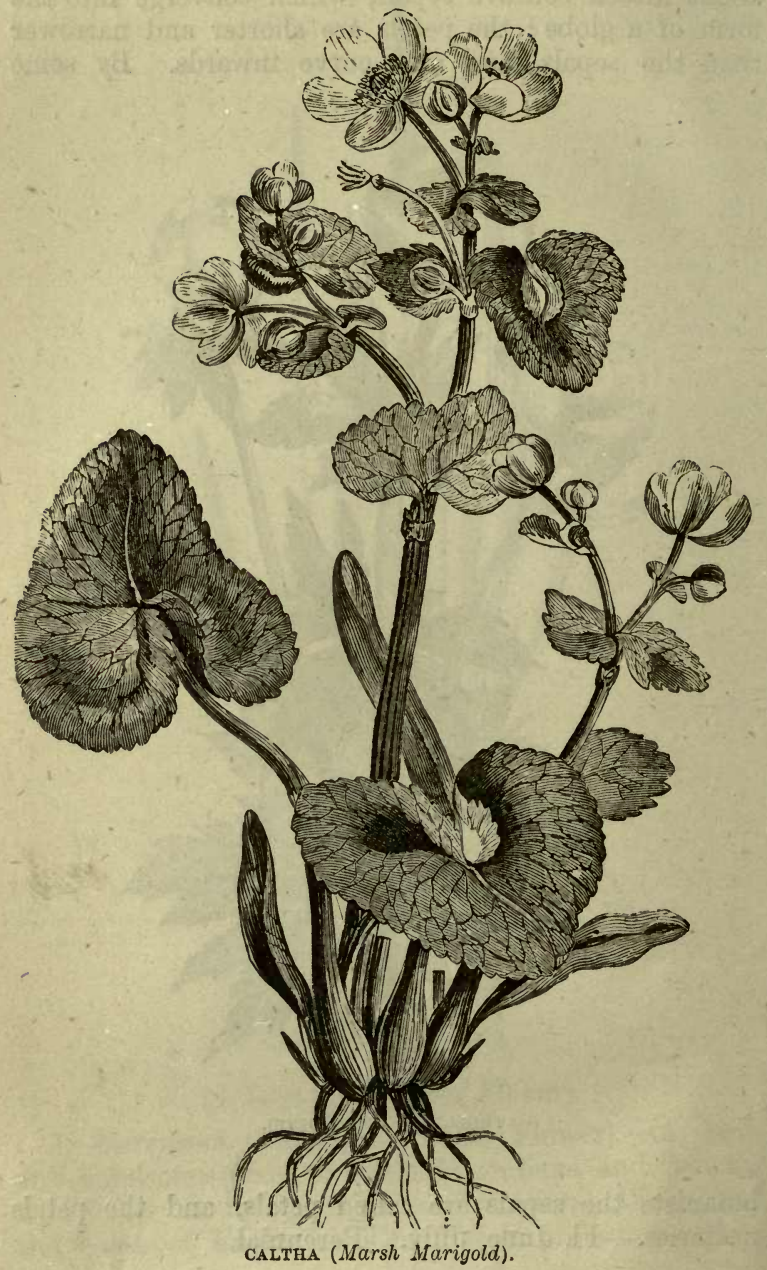




\section{Caltha (Marsh Marigold).}

1. C. palustris (Common Marsh Marigold).-A showy plant, resembling a gigantic Buttercup, abundant in marshes, and by the sides of streams. Leaves kidneyshaped, large and glossy. A double variety is common in gardens.

\section{Helléborus (Hellebore).}

1. H. víridis (Green Hellebore).-Leaves digitate; sepals spreading. - A coarse herbaceous plant, remarkable for the light green hue of its flowers. The petals, or as some botanists call them, the nectaries, of this plant, as well as of the following, are tubular, shorter than the calyx, and contain honey, which is said, and perhaps with reason, to be poisonous.-Fl. March, April. Perennial.

2. $H$. foetidus (Stinking Hellebore).-Leaves pedate; sepals converging.-Best distinguished from the preceding by its evergreen leaves which are not divided to a common centre, and by the purple hue of its sepals. Both species are considered doubtful natives, being generally found in the vicinity of houses.-Fl. March, April. Perennial.

* These two species are remarkable for their green leaf-like petals, and for the large tubular nectaries, in which small flies may sometimes be found caught, as in a trap. $H$. niger is a handsome species, with large white flowers, tinged with rose-colour, which are best known by the name of Christmas Rose. This is by some supposed to be the Hellebore of the ancients, so famous as a specific for madness; but most probably it was that now called $H$. officinalis. Closely allied with this genus is the common garden flower Eránthis hyemális (Winter Aconite), a pretty little plant, with yellow flowers and glossy leaves, appearing very early in spring. 


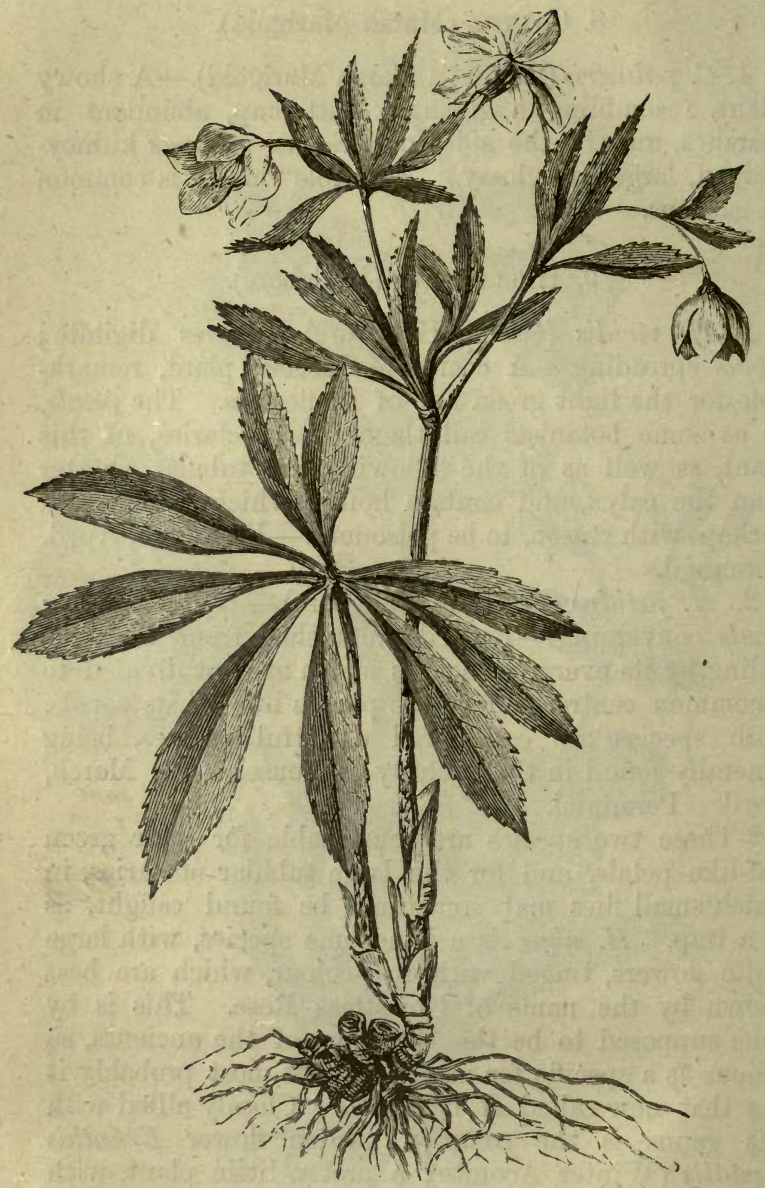

HELLEBORUS Víridrs (Green Hellebore). 


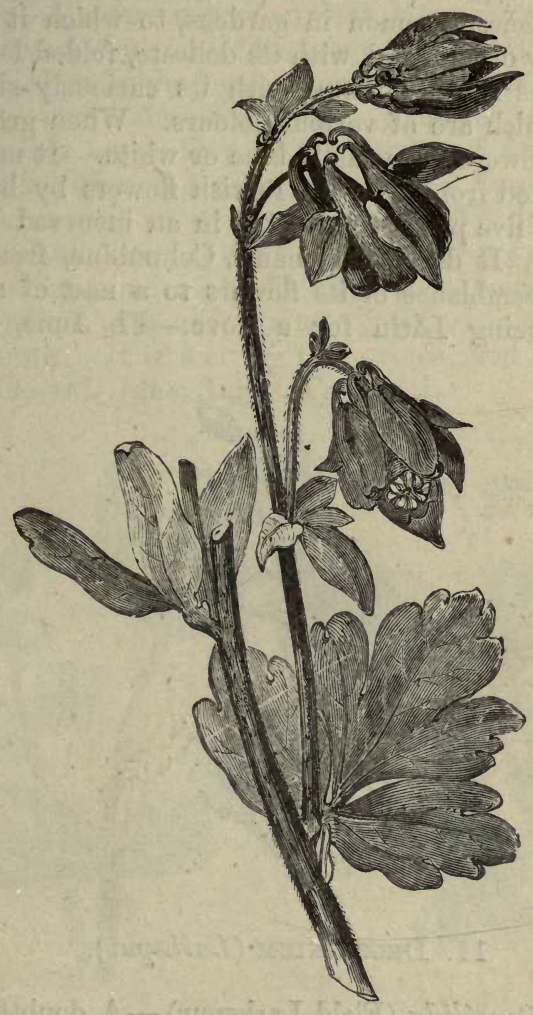

AQUIlÉgIa (Coĩumbine). 


\section{Aquilégia (Columbine).}

1. A. vulgáris (Common Columbine).-The only British species, common in gardens, to which it is in spring very ornamental, with its delicate, folded leaves ; and no less so in summer, with its curiously shaped flowers, which are of various colours. When growing wild, its flowers are usually blue or white. It may be distinguished from all other British flowers by having each of its five petals terminated in an incurved hornlike spur. It derives its name, Columbine, from the fancied resemblance of its flowers to a nest of doves, columba being Latin for a dove.-Fl. June, July. Perennial.

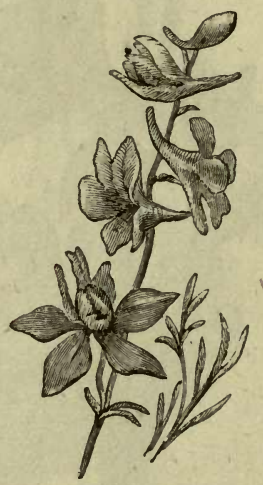

\section{Delphínium (Larkspur).}

1. D. Consólida (Field Larkspur).-A doubtful native, though often found in considerable quantities in sandy or chalky corn-fields. It closely resembles some of the species commonly cultivated in gardens.-Fl. June, July. Annual. 


\section{Aconítum (Monk's Hood).}

1. A. Napellus (Common Monk's-hood, or Wolf'sbane).-A common garden plant, more remarkable for the curious structure of its tubular nectaries, which are concealed under the hooded upper petal, than for beauty, or any other desirable qualities. Children often amuse themselves by pulling off the hood, and exposing the nectaries, when the remainder of the flower bears a fanciful resemblance to a car drawn by doves. The whole plant (especially the root) is very poisonous, and derives its name of Wolf's-bane from being used, in conjunction with more attractive food, as a bait in wolf-traps. It is scarcely to be considered a native of Britain.-Fl. June, July. Perennial.

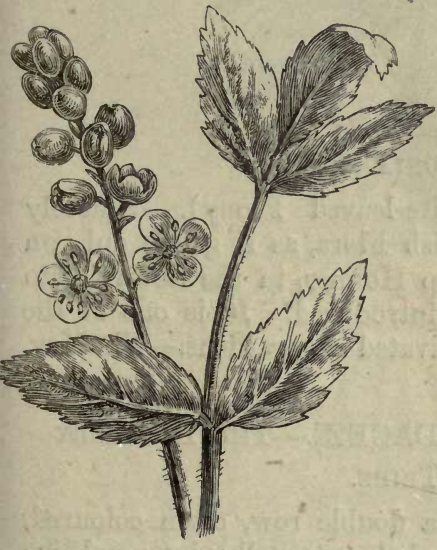

ACTAA (Bane-berry).

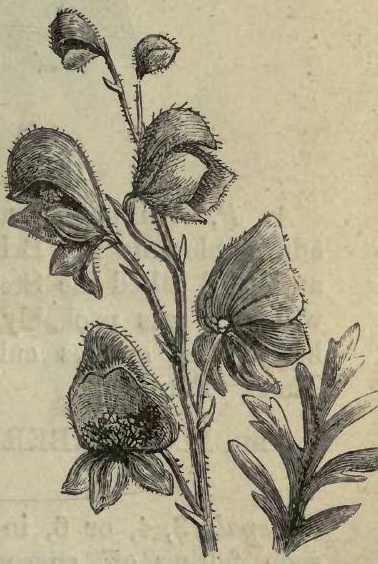

Aconítum (Monk's-hood).

\section{Aстаa (Bane-berry).}

1. A. spicata (Bane-berry, or Herb Christopher).The only British species, well distinguished by the 
generic characters given above, and by its triangular stem; it is a local plant, having been found only in Yorkshire-Fl. May. Perennial.

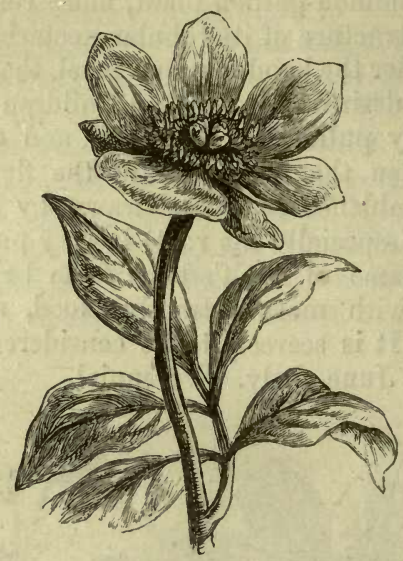

14. Pelonia (Peony).

1. P. corallina (Entire-leaved Peony).- Scarcely admissible into the British Flora, as it grows only on an island called the Steep Holmes, in the Severn, into which it was probably introduced. It is one of the herbaceous species cultivated in gardens.-Fl. May, June. Perennial.

\section{ORD. II.-BERBERIDACEA.-THE BARBERRY TrIBE.}

Sepals 3,4 , or 6 , in a double row, often coloured, soon falling off, surrounded externally by petal-like scales; petals either equal in number to the sepals, and opposite to them, or twice as many, often with a gland at the base; stamens equal in number to the petals, and opposite to them; anthers opening by a valve from the base upwards; ovary solitary, 1-celled, 1-3-seeded, 
generally turning to a berry.-Shrubs, growing principally in mountainous parts of the temperate zones, . especially in the north of India. Several species have thorny stems and astringent bark, and furnish a yellow dye ; the berries are acid, and may be made into an agreeable preserve ; those of one species, Bérberis Asiatica, are dried in the sun like raisins, Several handsome species are cultivated in gardens, under the name of Mahónia.

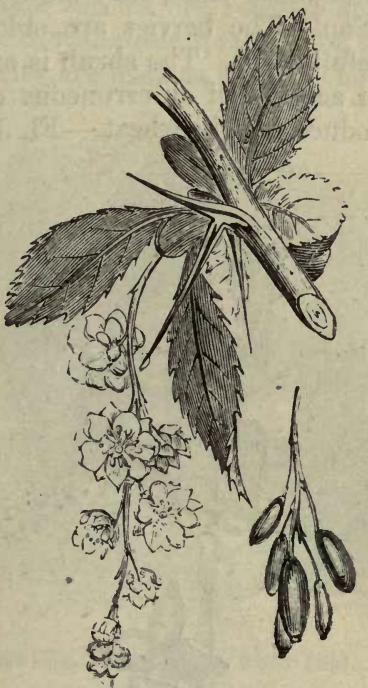

BÉRBERIS (Barberry).

1. BÉRBERIs (Barberry).-Sepals 6 ; petals 6, with 2 glands at the base of each within; berry 2 -seeded. (Name said to be of Arabic origin.)

2. Eprmédium (Barrenwort).-Sepals 4 ; petals 4, with a scale at the base of each within; pod manyseeded. (Name of uncertain origin.) 


\section{BÉRberis (Barberry).}

1. B. vulgáris (Common Barberry).-The only British species. A pretty shrub, not uncommon in woods and hedges ; remarkable for the light colour of its bark, which is yellow within, and for its 3 -forked spines. The flowers are yellow, and grow in drooping clusters; the filaments are elastic and irritable, so that when touched ever so lightly by the legs of an insect, or by any other small body, they spring forward and close on the pistil; after some time, they slowly recover their original position. The berries are oblong, red when ripe, and gratefully acid. The shrub is often rooted out by farmers, on account of an erroneous opinion that it is liable to produce rust in wheat.-Fl. June. Shrub.

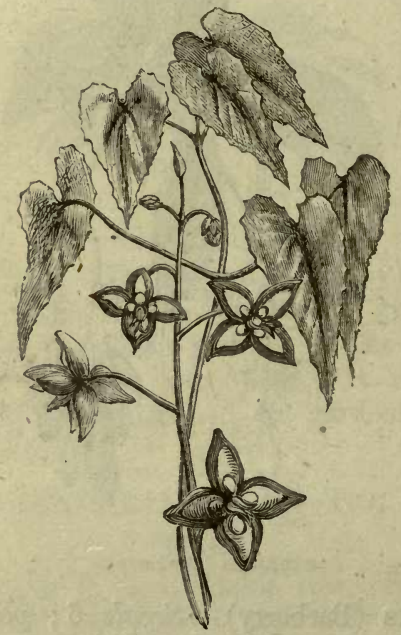

2. Epimédium (Barrenwort).

1. E. alpinum (Alpine Barrenwort).-The only species found in Britain; occurring here and there in mountainous woods in some parts of Scotland and the north of England, but not considered to be indigenous. 
Each stem bears a single leaf, which is composed of 3 ternate delicate leaflets.-Fl. May. Perennial.

\section{ORD. III.-NYMPH无ACEÆ.-WATER LILY TRIBE.}

Sepals 4-6, gradually passing into petals, and these into stamens, all being inserted on a fleshy disk, which surrounds the ovary ; stigma sessile, rayed ; berry manycelled, many-seeded.-Herbaceous aquatic plants, with peltate, floating leaves, and large, often fragrant, flowers. The roots of some species are roasted and eaten: the seeds contain a considerable quantity of starch, and in seasons of scarcity are used as food. The East Indian

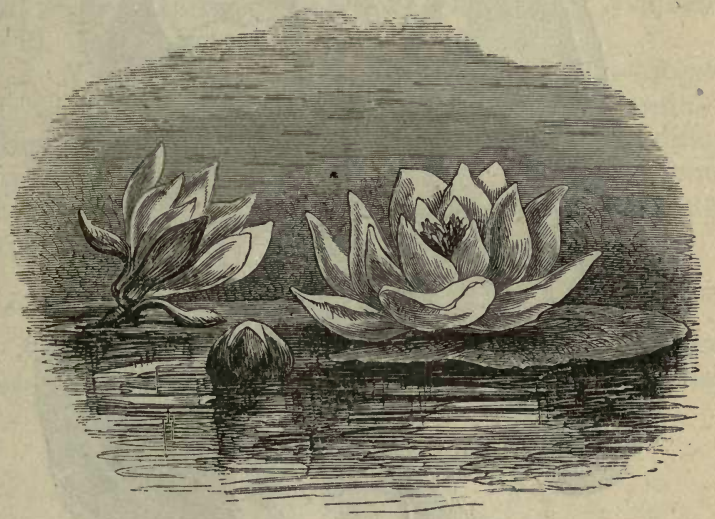

NyMPh.eA ALBA (White Water Lily).

Nelumbium speciosum is said to have been the sacred bean of Pythagoras. Its curious seed-vessels, filled with vegetating seeds, are thought to have originated the cornucopia of the ancients. One plant of this order, Victoria regális, the largest and most beautiful of aquatic plants, produces blossoms 15 inches, and leaves 6 feet, in diameter. The seeds are eatable, and are called in South America, Water Maize. 
1. Nrmpнaа (Water Lily).-Sepals 4 ; petals inserted on a fleshy disk. (Name from its growing in places which the nymphs were supposed to haunt.)

2. Nuphar (Yellow Water Lily).-Sepals 5 ; petals inserted on the receptacle. (Name of Greek origin.)

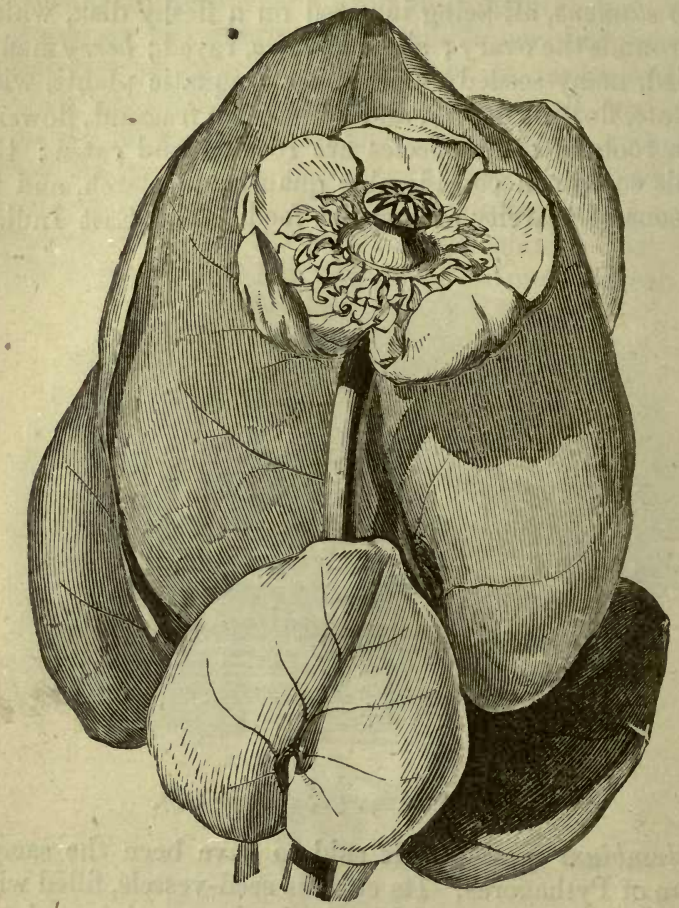

NUPHAR LUTEA (Common Yellow Water Lily).

1. Nyмpнда (Water Lily).

1. N. alba (White Water Lily).-The only British species, and, perhaps, the most magnificent of our native flowers, inhabiting clear pools and slow rivers. The 
flowers rise above the water under the influence of light, and expand only during sunshine, in the middle of the day. Towards evening they close and sink beneath the surface.-Fl. July. Perennial.

\section{Nuphar (Yellow Water Lily).}

1. N. lútea (Common Yellow Water Lily).-Stigma with $14-20$ rays, which do not extend to the margin. -Rivers and ditches, frequent. Much smaller than the last in all its parts. Flower yellow, and nearly globose, smelling like brandy, whence, in Norfolk, and other parts of England, it is called Brandy-bottle. The Turks prepare a cooling drink from the flowers, which they call Pufer (a corruption of the ancient name Nouphar). -Fl. July. Perennial.

2. N. púmila (Least Yellow Water Lily).-Stigma of 8-10 rays, which extend beyond the margin. Much smaller than the preceding, from which it differs principally in the toothed edge of the stigma. It grows in several of the small Highland lakes.-Fl. July, August. Perennial.

Ord. IV.-PAPAVERACEA.-The Poppy Tribe.

Sepals 2, soon falling off ; petals 4 ; ovary 1 ; stigma rayed, or lobed ; capsule 1-celled, many-seeded ; seeds

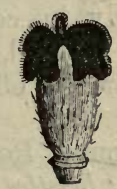

Ovary of the Poppy.

inserted on incomplete partitions, which radiate from the sides of the capsule, but do not meet at the centre.Herbaceous plants, abounding in a milky juice, which is narcotic, and, under the names of Opium, Laudanum, 
and Morphia, ranks among the most valuable of medicines. That produced by Papáver somniferum is alone used. The seeds of all contain a considerable quantity of oil, which is mild and wholesome.

1. Papáver (Poppy).-Stigma sessile, rayed; capsule opening by pores beneath the stigma. ("Named, because it is administered with pap (papa in Celtic) to induce sleep."-Sir W. J. Hooker.)

2. Meconopsis (Welsh Poppy).- -Style short; stigma of few rays ; capsule opening by pores beneath the top. (Name in Greek signifying, bearing resemblance to a Poppy.)

3. Glaucium (Horn Poppy).-Stigma 2-lobed; capsule pod-like, 2-celled, 2-valved. (Name from the glaucous hue of the foliage.)

4. Chelidónium (Celandine).-Stigma 2-lobed; capsule pod-like, 1-celled, 2-valved; seeds crested. (Named from chelidon, a swallow, because, as Pliny tells us, that bird discovered that its juice was efficacious in restoring sight to its young when blinded.)

\section{Papáver (Poppy). \\ * Capsules bristly.}

1. P. Argemóne (Long Rough-headed Poppy).-Capsule club-shaped; bristles erect; leaves twice pinnatifid. -A small species, with light scarlet petals, black at the base, occurring sparingly in corn-fields. (The name Argemóne, from argos, slothful, was formerly given to Poppies, from their narcotic effects.)-Fl. June, July. Annual.

2. P. hýbridum (Round Rough-headed Poppy).Capsule nearly globular; bristles spreading; leaves twice pinnatifid.-In corn-fields, lout not common. Flowers deep scarlet.-Fl. June, July. Annual.

$$
\text { ** Capsules smooth. }
$$

3. P. dubium (Long Smooth-headed Poppy).-Capsule oblong; bristles on the flower-stalks close pressed; 
leaves twice pinnatifid.-In cultivated fields. Flowers scarlet.-Fl. June, July. Annual.

4. P. Rhoeas (Common Red Poppy).-Capsules nearly globular; bristles spreading; leaves pinnatifid, cut.The common Poppy of corn-fields. Flowers scarlet, often black at the base.-Fl. June, July. Annual.

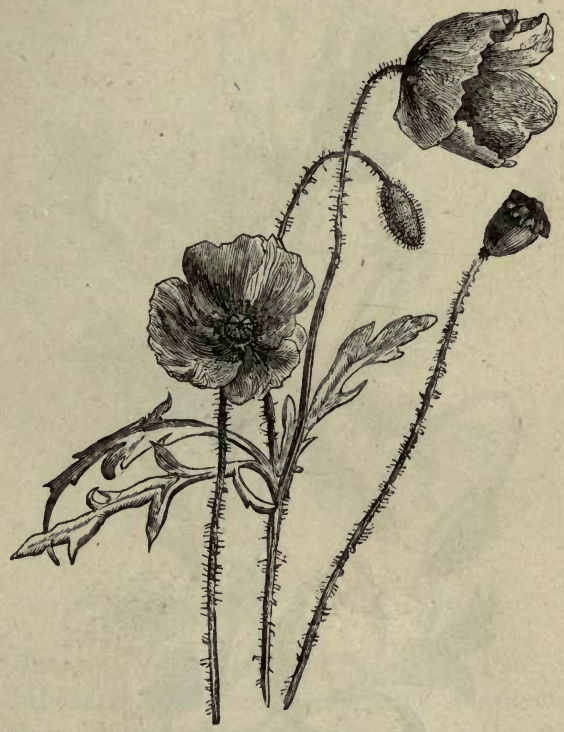

PAPAVER RHAas (Common Red Poppy).

5. P. somníferum (Opium Poppy).-Capsule nearly globular; whole plant smooth and glaucous.-Common in gardens, and sometimes found apparently wild in waste ground; but its native country is unknown. Opium is procured by puncturing the unripe capsules 
of this plant, and collecting the juice, which exudes and hardens. The seeds are destitute of narcotic properties, and afford a wholesome oil, which is said to be much used in adulterating olive oil. Flowers usually white, with a purple stain at the base of the petals; but the colours of garden varieties are endless.-Fl. July, August. Annual.

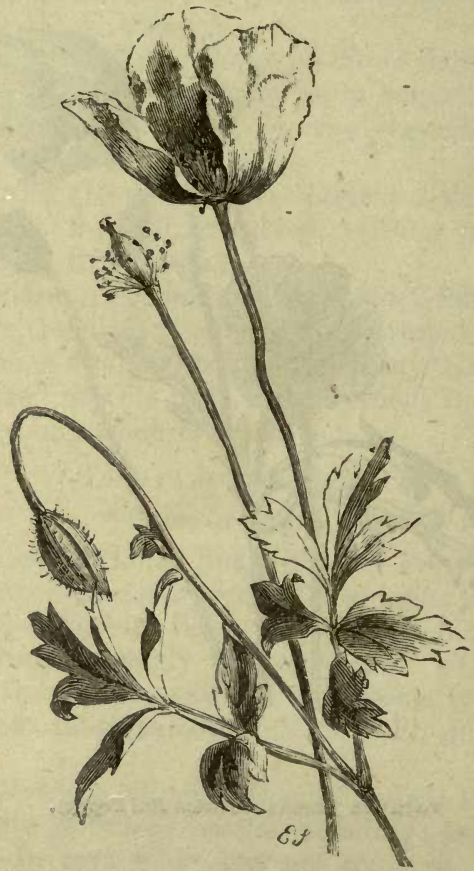

2. Meconopsis (Welsh Poppy).

1. M. Cámbrica (Yellow Welsh Poppy).-The only British species, easily distinguished from any of the fore- 
going by its golden yellow flowers, and juice of the same colour; and from the Horned Poppy, by its slender growth, and green, not glaucous foliage.-Rocky places in Wales, Devonshire, Westmoreland, \&c.-Fl. June, July. Perennial.

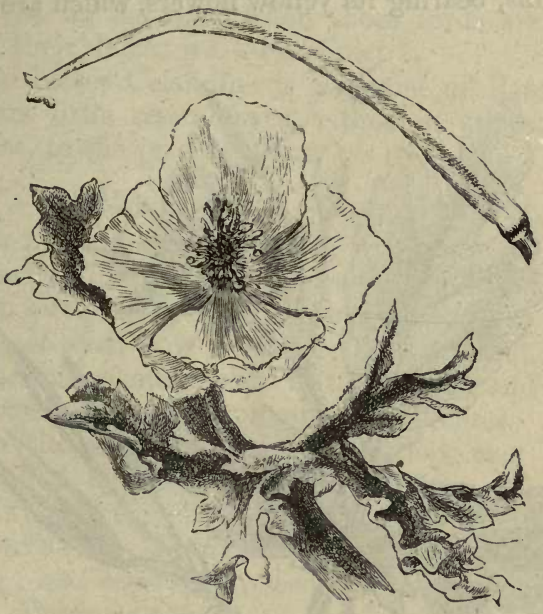

3. Glaucium (Horned Poppy).

1. G. lúteum (Yellow Horned Poppy)._Pod roughish; leaves embracing the stem, wavy, very rough and glaucous. A handsome plant, conspicuous on the sandy seashore with its hoary foliage, and-large yellow flowers. The pods are cylindrical, 6-10 inches long, and might at first sight be mistaken for flower-stems bare of leaves; juice yellow.-Fl. June-August. Biennial.

* Two other species have been found in England, M. phoeníceum, and M. violáceum, called by Hooker and Arnott Roeméria hýbrida; but they are not considered to be indigenous. 


\section{Chelidónium (Celandine).}

1. C. majus (Common or Greater Celandine).-The only British species; not uncommon in waste places and among ruins, bearing its yellow flowers, which are much

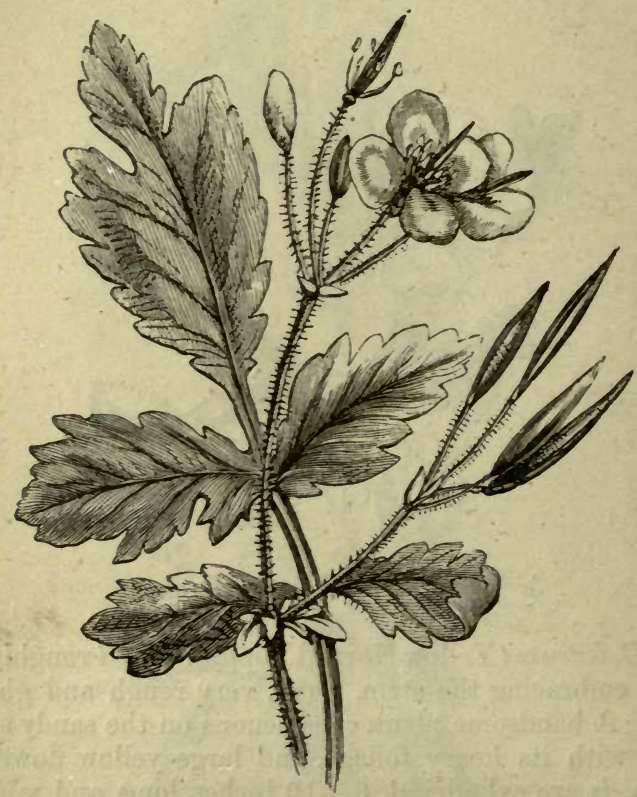

chrordúxium Majus (Common Celandine).

smaller than those of any others of the Poppy tribe, in stalked umbels; the leaves are irregularly pinnate, slightly hairy, and abound, as well as the rest of the plant, in an 
orange-coloured juice, which is a violent acrid poison. It is a popular remedy for warts, and has been employed successfully in removing films from the cornea of the eye ; a property which, Pliny tells us, was discovered by swallows ; and hence it derived its name from chelí don, a swallow. According to the same author, it comes into flower at the time when those birds arrive, and fades at their departure.-Perennial.

* The Lesser Celandine is a species of Ranunculus, and bears little resemblance, either in appearance or properties, to the present plant.

Ord. V.-FUMARIACEA-The Fumitory Tribe.

Sepals 2, deciduous; petals 4, irregular, and more or less united and swollen, or spurred at the base ; stamens 6 , in two sets ; ovary 1-celled ; style thread-like ; stigma lobed; seed-vessel 1-or 2-seeded; seeds shining, crested. -Herbaceous plants, with brittle stems, and watery juice, growing mostly in temperate climates. Closely allied to the Poppies, from which they may well be distinguished by their irregular corollas, and watery (not milky) juice.

1. Corýdalis.-Petals 4 , of which one is spurred at the base; seed-vessel many-seeded. (Name, the Greek name of Fumitory.)

2. Fumária (Fumitory).-Petals 4, of which one is swollen at the base; seed-vessel 1 -seeded. (Name from fumus, smoke; the smoke of this plant being said by the ancient exorcists to have the power of expelling evil spirits.)

\section{Corýdalis.}

1. C. claviculata (Climbing Corydalis).-Stem climbing ; leaves pinnate, ending in branched tendrils.Bushy places, in many parts of Great Britain. A long and slender plant, with delicate green stems and foliage, rising to the height of several feet, by the help of the bushes among which it grows. Flowers in small clusters, yellowish white.-Fl. June-August. Annual. 
* Two other species are naturalized in Britain; $C$. solida, distinguished by its unbranched stem and purple

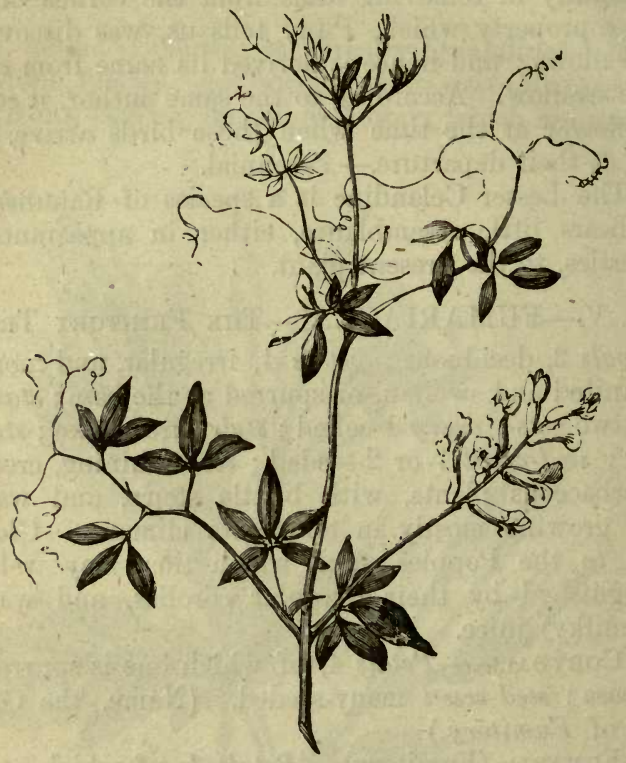

Corýdalis claviculata (Climbing Corydatis).

flowers, and $C$. lútea, not uncommon on old walls ; it is, like the last, destitute of tendrils, and bears bright yellow flowers.

\section{Fumária (Fumitory).}

1. F. capreoláta (Ramping Fumitory).-Sepals as broad as the corolla, and half as long; fruit globose, notched.-Hedges and corn-fields, common. Plant generally climbing by the help of its twisted leaf-stalks. Foliage of a delicate green; flowers pale pink, or cream-coloured, tipped with purple.-Fl. May-August. Annual. 
2. $F$. officinális (Common Fumitory).-Sepals narrower than the corolla; fruit nearly globose, terminating abruptly.-In fields and waste places, common. Distinguished from the last by its smaller sepals and petals,

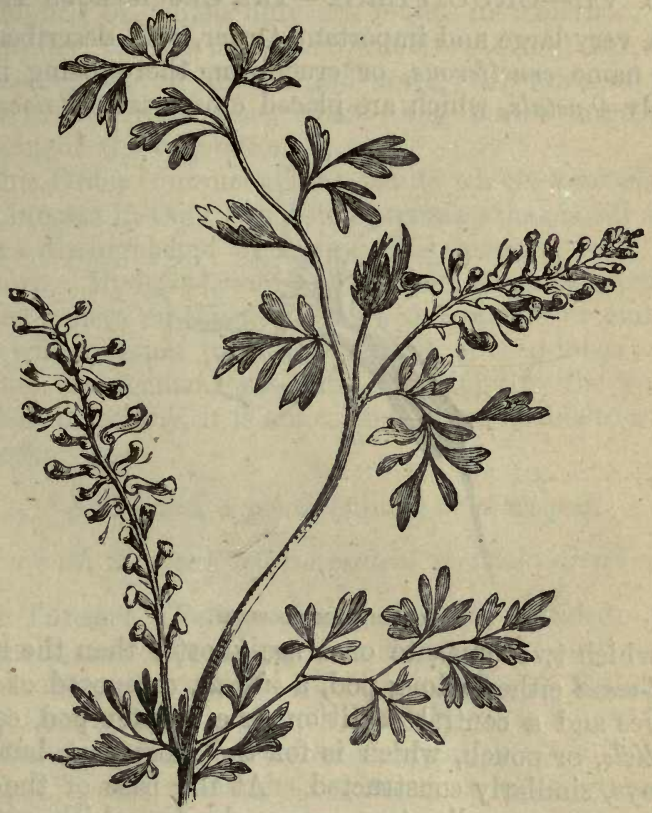

FUMÁRIA OFFICINÁLIS (Common Fumitory).

which are rose-coloured, tipped with purple; it generally grows erect.-Fl. nearly all the year round. Annual.

* Several smaller varieties of Fumitory are not unfrequently met with, which some botanists consider distinct species, and name as such. In these the fruit is more or less pointed; and there are other minute differences which cannot be detected without accurate 
examination. They are described by Hooker and Arnott, under the names of $F$. parviflora, Vaillantii and micrantha.

Ord. VI.-CRUCÍFER Æ.-The Cruciferous Tribe.

A very large and important Order, well described by the name cruciferous, or cruciform, there being invariably 4 petals, which are placed cross-wise ; stamens 6 ,

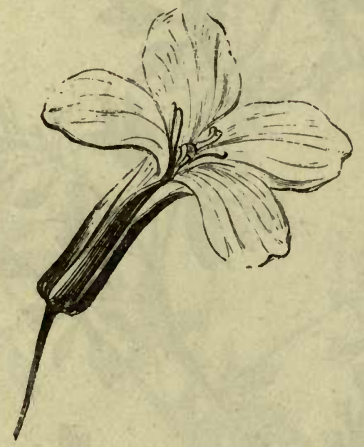

CRUCIFORM FLOWER.

of which two opposite ones are shorter than the rest; seed-vessel either a long pod, a silique, composed of two valves and a central partition, or a shorter pod, called a silicle, or pouch, which is for the most part, but not always, similarly constructed. At the base of the stamens are generally two green glands, which secrete honey. Most of the plants in this Order possess, in their wild state, stimulant properties and an acrid flavour; in medicine they afford a valuable remedy for the scurvy. Under cultivation, many of them assume a succulent habit of growth, and hold the first rank among esculent vegetables. The various kinds of cabbage, kale, brocoli, turnip, radish, and cress are the most remarkable examples. They contain a great deal of nitrogen gas, to the presence of which is to be 
attributed their unpleasant odour when rotting. Some contain a large portion of sulphur. Oil is contained in the seeds of many, in such quantities as to be a valuable article of commerce. There are about 800 species, one-eighth of which only are found in America; the remainder, for the most part, inhabit the cold and temperate regions of Europe and Asia. Upwards of 200 grow in the frigid zone, where they form a large proportion of the vegetation.

This Order contains all the plants which were placed by Linnæus in the Class Tetradynamia ; that is, all such as are distinguished by having 6 stamens, 4 long and 2 short. Modern botanists found the main distinctions of the genera on the position of the radicle or embryo root with relation to the cotyledons, or seed-lobes; but as this arrangement presents difficulties to the young student in botany, it is not considered advisable to adopt it here.

* Seed-vessel, a pouch (silicle) or short pod.

+ Pouch 2-valved, with a central vertical partition.

1. Thlaspi (Penny Cress).--Pouch rounded, flat, notched ; valves boat-shaped, winged at the back ; seeds numerous. (Name from the Greek, thlao, to flatten.)

2. CaPsella (Shepherd's Purse).-Pouch inversely heart-shaped, flat; valves boat-shaped, keeled, but not winged; seeds numerous. (Name, a little capsa, or seed-case.)

3. Hutchinsia.-Pouch elliptical, entire ; valves boatshaped, keeled, not winged; cells 2-seeded. (Named in honour of Miss Hutchins, of Bantry, Ireland, an eminent botanist.)

4. Teesdalia.-Pouch roundish, notched; valves boat-shaped, keeled; cells 2-seeded; stamens having a little scale at the base of each, within. (Named in honour of Mr. Teesdale, a Yorkshire botanist.)

5. Lepídium (Pepper-wort)._-Pouch roundish; valves 
keeled; cells 1-seeded; petals equal. (Name from the Greek lepis, a scale, from the shape of the pouches.)

6. Cochlearia (Scurvy Grass).-Pouch globose, or nearly so ; valves not flattened, 1-nerved; seeds numerous. (Name from cochlear, a spoon, from the shape of the leaves.)

7. Armorácia (Horse Radish).-Pouch globose, or nearly so ; valves - not flattened, nerveless ; seeds numerous. (Name from Armorica, Brittany, where it is abundant.)

8. Subularia (Awl-wort). - Pouch oval; valves flattened, boat-shaped; seeds numerous. (Name from súbula, an awl, from the shape of the leaves.)

9. Draba (Whitlow Grass).-Pouch oval, or oblong ; valves slightly convex; seeds many, in two rows. (Name from the Greek drabé, acrid.)

++ Pouch without a central vertical partition.

10. CaKílte (Sea Rocket).-Pouch angular, with a horizontal joint; lower division containing a pendent seed, the upper an erect seed, and soon falling off. (Name of Arabic origin.)

11. Crambé (Sea Kale).-Pouch 2-jointed; upper cell containing one pendent seed, which is supported on a stalk springing from the base of the cell; lower joint seedless. (Name from the Greek crambé, cabbage.)

12. Senebitera (Wart Cress).- Pouch 2-lobed, rough, not bursting; cells 1-seeded. (Name in honour of $M$. Senebier, an eminent Genevese naturalist.)

$$
\begin{gathered}
\text { ** Seed-vessel, a silique or long pod. } \\
\text { † Pod opening by two valves. }
\end{gathered}
$$

13. Dentaria (Coral-root).--Pod narrow, pointed; valves flat, nerveless; seeds in a single row, on broad stalks. (Name dens, a tooth, from the teeth-like division of the root.)

14. Cardamíné (Bitter Cress).--Pod linear; valves flat, nerveless, separating with an elastic spring; seeds 
in a single row, on thread-like stalks. (Name from the Greek cardia, the heart, and damao, to fortify, from its supposed strengthening properties.)

15. Árabis (Rock Cress).-Pod linear; valves flat, obtuse, with one nerve or several veins; stigma nearly sessile; seeds in a single row. (Name from being originally an Arabian genus.)

16. Turrítis (Tower Mustard).-Pod linear, 2-edged; valves prominently nerved; seeds in two rows. (Name from turris, a tower, either from its towering form, or its usual place of growth.)

17. Barbaréa (Winter Cress).-Pod linear, 4-angled; valves with prominent nerve; seeds in a single row; calyx erect. (Name from St. Barbara, to whom it was anciently dedicated.)

18. Nasturtium (Cress).- Pod nearly cylindrical, short; valves convex, nerveless; seeds irregularly placed in two rows ; calyx spreading. (Name from nasus tortus, a distorted nose, on account of the pungent properties of the plant.)

19. Sisymbrium (Hedge Mustard).-Pod rounded, or angular; valves convex, with three (or rarely one) nerves ; stigma entire ; seeds in a single row, not striated; seed stalks slender. (Name, the Greek name of the plant.)

20. Allíiria (Garlic Mustard).-Pod long, linear, rounded; valves slightly 3 -nerved; seeds striated; seedstalks flat. (Name from the Latin allium, garlic.)

21. Erýsimum ('Treacle Mustard).—Pod 4-sided; valves keeled; stigma obtuse, entire, or notched; seeds in a single row, smooth, not margined. (Name from the Greek eruo, to eure, on account of the supposed virtues of the plant.)

22. Cheíranthus (Wall Flower).-Pod flattened; valves with a prominent nerve ; stigma of two spreading lobes; calyx erect, two opposite sepals bulging at the base. (Name of Arabic origin.)

23. Matтhíola (Stock).-Pod cylindrical, or flattened; stigma of two converging lobes; seeds generally with a membranous border. (Named in honour of Dr. Matthiolus, an Italian botanist.) 
24. Brássica (Cabbage).-Pod nearly cylindrical, beaked; valves 1-nerved; seeds globose, in a single row; calyx erect. (Named from the Celtic Bresic, a cabbage.)

25. Sinápis (Mustard). - Pod nearly cylindrical, tapering, beaked; valves with 3 or 5 (rarely one) nerves; seeds globose, in a single row; calyx spreading. (Name from the Greek sinápi, mustard.)

26. Diplotaxis (Rocket).- Pod flattened; valves 1 nerved; seeds oblong, in two rows; calyx spreading. (Name in Greek, denoting two-rowed.)

\section{t+ Pod without valves.}

27. Ráphanus (Radish)._Pod swollen, imperfectly jointed, tapering; seeds globular; calyx spreading. (Name in Greek, denoting early appearance or quick growth.)

\section{Thlaspi (Penny Cress).}

1. T. arvensé (Mithridate Mustard, or Penny Cress). -Pouch round, flat, with very broad wings, and a deep notch; seeds striated; leaves oblong, arrow-shaped at the base, toothed, smooth. - In cultivated or waste ground, but not common. Penny cress derives its name from the resemblance which its seed-vessels in size and shape bear to silver pennies; its longer name it received from having been "formerly used in the Mithridate confection, an elaborate hodge-podge, now laid aside." Sir J. E. Smith. The flowers are white, and very small in comparison with the pouches.-Fl. all the summer. Annual.

2. T. perfoliatum (Perfoliate Penny Cress).-Pouch inversely heart-shaped; style shorter than the notch of the pouch; seeds 3 to 4 in a cell, smooth; stem-leaves oblong, heart-shaped at the base.-Limestone pastures in Oxfordshire and Gloucestershire, but rare. Flowers white. Fl. April, May. Annual.

3. T. alpestré (Alpine Penny Cress).-Pouch inversely heart-shaped, abrupt; style longer than the 
notch of the pouch; seeds numerous ; stem-leaves arrowshaped at the base; stem simple.-Mountainous limestone pastures in the north of England; rare.-Fl. June, July. Perennial.

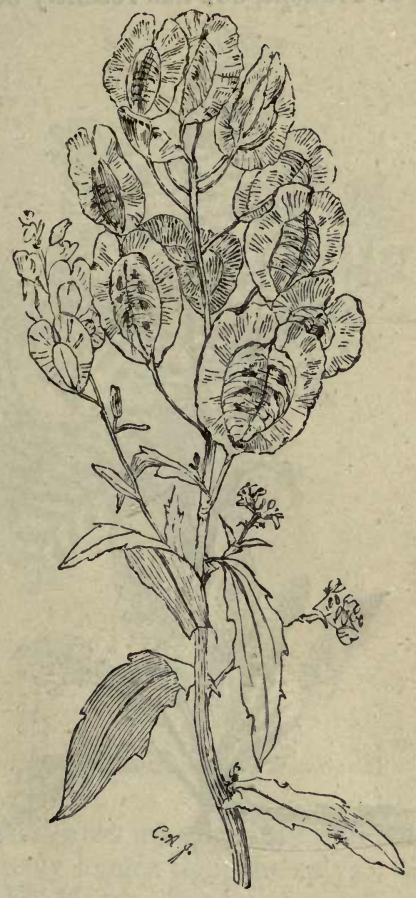

THLASPI ARVÉNsé (Penny Cress).

2. Capselua (Shepherd's Purse).

1. C. Bursa Pastóris (Common Shepherd's Purse).The only species. A common weed, to be found in 
almost every part of the world, varying considerably in luxuriance, according to soil and situation. In stony ground it grows only a few inches high, but in rich soil it attains two feet. It was known to the ancients by the name of Thlaspi, but has recently been separated

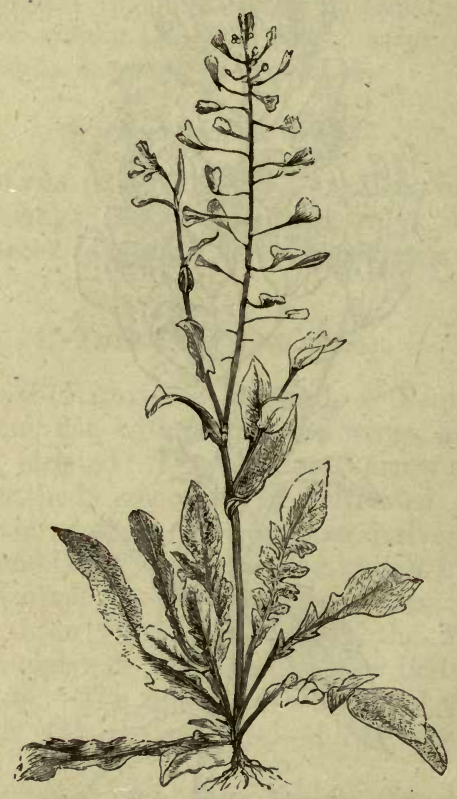

capsella bursa-pastóris (Common Shepherd's Purse).

from that genus, on account of its wanting the characteristic winged valves. The whole plant is more or less rough with hairs; the root leaves are pinnatifid, those on the stem oblong, toothed, and arrow-shaped at the base.-Fl. nearly the whole year round. Annual. 


\section{Hutchinsia.}

1. H. petroea (Rock Hutchinsia).-The only British species. A pretty little plant, from 2 to 4 inches high, growing on limestone rocks in several parts of England

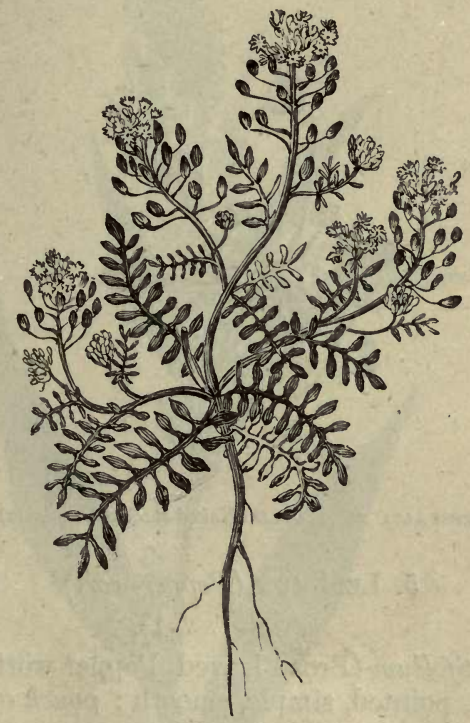

hUTOHINSIA PETRAa (Rock Hutchinsia).

and Wales. The leaves are elegantly pinnate; the petals white, and scarcely longer than the calyx; the seeds two in each cell.-Fl. March, April. Annual.

\section{Teesdália.}

1. T. nudicaulis (Naked-stalked Teesdalia).-The only British species. A minute and not an inelegant plant, bearing several stems, which terminate in small 
corymbs of white flowers, with unequal petals, the central stem being always bare of leaves. The leaves are pinnatifid, and grow in a horizontal direction, closely pressed to the ground.-Dry banks; not common.-Fl. May. Annual.

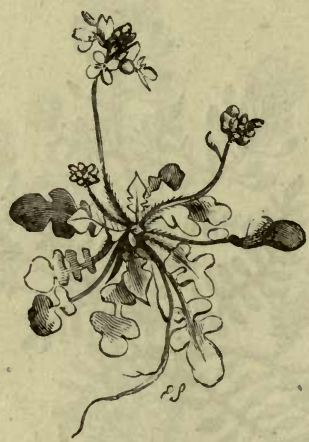

TEESDÁlta NUDTCAULIS (Naked-stalked Teesdalia).

\section{Lepídium (Pepper-wort).}

1. L. latifolium (Broad-leaved Pepper-wort).-Leaves egg-shaped, pointed, simple, smooth ; pouch oval, entire. - In salt marshes, and on the sea-coast; rare. The largest British species, remarkable for its dull glaucous hue. Flowers numerous, small, white, in leafy clusters. -Fl. July. Perennial.

2. L. ruderálé (Narrow-leaved Pepper-wort).-Leaves smooth, lower ones pinnatifid, toothed; upper ones linear, entire; petals wanting; stamens 2.-Waste places near the sea : smaller than the preceding.-Fl. June. Annual.

3. L. campéstré (Field Pepper-wort).-Leaves downy, upper ones arrow-shaped at the base; pouch rough with 
minute scales; style scarcely longer thon the notch.Fl. July, August. Annual.

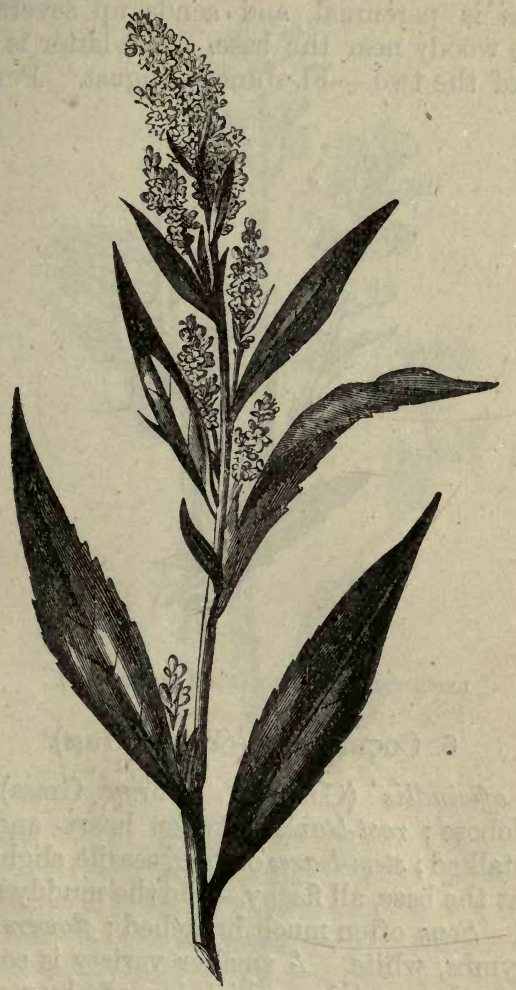

LePIDIOM LATIFoliom (Broad-leaved Pepper-wort).

4. L. Smithii (Hairy Pepper-wort).-Leaves downy, upper ones arrow-shaped at the base; pouch not scaly; style much longer than the notch.- These last two are common hedge-plants, of erect growth, and downy habit, 
made more conspicuous by their hoary foliage and numerous pouches, than by their minute white flowers. L. campestre is an annual, and sends up a single stem; L. Smithii is perennial, and sends up several stems, which are woody near the base. The latter is the less common of the two.-Fl. June-August. Perennial.

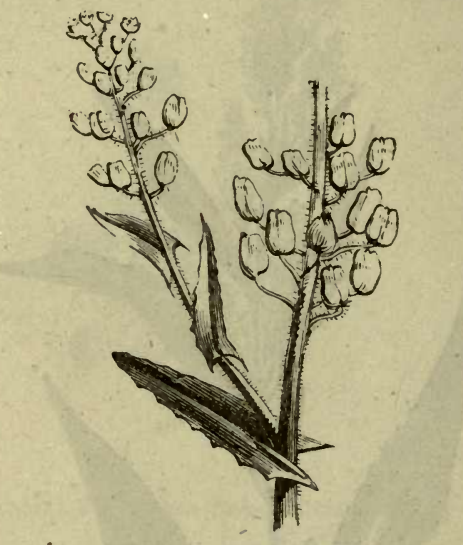

LePídium CAMPestee (Field Pepper-wort).

\section{Cochlearia (Scurvy Grass).}

1. C. officinális (Common Scurvy Grass).-Pouch nearly globose; root-leaves between heart- and kidneyshaped, stalked; stem-leaves oblong, sessile, slightly lobed, toothed at the base, all fleshy. - On the muddy sea-shore, common. Stem often much branched; flowers in rather large corymbs, white. A smaller variety is common on the Highland mountains, which is made by some botanists a distinct species under the name of $C$. Groenlandica (Greenland Scurvy Grass).-Fl. May. Annual.

2. C. Ánglica (English Scurvy Grass).-Pouch elliptical, veined; root-leaves oblong, entire, stalked ; stemleaves oblong, toothed at the base, sessile.-Sea-shores; 
common. Slenderer than the last, with leaves more entire, and larger pouches.-Fl. May-Aug. Annual.

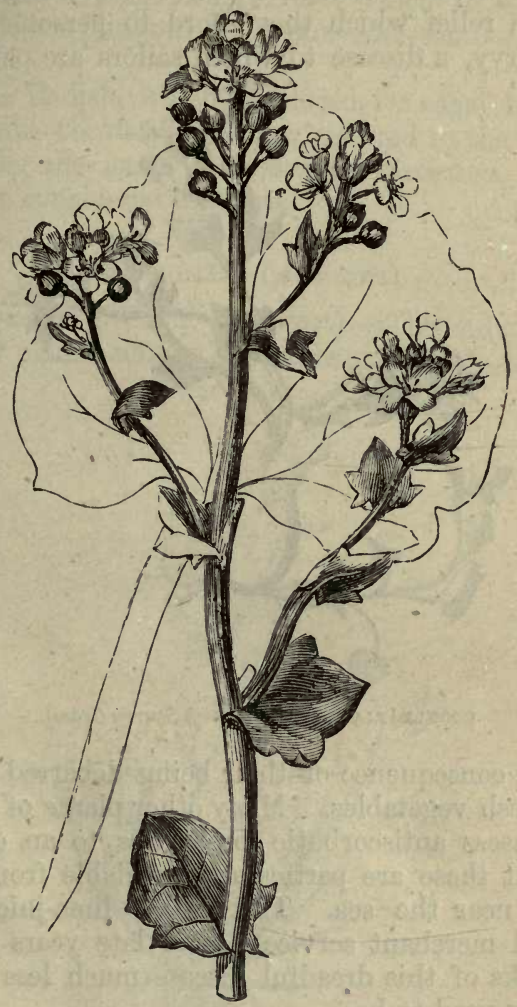

COChlearia OFficinális (Common Scurvy Grass).

3. C. Dánica (Danish Scurvy Grass).-Pouch ovate, veined; leaves all stalked, lobed and nearly triangular. -Cliffs and hedges near the sea, very common, much 
smaller than either of the preceding. Fl. March-June. Annual.

* The plants of this genus derive their English name from the relief which they afford to persons suffering from scurvy, a disease to which sailors are particularly

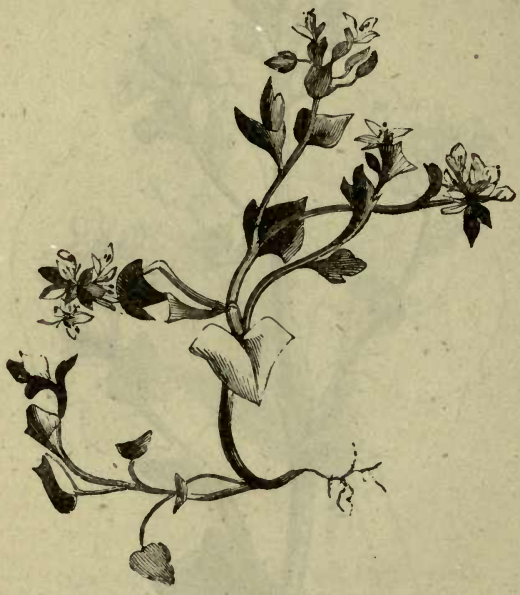

COCHLEÁRIA DÁNICA (Danish Scurvy Grass).

liable, in consequence of their being debarred from the use of fresh vegetables. Many other plants of the same tribe possess antiscorbutic properties to an equal degree; but these are particularly available from always growing near the sea. The use of lime-juice in the navy and merchant service has of late years rendered the attacks of this dreadful disease much less frequent than they used to be.

\section{Armorícia (Water Radish).}

1. A. amphíbia (Amphibious Yellow Cress, Great Water Radish).-Leaves pinnatifid or deeply serrated; roots 
stringy; petals yellow, longer than the calyx. - A large plant, growing on the banks of rivers, remarkable for the number of long stringy roots which it sends out from the lower joints of the stem.-Fl. June-August. Perennial.

* Horse Radish, which is placed by some botanists in the genus Cochleária, is now referred to the present genus under the name of Armorácia rusticana. It can scarcely be considered a native.

\section{Subulária (Awl-wort).}

1. S. aquática (Water Awl-wort).-The only species. -A small plant common on the banks of Alpine lakes.

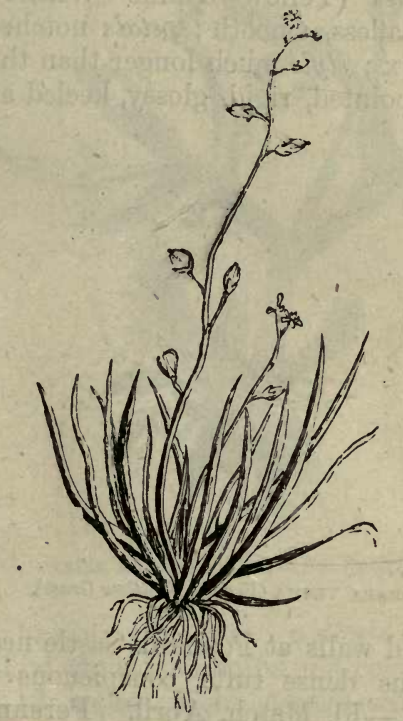

SUBULARIA AQUÁTICA (Water Aul-wort).

The roots are composed of long white fibres, the leaves 
all grow from the roots, and are awl-shaped. The flowers are small, and are sometimes perfected under water-Fl. July. Annual.

\section{Draba (Whitlow Grass).}

1. D. verna (Vernal Whitlow Grass).-Flower-stalk leafless; petals deeply cloven; leaves narrow-pointed, somewhat toothed, hairy.-A humble little plant with scanty foliage, and inconspicuous white flowers, but not without interest from its appearing very early in the year; common on walls and dry banks. A variety is found on Ben Lawers with inflated seed-vessels.-Fl. February-May. Annual.

2. D. aïzordes (Yellow Alpine Whitlow-grass). Flower-stalk leafless, smooth; petals notched, twice as long as the calyx ; style much longer than the stamens ; leaves narrow, pointed, rigid, glossy, keeled and fringed.

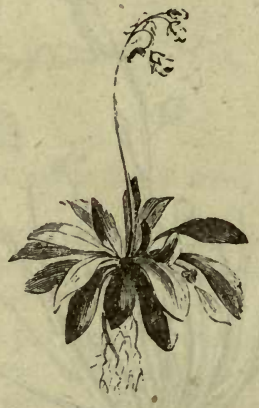

DRABA VERYA (Vernal W7:itlow Grass).

-On rocks and walls at Pennard Castle near Swansea, where it forms dense tufts, conspicuous with bright yellow flowers.-Fl. March, April. Perennial.

3. D. incána (Twisted Whitlow-grass).-Stem-leaves narrow, toothed, hoary; petals entire ; pouch twisted.- 
Mountainous rocks. Remarkable for the down on its leaves, which is forked in a star-like manner; Stems from 4 to 6 inches high, bearing white flowers.-Fl. June, July. Biennial.

4. D. murális (Speedwell-leaved Whitlow-grass).Stem leafy, branched; leaves rough, egg-shaped, blunt,

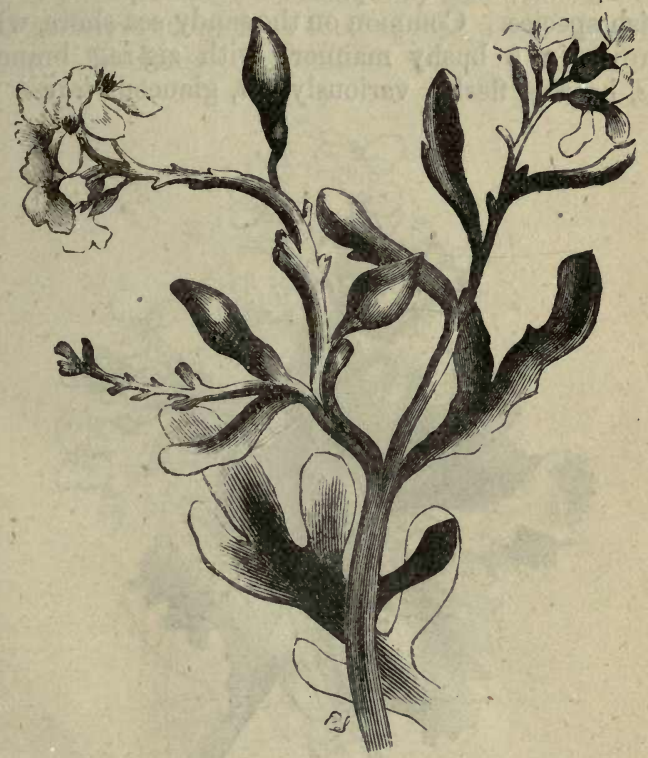

- Cakflé marítima (Purple Sea Rocke:).

toothed, embracing the stem; pedicels spreading horizontally.-Limestone mountains, not common ; growing from 6 to 12 inches high; flowers white.-Fl. May. Annual.

* Another species, D. rupéstris (Rock Whitlow-grass), grows on the summits of some of the Highland moun- 
tains, but is very rare. It is found in the crevices of the rocks, and among moss, scarcely reaching two inches in height, and forming tufts of soft fringed leaves with several flower-stems from the same root.

\section{Cakílé (Sea Rocket).}

1. C. marítíma (Purple Sea Rocket).-The only British species. Common on the sandy sea-shore, where it grows in a bushy manner, with zig-zag branched stems, bearing fleshy, variously cut, glaucous leaves, and

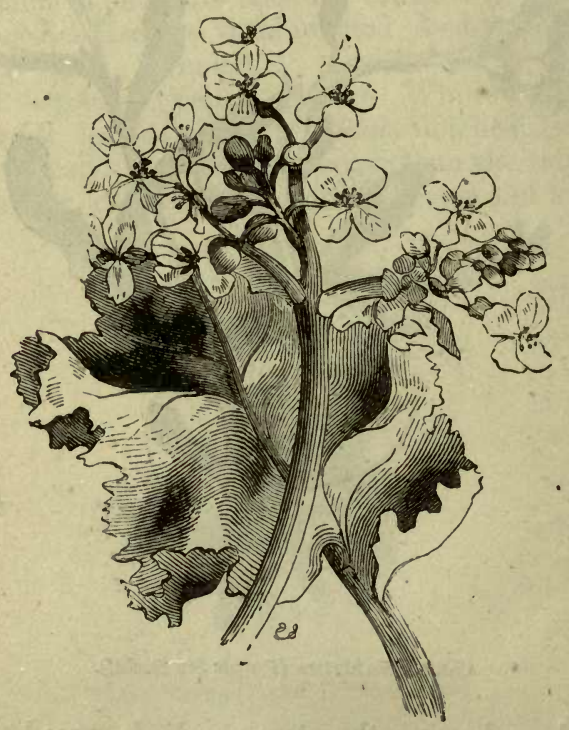

CRA mbé marftima (Sea Kale).

corymbs of lilac flowers. The seed-vessels are of very curious construction, each containing two seeds, of which the lower is erect, the upper pendent.-Fl. JuneSeptember. Annual. 


\section{Crambé (Sea Kale).}

1. C. maritima (Sea Kale).-This is the plant which is so well known in gardens as an esculent vegetable. The part which is eaten is the leaf-stalk blanched by being kept from the action of light.-It is found on various parts of the sea-coast, and differs in no respect from garden specimens as they appear when the forcing is over.-Fl. June. Perennial.

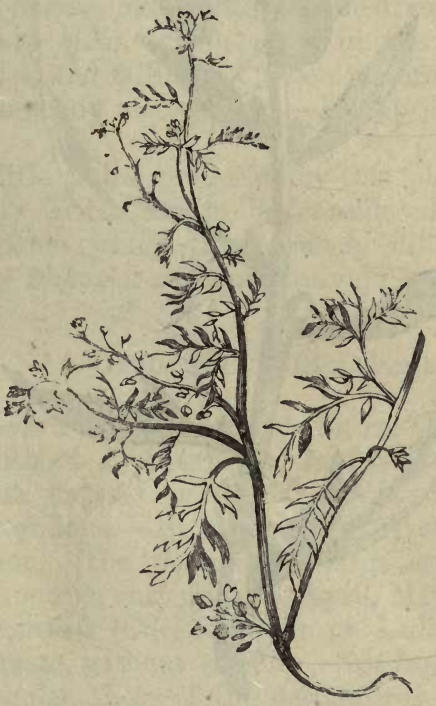

SENEBIÉRA CORONOPUS (Lesser Wart Cress),

\section{Senebiéra (Wart Cress).}

1. S. Corónopus (Water Cress, or Swine's Cress).Pouch undivided, rough with little sharp points; style prominent. - A common roadside weed, with trailingleafy 
stems, and clusters of very small whitish flowers.-Fl. all the summer. Annual.

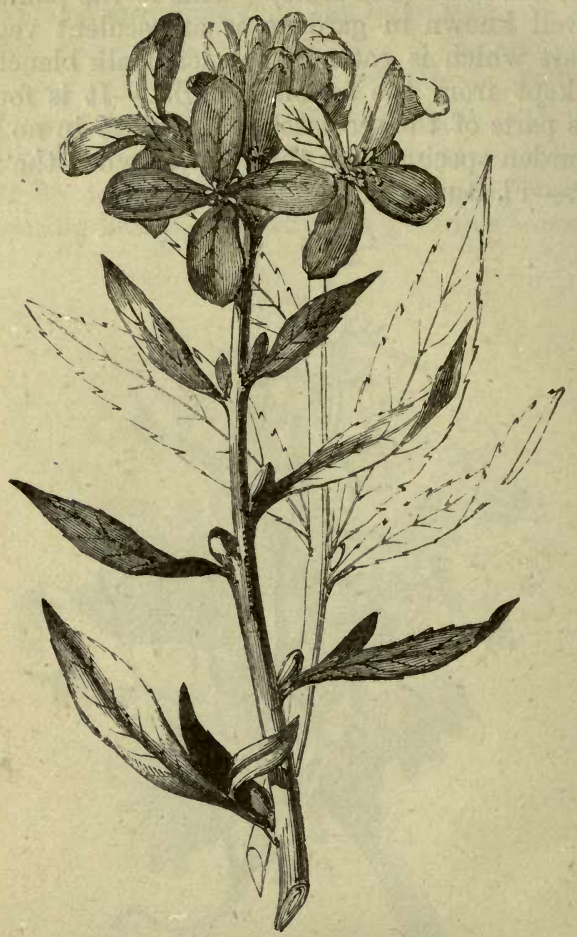

DENTÁRia BUlibfFera (Bulbiferous Coral-root).

2. S. didyma (Lesser Wart Cress).-Pouch notched of two wrinkled lobes; style very short.-A common roadside weed in the Suuth and West of England. It 
differs from the last in having a more slender stem, and more finely cut leaves. It emits a very powerful smell, like that of Pepper-cress, especially when trodden on, or in hot weather; and is particularly nauseous to the taste.-Fl. all the Summer. Annual.

\section{Dentákia (Coral-root).}

1. D. bulbífera (Bulbiferous Coral-root)-Well distinguished from any other British plant in the Order, by its purple flowers, its whitish toothed roots, and dark purple, scaly bulbs, which grow in the axils of the upper leaves, and falling off when mature produce new plants.-In shady places; rare.-Fl. April, May. Perennial.

* The little bulbs produced by this plant and some of the Lily Tribe, are to be considered as modified leaf-buds, from which they scarcely differ, except in being easily removed without receiving any injury.

\section{Cardamíné (Bitter Cress).}

1. C. amára (Large-flowered Bitter Cress).-Leaves pinnate, without stipules; root leaflets roundish, those of the stem toothed or angular; stem creeping at the base; style oblique.-By the banks of rivers and canals; not common. The flowers are large and handsome, white, with purple anthers.-Fl. April, May. Perennial.

2. C. pratensis (Cuckoo-flower or Ladies' smock).Leaves pinnate, without stipules; root leaflets roundish, slightly angular, those of the stem entire; style straight. A common and very pretty meadow plant with large lilac flowers. "They come with the Cuckoo," says Sir J. E. Smith, "whence one of their English as well as Latin names (Flos cuiculi); and they cover the meadows as with linen bleaching, which is supposed to be that of the other. They are associated with pleasant ideas of 


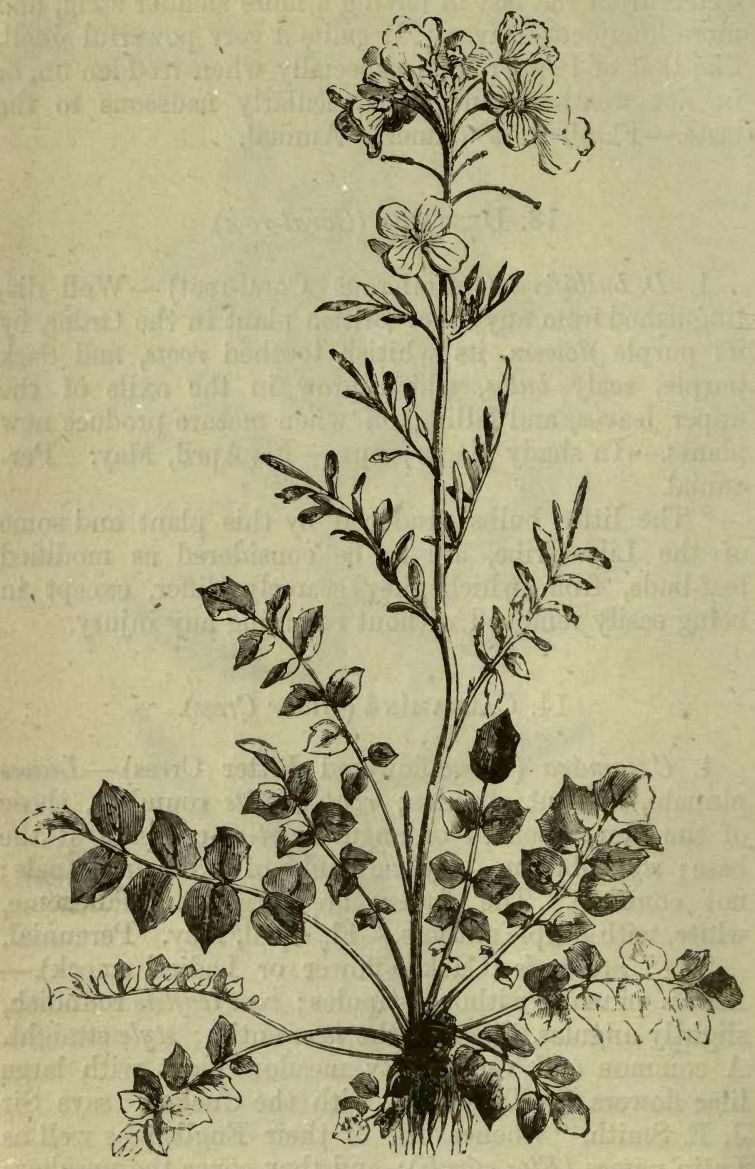

CARDAMíné PRATENSIS (Cuckoo-flower, or Ladies' Smock). 


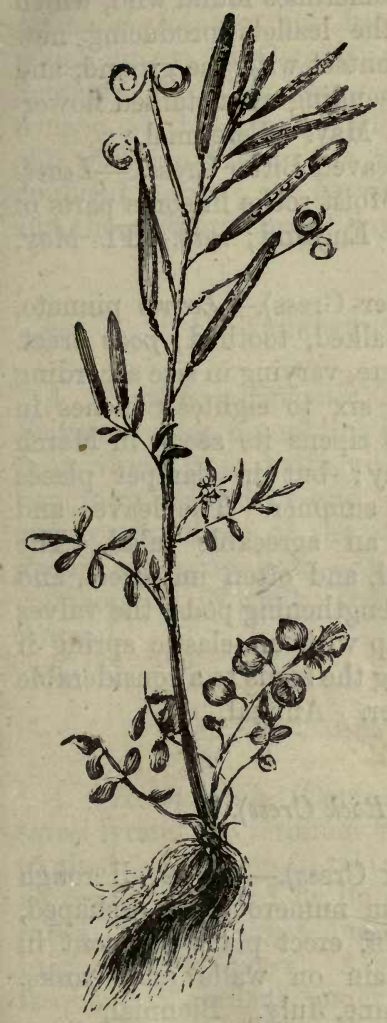

CARDAMINÉ HIRSÉTA (Hairy Bitter Cress).

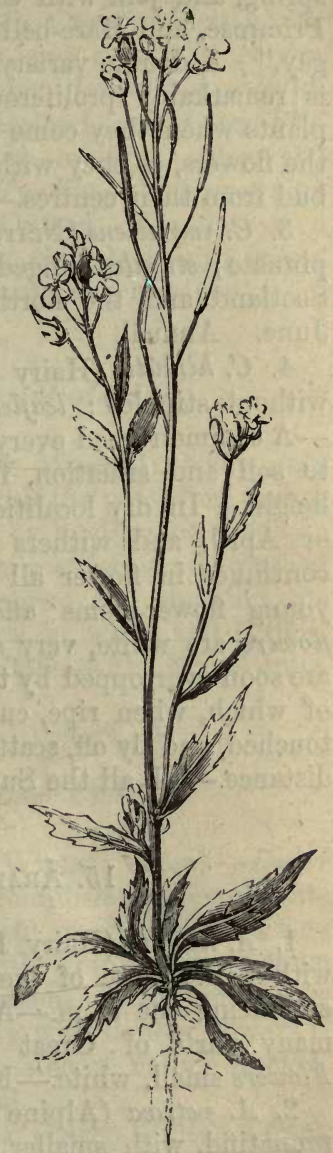

SISYMBRIUM THALIÁNUM, p. 64. (Thale Cress). 
spring, and join with the white Saxifrage, the Cowslip, Primrose, and Hare-bell to compose many a rustic nosegay." A double variety is sometimes found wild, which is remarkably proliferous, the leaflets producing new plants when they come in contact with the ground, and the flowers, as they wither, sending up a stalked flowerbud from their centres.-Fl. May. Perennial.

3. C. impatiens (Narrow-leaved Bitter Cress).-Leaves pinnate; stipules fringed.-Moist rocks in some parts of Scotland and the north of England; rare.-Fl. May, June. Annual.

4. C. hirsúta (Hairy Bitter Cress).-Leaves pinnate, without stipules; leaflets stalked, toothed; pods erect. -A common weed everywhere, varying in size according to soil and situation, from six to eighteen inches in height. In dry localities it ripens its seeds in March or April, and withers away; but in damper places continues in flower all the summer. The leaves and young flower-stems afford an agreeable salad. The flowers are white, very small, and often imperfect, and. are soon overtopped by the lengthening pods, the valves of which, when ripe, curl up with an elastic spring if touched, and fly off, scattering the seeds to a considerable distance.-Fl. all the Summer. Annual.

\section{5. Árabis (Rock Cress).}

1. A. hirsuita (Hairy Rock Cress).-Leaves all rough with hairs, those of the stem numerous, heart-shaped, embracing the stem.-A stiff, erect plant, frequent in many parts of Great Britain on walls and banks. Flowers small, white.-Fl. June, July. Biennial.

2. A. petraea (Alpine Rock Cress).-Leaves smooth, pinnatifid, with smaller lobes at the base ; those of the stem simple, sessile.-On rocks in Scotland and Wales. Flowers larger than the last, tinged with purple.-Fl. July, August. Perennial. 
* Three other species are found in various parts of Britain : A. stricta (Bristol Rock Cress), which grows on St. Vincent's Rocks, Clifton, and resembles Sisymbrium thaliánum, but has larger flowers; A. ciliata, which grows at Connemara, Ireland, and Glen Esk, Scotland, and has leaves smooth on both sides, and fringed at the edges; and A. Turríta, which grows on old walls in Cambridge and Oxford. The last is a doubtful native; its flowers are furnished with bracts, and the pods are curved downwards as they ripen.

\section{Turnítis (Tower Mustard).}

1. T. glabra (Smooth Tower Mustard).-The only British species, resembling in habit the preceding genus, from which it is distinguished by having the seeds in two rows instead of one. The root-leaves are toothed and rough, those of the stem entire and smooth; the flowers are pale yellow.-It grows on banks, and is most common in Norfolk and Suffolk.-Fl. May, June. Annual.

\section{Barbaréa (Winter Cress).}

1. B. vulgáris (Common Winter Cress).-Lower leaves lyrate, the terminal lobe roundish; upper obovate toothed.-Common in moist waste ground, where it may be readily detected by its smooth, shining, dark green leaves, and its erect angular stem bearing numerous bright yellow flowers. A variety with double flowers is frequent in gardens under the name of Yellow Rocket. -Fl. May-August. Perennial.

* Another species, B. proceox (Early Winter Cress), is not uncommon in the West of England, and is distinguished from the preceding by its slender habit and narrow leaves, and by being a Biennial. 


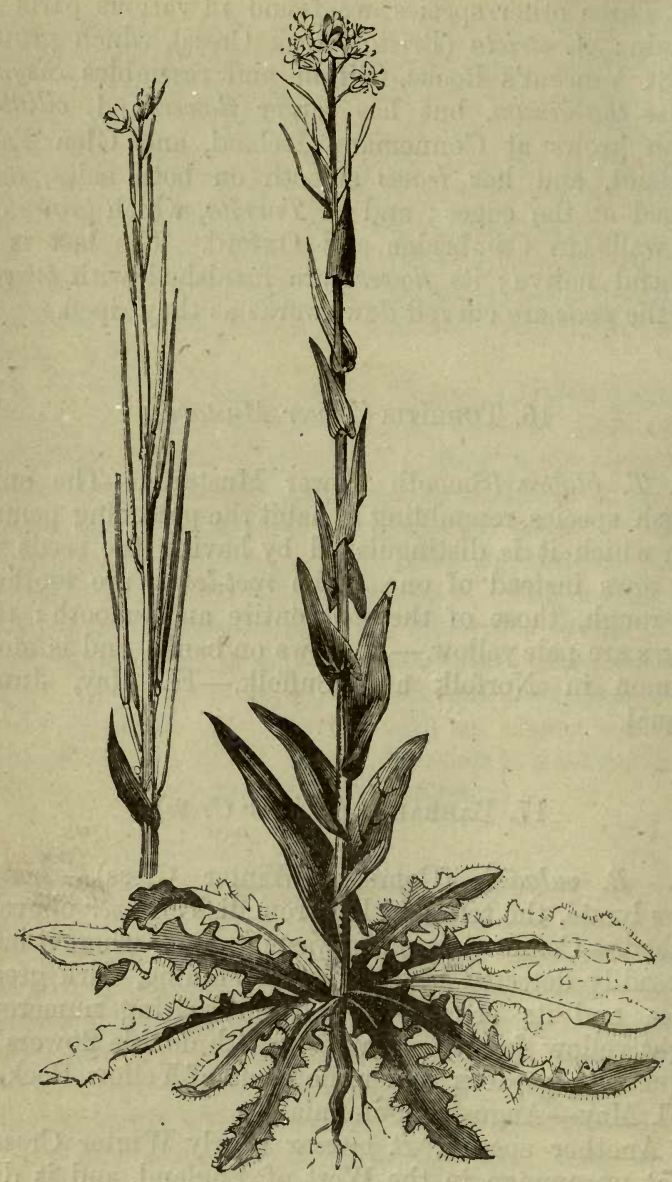

TUkRftis GLABRa (Smooth Tower Mustard). 


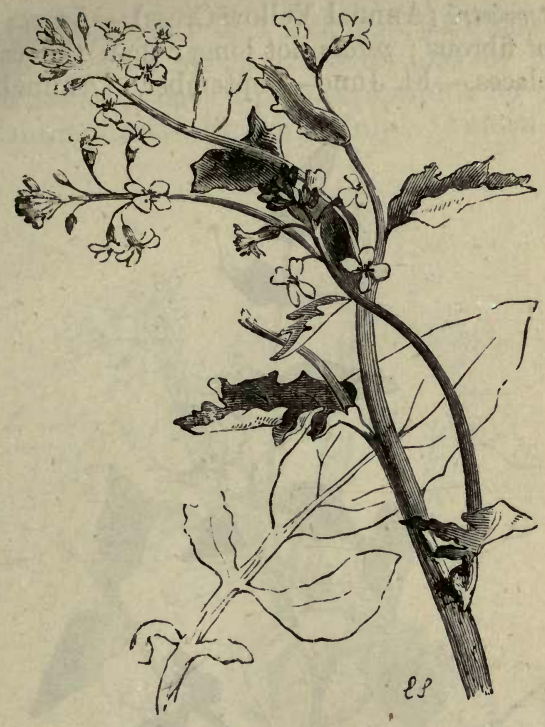

barbaréa vulgáris (Common Winter Cress).

18. NaSTURTium (Cress).

* Flowers white.

1. N. officinálé (Common Water Cress).-Leaves pinnate ; leaflets roundish or oblong, toothed.-Abundant in rivulets and ponds, and, near large towns, extensively cultivated as a salad. The only plant for which it can well be mistaken by water-cress gatherers has hollow leaf-stalks, and serrated leaflets, which this has not.Fl. June-August. Perennial.

$$
\text { * * Flowers yellow. }
$$

2. N. sylvéstré (Creeping Yellow Cress).-Leaves pinnate; root creeping.-Watery places; not common.Fl. June-September. Perennial. 
3. N. terréstré (Annual Yellow Cress).-Leaves pinnatifid; root fibrous; petals not longer than the calyx.Watery places._Fl. June-September. Annual.

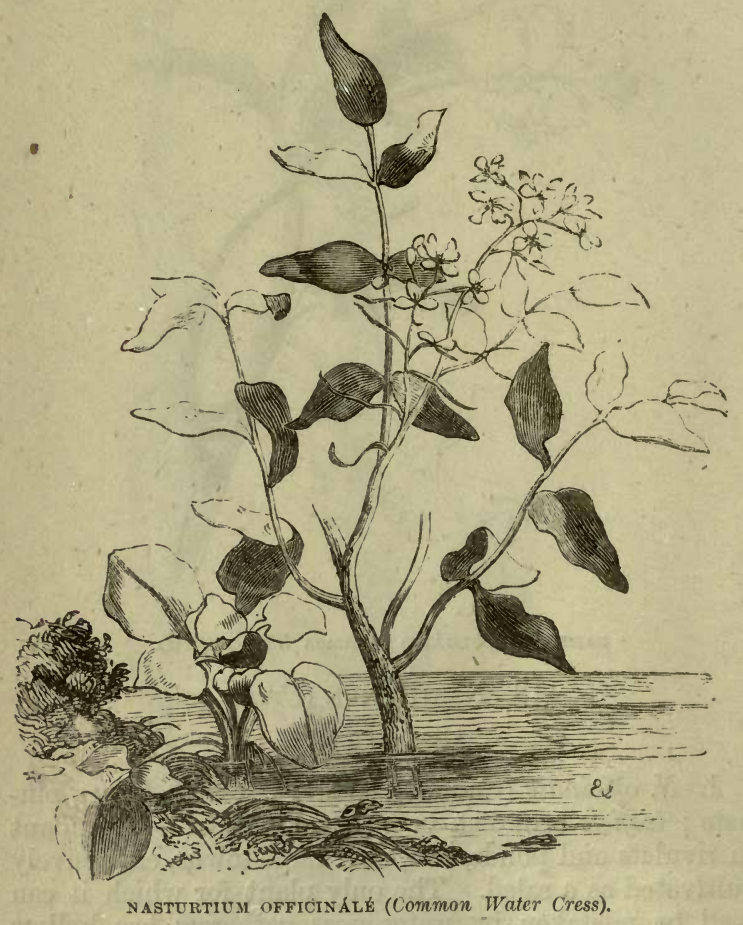

19. Sisýmbrium (Hedge Mustard).

1. S. officinálé (Common Hedge Mustard).-Pods downy, close pressed to the stem; leaves hairy, deeply lobed, with the points turned backward, the terminal lobe large; stem rough.-An unattractive plant, with 
erect branches, from 1 to 2 feet high, and small yellow flowers. It grows in waste places, and by roadsides, where it seems to have a peculiar aptitude for collecting and retaining dust.-Fl. June, July. Annual.

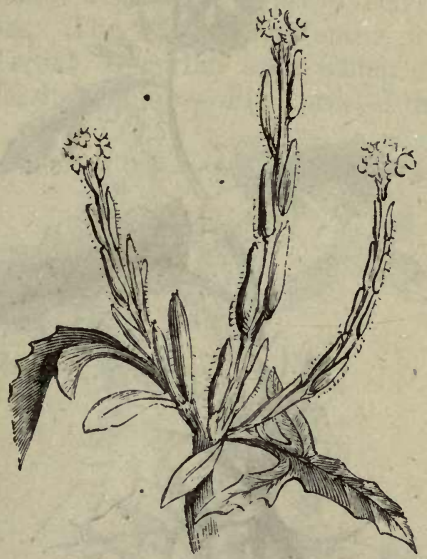

SISYMBriUM OFFICINALÉ (Common Hedge Mustard).

2. S. Írio (London Rocket).-Leaves deeply lobed, with the points turned backward, toothed, smooth as well as the stem; pods erect.-A leafy herb about 2 feet high, with small yellow flowers, growing in waste ground chiefly about London, where it covered the ground in the spring after the great fire--Fl. July, August. Annual.

3. S. Sophia (Flixweed).-Leaves twice pinnatifid, slightly hairy; petals shorter than the calyx.-More slender than either of the preceding, with small greenish yellow petals, which are almost hid by the calyx, and numerous erect pods, which when ripe have the appearance of being beaded, from the numerous projecting seeds. Not uncommon in waste places. It was called by the 
old herbalists Sóphia Chirurgórum, "the Wisdom of Surgeons," from its supposed virtue in curing wounds.

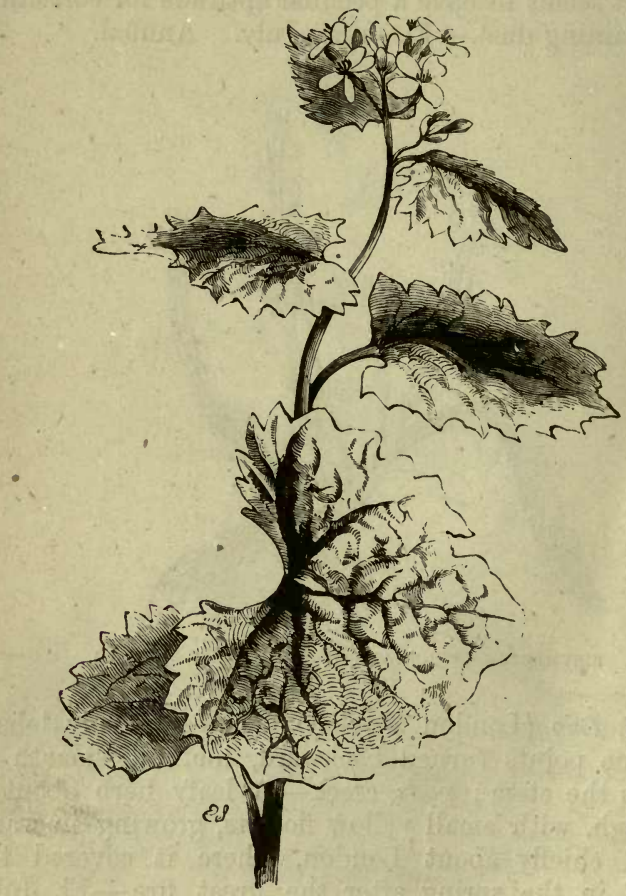

alliaria officinális (Gaiiic Mustard).

4. S. thaliánum (Thale Cress, or Wall Cress).-Leaves oblong, somewhat toothed, hairy; root-leaves slightly stalked; stem branched; pods angular, twice as long as their stalks.-Common on dry banks and walls. A slender plant, with few stem-leaves and minute white flowers, from 6 to 12 inches high.-Fl. May-JulyAnnual. 


\section{Alliária (Garlic-Mustard).}

1. A. officinális (Garlic-Mustard, Jack-by-the-Hedge, or Sauce-alone).-Leaves broadly heart-shaped, stalked, veiny, with numerous broad teeth.-An early flowering hedge-plant, with delicate green leaves and snowwhite flowers. The whole plant emits, when bruised, a nauseous scent of garlic, from which it derives its Latin and English names.-Fl. April-June. Ann.

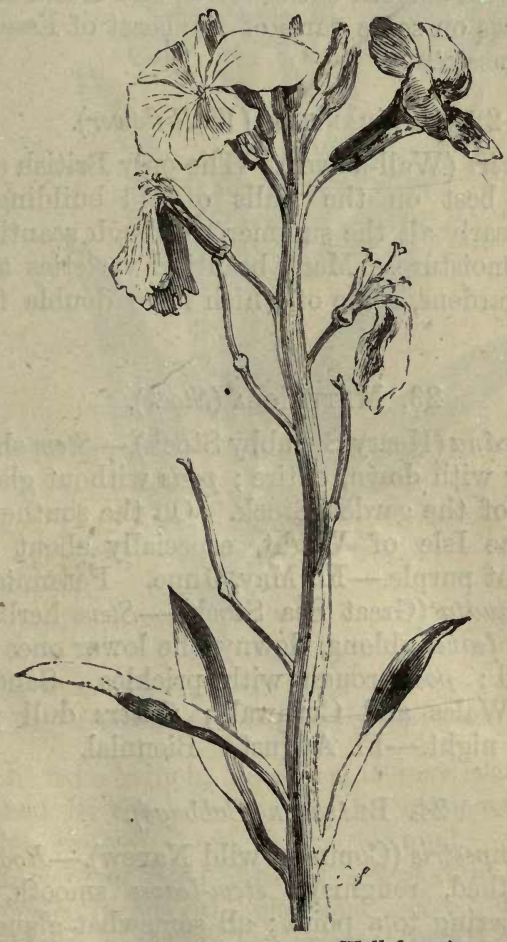

CheiranthUS Cheiri (Wall-flower). 


\section{Erýsimum (Treacle-Mustard).}

1. E. cheiranthoides (Worm-seed Treacle-Mustard).Leaves narrow, slightly toothed, roughish with threeforked bristles; pods erect on spreading stalks.-Fields, gardens, and waste places. A branched herb, 1 to 2 feet high, with dull green, sessile leaves, and small yellow flowers with whitish sepals. - Fl. July, August. Annual.

* Another species, E. orientálé (Hare's-ear 'TreacleMustard), with smooth entire leaves, and cream-coloured flowers, grows on some parts of the coast of Essex, Suffolk, and Sussex.

\section{Cheíranthus (Wall-flower).}

1. C. Cheiri (Wall-flower):-The only British species, flourishing best on the walls of old buildings, and flowering nearly all the summer, although scantily supplied with moisture. Many beautiful varieties are cultivated in gardens, some of which have double flowers. -Biennial.

\section{Matthíola (Stock).}

1. M. incána (Hoary Shrubby Stock). - Stem shrubby, leaves hoary with down, entire ; pods without glands.The origin of the garden Stock. On the southern seashore of the Isle of Wight, especially about Niton. Flowers light purple.-Fl. May, June. Perennial.

2. M. sinuáta (Great Sea Stock).-Stem herbaceous, spreading ; leaves oblong, downy, the lower ones imperfectly lobed; pods rough with prickles.-Sandy seacoasts of Wales and Cornwall; flowers dull purple, fragrant by night.-Fl. August. Biennial.

\section{Brássica (Cabbage).}

1. B. campestris (Common wild Navew).-Root-leaves lyrate, toothed, roughish; stem-leaves smooth, heartshaped, tapering to a point; all somewhat glaucous.Burders of fields; common. Often confounded with 


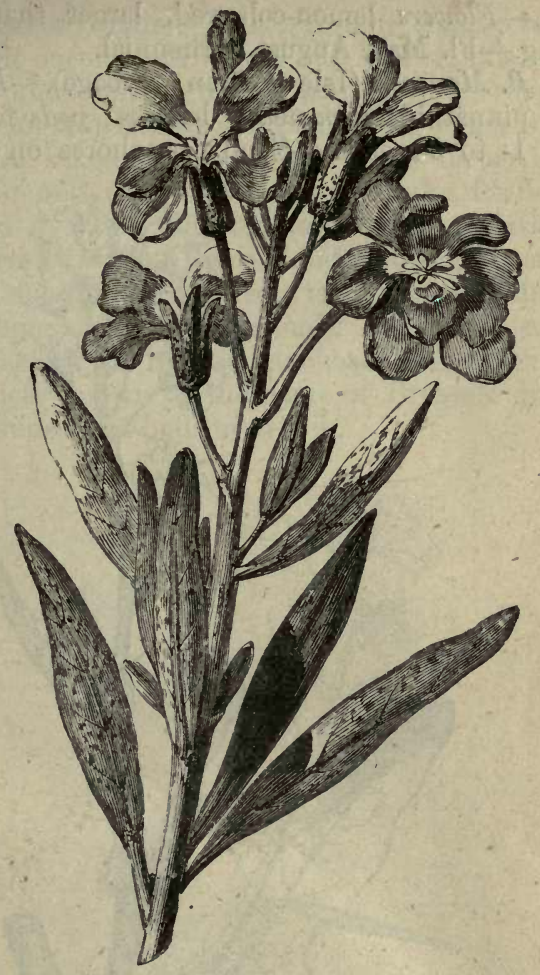

MATTHíla INCÁNA (Hoary Shrubby Stock).

Cherlock, from which, however, it may readily be distinguished by the smoothness and glaucous hue of its upper leaves.-Fl. June, July. Annual.

2. B. olerácea (Sea Cabbage).-_Root stem-like, fleshy ; leaves perfectly smooth, glaucous, waved, lobed; stem leaves oblong, obtuse.-The original of all the varieties of garden cabbage, growing on several parts of the sea- 
coast.-Flowers lemon-coloured, larger than the preceding.-Fl. May, August. Biennial.

3. B. Monensis (Isle of Man Cabbage). - Leaves glaucous, pinnatifid; stem nearly leafless; pods four-angled; beak 1- to 3-seeded.-Sandy sea-shores on the north-

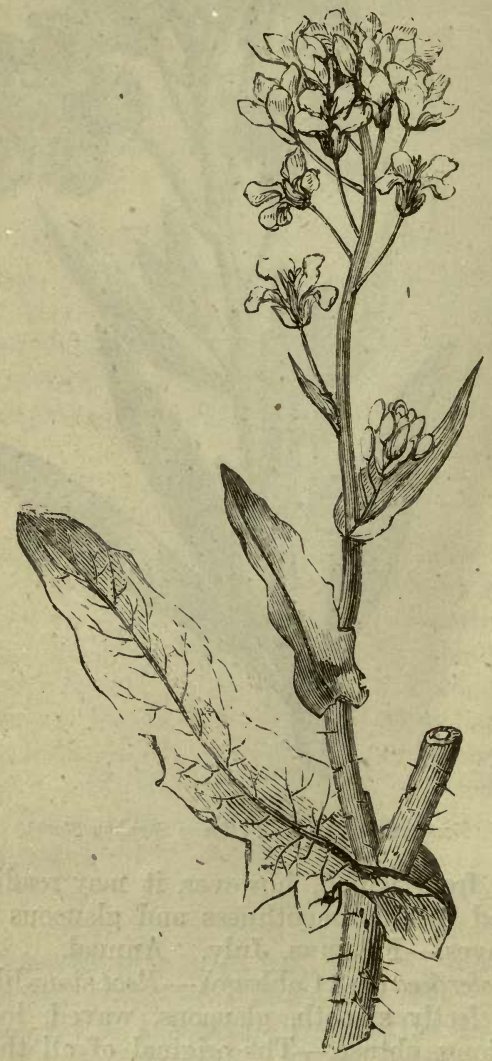

BRÁSSICA CAMPESTRIS (Common vild Navew). 
western coast of Britain. - Flowers bright lemon-coloured, veined with purple.-Fl. June, July. Perennial.

* Two other species of Brássica are described by botanists ; B. Nápus (Rape or Cole-seed), which is cultivated for the sake of the oil pressed from its seeds, the refuse being used, under the name of oil-cake, for feeding cattle; and $B$. Napa (the common Turnip); neither of which is really wild. Brocoli and Cauliflower are varieties of Cabbage, which have a tendency to produce an unusual abundance of flower-buds. They are cut for the table before the flowers have had time to expand. In the variety known by the name of Brussels sprouts, the unexpanded leaf-buds are eaten.

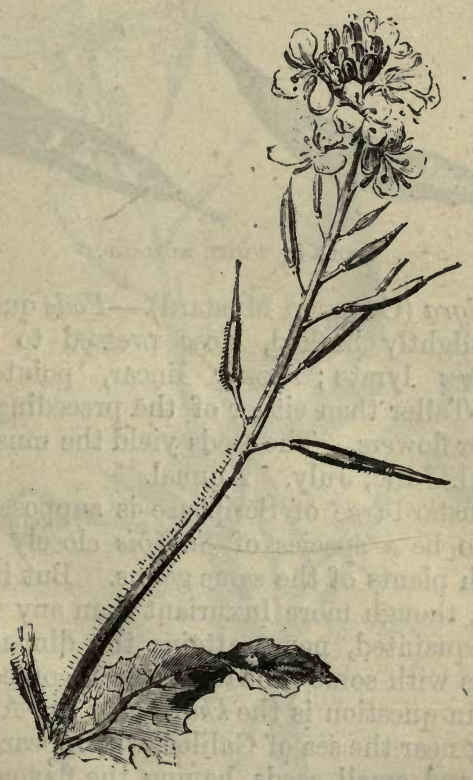

SINÁPIS ARVENSIS (Wild Mustard, Cherlock). 


\section{Sivípts (Mustard).}

1. S. arvensis (Wild Mustard, Cherlock).-Pods with many angles, rugged, longer than the awl-shaped beak; leaves toothed, rough.-A common weed in corn-fields, and sometimes springing up profusely from ground which has recently been disturbed, though unknown there before.-FL. all the summer. Annual.

2. S. alba (White Mustard)-Pods bristly, rugged, spreading, shorter than the flat two-edged beak; loaves pinnatifid.W Waste ground; flowers large, yellow. The young leaves of this species are used as salad-FL June. Annual.

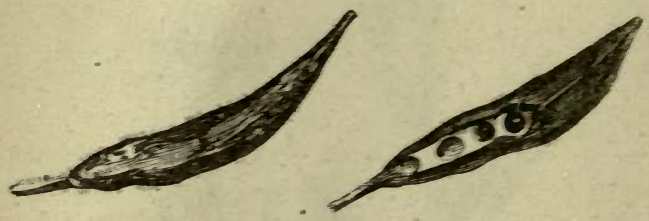

noDs of wHITE MUSTARD.

3. S. nigra (Common Xustard)-Pods quadrangular, smooth, slightly beaked, close pressed to the stalk; lower leaves lyrate; upper linear, pointed, entire, smooth.-Taller than either of the preceding, but bearing smaller flowers. The seeds yield the mustard of our tables.-Fl. June, July. Annual.

The Mustard-tree of Scripture is supposed, by some authors, to be a species of Sinápis closely resembling the British plants of the same genus. But inasmuch as this plant, though more luxuriant than any with which we are acquainted, never attains the dimensions of a tree, it has with some probability been conjectured that the plant in question is the Khandal of the Arabs, a tree abounding near the sea of Galilee, which bears numerous branches, and small seeds, having the flavour and properties of Mustand. 


\section{Diplotaxis (Rocket).}

1. D. tenuifólia (Wall Rocket).-Pods linear, slightly beaked, erect; stem erect, slender, smooth, leafy ; leaves very narrow, smooth, acute, deeply divided into narrow segments.-A slender, branched plant, from one to two feet high, with a tough stem, woody below, scattered foliage, and large light yellow flowers ; it grows on walls, quarries, and rubbish, principally in the neighbourhood of large towns. Fl. all the summer. Perennial.

* B. muralis (Sand Rocket), an annual, with a bristly stem, is very like the last, and grows in barren places near the sea, but is not cansidered indigenous.

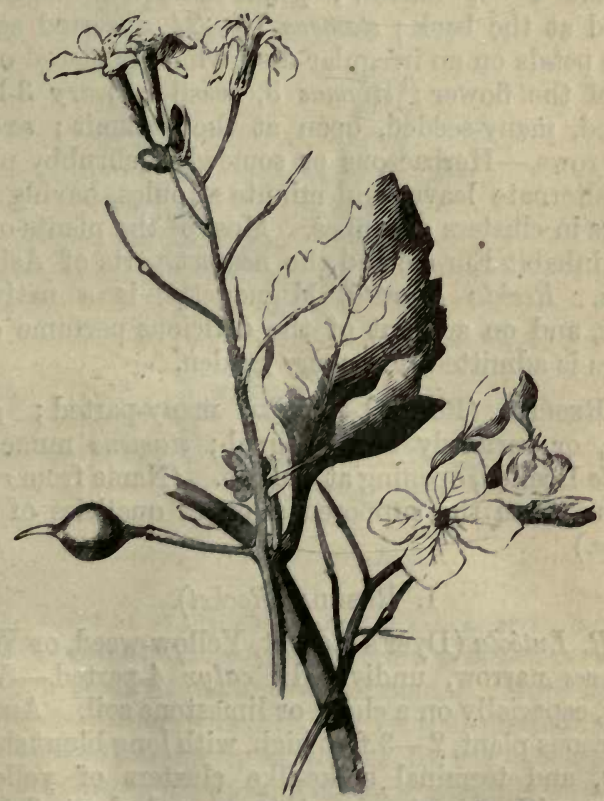

RÁPHANUS RAPUANistaUM (Wild Rodish). 


\section{Ráphanus (Radish).}

1. R. Raphanistrum (Wild Radish).-A bristly or almost prickly plant, with horizontal, lyrate leaves, and rather large straw-coloured flowers veined with purple; well distinguished when in seed by its jointed 1-celled pods. A variety named $R$ : marítimus, which grows on sea-cliffs, has its leaves composed of small and large leaflets arranged alternately, but is not otherwise distinct. In both varieties the flowers are sometimes almost white.

\section{ORD. VII.-RESEDACEA.-The Rocket Tribe.}

Sepals 4-6, narrow; petals unequal, ragged or fringed at the back; stamens $10-24$, inserted as well as the petals on an irregular disc, which is placed on one side of the flower; stigmas 3, sessile; ovary 3-lobed, 1-celled, many-seeded, open at the summit; seeds in three rows.-Herbaceous or somewhat shrubby plants, with alternate leaves and minute stipules, having their flowers in clusters or spikes. Most of the plants of this order inhabit Europe and the nearest parts of Asia and Africa. Reséda odoráta, Mignonette, is a native of Egypt, and on account of the delicious perfume of its flowers is admitted into every garden.

1. ResédA (Rocket).-Calyx many-parted; petals entire, or variously cut, unequal; stamens numerous; capsule 1-celled, opening at the top. (Name from resédo, to calm, from the supposed sedative qualities of some species.)

\section{Reś́da (Rocket).}

1. R. Lutéola (Dyer's Rocket, Yellow-weed, or Weld). - Leaves narrow, undivided; calyx 4-parted.-Waste places, especially on a chalk or limestone soil. An erect herbaceous plant, $2-3$ feet high, with long blunt shining leaves, and terminal spike-like clusters of yellowish flowers, with conspicuous stamens, and short, flattened 
capsules. It is used to dye wool yellow, or, with indigo, green; the whole plant, when in flower, being boiled for that purpose.-Fl. July. Biennial.

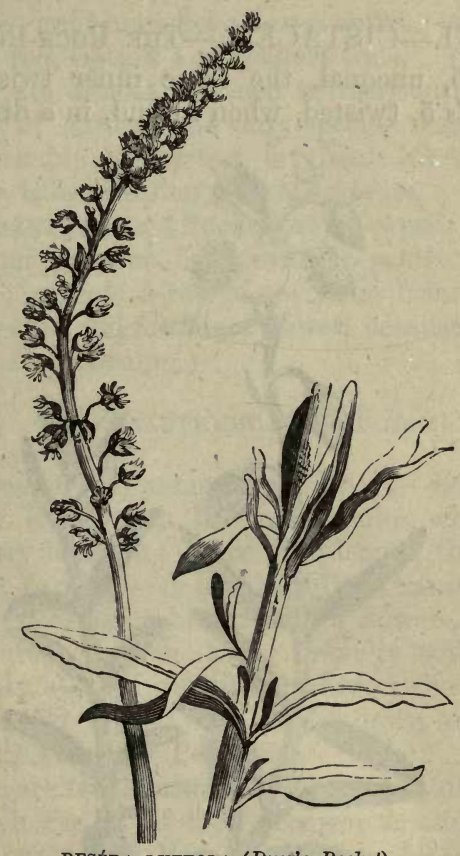

REséda LuTeola (Dyer's Rocket).

2. $R$. lútea (Wild Mignonette).-Leaves 3-cleft, lower ones pinnatifid ; calyx 6-parted ; petals 6 , very unequal.-On chalky hills and waste places. More bushy than the last, from which it may be well distinguished by the above characters, as well as by the shorter and broader clusters.-Fl. July, August. Biennial.

* Another species, R. fruticulosa (Shrubby Rocket), 
which is not uncommon in gardens, is occasionally found in waste places, but has little claim to be considered a native. It may be distinguished by the glaucous hue of its pinnate leaves, and by its 5 -cleft flowers.

\section{Ord. VIII.-CISTACEA.-The Rock-Rose Tribe.}

Sepals 5, unequal, the three inner twisted in the bud; petals 5, twisted, when in bud, in a direction con-

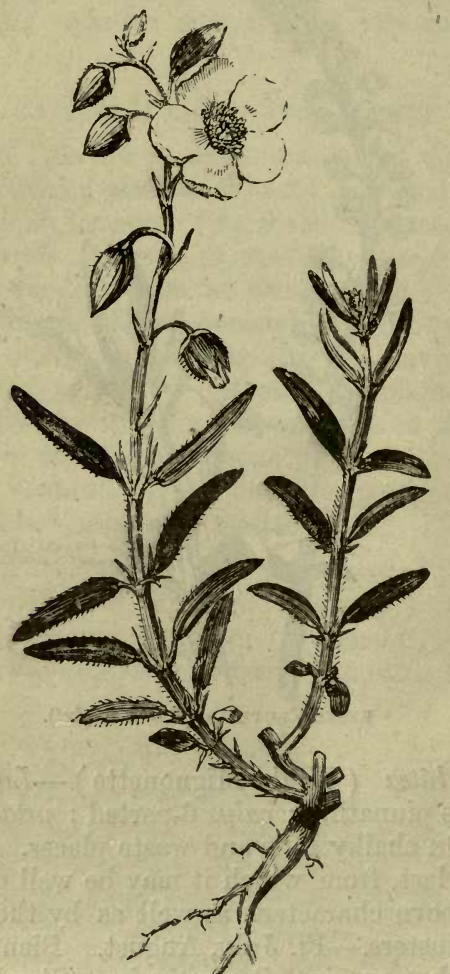

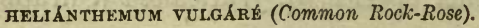


trary to the sepals, soon falling off ; stamens numerous ; ovary single, one- or many-celled; style and stigma simple ; capsule 3 - 5- or rarely 10 -valved; seeds numerous.-Mostly shrubby, but sometimes herbaceous, plants, often with viscid branches; leaves entire; flowers white, yellow, or red, lasting a very short time. The plants of this order are almost confined to the south of Europe and north of Africa; the only species which possesses any remarkable properties is Cistus Créticus, which affords the balsam called Gum Ladanum.

1. Helińnthemum (Rock-Rose).-Sepals 5, the two outer either smaller or wanting; petals 5; stamens numerous ; capsule 3-valved.-(Name from the Greek, helios, the sun, and anthos, a flower, because the flowers expand in the morning.)

\section{Heliánthemum (Rock-Rose).}

1. H. vulgáré (Common Rock-Rose).-Stem shrubby, prostrate; leaves with fringed stipules, oblong, green above, hoary beneath; salyx of 5 leaves, the two outer very small, fringed.-A beautiful little branching shrub, with clusters of large bright yellow flowers, frequent in hilly pastures on a chalky or gravelly soil, where its flowers only expand during sunshine; the stamens, if lightly touched, spread out, and lie down on the petals. -Fl. July, August. Perennial.

* There are three other British species of Heliánthemum, which are all of local occurrence, and rare:- $H$. canum (Hoary Rock-Rose) grows on Alpine rocks, in Wales and the north of England; the leaves are destitute of stipules, and very hoary beneath, the flowers are yellow. H. guttatum (Spotted Rock-Rose) is a herbaceous species and an annual ; the flowers are yellow, with a blood-red spot at the base of each petal. $H$. polifolium (White Rock-Rose), a small shrubby species with white flowers, grows on Brent Downs in Somersetshire, and on several parts of the sea-coast of Devonshire. 


\section{ORD. IX.-VIOLACE E.-The Violet Tribe.}

Sepals 5 ; petals 5 , sometimes unequal; stamens 5 ; anthers lengthened into a flat membrane; style with an oblique hooded stigma ; ovary 1-celled; seeds numerous, in three rows. $-\mathrm{A}$ beautiful and important tribe of herbaceous plants or shrubs, strongly marked by the above characters, inhabiting most regions of the world, except those parts of Asia which are within the tropies. Those which grow in temperate regions are mostly herbaceous ; but in South America, where they are abundant, most of the species are shrubs. The roots of some species are highly valuable in medicine, furnishing Ipecacuanha, well known for its sudorific and emetic properties. The British species also possess medicinal properties, though they are rarely used.

1. Víola (Violet). - Sepals 5, extended at the base; petals 5, unequal, the lower one lengthened into a hollow spur beneath; anthers united into a tube, two lower ones furnished with spurs, which are enclosed within the spur of the corolla; capsule with three valves. (Viola was the Latin name of some fragrant flower, which was called by the Greeks Ion.)

\section{Víola (Violet).}

* Leaves and Flowers all springing directly from the root.

1. V. hirta (Hairy Violet).-Leaves heart-shaped, rough, as well as their stalks, with hairs ; bracts below the middle of the flower-stalks ; sepals obtuse ; lateral petals with a hairy central line.-Common in chalk and limestone districts, or near the sea. Flowers various shades of blue, rarely white, scentless. Best distinguished from the sweet violet (to which it is nearly allied) by its very hairy leaves and capsules, by the position of the bracts, and by the absence of creeping scions.-Fl. April, May. Perennial.

2. V. odoráta (Sweet Violet).-Leaves heart-shaped, 
slightly downy, especially beneath; bracts above the middle of the flower-stalks; sepals obtuse; lateral petals with a hairy central line; scions creeping.-One of the most highly prized of all our wild flowers, unrivalled in fragrance, delicacy and variety of tinting, and doubly welcome from its appearing so early in spring. The flowers are deep purple, lilac, pale rose-coloured, or white,

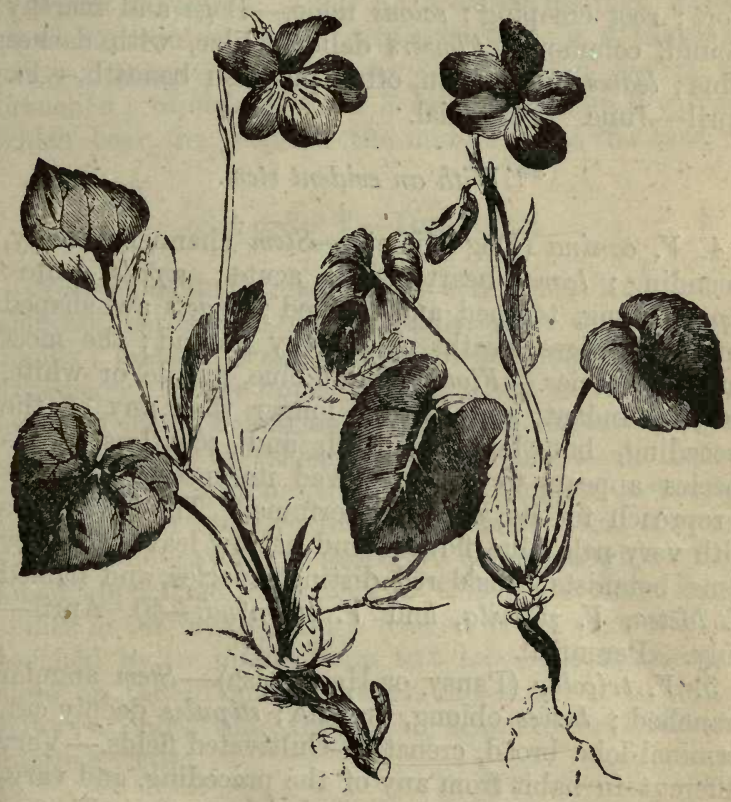

VfOLA CANINA, and v. ODORATA.

and all these tints may sometimes be discovered on the same bank. The roots possess the medicinal properties of Ipecacuanha, and the flowers are used as a laxative for children. An infusion of the petals is employed as 
a chemical test, being changed to red by acids, and by alkalies to green. The flowers are said to communicate their flavour to vinegar in which they have been steeped, and it is also said, that they are used in the preparation of the Grand Séignor's sherbets.-Fl. March, April. Perennial.

3. V. palustris (Marsh Violet).-Leaves heart- or kidney-shaped, quite smooth; sepals obtuse ; spur very short; root creeping; scions none.-Bogs and marshy ground, common. Flowers delicate lilac, with darker veins; leaves light green, often purplish beneath.-Fl. April-June. Perennial.

\section{** With an evident stem.}

4. V. canína (Dog Violet).-Stem channeled, leafy, ascending; leaves heart-shaped, acute; sepals acute ; stipules long, toothed and fringed; bracts awl-shaped entire.-Hedges, heaths, and rocky ground ; the most common species. - Flowers light blue, purple or white, more abundant, and lasting longer than any of the preceding, but less beautiful, and scentless. This species appears to have received its specific name as a reproach for its want of perfume. Three varieties with very pale blue flowers and narrow leaves, are by some botanists considered distinct species, and named $V$. láctea, $V$. púmila, and $V$. stagnéna.-Fl. AprilJuly. Perennial.

5. V. trícolor (Pansy or Heartsease).-Stem angular branched; leaves oblong, crenate; stipules deeply cut, terminal lobe broad, crenate.-Cultivated fields.-Very different in habit from any of the preceding, and varying considerably in the size and colour of its flowers, which are, however, most frequently light yellow, either pure, or tinged with purple. The cultivated varieties are countless.-Fl. all the summer. Generally annual.

6. V. lútea. (Yellow Mountain Violet, or Mountain Pansy).- Stem angular, branched principally at the 
base ; leaves oblong, crenate; stipules deeply cut, terminal lobe narrow, entire.-Mountain pastures.-Nearly allied to the preceding, and as variable in the size and colour of its flowers.-Fl. June, July. Perennial.

\section{ORD. X.-DROSERACEA-SUNDEW TribE.}

Sepals 5, equal; petals 5; stamens distinct, either equal in number to the petals, or 2,3 , or 4 times as many; ovary single; styles $3-5$, often 2-cleft or branched; capsule of 1 or 3 cells, and 3 or 5 valves, which bear the seeds at the middle or at the base.

\section{Sub-order I.-DRosÉREA.}

Styles elongated; leaves clothed with glandular hairs.Delicate, herbaceous, marsh plants, often covered with glands; leaves alternate, rolled in at the edges before expansion; flower-stalks curled when in bud. The leaves of plants belonging to this order are covered with irritable hairs, by which flies and other small insects are entangled and destroyed. The Sundews are acrid, and impart a red dye to the paper in which they are dried. The leaves of Dioncea are furnished with a twolobed appendage, each half of which has three sharp spines in the middle, and is fringed at the edge. When touched by an insect, these two lobes instantaneously close on the ill-fated intruder, and crush it to death. After a short time they open again in readiness for another victim.

1. Drósera (Sundew).-Sepals 5 ; petals 5 ; stamens 5 ; styles 3-5, deeply cleft; capsule 1-celled, 3-5 valved.-(Name from the Greek drosys, dew, the leaves being covered with red hairs, which exude drops of viscid fluid, especially when the sun is shining, and appear as if tipped with dew.) 


\section{Sub-order II.-PARNASSIEA.}

Stigmas sessile; leaves smooth.-The only British representative of this Sub-order is the beautiful plant Parnassia. By some botanists it is placed in the same Order with Hypericum; but with questionable propriety.

2. Parnassia (Grass of Parnassus).-Calyx deeply 5-cleft; petals 5 ; stamens 5, with 5 fringed scales interposed; stigmas 4 ; capsule 1-celled, with 4 valves.(Name from Mount Parnassus, but on what account is uncertain.)

\section{Drósera (Sundew).}

1. D. rotundifolia (Round-leaved Sundew).-Leaves all from the root, spreading horizontally, round ; leafstalks hairy; seeds chaffy.-An exceedingly curious little plant, $2-6$ inches high, growing in bogs. The root is small and fibrous, and takes a very slight hold in the ground ; the leaves are densely covered with red hairs, each of which is tipped with a drop of viscid fluid ; from the centre of the tuft of leaves rises a wiry leafless stalk, bearing several small whitish flowers which only expand in sunny weather; the flowers are all on one side of the stalk, which in its early stage is curled up, and gradually uncoils itself as the flowers severally expand.-Fl. July, August. Perennial.

2. D. longifolia (Long-leaved Sundew).-Leaves all from the root, erect, elongated, broad at the extremity, and tapering towards the base; leaf-stalks smooth; seeds with a rough, not chaffy coat.-Smaller than the last, and growing with it in boggy places.-Fl. July, August. Perennial.

3. D. Anglica (Great Sundew).-Leaves all from the roots, erect, oblong, on very long smooth stalks; seeds with a loose chaffy coat.- Stouter and taller than the last, and growing in similar situations, but rare.-Fl. July, August. Perennial. 


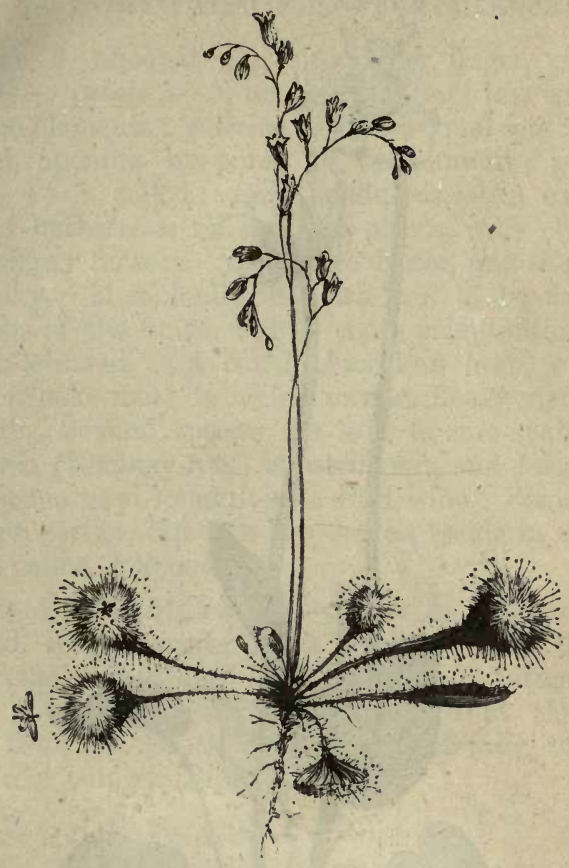

DRÓSERA ROTUNDIFOLIA (Round-leaved Sundew).

2. Parnassia (Grass of Parnassus).

1. P. palustris (Common Grass of Parnassus).-The only British species.-Bogs, principally in the north. An exceedingly elegant plant, 8-10 inches high, with solitary cream-coloured flowers, beautifully veined. The nectaries are fan-like scales, fringed with white hairs, and terminating in yellow wax-like glands.-Fl. August - October. Perennial. 


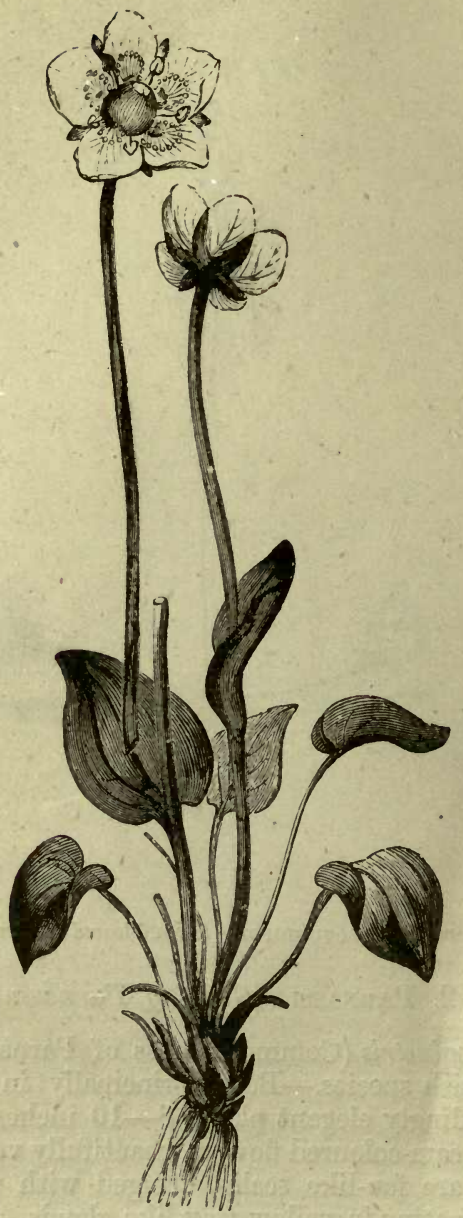

PARNASSIA PALUSTRIS (Common Grass of Parnassus). 
ORd. XI.-POLYGaLACEAE-The Milkwort Tribe.

Sepals 5, unequal, the two inner larger, generally petal-like ; petals 3-5, unequal, more or less combined with the filaments ; stamens 8 , in two equal sets ; anther 1-celled, opening by pores at the summit; pistil 1 ; capsute 1-3 celled; seeds pendulous.-An extensive tribe of herbaceous or shrubby plants, with clustered, often showy flowers. "Many are bitter, and their roots are milky. Medicinally they are said to be useful in affections of the lungs, and to excite perspiration. The most celebrated is a North American herb, Polýgala Senega (Snake-root), to which extraordinary virtues are ascribed. Several species are said to cure snake-bites. Krameria (Rhatany-root) is astringent, and furnishes a red infusion used to adulterate Port wine. Some of the above properties, but in a less degree, reside in the only British genus, Polýgala.

1. Polýgala (Milkwort).-Sepals 5, the two inner coloured, wing-shaped; petals combined with the filaments, the lower one keeled; capsule flattened, 2celled, 2-valved; seeds downy, crested at the base. (Name from the Greek, signifying much milk, the juice of the root being milky.)

\section{Polf́gala (Milkwort).}

1. P. vulgáris (Common Milkwort).-Lower petal crested in a star-like manner; calyx-wings about equal in length to the corolla; bracts 3 , at the base of each flower; stems simple, ascending, herbaceous ; leaves narrow.-Common on heaths and dry pastures, where it is highly ornamental during the later summer months, with its starlike, blue, pink or white flowers. -Fl. June-August. Perennial.

* In the chalk districts a Polýgala occurs, which is made by some botanists a distinct species, under the rather alarming name of P. calcárea (Chalk Milkwort). It differs from the preceding in having the lower leaves G 2 
tufted, blunt calyx-wings which are differently veined, and in ceasing to flower almost before the common

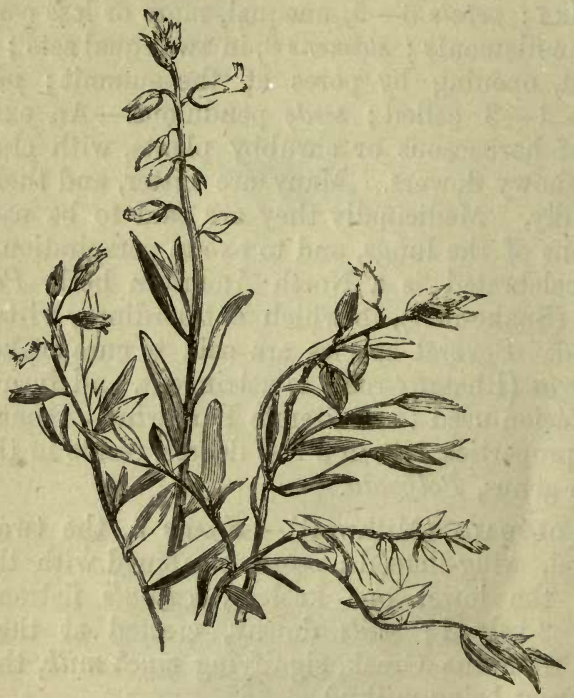

Pólygala vUlgáris (Common Milkwort).

Milkwort begins. Another variety or species with the leaves in a rosette, has been named $P$. Austríaca.

\section{ORD. XII.-FRANKENIACEA_-SEA-HeATHS.}

Sepals 4-6 united into a furrowed tube, not falling off; petals equal in number to the sepals, furnished with claws, and usually having scales at the junction of the claw and limb ; stamens equal in number to the petals ; ovary 1 ; style thread-like, 2, 3, or 4-cleft; capsule 1-celled, 2, 3, or 4-valved; seeds very minute, attached to the edges of the valves.-Herbaceous or somewhat 
shrubby plants, with branched stems, opposite leaves, which have a membranous sheathing base, and numerous small sessile flowers, inhabiting principally the north of Africa and south of Europe.

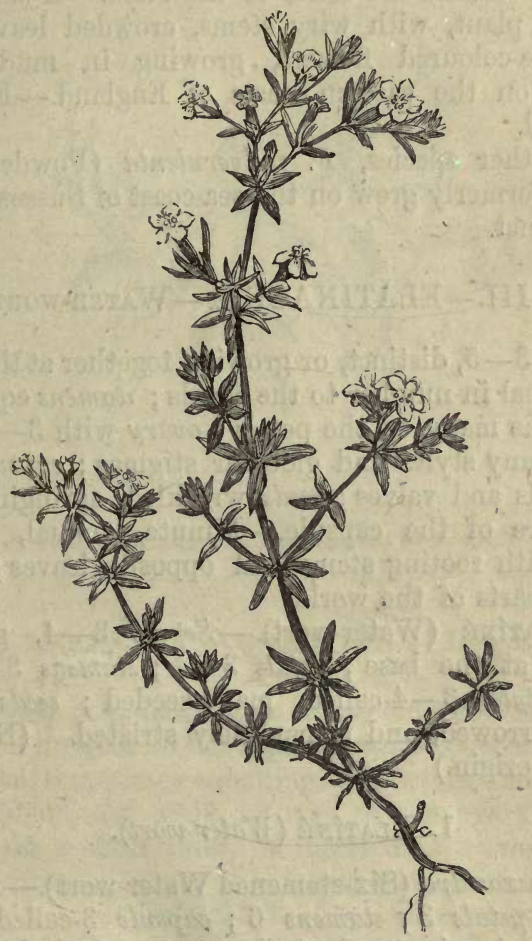

FRANKkNIA LEVIS (Smooth Sea-Heath).

1. Frankénia (Sea-Heath).-Style 3-cleft; lobes oblong, with the stigma on their inner side; capsule 3-4-valved. (Name from John Franken, a Swedish botanist.) 


\section{Franiénia (Sea-Heath).}

F. loevis (Smooth Sea-Heath).-Leaves narrow, rolled back at the edges, smooth, fringed at the base; flowers terminal, or from the forks of the stem.-A small procumbent plant, with wiry stems, crowded leaves, and pale rose-coloured flowers, growing in muddy salt marshes on the eastern coasts of England.-Fl. July. Perennial.

* Another species, F. pulverulenta (Powdery SeaHeath), formerly grew on the sea-coast of Sussex, but is now extinct.

ORdER XIII.-ELATINACEÆ._-WATER-WORT TRIBE.

Sepals 3-5, distinct, or growing together at the base ; petals equal in number to the sepals; stamens equalling, or twice as many as the petals ; ovary with $3-5$ cells, and as many styles and globular stigmas; capsule with $3-5$ cells and valves; seeds wrinkled, springing from the centre of the capsule.-Minute, annual, aquatic herbs, with rooting stems and opposite leaves; found in most parts of the world.

1. Elatíné (Water-wort). - Sepals 3-4, growing together at the base; petals $3-4$; stamens $3-4$, or $6-8$; styles 3-4-celled, many-seeded; seeds cylindrical, furrowed, and transversely striated. (Name of doubtful origin.)

\section{Elatíné (Water-wort).}

1. E. hexandra (Six-stamened Water-wort).-Flowers stalked; petals 3 ; stamens 6 ; capsule 3 -celled; seeds straight. - A minute plant, forming turfy beds on the margin of lakes, or growing entirely submersed. When left by the subsiding water it assumes a bright red hue, but the flowers are at all times inconspicuous. Rare. -Fl. July-September. Annual.

2. E. Hýdropiper (Eight-stamened Water-wort).- 
Flowers sessile; petals 4 ; stamens 8 ; capsule 4-celled; seeds curved.-Yet rarer than the preceding, and growing in similar situations.-Fl. July-September. Annual.

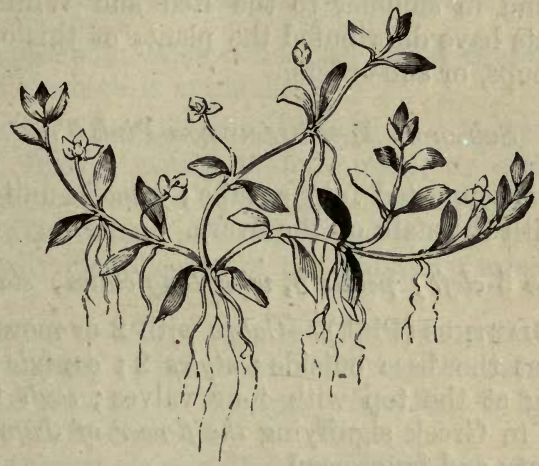

ELATINÉ HEXANDRA (Six-stamened Water-wort).

ORDER XIV.-CARYOPHYLLACEAE.

Sepals 5 or 4 , distinct, or connected into a tube ; petals equal in number to the sepals; stamens usually twice as many as, sometimes equalling, the petals, and like them inserted on the stalk or ring of the ovary; ovary 1 , raised on a short stalk, or inserted in a ring; stigmas 2-5, running along the inner surface of the styles; capsule 1 or imperfectly $2-5$-celled, opening by twice as many teeth, or valves, as there are styles ; seeds inserted on a central column.-An extensive and well marked order of herbaceous plants, inhabiting the temperate and frigid regions of the globe, and not unfrequently bearing ornamental flowers. The stems are swollen at the joints : the leaves always opposite and 
undivided, and frequently of a glaucous hue. Among garden flowers, the Pink, Carnation, Sweet William, and Scarlet Lychnis, all belonging to this order, are well known; and our hedges are much indebted for their showy appearance in spring to the great White Stitchwort, and in summer to the Red and White Robin. Botanists have distributed the plants of this order into two groups, or sub-orders.

\section{Sub-order I.-Silenes.-Pink Tribe.}

Sepals connected into a tube; stamens united at the base with the stalk of the ovary.

* Calyx 5-cleft; petals 5, with long claws; stamens 10.

1. Dianthus (Pink).-Caly $x$ with 2 or more opposite scales at the base outside; styles 2 ; capsule 1-celled, opening at the top with four valves; seeds flattened. (Name in Greek signifying the flower of Jupiter, from its beauty and fragrance.)

2. SaPonaria (Soapwort).-Calyx naked at the base; styles 2 ; capsule 1-celled, opening at the top with 4 valves; seeds rounded. (Name from sapo, soap, the plant abounding in a soapy juice.)

3. Siléne (Catchfly).-Calyx naked at the base; petals generally crowned at the top of the claw; styles 3 ; capsule imperfectly 3-celled, opening at the top with 6 valves. (Name of doubtful origin. The English name was given in consequence of flies being often caught in the viscid fluid which, in some species, surrounds parts of the stem.)

4. LYCHNis (Campion).-Calyx naked at the base; petals generally crowned at the top of the claw; styles 5 ; capsule opening at the top with 5 or 10 teeth. (Name from the Greek lychnos, a lamp; "the thick cottony substance on the leaves of some species, or some similar plant, having been employed as wicks to lamps." -Hooker.) 
5. Agrostemma (Corn-cockle).-Calyx naked at the base, tough, with leaf-like divisions ; petals undivided; capsule opening at the top with 5 teeth. (Name signifying in Greek, Crown of the Field.)

Sub-order II.-Ausínes.-Chickweed Tribe.

Sepals distinct; stamens inserted into a ring beneath the capsule, which is not stalked.

6. SaGína (Pearl-wort). - Sepals 4-5, spreading when in fruit; petals 4-5, minute, or sometimes wanting; stamens 4 to 10 ; styles $4-5$; capsule $4-5$ valved. (The name in Latin signifies fattening meat, but is totally inapplicable to the minute plants of this genus.)

7. Manchia.-Sepals 4, erect; petals 4 ; stamens 4 ; styles 4 ; capsule opening at the top with eight teeth. (Name in honour of Conrad Moench, Professor of Botany at Hesse-Cassel.)

8. Holósteum (Jagged Chickweed).-Sepals 5 ; petals 5 , toothed at the margin; stamens $3-5$; styles 3 ; capsule opening at the top with 6 teeth. (The name signifies in Greek, all bone; but why it was given is uncertain.)

9. Stellária (Stitchwort).-Sepals 5 ; petals 5, deeply 2-cleft ; stamens 10 ; styles 3 ; capsule opening with 6 valves, or teeth. (Name from stella, a star, which the expanded flowers resemble in shape.)

10. Honckénya (Sea Purslane).-Sepals 5; petals 5 , entire ; stamens 10 ; styles $3-5$; seeds few, large; flowers with the stamens or pistils imperfect. (Name from M. Honckeny, a German botanist.)

11. Arenária (Sandwort). - Sepals 5; petals 5, entire; stamens 10 ; styles 3 ; capsule opening with 6 valves; flowers all perfect; seeds many, minute. (Name from the Latin aréna, sand, many species growing in sandy ground.)

12. Cerástium (Mouse-ear Chickweed).-Sepals 5; 
petals 5, 2-cleft; stamens 10 or 5 ; styles 5; capsule tubular, opening at the end with 10 or rarely 5 teeth. (Name from the Greek keras, a horn, from the shape of the capsule in some species.)

13. Maláchium (Mouse-ear Chickweed).-Sepals 5 ; petals 5, deeply 2 -cleft; stamens 10 ; styles alternate with the sepals; capsule opening to the middle with 5 valves. (Name from the Greek málakos, feeble, from the nature of the plant.)

14. Cherleria (Cyphel).-Sepals 5 ; petals 0, or 5, exceedingly minute, notched; stamens 10 , the 5 outer with glands at the base; styles 3 ; capsule 3 -valved; flowers with their stamens or pistils imperfeet. (Name from $J . H$. Cherler, an eminent botanist.)

\section{Dianthus (Pink). * Flowers clustered.}

1. D. Arméria (Deptford Pink).-Stem and leaves downy ; flowers in close tufts ; calyx-scales very narrow, downy, as long as the tube.-Waste places ; rare. From 1 to 2 feet high, with rose-coloured scentless flowers, dotted with white.-Fl. July, August. Annual.

2. D. prólifer :(Proliferous Pink).-Stem smooth; leaves roughish at the edge; flowers in heads; calyx scales membranous, pellucid.-Gravelly pastures ; rare. Growing about a foot high, and readily distinguished by its heads of rose-coloured flowers, only one of which opens at a time, and by the brown dry scales in which the heads of flowers are enclosed.

\section{** Flowers not clustered.}

3. D. Caryophýllus (Clove Pink, Carnation, or Clove Gilly-flower, that is, July flower).--Flowers solitary; calyx scales 4 , broad, pointed, one-fourth as long as the calyx; petals notched; leaves linear, glaucous, with 
smooth edges.-On old walls, but scarcely indigenous. Well known, both in the gardens'of cottagers and of professed florists, where it is subject to countless varieties,

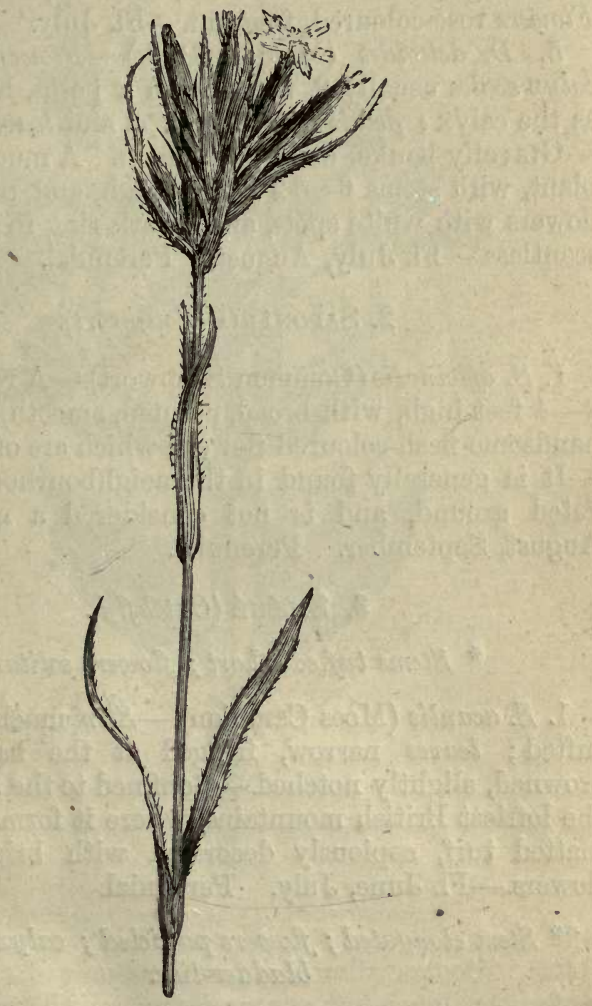

DIANTHUS ARMeria (Deptford Pink).

all of which are fragrant and beautiful.-Fl. July. Perennial. 
4. D. coesius (Mountain Pink).-Flowers mostly solitary; calyx scales 4, blunt, one-fourth as long as the calyx; petals jagged; leaves linear, glaucous, with rough edges.-Limestone Cliffs, Chedder, Somersetshire. Flowers rose-coloured, fragrant.-Fl. July. Perennial.

5. D. deltoŕdes (Maiden Pink).-Flowers solitary; calyx scales usually 2 , tapering to a point, half as long as the calyx ; petals notched; stem and leaves roughish. - Gravelly banks, but not common. A much branched plant, with stems $6-12$ inches high, and rose-coloured flowers with white spots, and a dark ring in the centre; scentless.-Fl. July, August. Perennial.

\section{SAPonária (Soapwort).}

1. S. officinalis (Common Soapwort).-A robust plant, 2-4 feet high, with broad, pointed, smooth, leaves, and handsome flesh-coloured flowers, which are often double. -It is generally found in the neighbourhood of cultivated ground, and is not considered a native.-Fl. August, September. Perennial.

3. Siléné (Catchfly).

* Stems tufted, short; flowers solitary.

1. S. acaulis (Moss Campion).-Stem much branched, tufted; leaves narrow, fringed at the base; petals crowned, slightly notched.-Confined to the summits of the loftiest British mountains, where it forms a densely matted turf, copiously decorated with bright purple flowers.-Fl. June, July. Perennial.

** Stem elongated; flowers panicled; calyx inflated,
bladder-like.

2. S. infláta (Bladder Campion).- -Stem erect; leaves oblong, tapering; flowers panicled, drooping; calyx inflated, bladder-like, with a net-work of veins ; petals deeply cloven, rarely crowned. $-\mathrm{A}$ common weed in 
corn-fields and pastures, growing from 1 to 2 feet high, and well marked by its numerous white flowers and veined calyces, often tinged with purple. The foliage

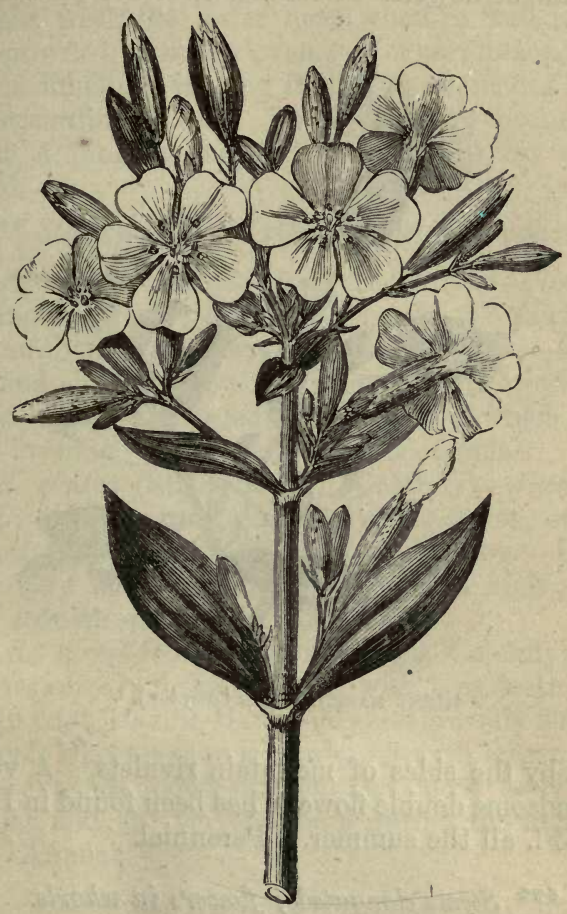

SAPONÁRIA OFFICINALIS (Common Soapwort).

and stem are glaucous, and generally smooth; but a variety which is downy all over is occasionally found.Fl. June-August. Perennial.

3. S. marítima (Sea Campion).-Stem numerous from the same root, spreading; leaves oblong, taper- 
ing, finely toothell at the margin ; flowers few on each stem, or solitary; petals slightly cloven, crowned.Resembling the last, but of humbler stature, though hearing larger flowers. Common near the sea-shore, as

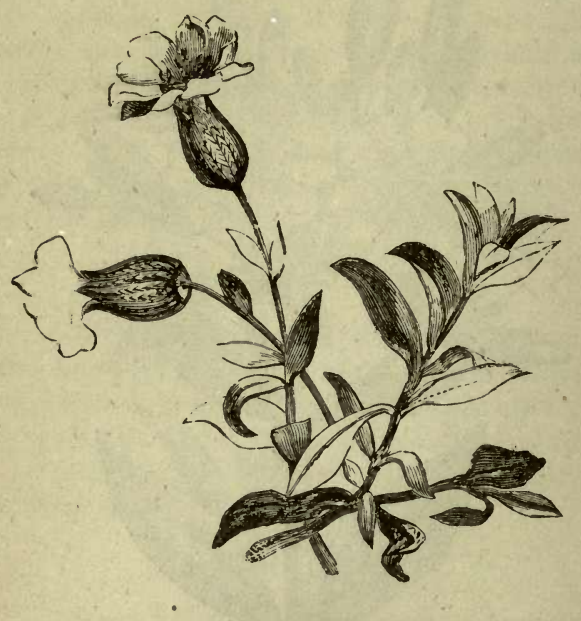

SILÉné marítima (Sea Campion).

well as by the sides of mountain rivulets. A variety, with handsome double flowers, has been found in Devonshire.-Fl. all the summer. Perennial.

*** Stems elongated; flowers in whorls.

4. S. Otítes (Spanish Catchfly).-Stems erect, with opposite, tufted branches; stamens and pistils on separate plants; petals narrow, entire, not crowned.Sandy fields in the east of England. The stems are about a foot high, viscid at the middle; flowers small, yellowish.-Fl. July. Perennial. 
*** Stems elongated; flowers in leafy clusters, alternate.

5. S. Ánglica (English Catchfly).-Whole plant hairy and viscid; leaves narrow, tapering; flowers lateral, alternate, erect, the lower ones when in fruit reflexed; petals crowned, slightly cloven. - Not uncommon in many parts of England, varying from 6 to 12 inches high, or more, according to soil. The flowers are inconspicuous and of a pinkish white hue.-Fl. all the summer. Annual.

***** Stems panicled, leafy; calyx not bladder-like.

6. S. nutans (Nottingham Catchfly).-Flowers all drooping one way; branches opposite, 3 -forked; calyx much swollen ; petals deeply cloven, crowned.-On limestone and chalk rocks; not common. It grows about $1 \frac{1}{2}$ foot high, with large fragrant flowers, which expand in the evening.-Fl. June, July. Perennial.

7. S. cónica (Striated Corn Catchfly).-Stem erect, forked; leaves narrow, downy; petals cloven, crowned; calyx of the fruit conical, with 30 furrows.-In sandy fields, very rare; from 6 to 12 inches high; flowers small, reddish.-Fl. July. Annual.

8. S. noctiflóra (Night-flowering Catchfly).-Stem erect, repeatedly forked; calỳx with long teeth, oblong when in fruit, 10-ribbed. - Sandy and gravelly fields; not common. Shorter than the last, and with larger flowers, which expand about sun-set, and close early in the morning, and are very fragrant during the night.-Fl. July. Annual.

\section{Lrchnis (Cumpion).}

1. L. Flos-Cúculi (Ragged Robin).-Petals deeply 4-cleft, crowned; capsule 5-toothed; leaves very narrow; flowers loosely panicled.-A pretty and well-known marsh plant, with a purplish green, angular stem, the lower part of which is roughish with short bristly hairs, the upper parts slightly viscid; flowers rose-coloured, 
with deeply-cut narrow segments.-Fl. when the cuckoo is in full song, hence its Latin name, Flos-Cúculi. Perennial.

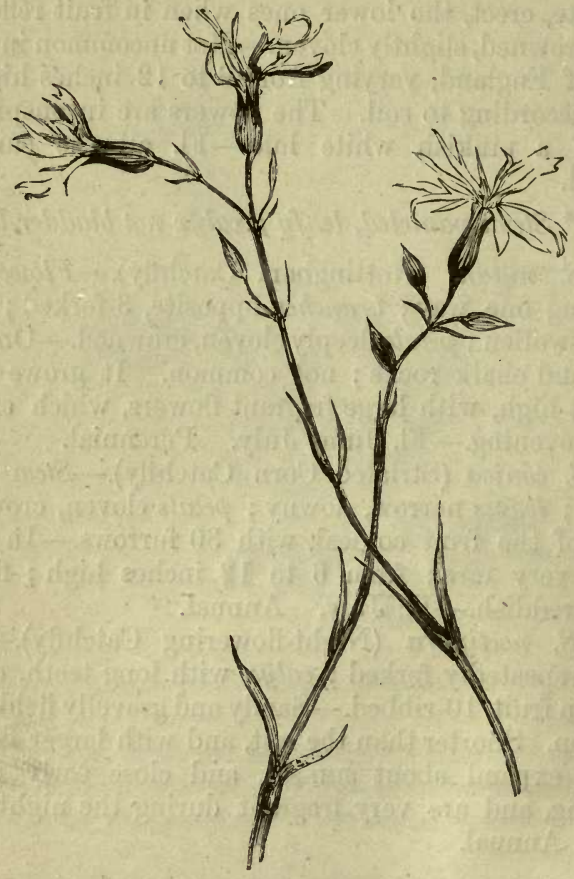

LYCHNIS FLOS-CÚCULI (Ragged Robin).

2. L. diúrna (Red Robin, or Campion).-Stamens and pistils on different plants; petals 2-cleft half-way down, crowned; capsule nearly globose 10 -toothed, the teeth recurved; leaves oblong, tapering, downy, as well as the stem.-An ornamental hedge plant, 2-3 feet high, with rose-coloured flowers.-Fl. all the summer. Perennial. 
3. L. vespertína (Evening Campion).-Stamens and pistils on different plants; petals 2-cleft half-way down, crowned; capsule conical, 10-toothed, the teeth erect; leaves as in $L$. diurna. Resembling the last, and in some districts equally common. The flowers are white,

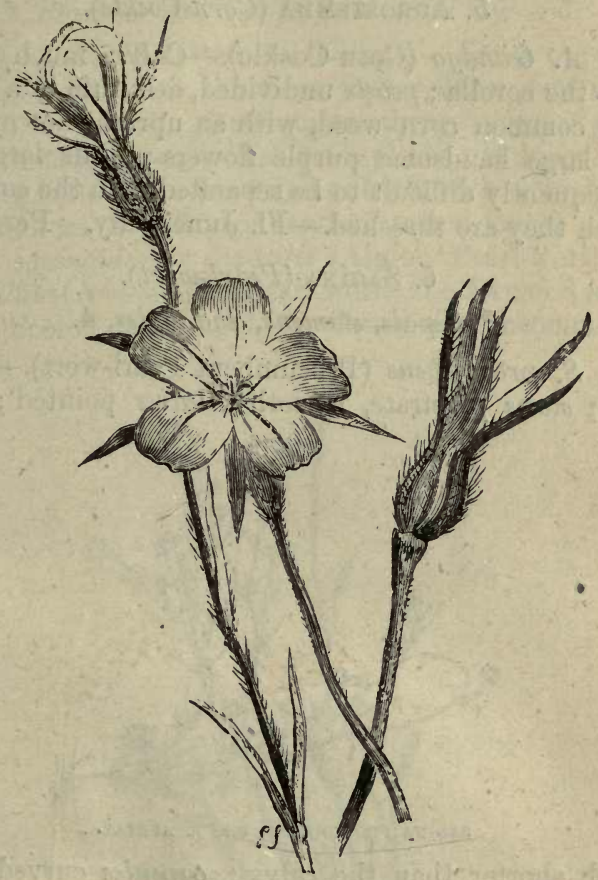

agrostemma (Corn-Cockle).

or sometimes reddish, fragrant in the evening.-Fl: all the summer. Perennial.

* Two other species of Lychnis are natives of Britain; L. viscária (Red German Catchfly), which is found in 
Montgomeryshire and in a few places in Scotland, distinguished by its slightly-notched petals, 5-celled capsules, and clammy stem; and $R$. alpina (Red Alpine Campion), a much smaller species, 5-6 inches high, which grows on the summits of the Clova mountains.

\section{Agrostemma (Corn-Cockle).}

1. A. Githágo (Corn-Cockle).-Calyx much longer than the corolla ; petals undivided, destitute of a crown. -A common corn weed, with an upright downy stem, and large handsome purple flowers; seeds large, and consequently difficult to be separated from the corn with which they are threshed.-Fl. June, July. Perennial.

\section{Sagína (Pearl-wort). \\ * Sepals, stamens, and styles, 4.}

1. S. procumbens (Procumbent Pearl-wort).-Perennial; stems prostrate, smooth; leaves pointed; petals

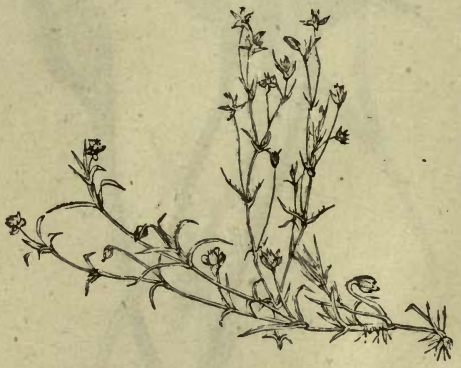

SAGINA PROCUMBENS, and s. APETALA.

much shorter than the calyx; capsules curved downwards before ripening. - Well known to gardeners as a troublesome weed infesting the paths, and so prolific as to require repeated eradication. The flowers are at all times inconspicuous; the stems are from 1 to 4 inches long.-Fl. all the summer. Perennial.

* Two other British species belong to this group, both 
very like the preceding: S. apétala (Annual Pearl-wort), distinguished by its slight, hairy, erect stems, and fringed leaves; the capsules, too, are erect: and $S$. maritima (Sea Pearl-wort), which has blunt, fleshy leaves, and flowers destitute of petals.

* Stamens 10 ; sepals, petals, and styles, 5.

4. S. nodósa (Knotted Pearl-wort). - Leaves opposite, growing together at the base, upper ones very short, growing in knots; flower-stalks always erect; petals longer than the calyx. - Wet sandy places, not uncommon. A pretty little plant $3-4$ inches high, with conspicuous white llowers, 2 or 3 together,' and tufted leaves.

* S. saginordes or saxátilis (Alpine Pearl-wort) and S. subuláta (Awl-shaped Pearl-wort), the former a native of the Scotch mountains, the latter not uncommon in

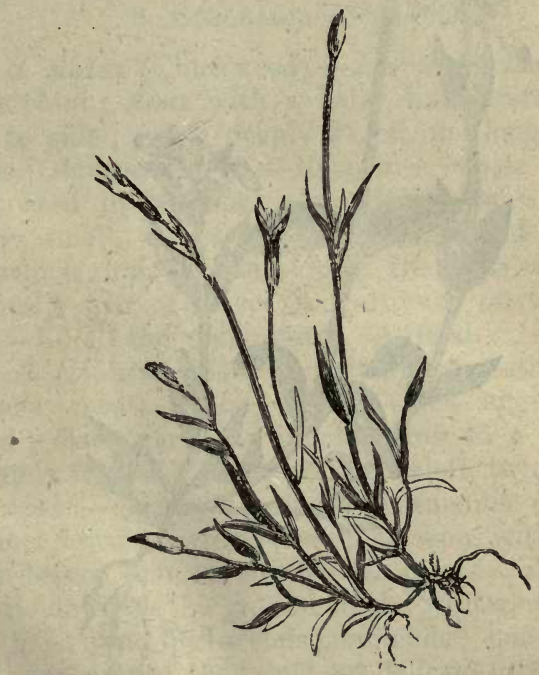

MCENCHIA ERECTA (Upright Monchia).

H 2 
gravelly pastures, have solitary flowers on long flowerstalks, and in habit approach very nearly to Sagina procumbens.

\section{Mgnchia.}

1. M. erecta (Upright Mœnchia), - A small upright

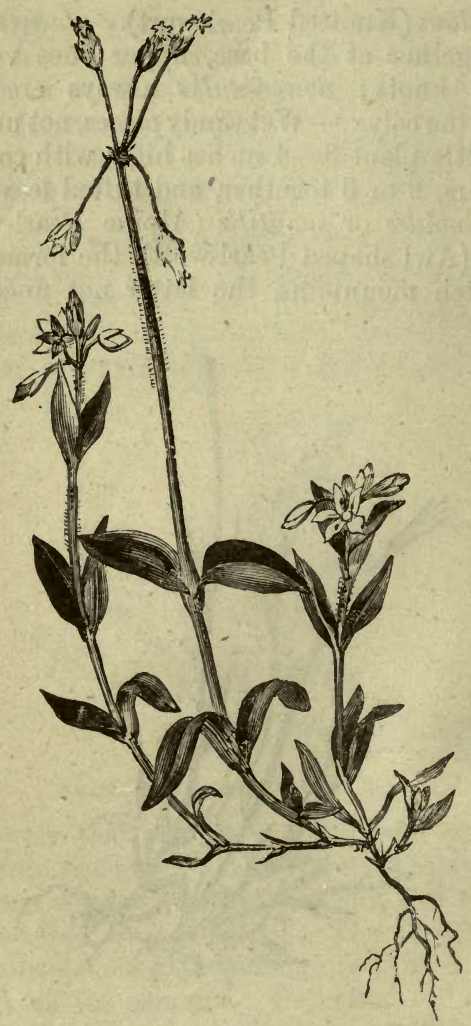

hos.Osteum Umbelcatum (Umbelliferuus Jagged Chickweed). 
plant 2-4 inches high, with rigid glaucous leaves, and white flowers, which are large in proportion to the rest of the plant; the sepals are sharp pointed, with a white membranous edge ; the petals expand only in the sunshine.-Fl. May. Annual.

\section{Holósteum (Jagged Chickweed).}

1. H. umbellatum (Umbelliferous Jagged Chickweed). -A singular little plant, $4-5$ inches high, with leafy stems which are smooth below, and hairy and viscid between the joints above. The flowers grow in terminal umbels about 5 together, and are bent back after flowering; petals white, with a reddish tinge.-Very rare, on old walls at Norwich and elsewhere.-Fl. April. Annual.

\section{Stellaria (Stitchwort).}

1. S. média (Chickweed).-Leaves egg-shaped, with a short point; stems with a hairy line alternating from side to side; petals deeply 2-cleft, not longer than the sepals ; stamens 5-10.-Roadsides, waste places, and as a weed in gardens; abundant. Leaves succulent; flowers small, white. Well distinguished by a hairy line which runs up one side of the stem and when it reaches a pair of leaves is continued on the opposite side.-Fl. all the year round. Annual.

2. S. Holóstea (Greater Stitchwort, Satin-flower, or Adder's meat).-Stem nearly erect, angular, roughedged; leaves very narrow, tapering to a long point, minutely fringed; petals deeply 2-cleft, twice as long as the sepals. - Among the most ornamental of our early summer flowers, scarcely less conspicuous with its delicate green leaves than its snow-white petals. The stems do not die down to the ground in the winter, as is the case with most other herbaceous perennials ; but though dead to all appearance, they send out delicate green tufts very early in the year, so that the flowering stems, especially 
inbushy places, seem to have made an unusually rapid growth.-Fl. May, June. Perennial.

3. S. gramínea (Lesser Stitchwort).-Stem nearly erect, angular, smooth; leaves very narrow, acute, smooth,

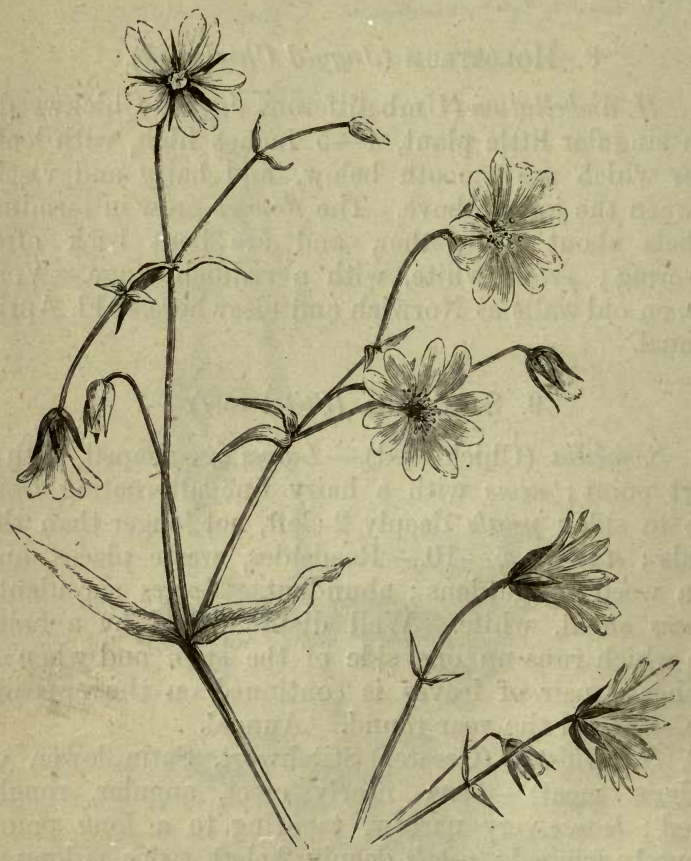

STELLARIA HOLÓSTEA (Greater Stitchwort).

edged; flowers in forked panicles; petals very deeply cleft, scarcely longer than the 3 -nerved sepals.-Dry heathy places. Much smaller than the preceding in all its parts, and distinguished at once by the very deeply divided petals, which are white, but not so showy.-Fl. June, July. Perennial. 
4. S. glauca (Glaucous Marsh Stitchwort).-Stem nearly erect, angular, smooth ; leaves narrow, tapering, entire, glaucous ; flowers solitary on long axillary stalks; petals very deeply 2 -cleft, much longer than the 3 -nerved sepals.-Marshy places. Resembling the preceding in habit, 6-12 inches high, but with larger flowers.-Fl. June-August. Perennial.

5. S. uliginósa (Bog Stitchwort).-Stems spreading, angular ; leaves broadly lanceolate, with a stiff tip, smooth; flowers panicled; petals deeply 2-clert, shorter than the 3-nerved sepals, which are united at the base.-Boggy places, frequent. A slender plant, about a foot long, with very small white flowers.-Fl. June. Annual.

* The other British species of Stellaria are S. némorum (Wood Stitchwort), which grows in woods in the north, and is distinguished by its heart-shaped leaves : S. cerastoídes (Alpine Stitchwort), a humble plant 4-6

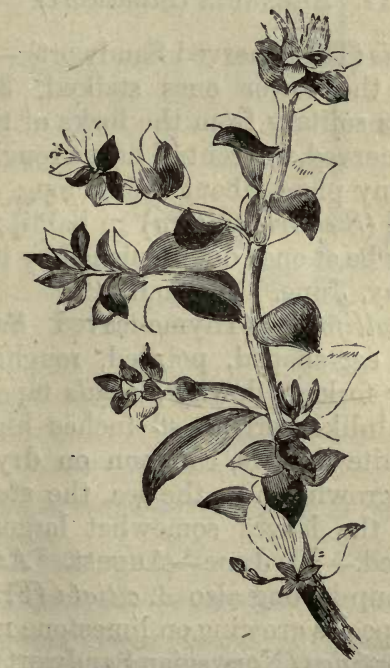

IIONCKÉNIA PEPLOIDES (Sea Purslane). 
inches high, with large white flowers, growing on tho Scottish mountains: and $S$. scapígera (Many-stalked Stitchwort), distinguished by its long flower-stalks, and growing both on the Scottish mountains north of Dunkeld, and about Loch Nevis.

\section{Honckénya (Sea Purslane).}

1. H. peplordes (Sea Purslane).-Leaves sessile, eggshaped, acute, fleshy, smooth; sepals obtuse.-A low, succulent, marine plant, with creeping roots, forked stems, and leaves arranged in four rows. The flowers are small and white, and grow from the forks of the stem. The plant forms tangled masses on the sea-shore, and approaches in habit the Sea Milkwort (Glaux marítima).-Fl. July. Perennial.

\section{Arenaria (Sandwort).}

1. A. trinervis (Three-nerved Sandwort).-Leaves eggshaped, acute, the lower ones stalked, 3-5-nerved, fringed; flowers solitary from the forks of the stem and axils ; sepals 3-nerved, the central nerve rough.-A weak, straggling, downy plant, about a foot long, approaching the Chickweed (Stellaria média) in habit, from which, however, it may be at once distinguished by its undivided petals.-Fl. May, June. Annual.

2. A. serpyllifolia (Thyme-leaved Sandwort). Leaves broadly egg-shaped, pointed, roughish, sessile; stem repeatedly forked, downy; sepals tapering, hairy. -A small shrub-like herb 2-6 inches high, with inconspicuous white flowers, common on dry banks and walls. When growing near the sea, the stems are less branched, and the leaves somewhat larger and more decidedly fringed.-Fl. June-August. Annual.

* To this group belong also A. ciliata (Fringed Sandwort), a small species growing on limestone mountains in Ireland ; A. Norvégica (Norwegian Sandwort), discovered 
in the Shetland Islands, in $1837 ; A$. verna (Vernal Sandwort), a small tufted plant with awl-shaped leaves, and comparatively large flowers, which grows in several parts of Scotland, and at the Lizard Point, Cornwall : A. rubella (Alpine Sandwort), a very rare species, confined to the summits of some of the Scotch mountains : A.tenuifolia (Fine-leaved Sandwort), a slender plant 46 inches high, with smooth forked stems and awl-shaped leaves, found in sandy fields in various parts of England and Scotland: and A. fastigiata (level-topped Sandwort), a rare Scotch species, with tufted flowers and leaves.

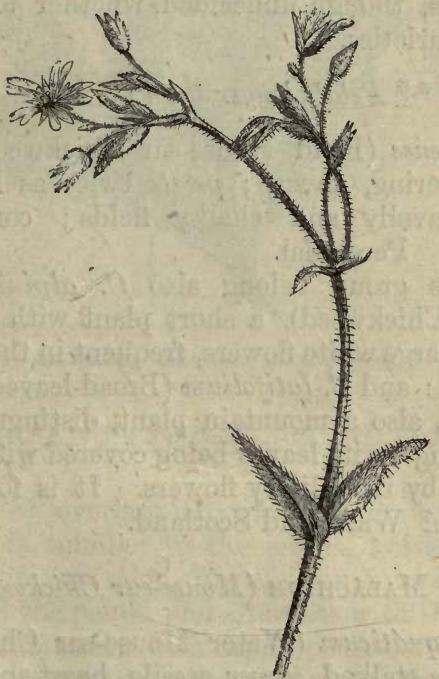

- Cerástium viscosum (Viscid Mouse-ear Chickweed).

12. Cerastium (Mouse-ear Chickweed). * Petals not longer than the calyx.

1. C. viscósum (Viscid Mouse-ear Chickweed).-Stems hairy, viscid; leaves oblong, tapering; flowers in pani- 
cles.-A common weed, with inconspicuous white flowers and straggling stems, which are generally covered with dust. Tho seed-vessels, when ripening, lengthen and become curved.-Fl. all the summer. Perennial.

* To this group belong C. vulgátum (Broad-leaved Mouse-ear Chickweed), which may be distinguished by its flowers being tufted: C. semidecandrum (Five-stamened Mouse-ear Chickweed), distinguished by the character to which it owes its name: C. tetrandrum (Four-stamened Mouse-ear Chickweed), distinguished in like manner : and several others to which botanists have given names, though undecided whether to call them species or varieties.

* Petals longer than the calyx.

2. C. arvense (Field Mouse-ear Chickweed).-Leaves narrow, tapering, downy ; petals twice as long as the sepals.-Gravelly and chalky fields; common.-Fl. June, July. Perennial.

* To this group belong also C. alpínum (Alpine Mouse-ear Chickweed), a short plant with white silky leaves and large white flowers, frequent in the Highlands of Scotland: and C. latifolium (Broad-leaved Mouse-ear Chickweed), also a mountain plant, distinguished from the preceding by its leaves being covered with yellowish down, and by its solitary flowers. It is found on the mountains of Wales and Scotland.

\section{Maláchium (Mouse-ear Chickweed).}

1. $M$. aquáticum (Water Mouse-ear Chickweed).Lower leaves stalked, upper sessile, heart-shaped, tapering to a point, all hairy on the margin ; capsule opening with 5 2-cleft teeth.-A much branched straggling plant, with white flowers in the angles of the stems, and in habit approaching Stellaria némorum (Wood Stitchwort).-Wet places, but not general.-Fl. July, August. Perennial. 


\section{Cherleria (Cyphel).}

1. C. sedoídes (Mossy Cyphel).-A mountain plant with long roots and numerous densely tufted stems, which scarcely rise above the ground, bearing crowded narrow leaves and solitary greenish flowers, which are generally without petals.-Highland mountains.-Fl. June-August. Perennial.

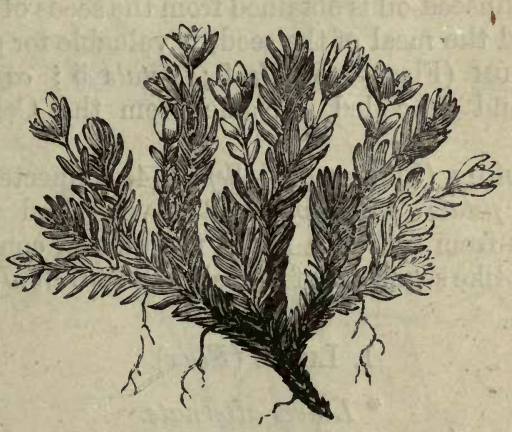

CHERLERIA SEDoÍdes (Mossy Cyphel).

Ord. XV.-LINACEA.-The Flax Tribe.

Sepals 3-5, overlapping when in bud, persistent; petals equal in number to the sepals, twisted when in bud, falling off very soon after expansion ; stamens equal in number to the petals, and alternate with them, united at the base into a ring with small teeth between them; ovary of about as many cells as there are sepals, and as many styles ; capsule approaching a globular form, tipped with the hardened base of the styles, each cell incompletely divided by a partition extending from the back inwards ; seeds 1 in each imperfect cell, pendulous.-Herbaceous, rarely shrubby, plants, with undivided leaves and remarkably fugacious petals, principally but not 
exclusively confined to Europe and the north of Africa. The flowers are in many cases highly ornamental, but the most striking feature of the Flax tribe is the toughness of the fibre contained in their stems, and the mucilaginous qualities of their seeds, which also yield considerable quantities of oil. One species, Linum usitatissimum, has for ages supplied the valuable article of clothing which takes its name, "Linen," from the plant which produces it; linseed-oil is obtained from the seeds of the same plant, and the meal of the seeds is valuable for poultices.

1. Linum (Flax).-Sepals 5 ; petals 5 ; capsule 10 valved, and 10-celled. (Name from the Celtic Lin, thread.)

2. Radíola (Flax-seed).-Sepals 4, connected below, 3-cleft; petals 4; capsule 8-valved, and 8-celled. ("Named from radius, a ray, I presume in consequence of the ray-like segments of the calyx."-Sir W.J.Hooker.)

\section{Linum (Flax). \\ * Leaves alternate.}

1. L. perenne (Perennial Flax).-Leaves very narrow, tapering to a sharp point; sepals inversely egg-shaped, obtuse, obscurely 5-ribbed.-Chalky fields. - A slender plant about a foot high, with wiry stems, very narrow sessile leaves, and elegant sky-blue petals, which are so fugacious as scarcely to bear being gathered.-Fl. June, July. Perennial.

2. L. angustifolium (Narrow-leaved Flax).-Leaves very narrow, tapering to a point; sepals elliptical, pointed, 3-ribbed.-Sandy pastures in the southern and western counties ; common. Like the last, but distinctly marked by its sharp-pointed sepals, and lighter blue flowers.-Fl. June, July. Perennial.

* To this group belongs $L$. usitatissimum, the flax of commerce, which, though not a native plant, is not unfrequently found in cultivated ground. It is distin- 
guished from the preceding by its somewhat broader and more distant leaves, by its stems being mostly solitary,

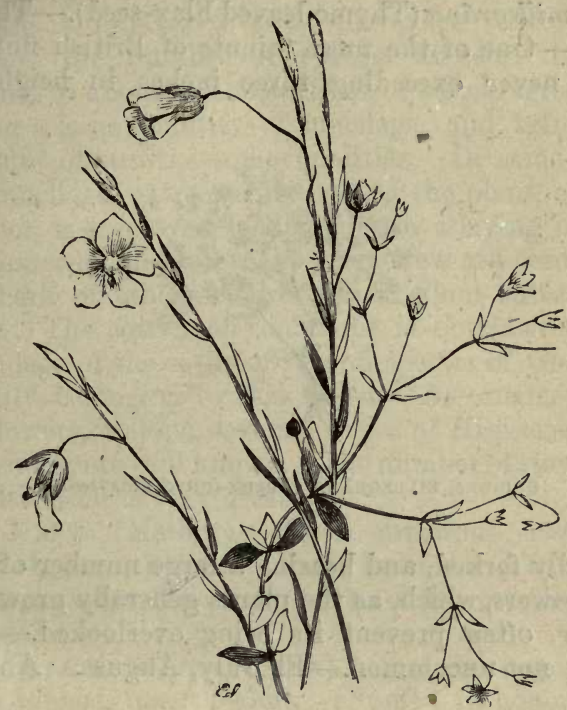

LINUM ANGUSTIFOLIUM, and L. CATHARTICUM.

instead of several from the same root, by its notched petals, and by its larger size.

\section{** Leaves opposite:}

3. L. cathárticum (Cathartic Flax).-Leaves oblong, broader at the base; sepals pointed.-Dry pastures; abundant.-Very different in size and habit from any of the preceding, rarely exceeding 6 inches in height, and bearing numerous small white flowers, which grow in panicles, and droop before expansion.-Fl. June, July. Annual. 


\section{Radíola (Flax-seed).}

1. R. millegrána (Thyme-leaved Flax-seed).-The only species. - One of the most minute of British flowering plants, never exceeding three inches in height, but

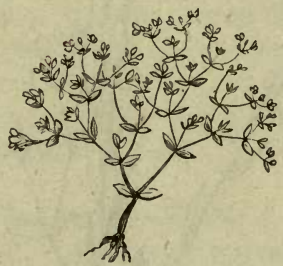

RADílA MILLEGRÁNA (Thyme-leaved Flax-seed).

repeatedly forked, and bearing a large number of small white flowers, which, as the plants generally grow many together, often prevent its being overlooked.-Damp heaths; not uncommon.-Fl. July, August. Annual.

ORd. XVI.-MALVACEA.-The Mallow Tribe.

Sepals 5, more or less united at the base, valvate in bud, often enclosed in an outer calyx; petals equalling the sepals in number, twisted when in bud; stamens numerous, united by their filaments into a tube; ovary formed of several carpels united in a radiate manner; styles equal in number to the carpels, either distinct or united; capsules (in all the British species) 1-seeded, arranged in a whorl round the styles. - - A large and important family of herbaceous plants, shrubs, and trees, with divided alternate leaves, which 
are furnished with stipules and axillary flowers. They are most abundant in the tropical regions, where they form a large proportion of the vegetation, and gradually decrease in number towards the poles. According to Lindley, the number of species hitherto discovered amounts to about a thousand, all of which agree in containing a large quantity of mucilage, and being totally destitute of unwholesome qualities. In some species, this mucilage, extracted by boiling the plant, especially the root, is employed medicinally in allaying irritation, both external and internal. Some few are used as food. The bark of others affords an excellent substitute for hemp. The cotton of commerce is obtained from the appendage of the seeds of several species of Gossypium, a family belonging to this Order. As ornamental garden flowers, Malópé, several species of Hibiscus, and the Hollyhock, are well known. The number of stove species in cultivation is very great.

1. Míalva (Mallow).-Styles numerous; outer calyx 3-leaved, inner 5-cleft. (Name from the Greek malake, soft, from the emollient properties of the mucilage which it contains.)

2. Lavatéra (Tree-Mallow).-Styles numerous; outer calyx 3-lobed, inner 5-cleft. (Named in honour of the two Lavaters, friends of Tournefort.)

3. Ацтнжа (Marsh-Mallow).-Styles numerous; outer calyx 6-9 cleft. (Name from the Greek áltho, to cure, from its healing properties.)

\section{Malva (Mallow).}

1. M. Sylvestris (Common Mallow).-Stem ascending, or erect; root-leaves kidney-shaped, with 7 acute lobes; fruit-stalks erect; fruit not downy, wrinkled.-Roadsides and waste ground; common. A robust herbaceous plant, with large downy, lobed, but not deeply divided leaves, branched stems, and showy purple flowers. When the flowers first expand the plant is handsome, but as 
the season advances, the leaves lose their deep green hue, and the stems put on a ragged appearance. The whole plant is mucilaginous and emollient. The pollen is a beautiful object for the microscope, being (like that of many other plants in this Order) globular, and studded with minute glandular prickles.-Fl. June-August. Perennial.

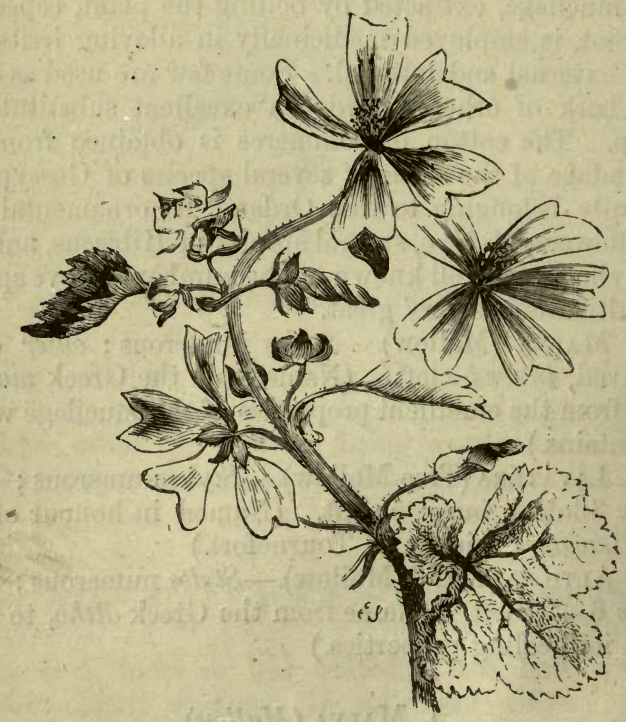

MALVA SYLVESTRIS (Common Mallow).

2. M. rotundifolia (Dwarf-Mallow).-Stem prostrate; leaves roundish, heart-shaped, with 5 shallow lobes; fruit-stalks bent down; fruit downy.-Waste places; not uncommon. Smaller than the last, and distinguished at once by its prostrate stems, and pale lilac flowers.-Fl. June-September. Annual. 
3. M. moscháta (Musk-Mallow).-Stem erect; rootleaves kidney-shaped, deeply 5 or 7-lobed and cut; stemleaves deeply 5-lobed, and variously cut into numerous narrow segments; outer calyx-leaves very narrow ; fruit hairy.-Hedges and borders of fields; not uncommon. Whole plant hairy, light green, with large handsome rose-coloured flowers, which are crowded towards the summit of the stem; the foliage emits a faint musky

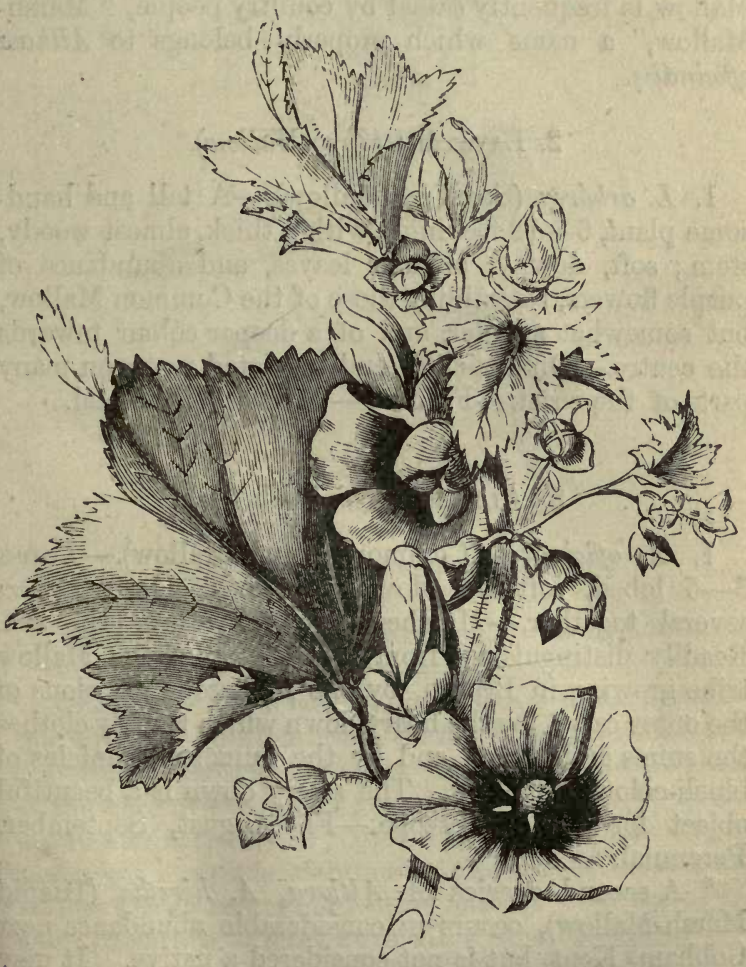


odour, especially in hot weather, or when drawn lightly through the hand. A white variety is not uncommon in gardens.-Fl. July, August. Perennial.

* The above species agree in yielding a plentiful tasteless mucilage, which, in some rural districts, is highly valued for making poultices and cough mixtures. Children often amuso themselves with gathering and eating the unripe seed-vessels, which they call " cheeses :" they are insipid, but not unwholesome. The common Mallow is frequently called by country people, "MarshMallow," a name which properly belongs to Althcea officinális.

\section{Lavatéra (Tree-Mallow).}

1. L. arbórea (Sea Tree-Mallow).-A tall and handsome plant, 6 -12 feet high, with a thick, almost woody, stem; soft, downy, angular leaves, and abundance of purple flowers, resembling those of the Common Mallow, but somewhat smaller, and of a deeper colour towards the centre.-On sea-cliffs and insulated rocks on many parts of the coast.-Fl. July-October. Biennial.

\section{3. Ацthaа (Marsh-Mallow).}

1. A. officinalis (Common Marsh-Mallow).-Leaves 3-5 lobed, soft and downy on both sides; flowers several together.-Marshes, especially near the sea. Readily distinguished from any others of the Mallow tribe growing in Britain, by the numerous divisions of the outer calyx, by the hoary down which thickly clothes the stems and foliage, and by the numerous panicles of blush-coloured flowers. The starry down is a beautiful object for the microscope.-Fl. August, September. Perennial.

* A second species of Althoea, A. hirsuita (Hispid Marsh-Mallow), occurs in considerable abundance near Cobham, Kent, but is not considered a native. It may 
be distinguished by its bristly stems and leaves, and by its flowers being solitary in the axils of the upper leaves.

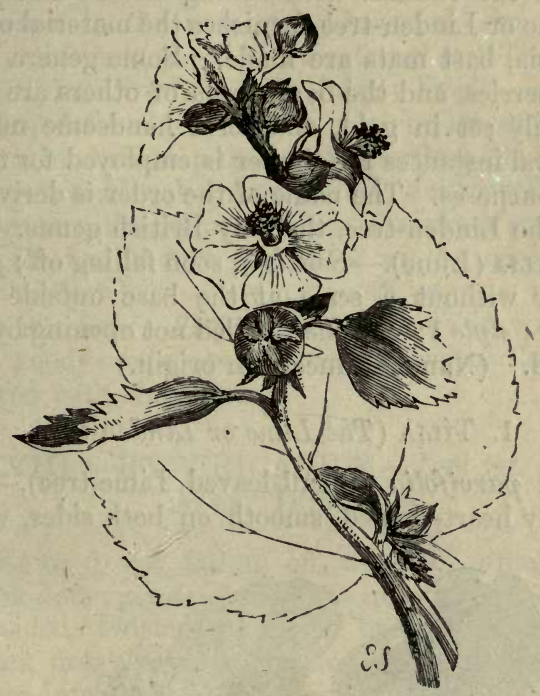

ALTHEA OFFICINALIS (Common Marsh-Mallow).

\section{ORD. XVII.-TILIACEA.-The Lime Tribe.}

Sepuls 4 or 5 , valvate when in bud; petals equalling the sepals in number, often with a little pit at the base, sometimes wanting; stamens numerous ; glands 4-5, at the base of the petals ; ovary single, of $2-10$ united, rarely distinct, carpels; style 1 , with as many stigmas as carpels ; capsule with one or more seeds in each cell. -The plants belonging to this natural order are mostly trees or shrubs. They have all a mucilaginous, wholesome juice, and many of them are remarkable for the 
toughness of the fibres of the inner bark. In a species of Aristotelia this is so strong, as to be converted into strings for musical instruments. One genus (Córchorus) supplies the Indians with fishing-lines and nets; and the Lime or Linden-tree furnishes the material of which, in Russia, bast mats are made. Some genera produce edible berries, and the bony seeds of others are not uncommonly set in gold, and form handsome necklaces. In several instances the timber is employed for the most useful purposes. The name of the order is derived from Tilia, the Linden-tree, the only British genus.

1. Tilia (Lime).-Sepals 5, soon falling off; petals 5, with or without a scale at the base outside; ovary 5 -celled ; style 1 ; capsule 1 -celled not opening by valves, 2 -seeded. (Name of uncertain origin.)

1. Tília (The Lime or Linden-tree).

1. T. parvifolia (Small-leaved Lime-tree).-Leaves obliquely heart-shaped, smooth on both sides, with the

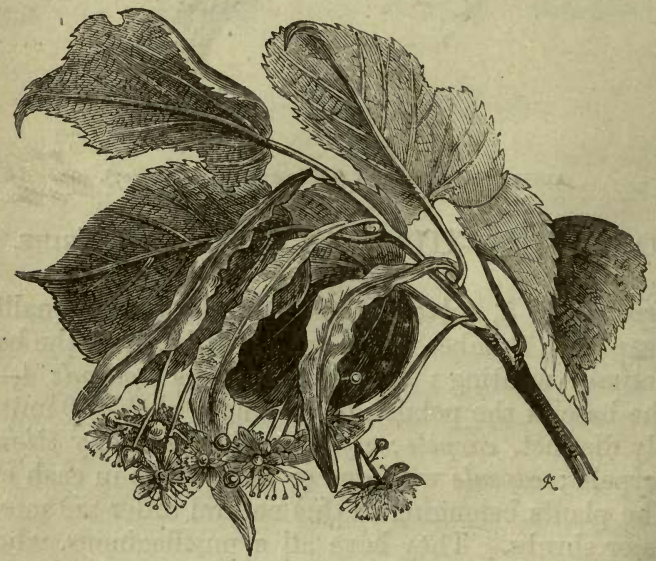

Tílua Europea (Common Lime-tree). 
exception of small tufts of downy hair beneath, scarcely longer than their stalks; peduncles springing from a leafy bract, many flowered; capsule brittle.-Peculiar interest attaches to the Linden-tree, from its having given a name to the immortal Linnæus. For a fuller account of this tree, the reader is referred to "The Forest Trees of Britain," vol. ii.-Fl. July. Tree.

* It is questionable whether any species of Lime is indigenous in Britain ; that just described has the best claim to be considered a native, but is not so well known as T. Europoea, the common Lime of avenues and parks. This species has flowers like those of the small-leaved Lime, but larger leaves, and a smooth capsule the rind of which is tough. T. grandifolia (Large-leaved Limetree) has woody seed-vessels, which, as well as the leaves, are covered with short down.

\section{ORD. XVIII.-HYPERICACEA.-The ST. JoHN'S Wort Tribe.}

Sepals 4 or 5 , not falling off, unequal, often fringed with black dots ; petals of the same number as the sepals, unequal-sided, twisted when in bud, often bordered with black dots; stamens numerous, free above, united at the base into three or more sets ; ovary single ; styles $3-5$; fruit a capsule or berry of several valves and cells, the valves curved inwards; seeds minute, numerous.Herbs, shrubs, or trees, generally with opposite leaves marked with pellucid dots, and yellow flowers, inhabiting most parts of the world. Most of the species are aromatic and resinous, and some contain a yellow juice, which has been used in medicine. The only British genus strictly belonging to this order is that which gives it its name, Hypéricum. The curious genus Parnassia was formerly placed here, but is now removed to the Order Droseracea (p. 79).

1. Hrpéricum (St. John's Wort).-Sepals 5 ; petals 5 ; stamens numerous; filaments united into 3 or 5 sets; 
styles 3 or rarely 5 ; capsule 3 -celled.-(Name, hypericon, the Greek name of the plant.)

\section{Hypéricum (St. John's Wort). * Styles 5.}

1. H. calycinum (Large-flowered St. John's Wort).Stems single-flowered.-A low shrub, with oblong, blunt leaves and large yellow flowers, which are very handsome, especially before the anthers have shed their pollen. Common in gardens and shrubberies, and naturalized in several places.-Fl. July-September. Perennial.

\section{** Styles 3, sepals not fringed.}

2. H.Androscemum(Common Tutsan).-Stem shrubby, two-edged; leaves egg-shaped, sessile; sepals unequal; capsule berry-like.-Woods and hedges, but not common, except in Devon and Cornwall. A handsome shrubby plant, 2-3 feet high, conspicuoas with clusters of largish yellow flowers, and afterwards with glossy, berry-like capsules. The leaves have a strong resinous smell, which they retain for some time after drying.Fl. July. Perennial. Shrub.

3. H. quadrángulum (Square-stalked St. John's Wort). - Stem herbaceous, erect, with 4 somewhat winged angles, branched ; leaves oblong, egg-shaped, with pellucid dots ; sepals erect, lanceolate.-Wet places, common, growing $1-2$ feet high, with flat panicles of yellow flowers.-July, August. Perennial.

4. H. perforátum (Perforated St. John's Wort).Stem herbaceous, erect, 2-edged; leaves elliptic-oblong, copiously perforated with pellucid dots; sepals erect, lanceolate, acute.-Woods and hedges, common ; easily distinguished from all the other smaller species of St. John's Wort by its decidedly 2-edged stem ; 2 feet high.-Fl. July, August. Perennial.

5. H. dúbium (Imperforate St. John's Wort). -Stem herbaceous, erect, 4-sided, with rounded angles ; leaves 
destitute of dots ; sepals reflexed, elliptical, blunt.Mountainous places, not common; very like the last, but well distinguished by the above characters.-Fl. July, August. Perennial.

6. H. humifúsum (Trailing St. John's Wort).-Stems prostrate, somewhat 2-edged; leaves oblong, obtuse, perforated with pellucid dots ; flowers somewhat cymose; stamens not more than 15.-Walls and gravelly banks, common; $3 \perp 9$ inches long, with several spreading slender stems and yellow flowers, which open most freely in the sunshine. Though usually placed in this group, the sepals are often fringed with black dots.Fl. July, August. Perennial.

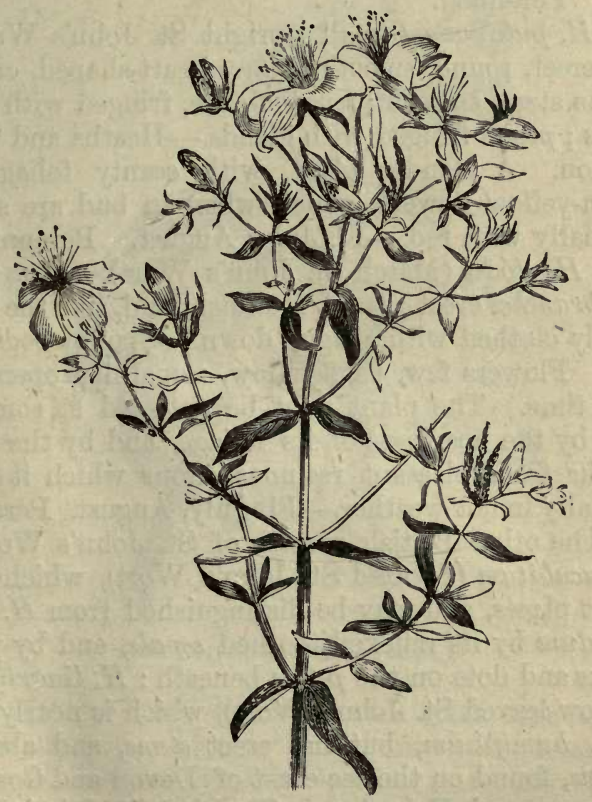

GYPERICUM PERFORATUM (Perforated St.John's Wort). 
*** Styles 3. Sepals fringed with glands.

7. 11. montánum (Mountain St. John's Wort). - Stem erect, round, smooth ; leaves oblong, sessile, smooth, with glandular dots near the margin; sepals acute, fringed with shortly stalked glands. - Limestone hills, not uncommon; growing about 2 feet high, and remarkable for the black fringe of its sepals, which at once distinguishes it from any of the preceding species.-Fl. July. Perennial.

8. H. hirsútum (Hairy St. John's Wort).-Stem erect, nearly round, downy ; leaves downy.-Woods, especially in a chalky or limestone soil ; about the same size as the last, but well marked by its downy herbage.-Fl. July. Perennial.

9. H. pulchrum (Small upright St. John's Wort).Stem erect, round, smooth ; leaves heart-shaped, embracing the stem, smooth ; sepals obtuse, fringed with sessile glands ; petals fringed with glands.-Heaths and woods, common. A slender plant, with scanty foliage and golden-yellow flowers, which when in bud are stained externally with red.-Fl. July, August. Perennial.

10. H. elódes (March St. John's Wort).-Stem creeping ; branches erect ; leaves roundish, and, like the stems, densely clothed with shaggy down.-Spongy bogs, common. Flowers few, pale yellow," remaining open but a short time. The plant may be detected at some distance by the hoariness of its foliage, and by the strong and far from pleasant resinous odour which it emits, especially in hot weather.-Fl. July, August. Perennial. * The other British species, of St. John's Wort are, H. maculátum (Spotted St. John's Wort), which grows in wet places, and may be distinguished from $H$. quadrángulum by its reflexed toothed sepals, and by purple streaks and dots on the petals beneath: $H$. linariifolium (Narrow-leaved St. John's Wort), which is nearly allied to $H$. humifúsum, but has erect stems, and about 30 stamens, found on the sea-coast of Devon and Cornwall, very rare ; and H. barbatum (Bearded St. John's Wort), 
a doubtful native, but said to grow wild in Perthshire; it has sepals fringed with long-stalked glands, and petals minutely fringed and dotted.

\section{Ord. XIX.-ACERACEÆ.-The Maple Tribe.}

Calyx divided into 5 parts (occasionally 4-9); petals of the same number; stamens about 8 , inserted on a flattened ring beneath the ovary; ovary 2-lobed; style 1 ; stigmas 2 ; fruit 2-lobed, 2-celled, not bursting; lobes winged on the outside; cells $1-2$ seeded.-Trees

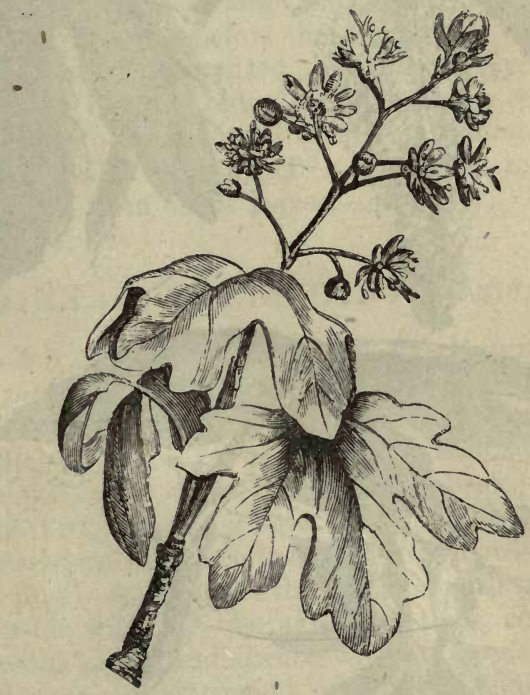

ACER CAMPEsTRE (Common Maple).

with opposite, stalked leaves, which are veined in a palmate manner. They are found only in the temperate regions of the northern hemisphere; several species abound in a sweet juice, which in North America is 
manufactured into sugar.-(See "Forest Trees of Britain," vol. i. p. 103.)

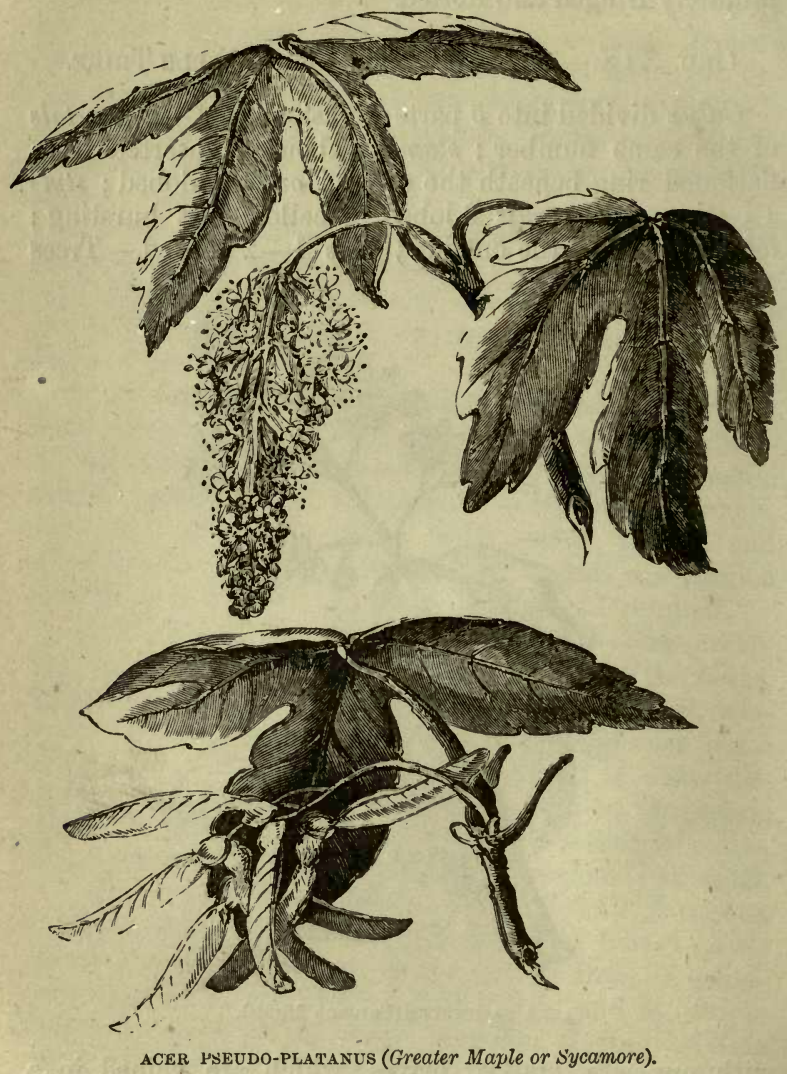

1. ACER (Maple).-Calyx 5-cleft; petals 5: capsules 2 , each furnished with a long wing.- (Name from the Celtic ac, a point, on account of the hardness of the 
wood, which was used for making spears and other sharp-pointed instruments.

\section{ACer (Maple).}

1. A. campéstré (Common Maple).-Leaves 5-lobed; lobes bluntish, scarcely cut; clusters of flowers erect. Woods and hedges; a small tree, with a very rugged corky bark, full of deep cracks.-Fl. May, June. Tree.

2. A. Pseudo-plátanus (Greater Maple or Sycamore). -Leaves 5-lobed; lobes unequally serrated; clusters of flowers drooping.-A large and handsome tree, introduced into England before the fourteenth century, and now completely naturalized.: The name Sycamore was given to it by the older botanists, who erroneously believed it to be identical with the Sycamore or Mulberry-fig of Palestine, which it somewhat resembles in the size and form of its leaves.-Fl. May. Tree.

\section{Ord. XX.-GERANIACE E.-Geranium Tribe.}

Sepals 5, not falling off, ribbed, overlapping when in bud; petals 5 -clawed, twisted when in bud; stamens 10 , sometimes alternately imperfect, generally united by their filaments ; ovary of 5 carpels placed round a long awl-shaped beak; styles 5, united to the beak; stigmas 5 ; fruit beaked, separating into 5 capsules, each of which is one-seeded, and terminates in the hardened style, which finally separates at the base and curls up, carrying the capsule with it.-An extensive tribe, consisting of herbaceous plants and shrubs with an aromatic or resinous flavour and astringent qualities, abounding at the Cape of Good Hope and in the temperate regions of the northern hemisphere. To the genus Pelargonium belong the innumerable varieties of handsome flowering plants which under the name of Geraniums are so ornamental as greenhouse or window flowers. The roots of one or two species are eatable, and some are used in medicine. 
1. Geránium (Crane's-bill).-Stamens 10, 5 of which are alternately larger and have glands at the base ; fruit beaked, separating into 5 capsules, each with a long awn which is naked (not bearded on the inside). (Name from the Greek géranos, a crane, to the beak of which bird the fruit bears a fancied resemblance.)

2. Eródium (Stork's-bill).-Stamens 10, of which 5 are imperfect; glands 5, at the base of the perfect stamens ; fruit beaked, separating into 5 capsules, each with a long spiral awn, which is bearded on the inside. (Name from the Greek erodion, a heron, to the beak of which bird the fruit bears a fancied resemblance.)

\section{Geranium (Crane's-bill). \\ * Flower-stalks single flowered.}

1. G. sanguineum (Bloody Crane's-bill).-Root-leaves nearly round, with 7 deeply cut lobes, each of which is 3-cleft, stem-leaves 5 or 3-lobed.-Limestone and magnesian rocks, not common. An exceedingly handsome plant with hairy stems, abundant foliage, and large, bright purple flowers. Fl. July-September. Perennial.

** Flower-stalks 2 flowered.

2. G. phoum (Dusky Crane's-bill).-Stem erect; flowers panicled; sepals slightly pointed; capsules keeled, hairy below, wrinkled above.-In woods and thickets, rare, but not an uncommon garden plant; remarkable for the dingy, almost black hue of its flowers. Fl. May, June. Perennial.

3. G. pratensé (Meadow Crane's-bill).-Stem erect; leaves palmate, 7-lobed; lobes cut and serrated ; stamens smooth, tapering from a broad base ; capsules hairy all over; fruit-stalks bent down.-The largest British species; growing in moist pastures ; about 2 feet high, with large and handsome purplish-blue flowers. Fl. June-August. Perennial. 
4. G. sylváticum (Wood Crane's-bill).-Stem erect, many flowered; leaves palmate, 7-lobed; lobes cut and serrated; stamens awl-shaped, fringed; capsules keeled, hairy; fruit-stalks erect.-Woods and pastures, chiefly

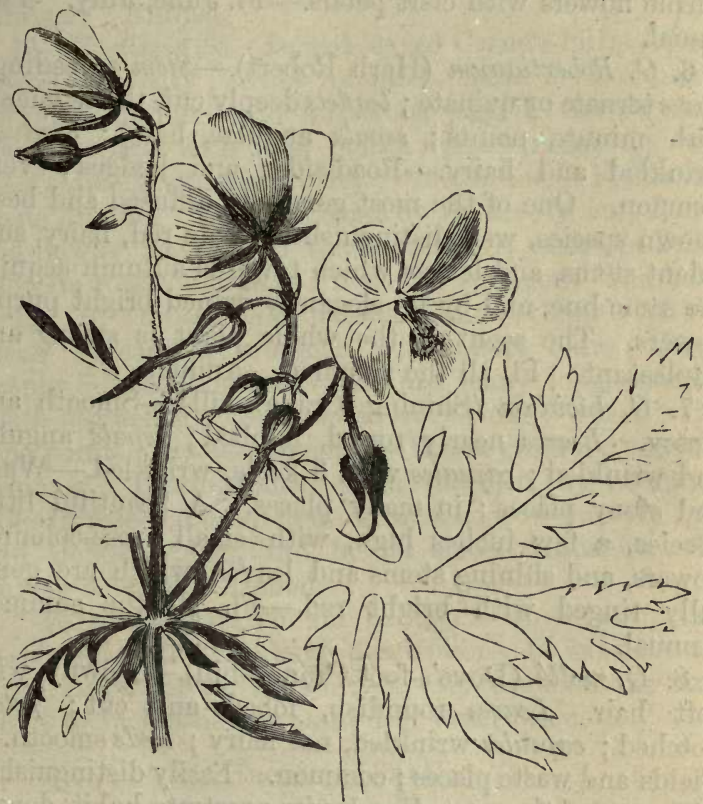

GERÁNIUM PRATÉNsta (Meadow Crane's-bill).

in the north, rare. Distinguished from the last by its smaller size, by its stamens being fringed half-way up, and by its capsules being most hairy about the keel. -Fl. June, July. Perennial.

5. G. Pyrenáicum (Mountain Crane's-bill).-Stem spreading, downy; root-leaves kidney-shaped, 5-7 
lobed; lobes oblong, obtuse, 3-cleft and toothed at the end; petals notched, twice as long as the pointed sepals. -Road-sides and meadows ; not common. 2-3 feet high. Well distinguished by the thick down on its stems and leaves, and by its numerous, rather small, purple flowers with cleft petals.-Fl. June, July. Perennial.

6. G. Robertianum (Herb Robert).-Stem spreading; leaves ternate or quinate ; leaflets deeply cut, the segments with minute points; sepals angular, hairy; capsules wrinkled and hairy.-Road-sides and hedges; very common. One of the most generally diffused and bestknown species, well distinguished by its red, hairy, succulent stems, and leaves which towards autumn acquire the same hue, and by its elegantly veined bright purple flowers. The scent of the whole plant is strong and unpleasant. Fl. all the summer. Annual.

7. G. licidum (Shining Crane's-bill).-Smooth and glossy. Leaves nearly round, 5-lobed; sepals angular and wrinkled; capsules with 3 keels, wrinkled.-Walls and stony places; in many places. A beautiful little species, a few inches high, with small, rose-coloured flowers, and shining stems and leaves, which are generally tinged with bright red.-Fl. all the summer. Annual.

8. G. mollé (Dove's-foot Crane's-bill).-Downy with soft hair. Leaves roundish, lobed and cut; petals notched; capsules wrinkled, not hairy ; seeds smooth.Fields and waste places ; common. Easily distinguished from any of the preceding by its prostrate habit, downy herbage, and small light purple flowers.-Fl. all the summer. Annual.

9. G. rotundifolium (Round-leaved Crane's-bill).Downy with soft hair. Leaves roundish, lobed, and cut ; petals entire; capsules hairy, not wrinkled; seeds dotted. - Fields and waste places; not common, but perhaps often confounded with the last, which it much resembles in size and habit.-Fl. June-August. Annual. 
10. G. pusillum (Small-flowered Crane's-bill).Downy with soft hair. Leaves roundish, lobed, and cut; petals notched; stamens 5 ; capsules keeled, downy, not wrinkled; seeds smooth.-Waste ground; common. Resembling $G$. mollé in habit, but smaller.-Fl. all the summer. Annual.

11. G. dissectum (Jagged-leaved Crane's-bill).-Stems spreading, hairy ; leaves roundish, more or less hairy, variously divided into numerous jagged, narrow segments; sepals with long points; petals notched; capsules scarcely wrinkled, hairy; seeds dotted.-Fields and waste ground. Distinguished by its deeply cut, hairy, not downy leaves, and the exceedingly short pedicels. Flowers rose-coloured.-Fl. all the summer. Annual.

12. G. columbinum (Long-stalked Crane's-bill).Stems spreading, roughish with short hairs; leaves deeply 5-lobed, the lobes cut into many long, narrow, acute segments; flower-stalks very long; sepals with long points ; capsules smooth.-Waste ground ; not very common. Distinguished from the last by its larger blueish rose-coloured flowers, which grow on very long and slender stalks, and by its smooth capsules.-Fl. June-August. Annual.

* Particular care should be taken when comparing specimens with the above descriptions, to examine the root-leaves; for the stem-leaves vary even on the same plant to such a degree as to defy description.

\section{Eródium (Stork's-bill).}

1. E. cicutarium (Hemlock Stork's-bill).-Stems prostrate, hairy; stalks many-flowered; leaves pinnate; leaflets sessile, pinnatifid, cut.-Waste places, especially near the sea ; common. A straggling plant, with much of the habit of the preceding genus, but distinguished at first sight by its pinnate leaves, and umbels of lilac (sometimes white) flowers, the petals of which soon fall off.-Fl. all the summer. Annual.

2. E. moschátum (Musk Stork's-bill).-Stems pro- 
strate hairy; stalks many-flowered; leaves pinnate; leaflets nearly sessile, unequally cut; perfect stamens toothed at the base.-Waste places, especially near the sea. Whole plant much stouter than the last, of a deeper

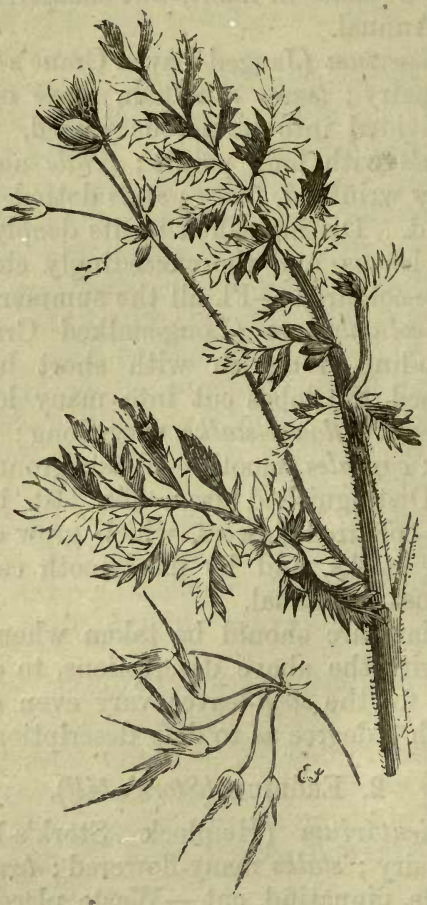

ERODIUM CICUTARIUM (Hemlock Stork's-bill).

green, somewhat clammy to the touch, and emitting when handled a strong scent of musk. Flowers bright purple.-Fl. all the summer. Annual.

3. E. marítimum (Sea Stork's-bill).-Stems prostrate, 
hairy ; stalks $1-3$ flowered ; leaves oblong, heart-shaped, variously lobed and notched; petals minute or wanting. -Warm places near the sea; not uncommon in the West of England. Whole plant roughish with minute hairs, and sending out several leafy stems, which lie remarkably close to the ground; the leaves are not pinnate, as in the other British species, and the flowers are rarely found with petals. Like many other sea-side plants, it is not unfrequently met with in inland mountainous districts, occurring plentifully on Dartmoor, in Devonshire, many miles from the sea.-Fl. all the summer. Perennial.

* The beaks attached to the capsules of the Stork'sbills become spirally twisted when ripe, often springing to a considerable distance from the parent plant. They are furnished on the inner side with long elastic bristles; and being hygrometric, uncurl when moistened. The combined action of the beak and bristles thus gives to the seed the power of locomotion at every change in the moisture of the atmosphere. A twisted capsule, if moistened and laid on a sheet of paper, will, in its effort to straighten itself, soon crawl an inch or more away from the spot on which it was laid.

\section{Ord. XXI.-BALSAMINACE E-BaLsam Tribe.}

The flowers of this order are so exceedingly irregular, that it is almost impossible to define the characters without employing terms which would be out of place in a work which professes to give merely a popular description of British wild flowers. The following description, however, of the only British species belonging to the Balsam Tribe, will serve to identify any others which are likely to fall in the reader's way.-An annual succulent plant, much swollen at the joints, with a solitary branched stem, and egg-shaped, deeply serrated leaves. From the axil of each of the upper leaves proceeds a flower-stalk, taking a horizontal direction, 
and hiding itself beneath the leaf. Each flower-stalk bears about four drooping flowers, which expand one at a time, and last a very little while. The calyx consists

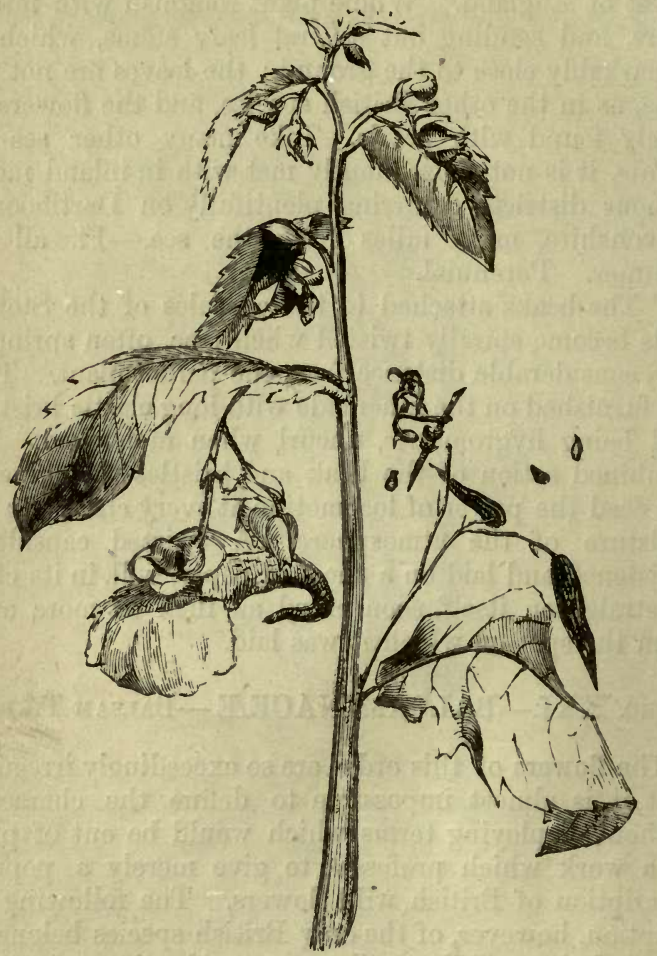

IMPATIENS (Balsam).

of two coloured, nearly round, concave sepals, with an oblique point; within these, on the side of the flower nearest to the stem, is inserted a horn-like petal or sepal, for botanists are undecided which to call it, wide 
at the mouth and curved downwards at the extremity; on each side of this is a large wavy petal unequally lobed, the largest lobe next the spur, the smaller being easily separable, and having the appearance of a distinct petal. Opposite the stem is a very broad, wavy petal ; and at its base are 5 stamens with short filaments, united just beneath the anthers into a ring, and enclosing a 5-celled ovary. The sepals and petals soon fall off, when the ovary enlarges to a 5-celled, 5-valved capsule, externally resembling a cylindrical, strongly ribbed pod. As the seeds approach towards maturity, the valves of the capsule acquire an extraordinary elastic power, and, if touched, instantaneously curl into a spiral form, and spring with considerable force many feet from the plant, dropping the seeds in the way.

Only one of the Balsam tribe is a native of Europe, but in India they are very numerous, and several are cultivated in British gardens.

1. Impatiens (Balsam).- Characters described above. The name signifying impatient, was given from the sudden curling of the valves of the capsule when touched. The only English species, I. Noli-me-tangere (Do-nottouch-me), is an elegant plant, $1-2$ feet high, with large flowers of a delicate yellow, beautifully spotted with orange colour.-It grows in moist shady woods and on the stony banks of rivers in Yorkshire and Westmoreland.-Fl. July, August. Annual.

ORdER XXII.-OXALIDACE E.-ThE WOOD-SORREL TRIBE.

Sepals 5, persistent; petals 5, equal, often united at the base, twisted when in bud; stamens 10 , with the filaments generally combined at the base, the 5 outer shortest ; ovary $3-5$ celled; styles $3-5$; capsule $3-5$ celled, with as many, or twice as many, valves; seeds enclosed each in an elastic case, which curls back when the fruit is ripe, and throws the seeds to a distance.- 
Herbaceous plants, shrubs, or trees, remarkable for the quantity of oxalic acid contained in their foliage, on which account some species are used as sauces, salads, or even pickles. Oxalis crenáta was a few years back recommended to be extensively cultivated for the sake of its tuberous roots, which, it was said, would form an excellent substitute for the potato. It has, however, proved to be of little value. Some species have sensitive leaves, and a few are used in medicine.

1. Oxalis (Wood-Sorrel).-Sepals 5, united below; petals 5 , often united below; stamens united by the base of their filaments; styles 5; capsules 5-celled, angular. (Name from the Greek oxys, sharp or acid, from the acidity of the leaves.)

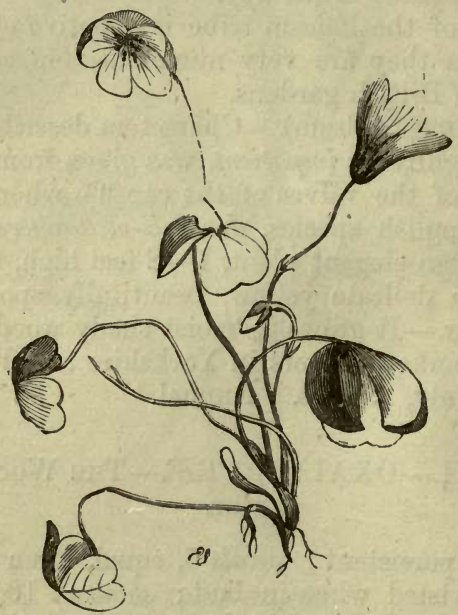

óxalis ACETOSELla (Common Wood-Sorrel).

1. Óxalis (Wood-Sorrel).

1. O. Acetosella (Common Wood-Sorrel).-Leaves all springing directly from the root, ternate, hairy ; scape 
with two bracts about the middle, single flowered ; root toothed.-An elegant little plant, with delicate drooping clover-like leaves, and white or lilac veined flowers, growing abundantly in woods and shady places. The leaves, though not so sensitive as some foreign species, fold together at night. This plant is supposed by many to be the true shamrock which was used by St. Patrick to illustrate familiarly the doctrine of the Trinity.-Fl. May, June. Perennial.

* O. corniculata (Yellow Wood-Sorrel) has a prostrate stem and small yellow flowers. It occurs only in the West of England, and is by no means so pretty a plant as the last.

\section{SUb-CLASS II. \\ CALYCIFLORA.}

Sepals distinct or united; petals distinct; stamens inserted on the calyx, or close to its base.

\section{Order XXIII. - CELASTRACEAE. - SPINDle-treE TRIBE.}

Sepals 4-5, imbricated when in bud, inserted on a fleshy disk; petals equal in number to the sepals; stamens equal in number to the petals, and alternate with them; ovary sunk in the disk, 2-5 celled; fruit either a capsule of $2-5$ cells, opening with valves, or berry-like ; seeds often wrapped in a covering distinct from the capsule (called an arillus). $-\mathrm{A}$ rather large number of plants are included in this order, but not many of great interest. They are natives of the warmer parts of Europe, North America, and Asia, and a great number inhabit the Cape of Good Hope. A few also occur in Chili, Peru, and New Holland. Many of them 
possess an acrid, stimulant principle. The green leaves of one species are said to be eaten by the Arabs to produce watchfulness, and a sprig of it is believed to be,

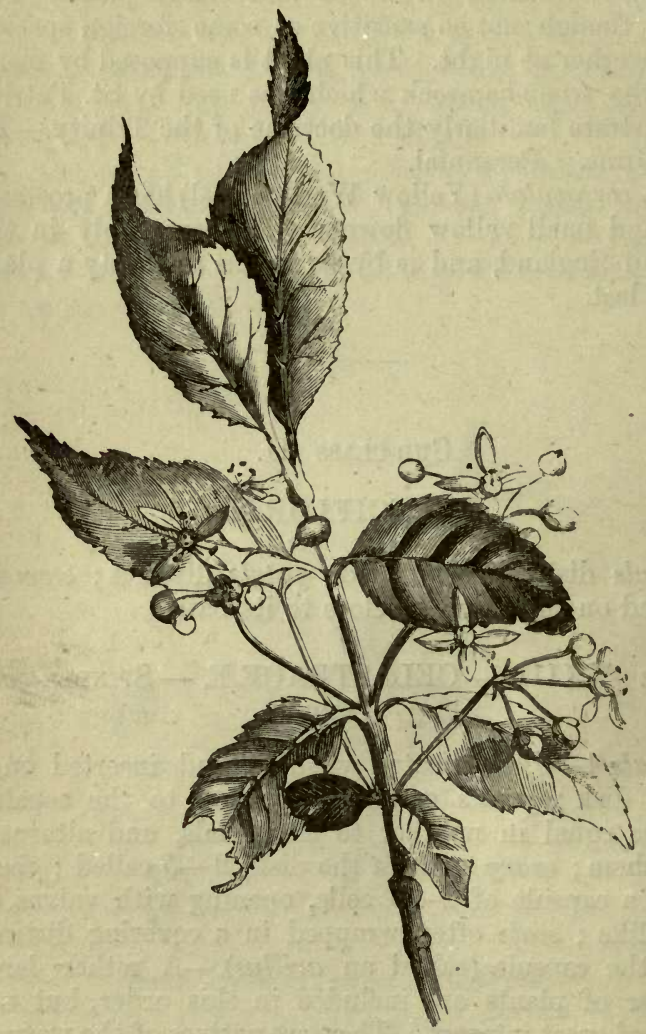

FLOWER OF EU6NYMUS EUROPAUS (Common Spindle-Tree).

to the person who carries it, a protection from the plague. The only British species, the spindle-tree, is 
most remarkable for its pink lobed seed-vessels, which, in autumn, render the tree a conspicuous object. One species of Celastrus (the genus from which the order takes its name) is said to inflict very painful wounds.

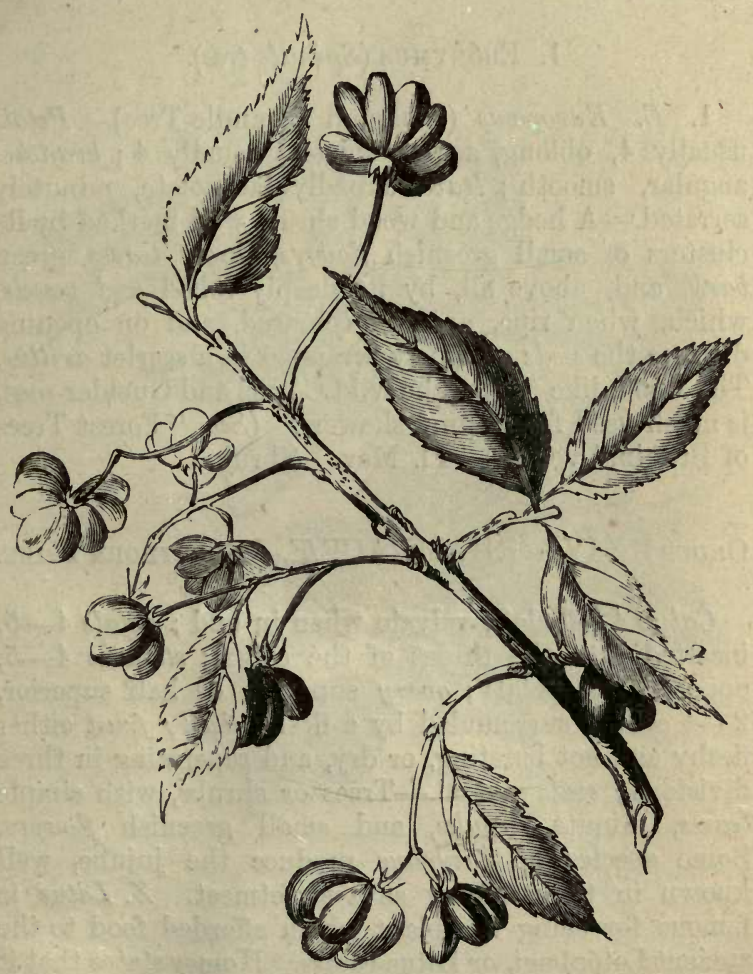

FRUIT OF EUGNYMUS EUROPAUS (Common Spindle-Tree).

The English name, Spindle-tree, is derived from the use made of its very compact wood. 
1. Euónrmus (Spindle-tree).-Capsule 3-5 angled, with 3-5 cells and valves; seeds solitary in each cell, coated with a fleshy arillus. (Name from Euónymé, the mother of the Furies, in allusion to the injurious properties of the fruit.).

\section{Euónymus (Spindle-tree).}

1. E. Europaeus (Common Spindle-Tree).-Petals usually 4, oblong, acute; stamens usually 4 ; branches angular, smooth; leaves broadly lanceolate, miriutely serrated.-A hedge and wood shrub, well marked by its elusters of small greenish flowers, glossy leaves, green bark, and, above all, by its deeply lobed seed vessels, which, when ripe, are rose-coloured, and on opening disclose the seeds curiously wrapped in a scarlet arillus. The wood, like that of the wild Cornel and Guelder-rose, is much used for making skewers. (See "Forest Trees of Britain," vol. ii.)-Fl. May. Shrub.

\section{ORdER XXIV.-RHAMNACE A.-BuCkTHoRN TRIBE.}

Calyx 4-5 cleft, valvate when in bud; petals 4-5, inserted into the throat of the calyx; stamens $4-5$, opposite the petals ; ovary superior, or half superior, $2-4$ celled, surrounded by a fleshy disk; fruit either fleshy and not bursting, or dry, and separating in three divisions; seeds several.-Trees or shrubs, with simple leaves, minute stipules, and small greenish flowers. Some species of Zizyphus produce the jujube, well known in this country as a sweetmeat. $Z$. Lotus is famous for being the plant which afforded food to the ancient Lotóphagi, or Lotus-eaters. Homer states that it was so delicious, that whatever stranger once tasted it, immediately forgot his friends and native country, and desired only to dwell within reach of it. It is a prickly shrub, and bears an abundance of purplish berries, of 
the size of sloes, and containing large stones. The pulp is mealy, and of a delicious flavour. Under the name of seedra, or sadr, it still affords food to the Arabs, who separate the pulp from the stone by gently pounding the

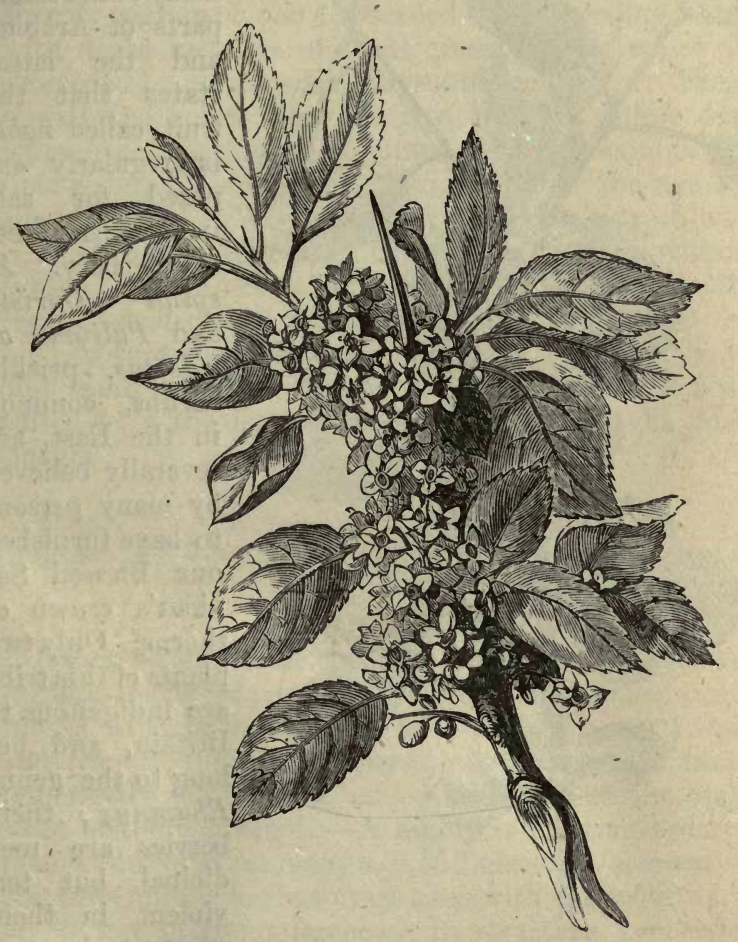

RHAMNUS CATHARTICUS (Common Buckthorn).

fruit in a mortar, and either convert it into a kind of bread at once, or lay it by for winter use. A kind of wine is also made from the fruit, but this will not.keep 
for more than a few days. Mungo Park, Dr. Shaw, and other travellers,

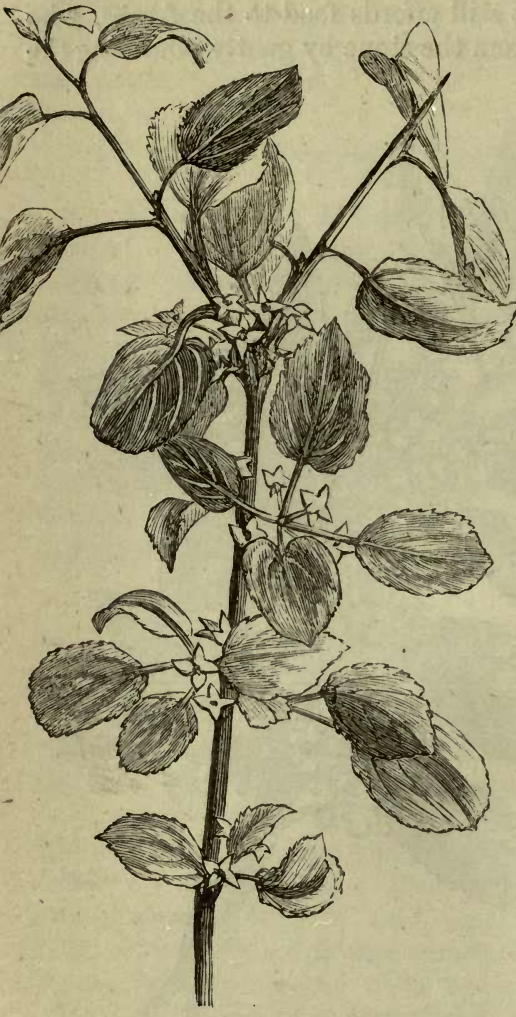

Rhamnus Cathaticus (Common Buckthorn). found the tree in abundance in many of the sandy parts of Arabia; and the latter states that the fruit, called nabk, is regularly exposed for sale in the markets of Barbary. $Z$. spina - Christi, and Paliúrus aculeátus, -prickly shrubs, common in the East, are severally believed by many persons to have furnished our Blessed Saviour's crown of thorns. Only two plants of this tribe are indigenous to Britain, and belong to the genus Rhamnus; their berries are medicinal, but too violent in their effects to be used with safety.

1. Rhamnus (Buckthorn).-Caly $x$ vase-like, 4-5 cleft; petals 4-5 (sometimes wanting); stamens $4-5$, inserted with the petals into the throat of the calyx; berry 2-4-celled. (Name from the Greek rhamnos, a branch.) 


\section{Rhamnus (Buckthorn).}

R. cathárticus (Common Buckthorn).-Branches terminating in thorns; flowers 4-cleft, diœcious (stamens and pistils on separate plants); leaves egg-shaped, sharply serrated; berry 4-seeded.-A spreading shrub with dense branches of small green flowers, which are succeeded by black, powerfully cathartic berries. These, if gathered before they are ripe, yield a yellow dye; when ripe, they form, if mixed with gum-arabic and lime-water, the green coloür known under the name of Bladder-green.-Woods and thickets.-Fl. May. Shrub.

R. Frángula (Alder Buckthorn).-Branches without thorns; flowers 5-cleft, all perfect; leaves entire, smooth; berry 2-seeded.-A rather slender shrub, 6-10 feet high, with smooth blackish branches, deep green leaves, and small greenish flowers, which are not so densely tufted as in the last.-Woods and thickets.-Fl. May. Shrub.

Order XXV.-LEGUMINOSAE.-PeA and Bean TRIBE.

Calyx 5-cleft, with the odd lobe in front; petals 5, papilionaceous ; stamens 10 , their filaments either united into a tube, or forming 2 sets of 9 and 1 ; ovary, style, and stigma, single; seed-vessel a 2 -valved, sometimes imperfectly jointed pod, or legume; seeds on the upper seam of the pod-valves.-A highly interesting order of plants, containing as many as 6,500 species, which vary in size from minute herbs to vast trees with trunks upwards of 80 feet in circumference. In structure, properties, colour of flowers, and range of growth; they vary scarcely less than in dimensions; they are found in all parts of the known world, except St. Helena and another remote island; many species, under the general name of pulse, afford most nutritious food-for example, Peas, 
Beans, and Lentils; others supply valuable fodder for cattle, as Clover, Vetches, and Lucerne ; Rosewood, Logwood, and Acacia offer examples of timber ; Gum Arabic, Càtechu, Senna, Kino, Liquorice, Balsam of Tolu, and Tamarinds, are the products of other species ; Tonka Bean and Balsam of Peru are well-known perfumes; several species of Indigofera afford the valuable article of commerce, Indigo ; and in Persia and Bokhara, a tree called Camel's Thorn produces abundance of Manna, which in those countries is an important article of food. Other species possess medicinal properties of various kinds; not a few are poisonous; and it is worthy of remark that some, the seeds of which are eminently nutritious, have properties of an opposite nature residing in other parts of the plant. The roots of the Kidney Bean, for instance, are dangerously narcotic. The dry pulp which encloses the seeds of the Carob-tree is by some supposed to have been the food of John the Baptist in the wilderness, on which account it is called Locust-tree, and St. John's Bread. The Locust-trees of America (different from the eastern tree) attain an immense size. Martius represents a scene in Brazil, where some trees of this kind occurred of such enormous dimensions, that 15 Indians with outstretched arms could only just embrace one of them. At the bottom they were 84 feet in circumference, and 60 feet where the boles became cylindrical. According to one estimate, they were 2,052 years old, while another carried it up to 4,104. Many plants belonging to the Mimosa group display peculiar irritability in their pinnate leaves. This is particularly the case with $M$. sensitiva and $M$. pudica, which are commonly called Sensitive plants. Almost all the plants of the order which have compound leaves fold them together during the nights. In some foreign species of Leguminosæ the legume loses its characteristic form, and assumes the appearance of a drupe, the papilionaceous form of the flower remaining ; in others the petals lose the papilionaceous arrange- 
ment; but the seed-vessel retains the form of a legume. All the British species, however, are decidedly papilionaceous, and the principal varieties of form in the pod are those of the Bird's-foot and others, where it is imperfectly jointed, and in Medick, where it is often spirally twisted, so as to resemble a snail-shell. The number of British species amounts to nearly seventy, of which two species of Furze, three of Genista, and one of Broom, are shrubs ; the rest are herbaceous. For convenience of reference, these are divided into groups.

$$
\text { Group I.-Lotes.-The Lotus group. }
$$

Legume not jointed; leaves simple, of 3 leaflets, or pinnate with an odd one.'

* Leaves simple, or of 3 leaflets ; stamens all united by their filaments.

1. Ulex (Furze).-Calyx of 2 sepals, with 2 minute bracts at the base; legume swollen, few-seeded, scarcely longer than the calyx. (Name from the Celtic ec or $a c$, a prickle.)

2. Genista (Green-weed).-Calyx 2-lipped, the upper lip 2-cleft, the lower with 3 teeth; standard oblong; style awl-shaped; legume swollen, or flat. (Name from the Celtic gen, a shrub ; Planta Genista originated the distinctive name of the Plantagenet family.)

3. Sarothámus (Broom). - Calyx 2-lipped, the upper lip with 2 , the lower with 3 teeth; standard broadly ovate; style thickened upwards; legume flat, manyseeded. (Name, the Greek name of the plant.)

4. ONónis (Rest-harrow).-Calyx 5-cleft, its segments very narrow; keel beaked; style thread-like; legume swollen, few-seeded. (Name from the Greek onos, an ass, by which animal the plant is eaten.)

* Leaves of 3 leaflets; stamens in 2 sets of 9 and 1 .

5. Medicágo (Medick).-Legume sickle-shaped, or 
spirally twisted. (Name of Greek origin, and denoting that some plant of the family was introduced from Media.)

6. MeLriótus (Melilot).-Calyx with 5 nearly equal teeth; petals distinct, soon falling off ; legume of few seeds, longer than the calyx. (Name from mel, honey, and lotus, the plant so called.)

7. Trigonélla(Fenugreek).-Caly $x$ with 5 nearly equal teeth; petals distinct; ktel obtuse; legume straight or nearly so, many-seeded. (Name in Greek denoting threeangled, from the form of the corolla).

8. Trifólium (Trefoil).-Calyx with 5 unequal teeth; petals combined by their claws, and persistent; legume of few seeds, concealed in the calyx. (Name from tria, three, and folium, a leaf, each leaf being composed of 3 leaflets.)

9. Lotus (Bird's-foot Trefoil).-Calyx with 5 nearly equal teeth; keel beaked; legume cylindrical, manyseeded, and imperfectly many-celled. (Name from the Greek lotos.)

\section{*** Leaves pinnate, with a terminal leaflet.}

10. Anthylurs (Lady's Fingers).-Stamens all united by their filaments ; caly $x$ inflated, 5 -toothed; legume enclosed in the calyx. (Name from the Greek anthos, a flower, and ioulos, down, from the downy calyx.)

11. OxÝtropis.-Stamens in 2 sets, 9 and 1 ; keel of the corolla pointed; legume more or less perfectly 2-celled. (Name from the Greek oxys, sharp, and tropis, a keel.)

12. Astrágalus (Milk Vetch).-Stamens in 2 sets, 9 and 1 ; keel of the corolla blunt; legume more or less perfectly 2-celled. (Name from the Greek astrágalos, a pastern bone, from the knotted form of the root of the plant to which the name was originally given.) 


\section{Group II.-VICIEs.-The Vetch Group.}

Legume not jointed; stamens in 2 sets, 9 and 1 ; leaves pinnate, terminating in a tendril or short point.

13. VícIa (Vetch).-Calyx 5-cleft; style thread-like, or angular, with a small ring of down near the extremity, or a tuft on the under side; leaves with tendrils. (Name originally derived, according to Théis, from gwig, Celtic; wicken, in German; bikion, in Greek; vesce, in French.Hooker.)

14. Láthyrus (Vetchling).-Calyx 5-cleft; style flattened on the upper side, downy beneath the stigma; leaves with tendrils, except in $L$. Nissolia. (Name from the Greek lathyros, a plant so called.)

15. ÓnoBus (Bitter Vetch).-Calyx 5-cleft, swollen at the base, oblique at the mouth, its upper segments deeper and shorter; style flattened on the upper side, downy on the upper side; leaves ending in a short point. (Name from the Greek oro, to stimulate, and bous, an ox, from its nutritive properties.)

\section{Group III.-HedysáREe.-The Joint-Vetch Group.}

Legume divided into 1-seeded joints or cells; leaves pinnate, with an odd leaflet.

* Flowers simple, in umbels.

16. ORNítropus (Bird's-foot). - Legume curved, divided into many equal-sided joints, each of which contains a seed; keel small, obtuse. (Name from the Greek ornis, a bird, and pous, a foot, to which the tufts of seed-vessels bear a singular resemblance.)

17. HipPocRÉPIS (Horse-shoe Vetch).-Legume composed of numerous crescent-shaped joints, so that each legume has many deep notches on one side; keel narrowed into a beak. (Name from the Greek hippos, a horse, and crepis, a shoe, from the form of the joints of the seed-vessels.) 
** Flowers in racemes.

18. ONóвRYchIs (Saint-foin).-Legume straight, 1celled, 1-seeded, not opening, the lower edge fringed or winged. (Name from the Greek, onos, an ass, and brycho, to bray, it being supposed that the smell excites braying.)

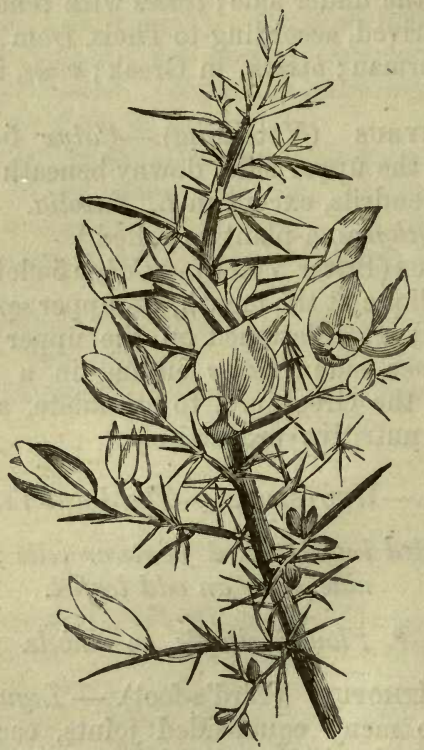

ULEX EUROPAUS (Common Furze.)

\section{Ulex (Furze).}

1. U. Europoeus (Common Furze, Gorse, or Whin). -Bracts ovate, not adhering closely to the calyx; branches copiously beset with branched thorns.-A much branched, spreading shrub, almost leafless, except in its seedling state, when the leaves are composed of 3 narrow, soft leaflets. It attains maturity in about four 
years, but in sheltered places continues to grow until it reaches a height of from 12 to 18 feet. Its natural habit is, however, to grow on dry, exposed commons, which, in its flowering season, it covers with a gorgeous sheet of golden blossoms, entirely concealing its somewhat unsightly branches. Perhaps no plant is so broadly characteristic of English scenery, and the English climate, as "Yellow Whin." It does not thrive in hot countries; and if removed to a much colder climate, pines and dies; it is rare even in the Highlands of Scotland. The seed-vessels burst elastically in hot weather with a crackling noise, scattering the seeds on all sides. The calyx-teeth of this species are so closely united as to be scarcely visible.-Fl. February-June. Shrub.

* A variety has been found in Ireland, which does not flower freely, and also differs from the common form of the plant in having a soft and succulent, instead of a rigid, habit. This variety has been cultivated with success as fodder for sheep and oxen.

2. U. nanus (Dwarf Furze).-Calyx-teeth spreading; bracts minute, closely pressed to the calyx.-A very distinct species from the last, with which, however, it is sometimes confounded. It may readily be distinguished by the above characters, by being smaller in all its parts, and by the spreading wings of its flowers, which, moreover, usually appear at the same season with the Heath; a plant with which it loves to intertwine its rigid branches.-Fl. August-November. Shrub.

\section{Genista (Green-weed).}

1. G. Ánglica (Needle Green-weed, or Petty Whin). - Stems thorny and leafless below; leaves narrow, smooth ; legumes smooth, inflated.-Not uncommon on heaths and moors. A low'shrub, about a foot high, with reclining tough stems, which are armed at intervals with groups of slender, very sharp thorns. The 
upper branches are destitute of thorns, and produce leafy clusters of yellow flowers, which (like some other yellow

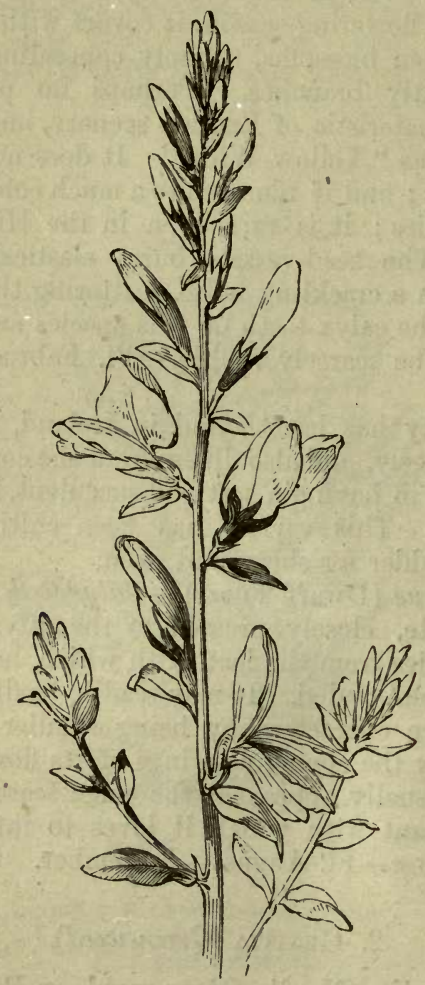

GENISTA TINCTORIA (Dyer's Green-weed, Woad-waxen).

flowers belonging to this Natural Order) are remarkable for turning green in drying,-Fl. May, June. Shrub. 2. G. tinctória (Dyer's Green-weed, Woad-waxen). 


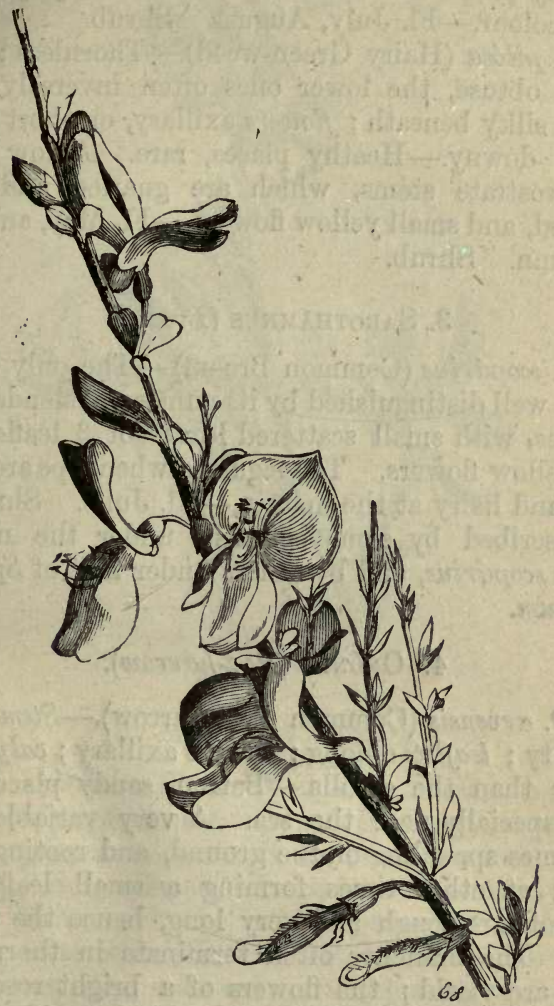

SAROTHÁMNUS SCOPARIUS (Common Broom).

-Thornless; leaves narrow, acute, nearly smooth; flowers in clusters; legumes flattened, smooth.-A low shrub, about a foot high, with tough stems, bright-green L 2 
foliage, and yellow flowers on short stalks. It grows in heathy places and fields, and is used to dye yarn of a yellow colour.-Fl. July, August. Shrub.

3. G. pilósa (Hairy Green-weed).--Thornless ; leaves narrow, obtuse, the lower ones often inversely heartshaped, silky beneath; flowers axillary, on short stalks ; legumes downy.-Heathy places, rare. A low shrub, with prostrate stems, which are gnarled and much branched, and small yellow flowers.-Fl. May, and again in autymn. Shrub.

\section{Sarothámús (Broom).}

'1. S. scoparius (Common Broom).-The only British species, well distinguished by its numerous, slender, erect branches, with small scattered leaves of 3 leaflets, and large yellow flowers. The legumes when ripe are nearly black, and hairy at the margin.-Fl. June. Shrub.

* Described by some botanists under the name of Cýtisus scopárius, and by others under that of Spartium scoparium.

\section{Onónis (Rest-harrow).}

1. O. arvensis (Common Rest-harrow).-Stem shrubby, hairy ; leaflets oblong ; flowers axillary ; calyx much shorter than the corolla.-Barren, sandy places, common, especially near the sea. A very variable plant, sometimes spreading on the ground, and rooting at the joints; at other times forming a small leafy bush. The roots are tough and very long, hence the English name. The branches often terminate in thorns; the leaves are viscid; the flowers of a bright rose-colour, and handsome. According to some botanists, several species are included under one name.-Fl. all the summer. Perennial.

* 0 . reclináta (Small Spreading Rest-harrow) is a herbaceous species which, as a British plant, occurs only near Tarbert, Galloway. 


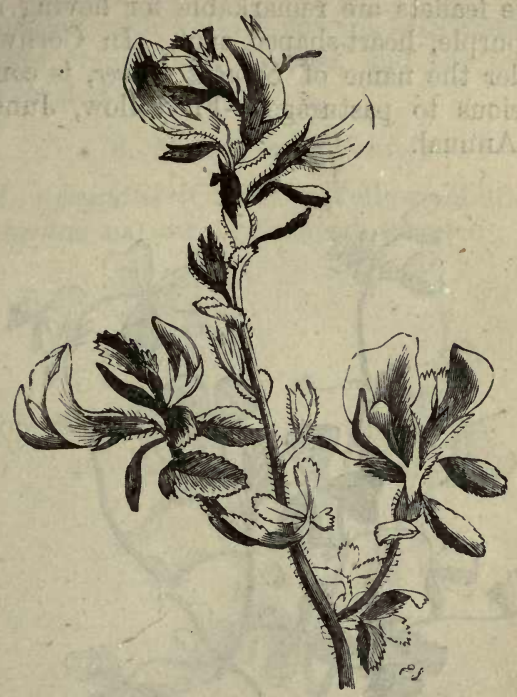

oNGNIS ARVENSis (Common Rest-harrow).

\section{MediCáGo (Medick).}

1. M. Tupulina (Black Medick, or Nonsuch).-Leaflets inversely egg-shaped, finely toothed; stipules scarcely notched; flowers in dense oblong heads; legumes rugged, 1-seeded, kidney-shaped. - In pastures, common. A herbaceous plant, with the habit of some of the smaller Clovers, from which it may be distinguished by its legumes not being enclosed within the calyx. Flowers yellow ; legumes black, not spirally curved.-Fl. JuneAugust. Annual.

2. M. maculáta (Spotted Medick).-Leaflets inversely heart-shaped; stipules toothed; flowers $2-4$ together; legumes spirally twisted into a prickly ball; prickles curved.-In the south and west of England, not uncom- 
mon. The leaflets are remarkable for having in their centre a purple, heart-shaped spot. In Cornwall this plant, under the name of Spotted Clover, is considered very injurious to pasturage.-Fl. yellow, June-September. Annual.

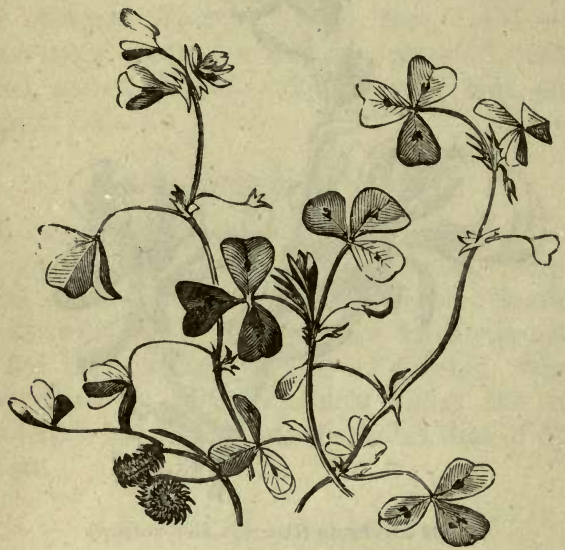

Medicago maculata (Spotted Medick).

3. M. mínima (Little Bur-Medick).-Leaflets inversely egg-shaped, downy; stipules scarcely toothed; flowers $2-4$ together; legumes spirally twisted into a prickly ball ; prickles hooked.-Sandy places, rare.-Fl. yellow, June, July. Annual.

4. $M$. denticulata (Toothed Medick).-Leaflets inversely heart-shaped, smooth ; stipules jagged; flowers 2-4 together; legumes loosely spiral; prickles hooked. -Very rare.-Fl. yellow, April-June. Annual.

* Besides the above, two other species of Medicágo are occasionally found, which are supposed to have escaped from cultivation. $M$. sativa (Lucerne), which has purple flowers, and $M$. falcáta (Sickle Medick), an 
allied species with yellow flowers. In these two the leaflets are oblong and toothed, and the legumes are slightly twisted.

\section{Melilótus (Melilot).}

1. $M$. officinális (Common Yellow Melilot).-Stem erect; leaflets narrow, egg-shaped, serrated ; flowers in

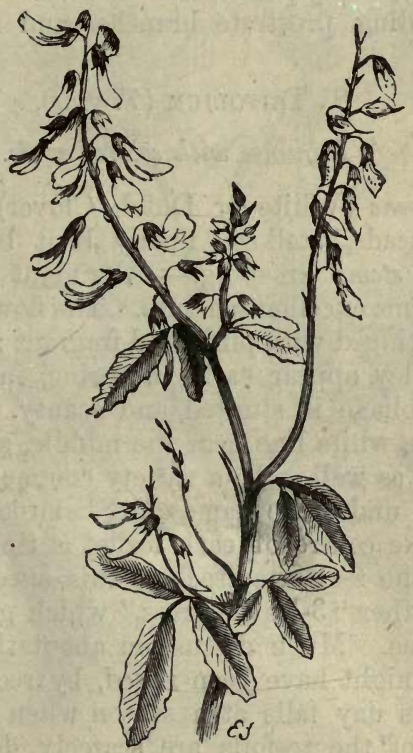

MELILÓTUS OFFICINÁlis (Common Yellow Melilot).

1-sided clusters; petals equal in length; legumes 2seeded, wrinkled.-A branched herbaceous plant, 2 to 3 feet high, with light green foliage, and small yellow flowers, not uncommon in waste places. This plant, while drying, smells like Woodruff, or new hay.-Fl. June-August. Annual. 
* M. leucantha (White Melilot), a much less common plant, differs from the preceding in having white flowers, in which the standard is longer than the wings and keel.

\section{Trigonella (Fenugreek).}

1. T.ornithopodioídes (Bird's-foot Fenugreek)._-Flowers $2-3$ together; legumes 8-seeded, twice as long as the calyx.-Dry, sandy places, not common. A small plant, with spreading prostrate branches and small reddish flowers.

\section{Trifolitum (Trefoil). \\ * Legumes with several seeds.}

1. T. repens (White or Dutch Clover).-Flowers in roundish heads, stalked, finally bent back; legumes 4-seeded; stems creeping.-Abundant in meadows, where it forms excellent pasture. The flowers are white, sometimes tinged with pink, and fragrant; on the sandy sea coast they appear early in spring, in which situations the foliage is stunted and scanty. The leaflets often have a white line near the middle, and sometimes a dark spot as well. In a variety commonly cultivated in gardens, under the name of Shamrock, nearly the whole of the centre of each leaflet is tinged with dark purple. The real Shamrock is this species, and, perhaps, any other " 3 -leaved grass" which grows in similar situations. Much discussion about the identity of Shamrock might have been saved, by recollecting that St. Patrick's day falls at a season when the botanical characters of the trefoils are scarcely developed, and that the devotees of that Saint can scarcely be expected to have possessed much botanical knowledge. Some antiquarians contend that, as Ireland was a well-wooded country in St. Patrick's time, the Saint very probably selected a leaf of Wood-Sorrel (Óxalis Acetosella) to illustrate the Doctrine of the Trinity.-Fl. through the summer.' Perennial. 
* Legumes 1 or 2 seeded; standard falling off; or remaining unaltered; calyx not inflated.

2. T. pratensé (Purple Clover).-Flowers in dense, roundish oblong heads; caly» hairy, its bristle-like

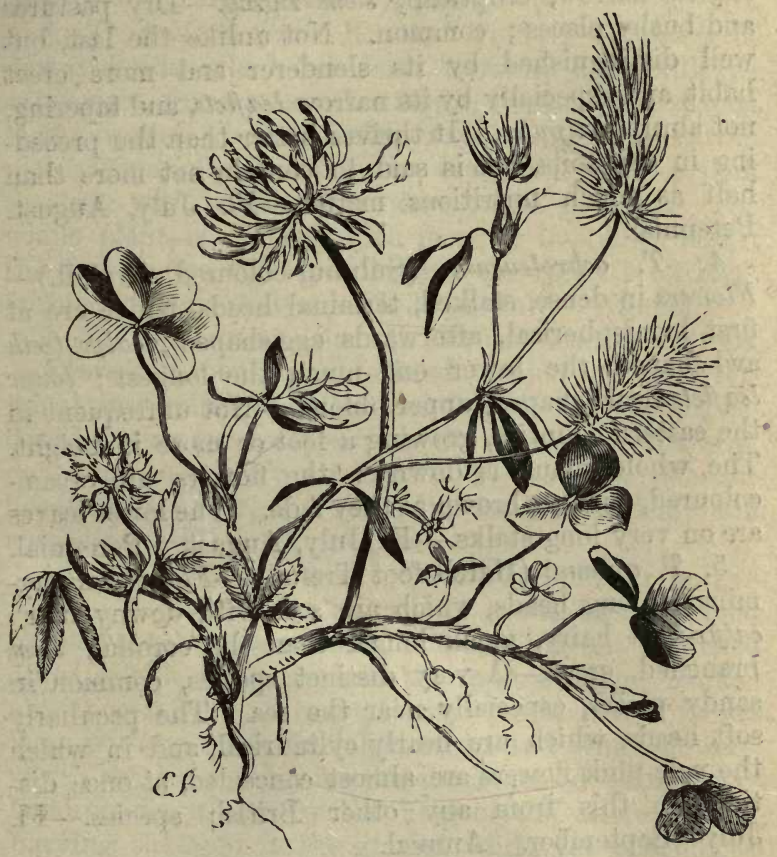

TRIFOLIUM STRICTUM, SUBTERRANEUM, REPENS, and ARVENSE.

divisions half as long as the corolla; stipules broad, terminating abruptly in a bristle-point; leaflets broad, notched, or entire.- The common Clover of meadows, where it forms a valuable part of the hay crop. The long tubes of the corolla abound in honey, on which 
account they are often called by children Honeysuckles. -Fl. all the summer. Perennial.

3. T. médium (Zigzag Clover).-Flowers in loose, stalked, round heads; calyx-teeth bristle-like, the 2 upper shortest; stipules narrow, tapering to a point; leaflets narrow, elliptical; stem zigzag.-Dry pastures and bushy places; common. Not unlike the last, but well distinguished by its slenderer and more erect habit, and especially by its narrow leaflets, and tapering, not abrupt, stipules. It thrives better than the preceding in dry soils, but is said to contain not more than half as much nutritious matter.-Fl. July, August. Perennial.

4. T. ochroleucum (Sulphur-coloured Trefoil.)Flowers in dense, stalked, terminal heads, which are at first hemispherical, afterwards egg-shaped; calyx-teeth awl-shaped, the lower one much the longest; lower leaflets heart-shaped, upper oblong.-Not unfrequent in the eastern counties, growing a foot or more in height. The whole plant is downy; the flowers are creamcoloured, turning brown as they fade. The lower leaves are on very long stalks.-Fl. July, August. Perennial.

5. T. arvensé (Hare's-foot Trefoil).-Flowers in terminal oblong heads, which are soft with downy hair; calyx-teeth hairy, much longer than the corolla; stem branched, erect.-A very distinct species, common in sandy places, especially near the sea. The peculiarly soft heads, which are nearly cylindrical, and in which the pale-pink flowers are almost concealed, at once distinguish this from any other British species.-Fl. July-September. Annual.

6. T. marítimum (Teazel-headed Trefoil).-Flowers in terminal roundish heads; calyx-teeth broad, pointed, and rigid, shorter than the corolla, finally becoming enlarged and spreading; stipules awl-shaped, very long. -Salt-marshes ; not common. Stem spreading; flowers pink, small.-Fl. June-July. Annual.

7. T. scabrum (Rigid Trefoil).-Flowers in dense 
prickly heads, which are both terminal and axillary; calyx-teeth unequal, very rigid, finally spreading; stems prostrate.-Barren places, especially near the sea. A small plant, with inconspicuous whitish flowers, and remarkable only for its prickly calyces, especially when in fruit.-Fl. June, July. Annual.

8. T. striátum (Soft Knotted Trefoil).-Flowers in downy heads, which are both terminal and axillary; calyx rigid, furrowed, with straight, unequal, awl-shaped teeth, swollen when in fruit ; stems ascending.-Barren places, especially near the sea; common. Larger than the last, with which it is often found growing. The whole plant is covered with more or less silky hairs; the flowers are light purple, and the calyx is striated with prominent nerves.-Fl. June, July. Annual.

9. T. glomeratum (Smooth Round-headed Trefoil). -Flowers in round prickly heads, which are both terminal and axillary; calyx-teeth broad, very acute, reflexed; stems prostrate.-Gravelly places near the sea; not common. Very similar to $T$. scabrum, but the heads are rounder, and the calyx-teeth more leafy and spreading.-Fl. June. Annual.

10. T. subterraneum (Subterraneous Trefoil).Flowers 3-5 together, in axillary heads, at first erect, in fruit abruptly bent down, and sending out branched fibres, which penetrate into the ground.-Dry banks; not uncommon. A curious little plant, a few inches long, with prostrate branched stems and white flowers, which are remarkable for the above-named character of bending down and, by the help of the altered calyx, burying the seed in the ground while yet attached to the plant.-Fl. May, June. Annual.

* To this group belong several other species of Trefoil, which are of local occurrence, and therefore not likely to be met with by the beginner in botany. $T$. stellátum (Starry-headed Trefoil) occurs only near Shoreham, on the coast of Sussex. It is distinguished by the remarkably large calyx of the fruit, which spreads 
in a star-like manner. T. Molinerii (a variety of the commonly cultivated $T$. incarnatum), T. Boccóni, and $T$. strictum, were, until recently, considered to be confined to the southern shores of continental Europe, but are now known to be undoubtedly wild on the cliffs of the extreme south coast of Cornwall. The first is a short downy plant, with large soft heads of white flowers ; T. Boccóni is a small plant, 2-4 inches high, with roundish heads of white or pink flowers, the heads always growing in pairs; and $T$. strictum, which is of about the same size, has globular heads of whitish flowers, and is well distinguished by its 2 -seeded legumes, which are bulged near the summit, and by its narrow-toothed leaflets, resembling in shape those of Melilótus officinális. (See "A Week at the Lizard," p. 313.)

\section{** Calyx inflated after flowering.}

11. T. fragíferum (Strawberry-headed Trefoil).Heads globose, on long stalks ; calyx, after flowering, membranaceous, downy, and remarkably inflated; stern creeping.-Meadows and pastures, often near the sea; not very common. This plant has somewhat of the habit of $T$. repens; but the flowers are light purple, and the heads of inflated calyces, which are often tinged with pink, are not unlike the fruit from which the plant receives its name.-Fl. July, August. Perennial.

*** Standard withering but not falling off, finally bending down and covering the legume; flowers yellow.

12. T. procumbens (Hop Trefoil).-Flowers in dense, roundish, oblong heads; leaves stalked.-Dry pastures; abundant. Not unlike Medicágo lupulina in habit, but at once distinguished when in fruit by the hop-like heads of withered flowers. Specimens occur on the sea coast, 2-3 inches high, with scanty foliage, and comparatively large flowers.-Fl. June, July. Annual. 
13. T. filiformé (Lesser Yellow Trefoil).-Flowers in loose heads, 3-12 together; leaves scarcely stalked.Dry pastures; abundant. Like the last, but smaller. -Fl. June, July. Annual.

\section{Lotus (Bird's-foot Trefoil).}

1. L. major (Greater Bird's-foot Trefoil).-Flowers in umbels, 8-10 together; calyx-teeth, while in bud,

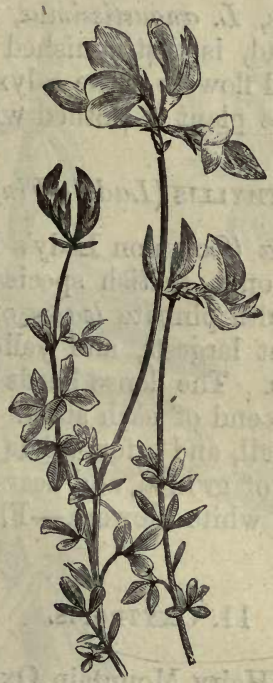

iotus CoRniculátus (Common Bird's-foot Trefoil).

spreading like a star; stems nearly erect, tubular. - In damp bushy places; common. Whole plant more or less covered with soft hair; $1-3$ feet high; stem weak, and usually supported by the bushes and other plants among which it grows.-Fl. deep yellow, July, August. Perennial. 
2. L. corniculatus (Common Bird's-foot Trefoil).Flowers in umbels, 8-10 together ; calyx-teeth straight in the bud; stems prostrate, not tubular.-Pastures; abundant. A pretty flower, familiarly known among children by the name of "Shoes-and-stockings." The foliage is usually smooth, with a few scattered hairs, or more rarely covered with long soft hairs. The flowers on the same plant, and even in the same umbel, vary from bright yellow to deep brownish orange.-Fl. July, August. Perennial.

* A third species, L. angustíssimus, which grows in the west of England, is distinguished by its bearing heads of $3-4$ small flowers ; the calyx-leaves are very long, and the whole plant is clothed with soft hairs.

\section{ANthyluis (Lady's Fingers).}

1. A. Vulneraria (Common Lady's Fingers, or Kidney Vetch).-The only British species. A handsome herbaceous plant, with pinnate leaves of a glaucous hue (the terminal leaflet largest), and yellow flowers, with pale inflated calyces. The dense heads of flowers grow two together at the end of each stalk. On some of the sea-cliffs of Cornwall, and a few other places, the plant has a stunted habit of growth, and bears crimson; purple, cream-coloured, or white flowers.-Fl. June, August. Perennial.

\section{OXÝTROPIS.}

1. O. Uralensis (Hairy Mountain Oxytropis).-Leaves and flowers rising directly from the roots; flower-stalks longer than the leaves, silky, like the rest of the plant; legume 2-celled.-Dry mountain pastures in Scotland. -Fl. in heads, bright purple, June, July. Perennial.

* Another species, O. campestris (Yellowish Mountain Oxytropis), grows on the Clova mountains. In this the leaves and flower-stalks are about equal in length; 


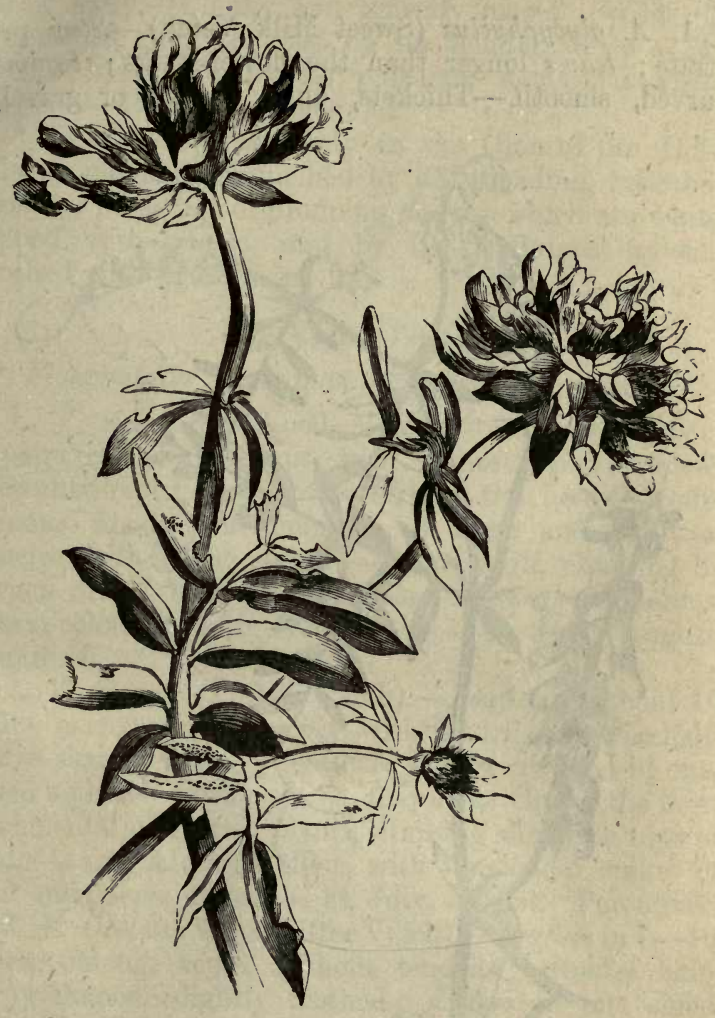

ANTHYLLIS vULNERARIA (Common Lady's Fingers).

the flowers are yellowish, tinged with purple, and the legume is imperfectly 2 -celled. 


\section{Astrágalus (Milk Vetch).}

1. A. glycyphyllus (Sweet Milk Vetch).-Stem prostrate; leaves longer than the flower-stalks; legumes, curved, smooth.-Thickets, on a chalky or gravelly

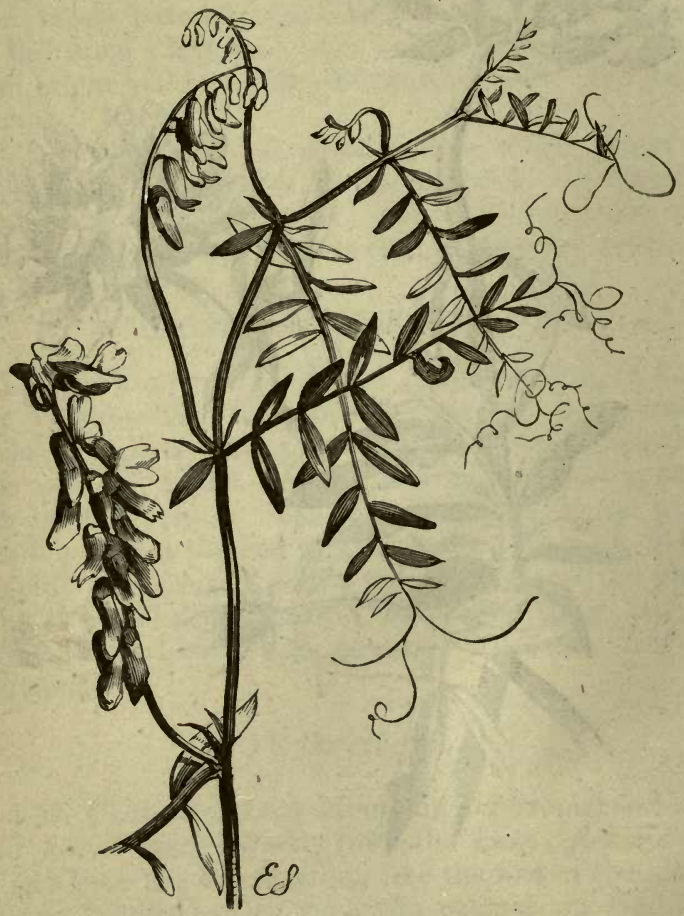

VIGIA CRACCA (Tufted Vetch).

soil. Stem 2-3 feet long; flowers in short dense spikes, dull yellow.-Fl. June, July. Perennial.

2. A. hypoglottis (Purple Milk Vetch).-Stem pro- 
strate; flower-stalks longer than the leaves; legumes erect, hairy.-Chalky and gravelly places. Well distinguished from the last by its slender stems a few inches long, and by its purplish, sometimes white, flowers.-Fl. July. Perennial.

* A. alpinus grows only in the Glen of the Dole, Clova, and is distinguished by its spreading, branched stem, by its spikes of drooping flowers, which are white, tipped with purple, and by its pendulous legumes, clothed with black hairs.

\section{Vícia (Vetch).}

* Flower-stalks longer than the leaves ; many-flowered.

1.V. sylvática (Wood Vetch).-Leaflets in about 8 pairs, elliptical, abrupt, with a short point; stipules crescent-shaped, deeply toothed at the base.-Mountainous woods, not common. A large and beautiful species, with a long stem, $3-6$ feet high, climbing by means of its branched tendrils. Flowers numerous, cream-coloured, with bluish veins.-Fl. July, August. Perennial.

2. V. Cracca (Tufted Vetch).-Leaflets in about 10 pairs, narrow, pointed, silky, with tendrils; stipules halfarrow-shaped, scarcely toothed; flowers crowded in onesided spikes.-Bushy places, frequent. One of the most ornamental of British plants, climbing along the tops of hedges, and adorning them with its slender spikes of blue and purple flowers.-Fl. July, August. Perennial.

3. V. Orobus (Wood-bitter Vetch).-Leaflets in 7-10 pairs, oblong, acute, without tendrils; stipules half arrow-shaped, slightly toothed; flowers in one sided clusters.-Rocky woods in the north. A branched herbaceous plant with many prostrate stems and purplish white flowers-Fl. May, June. Perennial.

** Flowers axillary, scarcely stalked.

4. V. sativa (Common Vetch).-Flowers in pairs, with very short stalks; leaflets oblong, in 5-7 pairs, 
the lower ones often inversely heart-shaped; stipules. half-arrow-shaped, toothed at the base, marked with a sunken dark spot; seeds smooth.-Fields; common. This species, being extensively cultivated as fodder for cattle, varies considerably in luxuriance, according to soil. It usually grows about 2 feet high, and bears blue and purple or red flowers. A small variety, $V$. angustifolia (Narrow-leaved Vetch), by some botanists considered a distinct species, has very narrow leaves, and crimson flowers.-Fl. June, July. Annual.

5. V. lathyroídes (Spring Vetch).-Flowers solitary, sessile; legumes smooth; leaflets in 2-3 pairs ; stípules entire, not marked with a dark spot; seeds nearly cubical, roughish.-Dry places, but not very common. Nearly allied to the last, but very much smaller, rarely exceeding 6 inches in length.-Fl. bright purple, April, May. Annual.

6. V. lútea (Rough-podded Yellow Vetch).-F'lowers solitary, sessile; legumes hairy; stipules marked with a deep red blotch.-Sea-coast; rare. About 2 feet high, with pale yellow, rather large flowers.-Fl. June, July. Perennial.

7. V. sépium (Bush Vetch).-Flowers in axillary clusters of from 4-6; legumes smooth; leaflets eggshaped, obtuse, gradually decreasing in size towards the end of the leaf-stalk.-Woods and shady hedges; common. Distinguished by its clusters of bluish purple flowers, which grow on short stalks in the axils of the leaves.-Fl. May, June. Perennial.

*** Flower-stalks elongated; few flowered; style, downy all round.

8. V. hirsúta (Hairy Vetch, or Tare).-F'lowers about 6 together; legumes hairy, 2-seeded.-Fields and hedges; very common. A slender, much-branched plant, forming tangled masses of stems and leaves, with minute bluish white flowers. This, though a mischievous weed, is not the Tare of the Holy Scriptures 
which is supposed to be the Darnel (Lólium temuléntum).-Fl. June, July. Annual.

This and the following species are by some botanists placed in a distinct genus, Ervum.

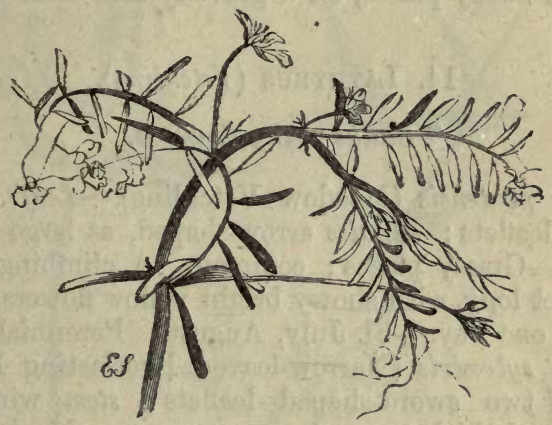

víla hirsúta (Hairy Tare).

9. V. tetraspérma (Smooth Vetch, or Tare).-Flowers about 2 together, on a slender stalk; legumes smooth, 4-seeded.-In similar situations with the last, but less common. The flowers are light purple, and the whole plant much slenderer and less branched than $V$. hirsúta. -Fl. June, July. Annual.

* $V$. grácilis (Slender Vetch, or Tare) is by some botanists considered a distinct species; others make it a variety of the last. The flowers grow $1-4$ together, and the legumes are 6-8-seeded. It has been found in Kent and the Isle of Wight. Other, but less common, species of Vetch, are $V$. hýbrida (flowers yellow); closely allied to $V$. lútea, but distinguished by having the outside of the standard clothed with abundance of shining yellowish hair; this is found only on Glastonbury-Tor Hill, and at Swan Pool, near Lincoln: $V$. laevigáta (flowers pale blue, or whitish), allied to the last, but having smooth, not hairy, legumes ; grow- 
ing on the pebbly shore of Weymouth, Dorsetshire : V. Bithýnica (flowers solitary, stalked, purple with whitish wings), which has 4 pairs of leaflets on the lower leaves, and only 2 on the upper. This last grows in bushy places, on a gravelly soil, near the sea.

\section{LÁthyRUS (Vetchling). \\ * Stalks many-flowered.}

1. L. pratensis (Meadow Vetchling).-Leaf of two narrow leaflets; stipules arrow-shaped, as large as the leaflets.-Grassy places; common. A climbing plant, 2-3 feet long, with showy bright yellow flowers, which all turn one way.-Fl. July, August. Perennial.

2. L. sylvestris (Narrow-leaved Everlasting Pea).Leaf of two sword-shaped leaflets; stem winged.Woods and thickets; not very common. Much resembling the "Everlasting Pea" of gardens (L. latifolius). The stems climb to the height of $5-6$ feet ; the flowers are large, greenish yellow tinged with purple, but not. so handsome as those of the garden species.-Fl. July, August. Perennial.

3. L. palustris (Blue Marsh Vetchling).-Leaf of $2-4$ pairs of very narrow acute leaflets ; stem winged.Boggy meadows ; rare. A climbing plant, with bluish purple flowers, smaller than the last.-Fl. July, August. Perennial.

4. L. marítimus (Sea-side Everlasting Pea).-F'lowerstalks shorter than the leaves; leaves of $3-8$ pairs of egg-shaped leaflets; stem angular, not winged.Pebbly sea-shores ; rare. Stems prostrate, about a span long; flowers purple, variegated with crimson and blue. -Fl. July, August. Perennial.

\section{** Stalks single-flowered.}

5. L. Áphaca (Yellow Vetchling).-Tendrils without leaves ; stipules very large, leaf-like, half-arrow-shaped. 
PEA AND BEAN TRIBE.

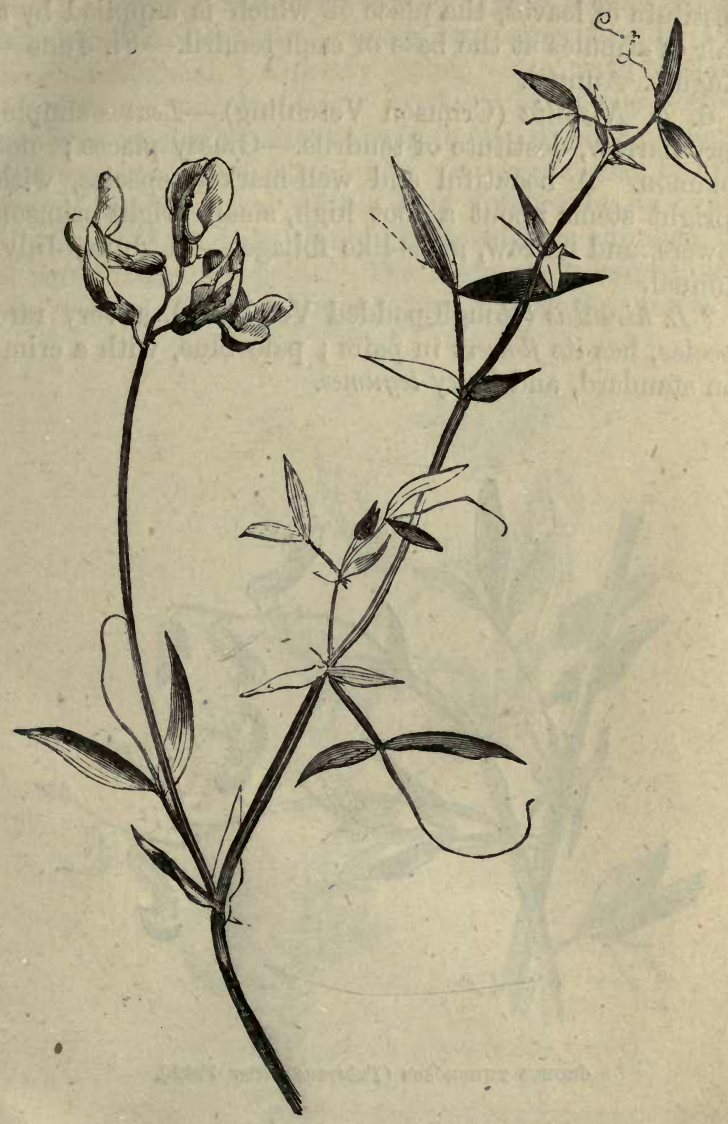

LATHyRus pratensis (Meadow Vetchling).

--Sandy and gravelly fields ; rare. A pretty little plant, with yellow flowers, and remarkable for being entirely 
destitute of leaves, the place of which is supplied by a pair of stipules at the base of each tendril.-Fl. JuneAugust. Annual.

6. L. Nissólia (Crimson Vetchling).-Leaves simple, very narrow, destitute of tendrils.-Grassy places; not common. A beautiful and well-marked species, with upright stems about a foot high, small bright crimson flowers, and narrow, grass-like foliage.-Fl. June, July. Annual.

* L. hirsútus (Rough-podded Vetchling), a very rare species, has its flowers in pairs ; pale blue, with a crimson standard, and hairy legumes.

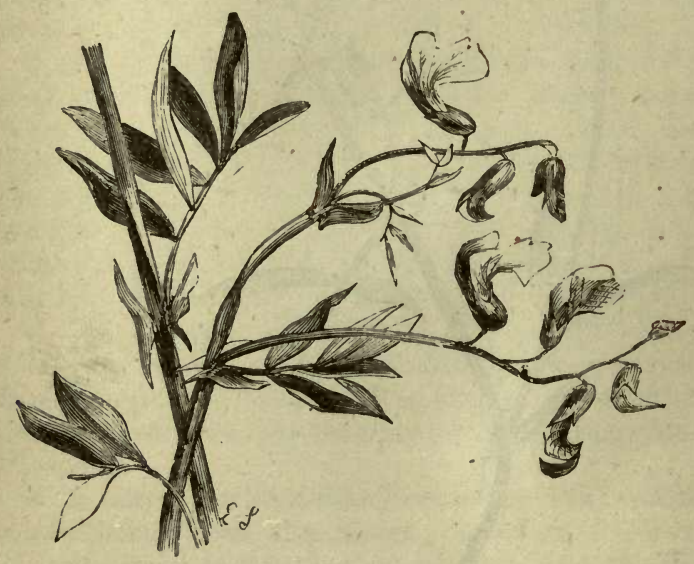

6ROBUS TUBERósus (Tuberous Bitter Vetch).

15. ÓROBUs (Bitter Vetch).

1. O. tuberósus (Tuberous Bitter Vetch).-Leaves of 2-4 pairs of oblong leaflets, which are glaucous be- 
neath ; stipules half-arrow-shaped; stem simple, erect, winged.-Woods; not uncommon, especially in the west of England. A pretty spring Vetch, with clusters of blue and purple flowers in the axils of the leaves, growing in similar situations with the Wood Anemone, but appearing somewhat later. It may at once be distinguished from any of the true. Vetches by its being destitute of tendrils, the place of which is supplied by a soft bristle-like point. The roots are tuberous, and are "eaten by the Highlanders, under the name of

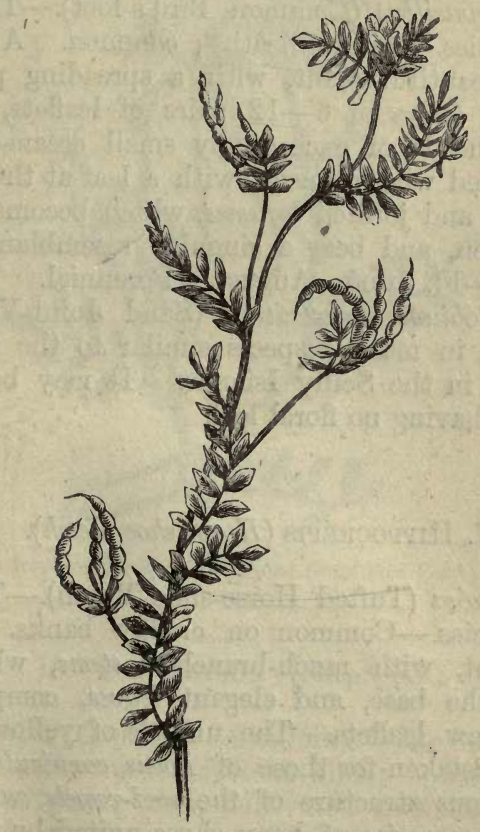

ORNITHOPUS PERPUSILLU'S (Common Bird's-foot). 
Cormeille, a very small quantity being said to allay and prevent hunger." (Sir W. J. Hooker.)-Fl. May, June. Perennial.

* Another species of Órobus is a native of Britain ; o. niger (Black Bitter Vetch), a rare Scottish plant, with very narrow stipules, and a branched stem, which is angular, but not winged.

\section{ORníthopus (Bird's-foot).}

1. O. perpusillus (Common Bird's-foot).-The only British species.-Sandy heaths; common. A minute and very beautiful plant, with a spreading prostrate stem, downy leaves of 6-12 pairs of leaflets, and an odd one; heads of exceedingly small cream-coloured flower's, veined with crimson, with a leaf at the base of each head; and jointed legumes, which become curved as they ripen, and bear a singular resemblance to a bird's foot.-Fl. June-August. Perennial.

* Arthrolóbium ebracteátum (Sand Joint-Vetch), a little plant, in many respects similar to the last, has been found in the Scilly Islands. It may be distinguished by having no floral leaf.

\section{Hippocrépis (Horse-shoe Vetch).}

1. H. comósa (Tufted Horse-shoe Vetch).-The only British species.-Common on chalky banks. A low tufted plant, with much-branched stems, which are woody at the base, and elegant leaves, composed of 6-12 narrow leaflets. The umbels of yellow flowers might be mistaken for those of Lotus corniculatus, but for the curious structure of the seed-vessels, which are shaped like a series of horse-shoes united by their extremities.-Fl. May-August. Perennial. 


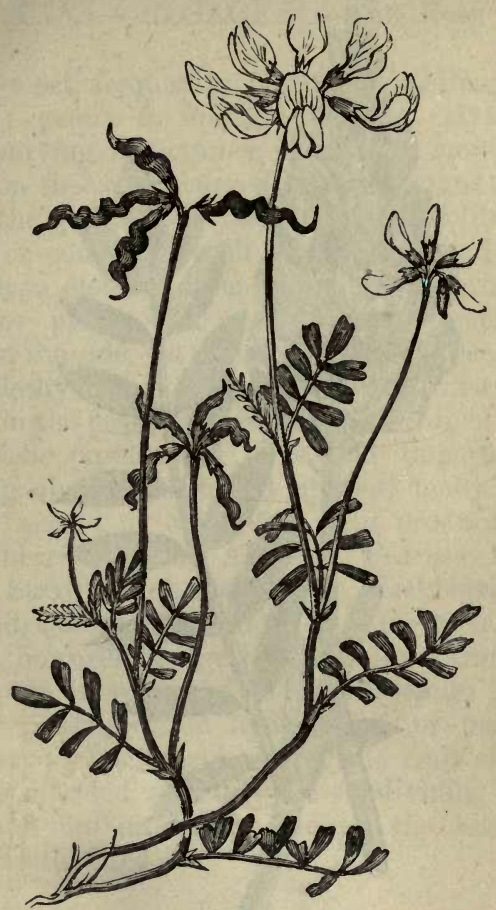

HIPPOCRÉPIS COḾ́sA (Tuftéd Horse-shoe Vetch).

18. ONóbrychis (Saint-foin).

1. O. sativa (Common Saint-foin).-The only British species.-Chalky and limestone hills; not uncommon. A handsome plant, often cultivated as fodder in dry, chalky and gravelly soils. The stems are $1-2$ feet long; the leaves are composed of 8-12 pairs of oblong 


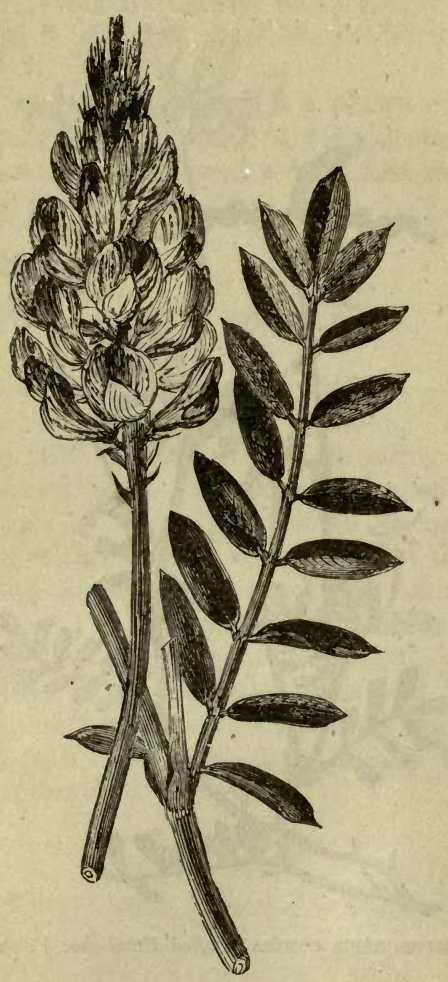

oNóbRychis satfia (Common Saint-foin).

leaflets, with an odd one, and the flowers, which grow in clusters, or rather spikes, are crimson, variegated with pink and white.-Fl. June, July. Perennial. 


\section{Ord. XXVI.-ROSACEA.-The Rose Tribe.}

Calyx most frequently 5-lobed, sometimes 4 , 8 , or 10-lobed; petals 5, inserted on the calyx, regular; stamens varying in number, generally more than 12 , inserted on the calyx, curved inwards before the expansion of the petals; carpels many, or solitary, either distinct, or combined with each other and with the calyx ; styles distinct, often lateral ; fruit either a drupe (cherry, or plum),-an assemblage of erect capsules opening at the side, - a number of nut-like seeds inserted into a fleshy receptacle (Strawberry, Blackberry), enclosed in the fleshy tube of the calyx (hip of the Rose), -or a pome (apple).-A large and important Order, containing about a thousand species, many of which, either in a wild or cultivated state, produce excellent fruit. Cherries, Plums, Almonds, Peaches, Nectarines, Apricots, Strawberries, Raspberries, Blackberries, Apples, Pears, and Quinces, all belong to this Order. It is to be noted, however, that valuable as these fruits are, the leaves, bark, flowers, and seeds, of many, abound in a deadly poison, called hydrocyanic or prussic acid. The variety of form displayed by the fruit of the Rose Tribe has afforded a facility for subdividing the Order into several Sub-orders, or Groups, the characters of which are subjoined.

\section{Sub-order I.-AMYgdíLeE.-The Almond Group.}

In plants belonging to this division, the pistil is solitary, and the fruit when ripe is a drupe, that is, a single seed enclosed in a hard case, which is itself surrounded by a fleshy or juicy pulp, with an external rind, or cuticle; the bark often yields gum, and prussic acid is generally abundant in the leaves and seeds. They are shrubs or trees, and inhabit the cold and tem- 
perate regions of the northern hemisphere. Examples of the deadly properties residing in these plants are afforded by the leaves of the common Laurel, Prunus Lauro-cerasus, even the vapour of which is destructive to insect life. The oil of Bitter Almonds is extremely poisonous, and many instances are recorded of its fatal

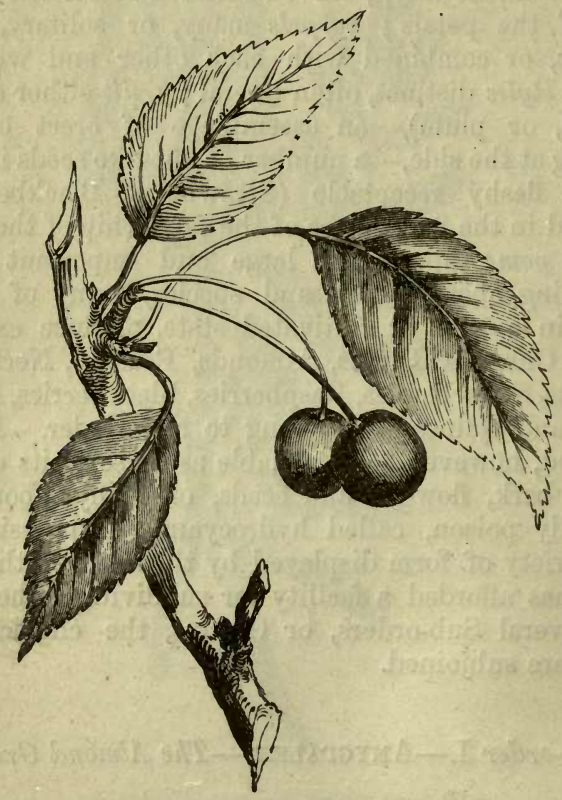

effects. But notwithstanding the presence of this destructive principle in the leaves and other parts of the trees belonging to this division, the fruit is, with the exception of the Laurel, harmless, or even a nourishing food. Amýgdalus communis, the Almond-tree, grows naturally in Barbary, and in Asia, from Syria to 
Affghanistan, and is extensively cultivated in the south of Europe. There are two varieties of the tree, one yielding the sweet, the other the bitter Almond. Jordan Almonds, which are considered the best, are brought from Malaga; bitter Almonds are imported from Mogadore. The varieties of Amýgdalus Pérsica produce the Peach, Nectarine, and Apricot. Prunus doméstica, and its varieties, afford Plums of many kinds. P. Lusitánica is well known by the name of Portugal Laurel.-(See "Forest Trees," vol. i. pp. 237-274.)

1. Prunus (Plum and Cherry).-Nut of the drupe smooth, or slightly seamed.-(Name from the Greek prouné, a plum: Cérasus, a name sometimes given to one division of this genus, is derived from Cerasus, a city of Pontus, whence the Roman general Lucullus introduced a superior kind, B. c. 67.)

\section{Sub-order II.-SPIRÉIDe.-Meadow-sweet Group.}

This division contains a limited number of herbaceous or shrubby plants, which bear their seeds in dry, erect capsules, opening at the side, termed follicles. Several species of Spircea are ornamental shrubs, and are commonly cultivated in gardens.

2. SpIRæa (Meadow-sweet, Dropwort).-Calyx 5-cleft ; stamens numerous; follicles $3-12$, bearing few seeds. (Name of Greek origin.)

Sub-order III.-PotentílLide.-The Strawberry Group.

In this division the form of the fruit varies much more than in either of the preceding; but in every case the calyx is permanent, and contains a number of nutlike seeds, with or without tails, placed on a pulpy, spongy, or dry receptacle; in the Bramble, each seed is 
enveloped in pulp, the fruit being an assemblage of small drupes; in Agrimony alone there are but two seeds, which are enclosed in a bristly, hardened calyx. The plants in this division are mostly herbaceous, but some few are shrubs. None of them are injurious; the leaves and roots of some are astringent, or tonic. The fruit of the Strawberry, Raspberry, and Bramble, is too well known to need any description.

3. Dryas (Mountain Avens).-Calyx in 8-10 equal divisions, which are all in one row ; petals 8-10; styles finally becoming feathery tails, not hooked at the extremity. (Name from the Greek drys, an Oak, from a fancied resemblance between the leaves.)

4. Géum (Avens).-Calyx 10-cleft, in two rows, the outer division smaller; petals 5 ; styles finally becoming jointed awns hooked at the extremity. (Name from the Greek geyo, to taste.)

5. Potentilla (Cinquefoil).-Calyx 10-cleft, in 2 rows, the outer divisions smaller; petals 5 ; seeds without awns, on a dry receptacle. (Name from the Latin potens, powerful, from the powerful properties supposed to reside in some species.)

6. Tormentilla (Tormentil).-Calyx 8-cleft, in 2 rows ; the outer divisions smaller; petals 4 ; seeds without awns, on a dry receptacle. (Name from the Latin tórmina, dysentery, for which disease it was considered a specific.)

7. Sibbaldia.-Calyx 10-cleft, in 2 rows, the outer divisions smaller; petals 5 ; stamens 5 ; seeds about 5 , without awns, on a dry receptacle. (Named after Robert Sibbald, a Scottish naturalist of the 17 th century.)

8. Cómarum (Marsh Cinquefoil).-Calyx 10-cleft, in 2 rows, the outer divisions smaller; petals 5 ; seeds without awns, on an enlarged spongy receptacle. (From the Greek cómaros, the name of a plant very distinct from the present.)

9. Fragaria (Strawberry).-Calyx 10-cleft, in 2 rows, the outer divisions smaller; petals 5 ; seeds without 
awns, on an enlarged, fleshy receptacle. (Name from the Latin fragum, a Strawberry, and that from fragrans, fragrant.)

10. RúBus (Bramble).-Calyx 5-cleft ; petals 5 ; fruit an assemblage of small drupes, arranged on and around a spongy receptacle. (Name from the Latin ruber, red.)

11. AGRimónia (Agrimony).-Calyx 5-cleft, topshaped, covered with hooked bristles ; petals 5 ; stamens about 15 ; seeds 2 , enclosed in the tube of the hardened calyx. (Name of Greek origin.)

\section{Sub-order IV.-SANGUISóRBIDe.-The Burnet Group.}

The plants of this group would seem at first sight to be scarcely connected with those already described. It will, however, be found, on a close examination, that in many important respects they agree with the characters given in the description of the Order ROSACEA, though in others scarcely less important they appear to differ; these are the absence of petals, and the hardened calyx of the fruit containing 1 or 2 nut-like seeds. The calyx is 3-8 cleft, and the stamens are usually few in number. The plants are either herbaceous or shrubby, and, like those of the last group, their properties are astringent, or tonic. In some species the flowers grow in round or oblong heads.

12. Alchemilla (Lady's Mantle).-Calyx 8-cleft, in 2 rows, the outer divisions smaller; ptals 0 ; stamens $1-4$, opposite the smaller divisions of the calyx ; seeds 1 or 2, enclosed in the hardened calyx. (Name from its pretended value in Alchemy.)

13. SANGuisónba (Burnet).-Calyx 4-cleft, coloured (not green), with $2-4$ scale-like bracts at the base; petals 0 ; stamens 4 ; seeds 1 or 2 , enclosed in the tube of the hardened calyx. (Name from the Latin sanguis, blood, and sorbeo, to staunch, from the supposed virtues of the plant.) 
14. Рот́́rium (Salad Burnet).-Stamens and pistits in separate flowers; flowers in heads; calyx 4-cleft, coloured, with 3 scale-like bracts at the base; petals 0 ; stamens numerous; stigma tufted. (Name from the Greek poterion, a drinking-cup, the plant being used in the preparation of Cool-tankard.)

Sub-order V.-Rósidæ.-The Rose Group.

This division contains the genus from which both the Order and Sub-order take their names. Here, also, the fruit furnishes the main characteristic ; it consists of a number of nut-like hairy seeds, enclosed within the

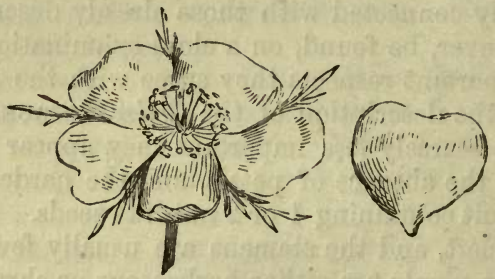

fleshy tube of the calyx, which is contracted at the top. The Roses are shrubs more or less prickly (not thorny), with pinnate leaves. The number of species is very great, of varieties incalculable, the beauty and fragrance of the flowers having rendered them favourite objects of cultivation from a very early period. The most fragrant of the British Roses are the common Dog-rose, Rosa canina, and the Scotch Rose, $R$. spinosissima, the latter being the origin of the numerous varieties of double Scotch Rose. From the petals of $R$. centifolia and $R$. Damascéna are made Rose-water, and Attar of Roses. It is stated that 100,000 Roses, the produce of 10,000 bushes, yield only nine drams of Attar. Some species, as $R$. rubiginosa, Sweet-brier, are copiously fur- 
nished with glands which secrete a fragrant viscid fluid. From the pulp of the fruit, called a hip, is made a conserve, which is used in the preparation of various medicines ; and the woody stems of the Dog-rose have of late years been much sought after for making walking sticks.

15. Rosa (Rose).-Calyx urn-shaped, contracted at the mouth, and terminating in 5 , often leaf-like, divisions; petals 5 ; stamens numerous ; seeds numerous. (Name from the Latin, rosa, and that from the Greek, rhodon, its ancient names.)

\section{Sub-order VI.-Pомеж.-The Apple Group.}

In the plants of this division the fruit is what is called a pome; that is, the tube of the calyx enlarges and becomes a fleshy or mealy fruit, enclosing $1-5$ cells, which are either horny, as in the Apple, or bony, as in the Medlar. The Apple Group contains many wellknown fruit-trees, namely the Apple, Pear, Quince, Medlar, Service, Mountain-Ash, and Hawthorn. The seeds, and occasionally the flower and bark of some, yield prussic acid. All the cultivated varieties of Apple are derived from the wild Apple, or Crab, Pyrus Malus; the garden Pears from a thorny tree, with hard astringent fruit, Pyrus communis. The wood of the Pear is very close-grained, and is sometimes used by woodengravers. The fruit of the Mountain Ash, and some other species, yields malic acid, and the leaves prussic acid, in as great abundance as the Laurel. All the plants of this division are either trees or shrubs.

16. Prrus (Pear, Apple, Service, and Mountain Ash). -Calyx 5-cleft ; petals 5; styles 2-5; fruit fleshy, or juicy, with 5 horny, 2-seeded cells. (Name from the Latin pyrus, a pear.)

17. MÉspiuus (Medlar).-Calyx 5-cleft, divisions leaflike; petals 5 ; styles $2-5$; fruit fleshy, top-shaped, 
terminating abruptly, with the ends of the bony cells exposed. (Name from the Greek mespile, a medlar.)

18. Crategus (Hawthorn).-Calyx 5-cleft, divisions acute ; petals 5 ; styles $1-5$; fruit oval, or round, concealing the ends of the bony cells. (Name from the Greek cratss, strength, in allusion to the hardness of the wood.)

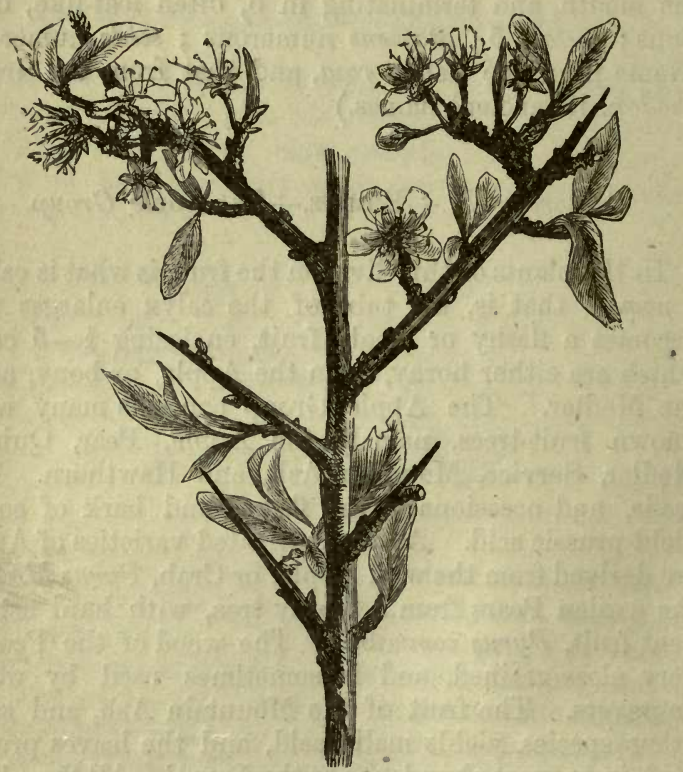

PRUNus SPINosa (Sloe, or Blackthorn).

1. Prunus (Plum and Cherry).

* Fruit covered with bloom; young leaf with the halves rolled together.

1. P. communis (Sloe, or Blackthorn; Bullace and Plum).-Flowers solitary or in pairs.-Under this name 
are now included the three following varieties, which were formerly considered to be distinct species. $P$. spinosa (Sloe, or Blackthorn).-Branches very thorny; leaves narrow, elliptical, smooth above, slightly downy near the midrib below ; flowers mostly solitary.-Woods and hedges; abundant. A well-known thorny bush, which probably derived its name Blackthorn from the hue of its bark, which is much darker than that of the Hawthorn. The flowers appear in March and April, and usually before the leaves have begun to expand. The latter are used to adulterate tea. The fruit is small, nearly round, and so austere that a single drop of its juice placed on the tongue will produce a roughness on the throat and palate which is perceptible for a long time. It enters largely into the composition of spurious port wine. - Fl. March-May. Shrub: $P$. insititia (Bullace).-Branches ending in a thorn ; leaves elliptical, downy beneath; flowers in pairs. - Woods and hedges. Larger than the last, and producing a more palatable fruit. In P. doméstica (Wild Plum), the branches are thornless, and the fruit oblong. From one or other of these three all the cultivated varieties of Plum are supposed to have originated.-Fl. April, May. Small tree.

\section{* Fruit without bloom; young leaf with the halves folded together.}

2. P. Padus (Bird-Cherry).-Flowers in clusters; leaves narrow egg-shaped; fruit oblong.-A handsome shrub, or small tree, not uncommon in the north of England in a wild state, and very generally admitted into gardens and shrubberies elsewhere. The clusters of flowers and drupes are not unlike those of the Portugal Laurel, but the leaves are not evergreen.-Fl. white, May. Small tree.

3. $P$. ávium (Wild Cherry).-Flowers in umbels; leaves drooping, suddenly pointed, downy beneath; calyx-tube contracted above; fruit heart-shaped. - 
Woods and hedges; common. A highly ornamental tree, not only on account of its elegant white flowers in spring, but even more so in autumn, when its leaves assume a bright crimson hue, which distinguishes them

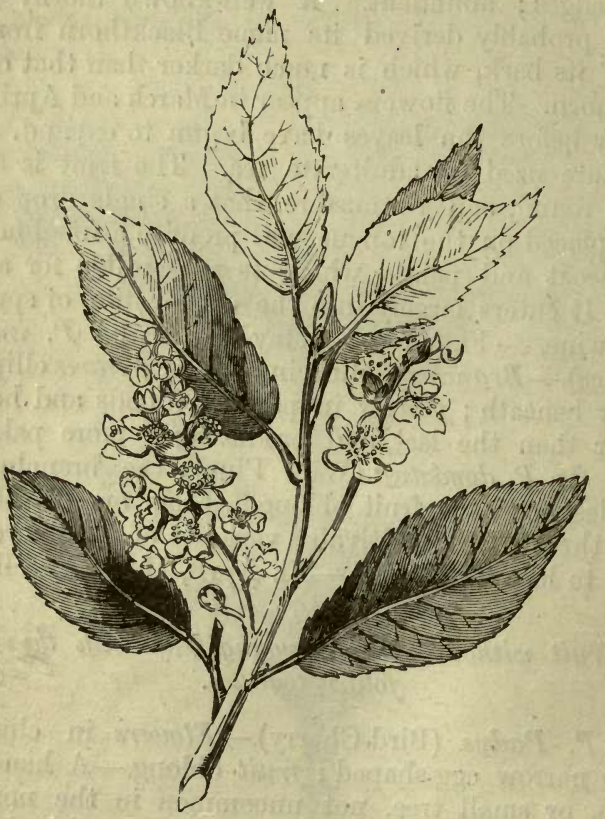

- PRUNUS PADUS (Bird-Cherry).

among all the varied tints of the fading year. The fruit is small, bitter, black, or red, and as soon as it is ripe is greedily devoured by birds.-Fl. May. Lofty tree.

5. P. Cérasus (Red Cherry).-Flowers in umbels; leaves not drooping, smooth on both sides; calyx-tube not contracted; fruit round.-Woods and hedges. This 
species is distinguished from the preceding by the characters given above, and by its lower stature, which is said not to exceed 8 feet, while the other attains a height of $30-40$ feet. The fruit also differs in being juicy, acid, and always red. Some botanists, however, consider them mere varieties of the same tree. From one or other all the cultivated kinds of Cherry are derived. -Fl: May. Shrub.

\section{Spirea (Meadow-sweet).}

1. S. Ulmária (Meadow-sweet, Queen of the Meadows).-Herbaceous ; leaves pinnate, the alternate leaflets smaller, white with down beneath, terminal leaflet very large and lobed; flowers in compound erect cymes. Moist meadows; common. A tall plant, 2-4 feet high, with densely crowded yellowish-white flowers, which are elegant and fragrant.-Fl. July, August. Perennial.

2. S. Filipéndula (Dropwort).-Herbaceous; leaves pinnate, with the alternate leaflets smaller, all deeply cut into narrow, serrated segments ; flowers in a panicled cyme.-Dry pastures, especially on a limestone soil, about a foot high; well distinguished from the last by its elegantly cut foliage, and less crowded flowers, the petals of which are pink externally before they expand, and when open are white and scentless. A variety with double flowers is common in gardens.-Fl. July-September. Perennial.

* S. salícifolia (Willow-leaved Spiræa), is a shrubby species, with spike-like clusters of rose-coloured flowers, and simple (not pinnated) leaves. It is occasionally found in Scotland, Wales, and the north of England, but is not considered to be a native. Several other species of Spircea are common in gardens, to which they are very ornamental. They are easily propagated by cuttings, and will grow in any moist situation. 


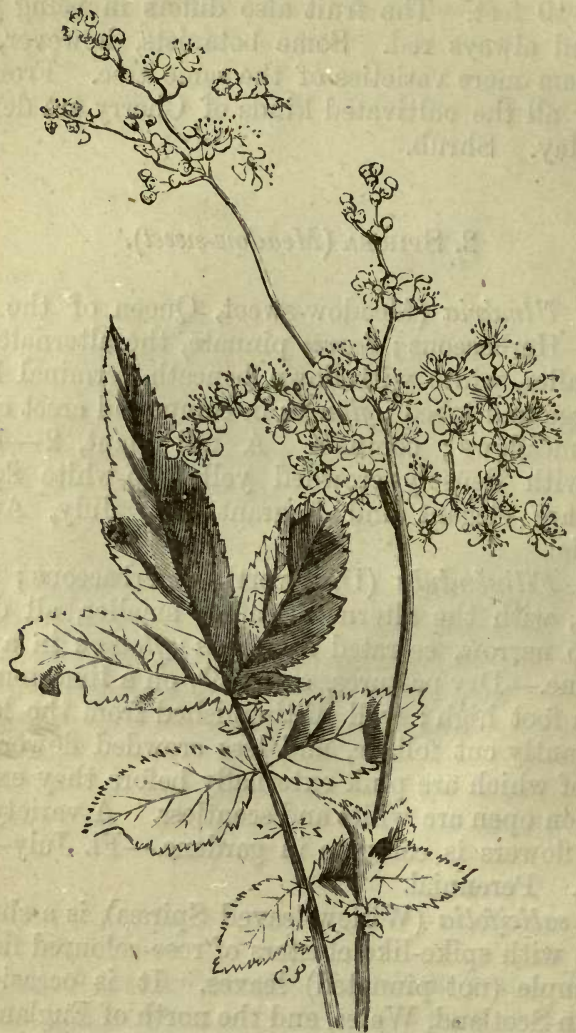

SPIRAA ULMARIA (Meadow-sweet, Queen of the Meadows). 


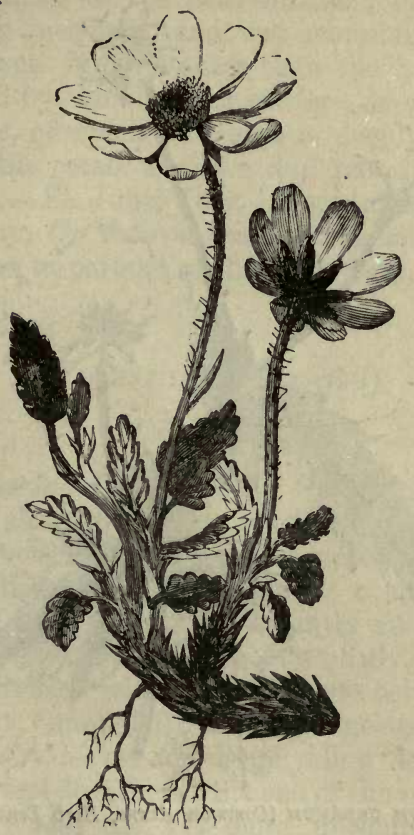

DRYAS octopétala (Mountain Avens).

\section{Dryas (Mountain Avens).}

D. octopétala (Mountain Avens). - The only British species; not uncommon in the mountainous parts of England, Scotland, and Ireland, and at once distinguished from all other plants of the Order by its oblong deeply-cut leaves, which are white with woolly down beneath, and by its large and handsome white flowers, each of which has 8 petals.-Fl. June, July. Perennial. 


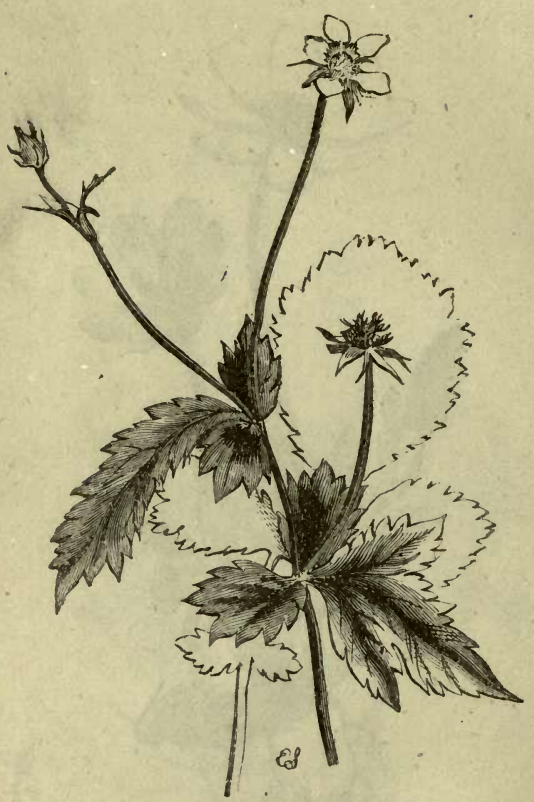

GÉUM URBANUM (Common Avens, Herb Bennet).

\section{Géum (Avens).}

1. G. urbánum (Common Avens, Herb Bennet).Flowers erect; awns rigid; root-leaves pinnate, with smaller leaflets at the base ; stem-leaves ternate.-Hedges and thickets; common. A somewhat slender, littlebranched plant, $1-2$ feet high, with yellow flowers, which are less conspicuous than the round heads of awned seeds which succeed them; the stipules are large, rounded, and cut.-Fl. June-August. Perennial.

2. G. riválé (Water Avens).-F'lowers drooping; 
awns feathery; root-leaves pinnate, with the alternate leaflets and those at the base smaller; stem-leaves ternate.-Damp meadows, and wet mountainous woods; not unfrequent. Much stouter than the last, and well distinguished by the above characters, as well as by its larger flowers, of which the calyx is deeply tinged with purple, and the petals are of a dull purplish hue, with darker veins.-Fl. June, July. ' Perennial.

* A variety, G. intermedium, is sometimes found, which appears to partake of the characters of both the above species.

\section{Potentilla (Cinquefoil). * Leaves pinnate.}

1. P. Anserína (Silver-weed, Goose-grass).-Leaves pinnate, the alternate leaflets smaller; leaflets sharply cut, silky on both sides, especially beneath ; flower-stalks solitary, axillary.-Waste ground; common. Well marked by its creeping stem, its elegantly cut silky foliage, and showy yellow flowers.-Fl. June, July. Perennial.

* To the division with pinnate leaves belong $P$. fruticosa (Shrubby Cinquefoil), a bushy species, 3-4 feet high, with hairy leaves and large yellow flowers, which last grow several together at the end of the stems : bushy places; rare; and the yet more uncommon species, $P$. rupestris (Rock Cinquefoil), which has large white flowers, and is found only in Montgomeryshire.

\section{** Leaflets 5 on a stalk (quinate).}

2. P. reptans (Creeping Cinquefoil).- Stem creeping, rooting at the joints; leaves stalked; leaflets inversely egg-shaped, tapering at the base, serrated ; flower-stalks solitary.-Meadows and way-sides; common. Flowers handsome, yellow, on long stalks.-Fl. June-August. Perennial.

3. P. argéntea (Hoary Cinquefoil)._-Stem prostrate; 
leaflets inversely egg-shaped, cut, white and downy. beneath, their edges rolled back.-Pastures and roadsides, on a gravelly soil ; not common. Flowers yellow, small, several together at the ends of the stems.-Fl. June. Perennial.

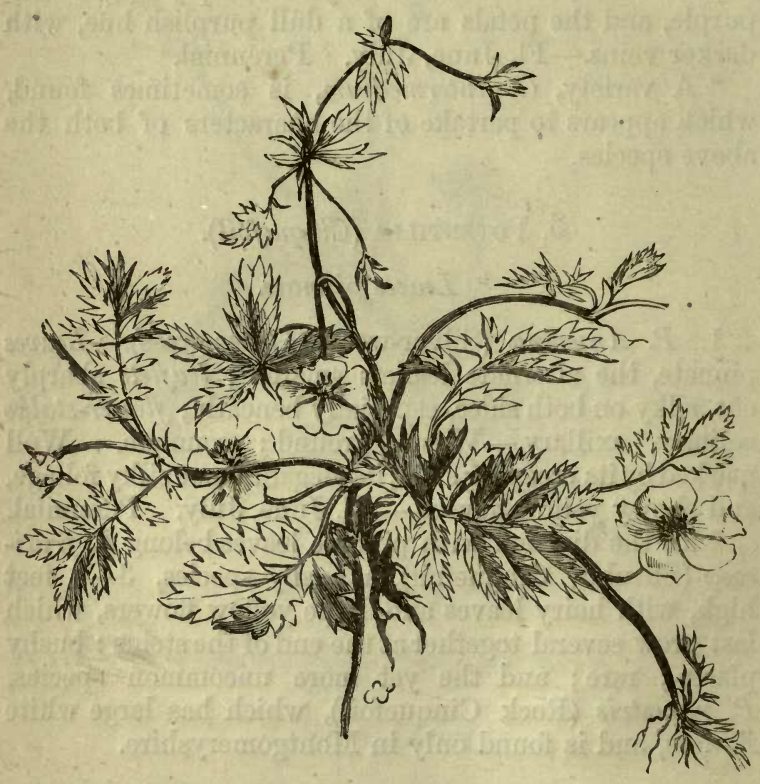

POTENTILla ANSERINa and P. REPTANS.

4. P. verna (Spring Cinquefoil).-Stem prostrate; leaflets sometimes 7 on the root-leaves, inversely eggshaped, serrated towards the end, hairy on the edge and ribs beneath, not downy.-Dry pastures in various parts of England, but not common. A small woody plant, about 5 inches long, with yellow flowers, $2-3$ together at the ends of the stems. 
* P. alpestris (Alpine Cinquefoil), is considered by some botanists a variety of the preceding; by others, a distinct species. It is somewhat larger, and the stem has a more upright growth. $P$. opáca (Saw-leaved Hairy Cinquefoil) occurs only on the hills of Clova and Braes of Balquidder, Scotland. The leaves are deeply cut throughout, and the stem is stouter than in the two last, but in other respects it is very like.

\section{*** Leaves 3 on a stalk, ternate.}

5. P. Fragariastrum (Strawberry-leaved Cinquefoil). -Stem prostrate; leaflets inversely egg-shaped, cut, silky on both sides; petals equalling the calyx in length. - Banks and hedges; abundant. One of the earliest spring flowers, often confounded by young botanists with the wild Strawberry, Fragaria vesca. It may, however, be always distinguished by its prostrate mode of growth, and short, notched petals ; the flower-stalks of the Strawberry being erect, and the petals entire.-Fl. JanuaryMay. Perennial.

* P. tridentáta (Three-toothed Cinquefoil), a rare species, found only on the Clova hills, is distinguished from the last by its oblong, wedge-shaped leaflets, each of which ends in 3 points. The petals are white, and longer than the calyx.

Upwards of a hundred and fifty species of Potentilla are described by botanists, inhabiting both the Eastern and Western Hemispheres, and preferring, generally, moist or rocky situations. They are all easy of cultivation, and some of them are handsome when in flower. They will grow in any common garden soil, and are easily increased, either by dividing the plants or by seed. 


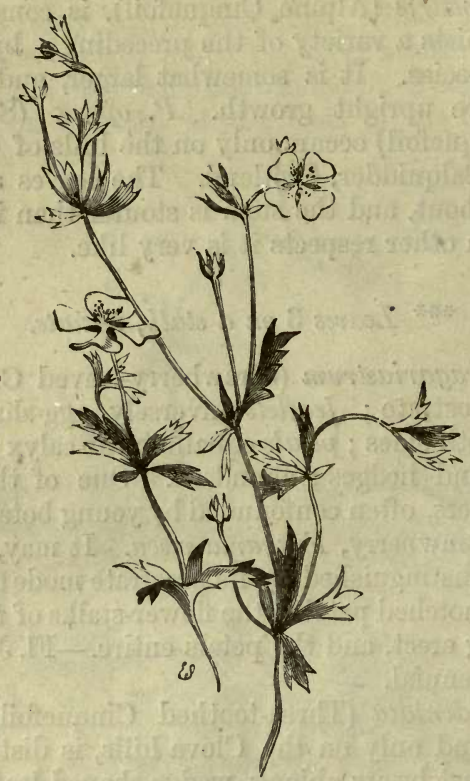

TORMENTILLA OFFICINALIS (Common Tormentil).

\section{Tormentilla (Tormentil).}

1. T. officinalis (Common Tormentil).-Leaves of 3 leaflets, ternate, sessile ; root-leaves of 5 leaflets (quinate) stalked ; leaflets narrow, acute, cut; stem ascending.-Banks and woods; common. Closely allied to the preceding genus, from which it is distinguished by its having only 4 petals; but even this character is not constant. A small plant, with bright yellow flowers, and very woody roots, which latter are astringent, and are employed in medicine. Specimens are not uncommon in which the stem is prostrate ; this is by some botanists considered a distinct species, and is called 
T. reptans (Trailing Tormentil).-Fl. all the summer. Perennial.

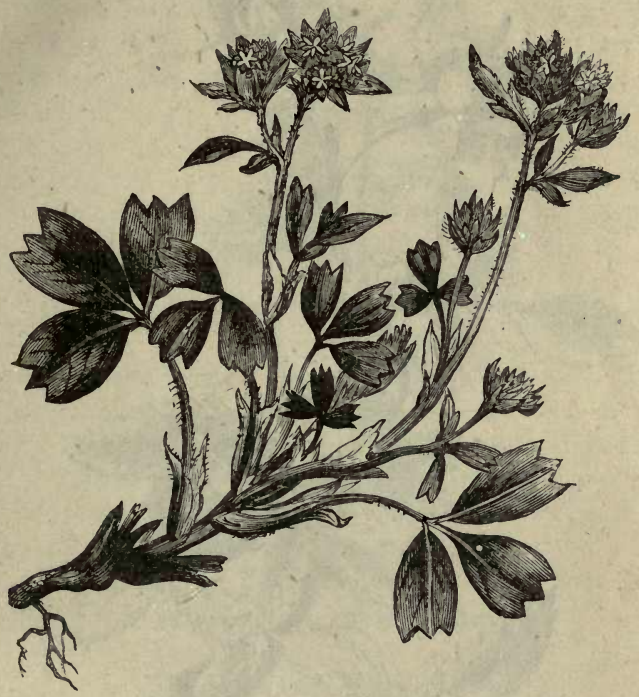

SIBBALDIA PROCUMBENS (Procumbent Sibbaldia).

7. SibBaldia.

1. S. procumbens (Procumbent Sibbaldia).-The only British species.-A small prostrate plant, with ternate, hairy leaves, and yellowish flowers, growing abundantly on the summits of the Highland mountains. The leaflets are wedge-shaped, and end in 3 points. The number of stamens and pistils is very variable.-Fl. June, July. Perennial.

\section{Cómarum (Marsh Cinquefoil).}

1. C. palustré (Marsh Cinquefoil).-The only species. -A herbaceous bog-plant, growing about a foot high, 


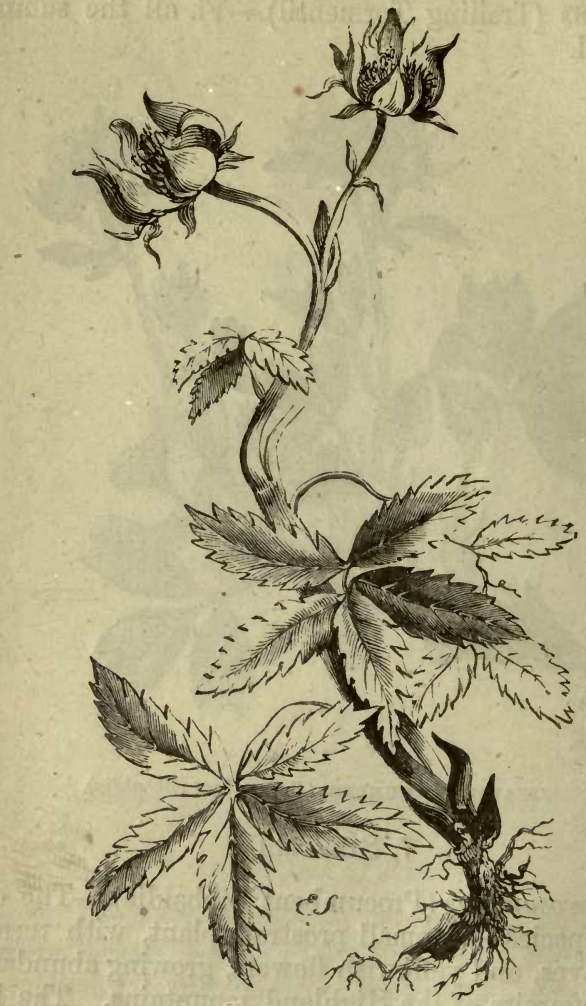

CómaRUM PALUSTRÉ (Marsh Cinquefoil).

with much of the habit of a Potentilla, but stouter. The lower leaves are usually of 7 long, cut leaflets, the upper of 5 or 3 ; and each stem bears several leaves, and a number of large dingy purple flowers.-Fl. July. Perennial. 


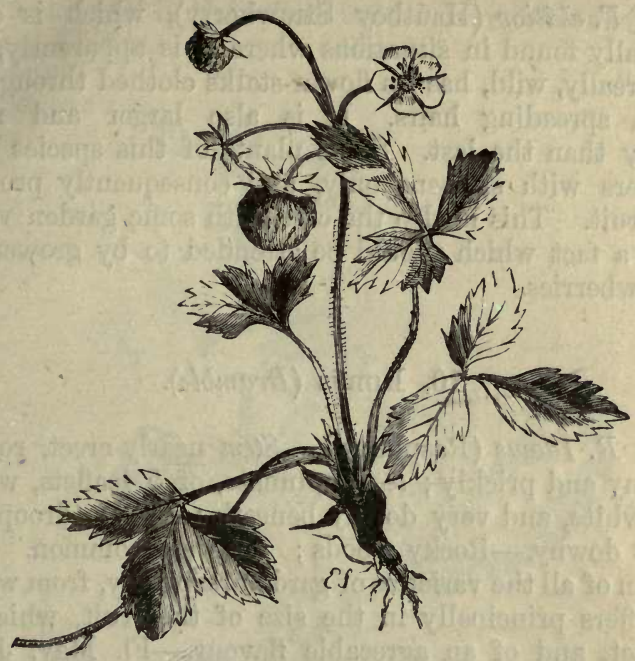

FRAGARIA VESCA (Wood Strawberry).

9. Fragaria (Strawberry).

1. F. vesca (Wood Strawberry).-Calyx of the fruit bent back; hairs on the general flower-stalk widely spreading, on the partial flower-stalks close pressed, silky.-Woods and thickets ; common. A well-known plant, with bright-green hairy leaves, rooting scions, and erect flower-stalks. By these last two characters, as well as by the drooping fruit, this plant may be distinguished from Potentilla Fragariastrum (Strawberryleaved Cinquefoil), which is often mistaken for it by young botanists. The Strawberry derives its name either from the custom of laying straw between the rows of plants in gardens, or from the habit adopted by children of stringing the fruit on straws of grass.-FL. May-July. Perennial. 
* F. elátior (Hautboy Strawberry), which is occasionally found in situations where it is apparently, but not really, wild, has its flower-stalks clothed throughout with spreading hairs. It is also larger and more hairy than the last. Some plants of this species bear flowers with stamens only, and consequently produce no fruit. This is also the case with some garden varieties, a fact which should be attended to by growers of Strawberries.

\section{Rubus (Bramble).}

1. R. Idoeus (Raspberry).-Stem nearly erect, round, downy and prickly; leaves pinnate, of 5 leaflets, which are white, and very downy beneath ; flowers drooping; fruit downy.-Rocky woods; not very common. The origin of all the varieties of garden raspberry, from which it differs principally in the size of the fruit, which is scarlet, and of an agreeable flavour.-Fl. May, June. Shrub.

2. R. fruticósus (Common Bramble, or Bỉackberry). -Stem arched, angular, prickly, rooting; leaves of 5 crowded leaflets ; flowers erect, in compound panicles ; calyx of the fruit spreading, or bent back.-Common everywhere. This description includes a large number of species and varieties to which names have been severally given, but it is not here thought necessary to describe the characters at length, the genus being confessedly a difficult one, and on other accounts uninviting to the young botanist.-Most of the species flower from July to August, and ripen their fruit in September and October. Shrub.

3. $R$. coesius (Dewberry).-Stem prostrate, nearly round, prickly below, bristly above ; leaves of 3 or 5 leaflets; panicle simple; calyx clasping the fruit.Thickets and borders of fields; not uncommon. In this species the fruit, which consists of a few large drupes, 
is half enclosed in the calyx, and is covered with a grey bloom.-Fl. June-August. Shrub.

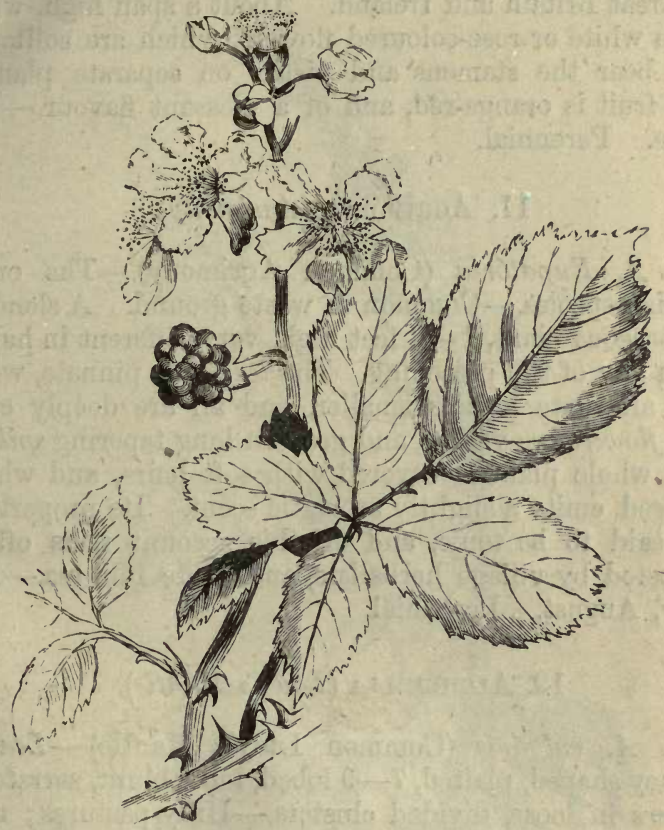

RUBUS FRUTICUSUS (Blackberry).

4. R. saxátitis (Stone Bramble).-Stem herbaceous, rooting ; prickles few, small ; leaves of 3 leaflets ; flowers few together.-Stony, mountainous places, especially in the north. A small herbaceous species, about a span high, with greenish-yellow flowers, and scarlet fruit consisting of 1-4 large drupes.-Fl. July, August. Perennial. 
5. R. Chamaemórus (Cloudberry).-Stem herbaceous, without prickles, 1-flowered; leaves simple, lobed.-A very disitinct species, growing in the mountainous parts of Great Britain and Ireland. About a span high, with large white or rose-coloured flowers, which are solitary, and bear the stamens' and pistils on separate plants. The fruit is orange-red, and of a pleasant flavour.-Fl. June. Perennial.

\section{Agrimónia (Agrimony).}

1 A. Eupatória (Common Agrimony).-The only British species.-Common in waste ground. A slender herbaceous plant, $1-2$ feet high, very different in habit from any of the preceding. The leaves are pinnate, with the alternate leaflets smaller, and all are deeply cut. The flowers are yellow, and grow in long tapering spikes. The whole plant is covered with soft hairs, and when bruised emits a slightly aromatic scent. Its properties are said to be tonic, and on this account it is often. collected by village herbalists, and made into tea.-Fl. July, August. Perennial.

\section{Alchemilla (Lady's Mantle).}

1. A. vulgáris (Common Lady's Mantle).-Leaves kidney-shaped, plaited, 7-9 lobed, lobes blunt, serrated; flowers in loose, divided clusters.-Hilly pastures; not uncommon. A herbaceous plant, about a foot high, with large and handsome soft leaves, and numerous small, yellowish-green flowers,-Fl. June-August. Perennial.

2. A. alpína (Alpine Lady's Mantle).-Leaf of $5-7$ oblong, blunt leaflets, serrated at the end, white and satiny beneath.-Mountains in Scotland and the north of England. A very beautiful plant, remarkable for the lustrous, almost metallic hue of the under side of its leaves.-Fl. July, August. Perennial. 


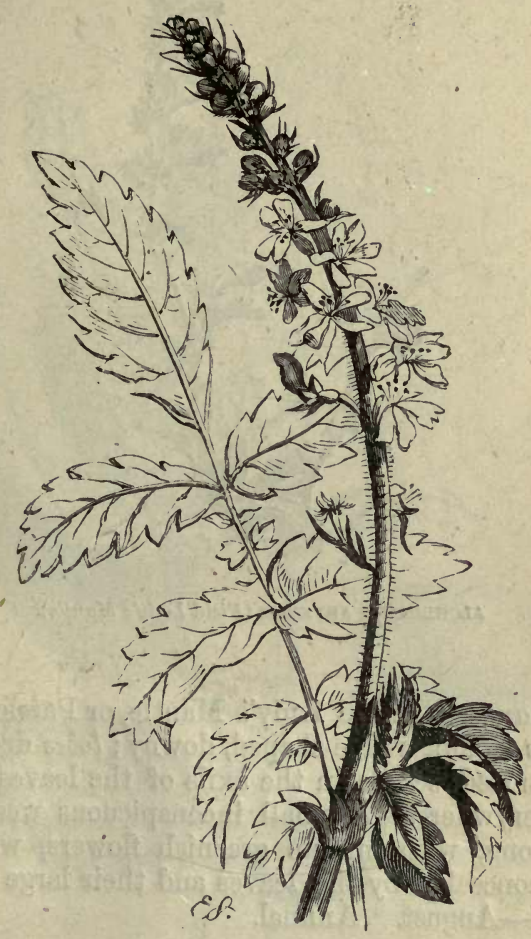

agrimónia eUpatória (Common Agrimony). 


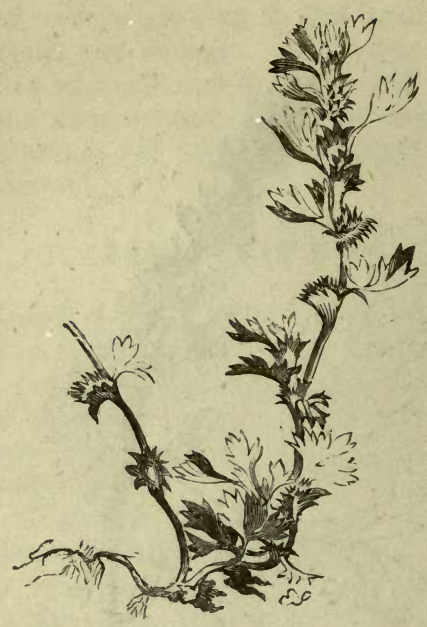

ALChEMILla ARVENsis (Field Lady's Mantle).

3. A. arvensis (Field Lady's Mantle, or Parsley Piert). - Leaves 3-cleft, wedge-shaped, downy; lobes deeply cut; flowers tufted, sessile in the axils of the leaves. - Common everywhere. A small inconspicuous weed, 3-6 inches long, with minute greenish flowers, which are almost concealed by the leaves and their large stipules. Fl. May-August. Annual.

\section{SANGuisorba (Burnet).}

1. S. officinalis (Common Burnet).-The only British species. - A tall and not inelegant plant, with pinnate. leaves; erect, branched stems, sparely clothed with 
leaves ; and oblong heads of deep purple-brown flowers. Moist pastures ; not uncommon:-Fl. June-September. Perennial.

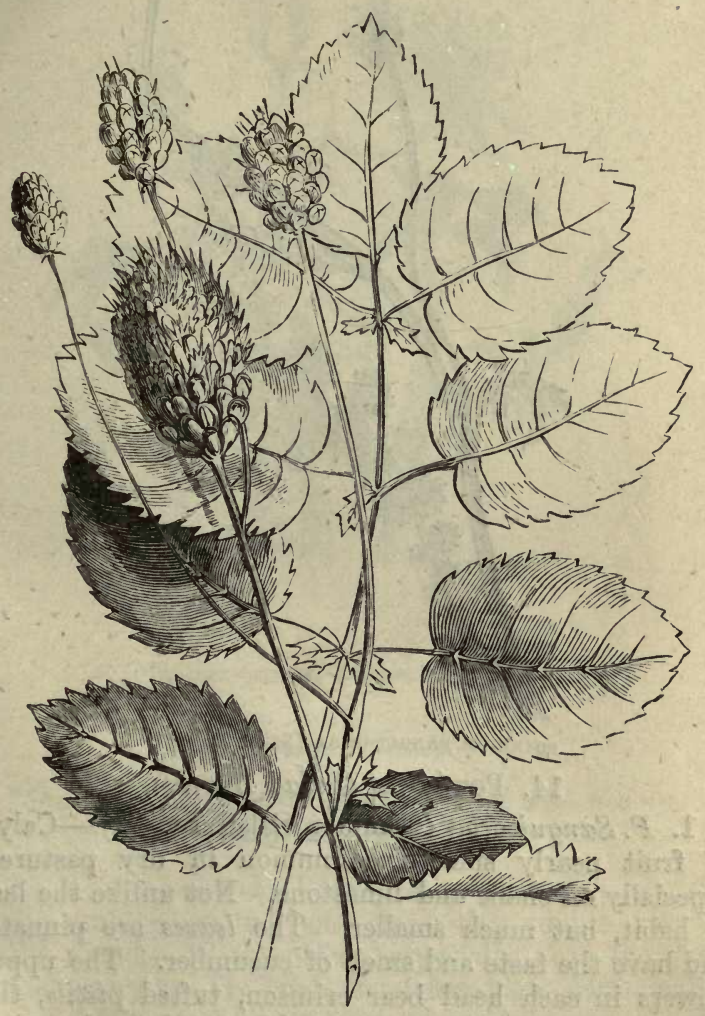

SANGUISORBA OFFICINALIS (Common Burnet). 


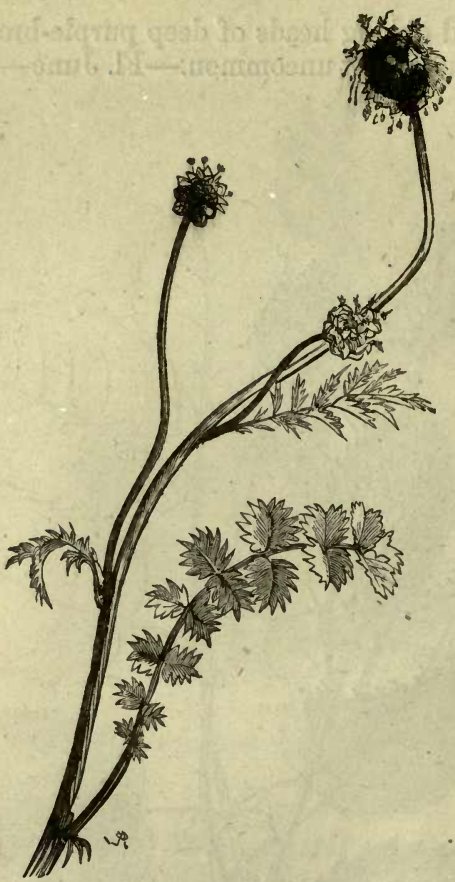

poterium sanguisorba (Salad Burnet).

14. Potḱrium (Salad Burnet),

1. P. Sanguisorba (Common Salad Burnet).-Calyx of fruit nearly smooth.-Common in dry pastures, especially on chalk and limestone. Not unlike the last in habit, but much smaller. The leaves are pinnate, and have the taste and smell of cucumber. The upper flowers in each head bear crimson, tufted pistils, the lower ones $30-40$ stamens, with very long drooping filaments.-Fl. July, August. Perennial.

- 2. P. Muricatum (Prickly Salad Burnet)-Calyx of fruit wrinkled and prickly.-Chalk pastures. Closely resembling the last. 


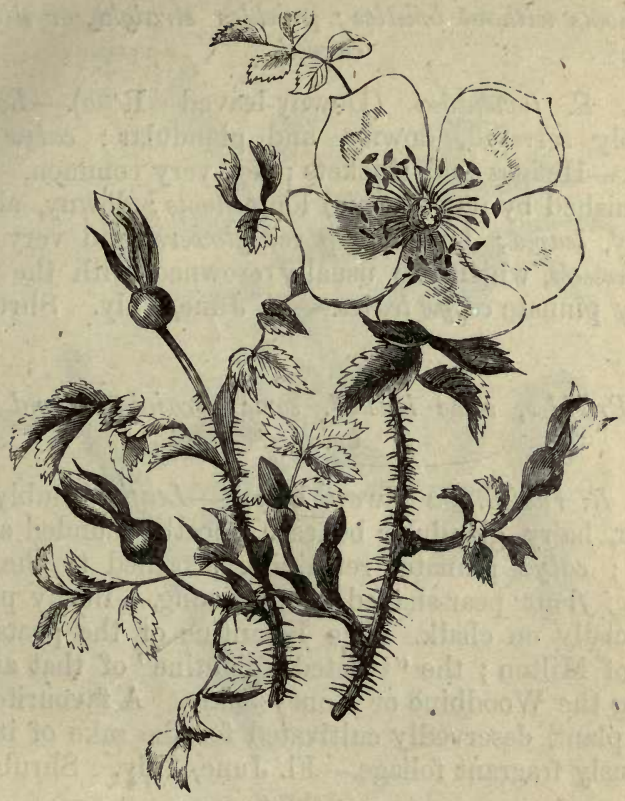

ROSA SPINOSISSIMA (Bumnet-leaved Rose).

15. Rosa (Rose).

*Shoots thickly set with bristles, mixed with nearly straight prickles.

1. R. spinosissima (Burnet-leaved Rose).-Leaflets small, simply serrated, smooth; calyx simple; fruit nearly round.-Waste places, especially near the sea. A thick, very prickly bush, 2-4 feet high, with small, elegant foliage, and large cream-coloured flowers, which are deliciously fragrant; fruit dark purple or black. The origin of the garden varieties of Scotch Rose.May, June. Shrub. 
** Shoots without bristles; prickles straight, or slightly curved.

2. R. tomentósa (Downy-leaved Rose).-Leaflets doubly serrated, downy, and glandular; calyx pinnate.-Hedges and thickets; not very common. Distinguished by its stout and long shoots; downy, almost hoary, leaves; large, deep red flowers, and very long seed-vessels, which are usually crowned with the copiously pinnate calyx leaves.-Fl. June, July. Shrub.

*** Prickles, some hooked, some straight, mixed with bristles.

3. R. rubiginosa (Sweet Brier).-Leaflet doubly serrated, hairy, glandular beneath, mostly rounded at the base; calyx pinnate, remaining attached to the ripe fruit ; fruit pear-shaped when young.-Bushy places, especially on chalk. The Eglantine of the poets, but not of Milton ; the "twisted Eglantine" of that author being the Woodbine or Honeysuckle. A favourite garden plant, deservedly cultivated for the sake of its deliciously fragrant foliage.-Fl. June, July. Shrub.

**** Bristles none; prickles hooked.

4. R. canina (Dog Rose).-Leaves smooth, or slightly hairy; calyx pinnate, not remaining attached to the fruit; styles distinct.-Hedges and bushy places; abundant. This is the Common Hedge Rose, a flower belonging exclusively to summer, and welcomed at its first appearance scarcely less warmly than the early Primrose in spring. The colour of the flower varies from white to a deep blush, and the leaves also differ considerably; but the above characters will be found to include all the principal varieties.-Fl. June, July. Shrub. 


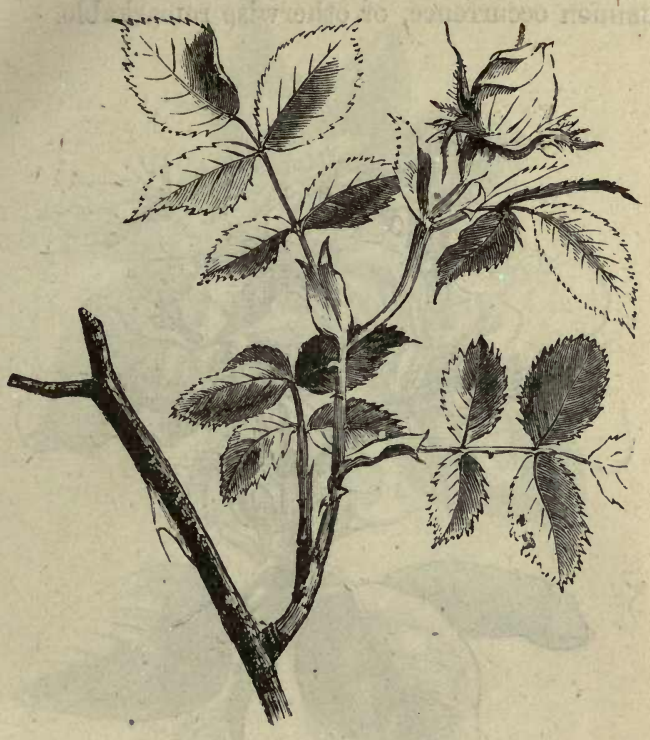

Rosa Canina (Dog Rose).

5. R. arvensis (Trailing Dog Rose).-Prickles on the young shoots feeble; leaves smooth; calyx slightly pinnate, not remaining attached to the fruit; styles united ; stigmas forming a round head.-Woods and hedges; common in the south of England. Distinguished from all the other British species of Rose by its slender, trailing stems. The flowers are white and scentless, and there are fewer prickles than in most other species.-Fl. June-August. Shrub.

* Botanists describe no less than nineteen species of native Roses, but, as many of these are rare, and the characters of others are difficult to discriminate, it has 
been thought best to describe here only those which are of common occurrence, or otherwise remarkable.

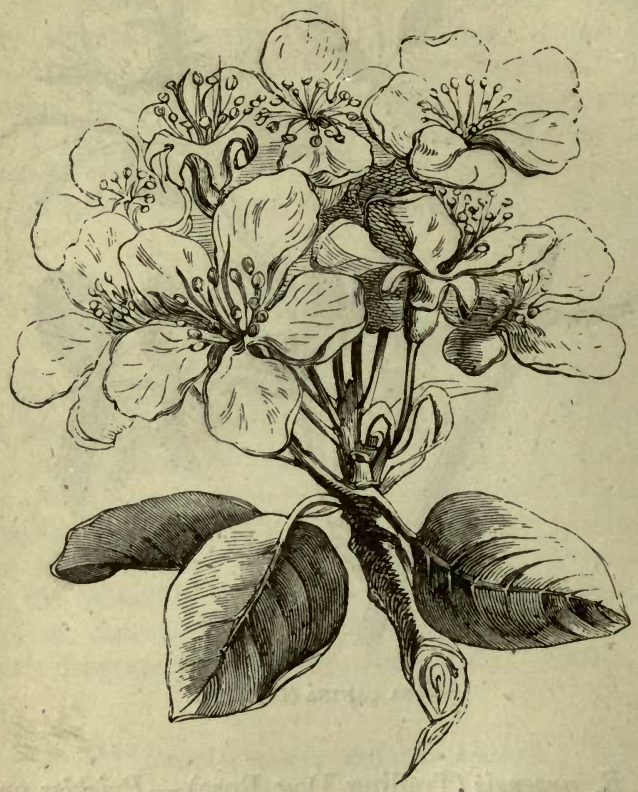

pyrus commónis (Wild Pear).

16. Prrus (Pear, Apple, Service, and Mountain Ash).

1. P. commúnis (Wild Pear)-_Leaves simple, eggshaped, serrated ; flowers in corymbs ; fruit tapering at the base.-Woods and hedges. A small upright tree, often bearing thorns at the extremities of its branches. The seed vessel, in a wild state, is woody, austere, and worthless, yet is converted by cultivation into a most luscious fruit.-Fl. white.-April, May. Tree. 


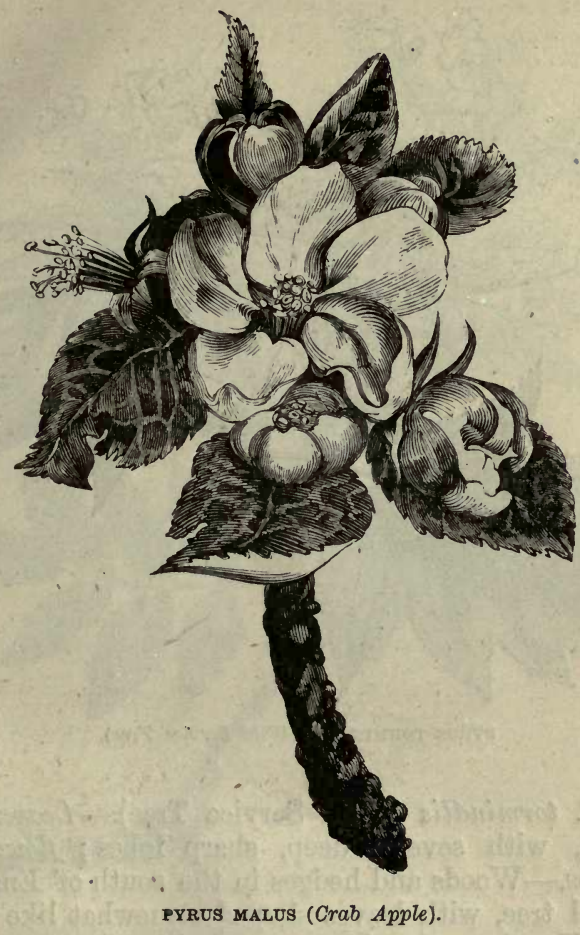

2. P. Malus (Crab Apple).-Leaves simple, eggshaped, serrated, flowers in a sessile umbel ; styles combined below ; fruit with a hollow beneath.-Woods and hedges. A small spreading tree, with thornless branches, umbels of white flowers delicately shaded with pink, and nearly round fruit, which is intensely acid. It was formerly much used in making verjuice, and in the preparation of pomatum, so called from pomum, an apple.Fl. May. Tree. 


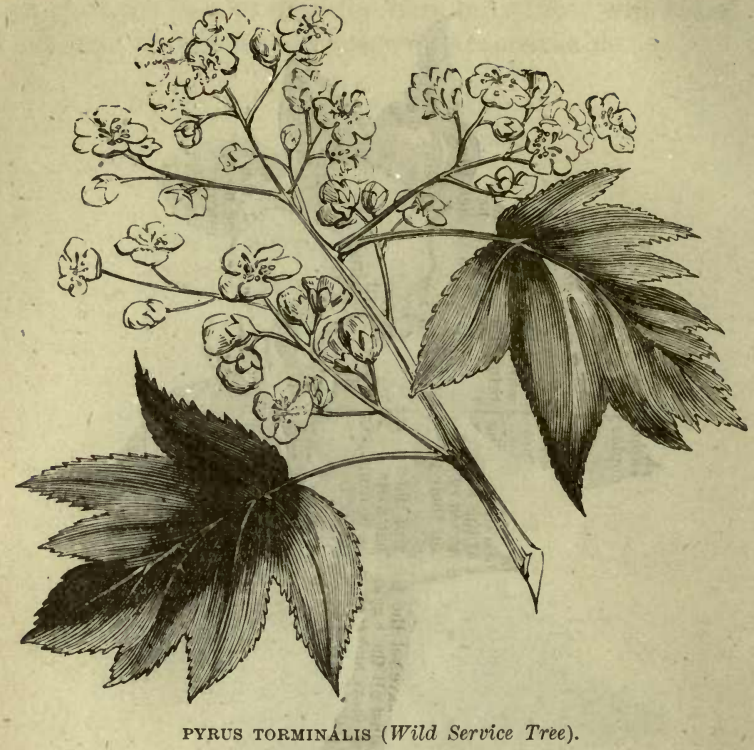

3. P. torminális (Wild Service Tree).-Leaves eggshaped, with several deep, sharp lobes; flowers in corymbs.-Woods and hedges in the south of England. A small tree, with leaves shaped somewhat like those of the Hawthorn, but larger, and white flowers, which are succeeded by brownish, spotted, berry-like fruit.Fl. May. Tree.

4. P. aucuparia (Fowlers' Service, Mountain Ash, Quicken, or Rowan Tree).-Leaves pinnate, serrated; flowers in corymbs; fruit nearly round.-Mountainous woods. One of the most elegant of British trees, conspicuous in the flowering season by its delicate green foliage, and large corymbs of blossiom, and in autumn by its clusters of scarlet berry-like pomes, which are greedily 


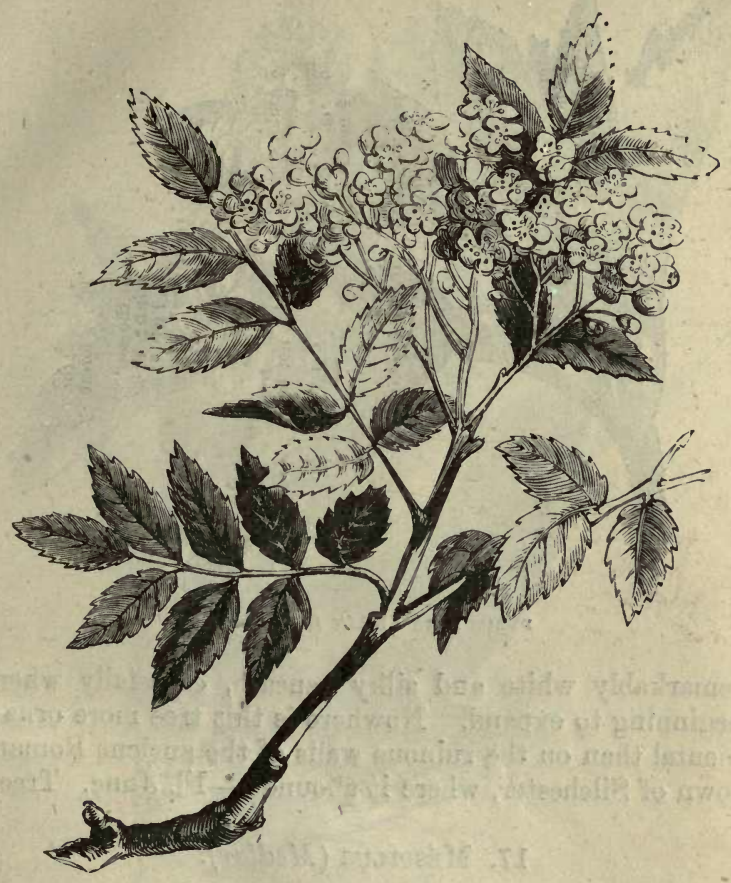

PYRUS AUCUPÁIA (Fowlers' Service Tree).

eaten by birds, and often used as a lure by the birdcatcher or fowler, auceps. For a further account of this tree, as well as the rest of the genus, see "Forest Trees of Britain," vol. i.-Fl. May. Tree.

5. P. Ária (White Beam Tree).-Leaves egg-shaped, deeply and irregularly serrated, white below; flowers in corymbs ; fruit nearly round.-Woods. A small tree, well distinguished by its very large leaves, which are 


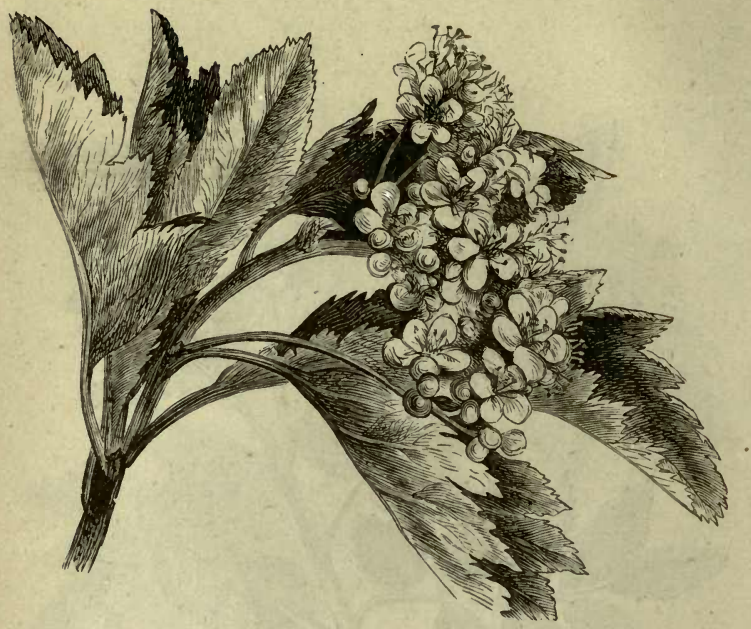

PYRus ária (White Beam-Tree).

remarkably white and silky beneath, especially when beginning to expand. Nowhere is this tree more ornamental than on the ruinous walls of the ancient Roman town of Silchester, where it abounds.-Fl. June. Tree.

\section{Méspilus (Medlar).}

1. M. Germánica (Common Medlar).-A tree well known in a cultivated state, but nowhere, perhaps, in Great Britain truly wild. The flowers are white and very large, and the fruit is remarkably flattened at the top, exposing the upper ends of the long seed-cells.Fl. May. Tree.

\section{Crategus (Hawthorn).}

1. C. Oxyacantha (Hawthorn, White-thorn, or Maybush). - A tree which, though it varies considerably in 


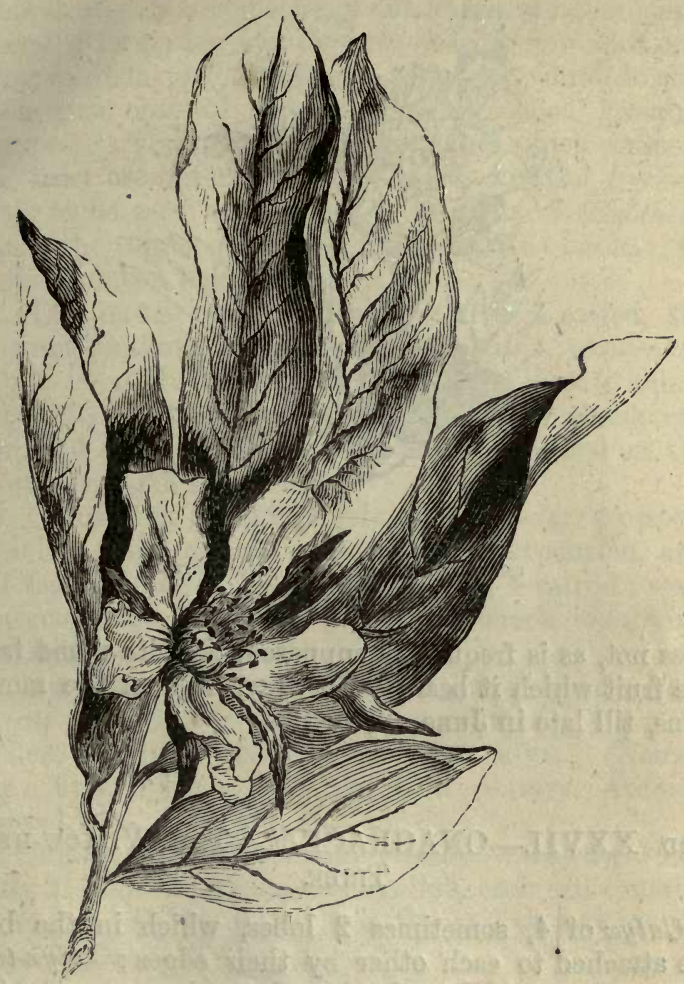

méspilus germa nica (Common Medlar).

its mode of growth, shape of its leaves, and colour of its flowers and fruit, is so well known as to need no description. The name Hawthorn is supposed to be a corruption of the Dutch hag or hedge thorn ; although, therefore, the fruit is generally called a haw, that name is derived from the tree which produces it, and the tree 


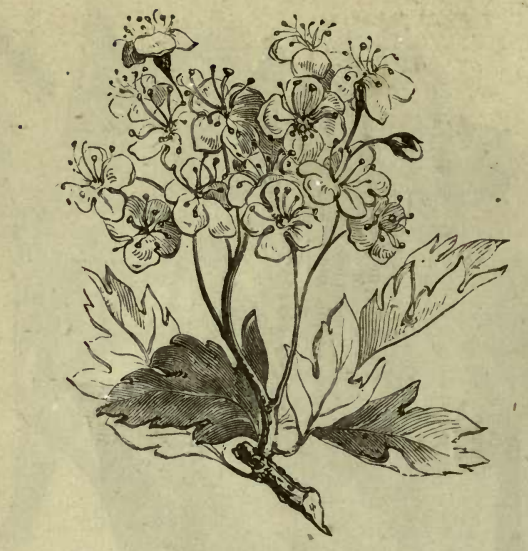

CRATAGUS OXYACANTHA (Hawthorn).

does not, as is frequently supposed, take its name from the fruit which it bears.-Fl. May, and, in the mountains, till late in June. Tree.

\section{ORD. XXVII.-ONAGRACEA_-THE WILLOW-HERB Tribe.}

Calyx of 4, sometimes 2 lobes, which in the bud are attached to each other by their edges; calyx-tube more or less united to the ovary; petals as many as the lobes of the calyx, twisted while in bud ; stamens 4 or 8 , rarely 2, springing from the mouth of the calyx; ovary of 2 or 4 cells, often crowned by a disk ; stigma knobbed, or 4-lobed ; fruit a berry, or 4-celled capsule. -Herbaceous plants or shrubs, principally inhabiting the temperate parts of the globe, especially America and Europe. In this Order we find the elegant American genus Fuchsia, with its coloured 4-cleft calyx, and often 
edible fruit. Many species of Enothéra are commonly cultivated as garden plants, some bearing flowers 3 or 4 inches in diameter; those with yellow or white flowers which open only in the evening, are called Evening Primroses. The properties of the plants which compose this Order are unimportant. The wood of the Fuchsia is said to be used as a dye, and the roots of Enothéra biennis, the common Evening Primrose, are eatable. In all, the number 4 predominates.

1. Epilóbium (Willow-Herb).-Calyx 4-parted, the lobes not combined after expansion; petals 4 ; stamens 8 ; capsule long, 4-sided, 4-celled, 4-valved; seeds numerous, tufted with down. (Name from the Greek epi, upon, and lobos, a pod, the flowers being placed on the top of a pod-like seed-vessel.)

2. Enothéra (Evening Primrose).-Calyx 4-parted, the lobes more or less combined after expansion, and bent back; stamenes 8; capsule 4-celled, 4-valved; seeds numerous, not bearded. (Name in Greek signifying " catching the flavour of wine.")

3. Isnardia.-Calyx 4-parted; petals 4, or none; stamens 4 ; capsule inversely egg-shaped, 4-angled, 4-celled, 4-valved, crowned with the calyx. (Named after a French botanist of the 18th century, Antoine d'Isnard.)

4. Circ.éa (Enchanter's Nightshade).-Calyx 2-parted; petals 2 ; stamens 2 ; capsule 2 -celled, each cell containing a seed. (Name from Circe, the enchantress so celebrated in Greek Mythology.).

\section{Epilóbium (Willow-Herb).}

* Petals unequal in size; stamens bent down.

1. E. angustifolium (Rose Bay, or Flowering Willow). -Leaves narrow, pointed, smooth.-Damp woods ; rare. A tall and handsome species not often met with in a wild state, but very common in gardens, where it is cul- 
tivated for the sake of its large, rose-coloured flowers. Caution should be used in admitting it into a small garden, as its roots creep extensively, and are very difficult to eradicate.-Fl. July. Perennial.

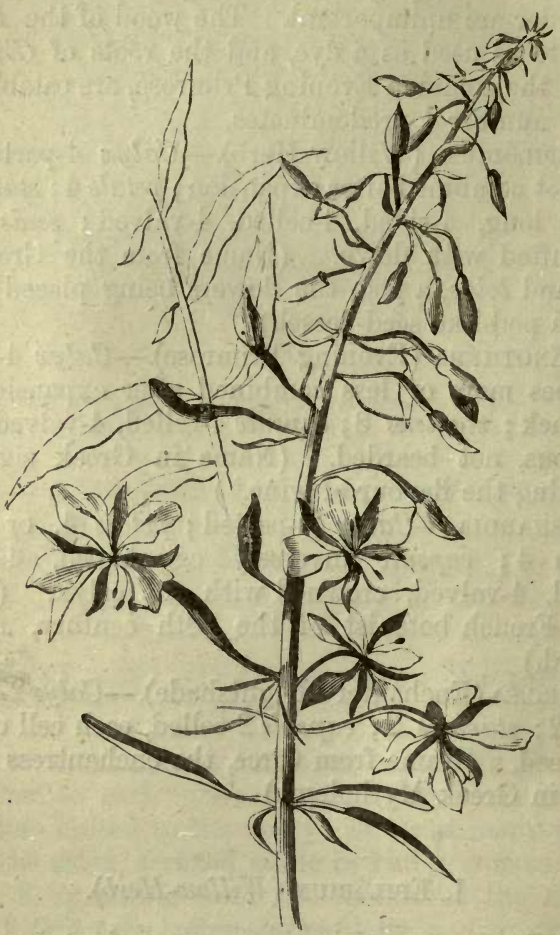

EPILOBIUM ANGUSTIFOLIUM (Rose Bay, or Flowering Willow).

** Petals all equat ; stamens erect ; stigma 4-cleft.

- 2. E. hirsútum (Great Hairy Willow-Herb).-Woolly ; leaves clasping the stem, narrow-oblong, serrated; stem 
much branched; root creeping.-Wet places ; common. A handsome species, 4-6 feet high, with large rosecoloured flowers. Well marked by its very downy stems and leaves, and creeping roots.-Fl. July, August. Perennial.

3. E. parviflórum (Small-flowered, Hairy WillowHerb).-Downy ; leaves sessile, narrow, toothed; stem nearly simple; root fibrous.-Wet places ; common. Distinguished from the last by its smaller size, unbranched mode of growth, and fibrous roots.-Fl. July, August. Perennial.

4. E. montánum (Broad, Smooth-leaved Willow-Herb). -Leaves egg-shaped, acute, smooth, toothed, the lower ones shortly stalked; stem round, slightly downy.-Dry banks, and hilly places; frequent. A small species, about a foot high, with rose-coloured flowers, which are most frequently found in a half-open state. It may often be detected when in seed by its capsules, the valves of which open lengthwise, and disclose the numerous seeds bearded with cottony down.-Fl. July, August. Perennial.

*** Petals all equal ; stamens erect; stigma knobbed, not 4-cleft.

5. $\boldsymbol{E}$. tetragónum (Square-stalked Willow-Herb).Leaves narrow, sessile, toothed; stem 4-angled, nearly smooth.-Wet places; common. From 1 to 2 feet high, and often, like the last and following species, more conspicuous when in seed than in flower.-Fl. July, August. Perennial.

6. E. palustré(Narrow-leaved Marsh Willow-Herb).Leaves narrow, wedge-shaped at the base, slightly toothed, sessile; stem round, nearly smooth.-Wet places ; frequent. From 6 to 18 inches high, with very narrow, nearly entire leaves, small flowers, which droop while in bud, and a round stem, which often has 2 downy lines on opposite sides.-Fl. July, August. Perennial.

* To this group, with undivided stigmas, belong also 
E. róseum (Pale Smooth-leaved Willow-Herb), growing in wet places about London, with stalked, egg-shaped leaves, and an imperfectly 4-angled stem; E. alsínifolium. (Chickweed-leaved Willow-Herb), a mountainous species, from 6 to 12 inches long, with very thin eggshaped, pointed leaves, and a few rather large flowers; and E. alpinum (Alpine Willow-Herb); also a mountain species, 3 to 4 inches high, which is distinguished from the last by its obtuse leaves, and 1 or 2 flowers, which droop while in bud.

\section{CEnothéra (Evening Primrose).}

1. EE. biennis (Common Evening Primrose).-A tall and stout herbaceous plant, with long, light-green, smooth leaves, and large, pale yellow, fragrant flowers, which open in the evening, and wither towards the middle of the next day. It is common in gardens, and in a few places appears to be naturalized.-Fl. JulySeptember. Biennial.

\section{IsNáRdia.}

1. I. palustris (Marsh Isnardia).-The only British species.-A small herbaceous plant, 6-8 inches long, with prostrate rooting stems, and axillary sessile flowers, which are destitute of petals.-Very rare ; in a pool, at Buxstead, Sussex, and on Petersfield Heath, Hampshire. -Fl. July. Annual.

\section{Circata (Enchanter's Nightsháde).}

1. C. Lutetiána (Common Enchanter's Nightshade). -Stem downy, branched; leaves egg-shaped, tapering to a point, toothed; calyx hairy.-Damp shady places; common. A slender herbaceous plant, $1-2$ feet high, with creeping roots, spreading foliage, and terminal clusters of minute white flowers, with pink stamens, 


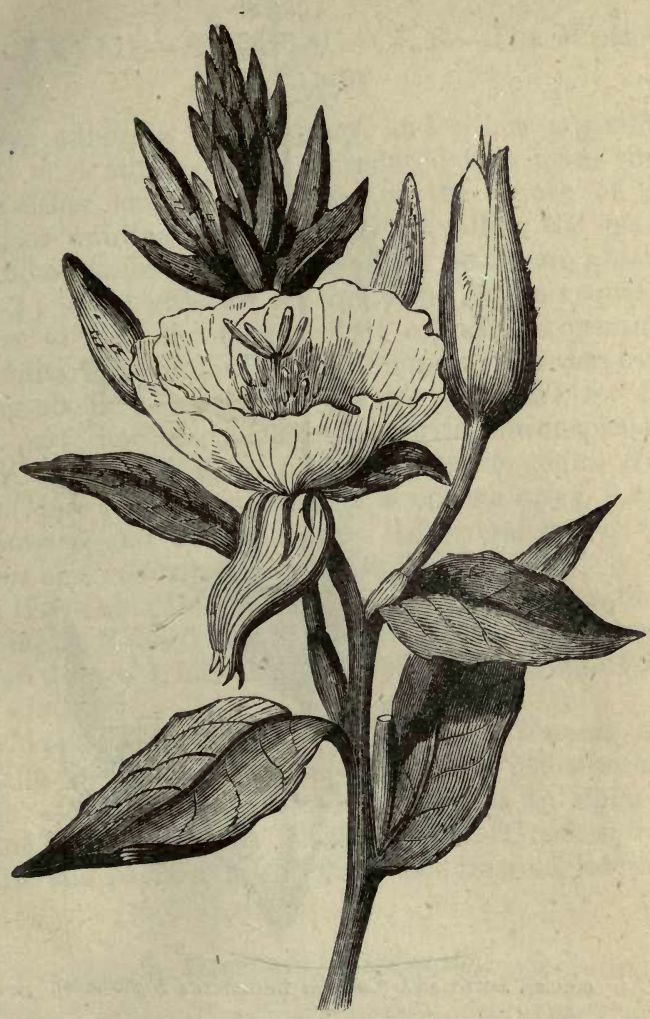

Genothéra BIENnis (Common Evening Primrose).

which are succeeded by 2-lobed hairy seed-vessels ; often a troublesome weed in damp gardens.-Fl. July, August. Perennial. 


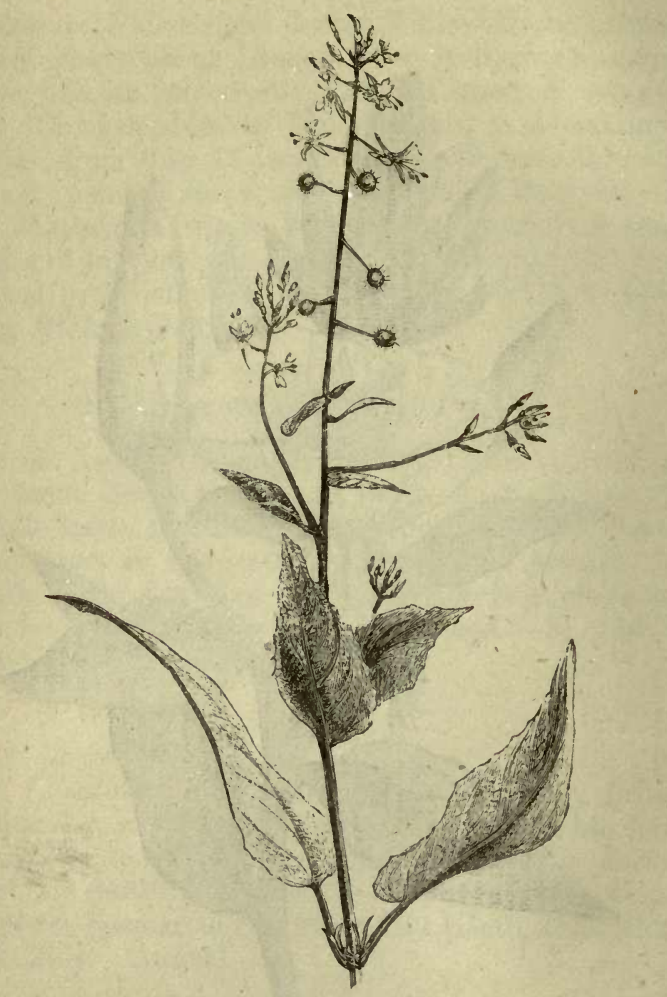

CIRCeAa LUtitiána (Common Eicciuanter's Nightshade).

2. C. alpína (Alpine Enchanter's Nightshade).-Stem nearly smooth; leaves heart-shaped, toothed, shining; calyx smooth.-Mountainous woods. Closely resembling the last, but smaller, and less branched. The leaves are remarkable for their delicate texture, and, when dried, are nearly transparent.-Fl. July, August. Perennial. 


\section{ORd. XXVIII.-HALORAGACE.E.-The Mare's- taIL Tribe.}

Calyx adhering to the ovary, and either expanding into 3 or 4 minute lobes, or reduced to a mere rim; petals either minute and placed on the mouth of the calyx, or wanting; stamens either equalling the petals in number, twice as many, or, when petals are absent, 1 or 2 ; ovary with one or more cells ; stigmas equal in number to the cells of the ovary ; capsule not opening; seeds solitary, pendulous.-An unimportant Order, comprising abcut 70 species of plants, which are for the most part herbaceous aquatics, with inconspicuous flowers often destitute of petals, and in one genus, Hippuris (Mare's-tail), composed of a minute calyx, a solitary stamen, and a single seed. In several species the stamens and pistils are in separate flowers.

1. Hippúris (Mare's-tail).-Calyx forming a minute, indistinctly 2-lobed rim to the ovary; petals 0 ; stamen 1 ; style 1 ; seed 1 , nut-like. (Name in Greek signifying mare's tail.)

2. Myriophýllum (Water Milfoil).-Stamens and pistils in separate flowers, but on the same plant (monoecious) ; calyx 4-parted; petals 4 ; stamens 8 ; styles 4 ; fruit of 4 nut-like seeds. (Name from the Greek myrioi, 10,000 , and phyllon, a leaf, from its numerous leaves.)

\section{Hippúris (Mare's-tail). .}

1. H. vulgáris (Common Mare's-tail).-The only British species, not uncommon in stagnant water. A singular plant, with erect, jointed stems, which are unbranched, except at the base, and taper to a point, bearing whorls of very narrow leaves with hard tips. The inconspicuous flowers are sessile in the axils of the upper leaves, and are often without stamens. - Not to be 


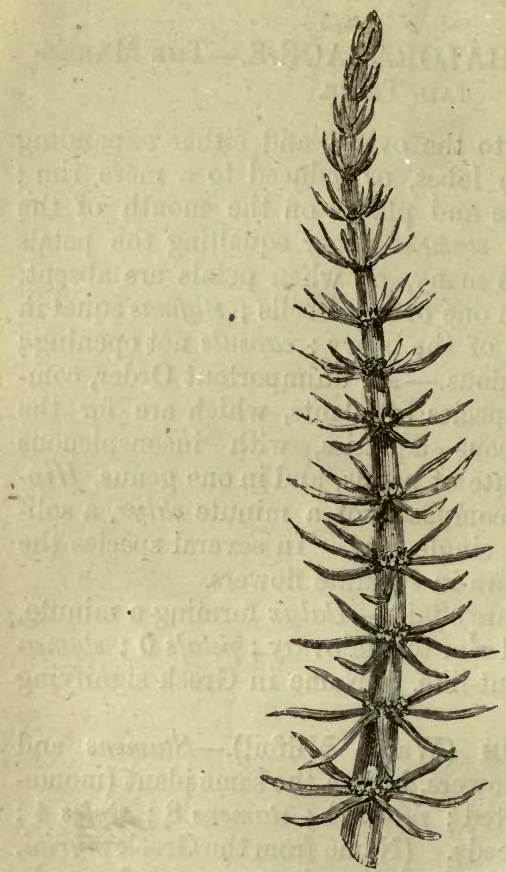

HIPPÚRIS VULGÁRIS (Common Mare'stail).

confounded with the genus Equisétum (Horse-tail), a plant allied to the Ferns, which also has a jointed stem and rigid leaves, but bears its fructification in terminal spikes, or heads.-Fl. June, July. Perennial.

\section{Myriophýllum (Water Milfoil).}

1. M. spicátum (Spiked Water Milfoil).-Flowers in whorls, forming a slender leafless spike.-Stagnant 
water ; frequent. An aquatic plant, forming a tangled mass of slender, much branched stems; leaves 4 in a whorl, finely divided into numerous hair-like segments, the whole plant being submerged, except the spikes of inconspicuous greenish flowers, which rise a few inches above the surface.-Fl. July, August. Perennial.

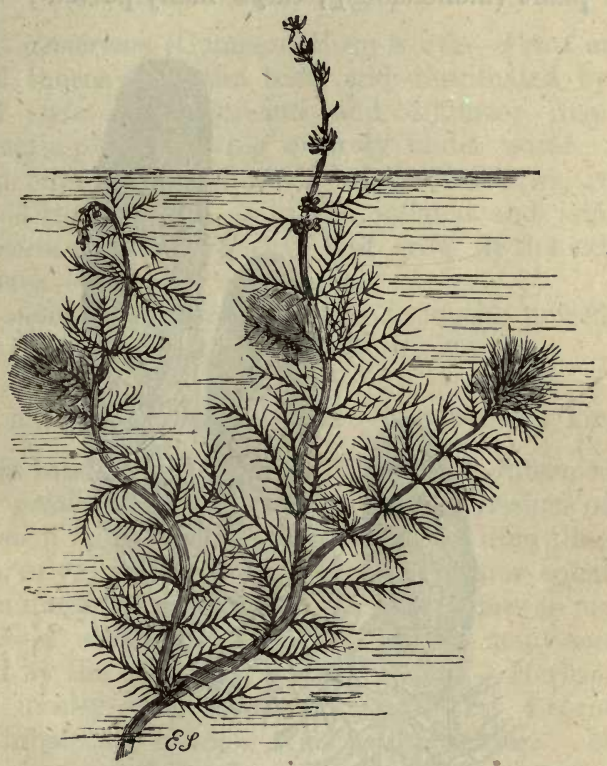

MYRIOPHÝLLUM SPICÁTUM (Spiked Water Milfoil).

* M. verticillatum (Whorled Water Milfoil) differs from the preceding in having the flowers in whorls at the base of the leaves; $M$. alterniflorum (Alternateflowered Water Milfoil) has the barren flowers alternately arranged in a short leafless spike, with the fertile flowers about 3 together, in the axils of the leaves, at its base. The last two are rare. 


\section{ORDER XXIX.-CERÁTOPHYLLACEÆ.-THE HorN-WORT TrIBE.}

Stamens and pistils in separate flowers, but on the same plant (monœcious); calyx many-parted; corolla

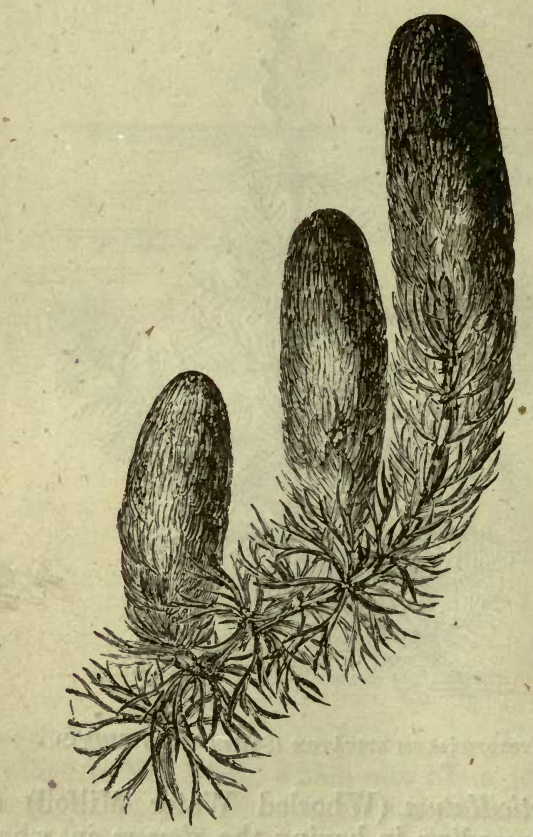

CERÁTOPHYLLTM DEḾ́RSUM (Common Horn-wort).

none ; stamens 12-20, without filaments; anthers 2-pointed ; ovary 1-celled ; style curved ; seed-vessel nutlike, 1-seeded, not opening.-This Order contains only 
Cerátophyllum (Horn-wort), an unimportant family of aquatic plants, very distinct in structure from any other known plants, with rigid whorled leaves, which are repeatedly forked, and inconspicuous flowers. (Name in Greek signifying horn-leaved.)

\section{Cerátophýllum (Horn-wort).}

1. C. demérsum (Common Horn-wort).-Fruit armed with 2 thorns near the base, and terminated by the curved style.-Slow streams and ditches; frequent. An aquatic plant, growing entirely under water; with long, slender stems; whorled, bristle-like leaves, which are 2-4 times forked, and often inflated and jointed ; the flowers also are whorled, and grow in the axils of the leaves.-Fl. July. Perennial.

${ }^{*} C$. submérsum scarcely differs from the preceding, except in having fruit without thorns.

\section{Ord. XXX.-LYTHRACE.A-Loosestrife Tribe.}

Calyx tubular, many-parted, often with intermediate teeth; petals inserted between the outer divisions of the calyx, soon falling off ; stamens springing from the tube of the calyx, within the petals, and either equalling them in number, or twice, thrice, or four times as many ; ovary $2-4$ celled; style single ; capsule many-seeded, covered by the calyx, but not united to it.-Herbaceous plants, mostly with opposite leaves, and 4-cornered stems, inhabiting Europe, America, and India. Many of the plants of this tribe possess astringent properties, and some are used for dyeing. The common Purple Loosestrife is found in Australia. Lawsonia inermis is the plant from which the Henna of Egypt is obtained. It is used by the women of that country to stain their nails of an orange colour, and is also employed for dyeing Morocco leather reddish-yellow.

1. Lythrum (Purple Loosestrife).-Calyx cylindrical, with 12 divisions, alternately smaller ; petals 6 ; stamens 
6 or 12 ; style thread-like. (Name from the Greek lythron, blood, from the colour of the flowers.)

2. Peplis (Water Purslane).-Caly $x$ bell-shaped with 12 divisions, alternately smaller; petals 6 , minute, soon falling off; stamens 6 ; style very short. (Name of Greek origin, and anciently applied to another plant.)

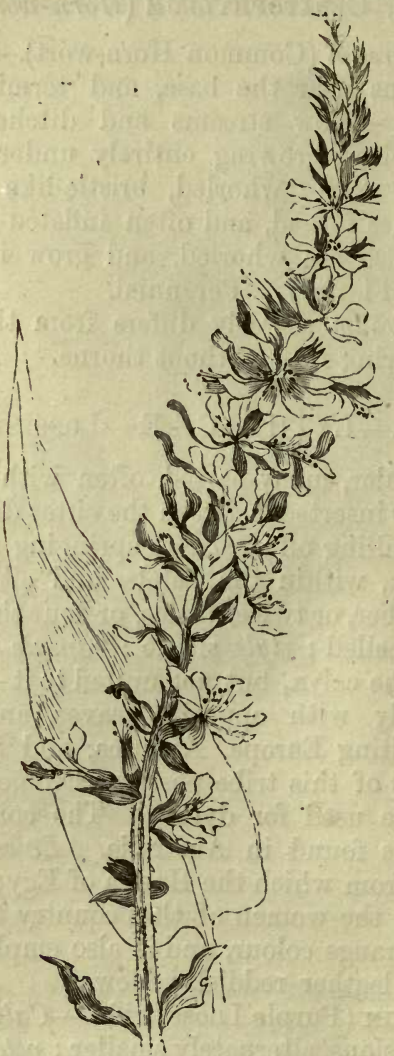

LyTHRUM SALICARIA (Purple Loosestrife, or Willowstrife). 


\section{LÝthrum (Purple Loosestrife).}

1. L. Salicária (Purple Loosestrife, or Willowstrife). -Leaves opposite, long, and narrow, heart-shaped at the base ; flowers whorled, in leafy spikes ; stamens 12 . -Watery places ; abundant. An exceedingly handsome plant, $2-4$ feet high, generally growing on river banks, among sedges and rushes, and sending up tall, tapering spikes of purple flower, which seen from a distance might be mistaken for Foxgloves.-Fl. July, August. Perennial.

* L. hyssopifolia (Hyssop-leaved Purple Loosestrife) is a much smaller plant, 4-6 inches high, with alternate leaves, and solitary purple flowers, with 6 stamens. It grows in moist places, but is far from common.

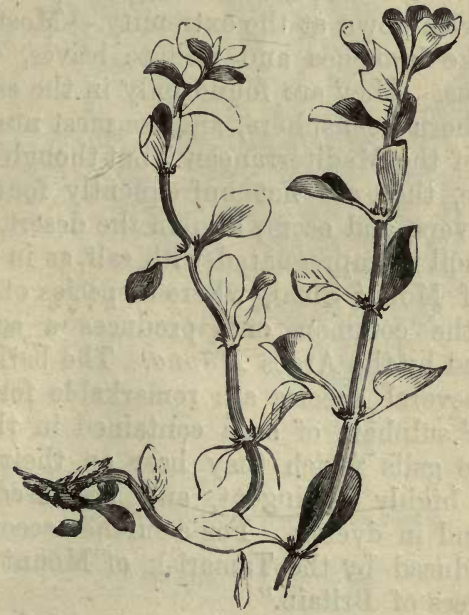

PEPLIS PORTULA (Water Purslane).

2. Pepuis (Water Purslane).

1. P. Pórtula (Water Purslane).-A humble, creeping, aquatic plant, with opposite smooth leaves, and 
inconspicuous axillary flowers. The stems are usually more or less tinged with red; and when the plant grows in places from which the water has been dried up, the leaves acquire the same hue.-Fl. July, August. Annual.

\section{ORD. XXXI.-TAMARICACEAE-The TAMARISK TRIBE.}

Calyx 4-5 parted, overlapping when in bud, remaining after the petals have withered; petals 4-5, from the base of the calyx; stamens either equal to the petals in number, or twice as many, distinct, or united by their filaments ; ovary not combined with the calyx ; styles 3 ; capsule 3 -valved, 1-celled, containing many seeds, which are tufted with down at the extremity.-Mostly shrubs, with rod-like branches and minute leaves, which resemble scales. They are found only in the eastern half of the northern hemisphere, and are most numerous on the shores of the Mediterranean ; but though preferring the sea-side, they are not unfrequently found on the banks of rivers, and occur, also, in the desert, especially where the soil is impregnated with salt, as in the neighbourhood of Mount Sinai, where a species of Tamarisk very like the common one, produces a sugary substance, called by the Arabs Manna. The bark is astringent, and several species are remarkable for the large quantity of sulphate of soda contained in their ashes, and for the galls which they bear on their branches. These are highly astringent, and are used both in medicine and in dyeing. For a further account of the Manna produced by the Tamarisk of Mount Sinai, see "Forest Trees of Britain."

1. Támarix (Tamarisk).-Calyx 5-parted; petals 5 ; stamens 5 or $10 ;$ stigmas feathery. (Named from the Tamarisci, a people who inhabited the banks of the Tamaris, now Tambra, in Spain, where the Tarnarisk abounds.) 


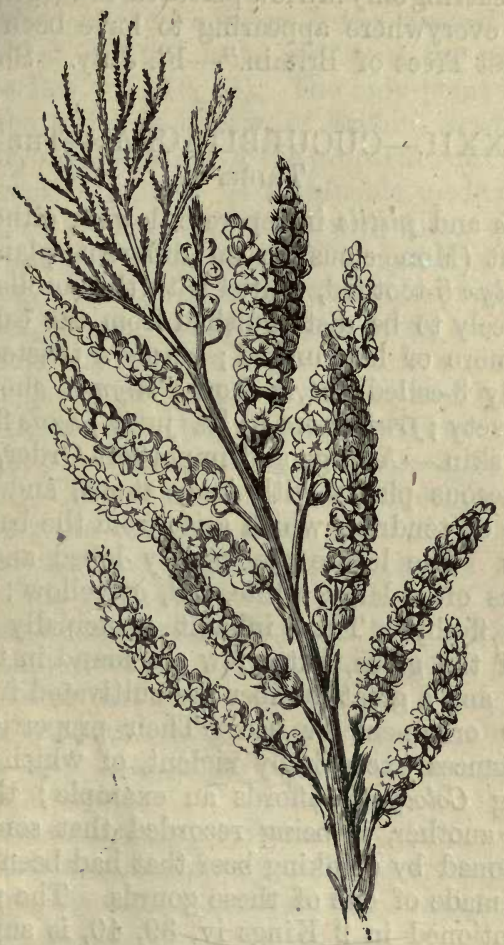

TÁMARIX GÁLLICA (Common Tamarisk).

Támarix (Tamarisk).

1. T. Gállica (Common Tamarisk).-A handsome shrub or small tree, with long flexible branches, and minute scale-like leaves, which are close pressed to the twigs, and give the tree a light feathery appearance. The flowers, which are rose-coloured, grow in clusters of 
spikes. This can scarcely be considered a native of Britain, occurring only in a few places on the south-western coast, and everywhere appearing to have been planted. See "Forest Trees of Britain."-Fl. July. Shrub.

\section{ORD. XXXII.-CUCURBITACEA-ThE Gourd TRIBE.}

Stamens and pistils in separate flowers, either on the same plant (Monœecious) or on different plants (Diœcious); calyx 5-toothed, united with the corolla ; corolla often scarcely to be distinguished from the calyx ; stamens 5, more or less united; anthers twisted; ovary imperfectly 3-celled; style short; stigmas short, thick, lobed, velvety ; fruit more or less juicy ; seeds flat, wrapped in a skin. - A large and important Order, containing herbaceous plants with juicy stems, and climbing by means of tendrils, which arise from the base of the leaf-stalks. The leaves are usually lobed and rough; the flowers often large, white, red, or yellow; the fruit juicy, or fleshy. They inhabit principally the hot regions of the globe, but a few are found in temperate climates; and a great number are cultivated in Europe, either for ornament or use. Their properties are in many instances exceedingly violent, of which the common drug Colocynth affords an example; the Bottle Gourd is another, it being recorded that some sailors were poisoned by drinking beer that had been standing in a flask made of one of these gourds. The poisonous plant mentioned in 2 Kings iv. 39, 40, is supposed to be a plant of this tribe, the Wild, or Ass Cucumber, which bears an oval fruit of a very bitter taste, and grows in sandy and desert places. As this cucumber has very much the same appearance as that which is cultivated in gardens, but only is somewhat smaller, and as even its leaves and tendrils are similar, it might easily happen that the man sent out by the disciples of the prophets took wild Cucumbers for a harmless fruit, and 
prepared a meal of them. But the bitter taste of the boiled Cucumber made those who tasted it fear that it was poisonous, the opinion being general with the Hebrews that a bitter taste indicated the presence of poison (see Rev. viii. 10,11). The only plant belonging to this tribe which is a native of Britain, Bryónia dioíca (White Bryony), partakes of the properties of Colocynth, and the root is said to be a valuable medicine. The Spirting Cucumber, so called from the force with which it expels the poisonous juice when ripe, is a very dangerous drug, a few grains of Elaterium, a prepared form of this juice, having been known to bring on symptoms of poisoning. A case even is recorded, when a person was taken dangerously ill from having merely carried a specimen in his hat. Many species, however, produce edible fruit; for instance, the numerous varieties of Melon and Cucumber, the Water Melon, so highly esteemed for the cool refreshing juice of its ripe fruit, and one of our finest table vegetables, the Vegetable Marrow. It is said that the tender shoots of the White Bryony may be used with safety after having been boiled, and that they resemble Asparagus in flavour; but it is highly probable that the shoots of Black Bryony (Tamus communis), a plant belonging to a different Order, may have been used instead; in either case the experiment is a dangerous one.

1. Bryónia (Bryony).-Stamens 5 , in 3 sets; style 3-cleft; fruit a globose berry. (Name from the Greek bryo, to bud, the rapid growth of the Gourd tribe being proverbial.)

\section{BRYónia (Bryony).}

1. B. dioíca (White Bryony).-The only British species ; frequent in England, except in the extreme western counties. An elegant climbing plant, with large, light green, rough leaves, having undivided tendrils at the base, and bunches of whitish flowers, with green veins. The fertile flowers may be distinguished at once from 


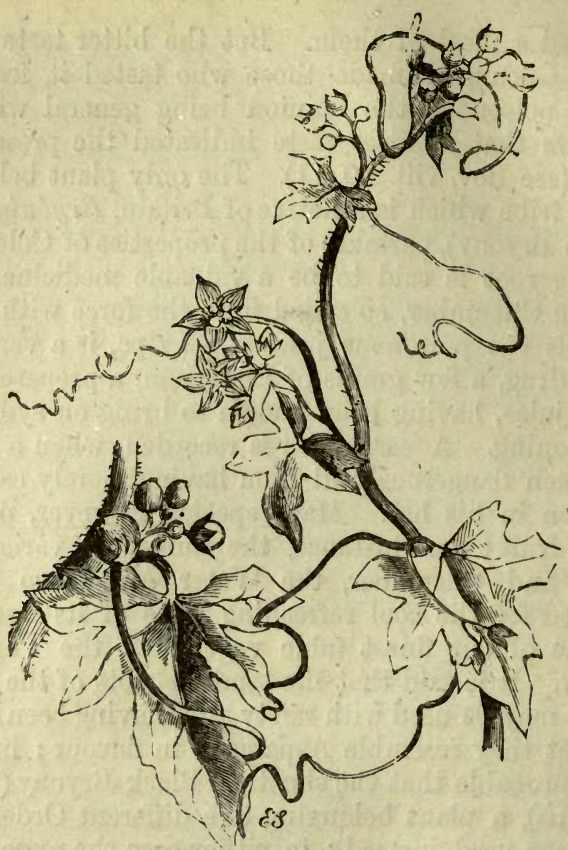

BRYÓNIA DIOICA (White Bryony).

the barren, by the presence of an ovary below the calyx. These are succeeded by globular scarlet berries, which hang about the bushes after the stems and leaves have withered. The berries of Black Bryony (Tamus commúnis) are larger, and elliptical in shape ; both should be avoided as injurious, if not poisonous.-Fl. MayAugust. Perennial.

Ord. XXXIII.-PORTULÁCEA.The Purslane TRIBE.

Calyx of 2 sepals, united at the base; petals usually 5 , from the base of the calyx; stamens 3 or more, 
inserted with the petals; ovary 1-celled; style 1 or 0 ; stigmas several; capsule 1-celled, opening transversely, or by 3 valves; seeds usually more than 1.-Herbs or shrubs, with juicy stems and leaves, and irregular flowers, which open only during sunshine. The most remarkable plant in this Order is the common Purslane, which has been used from all antiquity as a pot-herb. Many species have large, showy flowers, but the only one which occurs in Britain is a humble plant, with very inconspicuous flowers.

1. Montia (Water Blinks).-Calyx of 2 sepals ; corolla of 5 petals, 3 smaller than the others, and all united at the base ; tube of the corolla split to the base; capsule 3-valved, 3-seeded.

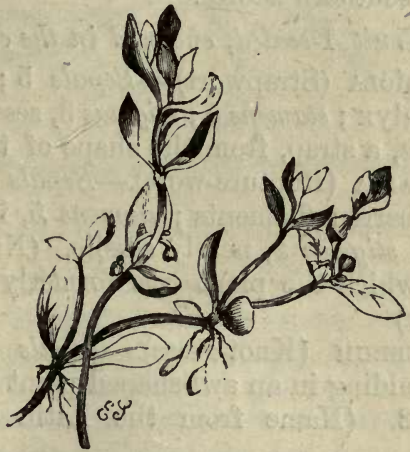

MONTIA FONTÁNA (Water Blinks).

1. Móntia (Water Blinks).

1. M. fontána (Water Blinks). - The only species; abundant in wet places. An unpretending little plant, well marked by its 2-leaved calyx, irregular corolla, the tube of which is split in front, and by its capsules containing 3 dotted seeds.-Fl. June-August. Annual. 
ORD. XXXIV.-PARONYCHIACEA-THE KNOTgRAsS TrIBE.

Sepals usually 5 ; petals 5 , minute, inserted between the lobes of the calyx, sometimes wanting; stamen varying in number, opposite the petals, if equalling them in number ; ovary not combined with the calyx; pistils $2-5$; fruit 1-celled, opening with 3 valves, or not at all.-Small, branching, herbaceous, or somewhat shrubby plants, with sessile undivided leaves and minute flowers, principally confined to the south of Europe and north of Africa, where they grow in the most barren places, covering with a thick vegetation soil which is incapable of bearing anything else. A few only are found so far north as Great Britain, and nearly all of these are confined to the southern shores.

\section{* Fruit 1-seeded, enclosed in the calyx.}

1. Corrigíola (Strapwort). - Sepals 5 ; petals 5, as long as the calyx ; stamens 5; stigmas 3, sessile. (Name from corrigia, a strap, from the shape of the leaves.)

2. Herniaria (Rupture-wort).-Sepals 5 ; petals 5, resembling barren filaments; stamens 5 , inserted on a fleshy ring; stigmas 2, nearly sessile. (Name from the disease for which the plant was formerly supposed to be a remedy.)

3. Illécebrum (Knot-grass).-Sepals 5, coloured, thickened, ending in an awl-shaped point ; petals 0 , or 5 ; stigmas 2. (Name from the Latin illécebra, an attraction.)

\section{** Fruit, a many-seeded capsule.}

4. Polycarpon (All-seed).-Sepals keeled at the back ; petals 5, small, notched ; stamens $3-5$; stigmas 3 , nearly sessile ; fruit 1 -celled, 3-valved. (Name from the Greek polys, many, and carpos, fruit.)

5. Spergularia (Sandwort Spurrey).-Sepals flat; petals ovate, entire, as large as the calyx ; styles usually 3. (Name from the resemblance to the next genus.) 
6. Spergula (Spurrey).- - Petals ovate, entire, as large as the calyx ; styles 5, alternate with the sepals. (Name from the Latin spargo, to scatter, the genus being widely diffused.)

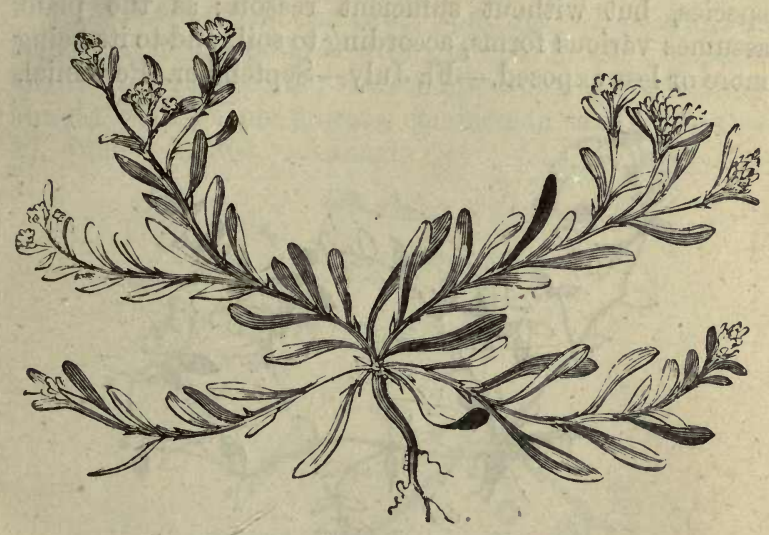

CORRIGIOLA LITTORALIS (Sand Strapwort).

1. Corrigíola (Strapwort).

1. C. littorális (Sand Strapwort).-A small but pretty plant, with slender spreading stems, which lie quite prostrate, very narrow strap-shaped leaves, of a glaucous hue, and tufts of small white flowers.-It grows in two or three places on the sea-shore of Devon, and is very abundant on the banks of the Loe Pool, near Helston, Cornwall.-Fl. August-October. Annual.

\section{Herniaria (Rupture-wort).}

1. H. glabra (Smooth Rupture-wort). - A small prostrate plant, with much of the habit of Wild Thyme; abundant in the neighbourhood of the Lizard Point, Cornwall, but very rare elsewhere. Though called smooth, the leaves are always more or less hairy, and sometimes 
strongly fringed at the edges. The flowers are green, and grow in sessile tufts in the axils of the leaves, or, not unfrequently, crowded into leafy spikes. Some botanists consider the more hairy variety a distinct species, but without sufficient reason; as the plant assumes various forms, according to soil, and to its being more or less exposed.-Fl. July - September. Perennial.

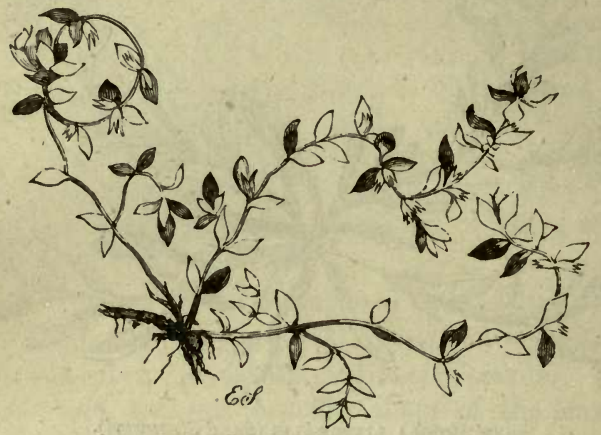

ILLÉCEBRUM VERTICILLATUM (Whorled Knot-grass)..

3. Illé́CeBrum (Knot-grass).

1. I. verticillatum (Whorled Knot-grass).-In boggy ground, and standing water, among other aquatic plants ; in Cornwall, not uncommon ; much rarer in Devonshire. A pretty plant, with slender tangled stems, of a red tint, glaucous, sessile leaves, and axillary whorls of white flowers, which are remarkable for their thickened calyxleaves terminating in a soft point.-Fl. July-September. Perennial.

\section{Polycarpon (All-seed).}

1. P. tetraphyllum (Four-leaved All-seed).-OOn the southern coast, but far from common. A small plant, with prostrate, branched stems, and many minute greenish- 
white flowers, with 3 stamens. The lower leaves grow in fours, the upper in pairs. -Fl. May-August. Annual.

5. Spergularia (Sandwort Spurrey).

1. S. rubra (Field Sandwort Spurrey).-Leaves linear, somewhat fleshy, pointed with a minute bristle ; stipules chaffy ; stems prostrate ; seeds rough.-A small branching annual, with purple flowers, common in sandy fields. Fl. June-August. Annual.

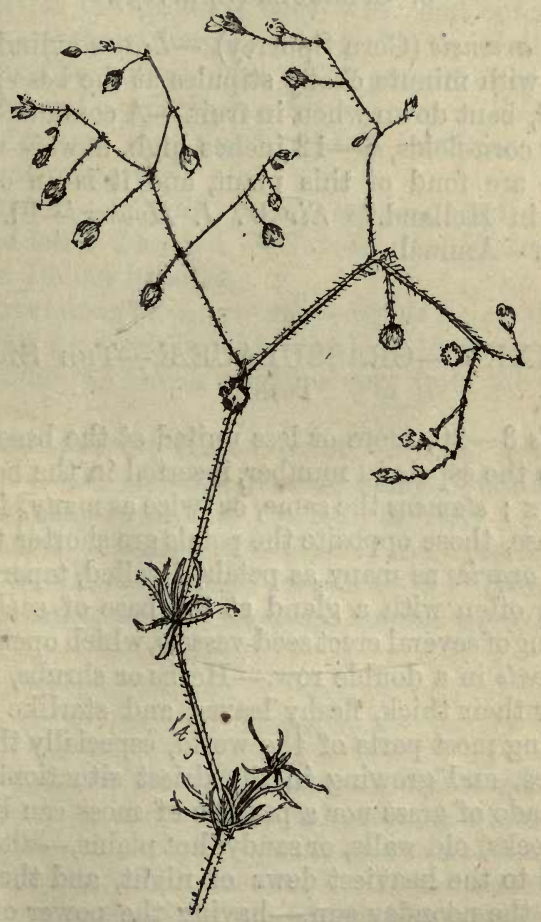

SPÉRGLA ARvéxis (Corn Spurrey). 
2. S. marina (Seaside Sandwort Spurrey).-Leaves semi-cylindrical without points; stipules chaffy ; stems prostrate; seeds smooth, flattened, bordered.-On the sea-shore; common. Stouter and larger than the last, but nevertheless so nearly resembling it, that it is doubtful whether both may not belong to the same species, varied, however, by soil and situation.-Fl. June-August. Annual.

\section{Spérgula (Spurrey).}

1. S. arvensis (Corn Spurrey). - Leaves cylindrical, in whorls, with minute chaffy stipules at the base; flowers panicled, bent down when in fruit.-A common weed in gravelly corn-fields, $6-12$ inches high, flowers white."Cattle are fond of this plant, and it is an object of culture in Holland." Sir W. J. Hooker.-Fl. all the summer. Annual.

\section{Ord. XXXV.-CRASSULACEA.-The Stonecrop TrIBE.}

Sepals 3-20, more or less united at the base; petals equal to the sepals in number, inserted in the bottom of the calyx ; stamens the same, or twice as many, in which latter case, those opposite the petals are shorter than the others ; ovaries as many as petals, 1-celled, tapering into stigmas, often with a gland at the base of each ; fruit consisting of several erect seed-vessels, which open lengthwise ; seeds in a double row.-Herbs or shrubs, remarkable for their thick, fleshy leaves, and starlike flowers, inhabiting most parts of the world, especially the south of Africa, and growing in the driest situations, where not a blade of grass nor a particle of moss can live ; on naked rocks, old walls, or sandy, hot plains, - alternately exposed to the heaviest dews of night, and the fiercest rays of the noonday sun,-having the power of laying in during the rainy season a large store of moisture, 
which they obstinately retain, and requiring no further nourishment, save what they derive from the atmosphere through myriads of mouths invisible to the naked eye, but coviering all their surface. A common British species, Sedum Teléphium, "Orpine living long," will grow for months, if suspended by a string from the ceiling of a room, without being once supplied with water. An African species, Bryophyllum calycinum, will not only grow if similarly treated, but if its leaves be gathered and laid on the ground, they will send out from the notches on their margin, young shoots, in all respects resembling the parent plant. The properties of the tribe are in general acrid ; some few contain malic acid, and one or two are sometimes used in medicine, for their astringent properties.

1. Tillæa.-Sepals, petals, stamens, and carpels, 3 or 4, the latter 2-seeded. (Named after Michael Angelo Tilli, an Italian botanist.)

2. Cotyledon (Pennywort).-Sepals 5 ; corolla tubular, 5-cleft; carpels 5, with a scale at the base of each. (Name from the Greek cótylé, a cup, from the shape of the leaves.)

3. Sempervívom (House-leek).-Sepals, petals, and carpels, 6-10 ; stamens twice as many. (Name from the Latin semper, always, and vivo, to live.)

4. SEDUM (Stonecrop). - Sepals and petals 4-6; stamens 8-12, spreading; carpels 4-5. (Name from the Latin sedeo, to sit; from the humble growth of the plants.)

\section{Tillean.}

1. T. muscósa (Mossy Tillæa).-A minute plant, with small, opposite, blunt leaves, and greenish-white flowers tipped with red; more frequent as a troublesome weed in gravel walks, than elsewhere. It has somewhat of the habit of a Sagina, from which, however, it is very distinct.-Fl. May, June. Annual. 


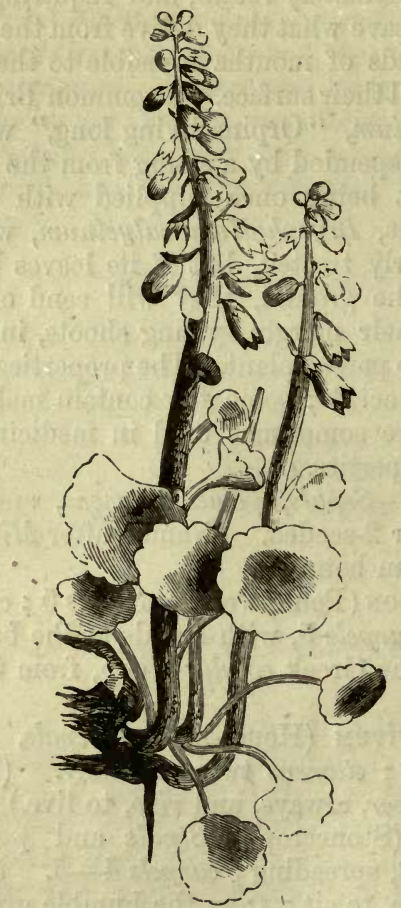

COTYLídon umbilícus (Wall Pennywort).

2. СотYLÉdon (Pennywort).

1. C. Umbilicus (Wall Pennywort). -A remarkably succulent plant, with circular, notched leaves, which are more or less sunk above, and are supported on their stalks by their centres, or peltate. The flowers are pendulous, and grow in spike-like clusters, $6-18$ inches high, of a greenish yellow colour. The leaves are well known to children by the name of "penny pies."-Fl. June-August. Perennial. 


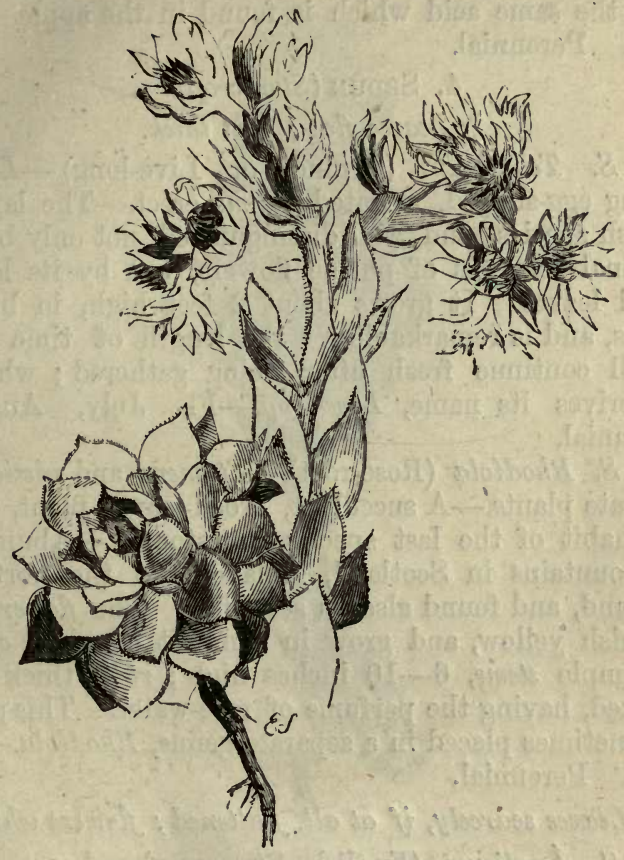

SEMPERVÍvUM TECTÓRUM (Common House-leek).

3. Sempervívum (House-leek).

1. S. tectórum (Common House-leek).-A common but scarcely indigenous plant, growing on the roofs of cottages. The leaves are thick and juicy, fringed at the edges, and grow in compact rose-like tufts. Each of the purple flowers contains 12 perfect and 12 imperfect stamens; the latter, which are arranged alternately with the petals, frequently bearing anthers containing embryo seeds, like those found in the carpels, but of course 
never attaining maturity. The leaves contain malic acid, the same acid which is found in the apple.-Fl. July. Perennial.

\section{Sedum (Stonecrop). * Leaves flat; root thick.}

1. S. Teléphium (Orpine, or Live-long).-Leaves oblong egg-shaped, serrated; stems erect.-The largest British species, and well distinguished, not only by its terminal corymbs of purple flowers, but by its large, broad leaves. It grows about 2 feet high, in bushy places, and is remarkable for the length of time that it will continue fresh after being gathered; whence it derives its name, Live-long.-Fl. July, August. Perennial.

2. S. Rhodíola (Rose-root).-Stamens and pistils on separate plants.-A succulent, broad-leaved plant, with the habit of the last species, but stonter.-Abundant on mountains in Scotland, Ireland, and the north of England, and found also on sea-cliffs. The flowers are greenish yellow, and grow in compact terminal cymes on simple stems, 6-10 inches high ; roots thick and knotted, having the perfume of rose-water. This plant is sometimes placed in a separate genus, Rhodiola.-Fl. June. Perennial.

* Leaves scarcely, if at all, flattened; flowers white.

3. S. Ánglicum (English Stonecrop).-Leaves eggshaped, fleshy, spurred at the base beneath, sessile; cymes 2-cleft; petals very sharp.-Rocky and sandy places, especially near the sea.-A small plant, 3-4 inches high, with stems which at first are prostrate and rooting, afterwards erect ; the leaves are mostly alternate, often tinged with red, small, and very thick; the flowers conspicuous from their star-like form, their white petals spotted with red, and bright purple anthers.Fl. June, July. Annual.

4. S. album (White Stonecrop).-Leaves oblong, cylindrical, blunt, spreading; cyme much branched, 


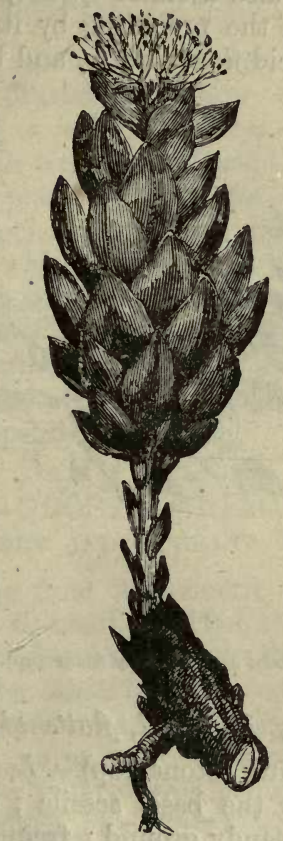

SEDUM RHODÍOLA (Rose-root).

drooping when in bud.-Rocks and walls ; not common. Rather taller and more slender than the last, and easily distinguished by its much longer cylindrical leaves, and more numerous white, not spotted, flowers. This species is not uncommon on garden walls, and the roofs of outhouses.-Fl. July, August. Perennial.

* To this group belong $S$. villósum (Hairy Stonecrop), a small species, with hairy, viscid stems and leaves, and pinkish white flowers; frequent in Scotland and the north of England: and $S$ dasyphyllum (Thick- 
leaved Stonecrop), also a small species, but very rare ; distinguished from the preceding by its fleshy, almost globular leaves, viscid flower-stalks, and blunt petals.

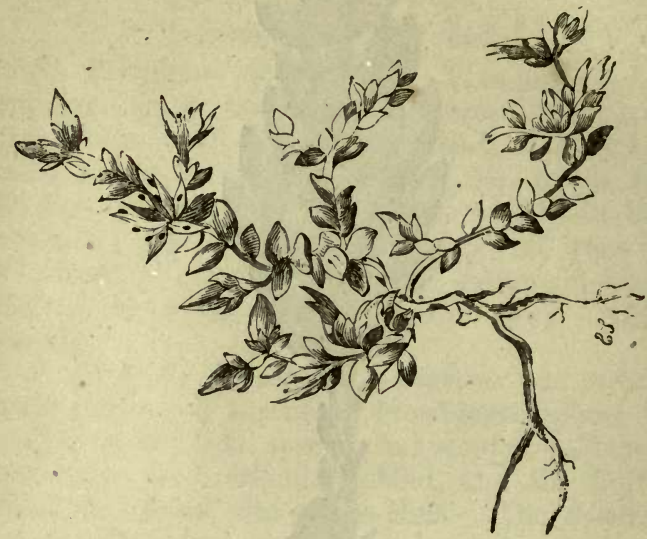

SEDUM ACRE (Biting Stonecrop).

** Leaves scarcely, if at all, flattened; flowers yellow.

5. S. acré (Biting Stonecrop).-Leaves egg-shaped, fleshy, spurred at the base, sessile ; cymes 3-cleft.Walls, rocks, and sandy ground ; frequent. Very like $S$. Ánglicum in habit, but with yellow flowers, and growing in similar situations ; it may, however, be distinguished, when not in flower, by its thicker and more crowded leaves, which are very acrid, and have gained for the plant the name of Wall-pepper.-Fl. June, July. Perennial.

6. S. reflexum (Crooked Yellow Stonecrop).-Leaves awl-shaped, spurred at the base, nearly cylindrical ; the lowermost curved back.-Walls and dry banks; not uncommon. Easily distinguished from any of the preceding by its slender, but tough stems, 6-10 inches high, clothed with spreading, or reflexed leaves, which 
are cylindrical and pointed.-Fl. July, August. Perennial.

Other British species, belonging to this group, are S. sexangulare (Tasteless Yellow Stonecrop), distinguished from $S$. acre by its leaves, which are 6 in a whorl, growing in Greenwich Park, the Isle of Sheppey, and a few other places ; S. rupestre (St. Vincent's Rock Stonecrop), a species allied to $S$. reflexum, with slightly flattened leaves, which grow 5 in a whorl, found on St. Vincent's Rocks, and other limestone cliffs ; rare : and S. Forsterianum (Welsh Stonecrop), another species allied to $S$. reflexum, with leaves flattened at the base, and compact cymes of flowers, which grows on rocks in Wales and Shropshire.

ORD. XXXVI.-GROSSULARIACE Æ.-The GooseberRy aNd Currant Tribe.

Calyx growing from the summit of the ovary, 4-5 cleft; petals $4-5$, small, inserted at the mouth of the calyx-tube, and alternating with the stamens; ovary 1-celled, with the ovules (young seeds) arranged in two opposite rows ; style $2-4$ cleft ; berry crowned with the withered flower, pulpy, containing many stalked seeds. - Shrubs with or without thorns, and having alternate lobed leaves, which are plaited when in bud. The flowers grow in clusters in the axils of the leaves, each flower with a bract at its base, and are succeeded by pulpy berries, which in several species are highly prized for their agreeable flavour. In other species the taste is mawkish, or extremely acid. The plants of this tribe grow only in the temperate parts of the world, especially in North America, and on the mountains of Northern India. In Africa they are unknown.

1. Ribes (Currant and Gooseberry).-Calyx 5-cleft; petals 5, inserted at the mouth of the calyx-tube; stamens 5 ; berry many-seeded, crowned by the withered flower. (Name anciently given to a species of Rhubarb.) 


\section{Ribes (Currant and Gooseberry).}

* Flowers 1-3 together; branches thorny.

1. R. Grossularia (Gooseberry).-The common gooseberry of gardens. Frequently met with in hedges and thickets; but not considered to be a native plant. It is well distinguished by its sharp thorns, which grow either singly, or 2-3 together, below the leaf-buds.Fl. April, May. Shrub.

** Flowers in clusters; branches without thorns.

2. R. rubrum (Red Currant).-Clusters drooping; bracts very small ; calyx smooth; leaves bluntly 5-lobed. - The Red and White Currant of gardens ; not uncommon in hedges near houses; and in Scotland and the north of England supposed to be wild.-Fl. April, May. Shrub.

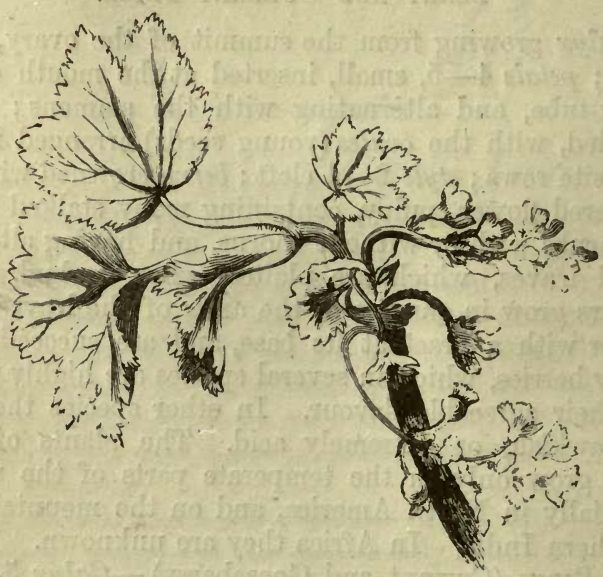

RIBES NIGRUM (Black Currant).

3. R. nigrum (Black Currant).-Clusters loose, drooping, with a single stalked flower at.the base of each; 
calyx downy; leaves sharply 3-5-lnbed, dotted with glands beneath. - The Black Currant of gardens; occasionally wild in damp woods. Easily distinguished, at all seasons, by the strong perfume of its buds and leaves.-Fl. April, May.' Shrub.

* R. alpínum (Tasteless Mountain Currant) has the stamens and pistils on separate plants; the flowers also grow in erect clusters, with very long bracts at the base of each. It grows in the mountainous parts of England and Scotland.

\section{ORD. XXXVII.-SAXIFRAGACEA-The SAXI- FRAGE TRIBE.}

Sepals 5, rarely 4, more or less united at the base ; petals equalling the sepals in number, inserted between the sepals, rarely 0 ; stamens 5-10; ovary of two united carpels; styles 2, usually spreading in opposite directions ; capsule 2-celled, opening on the inside; seeds numerous. This Order is principally composed of herbaceous, mountainous plants, with tufted foliage, and glandular stems. They abound in temperate and cold climates, but are not found in tropical countries. The genus Saxifraga (Saxifrage) is an extensive one, and contributes greatly to the beauty of the vegetation high up in the mountains; but some species grow on old walls, by the sides of rivulets, and in moist meadows. Chrysosplenium (Golden Saxifrage) has no petals. Few of the plants belonging to this tribe are applied to any use. Most of them have slight astringent properties, and some few are bitter and tonic.

1. Saxífraga (Saxifrage).-Calyx in 5 divisions; petals 5 ; stamens 10 ; styles 2 ; capsule 2-celled, 2 beaked, opening between the beaks; seeds numerous. (Name in Latin signifying rock-breaker, many of the species growing in crevices of rocks.)

2. Chrysosplenium (Golden Saxifrage).-Calyx in 4 divisions; petals 0 ; stamens 8 , rarely 10 ; styles 2 ; 
capsule 2-beaked. (Name from the Greek, chrysos, gold, and splen, the spleen, from some imaginary virtues of the plant.)

\section{Saxífraga (Saxifrage).}

* Calyx reflexed, inferior; flowers whitish, panicled.

1. S. stelláris (Starry Saxifrage).-Leaves oblong, wedge-shaped, toothed, scarcely stalked; panicle of few :flowers. - Wet rocks, and sides of rivulets, in Scotland, Ireland, and the north of England. A mountain plant, 3 -5 inches high, with coarsely toothed leaves, and rather large white petals, each with two yellow spots near the base.-Fl. June, July. Perennial.

2. S. umbrósa (London Pride, or St. Patrick's Cabbage).-Leaves roundish, egg-shaped, with white notches, tapering at the base into a flat stalk. - In the south and west of Ireland, plentiful; naturalized in many parts of England, and very common in gardens. A wellknown plant, with rose-like tufts of fleshy leaves, and panicles of small white flowers, dotted with pink. Though growing naturally on mountains, there is scarcely any situation where it will not make itself at home, even in the smoky gardens of London. Hence it varies considerably in form, and has been subdivided by some botanists into several species.-Fl. June. Perennial.

* 'To this group belong S. Géum (Kidney-shaped Saxifrage), distinguished by its kidney-shaped leaves; common on mountains in the south of Ireland: and S. hirsúta, a species intermediate between S. Géum and S. umbrósa, also an Irish plant, but very rare.

** Calyx spreading; leaves not divided.

3. S. nivális (Clustered Alpine Saxifrage).-Leaves all from the root, inversely egg-shaped, sharply crenate; calyx half inferior; flowers in a crowded head.-Mountains in Wales and Scotland. An alpine plant, 3-6 
inches high, with rather large, white flowers, which grow in a compact head.

4. S. aizoídes (Yellow Mountain Saxifrage).-Leaves very narrow, fleshy, fringed; flowers in a leafy panicle. Wet places in the mountains; abundant. A handsome species, about 6 inches high, with large, bright yellow flowers, spotted with scarlet.-Fl. June-September. Perennial.

* S. Hírculus (Yellow Marsh Saxifrage) differs from the last in having its flowers solitary, or nearly so ; it is of very rare occurrence : $S$. oppositifolia (Purple Mountain Saxifrage) has egg-shaped leaves, and large, solitary, purple flowers; it grows on the mountains of Wales, Yorkshire, and Scotland.

\section{*** Calyx spreading; leaves divided.}

5. S. granuláta (White Meadow Saxifrage).-Rootleaves kidney-shaped, with rounded lobes, stalked; stem-leaves nearly sessile, sharply lobed; flowers panicled; roots granulated.-Gravelly meadows ; not uncommon. A pretty plant, with slender leafy stems, 10-12 inches high, and rather large, pure white flowers. The roots are remarkable for producing numerous, downy, bulb-like tubers. A double variety is frequent in gardens.-Fl. May, June. Perennial.

6. S. tridactylítes (Rue-leaved Saxifrage).-Whole planit viscid with glandular hairs ; leaves wedge-shaped, 3-5-cleft; stem much branched; flowers terminal, each on a separate stalk.-On the tops of walls, and roofs of cottages ; common. A small species, rarely more than 3 inches high, with very hairy and viscid stems, and small white flowers. The whole plant has usually a red tinge-Fl. May, June. Annual.

7. S. hypnoídes (Mossy Saxifrage).-Root-leaves 3-5cleit; those on the creeping shoots 3-cleft, or entire; lr,bes of the leaves all very narrow, acute, bristle-pointed, and fringed.-Mountainous places; common. Distinguished by its dense tufts of finely divided leaves, and 


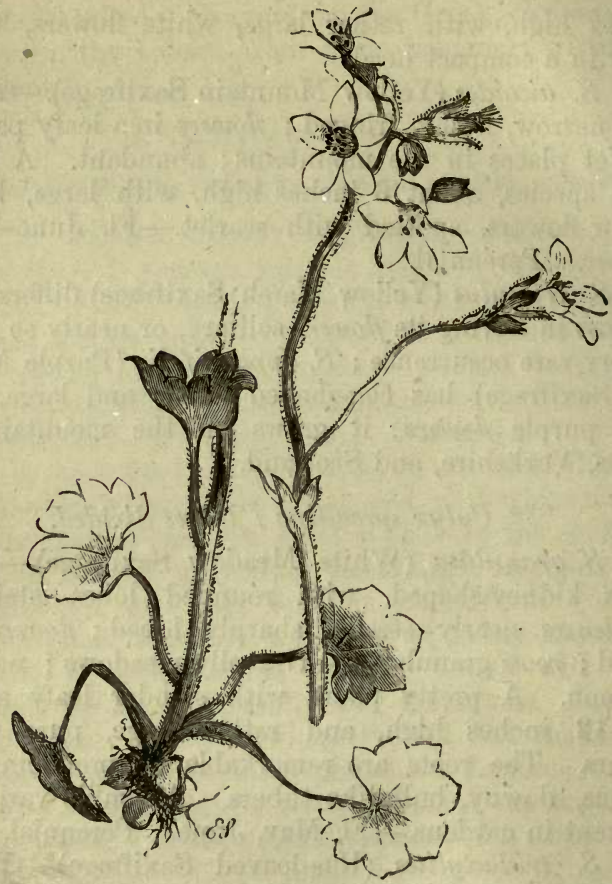

SAXfFraga GRANULATA (White Meadow Saxifrage).

loose panicles of rather large, white flowers. Very frequent in gardens.-Fl. May-July. Perennial.

* Closely allied to the preceding is S'. coespitósa (Tufted Alpine Saxifrage), distinguished by the obtuse lobes of its leaves, and by other minute characters : S. cernua (Drooping Bulbous Saxifrage) is a very rare species, which grows only on dry rocks on the summit of some of the Highland Mountains ; it is remarkable for bearing bulbs in the axils of the leaves, and a soli- 
tary terminal white flower: S. rivuláris (Alpine Brook Saxifrage), another very rare species, grows on moist rocks among the same mountains : besides which, other species and varieties have been described, but an enumeration of them is not thought necessary here.

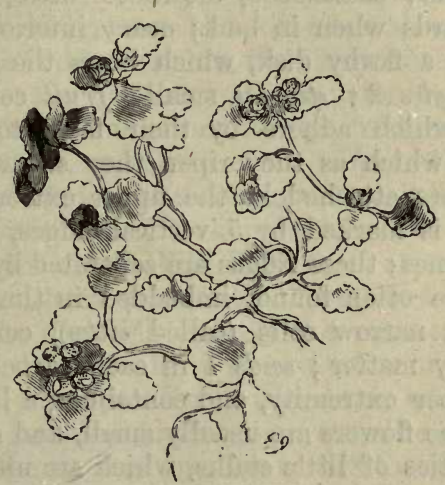

CHRYSOSPLENIUM OPPositifolium (Common Golden Saxifrage).

\section{Chrysosplenium (Golden Saxifrage).}

1. C. oppositifolium (Common Golden Saxifrage).Leaves opposite, roundish heart-shaped.-Sides of shady rivulets, and wet woods; common. A small aquatic plant, about 6 inches high, with abundance of bright green, tender foliage, and terminal, flat clusters of yellowish green flowers.-Fl. April, May. Perennial.

2. S. alternifolium (Alternate-leaved Golden Saxifrage).-Leaves alternate, lower ones kidney-shaped, on long stalks.- Very like the last, and growing in similar situations, but rare. The flowers in this species are of a deeper yellow ; in both, the number of stamens is usually 8.-Fl. April, May. Perennial. 
ORD. XXXVIII.-UMBELLÍFERA.-THE UMBELLIFEROUS TRIBE.

Calyx superior, 5-toothed, often reduced to a mere margin ; petals 5, usually ending in a point, which is bent inwards; stamens 5 , alternate with the petals, curved inwards when in bud; ovary inferior, 2-celled, crowned by a fleshy disk, which bears the petals and stamens; styles 2 ; stigmas small; fruit composed of 2 carpels, which adhere by their faces to a central stalk, from which as they ripen they separate below, and finally are attached by the upper extremity only; each carpel is marked by 5 vertical ridges, with 4 intermediate ones; these ridges are separated by channels, in which are often found, imbedded in the substance of the fruit, narrow cells (called vittoe), containing a coloured oily matter; seeds 1 in each carpel, attached by their upper extremity, and containing a large horny albumen; the flowers are usually small, and situated on the extremities of little stalks, which are united at the base, and form an umbel. When several of these smaller umbels proceed in like manner from a common stalk, the umbel is said to be compound; the larger being called a general umbel, the smaller partial. The small leaves which commonly accompany the flowers of this tribe are called general, or partial bracts, according to their position; each collection of bracts is sometimes termed an involucie.-All the British plants belonging to this order are herbaceous, with tubular, or solid, jointed stems. With two exceptions, Eryngium and Hydrocótylé, they have compound umbels. By far the larger number have also divided leaves, more or less sheathing at the base, and white flowers. Though it is easy to decide at a glance to what order they are to be assigned, no such facility exists in distinguishing the families of the Umbelliferæ. Indeed, were it not for the large number of species $(1,500)$, which are known to exist, it is probable that they would have been brought 
together by botanists, so as to form but a few genera, whereas they have been divided into as many as 267 ; and, as all these agree in the more important parts of fructification, the distinctions of the genera are necessarily founded on differences so minute, that, in the case of other plants, they would perhaps be considered sufficient to do no more than distinguish species. 'To the young botanist, therefore, the study of the Umbelliferæ is unusually difficult ; all the more important distinctions being founded on the ripe fruit, namely - the number, position, and shape of the ridges - the presence or absence of vittce - and the form of the albumen. As it would be absurd, in a work professing to be a popular description of British Wild Flowers, to attend solely, or even in any great degree, to these characters, it has been thought desirable to limit the number of species described to those which are of most common occurrence, and to notice any peculiarity in growth, which, though not strictly admissible into a systematic description, may assist the student in discovering the names of the plants he may meet with. For a fuller list, and for more accurate information, he is referred to works of a professedly scientific character, such as Hooker's British Flora, and Babington's Manual of British Botany.

Among the large number of species of which this tribe is constituted, one would naturally expect to find plants varying greatly in their properties. And such is the case to a certain extent; the roots, leaves, and seeds are variously employed; some as food and condiments, others, as medicine, while others are highly poisonous. Yet, when considered with reference to their properties, they may be conveniently arranged into 4 groups; all the members of each group being remarkably similar. The first comprises plants which abound in an acrid, watery juice, which is more or less narcotic in its effects on the animal frame, and which, therefore, when properly administered in minute doses, is a valuable medicine. Among these, the most important is 
Coníum (Hemlock) ; every part of this plant, especially the fresh leaves and green fruit, contains a volatile, oily alkali, called Conía, which is so poisonous that a few drops soon prove fatal to a small animal. It acts on the nervous system, and is a valuable medicine in cancerous and nervous diseases. Several other British species are poisonous, especially $\mathbb{E}_{n}$ anthé, Cicúta, and Athrisa, described below. The second group comprises those which abound in a resinous gum, of a fetid odour, which is supposed to be owing to the presence of sulphur in combination with the peculiar essential oil. Among these, the first place is held by Asafoetida, the hardened milky juice of various species of Férula, inhabiting Persia and the neighbouring countries. This drug was held in high repute among the ancients for its medical virtues; it was supposed to be an antidote to poison, to restore sight to the blind, and youth to the aged; and was besides considered a certain specific against various diseases. Gum Gálbanum is the produce of other umbelliferous plants, natives of the East. The third group comprises plants the seeds of which abound in a wholesome aromatic oil. The principal of these are well known, under the names of Caraway, Coriander, Dill, Anise, and Cumin. The fourth group comprises plants which contain some of the above properties in a very slight degree, or so modified as to form wholesome esculent vegetables. Among these, Carrots and Parsneps occupy the first place; Celery and Alexanders, in their wild state, are too acrid to be used as food, but, when blanched by artificial means, become mild and agreeable; Parsley, Fennel, and Chervil, the last now nearly out of use, are well-known potherbs ; Samphire affords the best of pickles; the root of Eryngo is sweet, aromatic, and tonic, and is commonly sold in a candied state; the root of Angelica (Angélica Archangélica) is fragrant and sweet when first tasted, but leaves a glowing heat in the mouth, and is commended by the Laplanders both as food and medicine: 
the candied stems form a favourite sweetmeat. Several species produce underground tubers, which, under the name of pig-nuts, or earth-nuts, are eaten by children and pigs ; and others, common in the East, afford valuable pasturage for cattle. Of all the British umbelliferous plants, the most dangerous are the Water Dropworts (Enanthé), the large tuberous roots of which, resembling Dahlia roots, are often exposed by the action of running water, near which they grow, and are thus easily got at by children and cattle.

The following table contains a description of all the common British species : a list of the rarer ones, and of introduced species, will be found at the end of the Order.

\section{* Umbels simple or irregular.}

1. Hydrocótylé (White-rot).-Flowers in simple umbels; fruit of two flattened, roundish lobes, united by the narrow edge; leaves round, peltate. (Name from the Greek, hydor, water, and cótylé, a platter, from the shape of the leaves, and place of growth.)

2. Sanícula (Sanicle).-Flowers in panicled tufts, the outer without stamens, the inner without pistils; fruit egg-shaped, covered with hooked prickles. (Name from the Latin, sano, to heal, the plant being formerly supposed to have remarkable healing qualities.)

3. ERyngium (Eryngo).-Flowers in a dense prickly head ; fruit egg-shaped, covered with chaffy scales. ** Umbels compound; fruit of two flattened lobes, which are united by the narrow edge, not prickly, nor beaked.

4. Coníum (Hemlock). - Fruit egg-shaped, each carpel with 5 wavy ridges; general bracts few, partial 3, all on the outside. (Name, the Greek for the plant.)

5. Suyrnium (Alexanders).-Fruit of two kidneyshaped carpels, each having 3 prominent ridges; bracts 0 . (Name from the Greek, smyrna, myrrh, from the scent of some of the species.)

6. Cicúta (Water Hemlock). - Fruit of 2 almost 
globose carpels, with 5 broad, flattened ridges ; general bracts 1 or 2 , very narrow, often 0 ; partial several, unequal. (Name from the Latin, cicúta, a Hemlock stalk.)

7. ApIum (Celery).-Fruit roundish egg-shaped, of 2 almost distinct carpels, each with 5 slender ridges; bracts 0 . (Name, the Latin name of this or some allied plant.)

8. Petroselínum (Parsley).-Fruit egg-shaped ; carpels each with 5 slender ridges; general bracts few, partial many. (Name from the Greek, petros, a rock, and selinon, parsley.)

9. Helosciadium (Marsh-wort).-Fruit egg-shaped, or oblong; carpels, each with 5 slender, prominent ridges ; general bracts 0, partial several. (Name from the Greek, helos, a marsh, and skiádion, an umbel.)

10. Sison (Stone Parsley).-Fruit egg-shaped ; carpels with 5 slender ridges; petals broad, deeply notched, with an inflexed point; bracts both general and partial, several. (Name, the Greek for some allied plant.)

11. Agopodium (Gout-weed).-Fruit oblong; carpels with 5 slender ridges; bracts 0 . (Name in Greek signifying goat's-foot, from some fancied resemblance of the leaves.)

12. Carum (Caraway).-Fruit oblong; carpels with 5 slender ridges; general bracts 0 , or rarely 1, partial 0 . (Name from Caria, a country of Asia Minor.)

13. Búnium (Earth-nut).-Fruit oblong, crowned with the conical base of the erect styles; carpels with 5 slender, blunt ridges; general bracts 0 , partial few. (Name from the Greek, bounos, a hill, where the plant delights to grow.)

14. Pimpinella (Burnet Saxifrage).-Fruit oblong, crowned with the swollen base of the reflexed styles; carpels. with 5 slender ridges, and furrows between; general bracts 0, or rarely 1, partial 0. (Name of doubtful etymology.)

15. Srum (Water Parsnep).-Fruit nearly globose; 
carpels with 5 slender, blunt ridges; bracts, general and partial, several. ("Name, according to Théis, from the Celtic word siw, water." -Sir W. J. Hooker.)

16. Bupleurum (Hare's-ear).-Fruit oblong ; carpels with 5 prominent ridges, crowned at the flat base of the styles; partial bracts, very large. (Name from the Greek, bous, an ox, and pleuron, a rib, from the ribbed leaves of some species.)

** Umbels compound; fruit not flattened, not prickly, nor beaked.

17. GEnánthé(Water Dropwort).-Fruit egg-shaped, cylindrical, crowned with the long straight styles; carpels with 5 blunt, corky ridges; flowers somewhat rayed, those of the centre only being fertile. (Name from the Greek, oinos, wine, and anthos, a flower, from the wine-like smell of the flowers.)

18. Eтнúsa (Fool's Parsley).-Fruit nearly globose ; carpels with 5 sharply-keeled ridges, crowned with the reflexed styles ; partial bracts 3 , all on one side, drooping. (Name from the Greek, aitho, to burn, from its acrid properties.)

19. Fanículum (Fennel).-Fruit elliptical ; carpels with 5 bluntly-keeled ridges ; bracts 0 . (Name from the Latin, foenum, hay, to which it has been compared in smell.)

20. Ligústicum (Lovage).-Fruit elliptical ; carpels with 5 sharp, somewhat winged ridges; bracts, both general and partial, several. (Name from Liguria, where the cultivated species abounds.)

21. Siláus (Pepper Saxifrage).-Fruit egg-shaped; carpels with 5 sharp somewhat winged ridges; petals scarcely notched (yellow) ; general bracts, 1 or 2, partial several. (Name given by the Romans to some probably allied plant.)

22. Méum (Spignel).-Fruit elliptical ; carpels with 5 sharp, winged ridges ; petals' tapering at both ends; 
general bracts few, partial numerous. (Name, the Greek for this or some allied plant.)

23. Crithmum (Samphire).-Fruit elliptical ; carpels spongy, with 5 sharp, winged ridges; bracts, both general and partial, numerous. (Name from the Greek crithé, barley, to which grain the fruit bears a fancied resemblance.)

**** Umbels compound; fruit of two flattened carpels, which are, united by their faces, not prickly, nor beaked.

24. ANGélica. - Fruit with three sharp ridges at the back of each carpel, and two at the sides, the latter expanding into an even border ; general bracts few, or 0 , partial numerous. (Named angelic, from its medicinal properties.)

25. 'Pastináca (Parsnep).-Fruit very flat, with a broad border; carpels with 3 slender ridges on the back, and 2 near the outer edge of the margin; general and partial bracts, rarely more than 1 ; flowers yellow. (Name from the Latin, pastus, pasture.)

26. Heraclém (Cow Parsnep).-Fruit nearly the same as in Pastináca; flower's rayed; general bracts several, soon falling off, partial numerous. (Name from Hercules, who is said to have brought this, or some allied plant, into use.)

***** Umbels compound; fruit prickly, not beaked.

27. Daucus (Carrot).-Fruit slightly flattened; carpels united by their faces, oblong; ridges bristly, with a row of prickles between; general bracts very long, often pinnatifid. (Name, the Greek name of tha plant.)

28. Caúcalis (Bur-Parsley).-Fruit slightly flattened; carpels united by thin narrow edges; ridges bristly, with $1-3$ rows of hooked prickles between. (Name, the Greek name of the plant.)

29. Torílis (Hedge Parsley).-Fruit slightly contracted at the sides; ridges of the carpels bristly, with 
numerous prickles between; partial bracts numerous. (Name of doubtful origin.)

****** Umbels compound; fruit more or less beaked.

30. Scandix (Shepherd's Needle).-Fruit contracted at the sides, with a very long beak; carpels with 5 blunt ridges ; general bracts 0 , partial several, longer than the flowers. (Name, the Greek name of the plant.)

31. Anthriscus (Beaked Parsley).-Fruit with a sl.ort beak ; carpels without ridges ; general bracts 0 , partial several. (Name, the Greek name of this or some allied plant.)

32. Cherophylum (Chervil).-Fruit contracted at the sides, with a short beak; carpels with 5 blunt ridges ; partial bracts several. (Name in Greek signifying pleasant leaf, from the agreeable perfume of some species.)

33. Mrrahis (Cicely).- Fruit contracted at the sides, with a deep furrow between the carpels; carpels with 5 sharply-keeled ridges; general bracts 0 , partial several. (Name from the Greek, myrrha, myrrh, from the fragrance of the leaves.)

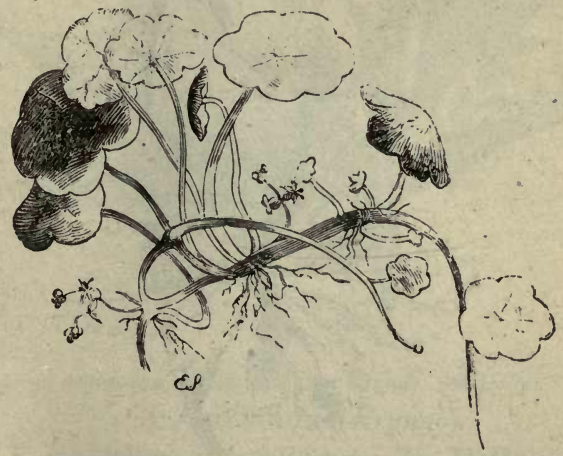

HYDRoơtyLé Vulgaris (Common White-rot, Marsh Pennywort). 


\section{Hydrocótylé (White-rot́).}

1. H. vulgáris (Common White-rot, Marsh Pennywort).-The only British species ; common in marshes and bogs. A small creeping plant,-very unlike the rest of the umbelliferous tribe, with round, smooth, crenate leaves, $1-1 \frac{1}{2}$ inch across, and inconspicuous heads of about 5, minute, reddish-white flowers, which never rise above the leaves, and require a close search to be detected at all. Each leaf is attached by its centre to the stalk, and resembles a little platter.-Fl. May, June. Perenniàl.

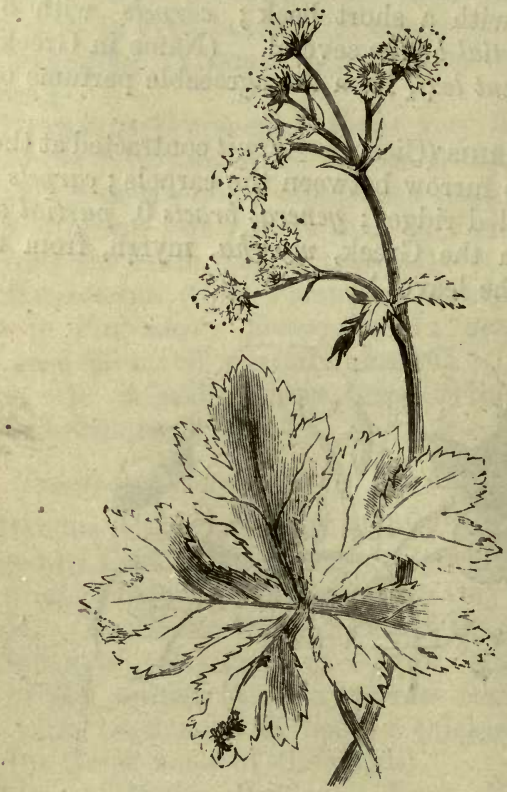

SANISULA FIROPAA (WoOd Sanic'e). 


\section{Sanícula (Sanicle).}

1. S. Europoea (Wood Sanicle).-The only British species ; common in woods. A slender, smooth plant, about $1 \frac{1}{2}$ foot high, with glossy leaves, which are 3-5lobed, and cut. The flowers are dull white, and grow in panicled heads, rather than umbels, and are succeeded by roundish seeds, which are covered with hooked prickles.-Fl. June, July. Perennial.

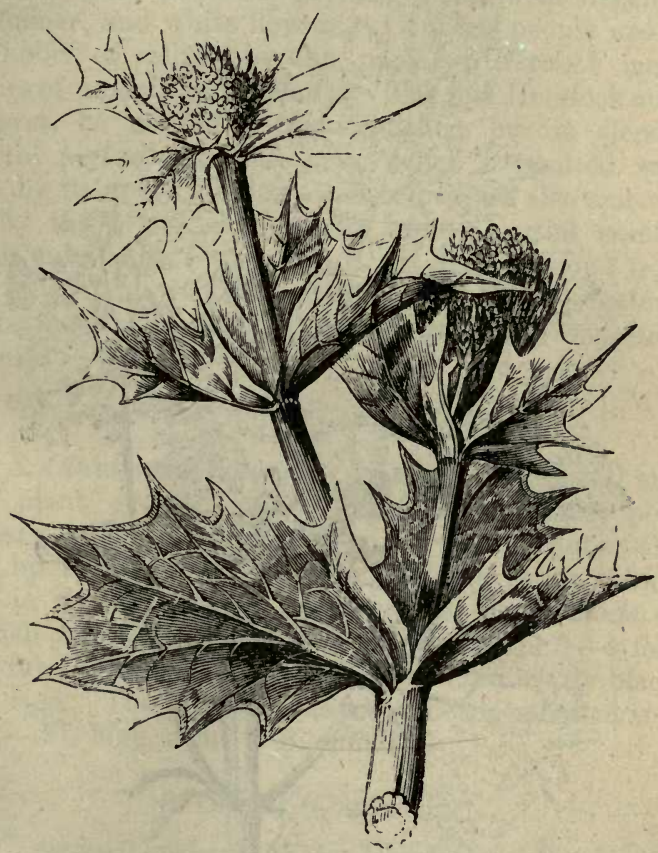

eryngium Marítimum (Sea Eryngo, Sea Folly).

3. Eryngium (Eryngo).

1. E. marítimum (Sea Eryngo, Sea Holly).-A stout prickly plant, with more of the habit of a Thistle than 
one of the Umbelliferous tribe. The whole plant is remarkably rigid and glaucous. The flowers are blue, and grow in dense heads. The roots are large, fleshy, and brittle, and extend for a distance of many feet into the sand. When candied they form a well-known sweetmeat.-Fl. July, August. Perennial.

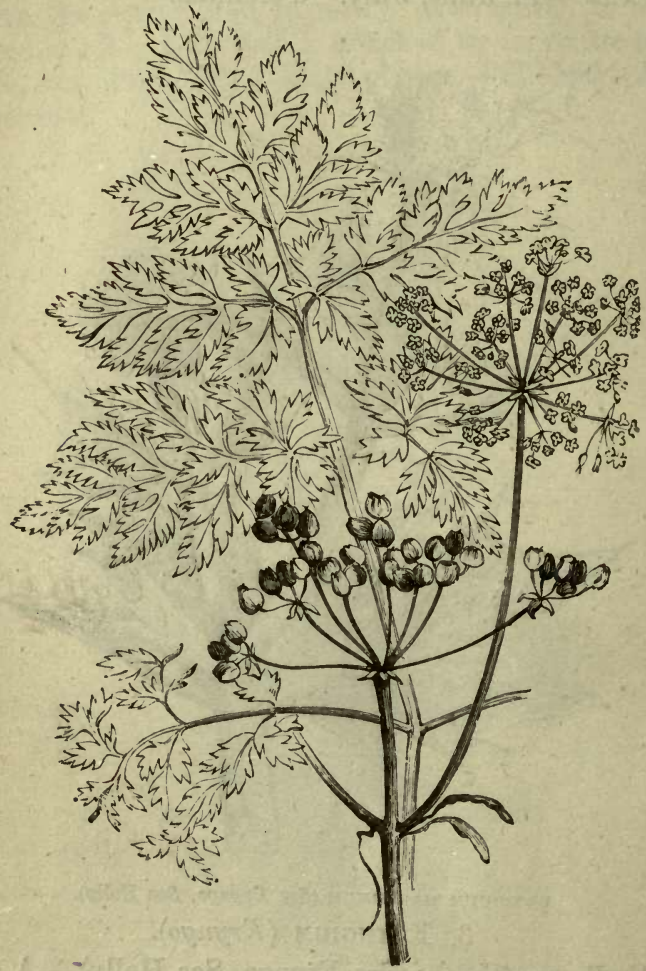

CONíum Macilatum (Common Hemlock), 
A second British species, E. campéstré (Field Eryngo), grows at Stonehouse, Devonshire, and in two or three other places, but it is very rare. It resembles the last in habit, but is taller and more slender.

\section{Coníum (Hemlock).}

1. C. maculátum (Common Hemlock).-A tall, much branched and gracefully growing plant, with elegantly cut foliage, and white flowers. Country people are in the habit of calling by the name of Hemlock many species of umbelliferous plants. The real Hemlock may, however, be accurately distinguished by its slender growth, perfectly smooth stem, which is spotted with red ; by its finely divided leaves, which are also smooth, and by the bracts at the base of the partial umbels, which only go half way round. It usually grows from 2 to 4 feet high, but in sheltered situations it sometimes attains more than double that height.-Fl. June, July. Biennial.

\section{SMÝRnium (Alexanders).}

1. S. Olusátrum (Common Alexanders).-A tall and stout plant, growing in waste ground, especially near the sea; well distinguished from any other plant of the tribe by its broad, bright green, glossy leaves, which grow in threes, and by its numerous large umbels of greenish yellow flowers. The stem is smooth, 3-4 feet high, furrowed and hollow. The seeds are nearly black when ripe. The young shoots are sometimes boiled and eaten.-Fl. May, June. Biennial.

\section{Cicúta (Cowbane).}

1. C. virósa (Cowbane, Water-Hemlock).-Ponds and ditches; rare. A poisonous, aquatic species; distinguished by its very stout hollow stem, pinnate and long-stalked lower leaves, twice ternate upper leaves, and stalked umbels of white flowers. The name Water-Hem- 


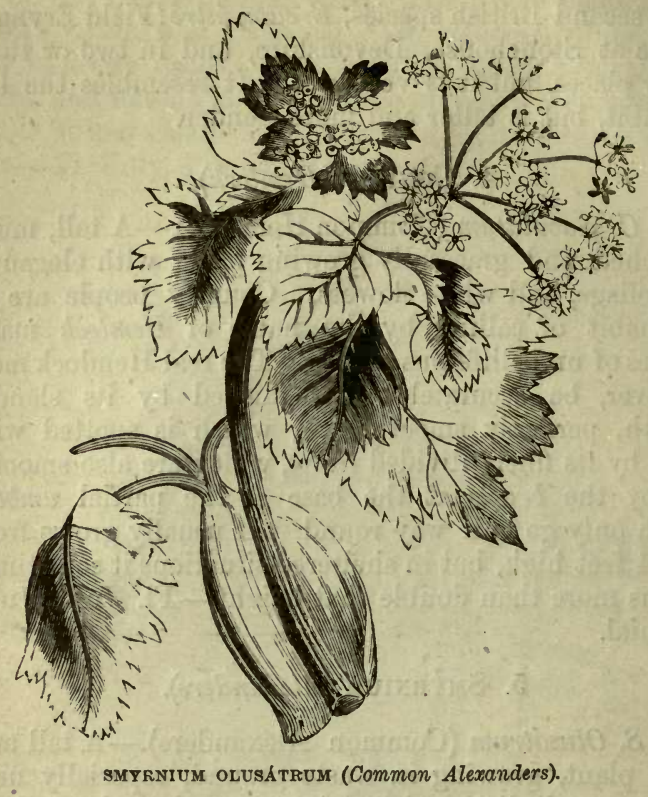

lock is often applied to several species of EEnanthé, which are also very poisonous.-Fl. July, August. Perennial.

\section{7. Ápium (Celery).}

1. A. gravéolens (Celery, Smallage)-Moist places near the sea. The origin of the garden Celery, and unmistakeably distinguished by its strong flavour and odour, which in no respect differ from those of the garden plant. The stem is usually $1-2$ feet high, branched, and leafy, but sometimes nearly prostrate. The flowers are small and white, and grow either in terminal or axillary umbels, which are often sessile and unequal. In its wild state the plant is not eatable, but 
when it has been cultivated on rich soil, and the leafstalks have been blanched by being deprived of light,

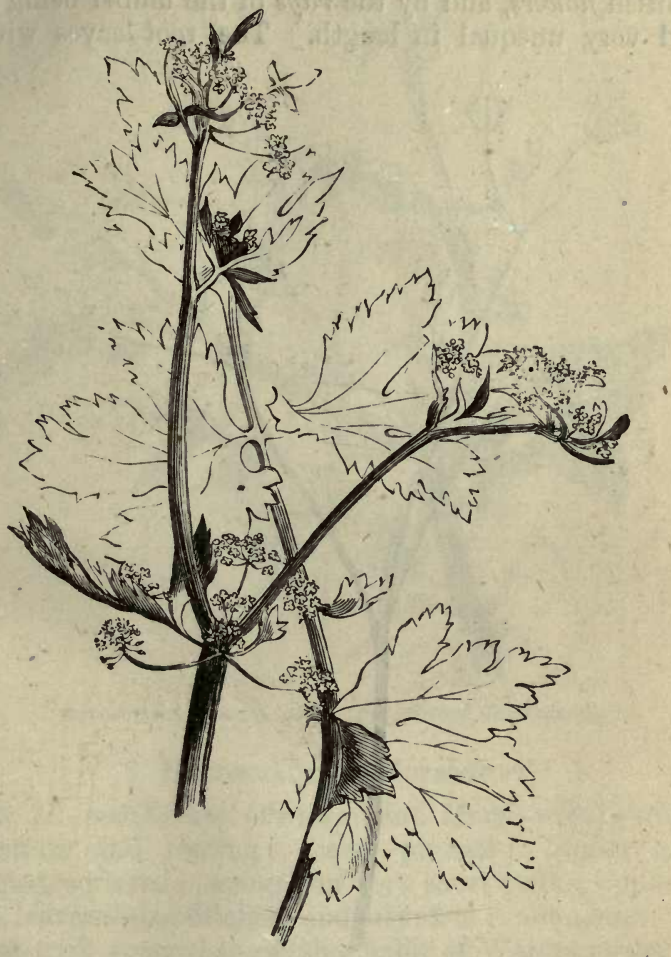

Ápium Gratiolens (Celery, Smallage).

it is a wholesome vegetable.-Fl. June-September. Biennial.

\section{Petroselínum (Parsley).}

1. P. ségetum (Corn Parsley).-Corn fields and waste places; not uncommon. Well distinguished by its s 2 
slender, branched stem, which is remarkably tough and wiry, by its small pinnated leaves, and umbels of small whitish flowers, and by the rays of the umbel being few and very unequal in length. The root-leaves wither

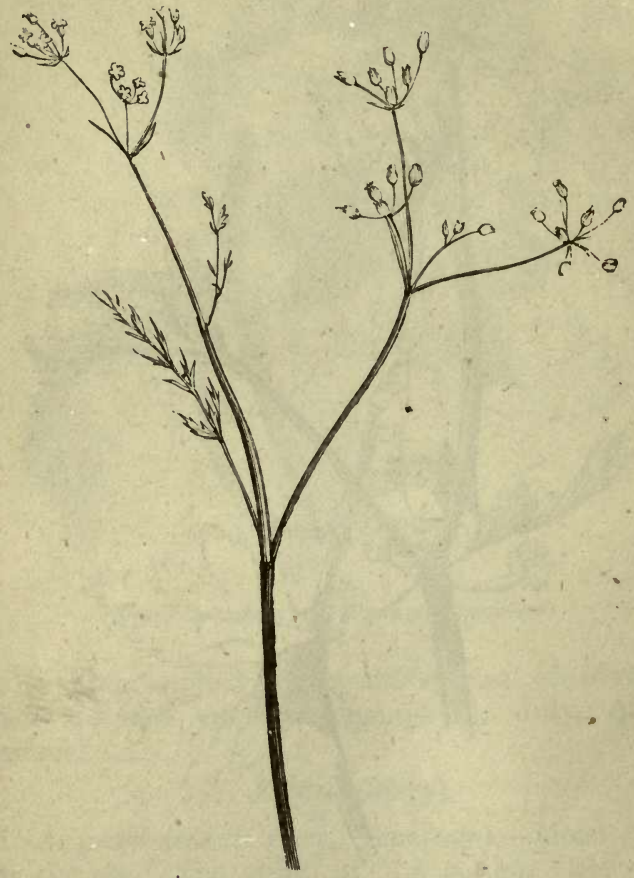

petroself́nom skaetum (Corn Parsley).

early, and the few which grow on the stem are small and inconspicuous.-Fl. August, September. Biennial. * P. satívum is the common Parsley of gardens, which, though often found seemingly wild, is not really indigenous. 


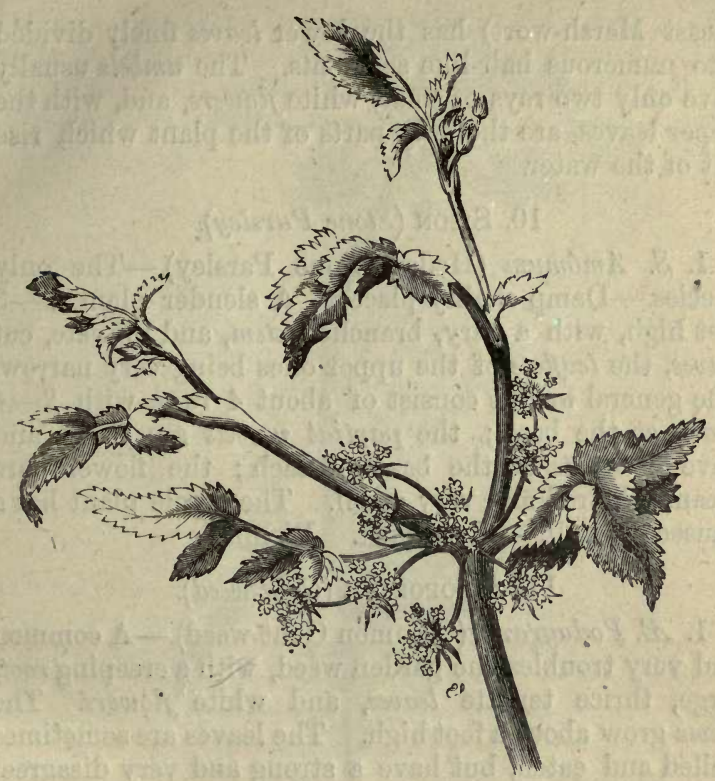

HELOSCIADIUM NODIFLÓRUM (Procumbent Marsh-wort).

\section{Helosciadium (Marsh-wort).}

1. H. nodiflorum (Procumbent Marsh-wort).-Stem prostrate and rooting; leaves pinnate; leaflets eggshaped, serrated; umbels on very short stalks, opposite the leaves.-In ditches and rivulets; abundant. A plant with somewhat of the habit of Water-cresses, in company with which it often grows, and for which it is sometimes mistaken. It may be distinguished, when out of flower, by its serrated and somewhat pointed - leaves, and by its hollow stems. The flowers are small and white.-Fl. July, August. Perennial.

* $H$. repens is a smaller plant, and has narrower leaves, but is scarcely a distinct species : H. inundatum 
(Least Marsh-wort) has the lower leaves finely divided into numerous hair-like segments. The umbels usually have only two rays of small white flowers, and, with the upper leaves, are the only parts of the plant which rise out of the water.

\section{Sison (Stone Parsley).}

1. S. Amómum (Hedge Stone Parsley).-The only species.-Damp chalky places. A slender plant, 2-3 feet high, with a wiry, branched stem, and pinnate, cut leaves, the leaflets of the upper ones being very narrow. The general umbels consist of about 4 rays, with 2-4 bracts at the base; the partial umbels are small, and have 4 bracts at the base of each; the flowers are cream-coloured and very small. The whole plant has a nauseous smell.-Fl. August. Biennial.

\section{Agopodium (Gout-weed).}

1. A. Podagraria (Common Gout-weed).-A common and very troublesome garden weed, with a creeping root, large, thrice ternate leaves, and white flowers. The stems grow about a foot high. The leaves are sometimes boiled and eaten, but have a strong and very disagreeable flavour.-Fl. May, June. Perennial.

\section{Carum (Caraway).}

1. C. Carui (Common Caraway).-A doubtful native, but occasionally growing wild in several parts of Great Britain. The root is spindle-shaped, the stem is much branched, about 2 feet high, the leaves twice pinnate, with leaflets cut into very narrow segments ; the flowers are white, and grow in rather large umbels, with rarely more than one bract, and that at the base of the general umbel. The seeds are too well known to need any description.-Fl. June. Biennial.

* C. verticillatum (Whorled Caraway) is a smaller plant with pinnate leaves, the leaflets of which are divided to the base into very numerous hair-like seg- 


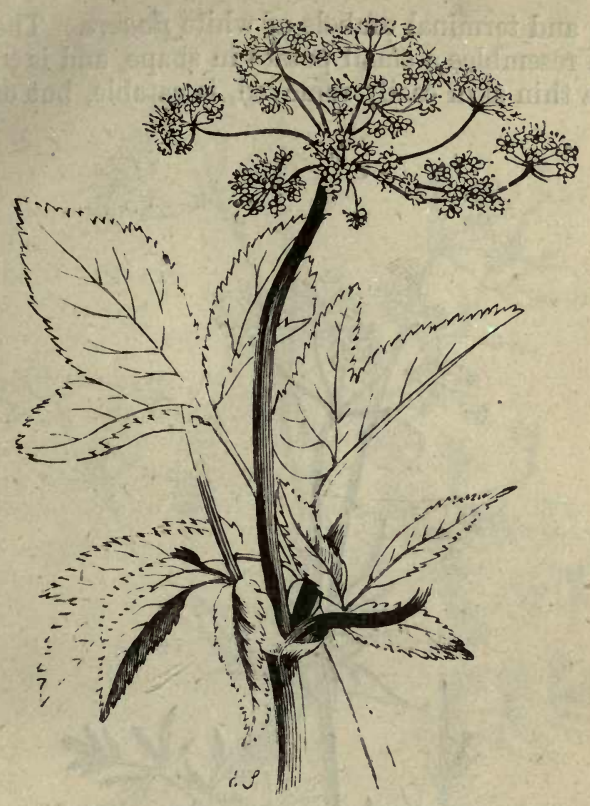

EGOPODIUM PODAGRARIA (Common Gout-weed).

ments, and are so crowded as to appear whorled. Very rare, except in the west of Scotland: C. Bulbocástanum (Tuberous Caraway) is a local plant, so abundant in the chalk district near Baldock, in Hertfordshire, that " the farmers turn their pigs upon the fallows to feed upon the roots." Hooker and Arnott. Found also in Cambridgeshire, but scarcely known elsewhere.

\section{BúNium (Pig-nut).}

1. B. Alexuósum (Common Pig-nut).-A very slender plant, about a foot high, bearing a few finely divided 
leaves, and terminal umbels of white flowers. The root, which resembles a small potato in shape, and is covered with a thin skin easily removed, is eatable, but only fit

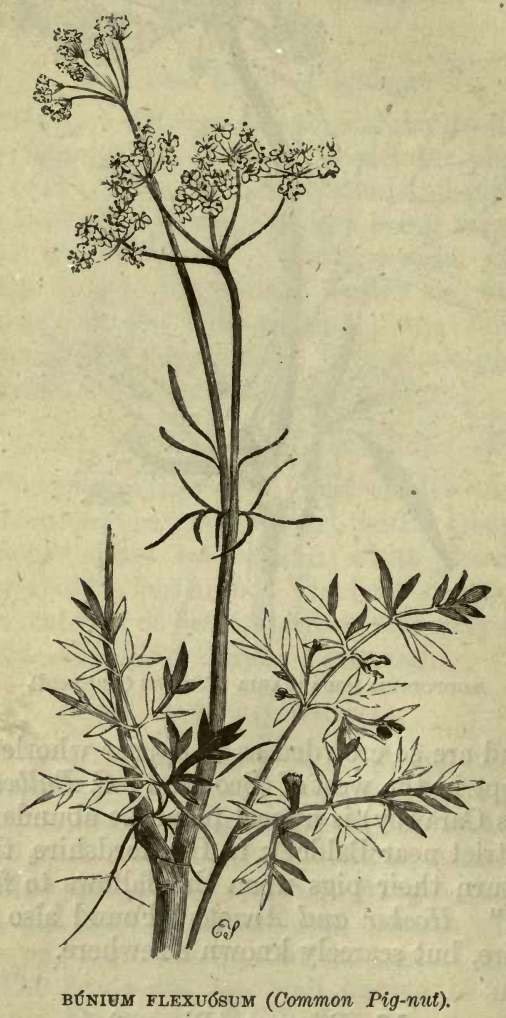

for the food of the animal after which it is named.Fl. May, June. Perennial. 


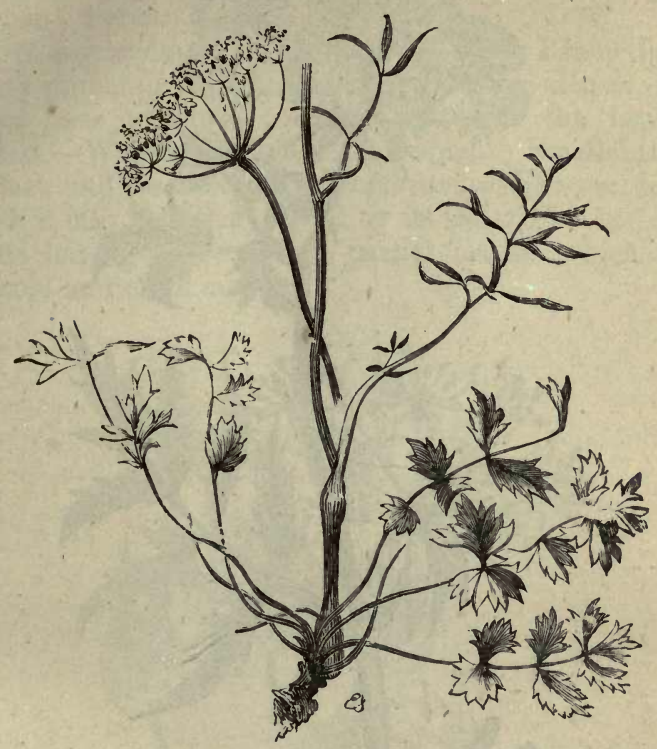

PIMPINELla SAXfFraga (Common Burnet Saxifrage)

\section{Pimpinella (Burnet Saxifrage).}

1. P. Saxífraga (Common Burnet Saxifrage).-A slender plant, 1-2 feet high, common in dry pastures. The lower leaves, which are pinnate, with sharply cut leaflets, grow on long stalks; the upper ones are twice pinnate, and deeply cut into very narrow, sharp segments.-Fl. July, August. Perennial.

$P$. magna (Greater Burnet Saxifrage) is stouter and larger than the last, and has all the leaves pinnate, the terminal leaflet on each being 3-lobed. It grows in shady places, but is far from common. 


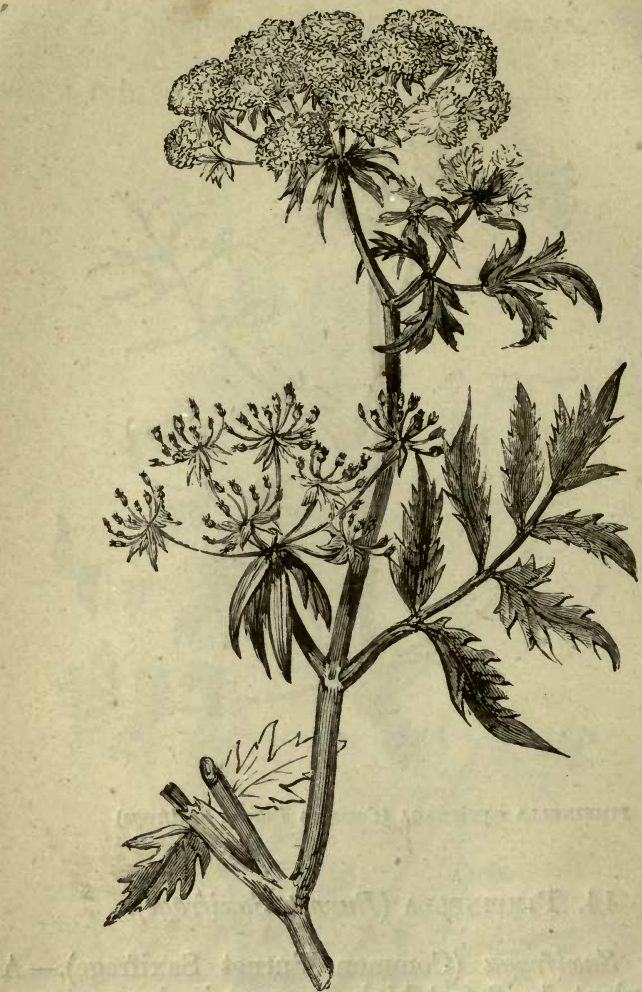

SIUN ANGUSTIFOLIUM (Narrow-leaved Water Parsnep).

\section{Sium (Water Parsnep).}

1. S. latifolium (Broad-leaved Water Parsnep).Leaves pinnate ; leaflets narrow, oblong, pointed, equally serrated; umbels terminal; bracts, both general and partial, narrow and pointed.-Watery places ; not common. A stout plant, with a furrowed stem, $3-5$ feet high, pinnated leaves of 5-13 large and distant leaflets, 
and long, flat umbels of white flowers.-Fl. July, August. Perennial.

2. S. angustifolium (Narrow-leaved Water Parsnep).Leaves pinnate ; leaflets unequally cut, egg-shaped, the upper ones narrower ; umbels opposite the leaves, stalked.-Watery places; not unfrequent. Smaller than the last, and resembling Helosciádium nodiflórum, from which it may be distinguished by its stalked umbels, and by its having general and partial bracts, which are reflexed and often cut.

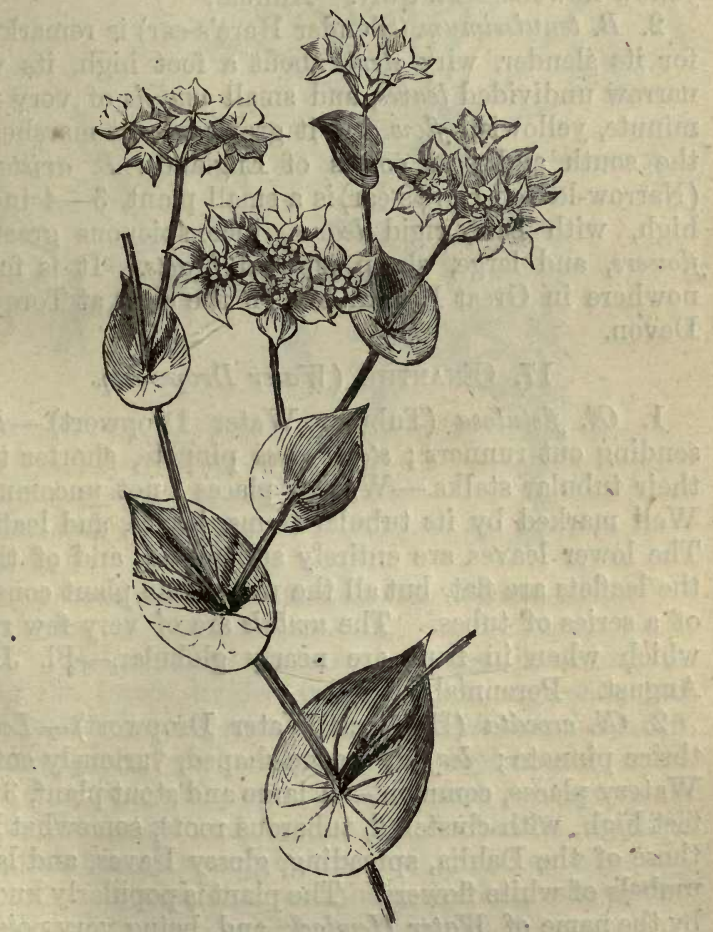

BUPLEURUM ROTUNDIFOLIUM (Conmmon Thorow-wax, Hare's-ear). 


\section{Bupleurum (Thorow-wax).}

1. B. rotundifolium (Common Thorow-wax, Hare's-ear). -Stem branched above ; leaves roundish, egg-shaped, undivided, perfoliate ; general bracts wanting, partial ones large, bristle pointed, thrice as long as the flowers.Corn-fields, on a chalky soil. A singular plant, well distinguished by its perfoliate leaves, which have a glaucous hue, and by its large, greenish yellow, partial bracts, which are far more conspicuous than the minute yellow flowers.-Fl. July. Annual.

2. B. tenuissimum (Slender Hare's-ear) is remarkable for its slender, wiry stem, about a foot high, its very narrow undivided leaves, and small umbels of very few, minute, yellowish flowers; it grows in salt marshes on the south and east coasts of England: $B$. aristatum (Narrow-leaved Hare's-ear) is a small plant, 3-4 inches high, with pale, rigid leaves, inconspicuous greenish flowers, and large, sharp pointed bracts. It is found nowhere in Great Britain but on the cliffs at Torquay, Devon.

\section{CEnanthé (Water Dropwort).}

1. E. fistulosa (Tubular Water Dropwort).-Root sending out runners; stem-leaves pinnate, shorter than their tubular stalks. - Watery places; not uncommon. Well marked by its tubular stems, leaves, and leaflets. The lower leaves are entirely submersed, and of these the leaflets are flat, but all the rest of the plant consists of a series of tubes. The umbels are of very few rays, which when in fruit are nearly globular.-Fl. July, August. Perennial.

2. QE. crocáta (Hemlock Water Dropwort).-Leaves thrice pinnate; leaflets wedge-shaped, variously cut. Watery places, common.-A large and stout plant, $3-5$ feet high, with clustered, tuberous roots, somewhat like those of the Dahlia, spreading, glossy leaves, and large umbels of white flowers. The plant is popularly known by the name of Water Hemlock, and, being very poison- 
ous, should not be allowed to grow in places where cattle are kept, as instances are numerous in which cows have been poisoned by eating the roots.

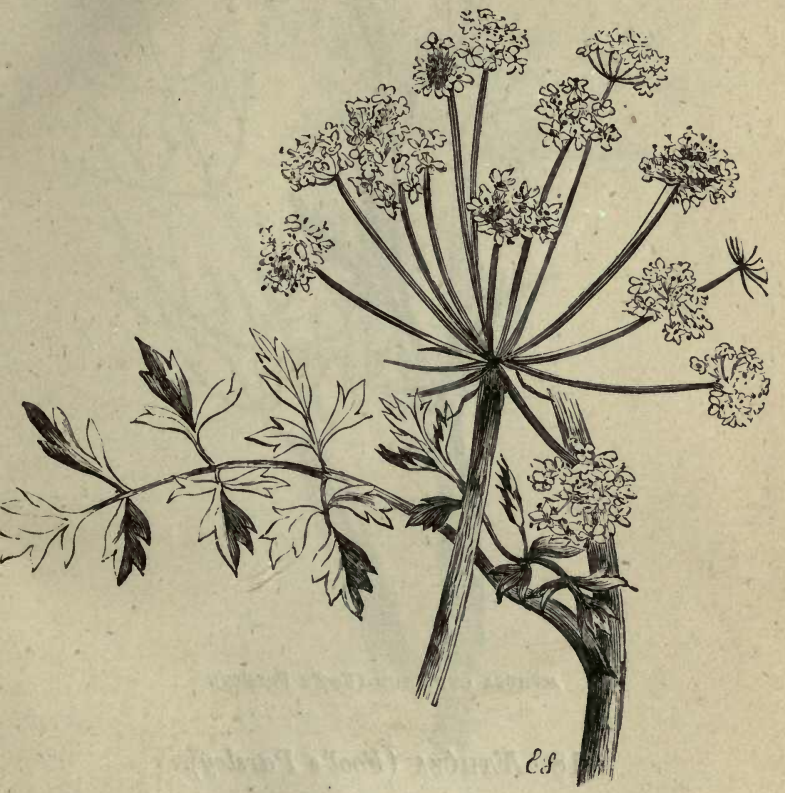

EnÁNTHÉ CROcATa (Hemlock Water Dropwort).

* É. Phellandrium differs from the preceding in aving the leaves divided into very fine segments, and ibrous, not tuberous, roots. E. pimpinelloides is a much lenderer plant, with very narrow leaflets and small white flowers crowded into round heads; it grows in narshes, both salt and fresh: $Q E$. Lachinálii is allied $o$ it, but has the umbels lax, and grows only in salt narshes. $Q E$. silaifólia resembles the last, but grows n fresh water. 


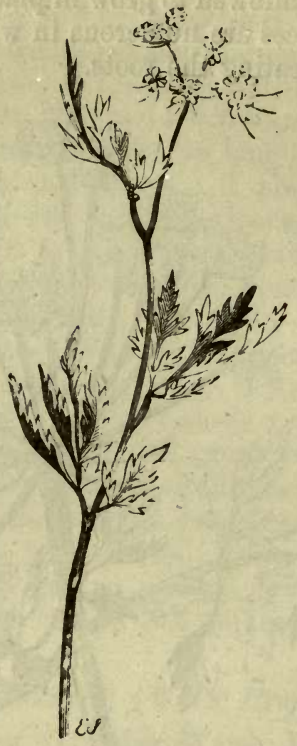

ethúsa cynapium (Fool's Parsley).

\section{Etrhúsa (Fool's Parsley).}

1. E. Cynapium (Fool's Parsley).-A slender plant about a foot high, with dark green, doubly pinnate leaves, and terminal umbels of white flowers. It is a common garden weed, and in its young state somewhat resembles Parsley, but when in flower may readily be distinguished from that and all other umbelliferous plants, by having no general bracts, but at the base of each partial umbel three very long and narrow leaves, which are all on the outer side, and point downwards. It is said, and probably with reason, to be poisonous.-Fl. July, August. Annual. 


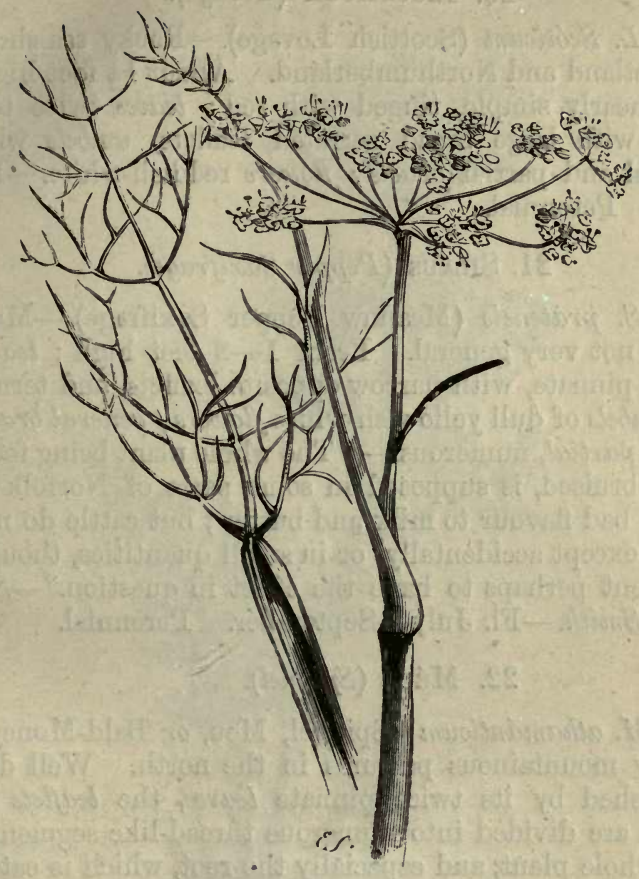

FCENICULUM VULGARE (Common Fennel).

\section{Fanículum (Fennel).}

1. F. vulgáre (Common Fennel).-Waste places, especially near the sea, common. A well-known plant, with an erect rod-like stem, numerous leaves, which are deeply divided into soft hair-like segments, and large terminal umbels of yellow flowers. The whole plant is aromatic, and the chopped leaves are often used as an ingredient in sauce for fish.-Fl. July, August. Perennial. 


\section{Ligústicum (Lovage).}

1. L. Scóticum (Scottish Lovage).-Rocky sea-shore in Scotland and Northumberland. About $1 \frac{1}{2}$ foot high, stem nearly simple, tinged with red; leaves twice ternate, with large broad serrated leaflets, umbels with general and partial bracts; flowers reddish-white.-Fl. July. Perennial.

\section{Siláus (Pepper Saxifrage).}

1. S. pratensis (Meadow Pepper Saxifrage).-Meadows, not very general. From $1-2$ feet high ; leaves thrice pinnate, with narrow opposite leaflets, and terminal umbels of dull yellowish-white flowers; general bracts 1-3, partial, numerous. - "The whole plant being fetid when bruised, is supposed in some parts of Norfolk to give a bad flavour to milk and butter; but cattle do not eat it, except accidentally, or in small quantities, though sufficient perhaps to have the effect in question." - Sir J. E. Smith. - Fl. July-September. Perennial.

\section{Méum (Spignel).}

1. M. athamánticum (Spignel, Meu, or Bald-Money). -Dry mountainous pastures in the north. Well distinguished by its twice pinnate leaves, the leaflets of which are divided into numerous thread-like segments. The whole plant, and especially the root, which is eaten by the Highlanders, is highly aromatic, with a flavour like Melilot, which it communicates to milk and butter, from the cows feeding on its herbage in spring."Bald, or Bald-Money, is a corruption of Balder, the Apollo of the northern nations, to whom this plant was dedicated." - Sir W. J. Hooker.-Fl. June, July. Perennial.

\section{Crithuum (Samphire).}

1. C. maritimum (Sea Samphire).-Rocks by the seaside, abundant. Well distinguished by its long, glaucous, 


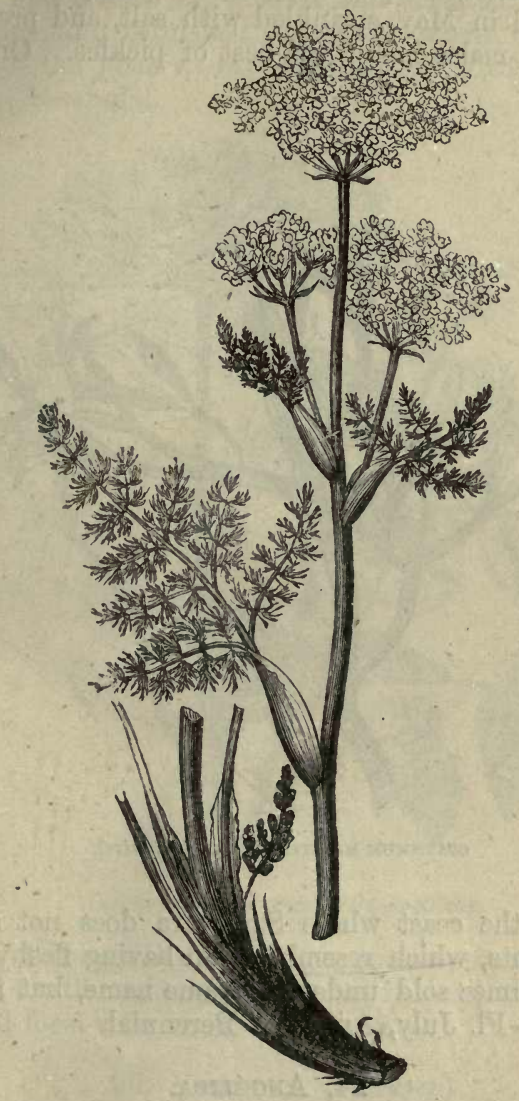

MĖUM AтHAMÁNTicuM (Spignel, Meu, or Bald-Mmey). 
fleshy leaflets, and yellow flowers. The whole plant is aromatic, and has a powerful scent. The young leaves, if gathered in May, sprinkled with salt,.and preserved in vinegar, make one of the best of pickles. On those

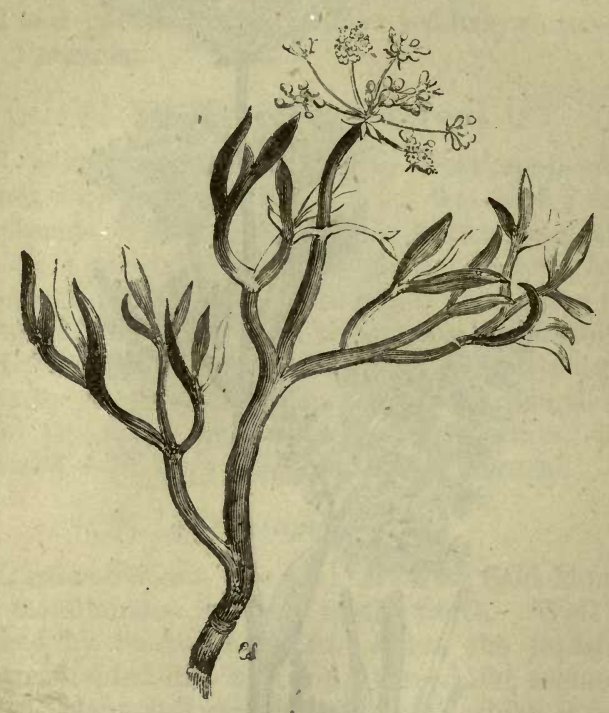

CRITHMUM MARÍTIMUM (Sea Samphire).

parts of the coast where Samphire does not abound, other plants, which resemble it in having fleshy leaves, are sometimes sold under the same name, but are very inferior.-Fl. July, August. Perennial.

\section{Angélica.}

1. A. sylvestris (Wild Angélica)-Wet places, common. A stout and tall plant, 2-4 feet high; the stem is furrowed, tinged with purple, and slightly downy, 
especially in its upper part; the leaves are twice pinnate; the leatlets egg-shaped and serrated, the umbels are large, and furnished with both general and partial bracts; the flowers are white, tinged with pink.-Fl. July. Perennial.

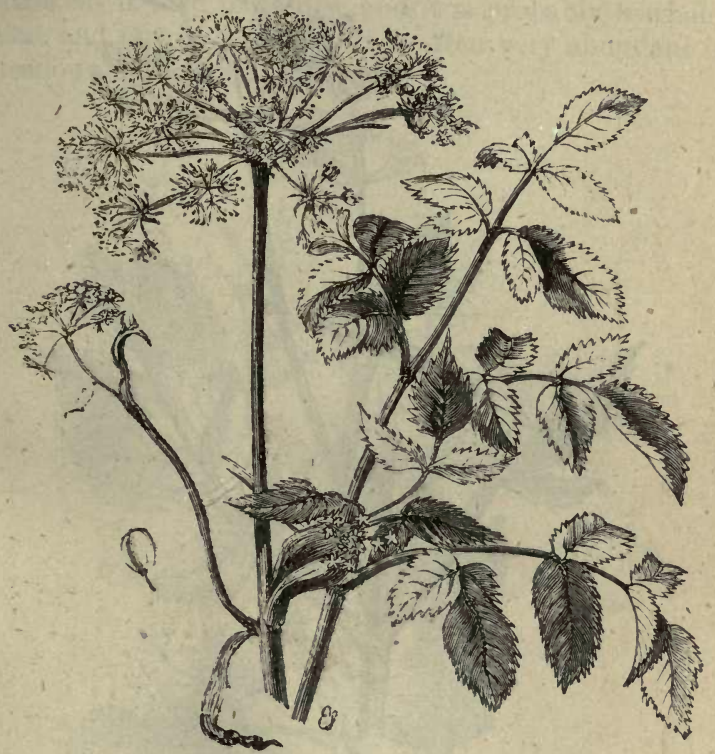

ANGÉltca sylvestris (Wild Angélica).

* A. Archangélica is a larger species, commonly cultivated for the sake of its aromatic stems, which when candied form a favourite sweetmeat.

\section{Pastináca (Parsnep).}

1. P. sativa (Common Parsnep).-Well known in gardens as an agreeable and nutritive vegetable. In its wild state, the plant, which is not uncommon in lime- 
stone and chalky pastures, closely resembles the cultivated variety, but has smaller roots and more downy

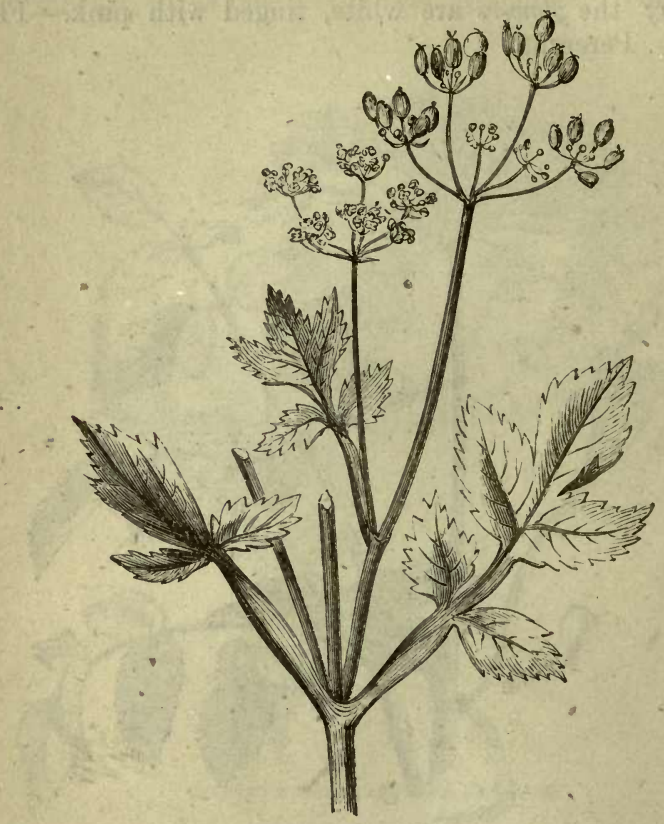

pastinaca sativa (Common Parsnep).

leaves. The flowers are yellow, and grow in terminal umbels.-Fl. July, August. Biennial.

26. Heracléum (Cozo-Parsnep).

1. H. Sphondýlium (Common Cow-Parsnep, Hogweed).-A very tall and stout plant, with a channeled, hairy stem, 4-6 feet high, large, irregularly cut, rough leaves, and spreading umbels of conspicuous white flowers. 
In spring the plant is remarkable for the large oval tufts formed by the sheathing base of the stem leaves, which contain the flower buds. This, with many other umbelliferous plants, is often confounded by farmers with Hemlock, and great pains are taken to eradicate it ; but cattle eat it with impunity, and it is probably a wholesome and nutritive food. It is often very abundant in meadows.-Fl. July. Biennial.

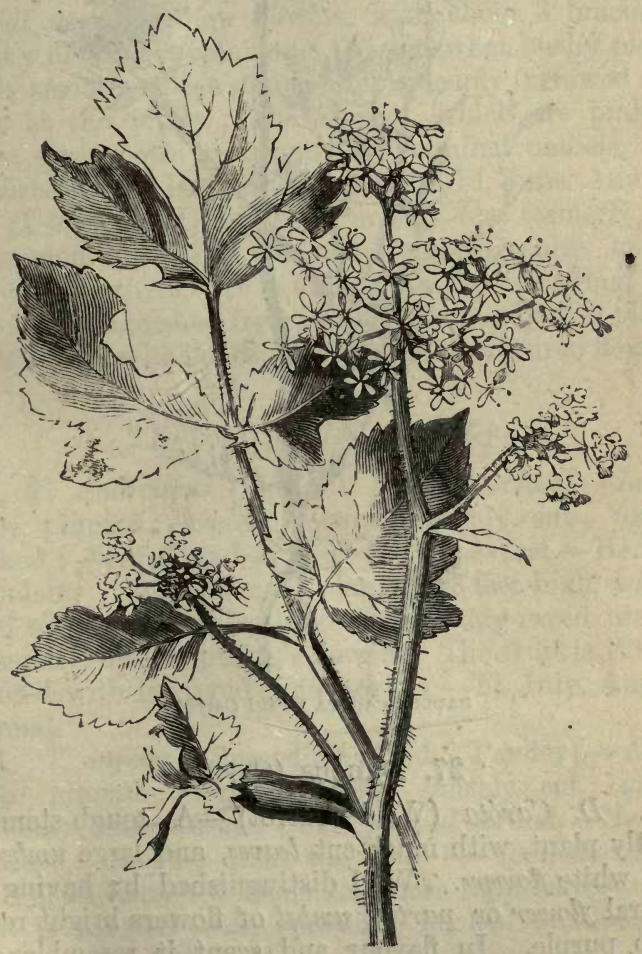

HERACleum SPhoNDYliom (Common Cov-Parsnep, Hog-weed). 


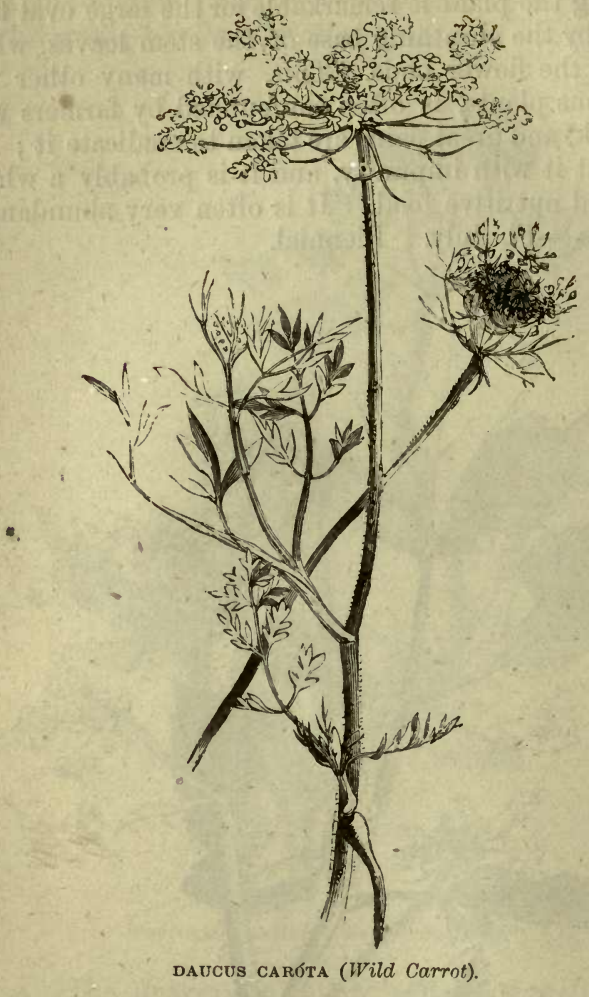

\section{Daucus (Carrot).}

1. D. Caróta (Wild Carrot).-A tough-stemmed bristly plant, with much-cut leaves, and large umbels of dull white flowers. Well distinguished by having the central flower or partial umbel of flowers bright red or deep purple. In flavour and scent it resembles the garden carrot.-Fl. July, August. Biennial. 
* A variety (D. marítimus), abundant on many parts of the sea-coast, differs from the preceding in having somewhat fleshy leaves, and in being destitute of the central purple flower, or umbel.

\section{Caúcalis (Bur-Parsley).}

1. C. daucoídes (Small Bur-Parsley).-Leaves repeatedly divided ; umbels of about 3 rays, without bracts ; partial umbels of few flowers, with about 3 bracts. Chalky fields, not common. A somewhat bushy plant, nearly smooth, with a stem which is deeply furrowed and hairy at the joints. The flowers, which are pinkish white, grow both in lateral and terminal umbels, and are succeeded by large prickly seeds.-Fl. June. Annual.

* C. latifólia (Great Bur-Parsley) was formerly not uncommon in chalky fields in Cambridgeshire, but is now extinct there. It is taller than the preceding, and is well distinguished from it and all other British plants of the tribe by its handsome, large, rose-coloured flowers.

\section{Tonílis (Hedge-Parsley).}

1. T. Anthriscus (Upright Hedge-Parsley).-Leaves twice pinnate; leaflets narrow, sharply cut; umbels stalked; general and partial bracts several.-Hedges, abundant. A tall slender plant $2-3$ feet high, with a solid rough stem, hairy leaves, and many-rayed umbels of small white or pinkish flowers. The fruit is thickly covered with incurved rigid bristles.-Fl. July, August. Annual.

2. T. infésta (Spreading Hedge-Parsley).-Leaves twice pinnate; leaflets oblong, sharply cut; umbels stalked; general bracts 1 or 0 , partial several.-Hedges, common. Smaller than the last, 6-18 inches high, with more branched stems and more rigid leaves. The fruit is covered with spreading hooked bristles.-Fl. July, August. Annual. 


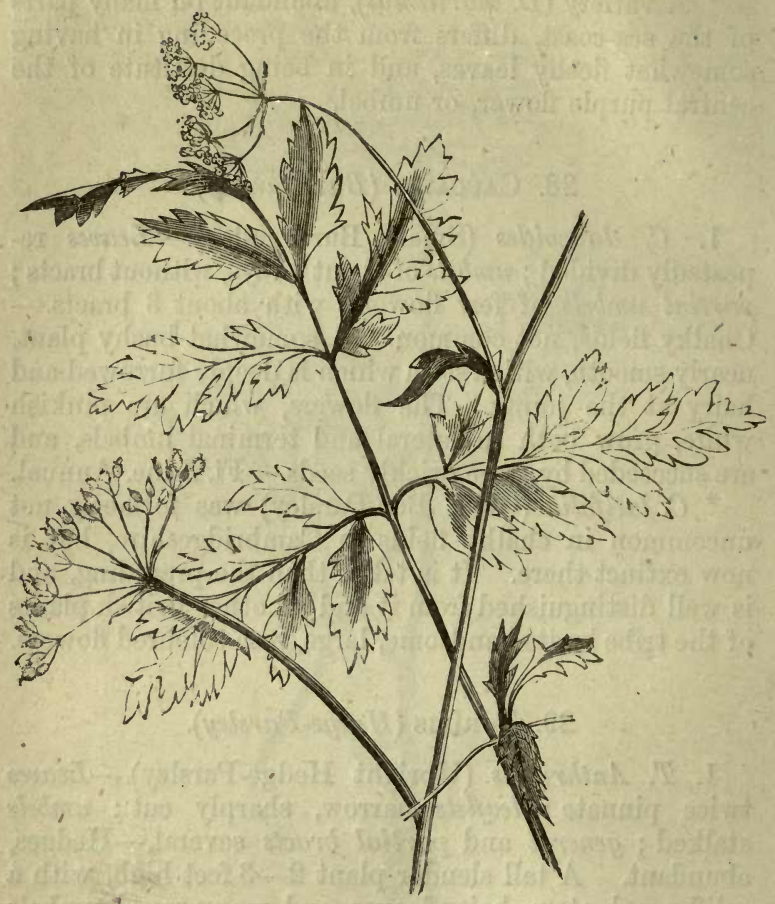

TORILIS ANTHRISCUS (Upright Hedge-Parsley).

3. T. nodósa (Knotted Hedge-Parsley).-Stem prostrate; umbels simple, lateral, nearly sessile.-Hedges and waste places, common. Well distinguished from all other British umbelliferous plants by its prostrate mode of growth, its very small, almost globular umbels of whitish flowers, and by the outer carpels in each umbel being covered with hooked prickles, while the inner are warty.-Fl. May, July. Annual. 


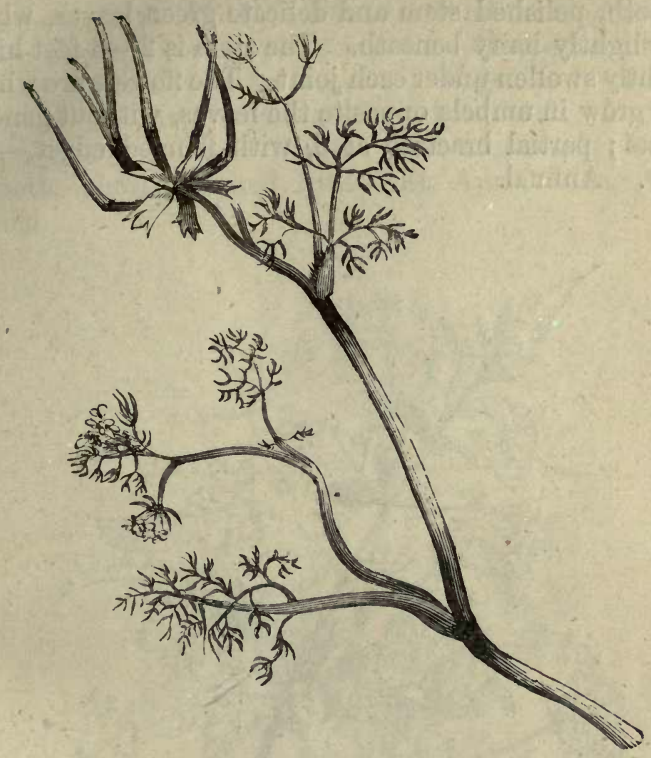

sCANDix PECTEN (Shepherd's Needle, Venus' Comb).

\section{Scandix (Shepherd's Needle).}

1. S. Pecten (Shepherd's Needle, Venus' Comb).Common in cultivated ground. A small plant, 3-9 inches high, with finely-cut bright-green leaves, and few-rayed umbels of small white flowers, which are succeeded by long, beaked seed-vessels.-Fl. June, September. Annual.

\section{Anthriscus (Beaked-Parsley).}

1. A. vulgáris (Common Beaked-Parsley).-Stem smooth; leaves thrice pinnate, with blunt segments; umbels lateral on rather short stalks; fruit bristly.Waste ground, chiefly near towns. Remarkable for its 
smooth, polished stem and delicate green leaves, which are slightly hairy beneath. The stem is $2-3$ feet high, slightly swollen under each joint. The flowers are white, and grow in umbels opposite the leaves, without general bracts; partial bracts 5 or 6 , with fringed edges.-Fl. May. Annual.

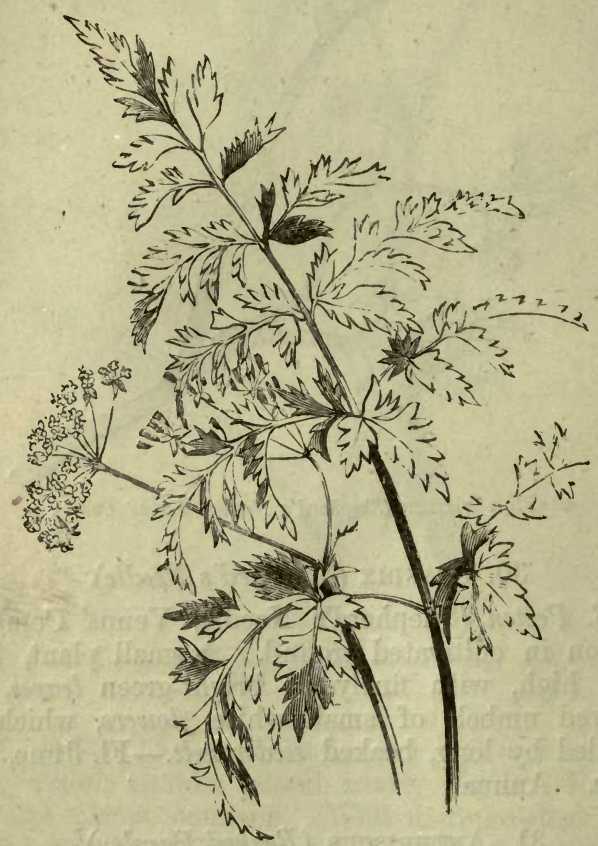

ANTHRiscus sylvestris (Wild Beaked-Parsley).

2. A. sylvestris (Wild Beaked-Parsley).-Stem slightly downy below, smooth above; leaves thrice pinnate, the 
segments rough-edged ; umbels terminal on long stalks, drooping when young; fruit smooth.-Hedges, common. One of our early spring flowers, distinguished, when in bud, by the drooping partial umbels, each of which has about 5 reflexed bracts ; and afterwards, by its smooth, shortly-beaked fruit.-Fl. April, June. Perennial.

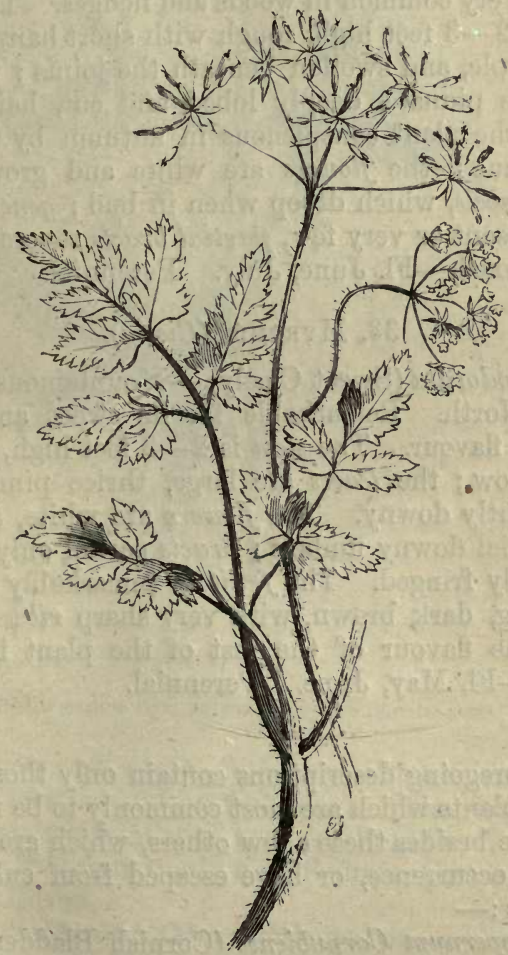

CHAROPHYLLUM TEMULENTUM (Rough Chervil). 
* A. Cerefolium (Garden Chervil) is not a native plant, though sometimes found in the neighbourhood of houses. It may be distinguished from the preceding by having only 3 partial bracts, lateral umbels, and smooth fruit.

\section{Charophyllum (Chervil).}

1. C. temulentum (Rough Chervil).-The only British species, very common in woods and hedges. The stem is slender, 2-3 feet high, rough with short hairs, spotted with purple, and swollen beneath the joints ; the leaves are twice pinnate, deeply lobed and cut, hairy, often making the plant conspicuous in autumn by their rich purple hue; the flowers are white and grow in terminal umbels, which droop when in bud; general bracts either absent or very few, partial bracts several, fringed and deflexed.-Fl. June, July. Perennial.

\section{MrrRhis (Cicely).}

1. M. odoráta (Sweet Cicely).-Mountainous pastures in the North. Remarkable for its sweet and highly aromatic flavour. The stem is $2-3$ feet high, furrowed and hollow; the leaves are large, thrice pinnate, cut, and slightly downy. The flowers are white, and grow in terminal downy umbels ; bracts partial only, whitish and finely fringed. The fruit is remarkably large, an inch long, dark brown, with very sharp ribs, and possesses the flavour of the rest of the plant in a high degree.-Fl. May, June. Perennial.

The foregoing descriptions contain only those umbelliferous plants which are most commonly to be met with. There are besides these a few others, which are either of unusual occurrence, or have escaped from cultivation; these are:-

Physospernum Cornubiense (Cornish Bladder-seed).An erect, smooth plant, about two feet high, with thrice 


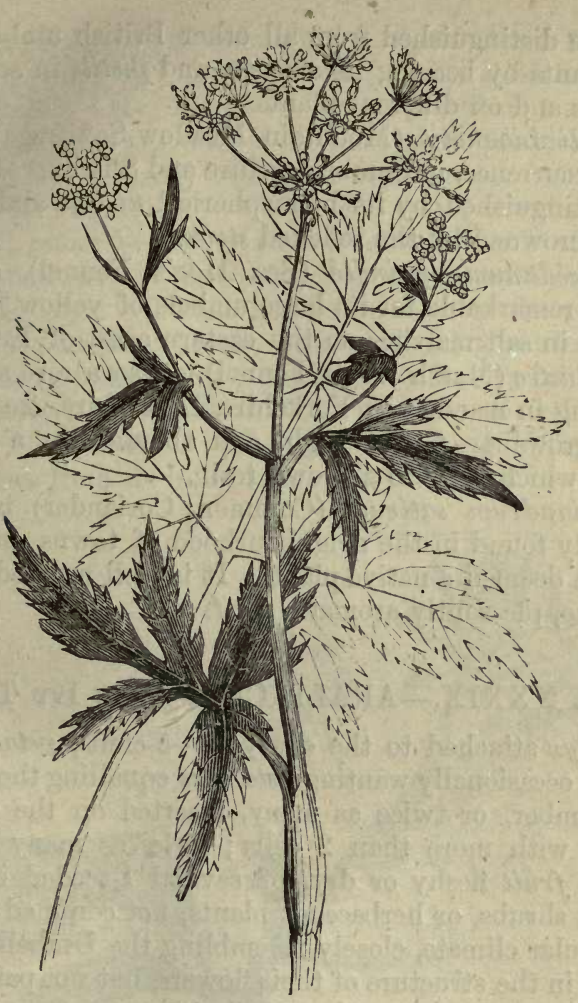

PHYSOSPERNUM CORNUBIENSE (Cornish Blalder-seed).

rnate leaves and white flowers, which are furnished ith both general and partial bracts. The fruit when pe is remarkably inflated and nearly globose, whence is name. It is found only near Bodmin, Cornwall, and avistock, Devon.

Trínia glabérrima (Honewort) grows on limestone cks in Somersetshire, and at Berry-head, Devon. It 
may be distinguished from all other British umbelliferous plants by bearing its stamens and pistils in separate flowers and on different plants.

Séseli Libanótis (Mountain Meadow-Saxifrage) is of rare occurrence, in Cambridgeshire and Sussex. It may be distinguished by its hemispherical umbels and hairy fruit, crowned by the reflexed styles.

Peucédanum officinálé (Sea Hog's Fennel), a rare plant, remarkable for its large umbels of yellow flowers, occurs in salt marshes on the eastern coast of England. P. palustre (Marsh Hog's Fennel) is also a rare species, growing in marshes in Yorkshire, Lancashire, \&c. The stem grows 4-5 feet high, and abounds in a milky juice, which dries to a brown resin.

Coriandrum sativum (Common Coriander) is occasionally found in the neighbourhood of towns, but cannot be deemed a native plant. It is well marked by its globose, pleasantly aromatic fruit.

\section{Ord. XXXIX.-ARALIACEA.-The Ivy Tribe.}

Calyx attached to the ovary, 4-5-cleft; petals 4, 5, or 10 , occasionally wanting; stamens equalling the petals in number, or twice as many, inserted on the ovary; ovary with more than 2 cells; styles as many as the cells; fruit fleshy or dry, of several 1-seeded cells.Trees, shrubs, or herbaceous plants, not confined to any particular clirnate, closely resembling the Umbelliferous Tribe in the structure of their flowers, but not partaking their dangerous properties. Only two species are natives of Britain; but one of these, Ivy, is so universally diffused as to be familiar to every one ; the other, Moschatell, is a humble plant, with solitary heads of green flowers, and delicate leaves strongly scented with musk. Ginseng, the favourite medicine of the Chinese, is the root of some species of Panax, a plant belonging to this tribe. Some species of Ivy furnish wood scented like Lavender and Rosemary, and others an aromatic gum. 
A remarkable plant belonging to this order is Gunnera scabra, found by Darwin growing on the sandstone cliffs of Chiloe. He describes it as somewhat resembling Rhubarb on a gigantic scale, each plant producing four or five leaves nearly eight feet in diameter.

1. HÉdera (Ivy).-Caiyx of 5 teeth, inserted on the ovary; petals 5-10; stamens 5-10; styles 5-10, often combined into 1 ; berry 5-celled and 5-seeded, crowned by the calyx. (Name, the Latin name of the plant.)

2. Adoxa (Moschatell).-Calyx 3-cleft, inserted above the base of the ovary ; corolla 4 or 5 -cleft, inserted on the ovary ; stamens 8 or 10, in pairs ; anthers 1-celled; berry 4 or 5-celled. (Name, in Greek signifying inconspicuous, from its humble growth.)

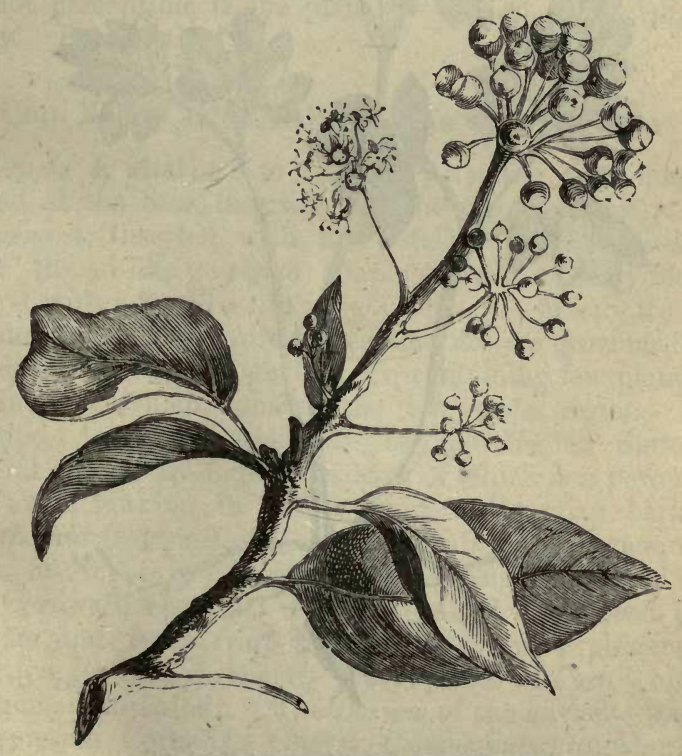

HÉDERA HELIX (Common (v)). 


\section{Hédera (Ivy).}

1. H. Helix (Common Ivy).-The only British species, too well known to need any description. (See "Forest Trees of Britain," vol. ii.)-Fl. Oct. Nov. Shrub.

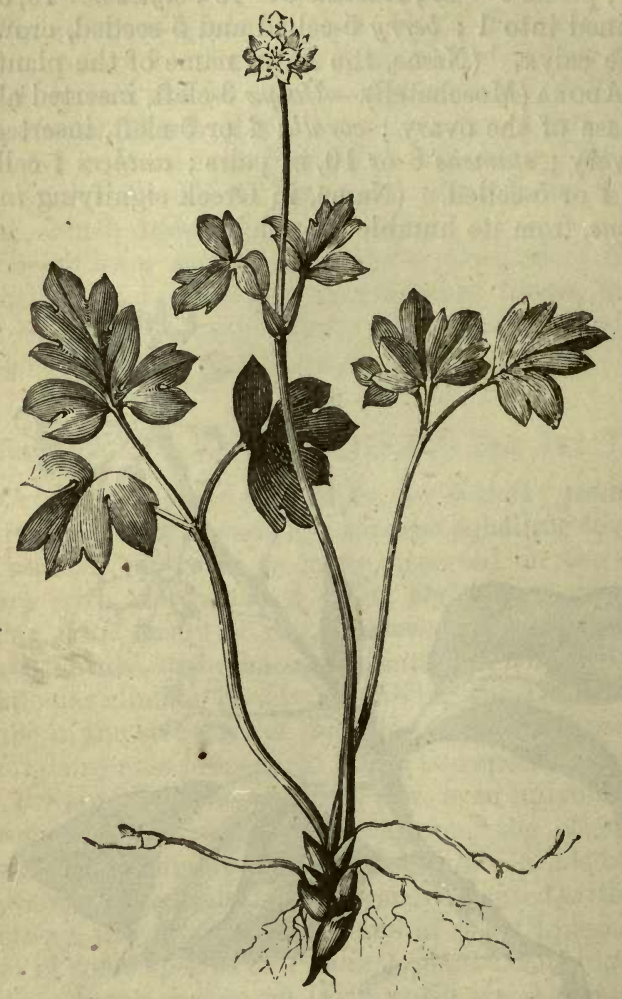

adoxa Moschathilina (Common Moschatell). 


\section{Adoxa (Moschatell).}

1. A. Moschatéllina (Common Moschatell).-The only species. A small herbaceous plant $4-6$ inches high, growing in damp woods and hedge banks, and not unfrequent at a great elevation among the mountains. Each plant bears several delicate root-leaves, and two smaller leaves half-way up the stem. The flowers grow in terminal heads of 5 each, the upper flower with 4 petals and 8 stamens, the four side flowers having 5 petals and 10 stamens each; the latter are remarkable for being inserted in pairs, and for bearing 1-celled anthers; or the filaments may be considered to be forked, each fork bearing the lobe of an anther. The whole plant diffuses a musk-like scent, which, however, is not perceptible if the plant be bruised.-Fl. April, May. Perennial.

\section{Ord. XL.-CORNACEA.The Cornel Tribe.}

Sepals 4, attached to the ovary; petals 4, oblong, broad at the base, inserted into the top of the calyx; stamens 4, inserted with the petals; ovary 2 -celled; style thread-like; stigma simple; fruit a berry-like drupe, with a 2-celled nut; seeds solitary.-Mostly trees or shrubs, with opposite leaves, and flowers growing in heads or umbels. A small order, containing few plants of interest, which inhabit the temperate regions of Europe, Asia, and America. In the United States several species are found, the bark of which is a powerful tonic, ranking in utility next to Peruvian bark. Benthamia fragifera, a handsome shrub from the mountains of Nepal, was introduced into England in 1825. In Cornwall, where it was first raised from seed, it flowers and bears fruit freely, and forms a pleasing addition to the shrubbery. Two species of Cornus are indigenous to Britain. The Cornus of the ancients was the present Cornelian Cherry, Cornus máscula, whose 
little clusters of yellow starry flowers are among the earliest heralds of spring. Its fruit is like a small plum, with a very austere flesh, but after keeping it becomes pleasantly acid. The Turks still use it in the manufacture of sherbet. A similar species is commonly cultivated in Japan for the sake of its fruit, which is a constant ingredient in the acid drinks of that country. The shrub now common in gardens under the name of spotted Laurel (Aícuba Japónica) belongs to this order.

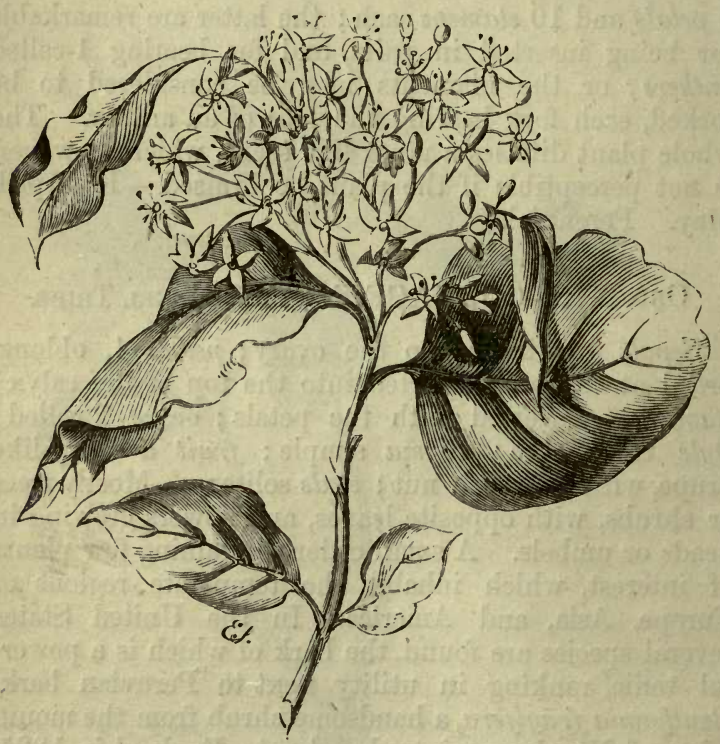

cornus sanguinea (Wild Cornel, Dog-wood).

1. Connus (Cornel).-Characters described above. (Name, from the shrub so called by the Latins, from the horn-like nature of its wood.) 


\section{Cornus (Cornel).}

1. C. sanguinea (Wild Cornel, Dog-wood).-Shrubby. Hedges and thickets, especially on a chalk or limestone soil. A bushy shrub 5-6 feet high, with opposite, egg-shaped, pointed leaves, and terminal cymes of

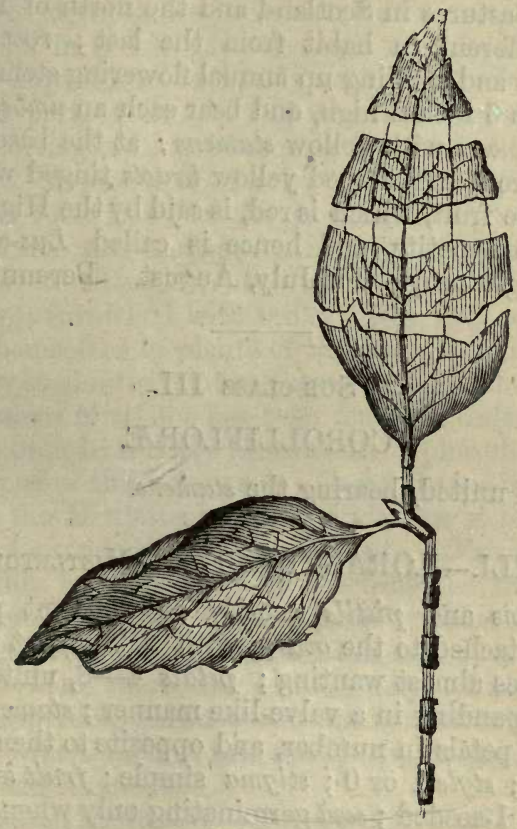

YOUNG SHOOT OF THE WILD CORNEL.

ull-white flowers. The bark on the old branches is of reddish hue ; the berries are small, and dark purple. he young shoots in spring, and the leaves at all seaons, are particularly well adapted for displaying the resence of spiral vessels in these parts, being numerous 
and remarkably strong. The wood is much sought after by butchers for making skewers. The name Dog-wood is often given to the Spindle Tree (Euónymus Europceus), and Guelder Rose (Viburnum Lantána), trees which have wood of similar texture.-Fl. June. Shrub.

2. C. Suécica (Dwarf Cornel).-Herbaceous.-Mountainous pastures in Scotland and the north of England. Very different in habit from the last; root woody, creeping, and sending up annual flowering stems, which are about 6 inches high, and bear each an umbel of dark purple flowers with yellow stamens; at the base of each umbel are 4 egg-shaped yellow bracts tinged with purple. The fruit, which is red, is said by the Highlanders to create appetite, and hence is called Lus-a-chraois, plant of gluttony.-Fl. July, August. Perennial.

\section{SUb-CLASS III. \\ COROLLIFLORA.}

Petals united, bearing the stamens.

\section{Ord. XLI.-LORANTHACEA.-Mistletoe Tribe.}

Stamens and pistils usually on different plants.Calyx attached to the ovary, with 2 bracts at the base, sometimes almost wanting; petals $4-8$, united at the base, expanding in a valve-like manner ; stamens equalling the petals in number, and opposite to them ; ovary 1-celled; style 1 or 0 ; stigma simple; fruit succulent, 1-celled, 1-seeded ; seed germinating only when attached to some growing plant of a different species.-Shrubby plants of singular structure and habit, growing only (with rare exceptions) on the branches of other trees, and therefore true parasites. The leaves are usually in pairs, fleshy, and without veins : the flowers inconspicuous ; but this is not always the case, for one species, Nuytsia floribunda, which grows in the neighbourhood 
of King George's Sound, bears an abundance of bright orange-coloured flowers, producing an appearance which the colonists compare to a tree on fire, and hence they call it the Fire-tree. This species is not a parasite, but the greater part of the tribe refuse to grow except on living vegetables. The seed of most species is coated with a viscid substance, by which it adheres to the bark, and which in a few days becomes a transparent glue. Soon, a thread-like radicle is sent forth, which, from whatever part of the seed it proceeds, curves towards the supporting tree, and becomes flattened at the extremity like the proboscis of a fly. Finally, it pierces the bark, and roots itself in the growing wood, having the power of selecting and appropriating to its own use such juices as are fitted for its sustenance. Though not themselves furnished with milky juices, they sometimes attach themselves to plants of that description, and extract only such nutriment as they require. The wood of the Common Mistletoe has been found to contain twice as much potash, and five times as much phosphoric acid, as the wood of the foster tree. Great virtues were attributed to the Mistletoe by the Druids, but at present its medicinal properties are in no repute. The Mistletoe may readily be propagated. by attaching the fresh seeds to the smooth bark of an Apple or other tree. A species of Loranthus is used in Chili as a dye, but with this exception there are scarcely any which possess useful properties. About 400 species have been discovered, which inhabit principally the tropical regions of Asia and America.

1. Viscum (Mistletoe).-Stamens and pistils on separate plants ; Barren flower, calyx 0 ; petals 4, fleshy, united at the base, each bearing an anther; Fertile flower, calyx a mere rim; petals 4, very small; stigma sessile ; berry 1-seeded, crowned by the calyx. (Name, the Latin name of the plant, derived, it is said, from the Celtic gwid, the shrub, as being the-most sacred of plants.) 


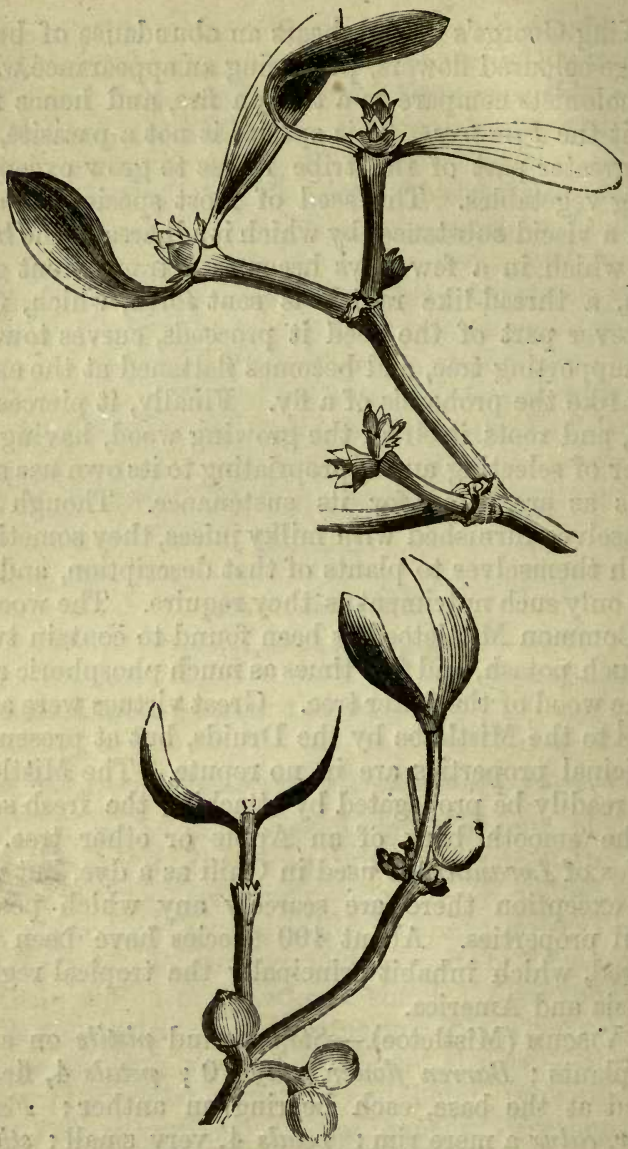

VISCUM ALBUM (Common Mistletoe).

1. Viscum (Mistletoe).

1. V. album (Common Mistletoe).-The only British species. Growing on a great variety of trees, especially 
the Apple, exceedingly rare on the Oak. The stem is green and smooth, separating easily when dead into bone-like joints ; the leaves are thick and leathery, of a yellow hue, the whole plant being most conspicuous in winter, when its white berries ripen.-Fl. March-May. Perennial.

\section{ORD. XLII.-CAPRIFOLIACEA.-The WoodBINE TrIBE.}

Calyx attached to the ovary, usually with bracts at the base; corolla regular or irregular, 4-5-cleft; stamens equal in number to the lobes of the corolla and alternate with them; ovary $3-5$-celled; stigmas $1-3$; fruit usually fleshy, crowned by the calyx.-This tribe comprises shrubs and herbaceous plants of very different habits, and is interesting from containing the fragrant Honeysuckle or Woodbine, and the elegant little plant which Linnæus fixed on to commemorate his name. They are principally confined to the northern hemisphere, and among them, several are natives of Britain, which will be found described at length in "Forest Trees of Britain," vol. ii. The common Elder was formerly held in high repute for its medicinal properties ; and preparations of the leaves, flowers, and fruit are still used as medicine in rural districts. The roasted berries of Triósteum perfoliatum have been used as a substitute for coffee. Leycestéria formósa, a beautiful shrub from the mountains of Nepal, where it flowers at an elevation of from 6,000 to 8,000 feet, is now becoming a common ornament in our gardens. It is most attractive when in a flowering state, from the contrast of the deep green hue of its stem and leaves with the purple colour of its floral leaves and berries.

1. SaMbúcus (Elder).-Calyx 5-cleft; corolla wheelshaped, 5-lobed; stamens 5 ; stigmas 3 , sessile; berry 3 -4-seeded. (Name from the Greek, sambriké, a musical 
wind-instrument, in making which the wood was anciently employed.)

2. Viburnum (Guelder Rose).-Calyx 5-cleft; corolla funnel-shaped, 5-lobed; stamens 5; stigmas 3, sessile; berry 1 -seeded. (Name, the Latin name of the plant.)

3. Lonicéra(Honeysuckle).-Calyx small, 5-toothed; corolla tubular, irregularly 5-cleft; stamens 5; style thread-shaped ; stigma knobbed ; berry 1-3-celled, with several cells. (Named in honour of Adam Lonicer, a German botanist.)

4. Linnza. - Calyx 5-cleft; corolla bell-shaped, 5-cleft, regular; stamens 4, two longer; fruit dry; 3 -celled, one cell only containing a single seed.

\section{Sambúcus (Elder).}

1. S. nigra (Common Elder).-Stem woody; cymes with 5 principal branches.-A small tree, abundant in most places. Remarkable for the large quantity of pith contained in the young branches, and for the elasticity of its wood. The leaves are pinnate, of a strong and unpleasant odour; the flowers white and of a sickly smell ; the fruit dark purple, or rarely white.-Evelyn, speaking in its praise, says : "If the medicinal properties of the leaves, bark, berries, \&c., were thoroughly known, I cannot tell what our countrymen could ail for which he would not find a remedy from every hedge, either for sickness or wound."-Fl. June. Tree.

* A smaller species (S. Ebulus), Dwarf Elder, is occasionally found in bushy places, and differs from the preceding in having an herbaceous stem 2-3 feet high, narrower leaves, and 3-cleft cymes.

\section{Viburnum (Guelder Rose).}

1. V. Lantána (Wayfaring-tree, Mealy Guelder-rose). -Flowers in cymes, all perfect ; leaves elliptical, heartshaped at the base, serrated, very downy beneath.- 
A large shrub, with white, mealy, flexible branches, and large leaves, which are very hoary beneath. The flowers are dull white and grow in terminal cymes; the berries are scarlet, turning black when fully ripe.-It is most frequently met with in a chalky or limestone soil.-Fl. May, June. Shrub.

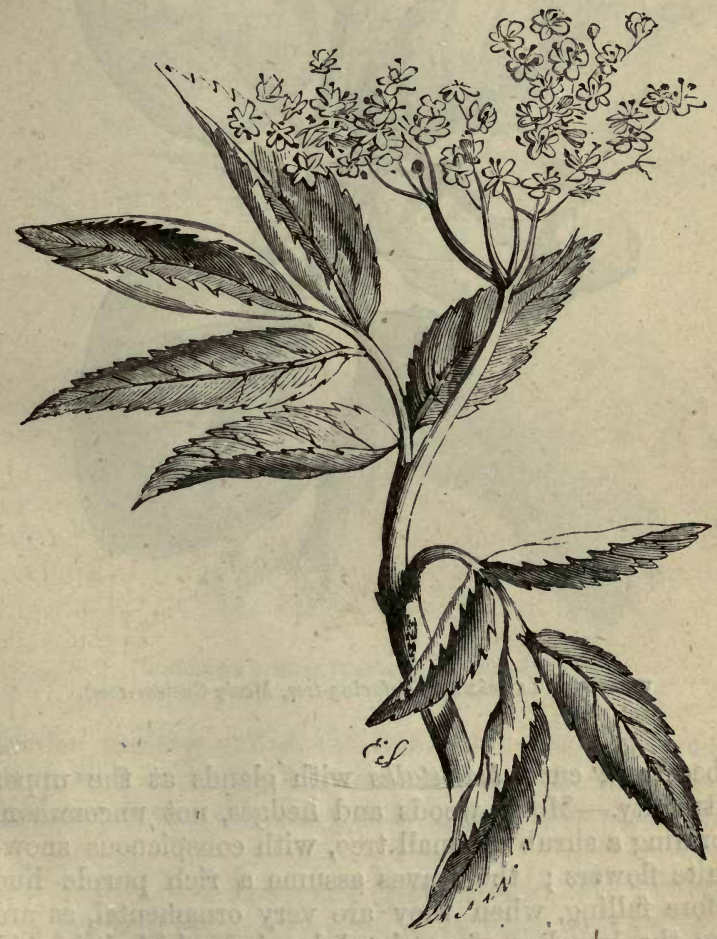

SAMBÚCUS NIGRA (Common Elder).

2. V. Opulus (Guelder-rose, Water Elder).-Flowers in cymes, the outer barren and radiant; leaves smooth, 


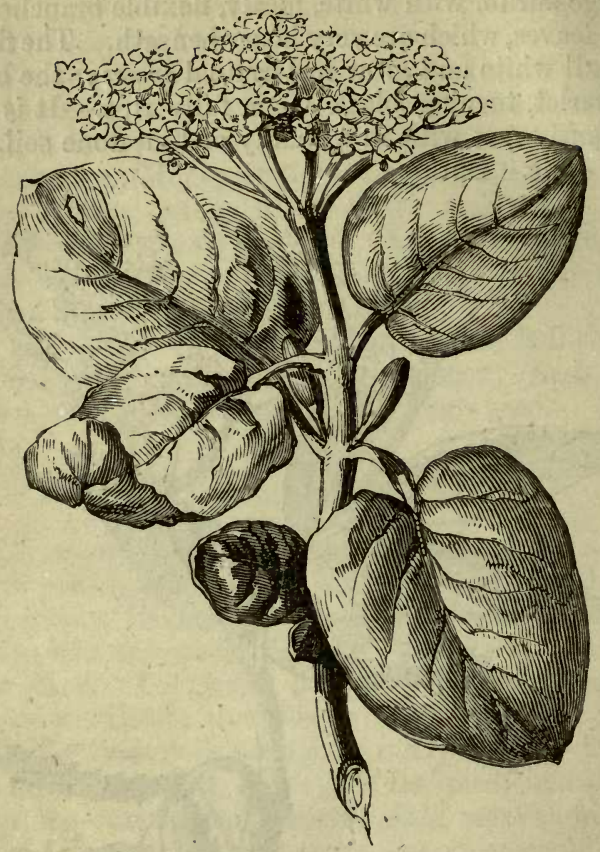

viBURNUM LANTÁNA (Wayfaring-tree, Mealy Guelder-rose).

lobed, and cut; leaf-stalks with glands at the upper extremity.-Moist woods and hedges, not uncommon. Forming a shrub or small tree, with conspicuous snowwhite flowers; the leaves assume a rich purple hue before falling, when they are very ornamental, as are also the bunches of coral-red berries, which it is said are sometimes fermented and eaten. This statement, however, seems scarcely credible to any one who has chanced to smell them. The bark is very acrid. In the 
wild plant the cyme is flat, the outer flowers being large and showy, but destitute of stamens and pistils; in the

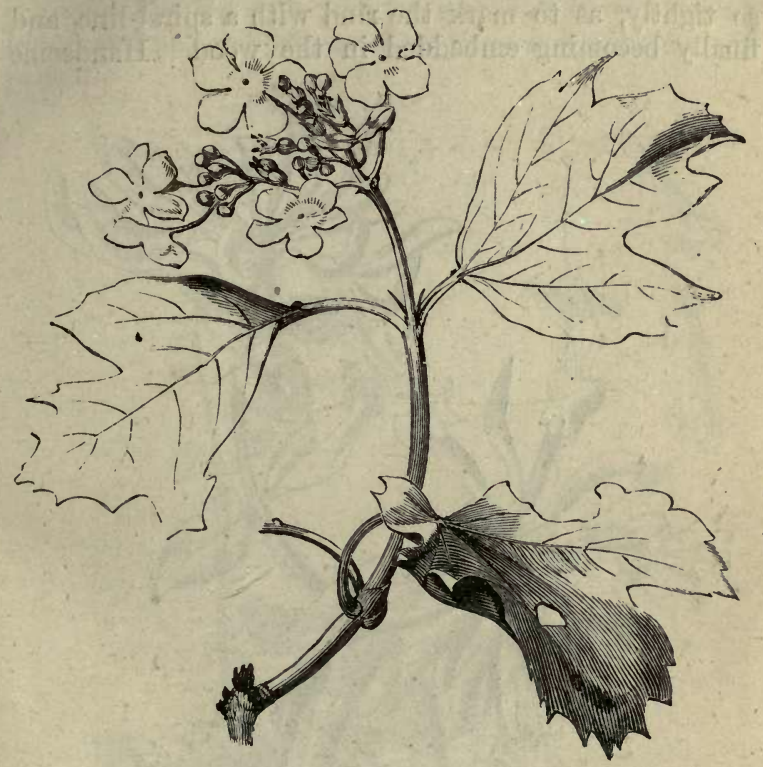

VIBURNUM 6́pULUS (Guelder-rose, Water Elder).

garden variety, called the Snow-ball tree, the cyme is composed entirely of barren flowers collected into a globular form.-Fl. June, July. Shrub, or small tree.

\section{Lonicéra (Honeysuckle).}

1. L. Periclýmenum (Honeysuckle, Woodbine).-Stem twining ; flowers gaping, in terminal heads ; leaves all distinct (not united at the base).-A common and favourite twining shrub, the first to expand its leaves in 
spring, or rather in winter, and almost the last to blosson in autumn. Though highly ornamental to our woods, it is decidedly injurious to young trees, clasping them so tightly, as to mark the rind with a spiral line, and finally becoming embedded in the wood. Handsome

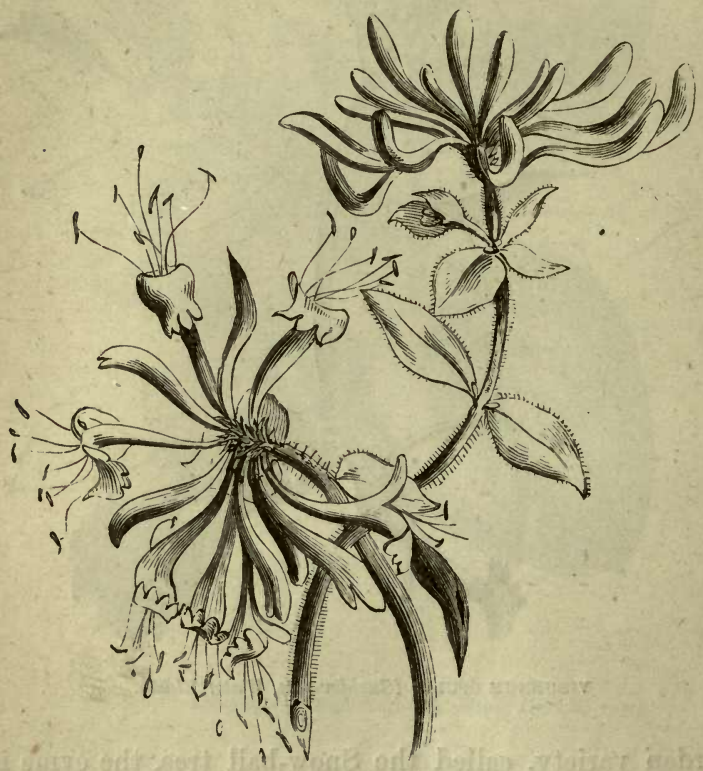

LONICÉRA PERICLYMENUM (Honeysuckle, Woodbine).

twisted walking-sticks are thus formed, but the growth of the tree is greatly checked. The leaves are not unfrequently lobed like those of the oak.-Fl. July, and again in October. Shrub.

* Two other species of Honeysuckle are occasionally found, but are not considered natives of Britain. $L$. 
perfoliatum (Pale perfoliate Honeysuckle), which is distinguished by having the uppermost pair of leaves connate, or united by their bases ; and L. Xylósteum (Upright Fly Honeysuckle), an erect shrub, with downy leaves, and pale-yellow, scentless flowers, which grow in pairs.

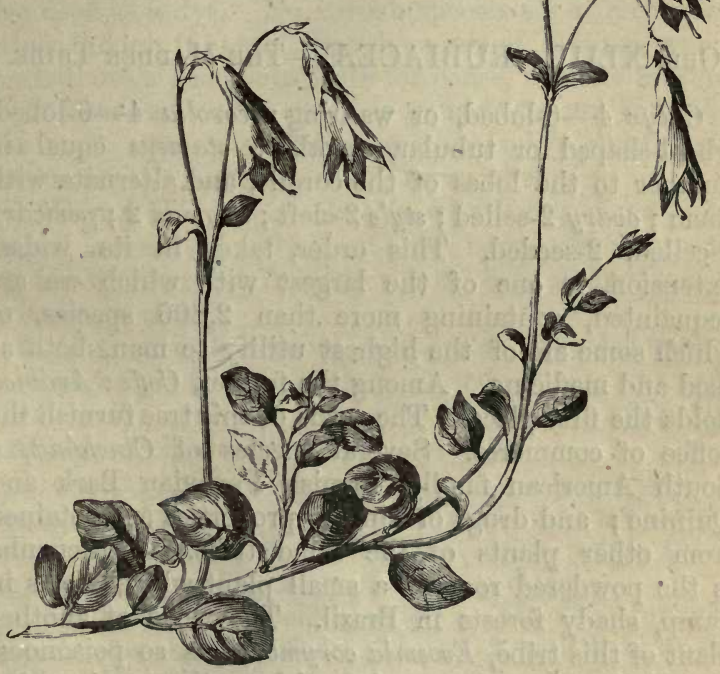

LINNAEA BOREALIS (Linnoea).

4. Linnata.

L. Boreális (Linnæa).-The only species. Deservedly regarded with peculiar interest as being the "little northern plant, long overlooked, depressed, abject, flowering early," which Linnæus himself selected as 
therefore most appropriate to transmit his name to posterity.- - It grows in woods especially of Fir, in Scotland and in one English station, namely, a plantation of Scotch Firs in the parish of Hartburn, Northumberland. The stem trails along the ground, and bears at intervals pairs of roundish, slightly crenate leaves. The flowering stalks are erect, and bear each two pendulous bellshaped flowers, which are fragrant and of a delicate pink colour.-Fl. June, July. Perennial.

\section{Ord. XLIII.-RUBIACEÆ.-The Madder Tribe.}

Calyx 4-6-lobed, or wanting; corolla 4-6-lobed, wheel-shaped or tubular, regular; stamens equal in number to the lobes of the corolla, and alternate with them ; ovary 2-celled; style 2-cleft; stigmas 2 ; pericarp 2 -celled, 2-seeded. This order, taken in its widest extension, is one of the largest with which we are acquainted, containing more than 2,800 species, of which some are of the highest utility to man, both as food and medicine. Among the former, Coffea Arábica holds the first place. The seeds of this tree furnish the coffee of commerce. Several species of Cinchóna, a South American family, furnish Peruvian Bark and Quinine; and drugs of similar properties are obtained from other plants of the same tribe. Ipecacuanha is the powdered root of a small plant which grows in damp, shady forests in Brazil. The wood of another plant of this tribe, Evosmia corymbósa, is so poisonous, that Indians have been poisoned by eating meat roasted on spits made of it. Not a few, moreover, are noted. for the fragrance and beauty of their flowers. All the above mentioned are natives of hot climates; the British species are very different, both in habit and properties. They are herbaceous plants, with slender angular stems, whorled leaves, and small flowers, possessing no remarkable properties, except that of con- 
taining a colouring matter in their roots, which is used as a dye. This group has been separated by some botanists, and made to constitute a distinct order, under the name of Stelláte, a name particularly appropriate to them, from the star-like arrangement of their leaves. The most important of all of these is Rúbia tinctoria, the roots of which afford Madder, a valuable dye, and possess the singular property of imparting a red colour to the bones of animals which feed on them. Other species of Rubia, growing in Bengal and China, are also used as a dye. No $\mathrm{No}_{0}$ British species are of any great value, though it is said that the seeds of Gálium, when roasted, are a good substitute for coffee, and the flowers of Gálium verum are used as rennet to curdle milk. The most attractive British species is Woodruff, well known for the fragrance of its leaves when dry.

1. Rúbia (Madder).-Corolla wheel-shaped; or bellshaped; stamens 4 ; fruit a 2-lobed berry. (Name, from the Latin ruber, red, from the dye of that colour afforded by some species.)

2. Gálium (Bed-straw). - Corolla wheel-shaped; stamens 4 ; fruit dry, 2-lobed, 2-seeded, not crowned by the calyx. (Name, from the Greek gala, milk, for curdling which some species are used.)

3. Aspérula (Woodruff).-Corolla funnel-shaped; stamens 4 ; fruit dry, 2-lobed, 2 -seeded, not crowned by the calyx. (Name, from the Latin asper, rough, from the roughness of the leaves of some species.)

4. Sherardia (Field-Madder). - Corolla funnelshaped ; stamens 4 ; fruit dry, 2-lobed, 2-seeded, crowned by the calyx. (Named in honour of James Sherard, an eminent English botanist.)

\section{Rúbia (Madder).}

1. R. peregrina (Wild-Madder).-The only British species, common in bushy places in the south-west of England. A long straggling plant, many feet in lengtls, with remarkably rough stems and leaves, the latter 


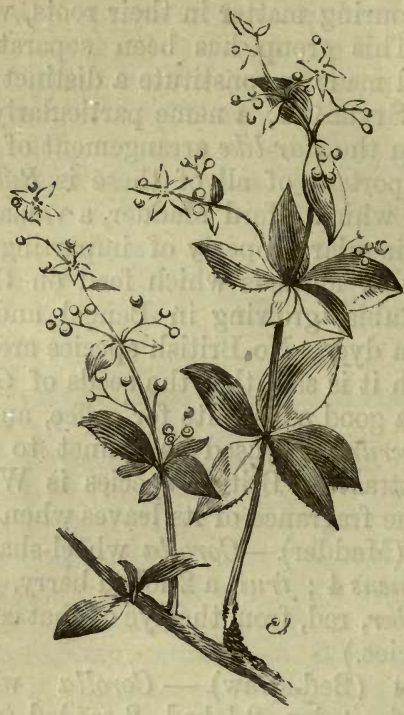

RUbia PEREgrína (Wild-Madder).

growing in whorls of $4-6$, glossy above, and recurved at the margin. The flowers are green, 5-cleft, and grow in panicles; the berries remain attached to the plant until late in winter; they are black, and about as large as currants.-Fl. June-August. Perennial.

\section{Galium (Bed-straw). \\ * Flowers yellow.}

1. G. cruciátum (Crass-wort).-Leaves 4 in a whorl, soft and downy; flowers clustered in the whorls, upper ones having pistils only, lower, stamens only.-Bushy hedges, common; well distinguished by its uniform leaves, and short clusters of dull yellow flowers. The 
stems are scarcely branched, 1-2 feet long.-Fl. May, June. Perennial.

2. G. verum (Yellow Bed-straw).-Leaves about 8 in a whorl, very narrow (almost thread-like), grooved and often downy below.-Dry banks, especially near the sea, where it forms a conspicuous object with its dense panicles of golden-yellow flowers. The Highlanders use the roots, in conjunction with alum, to dye red, and the rest of the plant as rennet to curdle milk.-Fl. July, August. Perennial.

\section{** Flowers white.}

+ Fruit smooth.

3. G. Molluigo (Hedge Bed-straw).-Leaves 8 in a whorl, oblong, tapering at each end, with a bristly point, roughish at the edge; flowers in a loose, spreading panicle.-Common everywhere in England, but said to be less frequent in Scotland. This and G. Apariné are the most abundant species, and resemble one another in having long straggling stems; G. Apariné has the prickles pointing backwards, and clings to the dress when touched, but in the present species, the prickles on the edges of the leaves are weak and point forwards. -Fl. July, August. Perennial.

4., G. palustré (Water Bed-straw).-Leaves 4-6 in a whorl, oblong, blunt, tapering at the base ; stem weak, straggling, more or less rough ; flowers in loose, spreading panicles.-Watery places, common. Variable in size and roughness; likely to be confounded with the following, from which it differs in its superior size and blunt leaves, which are frequently unequal in length, especially in the upper whorls.-Fl. July, August. Perennial.

5. G. uliginósum (Rough Marsh Bed-straw).-Leaves $6-8$ in a whorl, narrow, tapering at both ends, bristlepointed, their edges as well as the angles of the stem rough with prickles, which point backwards.-Watery 
places, common. Smaller than the last, the stem being rarely more than a foot high, slender and brittle; panicles of few flowers.-Fl. July, August. Perennial.

6. G. saxátilé (Heath Bed-straw).-Leaves about 6 in a whorl, inversely egg-shaped, pointed; stem much branched, smooth, prostrate below.-Heathy places, abundant. A small species, with numerous dense panicles of white flowers. The edges of the leaves are sometimes fringed with a few prickles, which point forwards. This and $G$. verum are the only British species which can be called ornamental.-Fl. JuneAugust. Perennial.

* Besides the above, seven or eight other species belonging to this group have been described by British botanists ; they are, however, of rare occurrence, with the exception of $G$. tricorné, which is tolerably common in some of the English counties, and in the Isle of Wight. The stems of this species are about a foot long, and rough, as well as the leaves, with prickles pointing backwards ; the flowers grow in threes, and the fruit is reflexed.

+十 Fruit rough.

7. G. Aparíné (Goose Grass, Cleavers).-Leaves $6-8$ in a whorl, very rough with prickles pointing backwards; flowers 2-3 together, axillary; fruit rough with hooked prickles.-Hedges, exceedingly common. Well distinguished by its rough stems and leaves, which cling to the fingers when touched. The globular seedvessels are also very tenacious, and disperse themselves by clinging to the coat of any animal that touches them; hence they derive their popular name of cleavers. The whole plant, when green, is greedily devoured by geese. The seeds, it is said, have been used as a substitute for Coffee.-Fl. June-August. Annual.

8. G. boreálé (Cross-leaved Bed-straw).-Leaves 4 in a whorl, 3-nerved, smooth ; stem erect ; fruit rough with hooked prickles.-Damp rocky places in the North. 


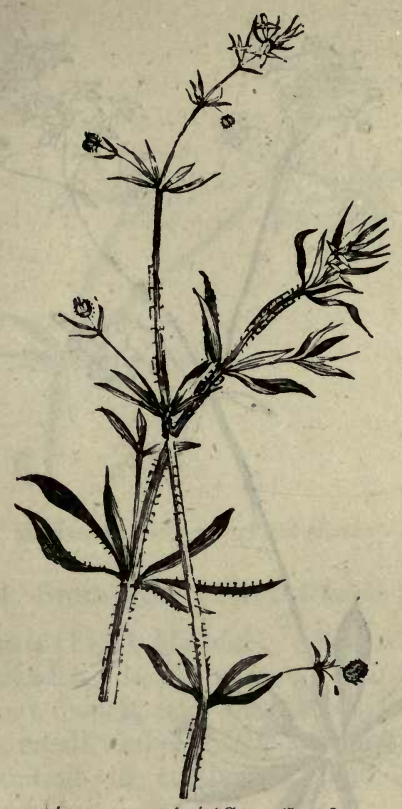

GÁLIUM APARÍNé (Goose-Grrass).

Well distinguished by its cruciform, smooth leaves, andprickly fruit.-Fl. July, August. Perennial.

\section{Aspérula (Woodruff).}

1. A. odoráta (Sweet Woodruff).-Leaves about 8 in a whorl; flowers in stalked, terminal panicles; fruit rough with bristles.-Moist woods, common. A deservedly favourite plant, not so much for its regularly whorled, bright green leaves and pretty snow-white flowers, as for its agreeable perfume when dry, which resembles that of new hay. When it is desired to preserve the leaves merely for their scent, the stem should $\mathrm{x} 2$ 


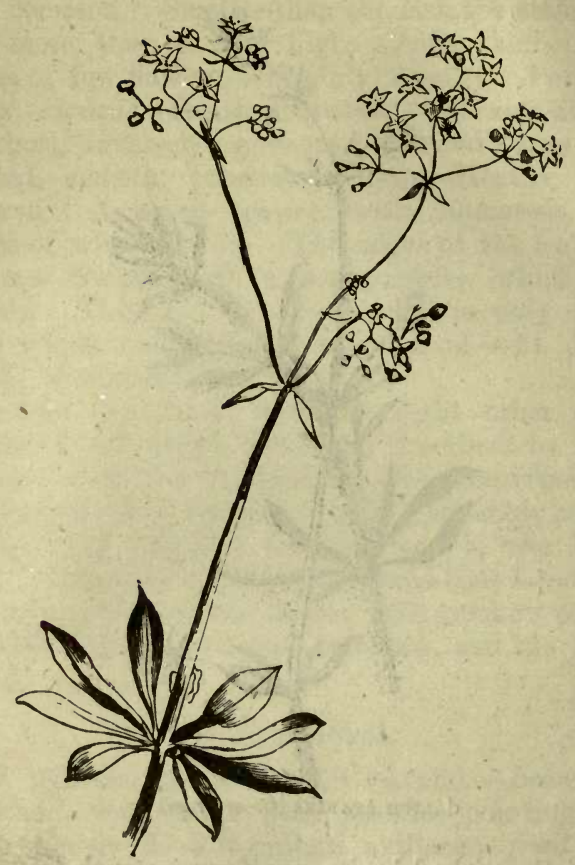

aspérula odorata (Sweet Woodmufi).

be cut through just above and below a joint, and the leaves pressed in such a way as not to destroy their star-like arrangement.-Fl. May, June. Perennial.

2. A. Cynánchica (Squinancy-wort).-Leaves 4 in a whorl, linear, uppermost very unequal.-Dry pastures, especially on a chalky or limestone soil, not common. A small plant, with very narrow leaves, and tufts of lilac or whitish flowers. It derives its name from having been formerly used as a remedy for the squinancy, or quinsy.-Fl. June, July. Perennial. 


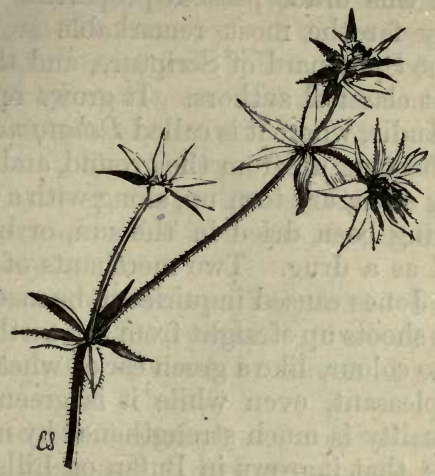

SHERARDIA ARVENSIS (Field Madder).

4. Sherardia (Field Madder).

1. S. arvensis (Field Madder). A small plant, with branched spreading stems, narrow, pointed leaves, in whorls of about 6 each, and minute bluish pink flowers, which form a small umbel in the bosom of the terminal leaves.-Abundant in cultivated land.-Fl. JuneAugust. Annual.

ORD. XLIV.-VALERIANACEA.-The VALERIAN TRIBE.

Calyx superior, finally becoming a border, or pappus, to the fruit ; corolla tubular, 3-6-lobed, sometimes irregular and spurred at the base; stamens $1-5$, inserted into the tube of the corolla; ovary with $1-3$ cells ; fruit dry, crowned with the calyx, not bursting, 1-seeded, two of the cells being empty.-Herbaceous plants, with opposite leaves, often strong-scented or aromatic, inhabiting temperate countries, especially the north of India, Europe, and South America. Many of 
the plants in this order possess properties worthy of notice, but by far the most remarkable is Valeriana Jatamansi, the Spikenard of Scripture, and the Nardus of the ancient classical authors. It grows on the hills of Butan, in India, where it is called Dshatamansi. The root leaves, shooting up from the ground, and surrounding the young stem, are torn up, along with a part of the root, and having been dried in the sun, or by artificial heat, are sold as a drug. Two merchants of Butan, of whom Sir W. Jones caused inquiries to be made, related, that the plant shoots up straight from the earth, and that it is then, as to colour, like a green ear of wheat; that its fragrance is pleasant, even while it is green, but that its odorous quality is much strengthened by merely drying the plant; that it grows in Butan on hills, and even on plains in many places ; and that in that country it is gathered and prepared for medicinal purposes. In ancient times, this drug was conveyed by way of Arabia to southern Asia, and thus it reached the Hebrews. Judas valued the box of ointment with which Mary anointed our blessed Lord's feet at two hundred denarii (6l. 9 s. $2 d$.). By the Romans, it was considered so precious, that the poet Horace promises to Virgil a whole cadus, or about three dozen modern bottles of wine, for a small onyx-box full of spikenard. It was a Roman custom, in festive banquets, not only to crown the guests with flowers, but also to anoint them with spikenard. Eastern nations procure from the mountains of Austria the Valeriana Céltica and V. Saliunca to perfume their baths. Their roots are grubbed up with danger and difficulty by the peasants of Styria and Carinthia, from rocks on the borders of eternal snow ; they are then tied in bundles, and sold at a very low price to merchants, who send them by way of Trieste to Turkey and Egypt, where they are retailed at a great profit, and passed onwards to the nations of India and Ethiopia. The seeds of Centranthus ruber (Red Valerian) were used in former times in the process of embalming the dead; 
and some, thus employed in the 12 th century, on being removed from the cere-cloth in the present century and planted, have vegetated. The roots of our common Valerian, $V$. officinális, are still used in medicine; their effect on cats is very remarkable, producing a kind of intoxication. The young leaves of Fédia olitoria (Lamb's Lettuce) are eaten as salad, and those of Centranthus ruber (Red Valerian) are, in Sicily, eaten in the same way.

1. Centranthus - (Spur Valerian).-Corolla 5-cleft, spurred at the base; stamen 1 ; fruit crowned with a feathery pappus. (Name in Greek denoting "Spurflower.")

2. Valerína (Valerian).-Corolla 5-cleft, bulged at the base ; stamens 3 ; fruit erowned with a feathery pappus. (Name from the Latin valeo, to be powerful, on account of its medicinal virtues.)

3. Fédia (Corn-salad).-Corolla 5-cleft, bulged at the base; stamens 3 ; fruit crowned with the calyx. (Name of uncertain origin.).

\section{Centranthus (Spur Valerian).}

-1. C. muber (Red Spur Valerian).-Corolla spurred at the base; stamen 1 ; leaves egg-shaped, pointed. Not a native plant, but nevertheless very common in limestone quarries and chalk-pits, as well as on old garden walls. The stems are $1-2$ feet high ; the leaves large, smooth, and glaucous; the flowers are deep red, and grow in terminal bunches. A white variety is not uncommon. -Fl. June-September. Perennial.

\section{Valeriána (Valerian).}

1. V. dioíca (Small Marsh Valerian).-Stamens and, pistils on different plants : corolla bulged at the base; stamens 3 ; root leaves egg-shaped, stalked; stem leaves pinnatifid, with a large terminal lobe.-Marshy ground, not unfrequent. Growing about a foot high, quite erect, 


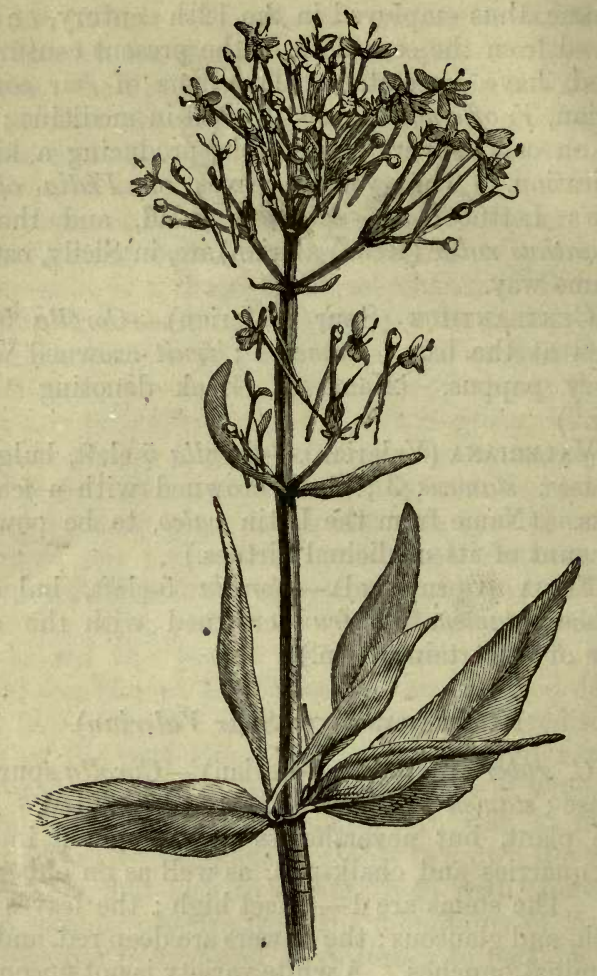

CENTRANTHUS RUBAR (Red Spur Valerian).

and unbranched, with a terminal corymb of light pink flowers. The flowers which bear stamens are the largest.-Fl. May. Perennial.

2. V. officinális (Great Wild Valerian).-Corolla bulged at the base; stamens 3 ; leaves pinnate.-Much taller and stouter than the last, but resembling it in habit, as well as in the colour and smell of the flowers. 'This is the species of which the roots are used in medi- 
cine, and of which cats are so fond; rats also are said to be attracted by their smell.-Fl. June, July. Perennial.

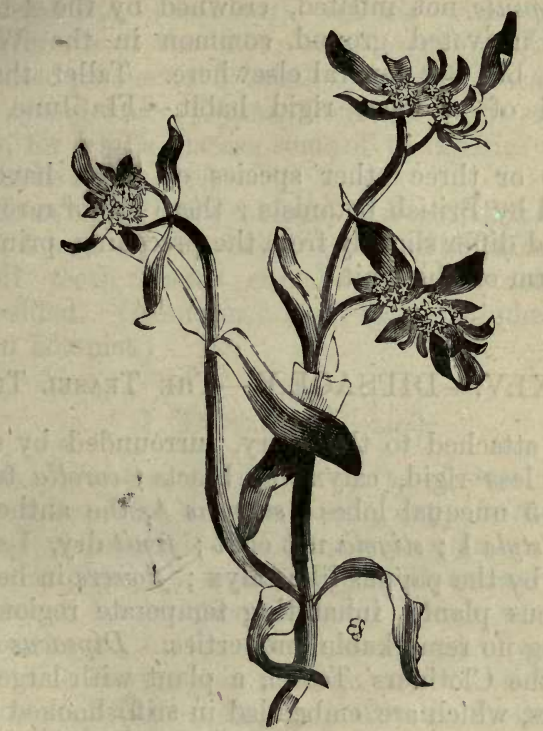

Fódia olitória (Common Corn salad, Lamb's Lettuce).

3. Fédia (Corn Salad).

1. F. olitória (Common Corn Salad, Lamb's Lettuce). -Leaves long and narrow, wider towards the end, a little toothed near the base : flowers in leafy heads; capsule inflated, crowned by the 3 calyx teeth.-Cultivated ground, abundant. A small plant 4-8 inches high, with tender bright green leaves, stems repeatedly 2 -forked, and terminal leafy heads of very minute flowers, which resemble white glass. It is sometimes cultivated as a salad.-Fl. May, June. Annual. 
2. F. dentáta (Toothed Corn-salad).-Leaves long and narrow, much toothed towards the base ; flowers in corymbs, with a solitary sessile one in the forks of the stem; capsule not inflated, crowned by the 4-toothed calyx.-Cultivated ground, common in the West of England, but not general elsewhere. Taller than the last, and of a more rigid habit.-Fl. June, July. Annual.

* Two or three other species of Fédia have been described by British botanists ; these are of rare occurrence, and differ slightly from the preceding, principally in the form of the fruit.

\section{Ord. XLV.-DIPSACEA.-The Teasel Tribe.}

Calyx attached to the ovary, surrounded by several more or less rigid, calyx-like bracts ; corolla tubular, with 4-5 unequal lobes; stamens 4 , the anthers not united ; style 1 ; stigma not cleft ; fruit dry, 1-seeded, crowned by the pappus-like calyx ; flowers in heads. Herbaceous plants, inhabiting temperate regions, and possessing no remarkable properties. Dípsacus Fullónum is the Clothiers' Teasel, a plant with large heads of flowers, which are embedded in stiff, hooked bracts. These heads are set in frames and used in the dressing of broad-cloth, the hooks catching up and removing all loose particles of wool, but giving way when held fast by the substance of the cloth. This is almost the only process in the manufacture of cloth which it has been found impossible to execute by machinery ; for although various substitutes have been proposed, none has proved, on trial, exactly to answer the purpose intended.

1. Dípsacus (Teasel).-Heads with numerous general bracts at the base; outer calyx forming a thickened mairgin to the fruit; inner, cup-shaped, entire ; receptacle bristling with rigid awns ; fruit with four sides. (Name; the leaves are united at their base, so as to 
form, round the stem, a hollow, in which water collects ; hence the plant was called dípsacus, or thirsty, from the Greek dipsao, to thirst.)

2. Scabiósa (Scabious).-Heads with numerous general bracts at the base; outer calyx membranaceous and plaited; inner of 5 bristles; receptacle scaly ; fruit nearly cylindrical. (Name, from the Latin scabies, the leprosy, for which disease some of the species were supposed to be a remedy.)

3. Knautia (Field Scabious).-Heads with numerous general bracts at the base; outer calyx minute, with 4 small teeth; inner cup-shaped; receptacle hairy; fruit 4-sided. (Name in honour of Christopher Knaut, a Saxon botanist.)

\section{Dípsacus (Teasel).}

1. D. sylvestris (Wild Teasel).-Leaves opposite, united at the base, and forming a cup ; bristles of the receptacle not hooked.-Waste places, common. A stout herbaceous plant, $3-6$ feet high, with an erect prickly stem, large bright green leaves, which are prickly underneath and united at the base, and often contain water. The flowers grow in large, conical, bristly heads, the terminal bristles being generally the longest. The flowers themselves are light purple, and expand in irregular patches on the head.-Fl. July. Biennial.

2. D. pilósus (Small Teasel).-Leaves stalked, with a small leaflet at the base on each side.-Moist shady places, not common. Smaller than the last in all its parts, and having more the habit of a Scabious than of a Teazel. The flowers are white, and grow in small, nearly globose, bristly heads ; the whole plant is rough with bristles.-Fl. August, September. Biennial.

* D. Fullónum (Fullers' Teasel) differs from D. sylvestris in having the bristles of the receptacle hooked; it is not considered a British plant, though occasionally found wild in the neighbourhood of the cloth districts. 


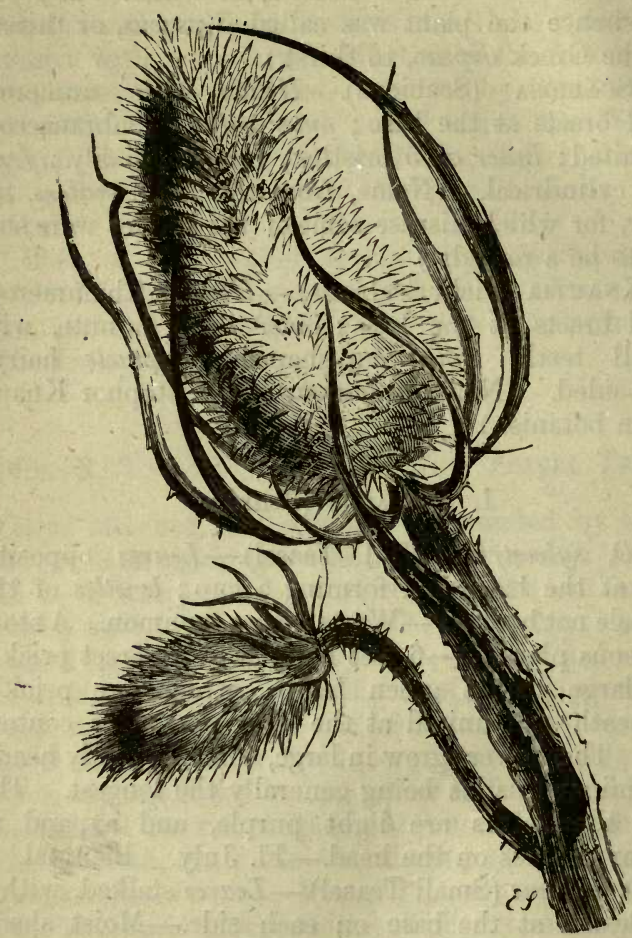

Dipsacus syLvestris (Wild Teasel).

2. Scabiósa (Scabious).

1. S. succisa (Premorse Scabious).-Corolla 4-cleft, nearly regular; heads nearly globose; leaves oblong, entire.-Heaths and pastures, common. A slender, littlebranched plant, with a hairy stem, few leaves, and terminal heads of purplish blue flowers. The root is solid 
and abrupt, as if bitten off (premorse).-Fl. JulyOctober. Perennial.

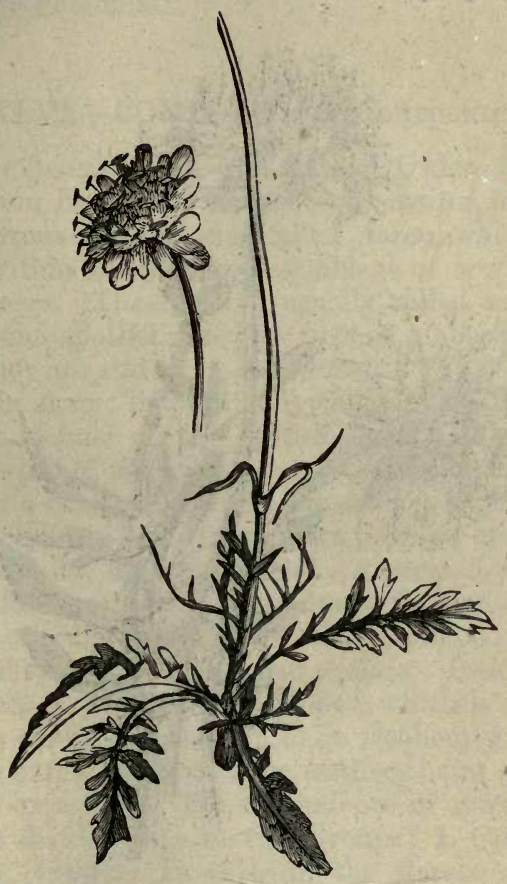

SCABIósa Columbara (Small Scabious).

2. S. Columbária (Small Scabious).-Corolla 5-cleft, the outer flowers longest; heads nearly globose; root leaves oblong, variously cut; upper pinnatifid.-Pastures 
on a chalky soil, not uncommon. Well distinguished from the last by its radiate flowers and cut leaves. The foliage is of a much lighter hue, and the flowers lilac rather than purple.-Fl. July, August. Perennial.

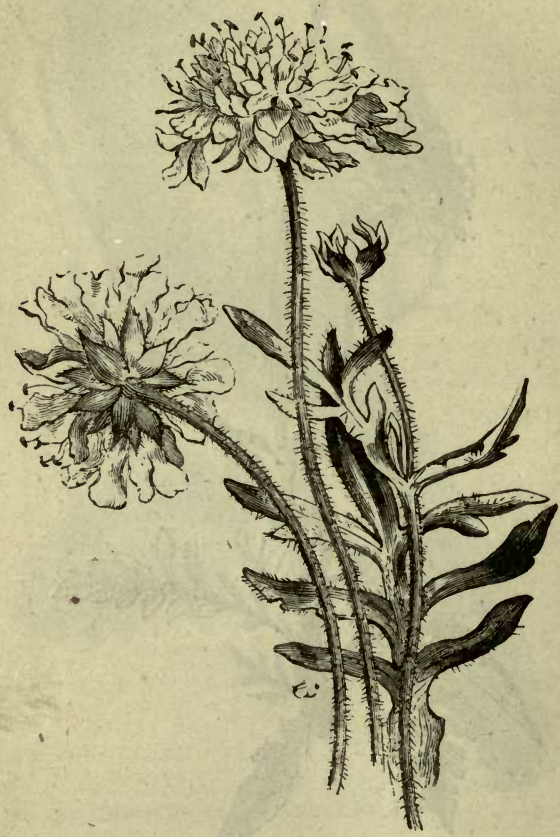

KNAUTIA ARVENSIS (Field Scabious).

3. Knautia (Field Scabrous).

1. K. arvensis (Field Scabious).-Root leaves simple; upper pinnatifid; inner calyx with a fringe of $8-16$ teeth; heads convex.-Corn-fields and way-sides, common. A tall bristly plant, $2-3$ feet high, not much 
branched, bearing several large handsome heads of lilac flowers, of which the inner are regularly cleft, the outer larger, and generally, though not always, radiate. It is sometimes called Scabiósa arvensis. - Fl. July, August. Perennial.

\section{ORD. XLVI.-COMPÓSITAE-COMPOUND FLOWERS.}

This extensive and well-marked Order derives its name from having its flowers compounded, as it were, of numerous smaller ones called florets, which are inclosed within a calyx-like assemblage of bracts, termed an involucre. These bracts, usually called scales, often overlap one another like the tiles of a house (imbrex); hence they are said to be imbricated. The flowers vary greatly in shape, but the following description will be found to include all the British species. Calyx rising from the top of the ovary, and becoming a pappus, that is, either a chaffy margin of the fruit, or a tuft or ring of bristles, hairs, or feathery down; corolla of one petal, either tubular. or strap-shaped; stamens 5 , united by their anthers (syngenesious); ovary inferior, 1 to each style, 1-celled; style simple, with a simple or 2-cleft stigma, sheathed by the tube of anthers ; fruit a solitary erect seed, crowned by the pappus, which is sometimes merely a chaffy margin, but more frequently an assemblage of simple, or serrated or feathery hairs, sometimes elevated on a stalk. For convenience of reference, this Order is divided into several Groups: I. CrCHORÁCEE (Chicory group). In this, all the florets are strapshaped and perfect; that is, each contains 5 stamens and a pistil. The prevailing colour of British species is yellow, as the Dandelion; but Salsafy (Tragopógon porrifolius) and Alpine Sow-Thistle (Sonchus alpinus) have purple flowers ; Chicory, blue. In II. CynarocePHAL (Thistle Group) the florets form a convex head, and are all tubular and perfect, except in Centauréa, 
where the outer florets, which are larger than the inner, are destitute both of stamens and pistils ; the stigma is jointed on the style. The flowers are purple, with a tendency to vary into white; but in Carline-Thistle (Carlina) they are brownish yellow ; in Corn-flower (Centauréa Cýanus) bright blue. In III. Tubiflóre (Tansy Group) all the florets are tubular and perfect, and form a flat head; the style passes into the stigma without a joint; the flowers are mostly yellow; but Hemp-Agrimony (Eupatórium cannábinum) has lilac flowers; Butter-bur (Petasites vulgáris) pale fleshcoloured, and in most species of Artemisia, Gnaphalium, and Filágo, the colour is determined rather by the involucre than the florets. In IV. RADIÁTA (Daisy Group) the florets are of two kinds ; those of the centre, or disk, being tubular and perfect, those of the margin, or ray, strap-shaped, and having pistils only. The prevailing colour of the disk is yellow, Yarrow (Achilléa) being the only exception, in which all the florets are white; the ray is either of the same colour, as in Colt's-foot (Tussilágo), Golden-rod (Solidágo), Rag-wort and Fleawort (Sénécio), Leopard's-Bane (Dorónicum), Elecampane (Inula), Flea-bane (Pulicaria), Corn-Marigold (Chrysánthemum ségetum), and Ox-eye Chamomile (Ánthemis tinctoria); white, as in Daisy (Bellis), Feverfow and Mayweed (Matricaria), Ox-eye (Chrysánthemum Leucánthemum), and several species of Chamomile (Ánthemis); or purple, as in Starwort (Aster), and Erígeron. In Groundsel (Senécio vulgáris) the ray is never perfected.

The limits of the Order Coмpósita are exactly the same as those of the Linnean Class Syngenesia; but the number of plants belonging to it exceeds the amount of all the plants known to Linnaeus, so extensive have been the researches in Botany since his time. According to Lindley, the number of genera alone amounts to 1,005 ; of species to 9,000 ; the whole number of plants known to Linnæus being but 8,500. It is supposed 
that the compound flowers constitute about one-tenth of all described plants; their properties vary considerably in different parts of the world, but not according to any known rule. The Chicory Group are, however, most abundant in cold regions, the Daisy Group in hot climates. Again, it may be remarked, that, in cold and temperate regions, the Compósitæ are mostly herbaceous ; but as we approach the equator they become shrubs, or even trees. The variety of properties which they possess is not proportionate to the immense number of species. Bitterness, in a greater or less degree, is a characteristic of nearly all, to which is sometimes added astringency, and many possess tonic or narcotic properties. Chicory, or Succory, is cultivated as a salad, but more frequently for the sake of its roots, which are roasted and mixed with ground coffee. The flavour is agreeable, but it is to be feared that less palatable and, perhaps, not so wholesome roots, procurable at a less cost, are often substituted for it. From the leaves a blue dye may be obtained. Endive is another species of Chicory (Cichórium Endivia), the blanched leaves of which afford a common winter salad. The common Dandelion (a corruption of Dent-de-lion, "Lion's tooth,") supplies an extract which is said to have valuable medicinal properties; its roots are also used to adulterate coffee. Lettuces afford a wholesome salad, as well as an extract, the properties of which resemble those of opium. The roots of Scorzonéra and Tragopógon porrifolius (Cardoons) are esculent, but almost grown out of use. These all belong to the Chicory Group.

Among the Thistle Group we have the Artichoke (Cýnara Scólymus), the young involucres and receptacles of which are edible; the Burdock (Arctium), the root of which is said to be useful in rheumatism; and the Carline Thistle, which was anciently used in magical incantations. In the third Group, Wormwood (Artemisia) is remarkable for its intense bitterness. One species (A. Abrótanum) is the Southernwood of gar- 
dens, a fragrant shrub, used on the Continent in making beer; A. Dracúnculus, the Tarragon of gardeners, is used for giving an agreeable flavour to vinegar. Some species of Eupatórium have the reputed power of healing the bites of venomous animals ; and E. glutinosum is said to be the plant which, under the name of Mático, is extensively used as a styptic. It is a shrubby plant, inhabiting the Andes, and derived its name from a soldier, nicknamed "Matico" (Little Matthew), who, having been wounded in battle, accidentally applied the leaves of this plant to his wound, which had the immediate effect of stopping the bleeding. To the Radiátes belong the gorgeous Dahlia, so called, from Dr. Dahl, who introduced it; and the "wee" Daisy, or Day's-eye, which opens only in sunny weather, and peeps up through the grass as if it were an eye indeed. The genus Helianthus contains the Sun-flower (H. annuus), and Jerusalem Artichoke (H.' tuberosus) ; "Jerusalem " being a corruption of an Italian word (girasole) of the same meaning as Sun-flower, the name Artichoke being given to mark the similarity of flavour in its roots with that of the true Artichoke mentioned above. It rarely flowers in England, but produces abundance of tubers, which hold a high rank among esculent vegetables. It is valuable, not only for its productiveness, but for the freedom with which it grows in any soil. Its roots are sometimes made into a dish, which, by an absurd piece of pedantry, is called "Palestine soup." Chamomile and Feverfew possess valuable medicinal properties, especially the former. Coltsfoot and Elecampane are useful in pectoral complaints; the flowers of Marigold are used to adulterate saffron; the Ox-eye Daisy is said to be destructive to fleas; the yellow Oxeye affords a yellow dye, and the petals of the Dahlia a beautiful carmine. 


\section{CichoráCex.-Chicory Group.}

All the florets strap-shaped, having stamens and pistils.

\section{Cynaroctíphale.-Thistle Group.}

All the florets tubular, 5-cleft, having stamens and pistils, (except in Centauréa, in which the outer florets are larger, and destitute of stamens and pistils,) and forming a convex head; style jointed below the stigma.

\section{TubiflóRs.-Tansy Group.}

All the florets tubular, 5-cleft, having stamens and pistils, and forming a flat head; style not jointed below the stigma.

\section{Radiátze.-Daisy Group.}

Central florets tubular, 5-cleft, having stamens and pistils; outer florets strap-shaped, forming a ray, and furnished with pistils only. (Senécio vulgáris, Common Groundsel, has no rays.)

\section{Cichoráces.-Chicory Group.}

1. Tragopógon (Goat's-beard).-Involucre simple, of 8-10 long scales, united below; receptacle dotted; fruit rough, with longitudinal ridges, tapering into a long beak; pappus feathery, with the down interwoven, concave above. (Name in Greek signifying a goat's beard.)

2. Helminthia (Ox-tongue).-Involucre of about 8 equal scales, surrounded by $3-5$ leaf-like, loose bracts; receptacle dotted; fruit rough with transverse wrinkles, rounded at the end and beaked; pappus feathery. (Name from the Greek helmins, helminthos, a worm, from the form of the fruit.) 
3. Picris.-Involucre of 1 row of equal, upright scales, with several small spreading ones at the base; receptacle lightly dotted; fruit rough with transverse ridges, not beaked; pappus of two rows, the inner only feathery. (Name from the Greek picros, bitter.)

4. Apárgia (Hawk-bit).-Involucre unequally imbricated, with the outer scales smaller, black and hairy, in several rows; receptacle lightly dotted ; fruit tapering to a point; pappus of 1 row, feathery. (Name of uncertain origin.)

5. Thrincia.-Involucre of 1 row, with a few scales at the base ; receptacle lightly dotted; fruit of the outer florets scarcely beaked; pappus a chaffy fringed crown; fruit of the inner florets beaked; pappus feathery. (Name from the Greek thrincos, a battlement, from the form of the seed-crown of the marginal florets.)

6. Нүросна́RIs (Cat's-ear).-Involucre oblong, imbricated; receptacle chaffy; fruit rough, often beaked; pappus feathery, often with a row of short bristles outside. (Name in Greek denoting its fitness for hogs.)

7. Lactúca (Lettuce).-Involucre oblong, imbricated, its scales membranous at the margin, containing but few flowers; receptacle naked; fruit flattened, beaked; pappus hairy. (Name from lac, milk, which the juice resembles in colour.)

8. Sonchus (Sow-thistle). - Involucre imbricated, with 2 or 3 rows of unequal scales, swollen at the base ; receptacle naked; fruit flattened, transversely wrinkled, not beaked ; pappus hairy. (Name in Greek, bearing allusion to the soft nature of the stems.)

9. CRePis (Hawk's-beard).-Involucre double, inner of 1 row, outer of short, loose scales; receptacle naked; fruit not flattened, furrowed, tapering upwards ; pappus, a tuft of soft, white down. (Name in Greek signifying a slipper, but why given to this plant is not known.)

10. Hierácium (Hawk-weed).-Involucre imbricated, with numerous oblong scales; receptacle dotted; fruit 
angular, furrowed, abrupt, with a toothed margin at the top; pappus bristly, sessile, not white. (Name from the Greek, hierax, a hawk, because that bird was supposed to use the plant to strengthen its sight.)

11. Leónтором (Dandelion).-Involucre imbricated with numerous scales, the outermost of which are loose, and often reflexed; receptacle dotted; fruit slightly flattened, rough, bearing a long and very slender beak ; pappus hairy. (Name from the Greek, leon, a lion, and odous, odontos, a tooth, from the tooth-like lobes of the leaves.)

12. Lapsína (Nipple-wort).-Involucre a single row of erect scales, with 4-5 small ones at the base, containing but few flowers ; receptacle naked; fruit flattened, furrowed ; pappus 0. (Name of Greek origin.)

13. Cichorium (Chicory).-Involucre in 2 rows, inner of 8 scales, which bend back after flowering; outer of 5 smaller loose scales; receptacle naker, or slightly hairy ; fruit thick above, tapering downwards ; pappus a double row of small chaffy scales. (Name of Arabic origin.)

\section{Cynarocéphalez.-Thistle Group.}

14. Arctium (Burdock).-Involucre globose, scales ending in hooked points ; receptacle chaffy ; fruit oblong, 4-sided; pappus short. (Name from the Greek arctos, a bear, from the roughness of the heads of flowers.)

15. Serrítula (Saw-wort).-Stamens and pistils on different plants ; involucre imbricated, scales not prickly ; receptacle chaffy or bristly ; fruit flattened, not beaked; pappus hairy. (Name from the Latin sérrula, a little saw, the leaves being finely serrated.)

16. Saussúrea. - Involucre imbricated, scales not prickly; anthers bristly at the base ; receptacle chaffy ; pappus double, outer bristly, inner longer, feathery. (Named in honour of the two Saussures, eminent botanists.) 
17. Cánduus (Thistle).-Involucre swollen below, imbricated with thorn-like scales; receptacle bristly; pappus hairy, united by a ring at the base, and soon falling off. (The Latin name of the plant.)

18. Cnicus (Plume-Thistle).--Resembling Carduus, except that the pappus is feathery. (Name from the Greek cnizo, to prick.)

19. ONopondum (Cotton-Thistle).-Receptacle honeycombed; fruit 4-angled; pappus hairy, rough; in other respects resembling Carduus. (Name of Greek origin.)

20. Carlína (Carline-Thistle).--Resembling Cnicus, except that the inner scales of the involucre are chaffy and coloured, and spread like a ray. (Name, the same as Carolina, from a tradition that the root of one species, C. acaulis, was shown by an angel to Charlemagne as a remedy for the plague which prevailed in his army.)

21. Centauréa (Knapweed, Blue-bottle, \&c.)-Involucre imbricated; receptacle bristly; pappus hairy, or 0 ; outer florets large, irregular, destitute of stamens and pistils. (Name from the Centaur Chiron, who is fabled to have healed wounds with it.)

\section{Tubiflóne.-Tansy Group.}

22. Bidens (Bur-Marigold).-Fruit crowned with 2 or 3 erect rigid bristles, which are rough with minute teeth pointing downwards. (Name from the Latin bis, double, and dens, a tooth, from the structure of the fruit.)

23. Eupatónium (Hemp-Agrimony). - Heads few flowered; involucre imbricated, oblong; receptacle naked; styles much longer them the florets. (Name from Mithridátes Exipator, who 1s. said to have brought the plant into use.)

24. Chrysócoma (Goldylocks).-Involucre a single row of loosely spreading scales; receptacle honey-combed; 
fruit flattened, silky; pappus hairy, rough. (Name from the Greek chrysos, gold, and comé, hair.)

25. Diótis (Cotton-weed).-Pappus 0 ; corolla with two ears at the base, which remain and crown the fruit. (Name from the Greek dis, double, and ous, ótos, an ear, from the structure of the fruit.)

26. Tanacétum (Tansy). - Involucre cup-shaped, imbricated; receptacle naked ; fruit crowned with a chaffy border. (Name altered from the Greek athánaton, everlasting.)

27. Artemísia (Wormwood).-Pappus 0 ; involucre roundish, imbricated, containing but few flowers. (Named after Ártemis, the Diana of the Greeks.)

28. Antennária (Everlasting).-Stamens and pistils on separate plants; pappus hairy, that of the barren flowers thickened or feathery upwards; involucre coloured, rigid. (Name from the antennæ of an insect, which the pappus of the barren flower resembles).

29. Gnaphílium (Cudweed).-Involucre roundish, dry, imbricated, often coloured; receptacle naked; pappus hairy. (Name from the Greek gnaphálion, soft down, with which the leaves are covered.)

30. FiLígo.-Involucre tapering upwards, imbricated, of a few long pointed scales; receptacle chaffy in the cireumference; pappus hairy; florets few, the outer ones bearing pistils only. (Name from the Latin filum, a thread, the whole plant being clothed with white thread-like hairs, or down.)

31. Petasítes (Butter-Bur).-Involucre a single row of narrow scales; receptacle naked; barren and fertile flowers mostly on different plants. (Name from the Greek pétasos, a covering for the head, from the large size of the leaves.)

\section{Radiáte.-Daisy Groutp.}

32. Tussilágo (Colt's-foot).- Involucre a single row of narrow scales; receptacle naked; florets of the ray 
narrow, in several rows ; of the disk few, all yellow. (Name from the Latin tussis, a cough, from the use to which it is applied.)

33. ERíGeron (Flea-bane).-Involucre imbricated with narrow scales; receptacle naked; florets of the ray in many rows, very narrow, different in colour from those of the disk. (Name in Greek signifying growing old at an early season, from the early appearance of the grey seed-down.)

34. Aster (Starwort).-Involucre imbricated, a few scales on the flower-stalk; receptacle naked, honeycombed; florets of the ray in 1 row, purple; of the disk yellow; pappus hairy, in many rows. (Name from the Greek aster, a star.)

35. Solidígo (Golden-rod).-Involucre and receptacle as in Aster ; florets all yellow ; pappus hairy, in 1 row. (Name from the Latin solidare, to unite, on account of its supposed qualities of healing wounds.)

36. Senécio (Ragwort, Groundsel and Flea-bane).Involucre imbricated, oblong or conical, a few smallepr scales at the base ; receptacle naked; florets all yellow, the outer in S. vulgáris wanting. (Name from the Latin senex, an old man, from the grey seed-down.)

37. Donónicum (Leopard's-bane).-Involucre cupshaped, scales equal, in 2 rows; florets all yellow; pappus hairy, wanting in the florets of the ray. (Name of uncertain etymology.)

38. Ínula (Elecampane).-Involucre imbricated, in many rows ; receptacle naked ; florets all yellow ; anthers with two bristles at the base ; pappus hairy, in 1 row. (Name probably a corruption of Helénula, Little Helen.) 39. Pulicária (Flea-bane).-Involucre loosely imbricated, in few rows; pappus in 2 rows, outer one short, cup-shaped, toothed, inner hairy, in other respects like ÍnuLA. (Name from the Latin pulex, a flea, which is supposed to be driven away by its powerful smell.)

40. BeLLis (Daisy).-Involucre of 2 rows of equal blunt scales; receptacle conical; outer florets white, 
inner yellow ; pappus 0. (Name from the Latin bellus, pretty.)

41. Chrysánthemum (Ox-eye).-Involucre nearly flat, the scales membranaceous at the margin; receptacle, naked; pappus 0. (Name from the Greek chrysos, gold, and anthos, a flower.)

42. Matricária (Wild Chamomile).-Involucre cupshaped or nearly flat, the scales imbricated; receptacle conical, naked; florets of the ray white, of the disk yellow ; pappus 0. (Name from some supposed medicinal virtues.)

43. Ánтнемis (Chamomile).-Involucre cup-shaped, or nearly flat, the scales membranaceous at the margin; receptacle convex, chaffy ; pappus 0 , or a narrow chaffy border. (Name from the Greek anthos, a flower, from the value of its blossoms as a medicine.)

44. Achilléa (Yarrow).-Involucre egg-shaped or oblong, imbricated; receptacle flat, chaffy; florets all of one colour, those of the ray $5-10$, broad; pappus 0 . (Named after Achilles.)

\section{Cíhoríces.-Chicory Group.}

\section{Tragopógon (Goat's-beard).}

1. T. pratensis (Yellow Goat's-beard). - Involucre about as long as, or longer than, the corolla; leaves broad at the base, very long, tapering, channelled, undivided; flower-stalks slightly thickened above.Meadows, not uncommon. An erect glaucous plant, about 2 feet high, with long grass-like leaves, and large bright yellow flowers, which always close early in the day, and have hence gained for the plant the name of John-go-to-bed-at-noon. The pappus is very beautiful, the feathery down being raised on a long. stalk, and interlaced so as to form a kind of shallow cup.-Fl. June, July. Biennial.

* T. porrifólius (Salsafy), though not a British 


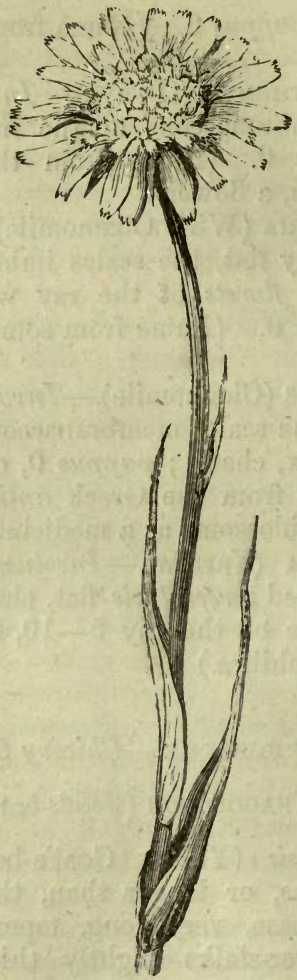

TRAGOPÓGON PRATENSIS (Yellow Goat s-beard).

species, is occasionally found in moist meadows. In habit it resembles the last, but has purple flowers. It was formerly much culfivated for the sake of its fleshy tapering roots, which were boiled or stewed, and eaten. Its place is now supplied by Scorzonéra Hispánica: but directions for its culture are still given in most gardeners' calendars. 


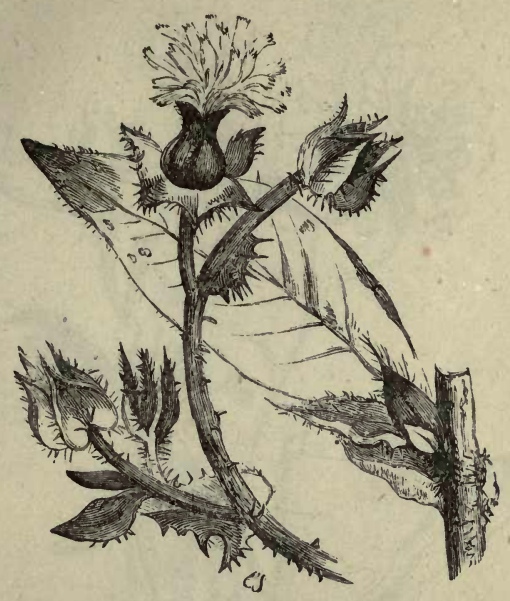

helmínthia ECHIOfDes (Bristly Ox-tongue).

2. Helmínthia (Ox-tongue).

1. H. echioides (Bristly Ox-tongue).-Waste places, not uncommon. A stout and much branched herb, 2-3 feet high, well distinguished by its numerous prickles, each of which springs from a raised white spot, and by the large heart-shaped bracts at the base of the yellow. flowers.-Fl. June, July. Perennial.

\section{PiCRIS.}

1. P. hieracioídes (Hawk-weed Picris).-Waste places, common. A rather slender plant, 2-3 feet high, branched principally above; the stems are rough with hooked bristles; the leaves narrow, rough and toothed, sessile ; the flowers numerous, yellow, with several scales on the stalks.-Fl. July-September. Biennial. 


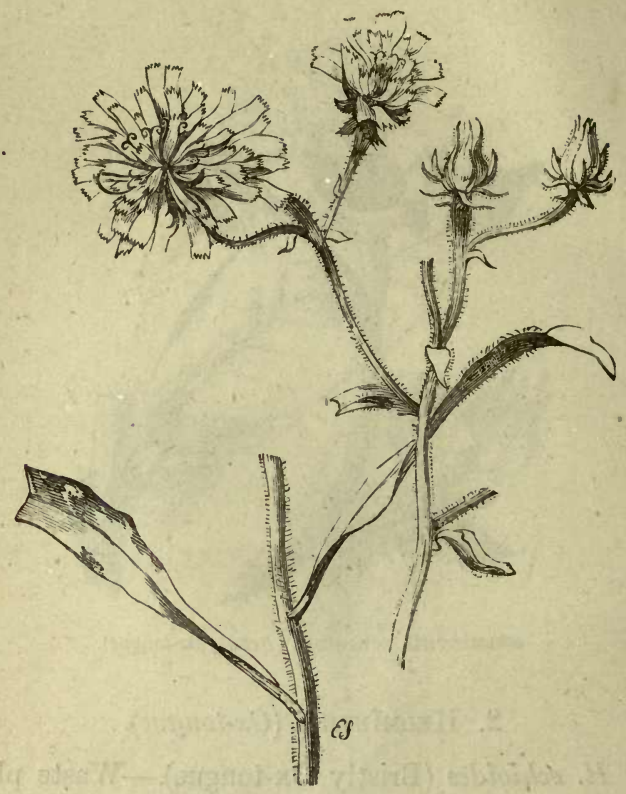

PICRIS hieraciof́des (Hawk-weed Picris).

\section{Apárgia (Hawk-bit).}

1. A. hispida (Rough Hawk-bit).-Leaves all from the root, pinnatifid, with the lobes pointing backwards, rough with forked bristles; stalk single-flowered.Meadows and waste places, frequent.-F'lowers yellow.Fl. June-September. Perennial.

2. A. autumnális (Autumnal Hawk-bit).-Leaves al. from the root, narrow, slightly hairy on the ribs beneath ; stalk many flowered, swollen beneath the flowers.-Meadows and cornfields, frequent. A tall plant, 2-3 feet high, with a downy involucre, and large deep-yellow flowers.-Fl. August. Perennial. 


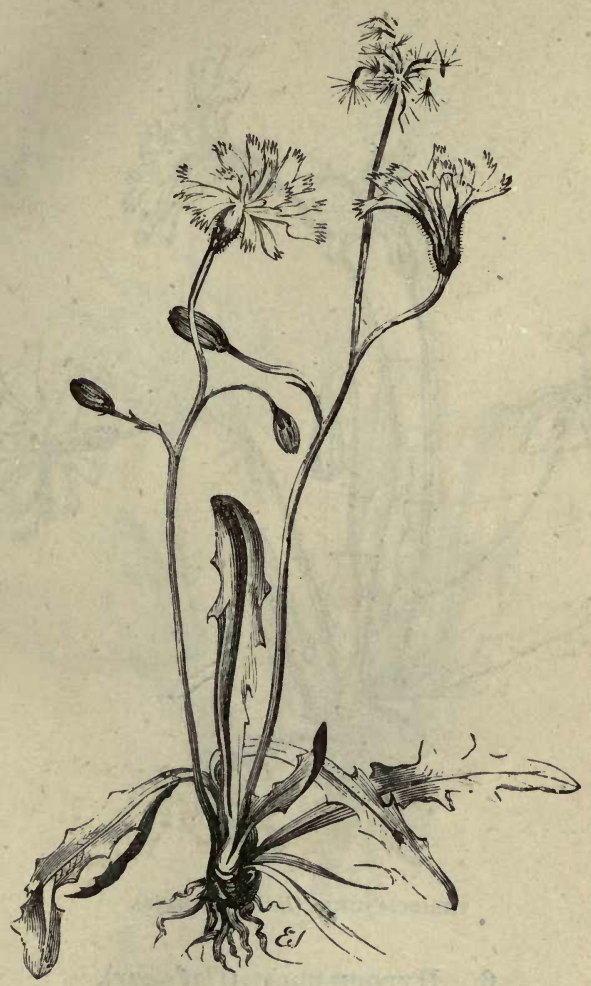

APÁRgIA AUTUMNALIS (Autumnal Hawk-bit).

\section{Thríncia.}

1. T. hirta (Hairy Thrincia).-Heaths and downs, common. A small plant, $4-6$ inches high, with spreading, more or less lobed, leaves, which are rough with forked bristles, and leafless somewhat hairy stalks, each of which bears a yellow flower.-Fl. July - Sept. Perennial. 


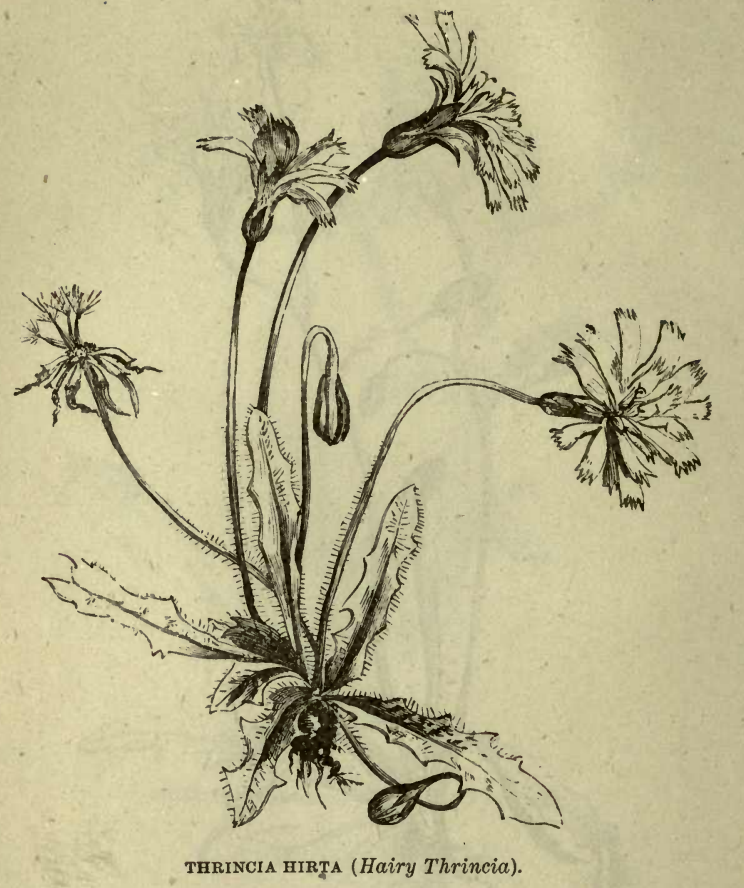

\section{Hyроснавis (Cat's-ear).}

1. H. radicáta (Long-rooted Cat's-ear).-Leaves all from the root, pinnatifid, with the lobes pointing backwards, bristly; stalks branched, smooth, with a few scales below the flowers. - Hedges and waste places, common. Well distinguished by its long branched flowerstalks, which are quite smooth throughout, and slightly swollen beneath the large yellow flowers, where there are also a few small scales.-Fl. July, August. Perennial. 


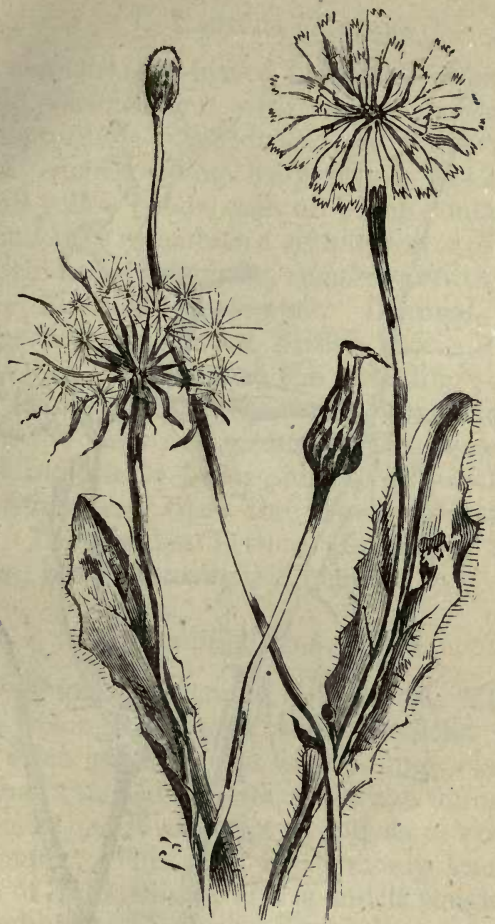

HYPOCHERIS RADICATA (Long-rooted Cat's-ear).

* Besides the above, there are two other British species of Hypochæris : H. glabra (Smooth Cat's-ear), which has nearly smooth leaves, and small yellow flowers scarcely larger than the invoicuce; gravelly places, not common; and $H$. maculáta (Spotted Cat'sear), which has rough spreading leaves, which are not lobed, and 1 (or rarely more) very large deep yellow flower; limestone and magnesian rocks, rare. 


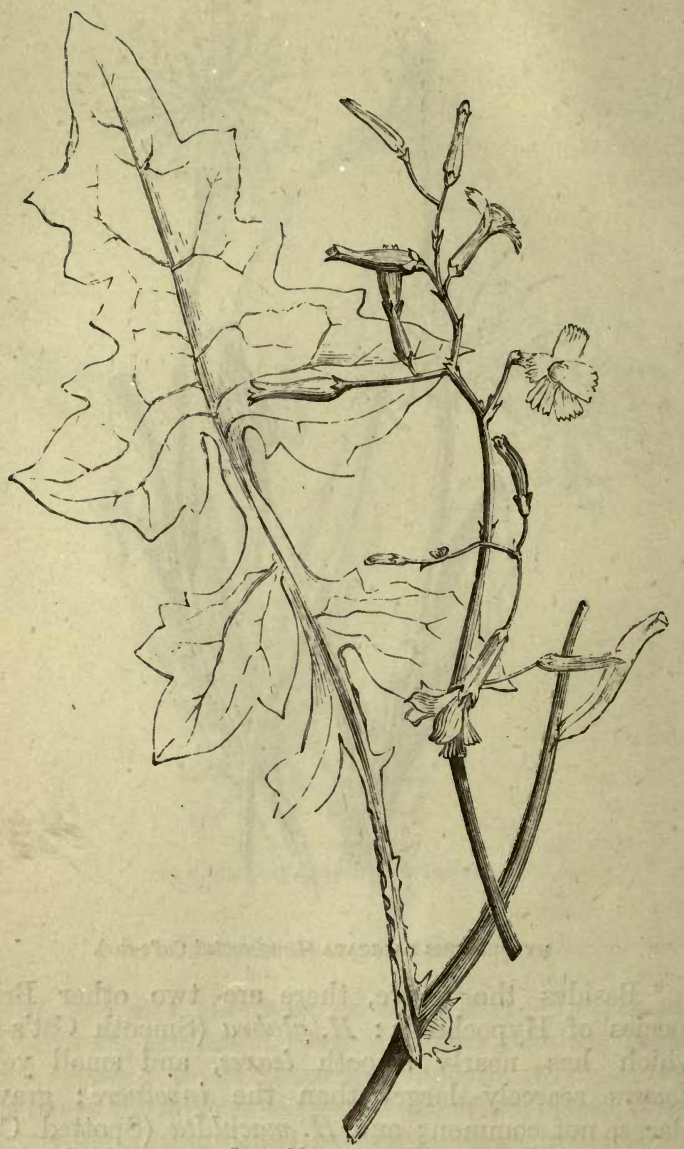

LACTĆCA MURÁlIS (Ivy-leaved Lettuce). 


\section{Lactúca (Lettuce).}

1. L. murális (Ivy-leaved Lettuce).-Florets 5 ; leaves pinnatifid, variously cut, with the terminal lobe largest; panicles spreading.-Woods and old walls, not uncommon. A slender plant, leafy below, $1-2$ feet high, with small yellow heads, each of which contains 5 equal florets, and thus resembles' a simple flower of five petals. The panicle has a singularly angular growth; the fruit is black.-Fl. July-September. Biennial.

* There are three other British species of Lactúca, which are less common than the preceding; L. Scoriola (Prickly Lettuce), which has nearly perpendicular leaves, prickly at the back ; L. virósa (Strong-scented Lettuce) has spreading prickly leaves; and $L$. saligna has narrow toothed leaves, and bears its flowers in lateral tufted clusters. The Garden Lettuce ( $L$. sativa) belongs to this genus, but is not a native plant.

\section{Sonchus (Sow-thistle).}

1. S. oleráceus (Common Sow-thistle, Milk-thistle). - Leaves oblong, more or less pinnatifid or entire, toothed, often prickly, the upper ones clasping the stem; stem branched; heads somewhat umbellate; involucres smooth.-Waste places, and as a weed in gardens, common. This plant is commonly known under the name of Milk-thistle, and is much sought after as food for rabbits.-Fl. June-September. Annual.

2. S. arvensis (Corn Sow-thistle, Milk-thistle). Leaves oblong, the lower ones pinnatifid, with the lobes pointing backwards, toothed, heart-shaped at the base; stem simple; heads corymbose; involucre and flower-stalks hairy. - In similar situations with the last, from which it may be readily distinguished by its simple stem and much larger flowers.-Fl. August, September. Perennial.

* S. palustris (Marsh Sow-thistle) is a much taller species than either of the preceding, growing $6-8$ feet 
high; the leaves are arrow-shaped at the base; the flowers large and yellow, with hairy involucres. It grows in marshy places ; rare. S. alpinus (Alpine Sow-thistle), - now called Mulgédium alpínum,-is a very handsome plant, with large blue flowers. It grows on the Clova mountains, but is rare.

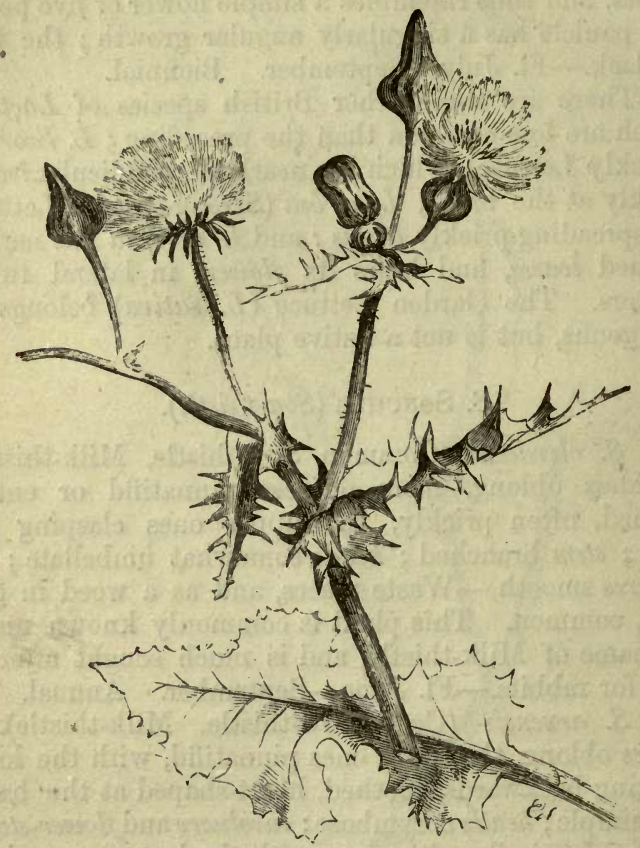

SONCHUS OLERACEUS (Common Sow-thistle, Milk-thistle).

9. Crepis (Hawk's-beard).

1. C. virens (Smooth Hawk's-beard). - Leaves smooth. pinnatifid, with the lobes pointing backwards, the upper 
ones narrow, arrow-shaped at the base, and clasping the stem; flowers numerous.-In waste ground, and on the roofs of cottages: common. Varying in height, from 6 inches to 2 feet, or more, and producing abundance of yellow flowers.-Fl. July-September. Annual.

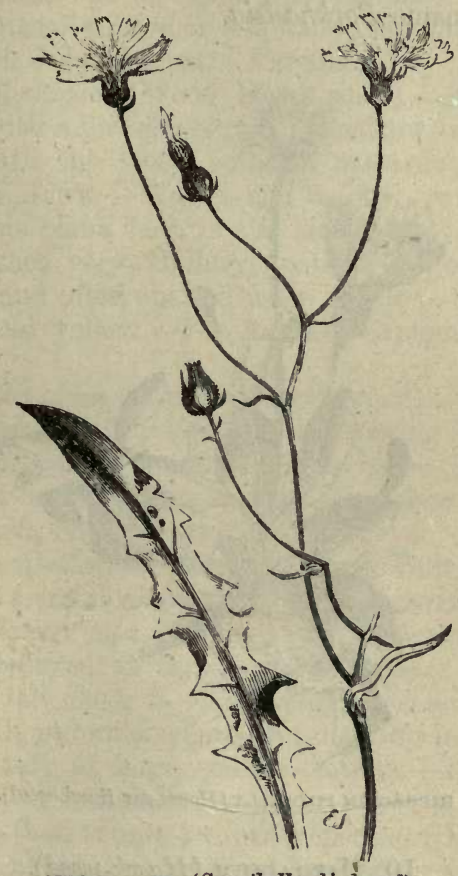

CREPIS VIRENS (Smooth Havok's-beard).

C. paludósa (Marsh Hawk's-beard).-Leaves smooth, the lower ones pinnatifid, with the lobes pointing backwards, tapering into a stalk; the upper ones narrow, heart-shaped at the base, and clasping the stem.-Damp 
woods ; not unfrequent.-Fl. July-September. Perennial.

* There are several other British species of Crepis, some of which are of common occurrence. For a description of these the student is referred to "Hooker and Arnott's British Flora." Two of them are described under the name Borkhaúsia.

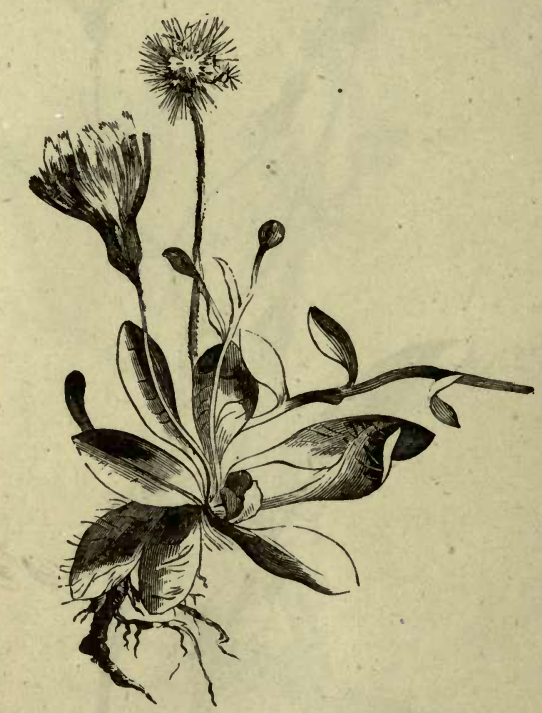

HIERÁCIUM PILOSELLA (Mouse-ear Hawk-weed).

\section{Hieracium (Hawk-weed).}

1. H. Pilosella (Mouse-ear Hawk-weed).-Stem singleflowered, leafless ; scions creeping; leaves entire, hairy. -Banks, and dry pastures ; common. Well distinguished from all other British plants of the Order by its creeping scions, by its hairy undivided leaves, which 
are hoary underneath, and by its bright lemon-coloured flowers.-Fl. May-July. Perennial.

2. $H$. murórum (Wall Hawk-weed).-Stem manyflowered, with 1 leaf, branched above ; root-leaves eggshaped, toothed at the base.-Walls and rocks ; common. A very variable plant, $12-18$ inches high, rarely having more than one leaf on the stem, sometimes none; the leaves are usually more or less hairy, the flowers small, yellow.-Fl. July, August. Perennial.

3. H. sylváticum (Wood Hawk-weed).-Stem manyflowered, with a few leaves ; leaves narrow, egg-shaped, toothed, with the teeth pointing upwards; involucre hoary with down.-Woods and banks; common. A very variable plant, both in size and habit. The leaves are sometimes very slightly toothed, at other times deeply so, and often spotted with purple; the flowers are large and yellow.-Fl. August, September. Perennial.

4. H. Sabaudum (Shrubby Hawk-weed).-Stem rigid, many-flowered, leafy ; lower leaves tapering into a short stalk, upper sessile, rounded at the base-Woods and banks; not unfrequent. As variable a plant as the last. -Fl. August, September. Perennial.

5. H. umbellatum (Narrow-leaved Hawk-weed).Stem rigid, many-flowered, leafy ; leaves narrow, slightly toothed; flowers in a terminal corymb; scales of the involucre reflexed at the point.-Woods; not unfrequent. A tall plant, 2-3 feet high, with a remarkably erect growth, unbranched, and terminating in an almost umbellate tuft of large, yellow flowers. - Fl. August, September. Perennial.

* No less than twenty-two other species of Hawk-weed besides the above are described by Hooker and Arnott, some of which are doubtful natives, the others rare. Of these it is not thought necessary to give even the names here, but most of the common species will agree with one or other of the descriptions given above. The student, however, must not be disheartened if he find 
himself occasionally at fault, the family being one of the most perplexing in this difficult Order.

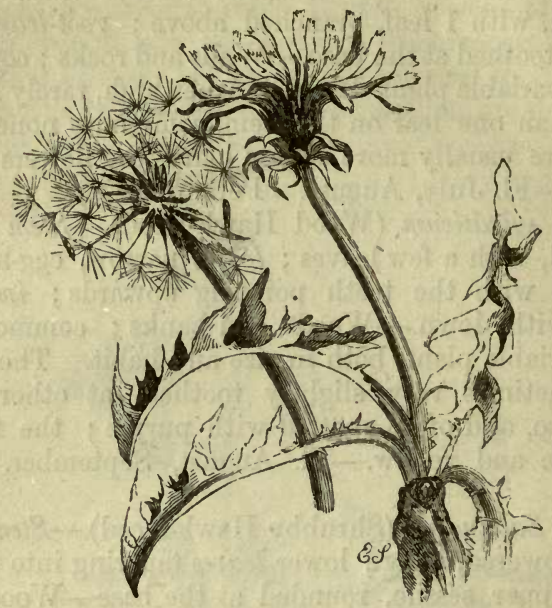

LEÓNTODON TARÁXACUM (Common Dandelion).

\section{Leóntodon (Dandelion).}

1. L. Taráxacum (Common Dandelion).-Cultivated ground ; abundant. Dandelion, from the French, Dentde-lion, lion's-tooth, is the popular name of nearly all the larger yellow flowers belonging to this Sub-order. The true Dandelion may, however, be readily known by the following characters. The leaves all spring from the root, and are deeply cut, with the sharp lobes pointing backwards; the flower-stalks are hollow, smooth, and leafless, and bear a single flower ; the outer scales of the involucre are reflexed; the pappus is stalked, and white; the heads when in fruit are of a globular form; and the receptacle, after the fruit has been blown away, is convex, and dotted.-Fl. nearly all the year round. Perennial. 


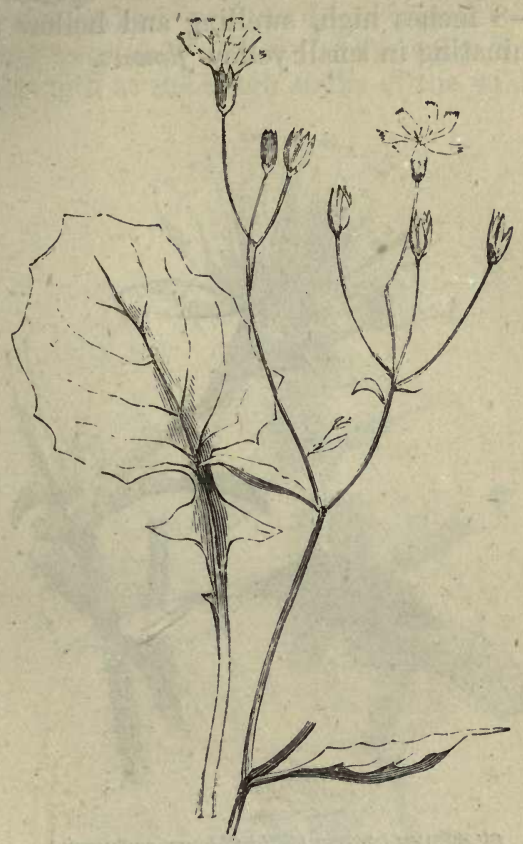

LAPSÁNA COMMỨNis (Common Nipple-wort).

\section{Lapsína (Nipple-wort).}

1. L. commúnis (Common Nipple-wort).-Leaves stalked, toothed, heart-shaped at the base; stem branched; flowers numerous. - Hedges and waste ground ; common. A leafy plant, 2-3 feet high, with numerous small yellow flowers; the lower leaves often have several small lobes running along the opposite sides of the stalks. Fl. July, August. Annual.

* L. pusilla is a rare species, occasionally found in 
cultivated ground. The stems in this species are leafless, $6-8$ inches high, swelling and hollow upwards, and terminating in small yellow flowers.

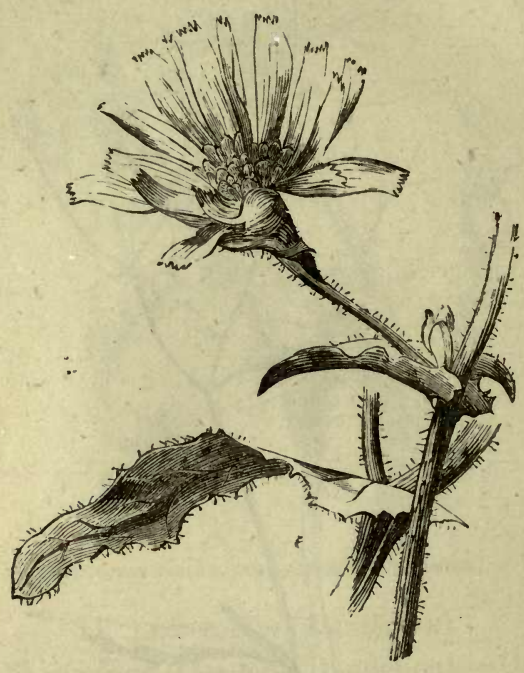

CICHORIUM fNTYBUS (Wild Chicory, or Succory).

\section{Cichórium (Chicory).}

1. C. Intybus (Wild Chicory, or Succory).-Well distinguished by its tough, twig-like stems, along which are ranged large, blue, sessile flowers. - Sir Jas. E. Smith, the distinguished founder of the Linnean Society, seldom saw the delicate blue flowers of the wild Succory without recalling to mind, that, when in infancy their beauty caught his eye and attracted his admiration above most others, he tried in vain to pluck them from the stalk. In an introductory lecture at the Royal 
Institution, he thus alludes to this circumstance :"From the earliest period of my recollection, when I can just remember tugging ineffectually with all my infant strength at the tough stalks of the wild Succory,

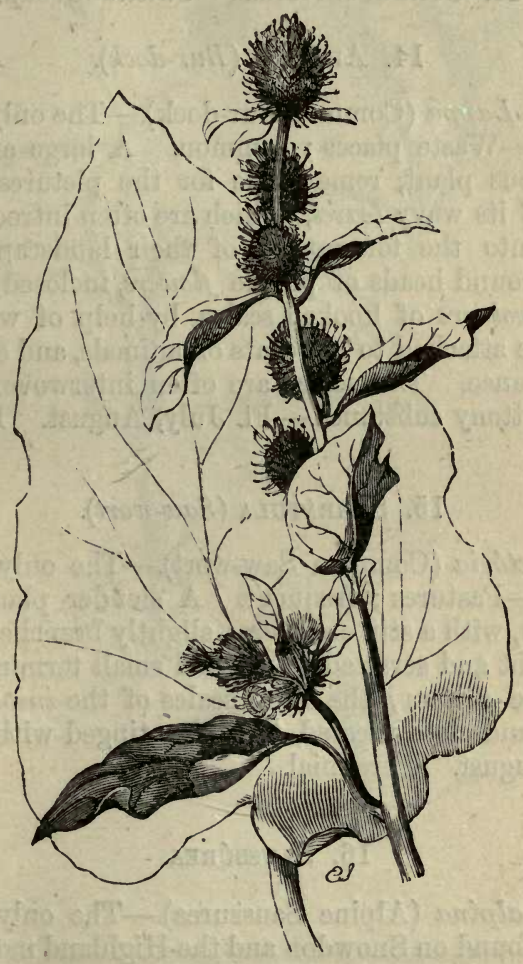

ARCTIUM I.APPA (Common Bur-dock). 
on the chalky hills about Norwich, I have found the study of nature an increasing source of unalloyed pleasure, and a consolation and a refuge under every pain."

\section{Cynarocéphale.-Thistle Group.}

\section{Arctium (Bur-dock).}

1. A. Lappa (Common Bur-dock). - The only British species.-Waste places; common. A large and stout herbaceous plant, remarkable for the picturesque character of its wavy leaves, (which are often introduced by artists into the foreground of their landscapes,) and for the round heads of purple flowers, inclosed in a globular involucre of hooked scales, by help of which the seeds are attached to the coats of animals, and conveyed to a distance. The scales are often interwoven with a white cottony substance.-Fl. July, August. Biennial.

\section{Serrátula (Saw-wort).}

S. tinctória (Common Saw-wort).-The only British species.-Pastures ; frequent. A slender plant, 1-2 feet high, with a stiff erect stem, slightly branched above, deeply cut and serrated leaves, and small terminal heads of purple flowers; the outer scales of the involucre are smooth and close pressed, the inner tinged with purple. -Fl. August. Perennial.

\section{SAussúrea.}

1. S. alpina (Alpine Saussurea).-The only British species, found on Snowdon and the Highland mountains. -The stem is from 8-12 inches high; the leaves cottony beneath ; and the flowers light purple, in a terminal cluster.-Fl. August. Perennial. 
COMPOUND FLOWERS.

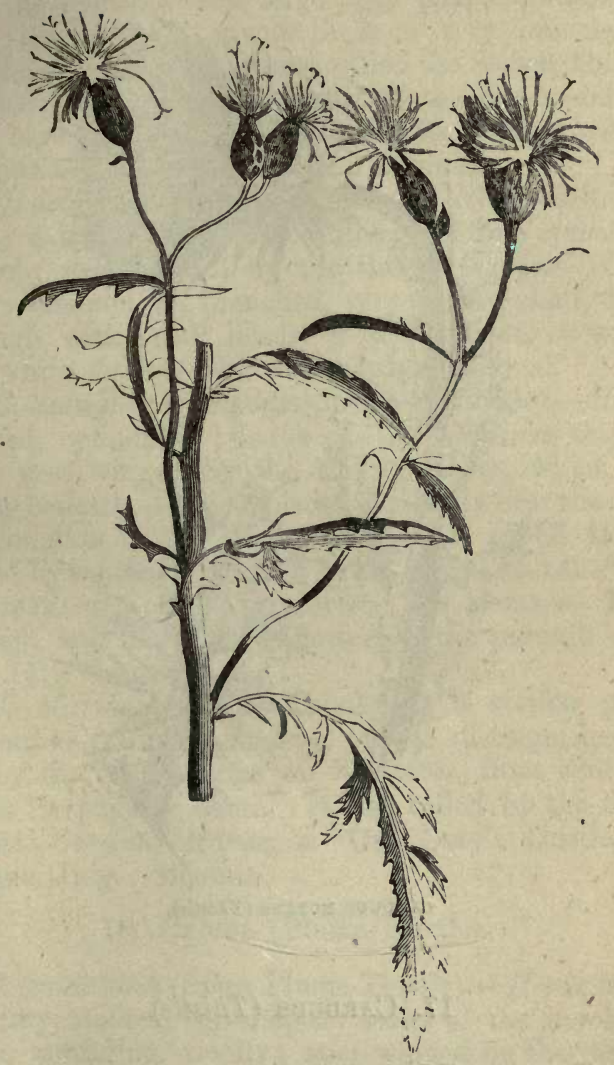

SERRÁtUla TINCTORIA (Common Saw-wort). 


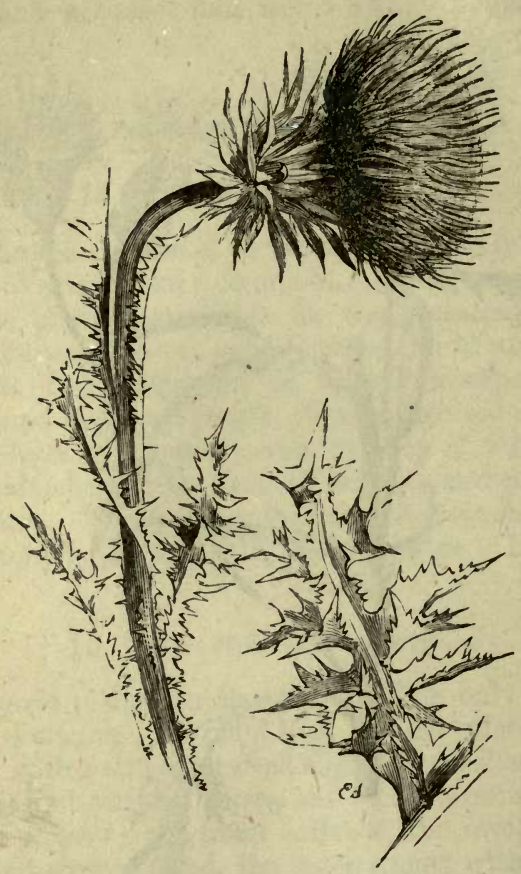

CARDUUS NUTANS (Thistle).

17. Carduus (Thistle).

1. C. nutans (Musk Thistle).-Heads solitary, drooping ; scales of the involucre tapering to a rigid point, cottony, the outer ones bent back; stem winged by the thorny leaves.-Waste places; common. A very hand- 
some plant, about 2 feet high, with a furrowed cottony stem, deeply lobed thorny leaves, which are downy on the veins beneath, and large deep purple flowers, to which the radiated involucre is a very ornamental appendage. This is sometimes called the Scotch Thistle, but incorrectly. The upper part of the flower-stalk is nearly bare of leaves, and the flower itself has a powerful odour.-Fl. June-August. Biennial.

2. C. acanthoídes (Welted Thistle).-Heads clustered, round; scales of the involucre linear, thorny, spreading or erect; stem winged by the thorny leaves. - Waste places; common. A branched, very thorny plant, $3-4$ feet high, with small heads, of deep purple, or sometimes white flowers. - Fl. June, July. Annual.

3. C. tenuiflóms (Slender-flowered Thistle).-Heads clustered, cylindrical ; scales of the involucre thorny, erect; stem winged -by the thorny leaves, which are cottony beneath. - Waste places, especially near the sea ; very common in the West of England. Well distinguished by the small heads of pink flowers, and the very long erect scales of the involucre. The stems are 2-4 feet high, and bear all the flowers at the summit.-Fl. June, July. Annual.

* C. Mariánus (Milk Thistle) is a stouter plant than either of the preceding, and is distinguished at once by the white veins on its leaves, from which it derives its popular name. It was called by the early botanists Carduus Marioe, or "Our Lady's Thistle."Fl. June, July. Biennial.

\section{CNicus (Plume-Thistle).}

1. C. lanceolátus (Spear Plume-Thistle).-Heads mostly solitary, stalked, egg-shaped; scales of the involucre thorny, spreading, woolly; stem winged by the thorny leaves, the lobes of which are 2-cleft.-Waste places and hedges ; common. This is more like the Cotton-Thistle (Onopordum) than any other species of this genus. It grows 3-4 feet high; the leaves are downy beneath, 
and the heads of flowers, though not so large as those of the Cotton-Thistle, have the same dull purple hue.Fl. July-September. Biennial.

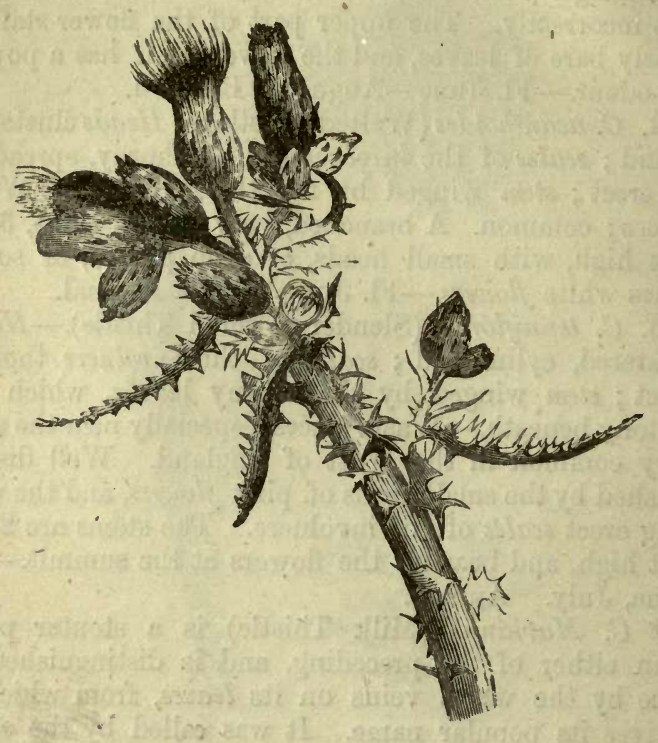

cNicus PaLustris (Marsh Plume-Thistle).

2. C. palustris (Marsh Plume-Thistle).-Heads clustered, egg-shaped ; scales of the involucre closely pressed, pointed; stem winged by the thorny leaves.-Moist meadows and borders of fields ; very common. The tallest of the British Thistles, 4-10 feet high, consisting of a single, stout, hollow stem, which is branched towards the summit, and bears numerous clusters of rather small, deep purple (sometimes white) flowers. The leaves are thickly armed with short thorns, which 
are often of a brownish hue.-Fl. July, August. Biennial.

3. C. arvensis (Creeping Plume-Thistle).-Heads of flowers numerous, stalked, egg-shaped; scales of the involucre closely pressed, pointed, but scarcely thorny ; stem not winged; root creeping.-Border of fields ; very common. A handsome weed, about two feet high; the flowers, which grow in a corymbose manner, are of a light purple colour, and smell like those of the Musk Thistle.-Fl. July. Perennial.

4. C. pratensis (Meadow Plume-Thistle).-Heads of flowers mostly solitary; stem-leaves few, soft, and wavy. -Moist meadows ; not general. A small plant, 1218 inches high, with a cottony stem, bearing a few leaves, and rarely more than one small purple flower.-Fl. July. Perennial.

5. C. acaulis (Dwarf Plume-Thistle).-Heads of flowers solitary and stemless, or nearly so.-Dry gravelly or chalky pastures : not general, but in some places very abundant, and a pernicious weed. A low plant, consisting of a few thorny leaves, and a single, almost stemless, purple flower, by which character it is readily distinguished from all the rest of the Thistle Tribe.Fl. July, August. Perennial.

* Less common species of Cnicus are C. erióphorus (Woolly-headed Plume-Thistle), distinguished by the thick white wool which clothes the scales of the very large flowers: C. tuberosus (Tuberous Plume-Thistle), which grows only in Wiltshire, an erect single-stemmed plant, with a single, large purple flower : $C$. heterophyllus (Melancholy Plume-Thistle), a mountain plant, with an erect, cottony stem, and a single, handsome, purple flower.

19. ONopondum (Cotton Thistle).

1. O. Acánthium (Scotch Thistle).-The commonest of the thistle-tribe, abounding in waste ground, and 
by road sides, in most soils. The involucre is globose, with the scales spreading in all directions; the stem is winged with the rough cottony leaves; the flowers are large, of a dull purple hue, and mostly solitary, or but slightly clustered, at the ends of the branches. The seeds are the favourite food of goldfinches, which may often be seen in autumn fluttering like butterflies round the withered stalks. This species is the true Scotch Thistle.-Fl. July, August. Biennial.

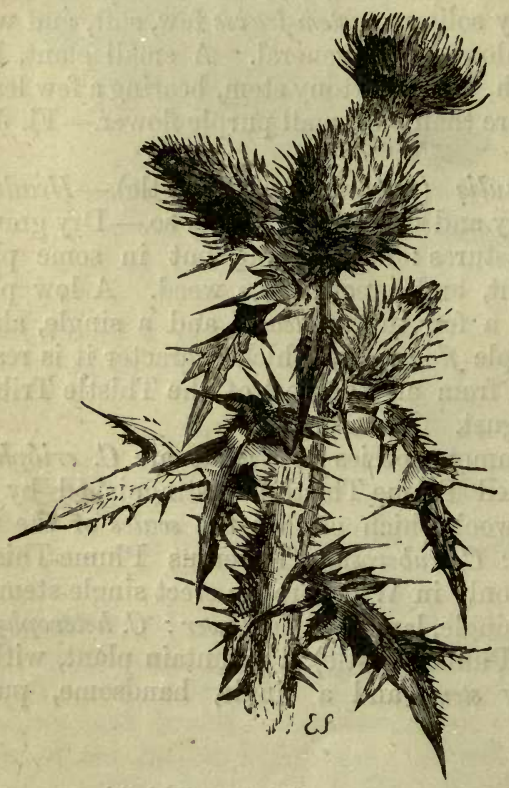

ONOPORDUM ACÁNTHIUM (Scotch Thistle). 


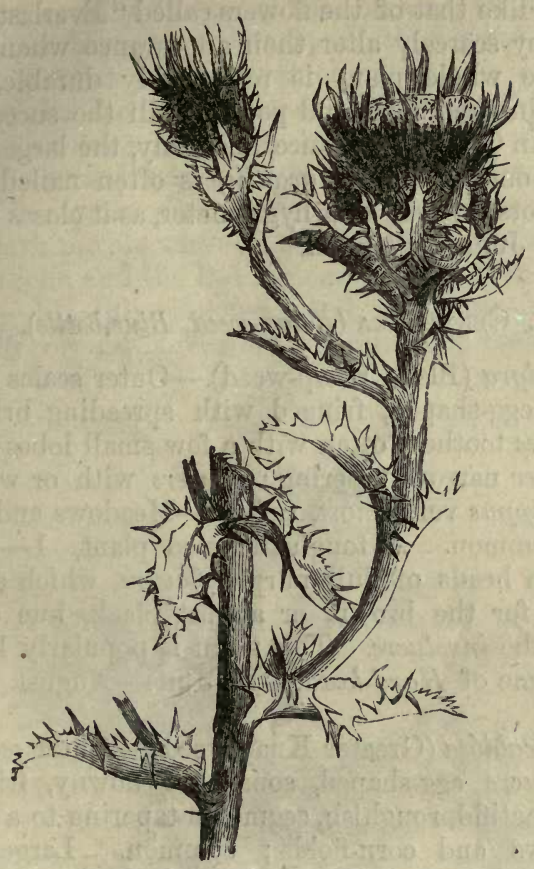

CarlíNa vulgáris (Common Carline Thistle).

20. Carlína (Carline Thistle).

1. C. vulgáris (Common Carline Thistle).-The only British species, growing on dry heaths, especially near the sea.-Readily distinguished from every other British Thistle by the long inner scales of the involucre, which are straw-coloured and glossy, and spread in a radiate manner so as to resemble petals. In dry weather they lie flat, but when the atmosphere is moist, they rise and form, as it were, a pent-house over the florets. Their 
texture is like that of the flowers called "Everlasting ;" hence, they scarcely alter their appearance when dead, and as the whole plant is remarkably durable, they often retain their form and position till the succeeding spring. In Germany, France, and Italy, the large white flower of one species, $C$. acaulis, is often nailed upon cottage-doors, by way of a hygrometer, as it closes before rain.-Fl. June. Biennial.

\section{Centauréa (Knap-weed, Blue-bottle).}

1. C. nigra (Black Knap-weed).-Outer scales of the involucre egg-shaped, fringed with spreading bristles; lower leaves toothed, often with a few small lobes at the base, upper narrow, tapering; flowers with or without a ray ; pappus very short, tufted.-Meadows and cornfields; common. A tough-stemmed plant, $1-2$ feet high, with heads of dull purple flowers, which are remarkable for the brown, or almost black, hue of the scales of the involucre. This plant is popularly known by the name of Hard-head.-Fl. June-August. Perennial.

2. C. Scabiósa (Greater Knap-weed).-Outer scales of the involucre egg-shaped, somewhat downy, fringed; leaves pinnatifid, roughish, segments tapering to a point. -Meadows and corn-fields; common. Larger and stouter than the last, from which it is distinguished by the brighter hue of its handsome radiate flowers, and the light-coloured fringe on the scales of the involucre. -Fl. July, August. Perennial.

3. C. Cyanus (Corn Blue-bottle).--Outer scales of the involucre deeply toothed; leaves very narrow, slightly toothed, cottony.-Corn-fields; frequent. One of the prettiest of flowers, and well meriting the distinctive name, often given to it, of Corn-flower. The flowers are bright blue, with dark anthers, and when mixed with Poppies and yellow Ox-daisies, form as brilliantlycoloured a bouquet as can be imagined. Children often 
string the outer florets by help of a needle and thread, and after bringing the ends together, press them in a book, to form a wreath, which retains its colour for a long while. Recently expanded flowers should be chosen, or their colour will fade. The juice of the flowers, expressed and mixed with cold alum-water, may be used in water-colour drawing. Rose-coloured, white and dark purple varieties are commonly to be met with in gardens, and the last are occasionally found in a wild state.-Fl. July, August; and, in turnip-fields, again in October and November. Annual, or Biennial.

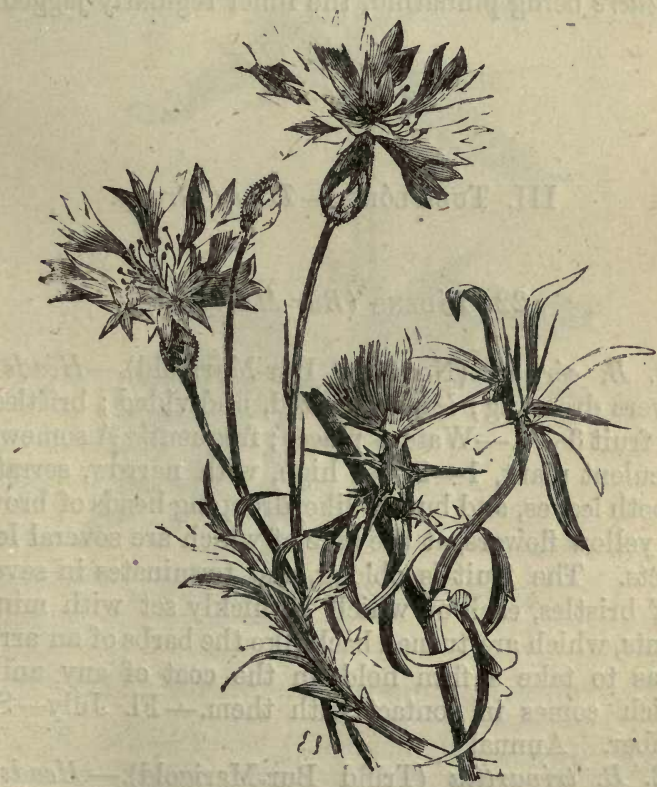

c. CÝanus and c. CAlcitraPA (Corn Blue-bottle and Star-Thistle).

A A 2 
4. C. Calcitrapa (Common Star-Thistle).-Scales of the involucre ending each in a long and stiff thorn.-Gravelly and sandy places in the South of England. Well marked by its purplish flowers, which are armed below with spreading thorns, and resemble in figure the cruel iron instrument, named a Caltrops, which is used in war to lame horses, being thrown on the ground where it is expected that cavalry will pass. The instrument is so constructed, that, in whatever position it lies, one point sticks upwards.-Fl. July, August. Annual.

* C. Jácea (Brown Radiant Knap-weed) is a very rare species, with purple flowers, the outer scales of the involucre being pinnatifid, the inner regularly jagged.

III. TUBIFLóR业-Tansy Group.

22. Bídens (Bur-Marigold).

1. B. cérnua (Nodding Bur-Marigold).-Heads' of flowers drooping; leaves serrated, undivided; bristles of the fruit 3-4.-Watery places; frequent. A somewhat succulent plant, $1-2$ feet high, with narrow, serrated, smooth leaves, and button-like, drooping heads of brownish yellow flowers, at the base of which are several leafy bracts. The fruit is oblong, and terminates in several stiff bristles, each of which is thickly set with minute points, which are turned back like the barbs of an arrow, so as to take a firm hold on the coat of any animal which comes in contact with them.-Fl. July-September. Annual.

2. B. tripartita (Trifid Bur-Marigold).-Heads of flowers nearly erect; leaves 3-parted.-Watery places; common. Distinguished from the last by its somewhat 
smaller heads of flowers, 3-parted leaves, and by having 2-3 bristles on the fruit. - Fl. July - September. Annual.

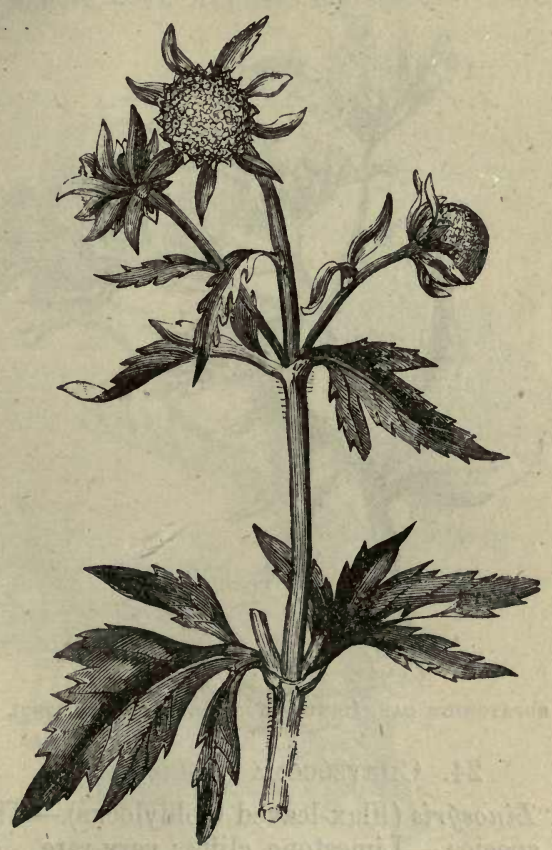

BIDENS TRIPARTITA (Trifid Bur-Marigold).

23. Eupatorium (Hemp-Agrimony).

1. $E$. cannábinum (Common Hemp-Agrimony).The only British species. - Moist shady places; common. A tall downy plant, $3-6$ feet high, with a reddish stem, 3-5 parted leaves, and terminal corymbs 
of small crowded heads of dull lilac flowers, which are remarkable for their very long, deeply cloven styles. Fl. July, August, Perennial.

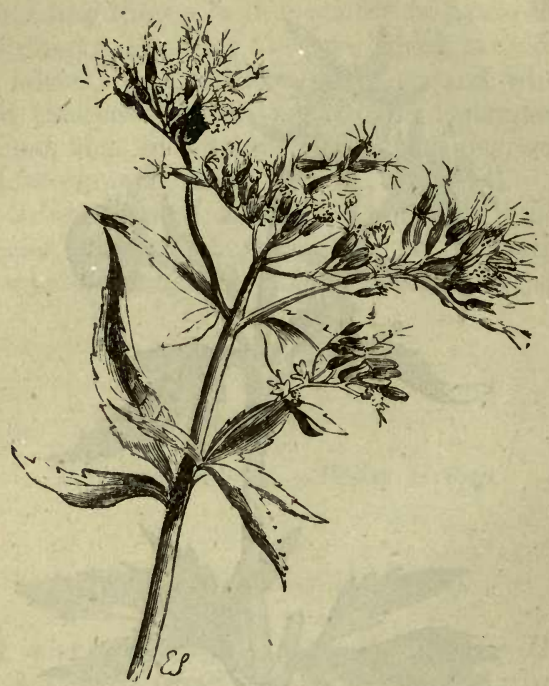

EUPATORIUm CANNábinum (Comman Hemp-Agrimony).

24. Chrysócoma (Goldylocks).

1. C. Linosýris (Flax-leaved Goldylocks).-The only British species.-Limestone cliffs ; very rare. An herbaceous plant, 12-18 inches high, with erect, simple stems, which are thickly set with smooth, linear leaves, and bear a few heads of yellow flowers at the extremity. -Fl. August, September. Perennial.

\section{Diótis (Cotton-weed).}

1. D. maritima (Sea-side Cotton-weed). - The only species.-Sandy sea-shores; rare. The roots run deeply 
into the sand; the stems, which are about a foot high, are thickly set with oblong, blunt leaves, which, as well as the rest of the plant, are covered with thick white cotton, and almost hide the small terminal heads of yellow flowers.-Fl. August, September. Perennial.

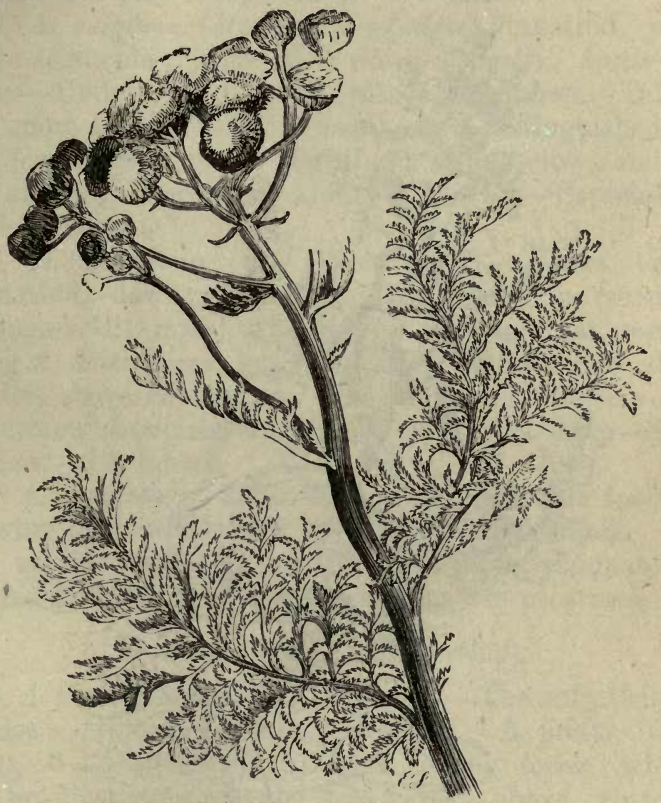

TANACÉTUM VULGÁRE (Common Tansy).

\section{Tanacétum (Tansy).}

1. T. vulgáre (Common Tansy).-The only British species.-Hedges, and waste ground ; common. Growing 2-3 feet high, and well distinguished by its deeply twice pinnatifid, cut leaves, and terminal corymbs of bright yellow, button-like flowers. The whole plant is 
bitter and aromatic, and is not only used in medicine, but forms the principal ingredient in the nauseous dish called Tansy pudding.-Fl. August. Perennial.

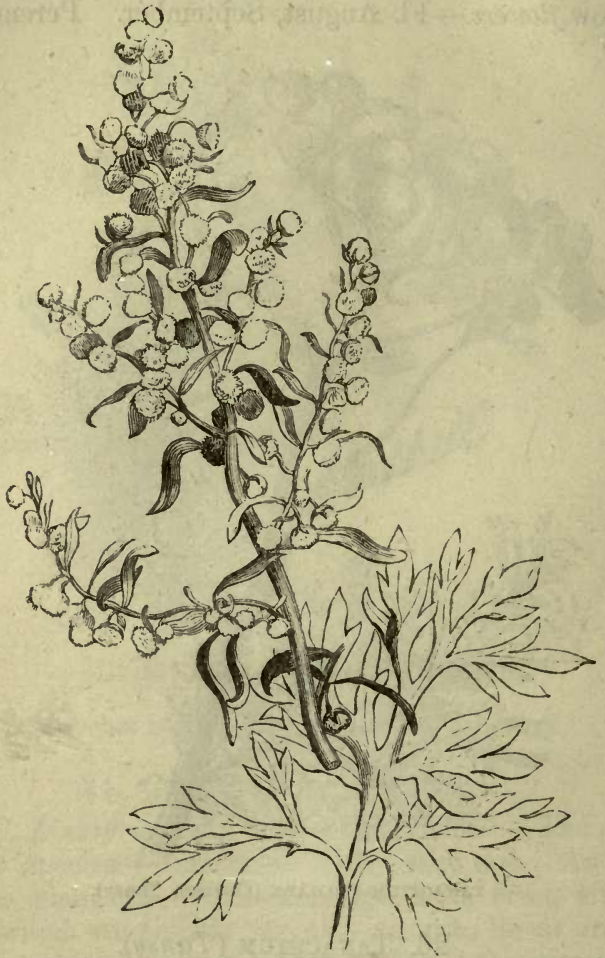

ARTEMISIA ABSINTHIUM (Common Wormwood).

27. Artemisia (Wormwood, Mugwort).

1. A. Absinthium (Common Wormwood).-Leaves with bluntish segments, twice pinnatifid, silky on both 
sides ; heads hemispherical, drooping.-Waste ground ; common. A bushy plant, with silky stems and leaves, and panicles of numerous small heads of dull yellow flowers. The whole plant is bitter and aromatic, and is much used, in the rural districts where it abounds, as a tonic.-Fl. July - September. Perennial.

2. A. vulgáris (Mugwort).-Leaves pinnatifid, with acute segments; white with down beneath; heads oblong.-Hedges, and waste places ; common. Taller, and more slender than the last; well distinguished by the leaves being green above and white below, and by the absence of aromatic odour.-Fl. July-September. Perennial.

3. A. marítima (Sea Wormwood).-Leaves twico pinnatifid, downy on both sides; heads in racemes, oblong.- Salt marshes ; frequent. Somewhat resembling $A$. Absinthium, but smaller and well distinguished by the above characters. The clusters of flowers are sometimes drooping, sometimes erect.-Fl. July-September. Perennial.

* A. campestris (Field-Wormwood) is a rare species, growing on sandy heaths in Norfolk and Suffolk. In this species the segments of the leaves terminate in points, and the stems, until flowering, are prostrate.

\section{Antennaria (Everlasting).}

1. A. dioŕca (Mountain Cud-weed).-The only British species.-Mountain heaths, frequent. A pretty little plant, 3-6 inches high, with oblong leaves, which are broadest towards the end, green above, cottony below ; the heads of flowers grow 4-6 together, and are rendered conspicuous by the white or rose-coloured involucre, which is of the texture commonly termed everlasting.-Fl. July, August. Perennial.

* The White Everlasting of gardens is A. margaritácea, a much larger plant. It is occasionally found in situations where it is apparently wild, but is not considered to be indigenous. 


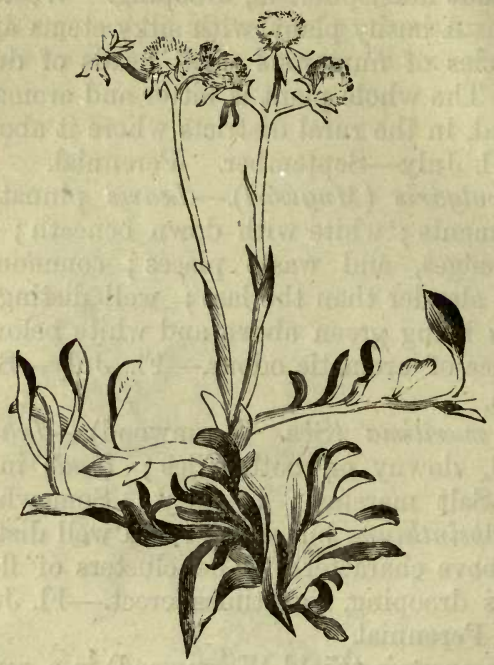

ANTENNARIA DIof́cA (Mountain Everlasting).

\section{Gnaphalium (Cud-weed).}

1. G. uliginosum (Marsh Cud-weed).-Stems much branched, woolly ; leaves very narrow, downy, overtopping the clustered, terminal heads.-Wet sandy places, especially where water has stood during winter ; common. A small plant, 3-6 inches high, rendered conspicuous by its tufted white stems and leaves, and by the glossy, yellowish-brown scales of its small clustered flowers.-Fl. August, September. Annual.

* Two other species of Cud-weed are found in Scotland: G. sylváticum (Highland Cud-weed), a cottony plant, with a simple stem, bearing its heads of flowers in a leafy spike; this species is also found in gravelly pastures in England: and G. supínum (Dwarf Cud- 
weed), common on the summits of the Highland mountains, also a cottony plant, but rarely exceeding $2-3$ inches in height, with tufted leaves, and flowering stems almost bare of leaves.

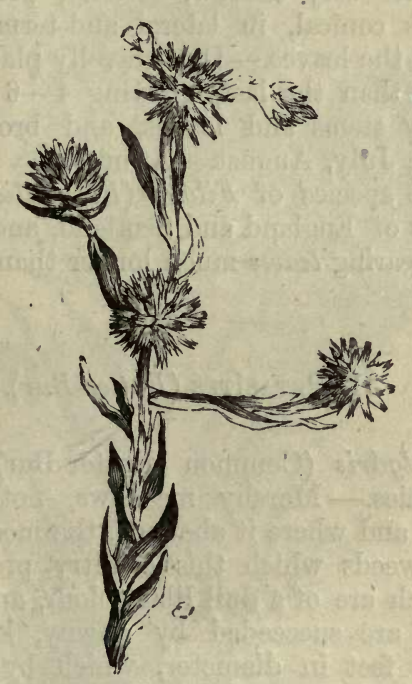

FILÁgo Germánica (Common Filago).

30. Filuágo.

1. F. Germanica (Common Filágo).-Stem cottony, erect, terminating in a globular assemblage of heads, from the base of which rise two or more flower-stalks, which are prolific in like manner.-Dry gravelly places, common. A singular little plant, $6-8$ inches high, 
well distinguished by the above charaeter. From this curious mode of growth, the plant was called by the old botanists Herba impia (the undutiful herb), as if the young shoots were guilty of disrespect by overtopping the parent.-Fl. June, July. Annual.

2. F. mínima (Least Filágo).-Stem erect, repeatedly forked; leaves very narrow, cottony, pressed to the stem; heads conical, in lateral and terminal clusters, shorter than the leaves.-Dry gravelly places, common. Yet smaller than the last, growing $4-6$ inches high, with cottony stems and leaves, and brownish-yellow flowers.-Fl. July, August. Annual.

* A third species of Filágo (F. Gállica) occurs in several parts of England and Scotland, and differs from the last in bearing leaves much longer than the flowers.

\section{Petasítes (Butter-Bur).}

1. P. vulgáris (Common Butter-Bur).-The only British species.- Marshy meadows, not unfrequent. The largest, and where it abounds, the most pernicious, of all the weeds which this country produces. The flowers, which are of a dull lilac colour, appear early in spring, and are succeeded by downy, kidney-shaped leaves, $1-3$ feet in diameter, which by shading the ground check the growth of all other plants. "The early blossoming of this rank weed induces the Swedish farmers to plant it near their bee-hives. Thus we see in our gardens the bees assembled on its affinities, $P$. $a l b a$ and $P$. fragrans, at a season when scarcely any other flowers are expanded."-Hooker and Arnott. These two last species are common in shrubberies, almost hiding the ground with their broad leaves, thriving beneath the shade of trees and shrubs, but overpowering all herbaceous plants, and eventually, it is said, even the shrubs themselves.-Fl. April, May. Perennial. 


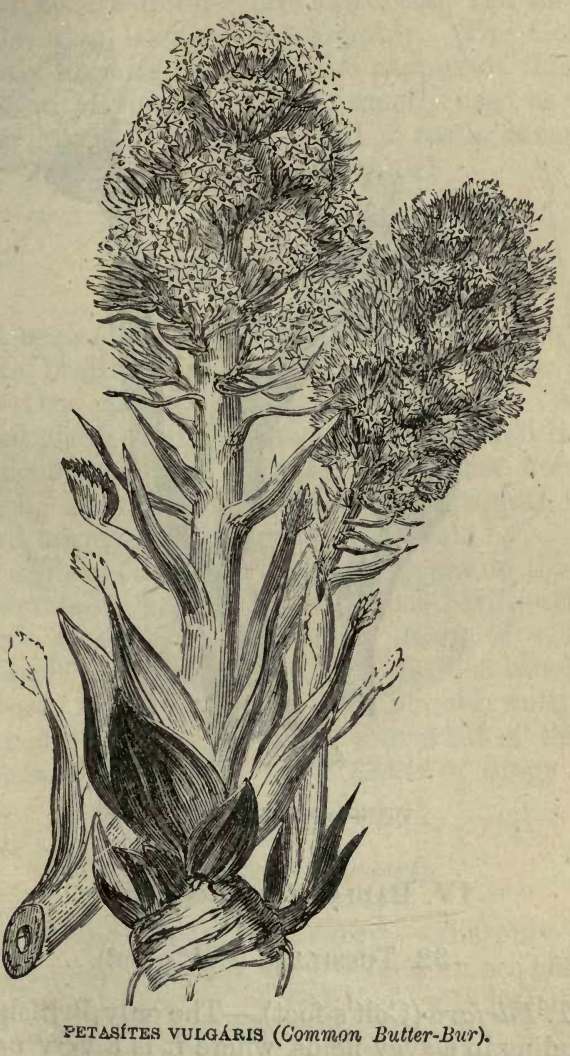




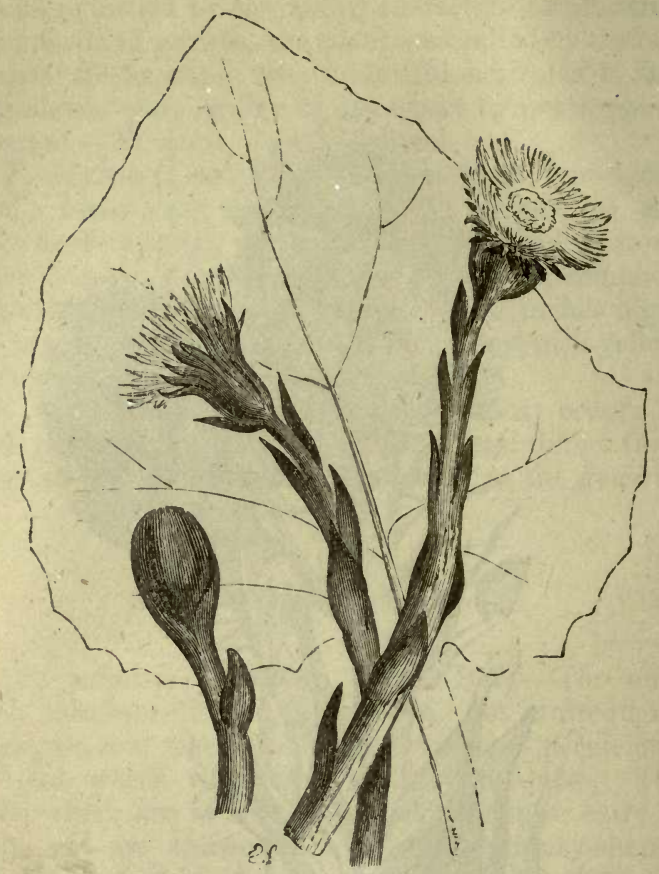

TUSSILẢgo FẢRFARA (Coltes-foot).

IV. Radiate.-Daisy Group.

32. Tussilágo (Colt's-foot).

1. T. Fárfara.(Colt's-foot). - The only British species, abounding in clayey fields, where it is a very pernicious weed. The flower-stalks, which spring directly from the roots, are covered with scale-like bracts, and bear each a single yellow flower, with numerous narrow rays; the 
leaves, which do not appear until the flowers have withered, are roundish heart-shaped and angular, with dark teeth, and are covered with cottony down. The heads of flowers droop before expansion, and the stalks after flowering lengthen considerably. The Goldfinch frequently lines its nest with the pappus of this plant. The cotton of the leaves was formerly used as tinder, and the leaves themselves afford a rustic remedy for coughs.-Fl. March, April. Perennial.

\section{Erígeron (Flea-bane).}

1. E. acris (Blue Flea-bane).-Branches erect, rough, alternate, bearing single heads; leaves narrow, entire, blunt.-Dry places and walls, not common. A much branched plant, 6-18 inches high, with small heads of inconspicuous flowers, of which the inner florets are yellowish, the outer dull blue. The pappus is very long and tawny.-Fl. August. Biennial.

* E. alpínus (Alpine Flea-bane) occurs on the Highland mountains, growing 3-5 inches high, each stem bearing a single flower, the outer florets of which are light purple; $E$. Canadensis (Canada Flea-bane) grows as a weed in waste ground and on old walls about Chelsea and elsewhere; it has somewhat of the habit of Groundsel, and bears small heads of dingy yellow flowers.

\section{Aster (Starwort).}

1. A. Tripólium (Sea Starwort).-The only British species, abundant in salt marshes and on sea-cliffs. A stout succulent plant, 2-3 feet high, with long, smooth, fleshy leaves, and corymbs of large handsome heads of flowers, the inner florets of which are yellow, the outer purple. In salt marshes the whole plant is often covered with mud, which gives it an unsightly appearance, but 
when growing on sea-cliffs, it is a highly ornamental plant.-Fl. August, September. Perennial.

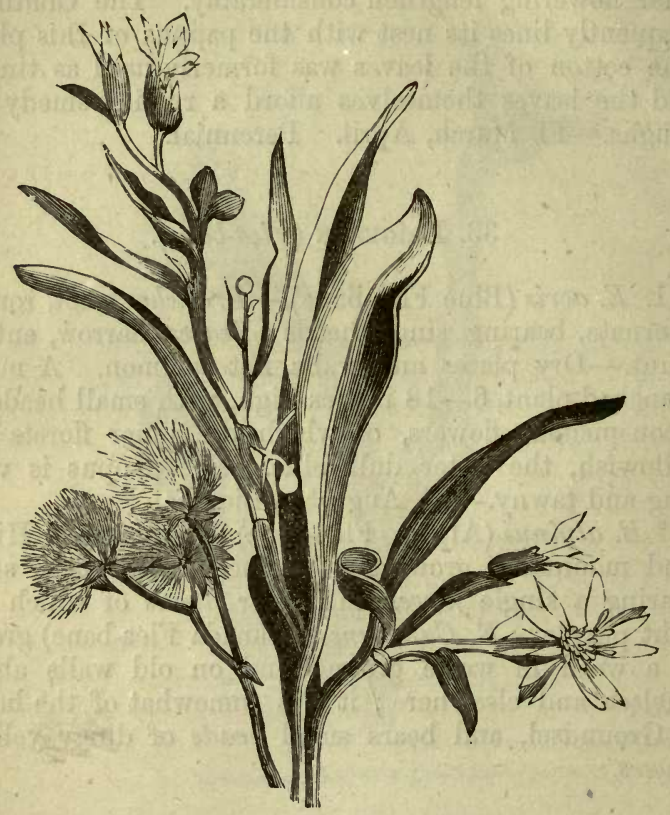

ASTER TRIPólIUM (Sea Starwort).

35. Solidígo (Golden-rod).

S. Virgaúrea (Golden-rod).- The only British species, common in dry woods. - An erect, scarcely branched plant, 2-3 feet high, with roughish, angular stems, simple, serrated leaves, which gradually become narrower the higher they are on the stem ; and conspicuous, terminal, crowded clusters of small bright yellow flowers. 
On mountainous heaths a variety occurs with very short stems and large leaves and flowers.-Fl. July-September. Perennial.

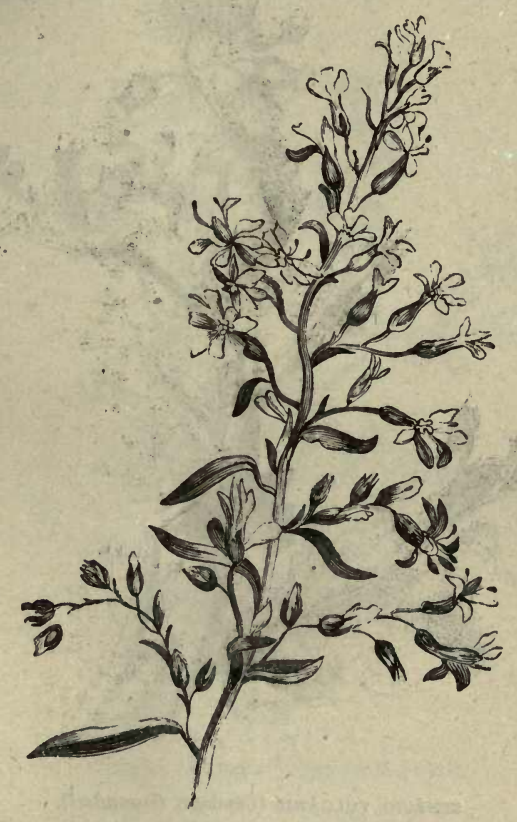

SOLIDÁGO VIRGAÚREA (Golden-rod).

36. SENECIO (Groundsel, Ragwort).

1. S. vulgáris (Common Groundsel).-Flowers without rays, in crowded clusters; leaves half-embracing the stem, deeply lobed and toothed. $-A$ common weed in 
cultivated ground; a favourite food of many small birds.-Fl. all the year round. Annual.

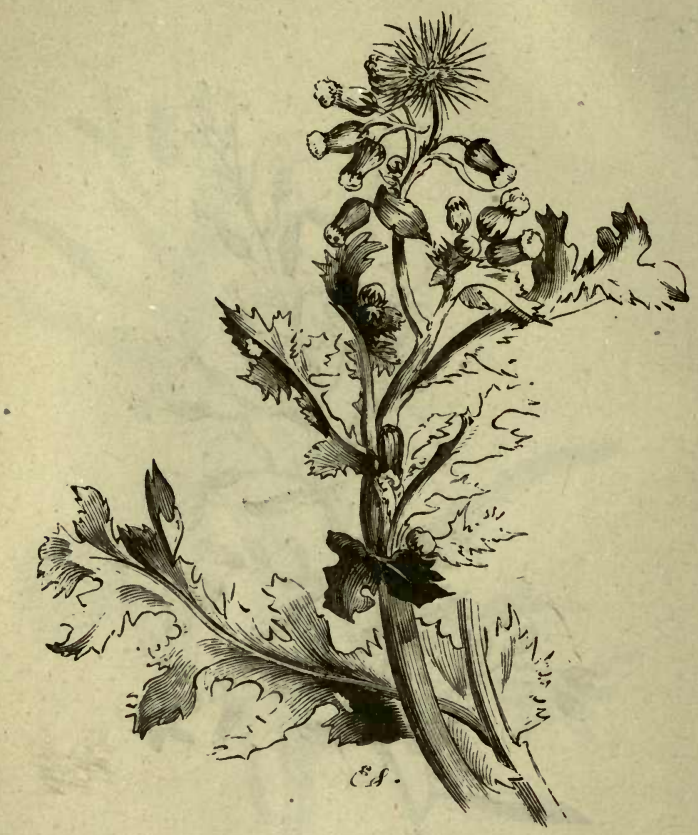

SENÉcio vULGÁris (Common Groundsel).

2. S. sylváticus (Mountain Groundsel).-Flowers with a few rays, which are rolled back and inconspicuous, or often wanting; leaves pinnatifid, with narrow lobes, toothed.-Gravelly places, common. Distinguished from the last by its larger size, its more copiously cut, often hoary leaves, and its conical rather than cylindrical heads of dull yellow flowers. The stem is branched, 1-2 feet high.-Fl. July-September. Annual. 
3. S. Jacobcea (Common Ragwort).-Flowers with spreading rays ; leaves pinnatifid, with smaller lobes at the base.-Meadows and wet places, common.-Stem erect, 2-3 feet high; flowers large, bright yellow, corymbose.-Fl. July - September. Perennial.

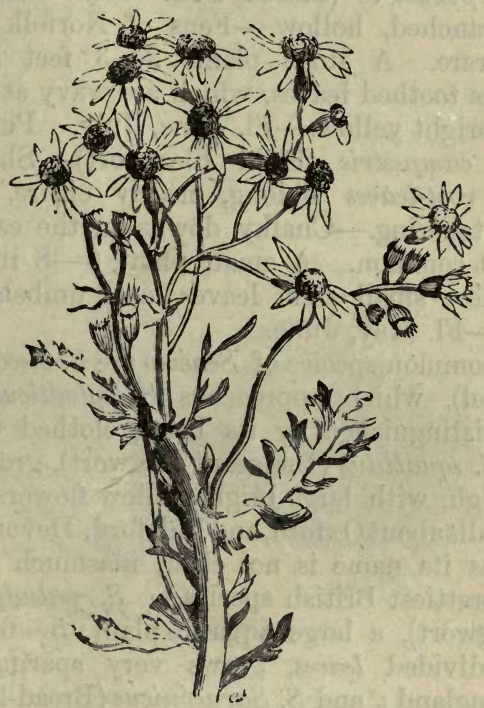

SENÉCIO JACOBAA (COmmon Raguort).

4. S. aquáticus (Marsh Ragwort).-F'lowers with spreading rays ; lower leaves undivided, toothed, upper with a few oblong lobes near the base.-Wet places, common. Resembling the last, but readily distinguished by its less divided leaves.-Fl. July-September. Perennial.

5. S. tenuifolius (Hoary Ragwort).-Flowers with spreading rays; leaves pinnatifid, with very narrow segments, downy beneath.-Dry banks in a limestone 
or chalky soil, not common. Of about the same size as the last, but distinguished by its sending up numerous cottony stems from the same root, and by its regularly divided leaves, the segments of which are slightly rolled back at the edges.-Fl. July, August. Perennial.

6. S. palustris (Marsh Flea-wort).-Shaggy; stem much branched, hollow.-Fens of Norfolk and Cambridge, rare. A stout plant, $2-3$ - feet high, with numerous toothed leaves, which are wavy at the edges; flowers bright yellow.-Fl. June, July. Perennial.

7. S. campestris (Field Flea-wort).-Shaggy ; stem simple; root-leaves oblong, nearly entire, stem-leaves narrow, tapering.-Chalky downs in the east of England, not common. A small plant, 6-8 inches high, with a few small stem leaves, and umbels of yellow flowers.-Fl. May, June.

Less common species of Senécio are S. viscósus (Viscid Groundsel), which approaches $S$. sylváticus in habit, and is distinguished by its being clothed with viscid hairs : S. squálidus (Inelegant Ragwort), growing about a foot high, with large bright yellow flowers, abundant on old walls about Oxford, and Bideford, Devon. (Whence it derives its name is not clear, inasmuch as it is by far the prettiest British species.) S. paludósus (Great Fen Ragwort), a large aquatic plant, 5-6 feet high, with undivided leaves, grows very sparingly in the - east of England : and S. Saracénicus (Broad-leaved Ragwort), also with undivided leaves, but much smaller than the last, is not considered to be indigenous.

\section{Dorónicum (Leopard's-bane).}

1. D. Pardalianches (Great Leopard's-bane).-Lower leaves heart-shaped, toothed, on long stalks, upper with two ears at the base, embracing the stem.-Damp hilly woods, rare, a doubtful native. Stem $2-3$ feet high, erect, solitary, hollow, hairy ; leaves soft; heads of flowers yellow, the earlier ones overtopped by the later. -Fl. May-July. Perennial. 
* D. plantagíneum (Plantain-leaved Leopard's-bane) differs from the last in having egg-shaped leaves and solitary heads of flowers. It is very rare, and is not considered to be indigenous.

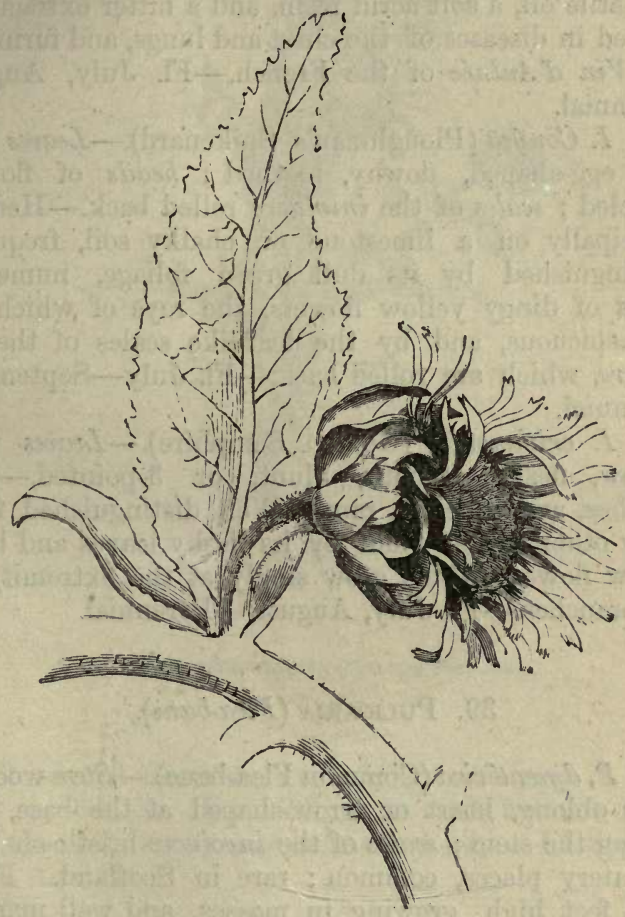

INULA HELÉNIUM (Elecampane).

38. Inula (Elecampane, Ploughman's Spikenard).

1. I. Helénium (Elecampane).-Leaves oblong or eggshaped, wrinkled, downy beneath, toothed, upper ones embracing the stem; scales of the involucre egg-shaped, 
downy.-Moist pastures, not common. A stout plant, $3-5$ feet high, with very large leaves and a few terminal very large heads of bright yellow flowers. The root contains a.white starchy powder, named Inuline, a volatile oil, a soft acrid resin, and a bitter extract ; it is used in diseases of the chest and lungs, and furnishes the Vin d'Aulnée of the French.-Fl. July, August. Perennial.

2. I. Conýza (Ploughman's Spikenard).-Leaves nar-row, egg-shaped, downy, toothed ; heads of flowers panicled; scales of the involucre rolled back.-Hedges, principally on a limestone or chalky soil, frequent. Distinguished by its dull green foliage, numerous heads of dingy yellow flowers, the rays of which are inconspicuous, and by the leaf-like scales of the involucre, which are rolled back.-Fl. July-September. Perennial.

3. I. crithmoídes (Golden Samphire).-Leaves very narrow, fleshy, smooth, blunt, or 3-pointed.-Salt marshes, and sea-cliffs, rare. Well distinguished from every other British plant by its fleshy leaves and large yellow flowers, which grow singly at the extremity of the branches.-Fl. July, August. Perennial.

\section{Pulicaria (Fllea-bane).}

1. P. dysentérica (Common Flea-bane).-Stem woolly ; leaves oblong, heart or arrow-shaped at the base, embracing the stem; scales of the involucre bristle-shaped. -Watery places, common ; rare in Scotland. From $1-2$ feet high, growing in masses, and well marked by its soft hoary foliage and large flat heads of bright yellow flowers, those of the ray being very numerous, narrow, and longer than the disk.-Fl. August. Perennial.

2. P. vulgáris (Small Flea-bane).-Stem hairy ; leaves narrow, tapering, hairy.-Sandy heaths, where water 


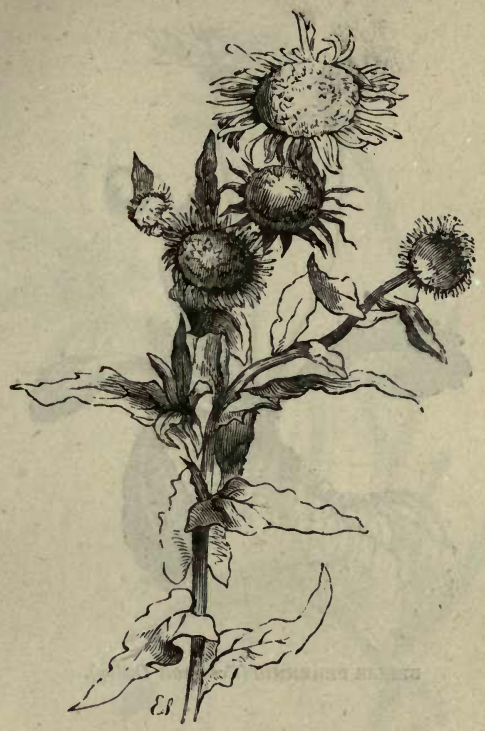

pulicarla DYsentérica (Common Flea-bane).

has stood, not common; said to be not found in Scotland or Ireland. Resembling the last, but not above half the size, nor by any means so hoary.-Fl. September. Annual.

\section{BeLlis (Daisy).}

1. B. perennis (Common Daisy).-The only British species, too well known and admired to need any description or comment.-Fl. nearly all the year round. Perennial. 


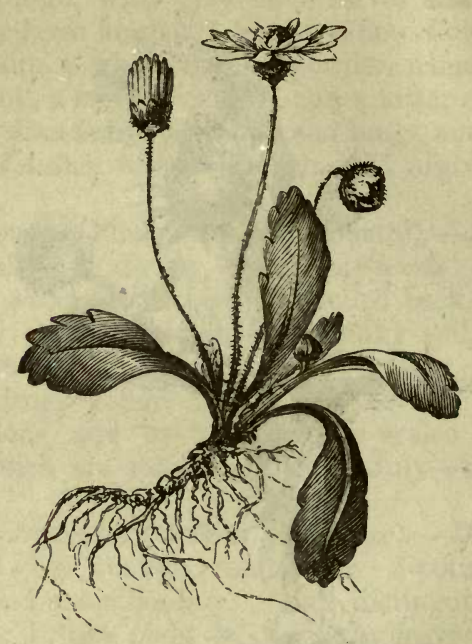

BELLIS PERENNIS (Common Daisy).

\section{Chrysánthemum $(O x-e y e)$.}

1. C. Leucánthemum (White Ox-eye).-Florets of the ray white ; lower leaves stalked, upper sessile, pinnatifid at the base--Meadows, abundant. Almost as well known as the common daisy. A great favourite of children, who string the flowers on a stout grass-straw, or bit of wire, and make a very fair imitation of the feather formerly worn by soldiers. It is said to be destructive to fleas.-Fl. June, July. Perennial.

2. C. ségetum (Yellow Ox-eye, Corn Marigold).Florets of the ray yellow; leaves clasping the stem, oblong, acute, toothed, glaucous.-Corn-fields, abundant, but local. Whole plant remarkably smooth and glaucous; the flowers are large, of a brilliant yellow, and 


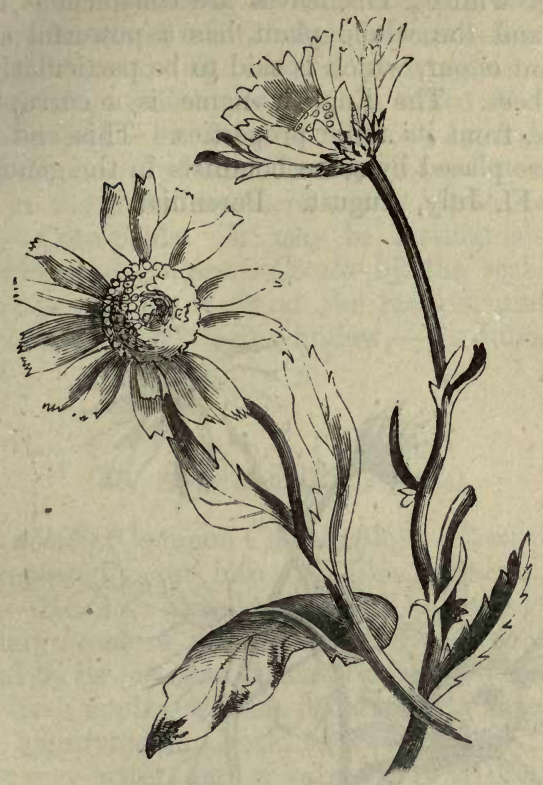

CHRYSANTHEMUM LEUCANTHEMUM (White Ox-eye).

contrast beautifully with Poppies and Blue-bottles.Fl. June, July, and, in summer-ploughed fields, again in October and November. Annual.

\section{Matricaria (Wild Chamomile, Feverfew).}

1. M. Parthénium (Common Feverfew).-Leaves stalked, pinnate; leaflets pinnatifid, and deeply cut; stem erect; flowers corymbose.-Hedges and waste ground, common. Well marked by its repeatedly cut, curled, delicate green leaves, and its numerous small heads of flowers, of which the central ones are yellow, 
the outer white. The leaves are conspicuous in midwinter, and the whole plant has a powerful and not unpleasant odour, which is said to be particularly offensive to bees. The English name is a corruption of Febrifuge, from its tonic properties. This and the following are placed by some botanists in the genus Pyréthrum.-Fl. July, August. Perennial.

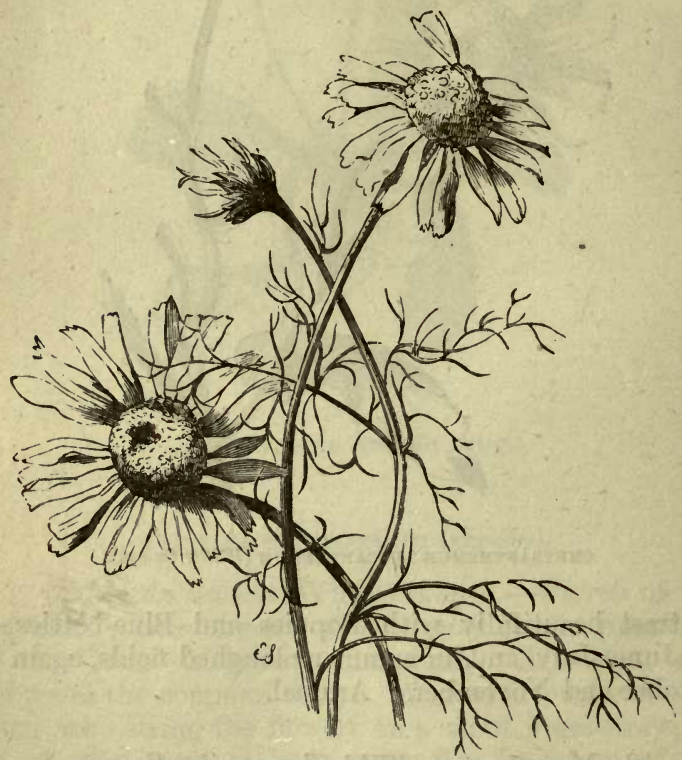

Matricaria inodóra (Corn Feverfew, Scentless May-weed).

2. M. inodóra (Corn Feverfew, Scentless May-weed). - Leaves sessile, repeatedly cut into numerous hair-like segments; stem branched, spreading; flowers solitary. -Corn-fields, common. Of a very different habit from 
the last, but resembling it in the colour of the flowers, which are, however, much larger, and are remarkable for their very convex disk. When growing near the sea, its leaves become fleshy, when it is called $M$. marítima (Sea Feverfew).-Fl. July-October. Annual.

3. M.Chamomilla (Wild Chamomile).-Leaves smooth, cut as in the last; involucre nearly plane; receptacle hollow.-Corn-fields. It may be distinguished from $M$. inodora and Anthemis Cótula by the scales of the involucre being not chaffy at the margin, and by the receptacle of the flower being hollow.-Fl. June, August. Annual.

\section{3. ÁNTHemis (Chamomile).}

1. A. nóbilis (Common Chamomile).-Stems prostrate; leaves repeatedly cut into hair-like segments, slightly downy.-Heaths, abundant. Well distinguished by its solitary heads of flowers, which droop before expansion, and by its pleasant aromatic smell, which resembles that of fresh apples, whence it derived its name of Chamomile, signifying in Greek, ground apple. The whole plant is very bitter, and is valuable in medicine for its tonic properties.-Fl. August. Perennial.

2. A. Cótula (Stinking Chamomile).-Stem erect, branched; leaves repeatedly cut into hair-like segments, smooth. -Waste places, common. Distinguished from the last by its strong disagreeable odour, and upright stems. The heads of flowers are solitary, coloured as in the last, but larger. The juice is very acrid, and is said to blister the hands of those who gather it.-Fl. July, August. Annual.

* Less common species of Chamomile are A. marítima (Sea Chamomile), which has repeatedly-cut fleshy leaves, which are somewhat hairy ; on the sea-coast, very rare: A. arvensis (Corn Chamomile), the deeply cut leaves of which are white with down; these two have white flowers 
with a yellow disk: and $A$. tinctória (Ox-eye Chamomile), which has downy, much divided leaves, and large bright yellow flowers, resembling those of Chrysanthemum ségetum.

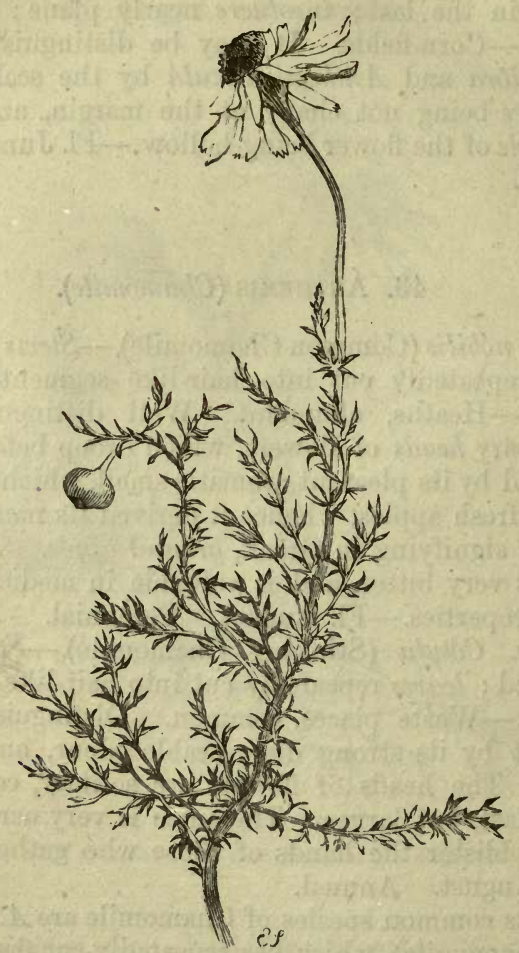

ÁNTHEMIS NóBILIS (Common Chamomile). 


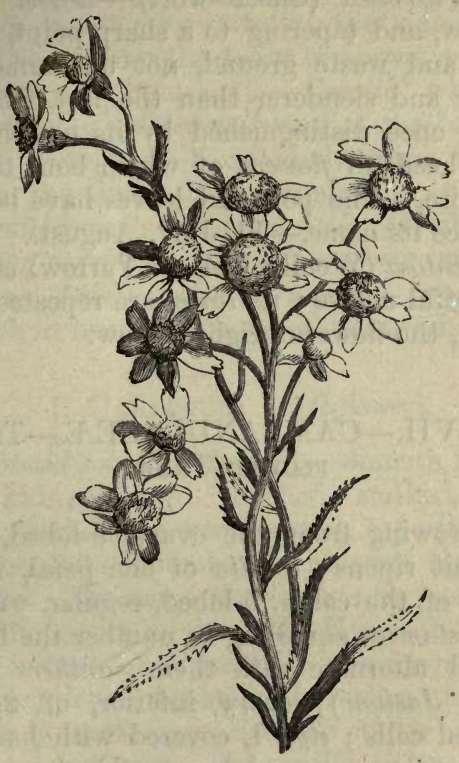

ACHILLÉA PTÁRMICA (Sneeze-wort).

\section{Achilléa (Yarrow).}

1. A. Millefólium (Common Yarrow, Milfoil). Leaves twice pinnatifid, woolly, or slightly hairy ; leaf. lets cut into hair-like segments; flowers in dense terminal corymbs. - Waste ground, frequent. A common road-side plant, with very tough, angular stems, $1-2$ feet high, and corymbs of small, white, pink, or purplish flowers, which, by an unpractised eye, might be supposed to belong to an umbelliferous plant. It has a strong and slightly aromatic odour, and is said to have the property of healing wounds.-Fl. June-September. Perennial. 
2. A. Ptármica (Sneeze-wort)- - Leaves undivided, very narrow, and tapering to a sharp point, serrated.Meadows, and waste ground, not uncommon. Somewhat taller and slenderer than the last, from which it may be at once distinguished by its undivided leaves and larger heads of flowers, of which both the disk and ray are white. The pounded leaves have been used as snuff; hence its name.-Fl. July, August. Perennial.

* A. tomentósa (Woolly Yellow Yarrow) is very rare, and a doubtful native; its leaves are repeatedly divided and woolly, the flowers bright yellow.

\section{ORD. XLVII.-CAMPANULACEE.ThE BeLI- FLOWER TRIBE.}

Calyx growing from the ovary, 5-lobed, remaining till the fruit ripens; corolla of one petal, rising from the mouth of the calyx, 5-lobed, regular, withering on the fruit ; stamens equalling in number the lobes of the corolla, and alternate with them ; anthers not united (except in Jasíoné); ovary inferior, of 2 , or more, many-seeded cells; style 1, covered with hairs; stigma simple, or with as many lobes as the ovary has cells; fruit dry, crowned by the withered calyx and corolla, splitting, or opening by valves, at the side or top; seeds numerous, fixed to a central column.-Herbaceous or slightly shrubby plants, with a milky bitter juice, mostly alternate leaves without stipules, and showy blue or white flowers, inhabiting principally the temperate regions of the northern hemisphere. Many species are highly ornamental, but very few are valuable either as food or medicine. The roots of Campánula Rapunculus, under the name of Rampion or Ramps, were formerly cultivated in this country for the table, but are now scarcely known.

1. Campínula (Bell-flower).-Corolla bell-shaped (rarely wheel-shaped), with 5 broad and shallow lobes; 
filaments broad at the base ; stigma $2-5$ cleft; capsule $2-5$ celled, opening by pores at the side, rarely near the top. (Name from the Latin campana, a bell.)

2. Phyteuma (Rampion).-Corolla $a^{\prime}$ wheel-shaped, with 5 deep lobes ; filaments broad at the base ; stigma 2-3 cleft; capsule $2-3$ celled, bursting at the side. (Name from the Greek phyton, a plant.)

3. JAsíoné (Sheep's Scabious).-Corolla wheel-shaped, with 5 long narrow segments; anthers united at the base ; stigma 2-cleft; capsule 2-celled, opening at the top ; flowers in heads. (Name of uncertain origin.)

\section{Campánula (Bell-flower).}

1. C. rotundifolia (Hair-bell).-Smooth; root-leaves roundish kidney-shaped, notched, stalked, very soon withering; stem-leaves very narrow, tapering.-Heaths and dry meadows, abundant. Flowers light blue or rarely white. The name Hair-bell is frequently, though not correctly, given to the Wild Hyacinth or Blue-bell (Agraphis nutans, or Hyacinthus non-scriptus), a plant with a thick juicy flower-stalk ; but when applied to this Campánula is most appropriate, its stalks being exceedingly slender and wiry. The specific name, rotundifolia (round-leaved), is far from being descriptive of the leaves which accompany the flower, as they are long and narrow, but is peculiarly applicable to the root leaves, as they appear in winter or early spring, at which season Linnæus is reported to have observed them on the steps of the university at Upsal.-Fl. July-September. Perennial.

2. C. Trachélium (Nettled-leaved Bell-flower).-Lower leaves stalked, heart-shaped ; upper nearly sessile, tapering to a sharp point, all strongly serrated and bristly; flowers in axillary clusters of 2-3.-Woods and hedges, not unfrequent. A remarkably rough plant, $2-3$ feet high, with leaves very like those of the nettle, and large, deep blue, bell-shaped flowers, the stalks of which are recurved when in fruit.-Fl. July, August. Perennial. 


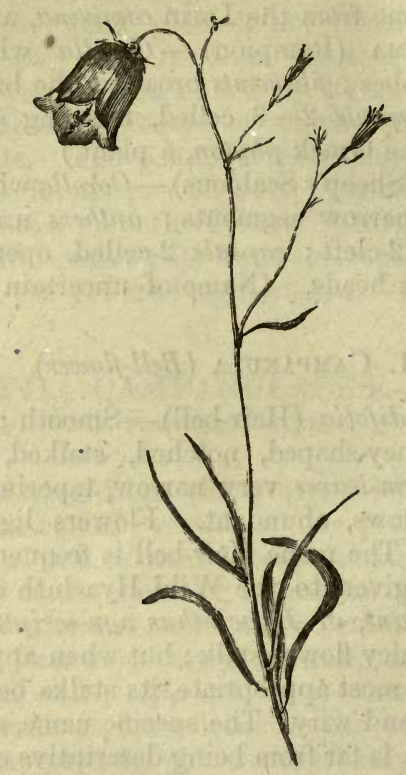

CAMPANULA ROTUNDIFOLIA (Hair-bell).

3. C. glomeráta (Clustered Bell-flower).-Stem simple, roughish ; leaves oblong, tapering, crenate, rough, the lower stalked and heart-shaped at the base, the upper sessile, embracing the stem ; flower's sessile, in heads. Dry pastures, not unfrequent. A stiff, erect plant, $3-18$ inches high, with terminal and (in large specimens) axillary heads of deep blue, funnel-shaped, erect flowers, which have a few clasping, taper-pointed bracts at the base.-Fl. July, August. Perennial. 


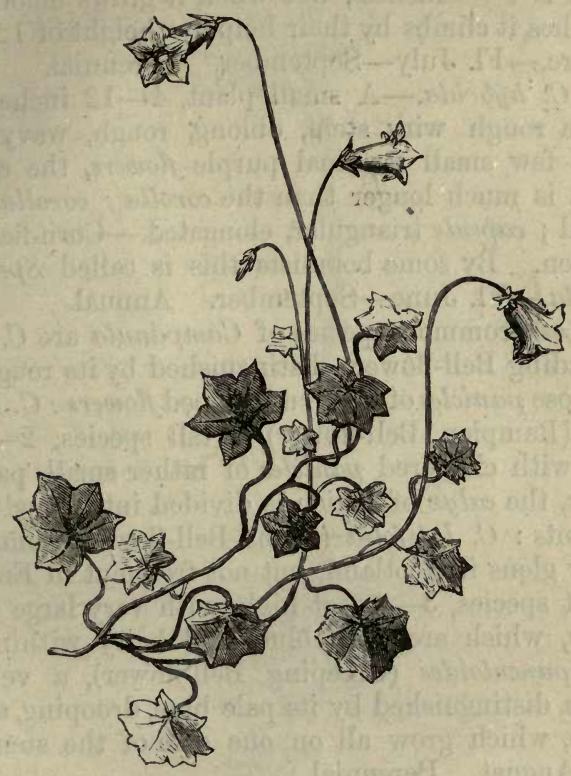

CAMPANULA HEDERACEA (Ivy-leaved Bell-flower).

4. C. hederácea (Ivy-leaved Bell-flower). - Stem , straggling, thread-like ; leaves stalked, roundish heartshaped, angular, and toothed ; flowers solitary, on long stalks. - Wet heaths, and by the side of streams in the south and west; very abundant in Cornwall. An exquisite little plant, generally growing with Anagallis tenella, and (in Cornwall) with Sibthorpia Europoea, plants certainly of a different habit, but scarcely less elegant than itself. The leaves are of a remarkably fine texture, and delicate green hue ; the flowers of a pale blue, sometimes slightly drooping, and supported on long stalks scarcely thicker than a hair. Its usual c C 
height is $4-6$ inches; but when it grows among grass or rushes, it climbs by their help to a height of 12 inches or more.-Fl. July-September. Perennial.

5. C. hýbrida. - A small plant, 4-12 inches high, with a rough wiry stem, oblong, rough, wavy leaves, and a few small terminal purple flowers, the calyx of which is much longer than the corolla; corolla wheelshaped ; capsule triangular, elongated.-Corn-fields, not common. By some botanists this is called Speculária hýbrida.-Fl. June-September. Annual.

* Less common species of Campánula are C. pátula (Spreading Bell-flower), distinguished by its rough stem, and loose panicles of wide cup-shaped flowers : C. Rapuin-। culus (Rampion Bell-flower), a tall species, $2-3$ feet high, with clustered panicles of rather small, pale blue flowers, the calyx of which is divided into 5 awl-shaped segments : C. latifolia (Giant Bell-flower), common in woody glens in Scotland, but not frequent in England; a stout species, $3-4$ feet high, with very large stalked flowers, which are deep blue, and hairy within: and C. Rapunculoídes (Creeping Bell-flower), a very rare species, distinguished by its pale blue, drooping, axillary flowers, which grow all on one side of the stem.-Fl. July, August. Perennial.

\section{Phyteuma (Rampion).}

1. P. orbiculáré (Round-headed Rampion).-Flowers in a round terminal head; lower leaves notched, heartshaped, stalked ; upper narrow, sessile.-Chalky downs, rare. A singular plant, consisting of a solitary, erect leafy stalk, 12 - 18 inches high, surmounted by a round head of blue flowers. The head when in fruit becomes oval.-Fl. July. Perennial.

* P. spicatum (Spiked Rampion) is found only in Sussex. It is much taller than the last, and bears its flowers, which are cream-coloured, in a terminal, oblong head. 


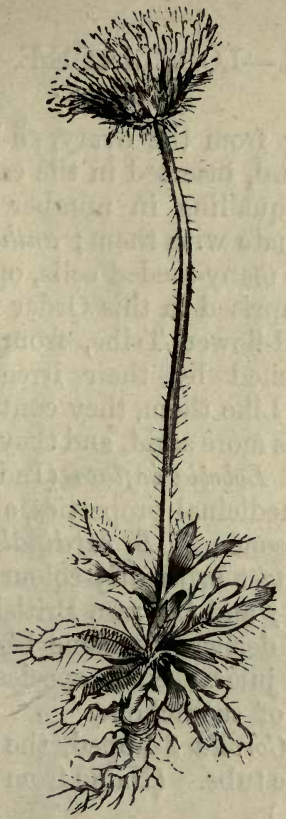

JASIONE MONTANA (Sheep's Scabiouts, Sheep's-bit).

3. Jasíoné (Sheep's Scabious).

1. J. montána (Sheep's Scabious, Sheep's-bit).-The only British species.-Dry heathy places, common. Growing about a foot high, and having a strong resemblance to a Scabious, from which it may be at once distinguished by its united anthers; or to a Compound Flower, from which it differs in having a 2-celled capsule. The leaves are oblong, blunt, and hairy; the flowers, which are blue, grow in terminal heads, with a leafy involucre at the base. The whole plant, when bruised, has a strong and disagreeable smell.-Fl. July, August.- Biennial. 


\section{ORD. XLVIII.-LOBELIACEA.-The LoBeLIA TRIBE.}

Calyx growing from the ovary, 5-lobed, or entire; corolla of one petal, inserted in the calyx, 5-lobed, irregular; stamens equalling in number the lobes of the corolla, and alternate with them; anthers united; ovary inferior, of $1-3$ many-seeded cells, opening at the top. - The plants comprised in this Order resemble in many respects the Bell-flower Tribe, from which they are mainly distinguished by their irregular corolla and united anthers. Like them, they contain a milky juice, which, however, is more acrid, and they inhabit generally warmer regions. Lobelia inflata (Indian Tobacco) possesses powerful medicinal properties, and when given in over-doses is poisonous. L. cardinalis (Scarlet Cardinal), one of our most brilliantly-coloured garden flowers, is also very acrid ; and the rare British species, L. úrens (Acrid Lobelia), derives its name from the blistering properties of its juice. Some species contain a considerable quantity of caoutchouc.

1. LoBELIA.-Corolla 2-lipped, the upper part split to the base of the tube. (Name from Matthias Lobel, a Flemish botanist.)

\section{Lobélia.}

1. L. Dortmanna (Water Lobelia).-Leaves almost cylindrical, of 2 parallel tubes.-Lakes in the north, frequent. An aquatic plant, often forming a matted bed at the bottom of the water, and sending above the surface slender, almost leafless stems having a long cluster of distant, light blue, drooping flowers.-Fl. July, August. Perennial.

* L. úrens (Acrid Lobelia) is a very rare species, found only near Axminster, Devon; it has a roughish leafy stem, which contains a milky, acrid juice, and leafy clusters of purple flowers. 
VACCINIACEE. - CRANBERRY TRIBE.

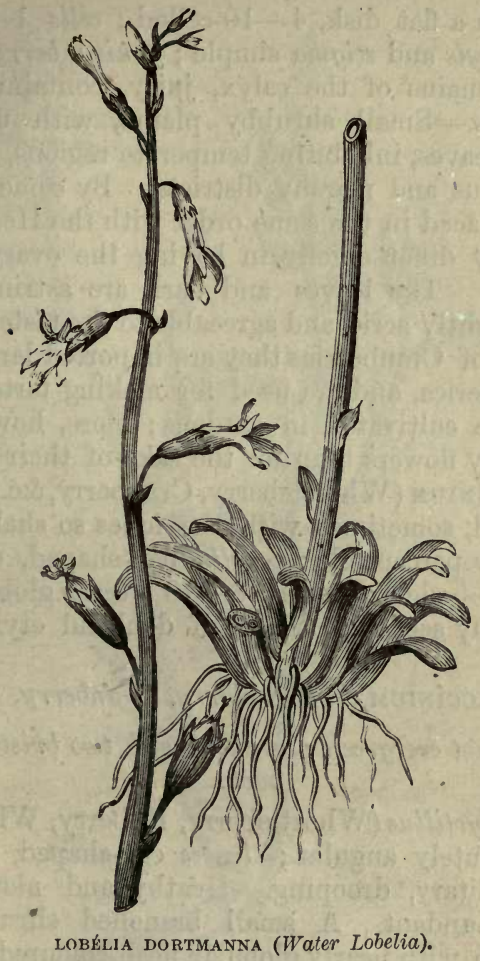

\section{Ord. XLIX. - VACCINIACEA.-The Cranberry TRIBE.}

Calyx growing from the ovary, of $4-6$ lobes, which are sometimes so shallow as to be scarcely perceptible; corolla of one petal, with as many lobes as the calyx; stamens not united, twice as many as the lobes of the corolla, inserted into the disk of the ovary ; anthers opening by 2 pores, and often furnished with 2 bristles; 
ovary with a flat disk, 4-10-celled; cells 1- or manyseeded; style and stigma simple ; fruit a berry crowned by the remains of the calyx, juicy, containing many small seeds.-Small shrubby plants, with undivided, alternate leaves, inhabiting temperate regions, especially mountainous and marshy districts. By some botanists they are placed in the same order with the Heaths, from which they differ chiefly in having the ovary beneath the calyx. The leaves and bark are astringent, the berries slightly acrid and agreeable to the taste. Under the name of Cranberries they are imported largely from North America, and are used for making tarts. Many' species are cultivated in gardens; more, however, for their pretty flowers than for the sake of their fruit.

1. VACCínium (Whortleberry, Cranberry, \&c.).-Calyx $4-5$ lobed, sometimes with the lobes so shallow as to be scarcely perceptible; corolla bell-shaped, or wheelshaped, 4-5 cleft ; stamens 8-10 ; berry globose, 4-5 celled, many seeded. (Name of doubtful etymology.)

\section{Vaccínium (Whortleberry, Cranberry, dcc.).}

* Leaves not evergreen; anthers with two bristles at the back.

1. V. Myrtillus (Whortleberry, Bilberry, Whinberry). -Stem acutely angular; leaves egg-shaped, serrated; flowers solitary, drooping.-Heathy and mountainous places; abundant. A small branched shrub, 6-18 inches high, with nearly globular, flesh-coloured, wax-like flowers, and black berries, which are covered with grey bloom. They are agreeable to the taste, and are often made into tarts ; but when thus used are rather mawkish unless mixed with some more acid fruit. In the west of England they are popularly known by the name of whorts.-Fl. May. Shrub.

2. V. uliginosum (Bog Whortleberry, or Great Bilberry).-Stem not angular ; leaves inversely egg-shaped, entire, glaucous and veined beneath.-Mountainous bogs 


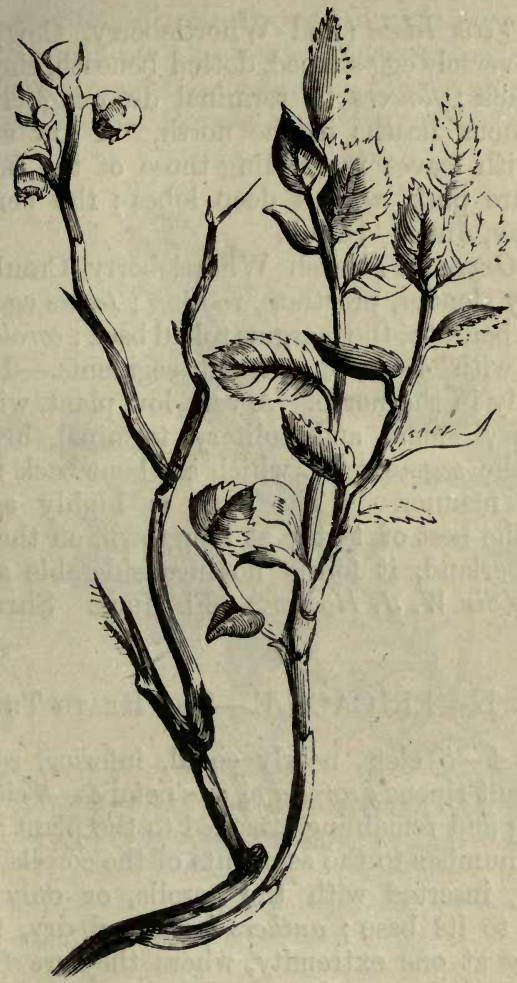

vacciNIUM MYRTILLUS (Whortleberry, Bilberry, Whinberry).

in Scotland and the north of England. Distinguished from the last by its more woody, rounded stem, and by its strongly veined, glaucous leaves, which are broader towards the extremity. The flowers are smaller and grow nearer together.-Fl. May. Shrub. 
** Leaves evergreen; anthers without bristles.

3. V. Vitis Id áa (Red Whortleberry, Cowberry).Leaves inversely egg-shaped, dotted beneath, the margins rolled back; flowers in terminal drooping clusters.Mountainous heaths in the north. A low straggling shrub, with leaves resembling those of the Box. The flowers are pink, with 4 deep lobes; the berries red. -Fl. May, June. Shrub.

4. V. Oxycoccos (Marsh Whortleberry, Cranberry).Stem very slender, prostrate, rooting; leaves egg-shaped, glaucous beneath, the margins rolled back; corolla wheelshaped, with 4 deep, reflexed segments.-Peat-bogs principally in the north. A very low plant, with straggling, wiry stems, and solitary terminal, bright red flowers, the segments of which are bent back in a very singular manner. "The fruit is highly agreeable, making the best of tarts; at Langtown, on the borders of Cumberland, it forms no inconsiderable article of trade."-(Sir W. J. Hooker.)-Fl. June. Shrub.

\section{Ord. L.-ERÍCACE}

Calyx 4-5 cleft, nearly equal, inferior, remaining till the fruit ripens; corolla of one petal $4-5$ cleft, often withering and remaining attached to the plant; stamers equal in number to the segments of the corolla, or twice as many, inserted with the corolla, or only slightly attached to its base; anthers hard and dry, the cells separating at one extremity, where they are furnished with bristles or some other appendage, opening by pores: ovary not adhering to the calyx, surrounded at the base by a disk or by scales, many-celled, many-seeded ; style, 1, straight; stigma 1 ; fruit a berry or dry capsule, many-seeded. - Shrubs or small bushy trees with evergreen, often rigid, opposite or whorled leaves. This well-known and highly prized Order contains a large number of beautiful plants, many of which are remark- 
for dyeing; its tough branches are a common material for brooms ; its flowers are the favourite resort of bees, and its seeds are said to enter largely into the food of moor-fowl. Of the plants belonging to the order, which produce juicy berries, the fruit is in some instances edible. Árbutus Únedo bears an abundance of handsome berries, which when thoroughly ripe are not unpalatable; and which, from the resemblance they outwardly bear to strawberries, give the plant its English name, Strawberry-tree. Some species, especially of Kálmia and Rhododendron, possess dangerous narcotic properties, which extend to the flesh of animals that have fed on them. It is stated that the honey which poisoned the Grecian troops during the famous Retreat of the 10,000 , had been collected by bees from the flowers of some plant of this order ; and that the honey still found on the shores of the Euxine, or Black Sea, possesses the same properties. The berries of some species are, nevertheless, used in medicine with good effect.

1. ErícA (Heath).-Calyx deeply 4-cleft; corolla bell-shaped, or egg-shaped, 4-cleft; stamens 8 ; capsule 4-celled. (Name from the Greek, eríco, to break, from some fancied medicinal properties.)

2. Callúna (Ling, Heather).-Calyx of 4 coloured sepals, which are longer than the corolla, having at the base outside 4 green bracts; corolla bell-shaped; stamens 8 ; capsule 4-celled. (Name from the Greek, calluino, to cleanse, from the frequent use to which its twigs are applied, of being made into brooms.)

3. Menziesia.-Calyx deeply $4-5$ cleft ; corolla inflated; stamens 8-10; capsule 4-5 celled. (Named in honour of Archibald Menzies, an eminent Scotch botanist.)

4. AzáLEA.-Calyx deeply 5-cleft; corolla bell-shaped, 5-cleft; stamens 5 ; anthers bursting lengthways; capsule 2-3 celled, and valved. (Name from the Greek azáleos, parched, from the nature of the places in which it grows.) 
5. Andrómeda.-Calyx deeply 5-cleft; corolla eggshaped, with a 5-cleft reflexed border ; stamens 10 ; anthers with two bristles at the back ; capsule dry, 5-celled, and 5-valved. ("Named in allusion to the fable of Andrómeda, who was chained to a rock, and exposed to the attack of a sea-monster: so does this beautiful tribe of plants grow in dreary and northern wastes, feigned to be the abode of preternatural monsters." Sir W. J. Hooker.)

6. Árbutus (Strawberry-tree).-Calyx deeply 5-cleft; corolla egg-shaped, with a 5-cleft reflexed border; stamens 10 ; fruit fleshy, rough, 5-celled; cells manyseeded. (Name, the Latin name of the plant.)

7. Arctostáphylos (Bear-berry).-Calyx deeply 5cleft ; corolla egg-shaped, with a 5-cleft reflexed border; stamens 10 ; fruit fleshy, smooth, 5-celled; cells 1-seeded. (Name in Greek denoting Bear's grape.)

\section{Eríca (Heath).}

1. E. Tétralix (Cross-leaved Heath).-Leaves 4 in a whorl, narrow, fringed; flowers in 1-sided terminal heads.-Peaty moors; abundant; well distinguished from all other English species by its leaves being placed cross-wise, and by its terminal heads of drooping, rosecoloured flowers, which are all turned to the same side, and are of a larger size than the other common species, E. cinérea. The part of the flower nearest the stem is of a lighter colour than that which is exposed, where it deepens to a delicate blush ; the whole flower appearing as if it had been modelled in wax. It is sometimes found of a pure white.-Fl. July, August, with occasional blooms throughout the autumn. Shrub.

2. E. cinérea (Fine-leaved Heath).-Leaves in threes, very narrow, smooth; flowers egg-shaped, in irregular, whorled, leafy clusters.-Heaths ; abundant. This and the preceding are the only Heaths which can be called common. It is a bushy plant, with tough, wiry stems, exceedingly narrow leaves, and numerous oblong, pur- 


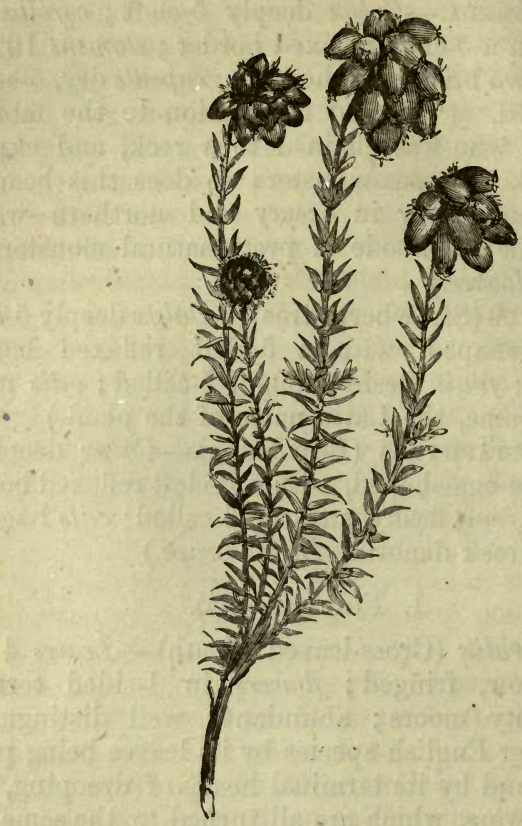

ERICA TÉTRALIX (Cross-leaved Heath).

ple flowers, which form broken, leafy clusters, not confined to one side of the stem. The flowers are sometimes white.-Fl. July, August. Shrub.

3. $E$. vagans (Cornish Heath).-Leaves $3-5$ in a whorl, crowded, very narrow, smooth; flowers bellshaped, shorter than the stamens, forming a leafy, regular, tapering cluster.-Heaths on the southern promontory of Cornwall, very abundant; found also in one or two other places in Cornwall, and on the coast of Waterford. Stems much branched, and, in the upper parts, very leafy, 2-4 feet high : flowers light purple, 


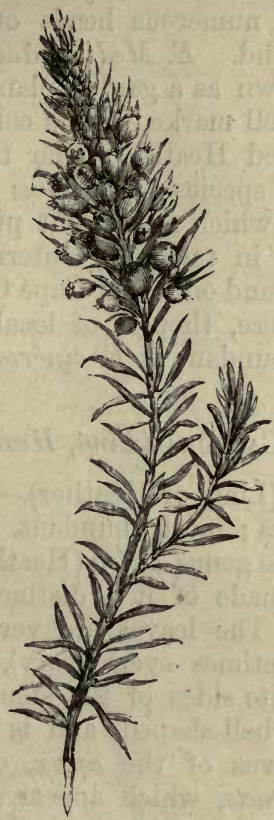

ERICA VAGANS (Cornish Heath).

rose-coloured, or pure white. In the purple variety the anthers are dark purple; in the white, bright red; and in all cases they form a ring outside the corolla until they have shed their pollen, when they droop to the sides. On the Goonhilley Downs, in Cornwall, all three varieties of this Heath grow together in the greatest profusion, covering many thousands of acres, and almost excluding the two species so common elsewhere.-Fl. July-September. Shrub.

* Less common species of Heath are $E$. Mackaii (Mackay's Heath), approaching closely to $E$. Tétralix, 
but growing in a more bushy manner, with broader leaves, and more numerous heads of smaller flowers. Cunnemara, Ireland. $E$. Mediterránea (Mediterranean Heath), well known as a garden plant, but found, also, in Cunnemara, well marked by its coloured calyx ; and $E$. ciliáris (Ciliated Heath), by far the most beautiful of all the British species; the leaves are 4 in a whorl, and the flowers, which are bright purple and half an inch long, grow in terminal, interrupted, spike-like clusters. It is found only near Cape Castle, Dorset, and in Cornwall, where, though of local occurrence, it is occasionally as abundant as $E$. cinérea is elsewhere.

\section{Callúna (Ling, Heather).}

1. C. vulgáris (Ling, or Heather).-The only species. Heaths and moors ; most abundant. This was placed by Linnæus in the genus Eríca (Heath); later botanists have, however, made of it a distinct genus, and not without reason. The leaves are very small, more or less downy (sometimes even hoary), and arranged in 4 rows, on opposite sides of the stem. The corolla is very small, and bell-shaped, and is concealed by the rose-coloured leaves of the calyx, outside which are 4 small green bracts, which appear to form a second calyx. The flowers remain attached to the plant long after the seed is ripe; indeed, it is not at all unusual to find plants in full bloom with the withered flowers of the preceding year still adhering to the lower part of the stem. A beautiful variety has been found in Cornwall, with double flowers.-Fl. July, August. Shrub.

\section{Menziesia.}

1. M. corrílea (Scotch Menziesia). - Leaves numerous, linear, minutely toothed; flower-stalks covered with glandular hairs ; flowers in terminal tufts ; corolla 5-cleft; stamens 10.-Very rare; found on the "Sow 


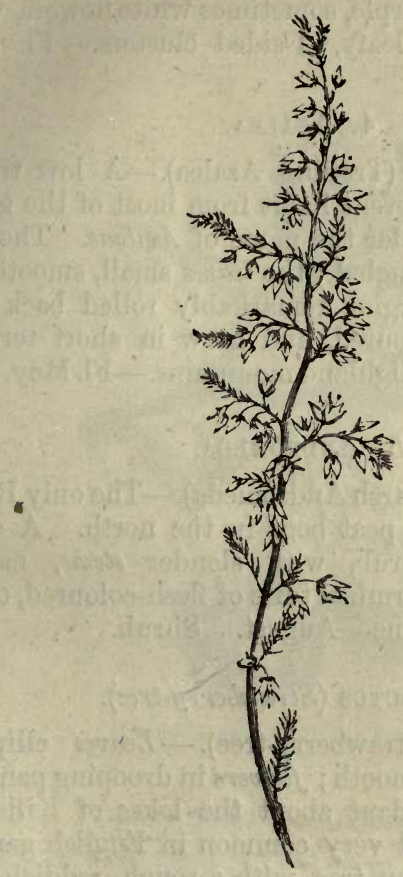

CALLE'NA VULGARIS (Ling, or Heather).

of Athol," in Perthshire, but "nearly, if not quite extirpated by an Edinburgh nurseryman."-Babington. A small shrubby plant, naked below, very leafy and hairy above, with large, pale purplish-blue flowers.Fl. June, July. Shrub.

2. M. polifólia (Irish Menziesia, or St. Dabeoc's Heath).-Leaves egg-shaped, with the margins rolled back, white, and downy beneath ; corolla 4-cleft; stamens 8.-Mountainous heaths in Ireland; ; rare. A small 
but growing in a more bushy manner, with broader leaves, and more numerous heads of smaller flowers. Cunnemara, Ireland. $E$. Mediterránea (Mediterranean Heath), well known as a garden plant, but found, also, in Cunnemara, well marked by its coloured calyx ; and E. ciliáris (Ciliated Heath), by far the most beautiful of all the British species; the leaves are 4 in a whorl, and the flowers, which are bright purple and half an inch long, grow in terminal, interrupted, spike-like clusters. It is found only near Cape Castle, Dorset, and in Cornwall, where, though of local occurrence, it is occasionally as abundant as $E$. cinérea is elsewhere.

\section{Callúna (Ling, Heather).}

1. C. vulgáris (Ling, or Heather).-The only species. Heaths and moors ; most abundant. This was placed by Linnæus in the genus Eríca (Heath); later botanists have, however, made of it a distinct genus, and not without reason. The leaves are very small, more or less downy (sometimes even hoary), and arranged in 4 rows, on opposite sides of the stem. The corolla is very small, and bell-shaped, and is concealed by the rose-coloured leaves of the calyx, outside which are 4 small green bracts, which appear to form a second calyx. The flowers remain attached to the plant long after the seed is ripe; indeed, it is not at all unusual to find plants in full bloom with the withered flowers of the preceding year still adhering to the lower part of the stem. A beautiful variety has been found in Cornwall, with double flowers.-Fl. July, August. Shrub.

\section{Menziesia.}

1. M. carílea (Scotch Menziesia). - Leaves numerous, linear, minutely toothed; flower-stalks covered with glandular hairs ; flowers in terminal tufts ; corolla 5-cleft; stamens 10.-Very rare; found on the "Sow 


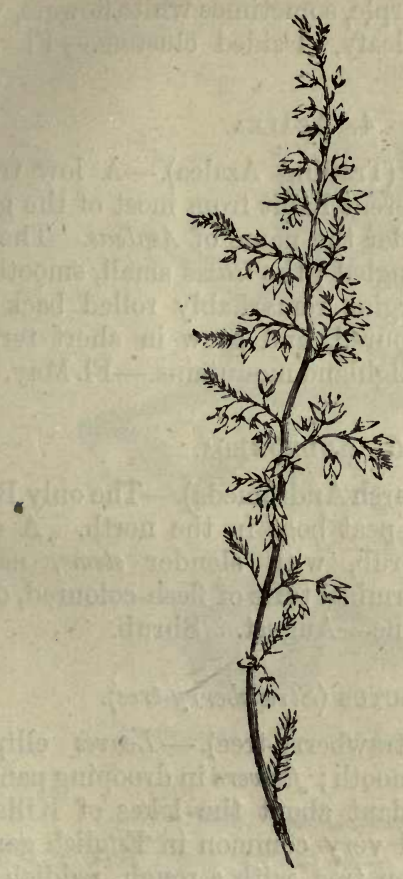

CALLEXA VULGÁRIS (Ling, or Heather).

of Athol," in Perthshire, but "nearly, if not quite extirpated by an Edinburgh nurseryman."-Babington. A small shrubby plant, naked below, very leafy and hairy above, with large, pale purplish-blue flowers.Fl. June, July. Shrub.

2. M. polifólia (Irish Menziesia, or St. Dabeoc's Heath).-Leaves egg-shaped, with the margins rolled back, white, and downy beneath ; corolla 4-cleft; stamens 8.-Mountainous heaths in Ireland; rare. A small 
shrub, with large, purple, sometimes white flowers, which grow in terminal, leafy, 1-sided clusters.-Fl. June, July. Shrub.

\section{Azálea.}

1. A. procumbens (Trailing Azalea).-A low trailing shrub, of a very different habit from most of the garden plants cultivated under the name of Azaleas. The stems are prostrate and tangled; the leaves small, smooth, and rigid, with the margins remarkably rolled back; the flowers are flesh-coloured, and grow in short terminal clusters, or tufts. Highland mountains.-Fl. May, June. Shrub.

\section{ANDRÓMEDA.}

1. A. polifolia(Marsh Andrómeda).-The only British species, growing in peat bogs in the north. A small, leafy, evergreen shrub, with slender stems, narrow, pointed leaves, and terminal tufts of flesh-coloured, drooping flowers.-Fl. June-August. Shrub.

\section{6. Árbutus (Strawberry-tree).}

1. Á. Únedo (Strawberry-tree).-Leaves elliptical, tapering, serrated, smooth; flowers in drooping panicles ; fruit rough.-Abundant about the lakes of Killarney, in a wild state, and very common in English gardens. A beautiful evergreen tree, with a rough, reddish bark, large deep-green leaves, and numerous terminal clusters of greenish-white flowers. The berries, which ripen in the following autumn, are nearly globular, scarlet, and rough with minute, hard grains. They are eatable, but so much less attractive to the taste than to the eye, as to have originated the name, "Unedo," "One-I-eat ;" as if no one would choose to try a second. The flowers are in full perfection at the time when the fruit, formed in the preceding year, is ripening; and then of course, the tree presents its most beautiful appearance.-Fl. September, October. Tree. 


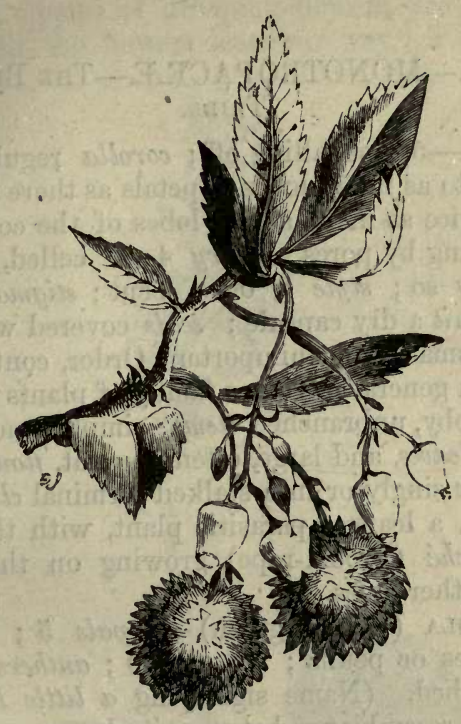

ARBUTUS ÚNEDO (Strawberry-tree).

\section{Arctostáphylos (Bear-berry).}

1. A.Uva-Ursi (Red Bear-berry).-Stems prostrate; leaves inversely egg-shaped, entire, evergreen; flowers in terminal clusters.-Mountainous heaths in the north ; abundant. A small shrub, distinguished by its long trailing stems, blunt leaves, which turn red in autumn, rose-coloured flowers, and scarlet berries, which are a favourite food of moor fowl. The leaves are used in medicine as an astringent.-Fl. May. Shrub.

* A. alpina (Black Bear-berry) resembles the last in its mode of growth, but the leaves are wrinkled and serrated, and not evergreen ; the flowers are.white, with a purplish tinge ; the berries black. It is most common on mountains in the north of Scotland. 


\section{ORD. LI.-MONOTROPACEÆE-ThE BIRD'S-NEST TRIBE.}

Sepals $4-5$, not falling off ; corolla regular, deeply divided into as many lobes or petals as there are sepals ; stamens twice as many as the lobes of the corolla ; anthers opening by pores; ovary 4-5 celled, sometimes imperfectly so ; style 1, often bent; stigma generally lobed; fruit a dry capsule; seeds covered with a loose skin.-A small and unimportant Order, containing but two British genera, Pýrola, a family of plants with somewhat shrubby, unbranched stems; simple, smooth, veiny evergreen leaves, and large, often fragrant, flowers, which grow either singly or in a stalked terminal cluster: and Monótropa, a leafless parasitic plant, with the habit of an Orobanché (Broom-rape), growing on the roots of Firs, and other trees.

1. Pýrola (Winter-green).-Sepals 5 ; corolla of 5 deep lobes or petals ; stamens 10 ; anthers 2-celled; stigma 5-lobed. (Name signifying a little Pear, from the fancied resemblance between its leaves and those of that tree.)

2. Monótropa (Bird's-nest).-Sepals 4-5; petals $4-5$, swollen at the base; stamens $8-10$; anthers 1-celled; stigma flat, not lobed. (Name from the Greek monos, one, and trepo, to turn, the flowers being turned all one way.)

\section{Púrola (Winter-green).}

1. $P$. uniflóra (Single-flowered Winter-green).Leaves nearly round ; flower solitary, drooping.-Mountainous woods in Scotland; rare. A remarkably pretty plant, bearing several roundish, egg-shaped, smooth, and veiny leaves, and running up into a single flower-stalk, which bears one large, elegant, white, highly fragrant flower.-Fl. July. Perennial.

* The other species of Winter-green, which bear each 
a terminal cluster of drooping flowers, are $P$. secuinda, in which all the flowers lean one way ; $P$. minor, dis-

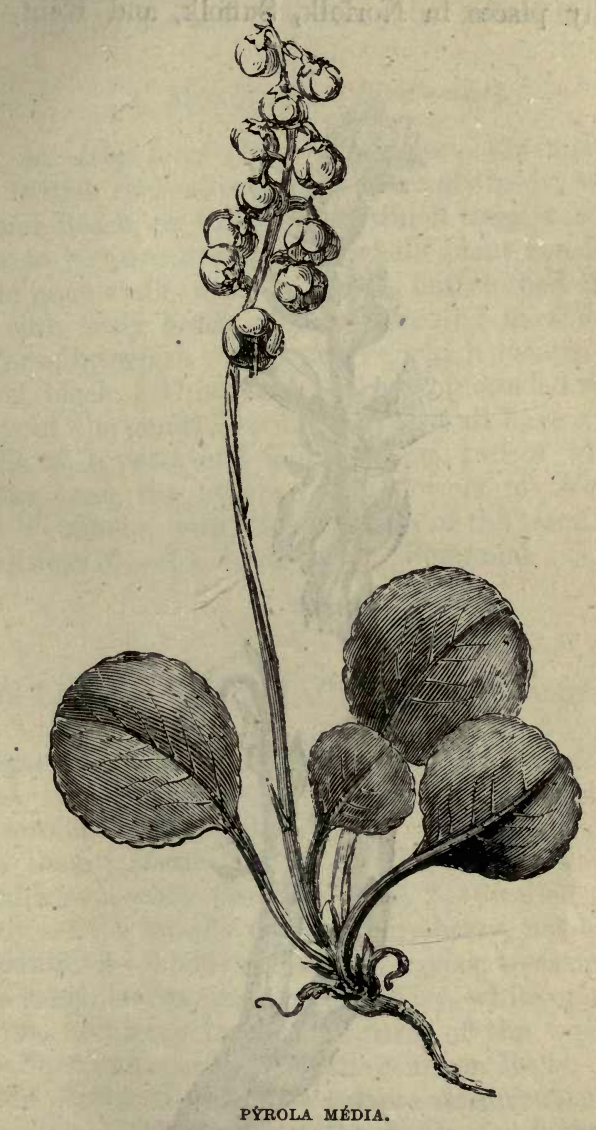

tinguished by its large stigma, which is included within the flower; these are found only in North Britain. D $\mathrm{D} 2$ 
404 MONOTROPACEA.-BIRD'S-NEST TRIBE.

$P$. rotundifólia is marked by its long style bent down, and, at the extremity, curved upwards; this is found in bushy places in Norfolk, Suffolk, and Kent, very

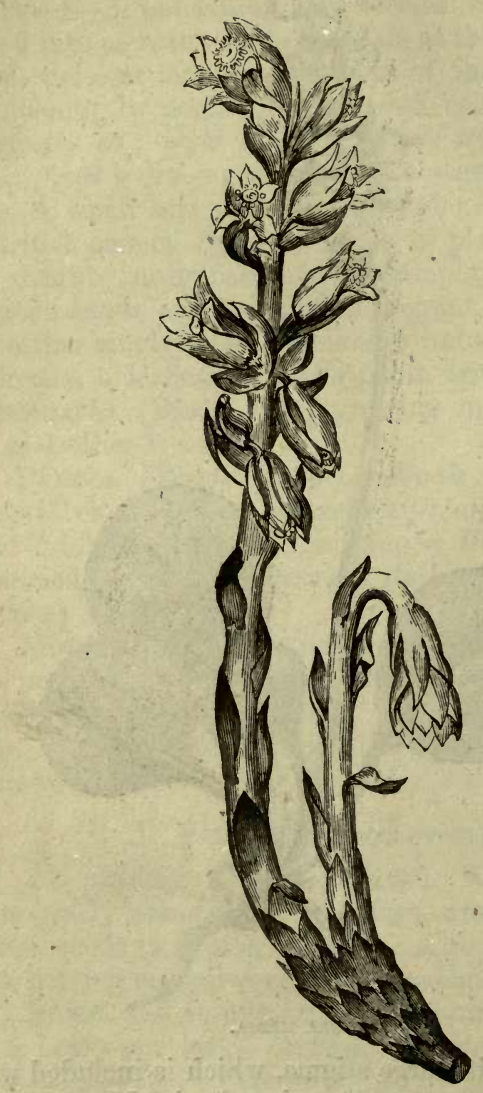

MONÓTROPA HYPÓPITYs (Pine Bird's-nest, Fir-rape). 
rare. $P$. média has an erect, nearly-straight style much longer than the stamens; this is very common in Scotland, and has also been found in Oxfordshire.

\section{Monótropa (Bird's-nest).}

1. M. Hypópitys (Pine Bird's-nest, Fir-rape).-The only British species, occurring sparingly in dry woods of Fir and Beech, on the roots of which trees it is said by some to be parasitical. The whole plant consists of a single juicy stalk, without leaves, but clothed throughout with scaly bracts, and terminating in a drooping cluster of brownish yellow flowers, which eventually turn almost black. This must not be confounded with the plants of the genus Orobanché, which all have a ringent corolla of 1 petal, and four stamens, two of which are shorter than the others. The flowers of Monótropa have 8 stamens, with the exception of the terminal one, which has 10.-Fl. June, July. Perennial.

\section{Ord. LII.-AQUIFOLIACE F.-The Holly Tribe.}

Sepals 4-6, imbricated when in bud ; corolla 4-6lobed, imbricated when in bud; stamens inserted into the corolla, equalling its lobes in number, and alternate with them: filaments erect; anthers 2-celled, opening lengthwise ; ovary fleshy, abrupt, 2-6-celled ; stigma nearly sessile, lobed; fruit a fleshy berry, not bursting, containing 2-6 bony seeds.-Evergreen trees or shrubs, with tough leaves, and small axillary, white or greenish flowers, occurring in various parts of the world; the only European species being the common Holly. Nearly all the plants of this tribe possess astringent and tonic properties. The leaves of the Holly, for instance, are said to be equal to Peruvian bark in the cure of intermittent fever. The berries are, undoubtedly, poisonous. 
The bark furnishes bird-lime, and the wood, which is white, and remarkably close grained, is much used by cabinet-makers in inlaying. I. Paraguayensis furnishes Maté, or Paraguay Tea, which is so extensively used in Brazil and other parts of South America; for a full account of which, see Forest Trees of Britain, vol. ii.

1. Itex (Holly).-Calyx 4-5-cleft; corolla wheelshaped, 4-5-cleft ; stamens $4-5$; stigmas $4-5$; berry round, containing $4-5$ bony seeds. (Name applied by the Latins to some tree, though not our Holly.)

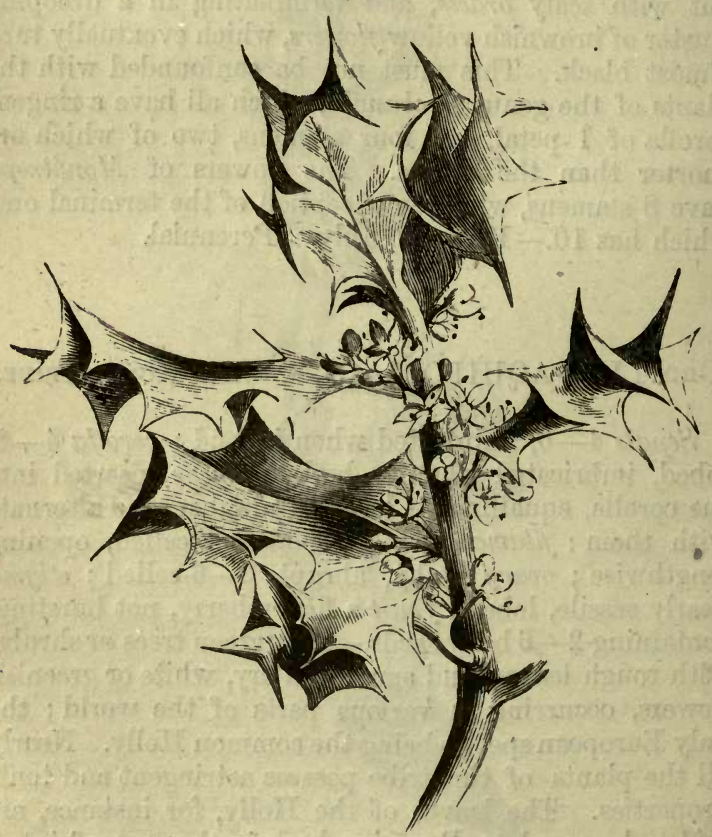




\section{Ilex (Holly).}

1. I. Aquifolium (Holly).-The only British species, for a full account of which see Frost Trees of Britain, vol. ii. The name Aquifolium means needle-leaved. Holly is a corruption of the word "holy," from the use to which its boughs are applied in ornamenting churches at Christmas. The berries, it should be borne in mind, are Porsonous.-Fl. May, June. Tree.

\section{Ord. LIII.-OLEÁCEA.-The Olive Tribe.}

Calyx divided, not falling off ; corolla of 1 petal, 4 -8-cleft, sometimes wanting; stamens 2 , alternate with the lobes of the corolla ; vvary 2 -celled; cells 2 -seeded; style 1 ; fruit a berry, drupe, or capsule, of 2 cells, each cell often perfecting only a single seed.-Trees, or shrubs, the branches of which often end in conspicuous buds; the leaves are opposite, either simple or pinnate: the flowers grow in clusters, or panicles. The plants of this Order inhabit the temperate regions of many parts of the world. By far the most important among them is the plant from which the Order takes its name, Ólea, the Olive, among the earliest of plants cultivated by man. The bark of the olive is bitter and astringent, the wood remarkably close grained and durable. The fruit is a drupe, or hard bony seed, enclosed in a fleshy, closely-fitting case. From this outer coat, and not from the seed itself, oil is obtained by pressure. Several kinds of ash (Fráxinus and Ornus) produce manna, and are valued for the strength and elasticity of their timber. (For a more detailed account of the Ash, see Forest Trees of Britain.)

1. Ligustrum (Privet).-Corolla funnel-shaped, 4cleft; calyx with 4 small teeth; fruit a 2-celled berry. (Name from the Latin name of the plant, and that from ligo, to bind, from the use made of its twigs.) 
2. Fráxinus (Ash).-Calyx 4-cleft, or 0 ; corolla 0 ; fruit a winged 2-celled capsule. (Name, the Latin name of the tree, denoting the ease with which it may be split.)

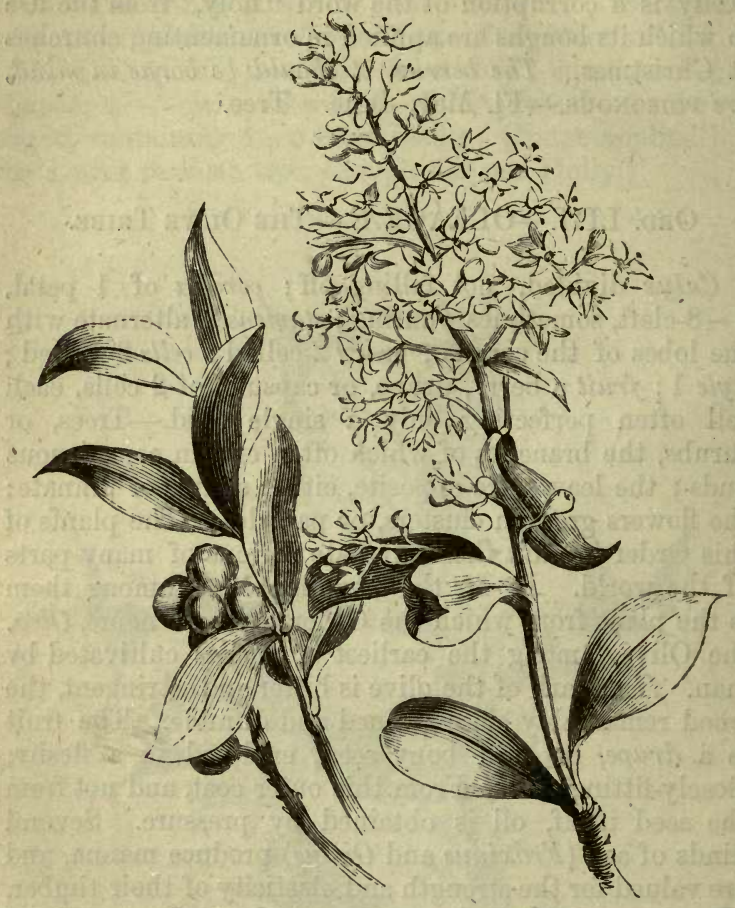

LIGUSTRUM VULGARE (Privet).

1. Ligustrum (Privet).

1. L. vulgáré (Privet).-The only British species.A common hedge-bush, with opposite, narrow-elliptical, 
evergreen leaves, dense panicles of white, sicklysmelling flowers, and black, shining berries, about the size of currants. It is much used for hedges, especially in conjunction with White-thorn, over which it has the advantage of being a rapid grower. It is commonly planted to form divisions in town gardens, not being liable to be injured by smoke.Fl. May, June. Shrub.

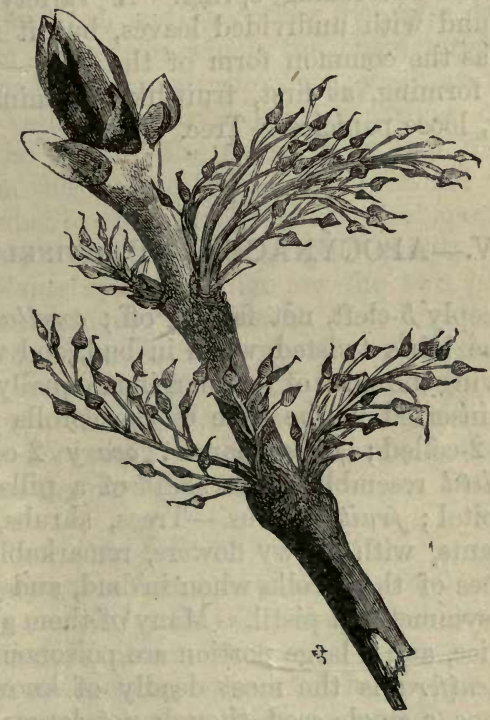

FRÁXINUS EXCELSIOR $(A s h)$. 


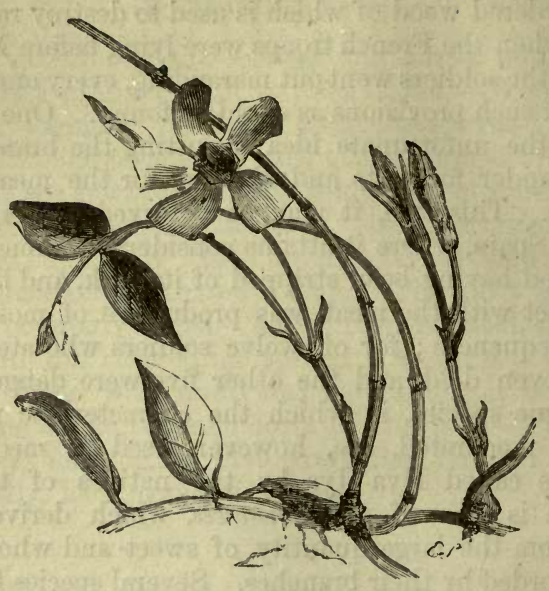

vINCA MínoR (Lesser Periwinkle).

2. V. minor (Lesser Periwinkle).-Stem trailing, sending up short, erect, leafy shoots, which bear the flowers; margins of the leaves not fringed.-Woods, especially in the West of England, where it often entirely covers the ground with its evergreen leaves. It is much smaller than the last. A white variety occurs in Devonshire, and in gardens it is often met with bearing variegated leaves and double purple, blue, or white flowers.-Fl. March-June. Perennial.

Ord. LV.-GENTIANACEAE-The Gentian Tribe.

Calyx usually 5-, sometimes 4-8-cleft, not falling off ; corolla of one petal, its lobes equalling in number those of the calyx, not falling off, twisted when in bud, often fringed about the mouth of the tube; stamens equalling in number the lobes of the corolla, and alternate with them ; ovary of 2 carpels, 1 - or imperfectly 
2-celled ; style 1 ; stigmas 2 ; fruit a many-seeded capsule or berry.-Mostly herbaceous plants, with opposite, generally sessile, leaves, and often large, brilliantly coloured flowers. This is an extensive Order, containing about 450 species, which are distributed throughout all climates, from the regions of perpetual snow to the hottest regions of South America and India. Though able to bear the most intense cold, they are very rare both in the Arctic and Antarctic regions. Under the equator, the lowest elevation at which they have been found is 7,852 feet: on the Himalaya range, one species has been found at a height of 16,000 feet; another in Ceylon at 8,000 feet : in southern Europe, one species, Gentiana prostrata, flourishes at between 6,000 and 9,000 feet ; the same species occurs in the Rocky Mountains of America at an elevation of 16,000 feet, and in the Straits of Magellan and Behring's Straits, just above the level of the sea. In South America and New Zealand, the prevailing colour of the flower is red; in Europe, blue ; yellow and white being of rare occurrence. All the known species are remarkable for the intensely bitter properties residing in every part of the herbage, hence they are valuable tonic medicines. That most commonly used in Europe is Gentiána lútea (Yellow Gentian); but there is little doubt that other species might be employed with equally good effect.

1. Gentiána (Gentian).-Calyx 4-5-cleft; corolla funnel or salver-shaped ; stamens 5, rarely 4 ; stigmas 2. (Name from Gentius, an ancient king of Illyria, who discovered its medicinal value.)

2. Erythraa (Centaury).-Calyx 5-cleft; corolla funnel-shaped, 5-cleft, not falling off ; stamens 5; anthers becoming spirally twisted; stigmas 2 ; capsule nearly cylindrical, imperfectly 2-celled. (Name from the Greek erythros, red, from the colour of the flowers.)

3. CiCEndia (Gentianella).-Calyx 4-cleft, tubular; corolla funnel-shaped, 4-cleft; stamens 4; anthers not twisted ; stigma undivided. (Name, according to Hooker 
and Arnott, from the Greek cicinnus, curled hair; but, if so, particularly inappropriate to the only British species, which is singularly rigid.)

4. Chlora (Yellow-wort).-Calyx deeply 8-cleft; corolla with a very short tube, 8-cleft; stamens 8; stigma 2-4-cleft. (Name from the Greek chloros, yellow, from the colour of the flowers.)

5. Menyanthes (Buck-bean).-Calyx deeply 5-cleft; corolla funnel-shaped, with 5 lobes, fringed all over the inner surface ; stamens 5; stigma 2-lobed. (Name of doubtful origin.)

6. Villársia.-Calyx deeply 5-cleft, corolla wheelshaped, with 5 lobes, which are fringed only at the base ; stamens 5 ; stigma with 2 toothed lobes. (Name in honour of M. de Villars, a French botanist.)

\section{Gentiána (Gentian).}

1. G. Amarella (Autumnal Gentian).-Stem erect, branched, many-flowered ; calyx 5-cleft ; corolla salvershaped, 5-cleft, fringed in the throat.-Dry chalky pastures, not common. A remarkably erect plant, with a square, leafy, purplish stem, 6-12 inches high, and numerous, rather large, purplish-blue flowers, which only expand in bright sunshine.-Fl. August, September. Annual.

2.G.campestris (Field Gentian).-Stem erect, branched, many-flowered; calyx 4-cleft, the two outer lobes much larger; corolla salver-shaped, 4-cleft, fringed in the throat.-Dry pastures, common. Resembling the last in habit, but at once distinguished by its 4-cleft flowers, which are of a dull purplish colour.-Fl. August, September. Annual.

3. G. Pneumonanthé (Marsh Gentian).-Stem erect, few-flowered ; calyx 5-cleft; corolla between bell and funnel-shaped, 5-cleft, not fringed.-Boggy heaths, rare. Well distinguished from the preceding by its large, bellshaped, deep blue flowers with 5 green stripes. There 


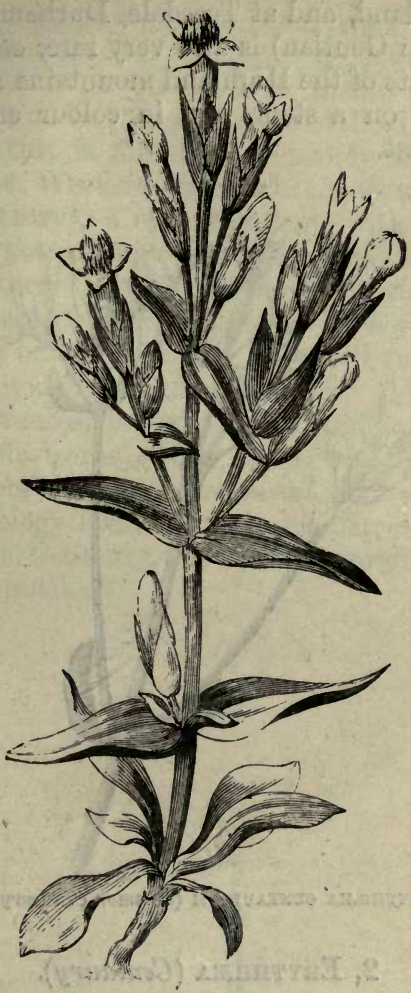

gentíána campestris (Field Gentian).

are rarely more than 1 or 2 flowers on the same stalk.Fl. August, September. Annual.

* G. verna (Spring Gentian) is a very rare species, having on each stem a single large, intensely blue flower, which is 5-cleft and has between the lobes 5 smaller 2-cleft segments ; it has been found only in one or two 
places in Ireland, and at Teesdale, Durham. G. nivális (Small Alpine Gentian) is also very rare, occurring only on the summits of the Highland mountains : the flowers grow several cn a stem, and in colour and shape resemble the last.

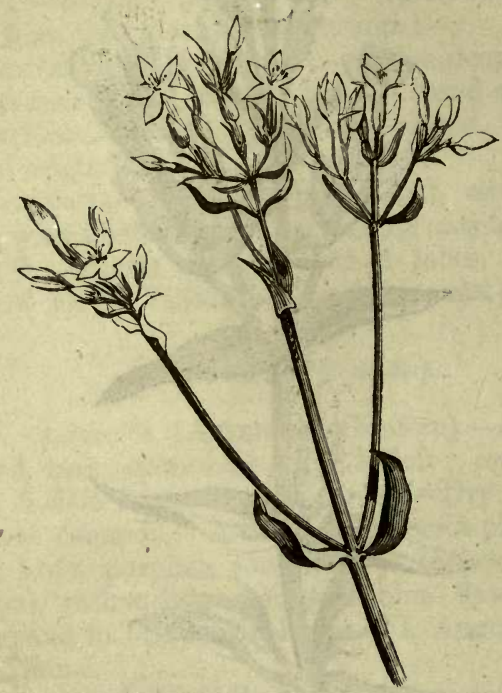

erythraea centaurium (Common Centaury).

\section{Erythraa (Centaury).}

1. E. Centaurium (Common Centaury).-A pretty herbaceous plant, 2-18 inches high, with square erect stems, which are much branched above, and terminate in variously divided flat tufts of small rose-coloured flowers ; the leaves are oblong, with strong parallel ribs, and remarkably smooth ; the flowers only expand in fine weather.-This is the common form of the plant as it occurs in dry fields and waste places. In other situa- 
tions it varies so greatly, that some botanists enumerate several distinct species, namely : $E$. pulchella (Dwarf Centaury), a minute plant, $2-8$ inches high, with an exceedingly slender stem, and a few stalked flowers (often only one); this is found on the sandy sea-shore, especially in the West of England: E. littoratis (Dwarf Tufted Centaury), a stunted plant, with broad leaves, and all the flowers crowded into a kind of head; this occurs on turfy sea-cliffs: and $E$. latifolia (Broadleaved Centaury), which has even broader leaves than the last, and bears its flowers in forked tufts, the main stem being divided into three branches. There are other minute differences, for which the student may consult more scientific works. The genus was formerly called Chirónia, from the Centaur, Chiron, who was famous in Greek mythology for his skill in medicinal herbs. The English name, Centaury, has the same origin.-Fl. July, August. Annual.

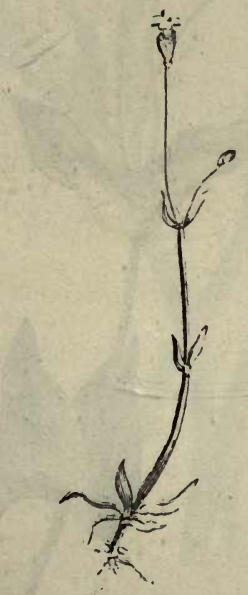




\section{Crcéndia (Gentianella).}

1. C. filifórmis (Least Gentianella).-The only British species. A minute, slender plant, in habit resembling Erythroea pulchella, and growing to about the same size, 2-4 inches; the leaves are very narrow, and soon wither; the flowers are yellow, and expand only in bright sunshine.-It grows in sandy heaths where water has stood during the winter. It is described by some authors under the name of Exácum filiforme.-Fl. July. Annual.

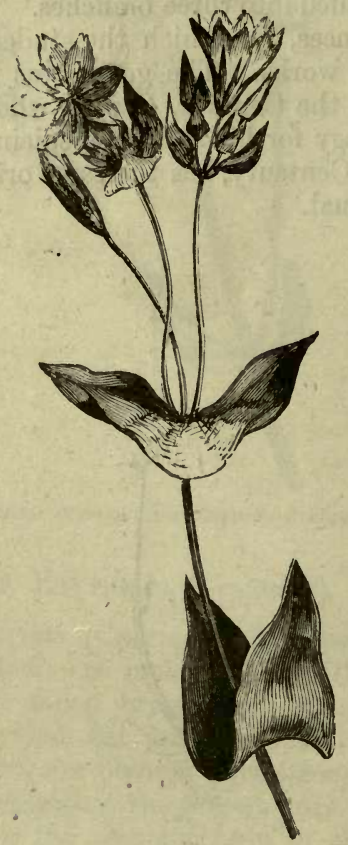




\section{Chlora (Yellow-wort).}

1. C. perfoliáta (Perfoliate Yellow-wort).-The only British species.-Chalk and limestone pastures; not uncommon. An erect plant, 12-18 inches high, re-

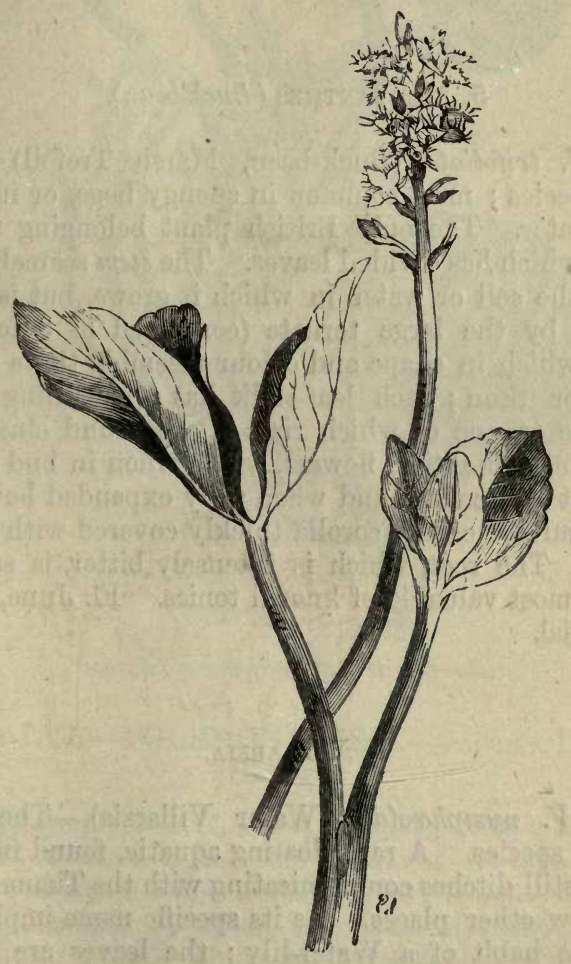

MENYANTHES TRIFOLIATA (Buck-bean, Marsh Trefoil).

E E 2 
markable for its glaucous hue, and for its pairs of leaves, which are rather distant, being united at the base (connate), with the stem passing through them; hence its name, Perfoliate. The flowers, which are large and handsome, are of a pale yellow, and expand only during sunshine.-Fl. June, September. Annual.

\section{Menyanthes (Buck-bean).}

1. M. trifoliata (Buck-bean, Marsh Trefoil).-The only species ; most common in spongy bogs, or in stagnant water. The only British plant belonging to the Order which has divided leaves. The stem scarcely rises above the soil or water in which it grows, but is overtopped by the large ternate (composed of 3 leaflets) leaves, which in shape and colour resemble those of the Windsor Bean; each leaf-stalk has a sheathing base, opposite to one of which rises a compound cluster of exceedingly beautiful flowers, which when in bud are of a bright rose colour, and when fully expanded have the inner surface of the corolla thickly covered with white fringe. The root, which is intensely bitter, is said to be the most valuable of known tonics. Fl. June, July. Perennial.

\section{Villarsia.}

1. V. nymphoeoides (Water Villarsia).-The only British species. A rare, floating aquatic, found in some of the still ditches communicating with the Thames, and in a few other places. As its specific name implies, it has the habit of a Water-lily ; the leaves are nearly round ; the flowers large, yellow, and fringed. Fl. July, August. Perennial. 


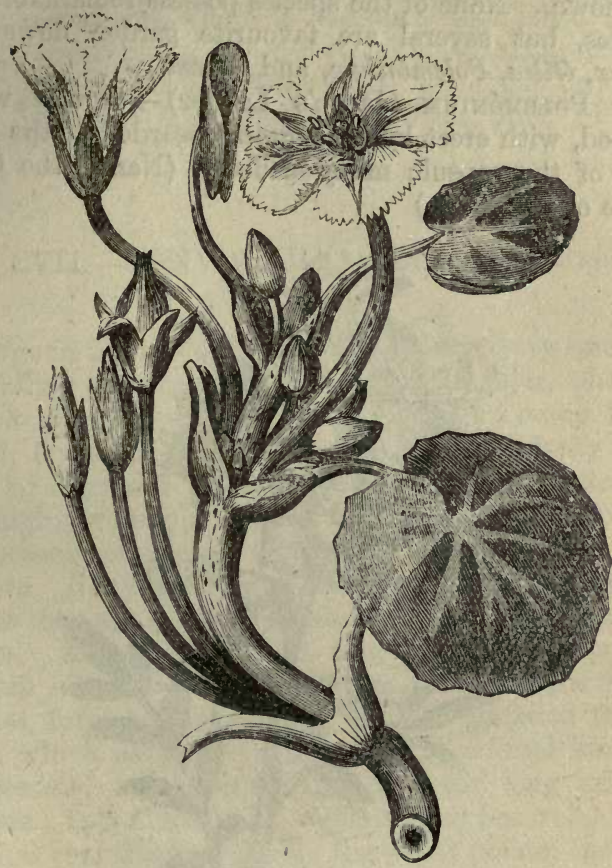

VILLARSIA NYMPHCEOIDES (Water Villarsia).

ORD. LVI.-POLEMONIACEAE-JACOB'S LADDER Tribe.

Calyx deeply 5-cleft, not falling off ; corolla regular, 5 -lobed; stamens 5, from the middle of the tube of the corolla ; ovary 3 -celled; style single ; stigma 3-cleft ; capsule 3-celled, 3-valved. Herbaceous plants, often with showy flowers, which are remarkable for the blue colour of their pollen. They are most common in the temperate parts of America; but within the tropics are 
unknown. None of the species possess remarkable properties, but several are favourite garden flowers, as Phlox, Gília, Polemónium, and Coboea.

1. Polemónium (Jacob's Ladder).-Corolla wheelshaped, with erect lobes; stamens bearded at the base; cells of the capsule many-seeded. (Name, the Greek name of the plant.)

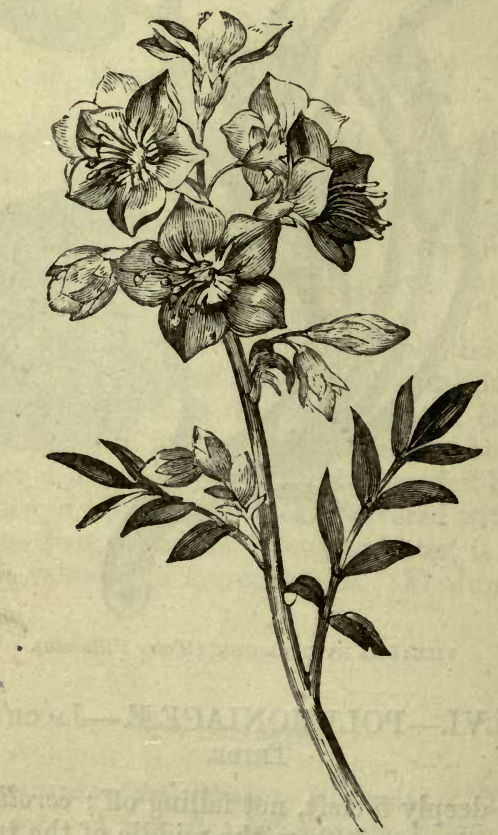

P. CaRt́leum (Greek Valerian, Blue Jacob's Ladder).

1. Polemónium (Greek Valerian).

1. P. coerúleum (Greek Valerian, Blue Jacob's Ladder). -The only British species, occasionally found in woods 
in the north, but rare; a common garden flower, not easily rooted out where it has once established itself. A tall, erect plant, $1-2$ feet high, with an angular stem; pinnate, smooth leaves; and numerous terminal, large, blue or white flowers.-Fl. June, July. Perennial.

ORd. LVII.-CONVOLVULACE.E.-The BindweEd TRIBE.

Calyx in 5 divisions, imbricated, often very unequal, not falling off ; corolla of one petal, regular, plaited; stamens 5, from the base of the corolla; ovary 2-4celled, few-seeded, surrounded below by a fleshy ring; style 1 ; stigmas 2 ; capsule 1-4-celled.-An extensive and highly valuable tribe of plants, most of which are herbaceous climbers, with large and very beautiful flowers. They are most abundant within the tropics, where they are among the most ornamental of climbing plants. As medicines, also, they occupy an important station. The roots of Convólvulus Scammonia, a Syrian species, furnishes scammony ; jalap is prepared from a resin which abounds in the roots of several kinds of Exogonium, a beautiful climber, with long crimson flowers ; and Convólvulus Batátas is no less valuable in tropical countries, supplying the sweet potato, the roots of which abound in starch and sugar, and are a nourishing food. Cúscuta (Dodder) is a parasitic genus, with branched, climbing, cord-like stems, no leaves, and globular heads of small wax-like flowers. The seeds germinate in the ground, and the young plants climb the stems of adjoining plants ; and when they have taken root in them, lose their connexion with the ground. One British species is very abundant on the Furze; another on Flax, with the seeds of which it is supposed to be introduced; and a third grows on Thistles and Nettles. 
1. Convólvulus (Bindweed).-Corolla trumpetshaped, with 5 plaits and 5 very shallow lobes; caly $x$ without bracts ; style 1 ; stigmas 2 ; capsule 2-celled, 2 valved. (Name, from the Latin convolvo, to entwine, from the twisting habit of many species.)

2. Calystégia (Bindweed).-Corolla as in Convólvulus; calyx enclosed within two bracts; style 1 ; stigmas 2 ; capsule 1-celled, 2-valved. (Name in Greek denoting a beautiful covering.)

3. Cúscuta (Dodder).-Calyx 4-5-cleft; corolla bell-shaped, $4-5$-cleft, with $4-5$ scales at the base within. (Name, said to be derived from the Arabic Kechout.)

\section{Convólvulus (Bindweed).}

1. C. arvensis (Field Bindweed).-Stem climbing; leaves arrow-shaped, with acute lobes; flowers 1-3 together; bracts minute, distant from the flower.-A common weed in light soil, either trailing along the ground amoifg short grass, or climbing wherever it finds a support. The flowers are rose-coloured, with dark plaits, handsome and fragrant, opening only in sunny weather.-Fl. June, July. Perennial.

\section{Calystégia (Bindweed).}

1. C. sépium (Great Bindweed).-Stem climbing; leaves arrow-shaped, with abrupt lobes ; flowers solitary on square stalks; bracts large, heart-shaped, close to the flower.-In bushy places, common, and a most mischievous weed in gardens, not only exhausting the soil with its roots, but strangling with its twining stems the plants which grow near. The flowers are among the largest which this country produces; while in bud they are entirely enclosed in the large bracts, and when expanded are pure white and very handsome. The fruit is not often perfected.-Fl. July-September. Perennial. 


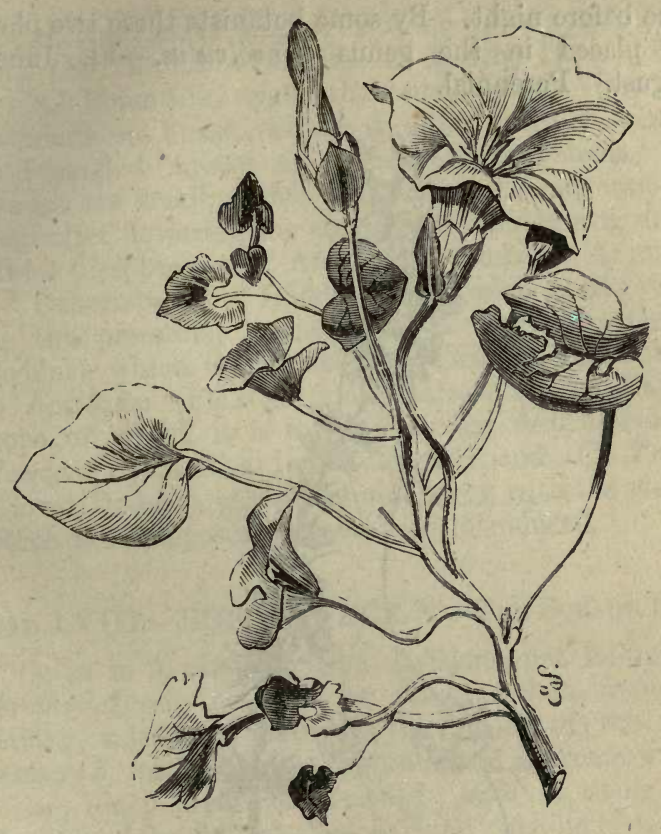

calystégia solda Nella (Sea Bindweed).

2. C. Soldanella (Sea Bindweed).-Stem not climbing; leaves fleshy, roundish, or kidney-shaped; flowers solitary, on 4-sided, winged stalks; bracts large, eggshaped, close to the flower.-A very beautiful species, growing only on the sandy sea-coast, and decorating the sloping sides of sand-hills with its large, pale rosecoloured flowers striped with red. The stems are usually almost entirely buried beneath the sand, and the flowers and leaves merely rise above the surface. The flowers, which are nearly as large as those of the preceding species, expand in the morning, and in bright weather 
close before night. By some botanists these two plants are placed in the genus Convólvulus.-Fl. JuneAugust. Perennial.

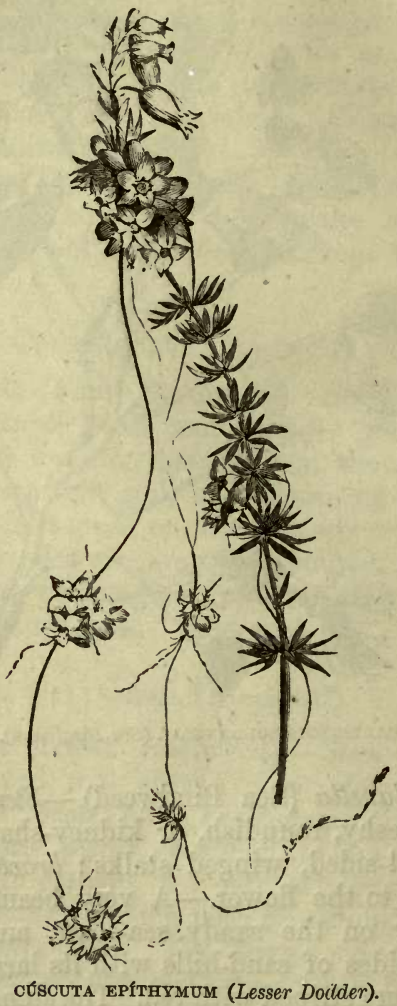

\section{Cúscuta (Dodder).}

1. C. Epithymum (Lesser Dodder).-Stems parasitical, thread-like, branched ; flowers in dense, sessile heads; 
tube of the corolla longer than the calyx; style longer than the corolla.-Parasitic on Heath, Thyme, Milk Vetch, Potentilla, and other small plants, but most abundant on Furze, which it often entirely conceals with tangled masses of red thread-like stems. The flowers are small, light. flesh-coloured, and wax-like. Soon after flowering the stems turn dark-brown, and in winter disappear.-Fl. August, September. Annual.

* Other species of Dodder, which more or less resemble the preceding species, are C. Europaca (Greater Dodder), which is parasitical on Thistles and Nettles; C. Epilinum (Flax Dodder), parasitical on Flax, to crops of which it is sometimes very destructive; $C$. Hassíaca, parasitical on Lucerne; and C. Trifolii (Clover Dodder), parasitical on Clover, with the seeds of which it is supposed to have been introduced.

Ord. LVIII.-BORAGINACEA.-The Borage T'ribe.

Calyx in 5, rarely 4, deep divisions, not falling off ; corolla of one petal, 5- or rarely 4-cleft, frequently having valves or teeth at the mouth of the tube; stamens 5 , inserted into the corolla and alternate with its lobes; ovary 4-parted, 4-seeded; style I, rising from the base of the divided ovary ; fruit consisting of 4, rarely 2 , nut-like, distinct seeds, each enclosed in a pericarp.Herbs or shrubs with alternate leaves, which are usually covered with hairs or bristles rising from a swollen base. This character was considered by Linnæus sufficiently constant to give to the natural order the name of ASPERIFOLIE, or Rough-leaved plants, but the present name of the order is now preferred as being more comprehensive, a few plants in it having perfectly smooth leaves. The Borage Tribe are natives principally of the temperate regions of the northern hemisphere, especially of the warmer parts, and are more numerous in the Old than the New World. Most of them bear their flowers in spikes or clusters, which are rolled up round the ter- 
minal flowers as a centre, and expand a few at a time. The prevailing colour is blue or purple, but many, when first opening, are of a reddish hue, which subsequently deepens, so that it is not unusual to see flowers of different tints in the same spike or cluster. They possess no remarkable properties, but abound in a soft mucilaginous juice, which gives a coolness to beverages in which they are steeped, on which account Borage is a constant ingredient in the drink known as "cool tankard." The roots of Alkanet and some others contain a red substance, which is used as a dye. Comfrey (Sýmphytum officinálé) is sometimes grown as an esculent vegetable, but is little valued except as food for horses. The plants of the genus Myosótis are popularly known by the name "Forget-me-not;" the true Forget-me-not is $M$. Palustris.

1. Échium (Viper's Bugloss).-Corolla irregular, with an open mouth; stamens unequal in length. (Name from the Greek, echis, a viper, against the bite of which it was formerly considered an antidote.)

2. Pulmonaria (Lungwort).-Calyx tubular, 5-cleft ; corolla funnel-shaped, its throat naked; stamens enclosed within the corolla. (Name from the Latin, Pulmo, the lungs, which the spotted leaves were supposed to resemble.)

3. Lithospermum (Gromwell).-Calyx deeply 5-cleft ; corolla funnel-shaped, its throat naked, or with 5 minute scales; filaments short; seeds stony. (Name from the Greek, lithos, a stone, and sperma, seed, from the hardness of the seeds.)

4. Merténsia (Smooth Gromwell).-Calyx deeply 5-cleft; corolla funnel-shaped; filaments long; seeds somewhat fleshy. (Name in honour of M. Mertens a German botanist.)

5. Sýmphyтum (Comfrey).-Calyx deeply 5-cleft; corolla bell-shaped, closed with 5 awl-shaped scales. (Name from the Greek symphyo, to unite, from its imagined healing qualities.) 
6. Borígo (Borage).-Calyx deeply 5-cleft; corolla wheel-shaped, its throat closed with 5 short, erect, notched scales; stamens forked. (Name, a corruption of corago, from cor, the heart, and ago, to bring, from its use in stimulating drinks.)

7. Lrcopsis (Bugloss).-Calyx deeply 5-cleft; corolla funnel-shaped, with a bent tube, its throat closed by prominent blunt scales. (Name in Greek signifying "a wolf's face," from some fancied resemblance between the flower and a wolf's head.)

8. ANchúsa (Alkanet).-Calyx deeply 5-cleft ; corolla funnel or salver-shaped, with a straight tube, its throat closed by prominent blunt scales. (Name from the Greek, anchousa, paint, from the use of its roots as a dye.)

9. Mrosótis (Scorpion Grass, Forget-me-not).-Calyx 5-cleft; corolla salver-shaped, its lobes blunt, twisted when in bud, and its throat nearly closed by blunt scales. (Name in Greek signifying a mouse's ear, from the shape of the leaves.)

10. Asperúgo (Madwort).-Calyx 5-cleft, with alternate smaller teeth; corolla funnel-shaped, with rounded scales in the throat. (Name from the Latin asper, rough, from the excessive roughness of the leaves.)

11. Cynoglossum (Hound's-tongue).-Calyx 5-cleft ; corolla funnel-shaped, with a short tube, its mouth closed by prominent blunt scales ; nuts flattened, prickly. (Name in Greek, signifying a dog's tongue, from the shape and size of the leaves.)

\section{1. Éсніuм (Viper's Bugloss).}

1. $E$. vulgáré (Common Viper's Bugloss).-Rough with prickly bristles ; leaves narrow, tapering; flowers in short lateral spikes; stamens longer than the corolla. -Walls, old quarries and gravel-pits. A handsome plant, $2-3$ feet high, remarkable for its bristly or almost prickly stems and leaves, and numerous curved spikes of flowers, which on their first opening are bright 
rose-coloured and finally of a brilliant blue. The roots are very long, and descend perpendicularly into the loose soil in which the plant usually grows. A variety is occasionally found, with white flowers. The name

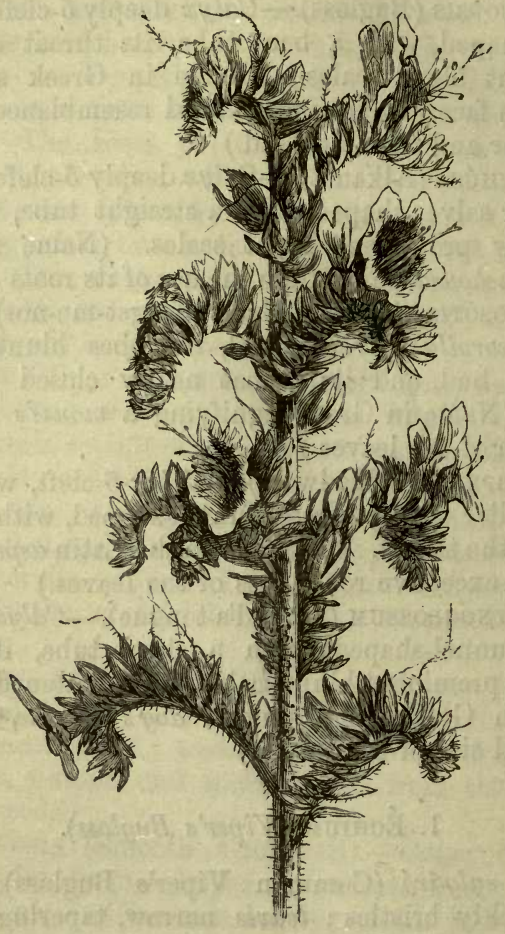

GCHIUM VUlgáR (Common Viper's Bugloss).

Bugloss, which is of Greek origin, signifies an $0 x^{\prime} s$ tongue, from the roughness and shape of the leaves.Fl. June, July. Biennial. 


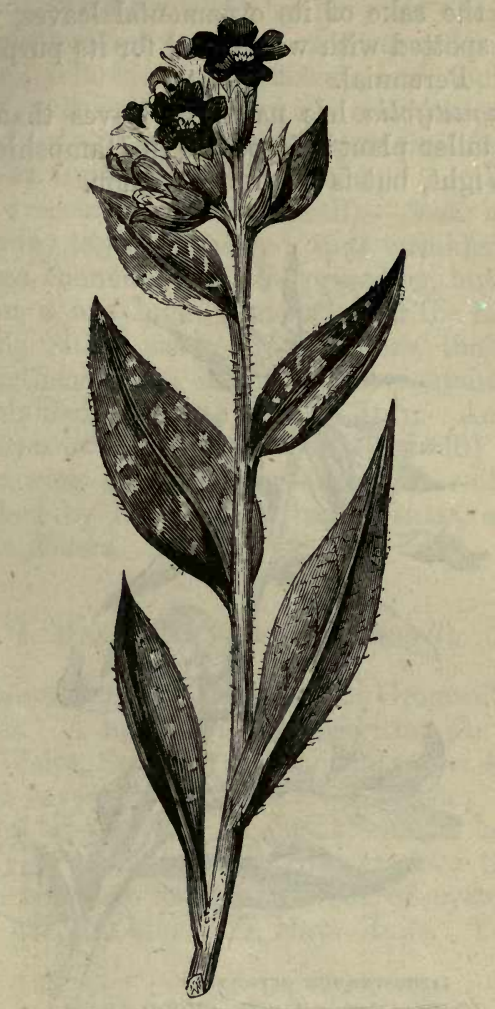

PULMONARIA OFFICINÁLIS (Common Lungwort).

\section{Pulmonaria (Lungwort).}

1. P. officinalis (Common Lungwort).-Leaves rough, lower ones stalked, egg-shaped or heart-shaped at the base, upper, egg-shaped, sessile.-Woods and thickets, rare ; often an outcast from gardens, where it is culti- 
vated for the sake of its ornamental leaves, which are curiously spotted with white, and for its purple flowers. Fl. May. Perennial.

* $P$. angustifolia has narrower leaves than the last, and is a taller plant; it occurs in Hampshire and the Isle of Wight, but is far from common.

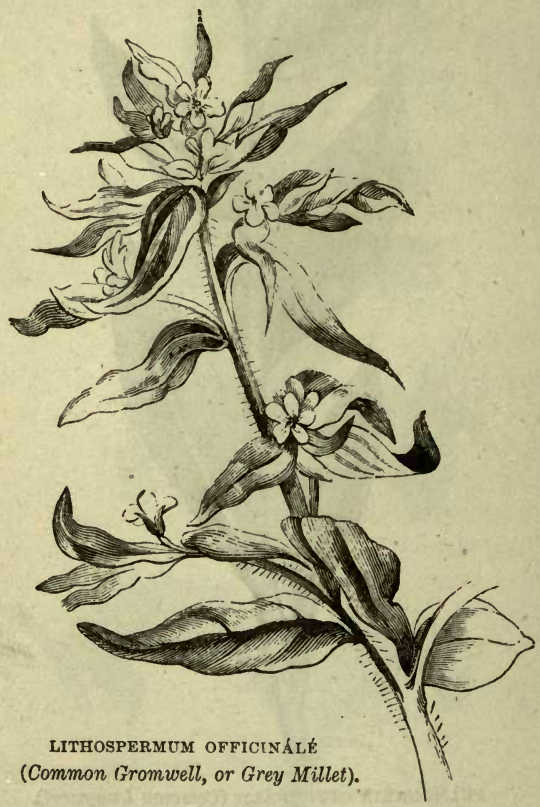

3. Lithospermum (Gromwell).

1. L. officinálé (Common Gromwell, or Grey Millet).Stem erect, much branched towards the summit; leaves oblong, tapering to a point, bristly above, hairy beneath ; nuts polished.-Dry, bushy, and stony places; not 
unfrequent. Distinguished by its erect stems, 2 feet high, which generally grow 5 or 6 from the same root, by its small yellowish white flowers, and above all, by its highly polished seeds, which resemble small seashells, and contain a considerable quantity of pure silica or flint.-Fl. June, July. Perennial.

2. L. arvénsé (Corn Gromwell).-Dtem branched; leaves narrow, tapering, hairy ; nuts wrinkled.-Cornfields; less common than the preceding, but not rare. Stem about a foot high, branched from the lower part, and having rather small white flowers, the calyx of which lengthens when in fruit, and contains 3 or 4 brown, wrinkled seeds.-Fl. May-July. Annual.

* L. púrpuro-ccerúleum (Purple Gromwell) is a rare species growing in chalky or limestone soil, and is distinguished by its prostrate barren stems, and large bright blue flowers.

\section{Merténsia (Smooth Gromwell).}

1. M. marítima (Sea-side Smooth Gromwell).-The only species. A singular plant inhabiting the sea-coast of North Wales, Scotland and Ireland; the leaves are fleshy, and covered with a glaucous bloom; they are destitute of bristles, but are sprinkled with hard dots, which are very evident in dried specimens; the plant when fresh is said to have the flavour of oysters; the flowers are purplish blue.-Fl. May-June. Perennial.

\section{Sýmphitum (Comfrey).}

1. S. officinalé (Common Comfrey).-Stem winged in the upper part; leaves elliptical, pointed, tapering towards the base and running down the stem; flowers drooping, in 2-forked clusters. - Watery places and banks of rivers, commion. A large and handsome plant 2-3 feet high, with branched leafy stems, and several clusters 


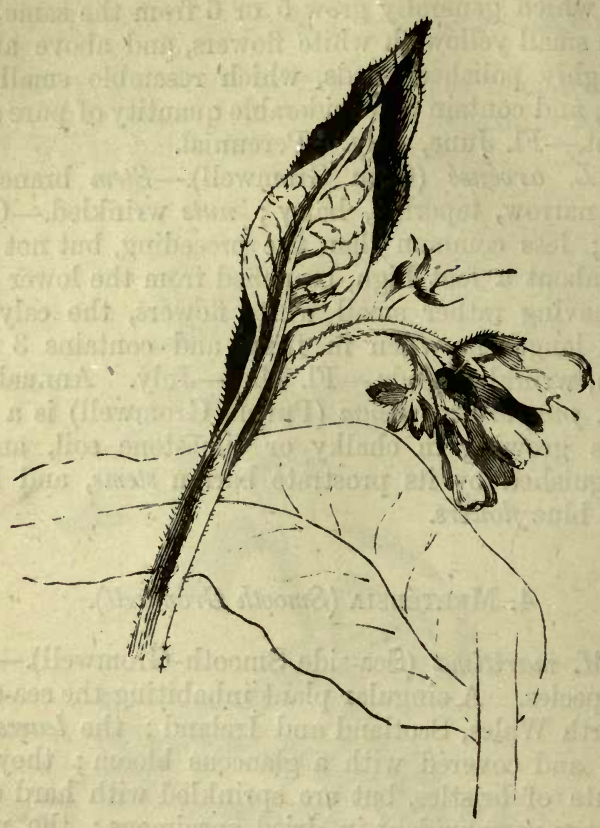

Sצ́MPHYTUM OFFiCiNálk (Common Comfrey).

of white, pink, or purple drooping flowers. Often introduced into gardens, from which it is very difficult to eradicate it when it has once established itself, owing to the brittleness of its fleshy roots, the least bit of which will grow.-Fl. May-August. Perennial.

* S. tuberésum (Tuberous Comfrey) is a more slender plant than the preceding, and is very rare, except in Scotland; the stem is scareely branched, and but slightly winged. 


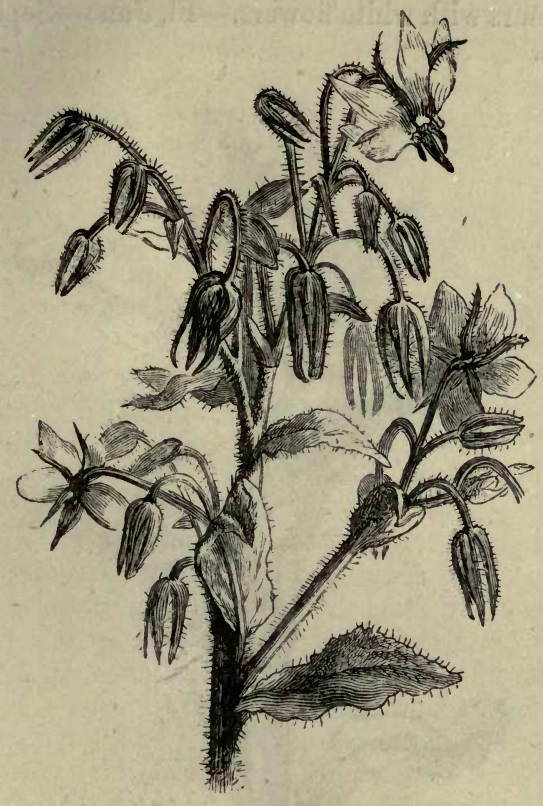

BORÁBO OFHIC NaLIS ('Ummon Borage).

\section{Borágo (Borage).}

1. B. officinális (Common Borage).-The only British species, not unfrequent in waste ground, especially near buildings. The stems are about 2 feet high, and, as well as the leaves, are thickly covered with stiff whitish bristles; the flowers, which are large, deep blue, and very handsome, grow in terminal drooping clusters, and may readily be distinguished from any other plant in the order by their prominent black anthers. The juice has the smell and flavour of cucumber, and is an ingredient in the beverage called "cool tankard." A variety some- 
times occurs with white flowers._Fl. June-September. Biennial.

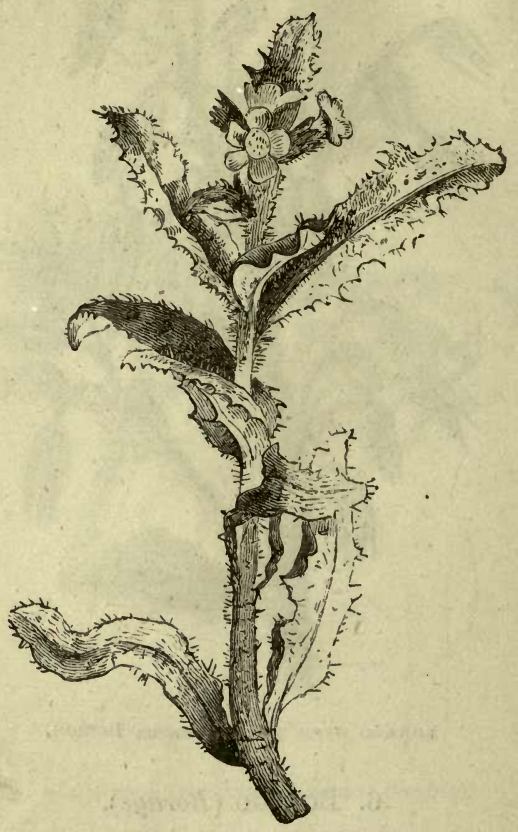

LYCopsis ARvínsis (Small Bugloss).

\section{Lycopsis (Bugloss).}

1. $L$. arvensis (Small Bugloss).-The only British species, common in waste ground, and on the sea-coast. A branched prickly plant, 6-18 inches high, with oblong wavy leaves, and forked, curved clusters of minute blue flowers, the tube of which is bent; in which respect it is unlike any other British plant of the order.-Fl. June, August. Annual. 


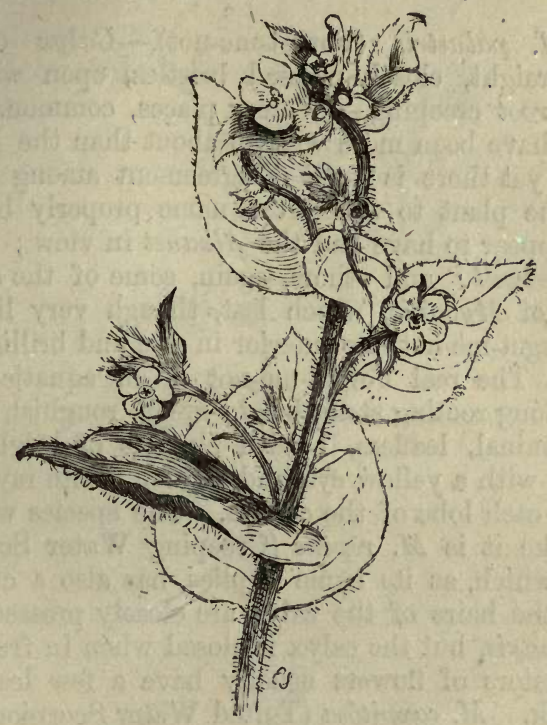

ANCHÚSA SEMPERVfRENS (Evergreen Alkanet).

\section{Anchúsa (Alkanet).}

1. A. sempervírens (Evergreen Alkanet).-A stout bristly plant, with deep green, egg-shaped leaves, and short spikes of rather large, salver-shaped flowers, which are of an intense azure blue. It is not generally considered to be a native, but in Devonshire it is not an uncommon hedge-plant.-Fl. June-August. -Perennial.

* A. officinalis (Common Alkanet) has purple, funnel-shaped flowers, which grow in 1-sided spikes, the segments of the calyx being longer than the corolla. It is frequent in gardens, from which it is supposed to have escaped; but it is not common in a wild state. 
9. Mrosótis (Mouse-ear, Scorpion-grass, Forget-me-not).

1. M. palustris (Forget-me-not).-Calyx covered with straight, closely-pressed bristles, open when in fruit; root creeping.-Watery places, common. Few flowers have been more written about than the Forgetme-not, yet there is great disagreement among writers as to the plant to which the name properly belongs. Some appear to have had the Alkanet in view ; others, the Speedwell; and others, again, some of the smaller species of Myosotis, which last, though very like the true Forget-me-not, are inferior in size and brilliancy of colour. The real Forget-me-not is an aquatic plant, with a long rooting stem, bright-green, roughish leaves, and terminal, leafless, 1-sided clusters of bright blue flowers, with a yellow eye, and a small white ray at the base of each lobe of the corolla. The species which is most like it is $M$. repens (Creeping Water Scorpiongrass), which, as its name implies, has also a creeping root; the hairs of the calyx are closely pressed, as in M. palustris, but the calyx is closed when in fruit, and the clusters of flowers usually have a few leaves on the stalk. $M$. coespitósa (Tufted Water Scorpion-grass) resembles the above, but has a fibrous root, and the flowers of both the last are smaller than those of $M$. palustris. All three grow in watery places; $M$. palustris being most common, and flowering from June to October, $M$. repens least so, and, as well as $M$. coespitósa, not flowering so late in the year. Three other and yet smaller species are common, but these do not grow in watery places, and are of a different habit.

2. M. arvensis (Field Scorpion-grass).-Calyx covered with spreading, hooked bristles, closed when in fruit; stalks of the fruit spreading.-In cultivated ground, hedges, and groves, abundant. Whole plant roughish with spreading bristles ; the stems are from $6-18$ inches high, or more; the flowers blue, small, but very beau- 
tiful. This is the commonest species of all,-Fl. JuneAugust. Annual.

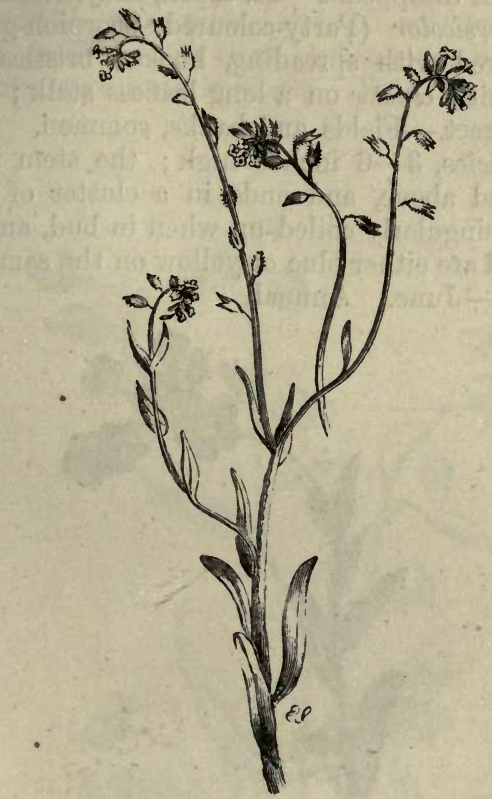

MYOSOTIS VERSICOLOR (Party-ioloured Scorpion-grass).

3. M. collína (Early Field Scorpion-grass).-Calyx covered with spreading hooked bristles, open when in fruit; cluster with a solitary flower in the axil of the uppermost leaf.-Dry banks, not uncommon, but frequently overlooked in consequence of its minute size. The whole plant rarely exceeds 3 inches in length; the stems usually spread near the ground, and terminate in clusters of very minute brightblue flowers (never pink or yellow). On its first appearance, in April, the flowers are 
buried among the leaves, but the stems finally lengthen into clusters, and as the season advances the whole plant dries up, and disappears.-Fl. April, May. Annual.

4. M. versícolor (Party-coloured Scorpion-grass).Calyx covered with spreading, hooked bristles, closed when in fruit; cluster on a long leafless stalk; stalk of the fruit erect.-Fields and banks, common. A very distinct species, 3-6 inches high; the stem is leafy below, naked above, and ends in a cluster of flowers which are singularly coiled up when in bud, and when they expand are either blue or yellow on the same plant. -Fl. April-June. Annual.

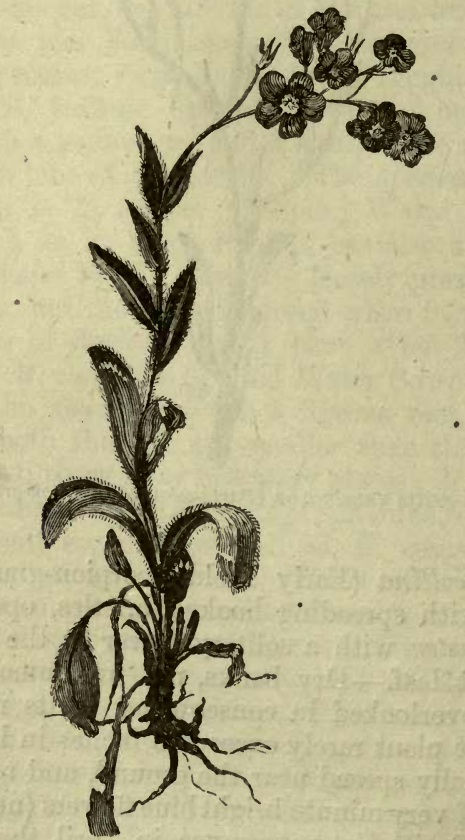

MYosótis ALPESTRIS (Mountain Forget-me-not). 
* There are two other British species of Myosótis, which approach the Forget-me-not in the size and beauty of their flowers-M. alpestris, which grows on the Scottish mountains, and $M$. sylvática, which is almost confined to Scotland and the north of England, where it grows in shady places. Both these species have

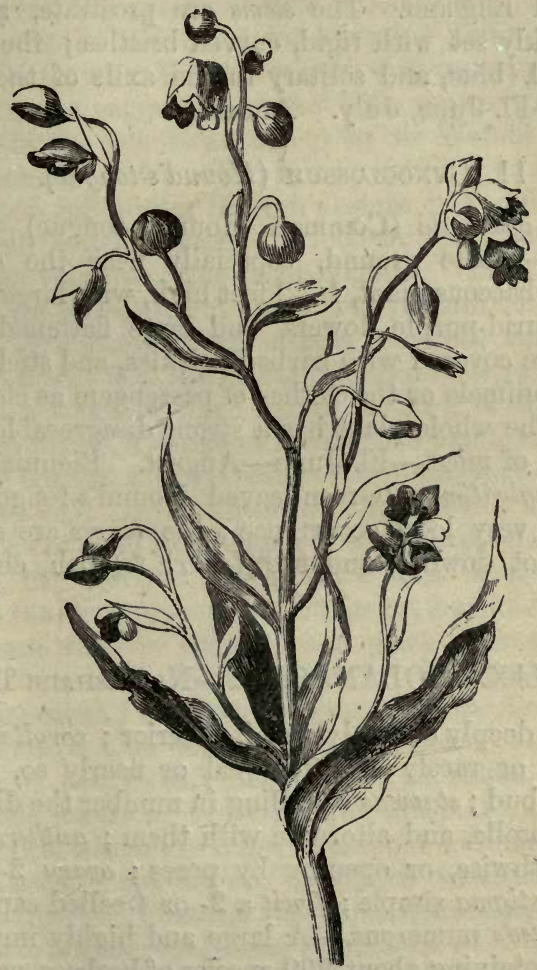

- crnoglossom officinálé (Common Hound's-Tongue). 
spreading bristles on the calyx. For a description of two foreign species well worthy of being cultivated, see "Gardening for Children."

\section{Asperúgo (Madwort).}

1. A. procumbens (German Madwort).-The only species occurring, very sparingly, in Scotland and the north of England. The stems are prostrate, angular, and thickly set with rigid, curved bristles ; the flower's are small, blue, and solitary in the axils of the upper leaves.-Fl. June, July. Annual.

\section{Cynoglossum (Hound's-tongue).}

1. C. officinálé (Common Hound's-tongue).-Leaves downy.-Waste ground, especially near the sea. A stout herbaceous plant, $1-2$ feet high, with large downy leaves, lurid-purple flowers, and large flattened seeds, which are covered with barbed prickles, and stick to the wool of animals or the clothes of passengers as closely as burs. The whole plant has a strong disagreeable smell, like that of mice.-Fl. June-August. Biennial.

* C. sylváticum (Green-leaved Hound's-tongue) is a plant of very local occurrence; the leaves are shining above (not downy), and the flowers reddish, changing to blue.

\section{Ord. LIX.—SOLANACEA.-Nightshade Tribe.}

Calyx deeply 5- rarely 4-cleft, inferior ; corolla of one petal, 5- or rarely 4-cleft, equal or nearly so, plaited when in bud; stamens equalling in number the divisions of the corolla, and alternate with them ; anthers bursting lengthwise, or opening by pores ; ovary 2-celled; style 1 ; stigma simple; fruit a 2-or 4-celled capsule or berry; seeds numerous. - A large and highly important order, containing about 900 species of herbaceous plants or shrubs, which inhabit most parts of the world except 
the coldest, and are most abundant within the tropics. The prevailing property of plants belonging to the Nightshade Tribe is narcotic, and many are, in consequence, highly poisonous ; in others, certain parts of the plant have poisonous properties, the rest being harmless, and some even contain a large quantity of nutritious matter. The genus Solánum is a very extensive one, comprising as many as 600 species. First among these in importance stands the Potato ( $S$. tuberósum), a native of Chili, Lima, Quito, and Mexico, which was introduced into Spain in the early part of the 16th century, and into Ireland by the colonists sent out by Sir Walter Raleigh, who brought it from Virginia in 1586 . It was first planted on Sir Walter Raleigh's estate at Youghall, near Cork, and was cultivated for food in that country long before its value was known in England. Its leaves and berries are narcotic, but its tubers contain no noxious matter, abounding in an almost tasteless starch; on which account it is less liable to cloy on the palate than any other vegetable food except bread. S. Melongena (the Egg-plant), a common greenhouse plant, is remarkable for bearing a large berry of the size and colour of a pullet's egg. S. Dulcamára, (Nightshade, or Bittersweet,) a common English plant, with purple and yellow flowers, has narcotic leaves and scarlet berries, which possess the same property. S. nigrum, a smaller species, a common weed in England and most other countries, except the coldest, has white flowers and black berries. It is narcotic to a dangerous degree. Átropa Belladonna, a stout herbaceous plant, with dingy purple bell-shaped flowers, is the Deadly Nightshade, so called from the poisonous nature of every part of the plant, especially the berries, which are large, black and shining, and of a very attractive appearance. Its juice possesses the singular property of dilating the pupil of the eye, on which account it is extensively used by oculists when operations are to be performed. The Mandrake (Mandrágora officinalis) was anciently thought to possess miraculous 
properties. It was said to shriek when taken from the ground, and to cause the instant death of any one who heard its cries. The person who gathered it, therefore, always stopped his ears with cotton, and harnessed a dog to the root, who, in his efforts to escape, uprooted the plant, and instantly fell dead. The forked root was then trimmed so as to resemble the human form, a berry being left to represent the head. The fruit is eatable. Tobacco is the foliage of several species of Nicotiana, a violent poison when received into the stomach, though commonly employed in other ways without apparent ill effects. Hyoscyamus niger, or Henbane, is a stout herbaceous plant, with sticky, foetid leaves, and cream-coloured flowers veined with purple; it is a powerful narcotic, and in skilful hands scarcely less valuable than opium. Datúra Stramonium (Thorn-apple) bears large, white, trumpet-shaped flowers, and prickly seed-vessels ; it is also a dangerous poison, though employed with good effect in several nervous and other disorders, especially asthma. Physalis Alkekengi is the Winter Cherry, remarkable for bearing a crimson berry enclosed in the enlarged calyx, which after exposure to the wet, decays, leaving the berry hanging within a case of network. The genus Cápsicum affords Cayenne pepper, which is prepared by grinding the dried seed-vessels with their contents. Finally, Lycopérsicum produces Tomatoes or Love Apples, which are much used in making sauce.

1. SolÁnum (Nightshade).-Corolla wheel-shaped, 5cleft, the segments spreading or reflexed; anthers opening by 2 pores, at the summit; berry roundish, with 2 or more cells. (Name of doubtful origin.)

2. Átropa(Deadly Nightshade).-Corolla bell-shaped, with 5 equal lobes; stamens distant; berry of two cells. (Name from Átropos, one of the Fates, who was supposed to cut the thread of human destiny.)

3. Hyoscýamus (Henbane).-Corolla funnel-shaped, with 5 unequal lobes; capsule 2-celled, closed by a lid. (Name in Greek signifying Hog's-bean.) 


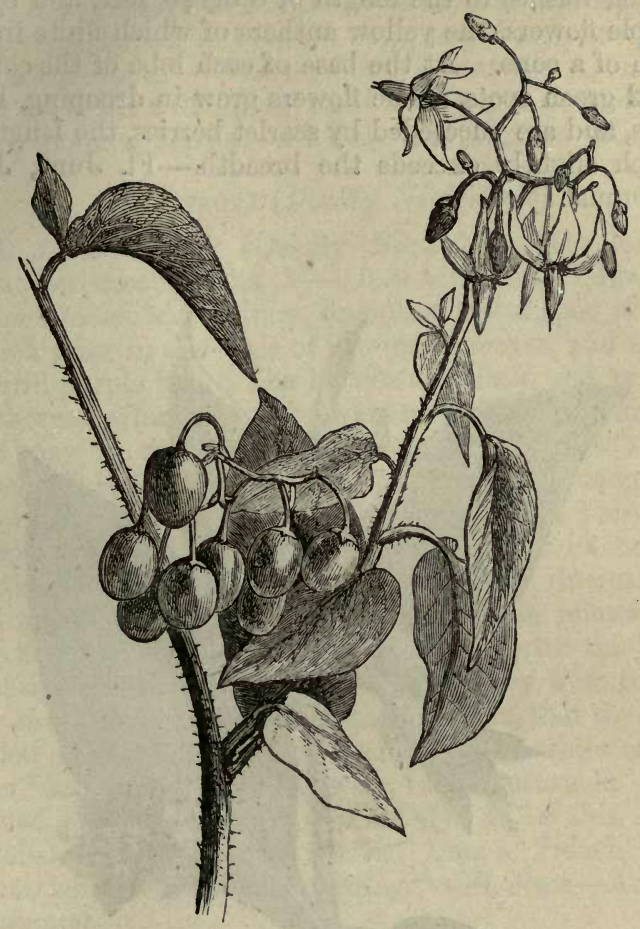

Solánum dulcamára (Woody Nightshade, Bittersweet).

\section{Solánum (Nightshade).}

1. S. Dulcamára (Woody Nightshade, Bittersweet).Stem shrubby, climbing; leaves heart-shaped, the upper ones eared at the base ; flowers drooping.-Damp hedges and thickets, common. This plant, which is frequently though incorrectly, called Deadly Nightshade, is well marked by its straggling, woody stem, which climbs 
among bushes to the length of 8 or 10 feet, and by its purple flowers, the yellow anthers of which unite in the form of a cone. At the base of each lobe of the corolla are 2 green spots. The flowers grow in drooping, loose tufts, and are succeeded by scarlet berries, the length of which slightly exceeds the breadth.-Fl. June, July. Perennial.

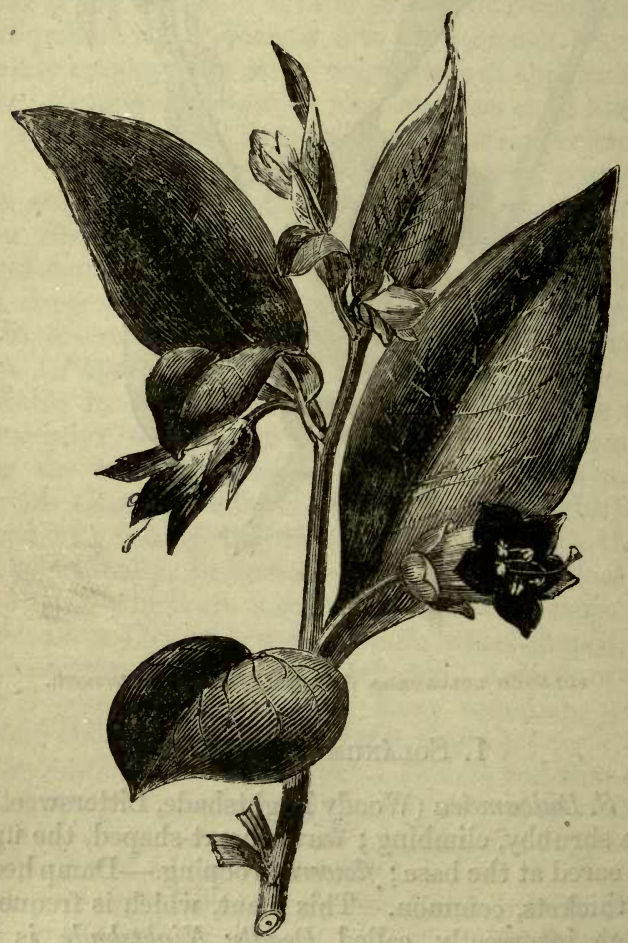

ÁTROPa BELLADONNa (Deadly Nightshade, Dwale). 
2. S. nigrum (Black Nightshade).-Stem herbaceous; leaves egg-shaped, wavy at the edge, and bluntly toothed; flowers drooping.-Waste ground, common. A branching herb, with drooping umbels of white flowers and black globular berries.-Fl. July - September. Annual.

\section{2. Átropa (Deadly Nightshade).}

1. A. Belladonna (Deadly Nightshade, Dwale).-A stout herbaceous plant, 3-4 feet high, with large eggshaped leaves, and solitary, drooping, bell-shaped flowers, which grow in the axils of the upper leaves, and are of a lurid purple hue. The berries are black, and as large as cherries, which they somewhat resemble in appearance, but may be readily distinguished by the calyx at the base. This noxious plant, which is the most dangerous growing in Britain, on account of its active poisonous properties and the attractive appearance of its berries, is fortunately of rare occurrence, growing principally in old quarries and among ruins. Buchanan relates that the Scots mixed the juice of Belladonna with the bread and drink, with which by their truce they were to supply the Danes, which so intoxicated them, that the Scots killed the greater part of Sweno's army while asleep. The "insane root that takes the reason prisoner," mentioned by Shakspeare, is also thought to be this. The English name Dwale is derived from a French word deuil, which signifies "mourning."-Fl. June-August. Perennial.

\section{Hroscŕamus (Henbane).}

1. H. niger (Common Henbane).-The only British species, common in waste places, especially on a chalky soil or near the sea. An erect, branched, herbaceous plant, 2-3 feet high, with large,' viscid, hairy leaves, and numerous funnel-shaped, cream-coloured flowers with purple veins and a dark eye. The flowers are arranged in rows along one side of the stem, and are succeeded by 2-celled capsules, which are enclosed by the calyx, and 
covered by a lid which falls off when the seeds are ripe. The whole plant has an exceedingly disagreeable smell, and is dangerously narcotic, especially at the time when

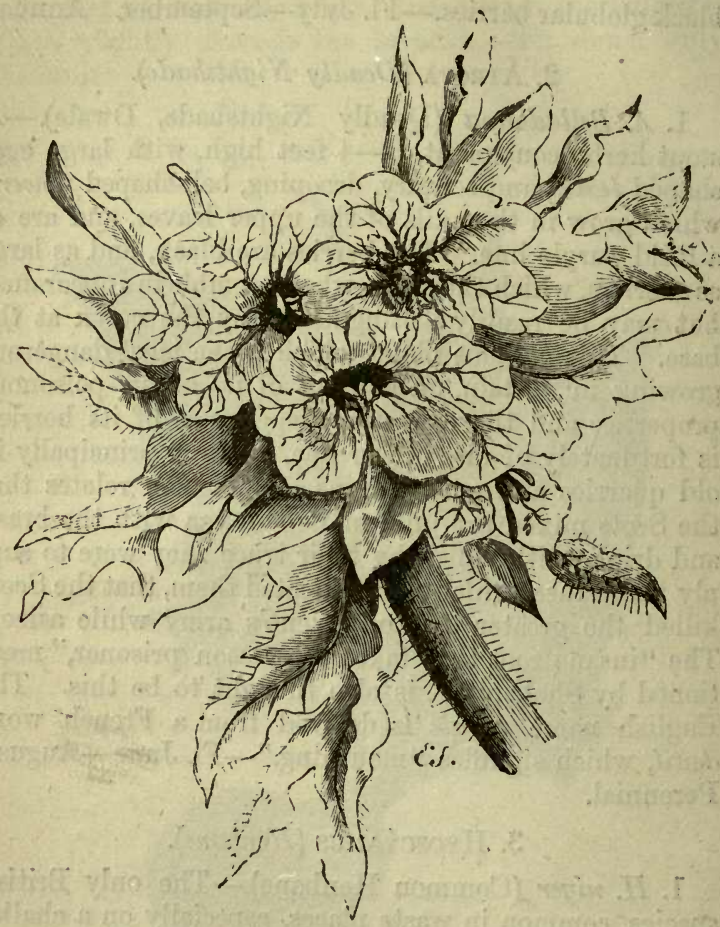

hyoscramus niaer (Common Henbane).

the seeds are ripening. An extract is used in medicine, and is often of great service, producing the effect of opium without the unpleasant symptoms which frequently follow the administration of that drug. The 
capsules and seeds of Henbane, smoked like tobacco, are a rustic remedy for the tooth-ache ; but convulsions and temporary insanity are said to be sometimes the consequences of their use.-Fl. June, July. Annual or Biennial.

\section{ORD. LX.-OROBANCHACEA.-BROOM-RAPE TrIBE.}

Calyx variously divided, not falling off ; corolla irregular, usually 2-lipped, imbricated in the bud; stamens 4, 2 long and 2 short; anthers often pointed or bearded at the base ; ovary in a fleshy disk, many-seeded; style 1 ; stigma 2-lobed; capsule 2-valved; seeds small, numerous, attached to the valves of the capsule in 2-4 rows. - A tribe of herbaceous plants, distinguished by a stout succulent stem, which is of a peculiar dingy red hue, bearing no leaves, but more or less clothed with taper-pointed scales, which are most abundant about the swollen base of the stem. The flowers are large for the size of the plant, and in all British species are of nearly the same hue as the stem, and arranged in a spike not unlike a head of asparagus, with one or more scale-like bracts at the base of each flower. All the species are parasitical on the roots of other plants. The seeds, it is said, will lie buried for some years in the ground without vegetating, until they come in contact with the young roots of some plant adapted to their wants, when they immediately sprout, and seize on the points of the roots, which swell, and serve as a base to the parasite. There are but two British genera belonging to this order, Orobánché and Lathroea, of which some attach themselves to particular species ; others infest particular tribes, and others, again, have a wider range of subjects. Several of those belonging to the genus Orobánché are very difficult of discrimination; botanists, indeed, are not agreed as to the number of species ; some uniting under a common name specimens found growing on various plants ; others considering a slight variation in structure, 
joined to a difference of situation, enough to constitute a specific distinction.

1. Orobínché (Broom-rape).-Calyx of two lateral sepals, which are usually 2-cleft, and often combined in front, with $1-3$ bracts at the base; corolla gaping, 4-5-cleft, not falling off.-(Name from the Greek, órobos, a vetch, and ancho, to strangle, from the injurious effects produced in the plants to which they attach themselves.)

2.LATHReA(Tooth-wort).-Calyx bell-shaped, 4-cleft; corolla gaping, 2-lipped, the upper lip arched, entire, not falling off.-(Name in Greek signifying concealed, from the humble growth of the plants among dead leaves.)

\section{Orobánché (Broom-rape). \\ * Bracts one to each flower.}

1. O. major (Greater Broom-rape).-Corolla tubular, the lower lip in 3 lobes, of which the middle one is blunt and longer than the others; stamens smooth below, downy above ; style downy.-On the roots of Furze, Broom, and other plants of the order Leguminosa, frequent. A stout, leafless, club-like plant, much swollen at the base, of a reddish-brown hue, viscid and clothed with tapering seales, which pass into bracts as they ascend the stem. The flowers are of a pinkish-brown hue, and are crowded into a dense spike. The juice is bitter and astringent, and has been used medicinally.-Fl. June, July. Perennial.

2. O. minor (Lesser Broom-rape).-Stamens hairy below, smooth above; style nearly smooth.-Under this description are included several species, or varieties, which are parasitical severally on Clover, Ivy, and SeaCarrot. They all resemble the last in habit, but are of smaller size.

* To this group belong 0. caryophyllacea (Clovescented Broom-rape), a species with hairy stamens, and 


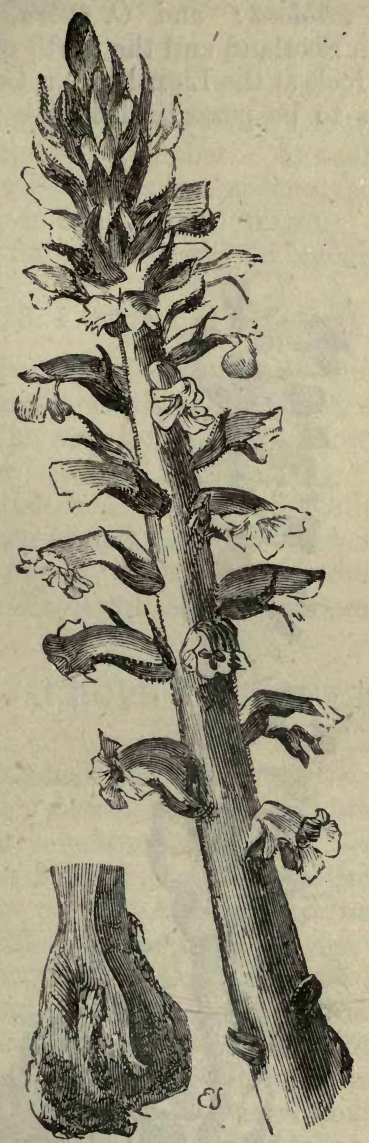

OROBÁNCHé MAJOR (Great Broom-rape).

a dark purple stigma; growing in Kent, on the roots of Galium Mollúgo: O. elatior, a rare species, parasitical G G 2 
on Centauréa scabiosá: and O. mubra, abundant on basaltic rock in Scotland and the north of Ireland, and on magnesian rock at the Lizard Point, Cornwall. This species appears to be parasitical on the roots of Wild Thyme.

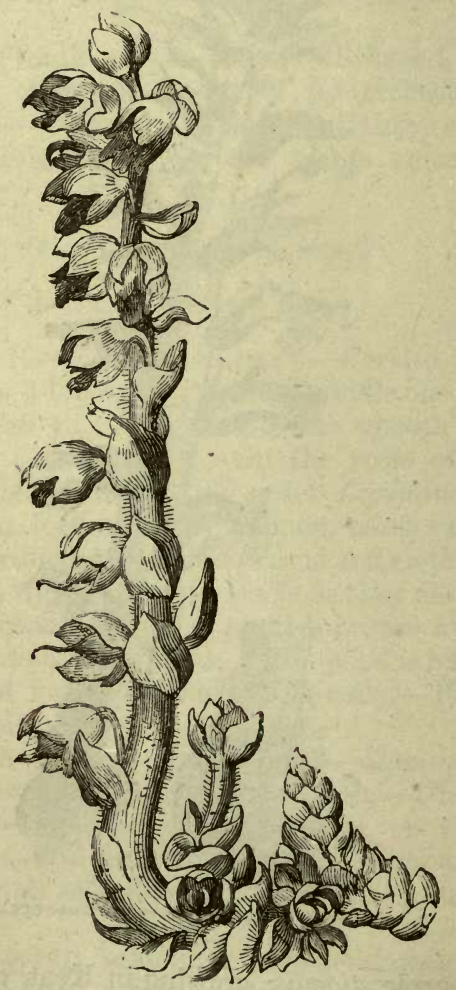

LATHRAA SQUTAMÁRIA (ToOthwort). 


\section{* Bracts 3 under each flower.}

3. O. ramósa (Branched Broom-rape).-Stem branched. -On the roots of Hemp, very rare. Distinguished from the preceding by its lighter colour, and branched stem.-Fl. August, September. Annual.

* 0 . coerulea is another rare species, found in Norfolk, Hertfordshire, and the Isle of Wight. It may be distinguished by its 3 bracts, and its bluish-purple hue.

\section{LathraAa (Tooth-wort).}

1. L. squamária (Tooth-wort).-The only British species, growing in woods and thickets, on the roots of the Hazel. The stem is branched below the surface of the ground, or withered leaves among which it grows; it is of a lightish hue, and thickly clothed with toothlike scales; each branch bears a 1-sided cluster of drooping purplish flowers, with rather broad bracts at the base of each.-Fl. April, May. Perennial.

\section{ORD. LXI.-SCROPHULARIACEAE-FIG-WORT} TrIBE.

Calyx 4-5-lobed, not falling off; corolla irregular, often 2-lipped; stamens usually 4, 2 long and 2 short (didynamous), sometimes 2 or 5 ; ovary 2-celled; style 1 ; stigma 2-lobed ; capsule 2-celled, 2-4-valved, or opening by pores.-A large and important order, containing nearly two thousand species, of which some are shrubs, but the greater number are herbaceous, inhabiting all parts of the world, from the Arctic regions to the tropics. The general character of the species is acrid and bitterish, and some have powerful medicinal properties. The powdered leaves of Foxglove (Digitális purpúrea) lower the pulse, and, if taken in large doses, are poisonous. Euphrásia (Eye-bright), the "Euphrasy" of Milton, makes a useful eye-water. Among foreign species, Gratiola is said to be the active ingredient in 
the famous gout medicine, "Eau médicinale." Foxglove, Snapdragon, Mullein, and Toad-flax, have showy and ornamental flowers ; and several kinds of Speedwell (Verónica) are deservedly admired for their small but elegant blue flowers.

\section{* Stamens 4, 2 long and 2 short (didynamous).}

1. Digitális (Foxglove).-Calyx in 5 deep, unequal segments ; corolla irregularly bell-shaped, with $4-5$ shallow lobes; capsule egg-shaped.-(Name from the Latin digitálé, the finger of a glove, which its flowers resemble.)

2. Antirrhínum (Snapdragon).-Calyx 5-parted ; corolla personate, swollen at the base (not spurred), its mouth closed by a palate ; capsule oblique, opening by pores at the top.- (Name in Greek signifying opposite the nose; from the mask-like appearance of the flowers.)

3. LiNíria (Toad-flax).-Like Antirrhinum, except that the corolla is spurred at the base.-(Name from Linum, Flax, which the leaves of some species resemble.)

4. ScropHUlaria (Fig-wort). - Calyx 5-lobed; corolla nearly globose, with two short lips, the upper 2-lobed, with a small scale within, the lower 3-lobed; capsule opening with 2 valves, the edges of which are turned in. -Name from the disease for which the plant was formerly thought a specific.)

5. Limosella (Mudwort).-Calyx 5-cleft; corolla bell-shaped, 5-cleft, equal ; capsule globose, 2-valved.(Name from the Latin limus, mud, from the character of the places in which the plant grows.)

6. Melampírum (Cow-wheat).-Calyx tubular, with 4 narrow teeth ; corolla gaping, upper lip flattened vertically, turned back at the margin, lower lip 3-cleft; capsule oblong, obliquely pointed, flattened; seeds 1 or 2 in each cell.-(Name in Greek signifying black wheat, the seeds, when ground and mixed with flour, being said to make it black.) 
7. Pedicularis (Red-rattle).-Calyx inflated, its segments somewhat leafy; corolla gaping, upper lip arched, flattened vertically, lower lip plane, 3-lobed; capsule flattened, oblique; seeds angular.-Name in allusion to the disease produced in sheep which feed in places where it gŕows.)

8. Rhinanthus (Yellow-rattle).-Calyx inflated, 4toothed; corolla gaping, upper lip flattened vertically, lower lip plane, 3-lobed; capsule flattened, blunt; seeds numerous, flat and bordered.-(Name in Greek signifying nose-flower, from its peculiar shape.)

9. Bartsia.-Calyx tubular, 4-cleft ; corolla gaping, with a contracted throat, upper lip arched, entire, lower lip 3-lobed; lobes bent back ; capsule flattened, pointed; seeds numerous, angular.-(Name in honour of John Bartsch, a Prussian botanist.)

10. Euphrasia (Eye-bright).-Calyx tubular, 4-cleft ; corolla gaping, upper lip divided, lower lip in 3 nearly equal lobes; anthers spurred at the base; capsule flattened, blunt or notched; seeds numerous, ribbed.(Name from the Greek, Euphrósyne, gladness, from the valuable properties attributed to it.)

11. Sibthorpia (Cornish Money-wort).-Calyx in 5 deep spreading segments ; corolla wheel-shaped, 5-cleft, nearly regular ; capsule nearly round, flattened at the top.- (Name in honour of Dr. Sibthorp, formerly professor of botany at Oxford.)

\section{* Stamens 2.}

12. Verónica (Speedwell).-Corolla wheel-shaped, unequally 4-cleft, lower segment the narrowest.-(Veronica is the name of a saint in the Romish Church, but why given to this plant is unknown.)

\section{*** Stamens 5 .}

13. Verbascum (Mullein).-Calyx 5-parted; corolla wheel-shaped, 5-cleft, irregular ; stamens hairy.-(Name 
from the Latin barba, a beard, from the shaggy leaves of some species.)

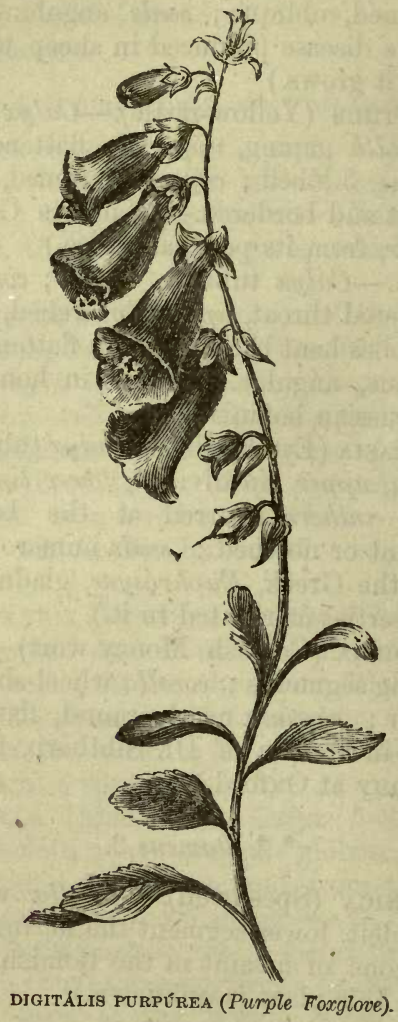

\section{Digitális (Foxglove).}

1. D. purpuirea (Purple Foxglove).-The only British species, common in many of the hilly districts of Great 
Britain, but almost unknown in the plains. A stately plant, 2-6 feet high, with large wrinkled leaves, and a tall stem, bearing numerous handsome, purple, bellshaped flowers, which are arranged in the form of a tapering spike, and droop after expansion. On the inside the flowers are beautifully spotted; occasionally they are found of a pure white ; but though this variety is elegant, it is by no means so striking a plant as the other. The name Foxglove is by some supposed to be a corruption of folk's glove ; that is, Fairies' gloves. The powdered leaf is a valuable medicine in cases where it is desired to lower the pulse.-Fl. June, July. Biennial.

\section{ANTiRrhínum (Snapdragon).}

1. A. majus (Great Snapdragon).-Leaves narrow, tapering; spikes many-flowered; sepals egg-shaped, blunt, much shorter than the corolla.-In limestone quarries, chalk-pits, and on old walls, common. A handsome plant, with numerous leafy stems, each of which bears a spike of large, erect, personate flowers of a purple hue sporting to rose-colour or white. Specimens are common in gardens, the tints of which vary considerably; the most beautiful is of a rich crimson ; one of a delicate lemon-colour is also frequent. Children derive much amusement from pinching the flowers between the finger and thumb, when the palate opens, as if in imitation of the fabulous monster from which it derives its name.Fl. June-August. Perennial.

2. A. Oróntium (Lesser Snapdragon).-Leaves very narrow, tapering; spikes few-flowered; sepals much longer than the corolla.-Corn-fields, not uncommon. Smaller than the last, and at once distinguished by its leafy sepals, which are much longer than the small purple flowers.-Fl. July-September. Annual.

\section{Linaria (Toad-flax).}

1. L. vulgáris (Yellow Toad-flax).-Leaves linear, tapering to a point, crowded; flowers in dense spikes; 


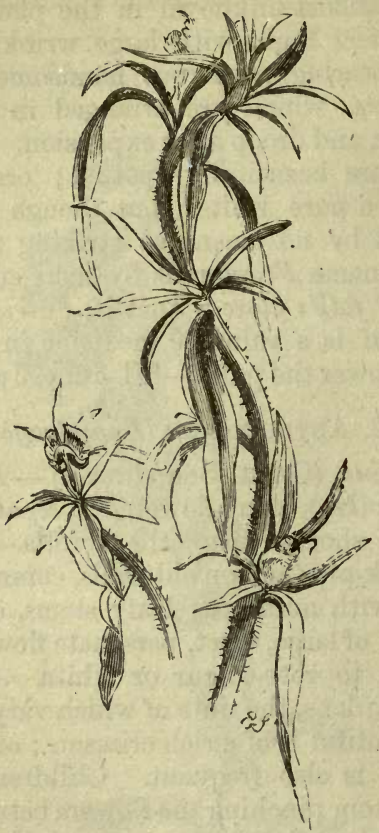

ANTIRRHINUM ORONTIUM (Lesser Snapdragon).

sepals smooth, shorter than the spur or capsule.-Hedges, very common. An erect herbaceous plant, 1-2 feet high, with numerous grass-like leaves of a glaucous hue, and dense spikes or clusters of yellow flowers, which are shaped like those of the Snapdragon, but spurred at the base. A variety is sometimes found with a regular corolla and five spurs.-Fl. August, September. Perennial.

2. L. Elatiné (Sharp-pointed Fluellen, or Toad-flax). -Leaves halbert-shaped; stem trailing.-Corn-fields, 
frequent. A small prostrate plant, with downy stem and leaves ; solitary, axillary flowers, of which the upper lip is deep purple, the lower, yellow.-Fl. July-September. Annual.

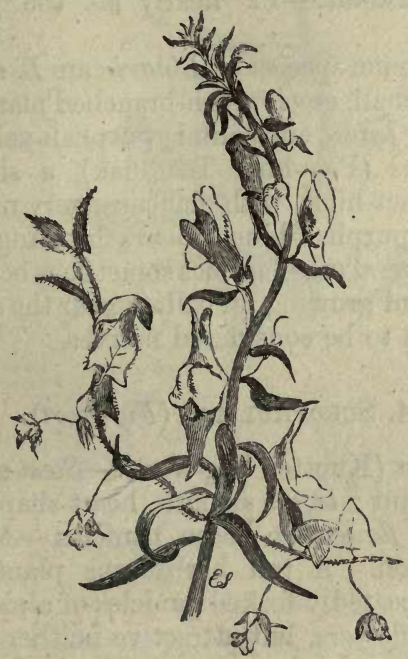

LINÁRIA VULGÁRIS (Yellow Toad-flax), and LINÁRIA ELÁTINE (Sharp pointed Fluellen, or Toad-flax).

3. L. spuria (Round-leaved Toad-flax).-Leaves eggshaped; stem trailing.-Corn-fields, not general. Resembling the last so closely, that it might be mistaken for a luxuriant specimen. The flowers are of the same colour, but larger ; the leaves, however, are always rounded at the base, not halbert-shaped.-Fl. JulySeptember. Annual.

4. L. Cymbalária (Ivy-leaved Toad-flax).-Leaves heart-shaped, 5-lobed, smooth ; stem creeping.-On old garden walls, common. Not a native species, but quite 
naturalized; growing freely from seed, and extending widely, by help of its long, rooting stems. The flowers are small, solitary, and light purple ; the leaves somewhat fleshy, and of a purple hue beneath. In the west of England it is commonly known by the name of Mother-of-thousands.-Fl. nearly all the year round. Perennial.

* Less common species of Linaria are $L$. minor (Least Toad-flax), a small, erect, much-branched plant, with very narrow downy leaves, and solitary purplish-yellow flowers: and $L$. repens (Pale-blue Toad-flax), a slender, erect plant, 1-2 feet high, with glaucous, very narrow leaves, and veined, purplish-blue flowers growing in spiked clusters. Several other species sometimes occur as weeds in gardens, and growing on ballast near the sea, but they have no claim to be considered natives.

\section{Scrophulária (Fig-wort).}

1. S. nodósa (Knotted Fig-wort).-Stem square, with the angles blunt; leaves smooth, heart-shaped, tapering to a point ; flowers in loose panicles.-Moist bushy places, common. A tall herbaceous plant, 3-4 feet high, with repeatedly-forked panicles of almost globular, dingy purple flowers, but attractive neither in form nor colour.-Fl. June, July. Perennial.

2. S. aquática (Water Fig-wort). - Stem square, with the angles winged; leaves smooth, heart-shaped, oblong, blunt; flowers in close panicles.-Sides of streams and ditches, common. Resembling the last, but at once distinguished by the winged angles of its stems, which, though hollow and succulent, are rigid when dead, and prove very troublesome to anglers, owing to their lines becoming entangled in the withered capsules.-Fl. July, August. Perennial.

* S. Scorodónia (Balm-leaved Fig-wort) is found only in Cornwall, and at Tralee, in Ireland ; it is distinguished by its downy, wrinkled leaves : $S$. vernális 


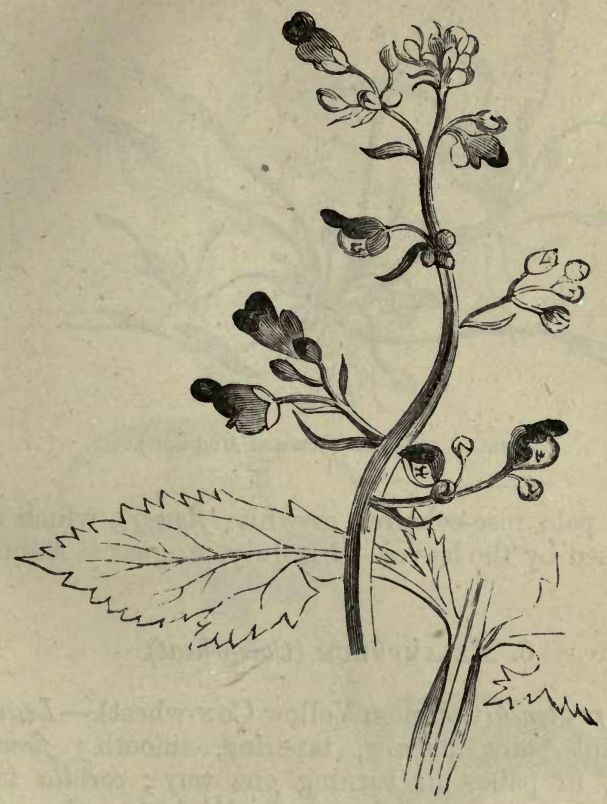

SCROPHULÁRIA AQUÁtICA (Water Fig-wort).

(Yellow Fig-wort) is a plant of local occurrence, and is well distinguished by its remarkably bright-green foliage and yellow flowers. It appears early in spring, and is the only British species which can be called ornamental.

\section{Limosella (Mud-wort).}

1. L. aquática (Common Mud-wort).-The only British species; growing in watery places, but not general. - A small plant, throwing up from the roots a number of smooth leaves on long stalks, and several 


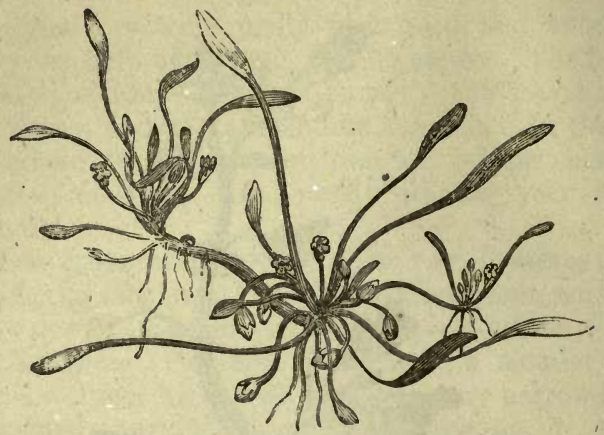

LIMOSElla AQUÁtica (Common Mud-wort).

minute, pale rose-coloured or white flowers, which are overtopped by the leaves.-Fl. July, August. Annual.

\section{Melampýrum (Cow-uheat).}

1. M. pratensé(Common Yellow Cow-wheat).-Leaves, in distant pairs, narrow, tapering, smooth; flowers axillary, in pairs, all turning one way; corolla four times as long as the calyx, lower lip longer than the upper.-Woods, common. A slender plant, about a foot high, with opposite pairs of straggling branches below, very narrow leaves, and long-tubed, yellaw flowers. Cows are said to be fond of it, and, according to Linnæus, the best and yellowest butter is made where it abounds. The name pratensé (growing in meadows) was given to it erroneously, as it is never found in such situations.-Fl. June-August. Annual.

* M. sylváticum is a smaller species, occurring in mountainous woods, but not common. The corolla is only twice as long as the calyx, and the lips are equal.

2. $M$. arvensé (Purple Cow-wheat).-Flowers in oblong spikés; bracts leaf-like, very much cut and toothed. 


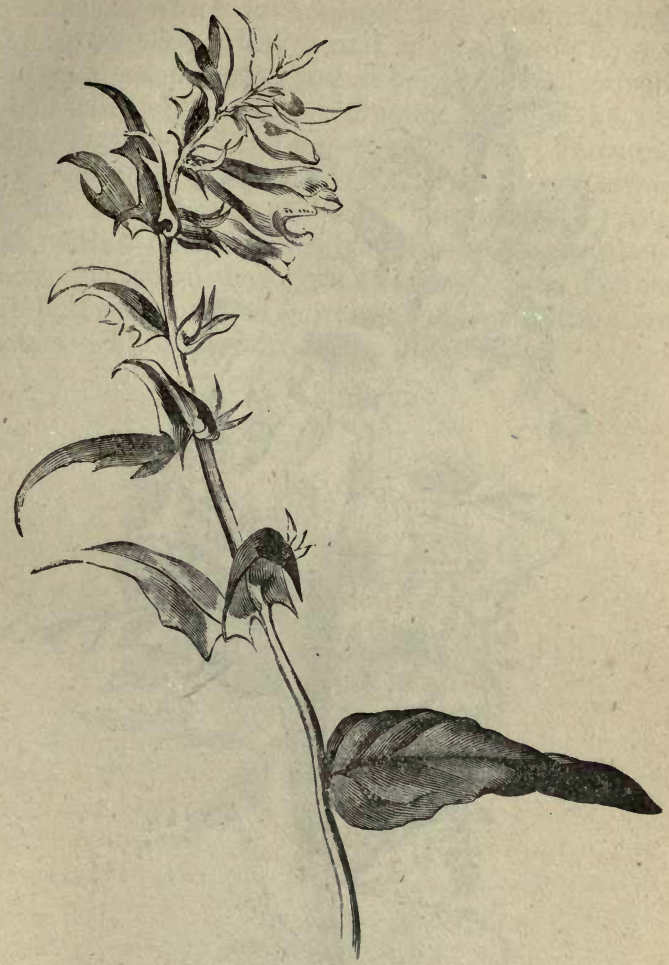

MELAMPÝRUM PRATENSÉ (Common Yellow Cow-vheat).

-Corn-fields in Norfolk and the Isle of Wight. Very distinct from the preceding, and well-marked by its terminal spikes of yellow and purple flowers, which are almost buried among numerous bright rose-colourec? bracts.-Fl. June, July. Annual.

* M. cristátum (Crested Cow-wheat) is distinguished from the preceding by bearing its flowers in 4-sided spikes. Both are beautiful plants. 


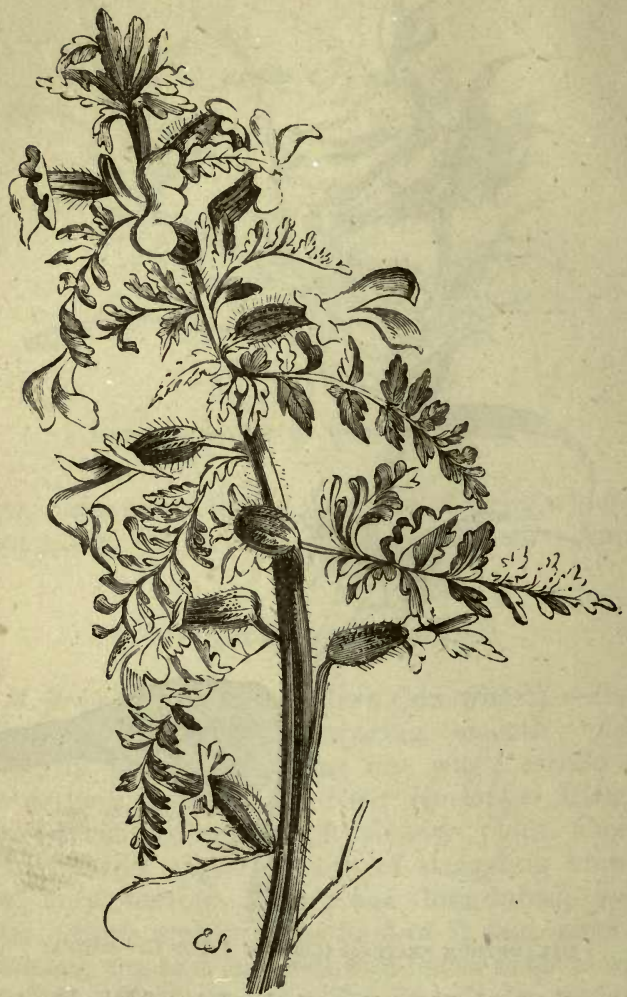

PEDICULÁRIS PALUSTRIS (Marsh Red-rattle).

7. Pediculáris (Red-rattle).

1. P. palustris (Marsh Red-rattle).-Stem solitary, erect, branched throughout; calyx downy, with 2 deeply-cut lobes.-Marshes and bogs, common. An herbaceous plant, well distinguished by the purple tinge 
of its branches, which are arranged in a pyramidal manner, by its deeply-cut leaves, and large, crimson flowers. It is often a conspicuous plant in boggy ground, growing 12-18 inches high, and overtopping most of the surrounding herbage.-Fl. June-September. Perennial.

2. P. sylvática (Dwarf Red-Rattle).-Stems, several from the same root, prostrate, unbranched; calyx smooth, with 5 unequal, leaf-like lobes.-Heathy places, common. Distinguished from the last by its humbler growth and rose-coloured flowers, as well as by the above characters.-Fl. June-August. Perennial.

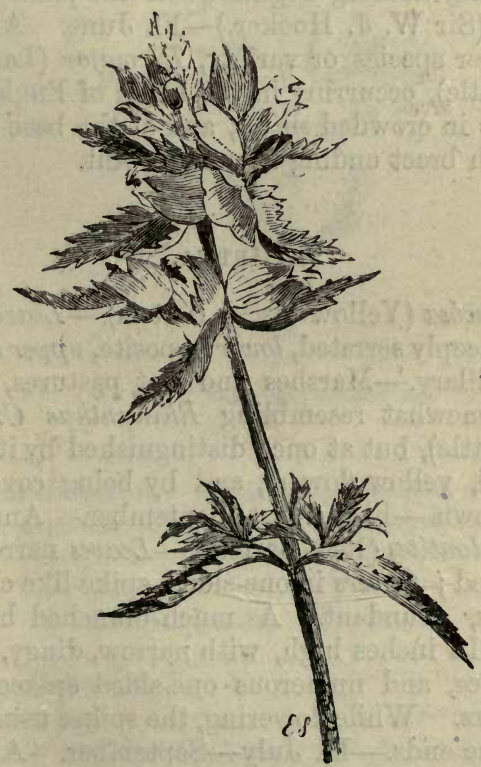

RHINANThUS CRISTA-GaLLI (Cock's-comb, Yellow-ratile). 


\section{Rhinanthus (Yellow-rattle).}

1. R. Crista-galli (Cock's-comb, Yellow-rattle).Leaves narrow-oblong, tapering to a point, serrated; flowers in loose spikes; bracts egg-shaped, deeply serrated. -In cultivated land, common. An erect, somewhat rigid plant, 12-18 inches high, composed of a single stem, and terminating in a loose spike of yellow flowers, which are rendered conspicuous by their inflated calyces. "When the fruit is ripe, the seeds rattle in the husky capsule, and indicate to the Swedish peasantry the season for gathering in their hay. In England, Mr. Curtis well observes, hay-making begins when the plant is in full flower." (Sir W. J. Hooker.)-Fl. June. Annual.

* Another species or variety, $R$. major (Large bushy Yellow-rattle), occurring in the north of England, bears the flowers in crowded spikes, and at the base of each is a yellowish bract ending in a fine point.

\section{BáRTSIA.}

1. B. viscósa (Yellow viscid Bartsia).-Leaves narrow, tapering, deeply serrated, lower opposite, upper alternate ; flowers axillary.-Marshes and wet pastures, not common. Somewhat resembling Rhinanthus Crista-galli (Yellow-rattle), but at once distinguished by its solitary, not spiked, yellow flowers, and by being covered with clammy down.-Fl. August, September. Annual.

2. B. Odontítes (Red Bartsia).-Leaves narrow, tapering, serrated ; flowers in one-sided, spike-like clusters.Corn-fields, abundant. A much-branched herbaceous plant, 6-12 inches high, with narrow, dingy, purplishgreen leaves, and numerous one-sided spikes of small pink flowers. While flowering, the spikes usually droop towards the ends.-Fl. July-September. Annual.

* B. alpína (Alpine Bartsia) is a rare species, found in Scotland and the north of England, and approaching 


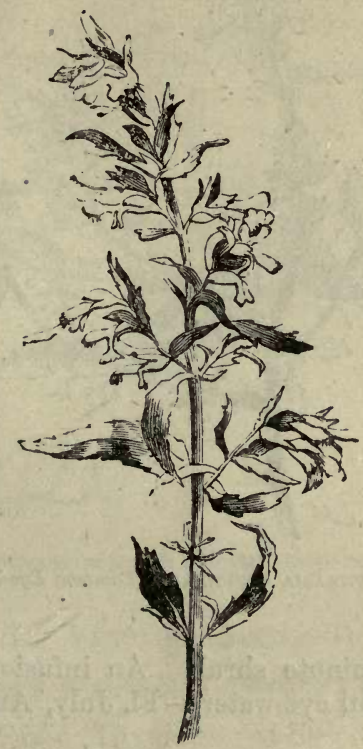

ELRTSIA ODONTfTES (Red Bartsia)

5. viscósa in habit. In this species the leaves are all opposite, and the flowers grow in a short, leafy spike.

\section{EUPHRásia (Eye-bright).}

1. $E$. officinalis (Common Eye-bright).-The only British species. An elegant little plant, $2-6$ inches high, with deeply-cut leaves and numerous white or purplish flowers variegated with yellow. On the mountains and near the sea, the stem is scarcely branched, and the leaves are fleshy; but in rich soil it assumes the н н 2 


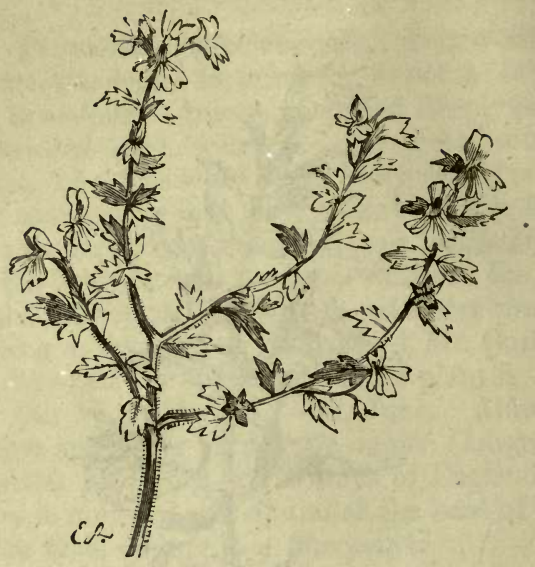

EUPHRÁSIA OFFICINÁlis (Common Eye-bright).

habit of a minute shrub. An infusion of this plant makes a useful eye-water.-Fl. July, August. Annual.

\section{SibthóRPIA (Cornish Money-wort).}

1. S. Europcea (Cornish Money-wort).-The only species. An elegant little plant, clothing the banks of springs and rivulets in most parts of Cornwall, and occasionally met with in some of the other southern counties. It approaches in habit Hydrocótylé vulgaris (Marsh Penny-wort), but is smaller, and has downy, notched leaves. The stems, which creep along the ground in tangled masses, are slender and thread-like ; the leaves small and of a delicate green; the flowers very minute and of a pale flesh-colour.-Fl. JuneSeptember. Perennial. 


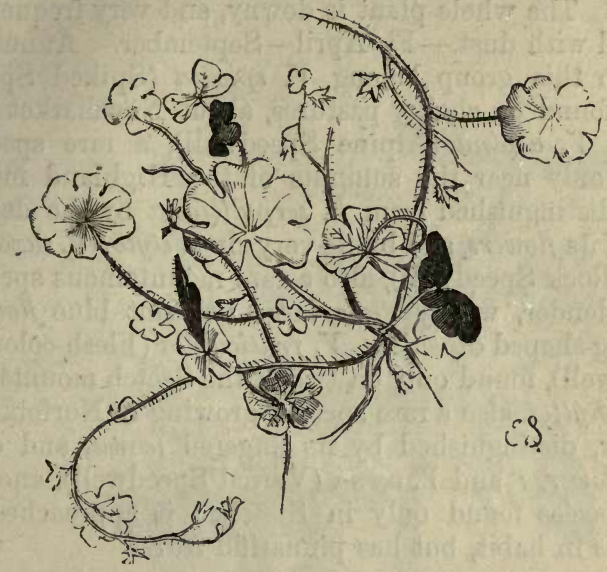

SIBTHORPIA EUROPAA (Cornish Money-wort).

\section{Verónica (Speedwell).}

* Flowers in terminal spikes or clusters.

1. V. serpyllifolia (Thyme-leaved Speedwell).-Leaves egg-shaped, or elliptical, slightly notched, smooth ; capsules inversely heart-shaped, with a long style.Waste ground, common. A small plant, with prostrate, or slightly ascending stems, and several many-flowered spikes of very light blue flowers, striped with dark blue veins. A variety occurs, high up in the mountains, which might easily be mistaken for a distinct species; but on examination it will be found to differ only in the superior size of the flowers.-Fl. May-July. Perennial.

2. V. arvensis (Wall Speedwell).-Leaves egg-shaped, heart-shaped at the base, crenate, stalked; bracts sessile, longer than the flowers.-Walls and fields, common. Also a small plant with inconspicuous, light blue flowers, which are almost concealed among the upper leaves or 
bracts. The whole plant is downy, and very frequently covered with dust.-Fl. April-September. Annual.

* To this group belong $V$. spicáta (Spiked Speedwell), found on chalky pastures, about Newmarket and Bury: V. alpina (Alpine Speedwell), a rare species, found only near the summits of the Highland mountains, distinguished from $V$. serpyllifolia by the deeper blue of its flowers, and by its very short style: V. saxátilis (Blue Rock Speedwell), also a rare mountainous species, with slender, woody stems, large brilliant blue flowers, and egg-shaped capsules : V. fruticulósa (Flesh-coloured Speedwell), found only on two of the Scotch mountains : $V$. triphyllos, also a rare species, growing in Norfolk and Suffolk, distinguished by its fingered leaves, and dark blue flowers : and V. verna (Vernal Speedwell), another rare species found only in Suffolk; it approaches $V$. arvensis in habit, but has pinnatifid leaves.

$$
\text { * *lusters axillary. }
$$

3. V. Chamoedrys (Germander Speedwell).-Stem with two hairy opposite lines; leaves sessile, deeply serrated; clusters very long; capsule shorter than the calyx.Hedge-banks, abundant. A well-known plant, which, under the popular names of Blue Speedwell and Bird'seye, is a favourite with every one. No one can have walked in the country in Spring without admiring its cheerful bright blue flowers, but few perhaps have remarked the singular pair of hairy lines, which traverse the whole length of the stem, shifting from side to side whenever they arrive at a fresh pair of leaves. It is sometimes, but erroneously, called Forget-me-not.-Fl. May, June. Perennial.

4. V. montána (Mountain Speedwell).-Stem hairy all round ; leaves stalked ; clusters few-flowered; capsule much longer than the calyx.-Woods, common. Approaching the last in habit, but well distinguished by the above characters, and by its smaller, light blue flowers.-Fl. May, June. Perennial. 


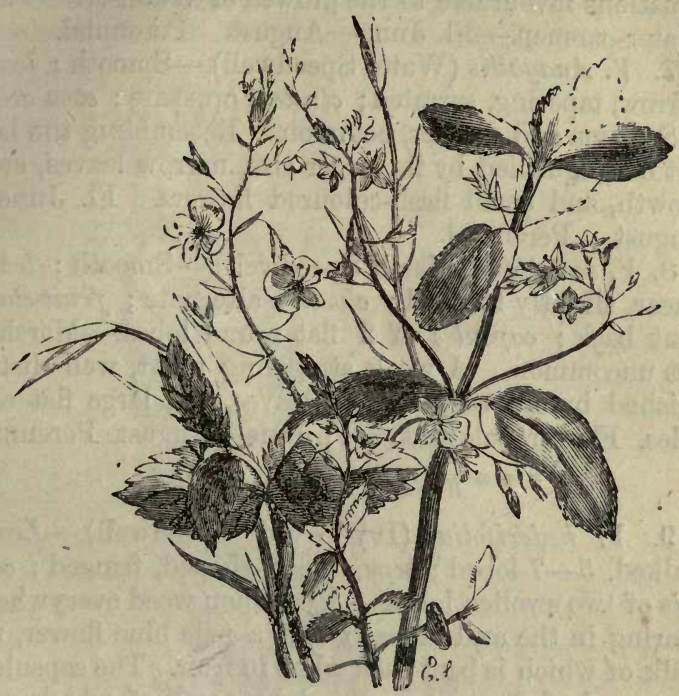

VERÓNLCA CHAMADRYS (Germander Speedwell), v. OFFICINÁlis (Common Speedwell), v. scuTElláta (Marsh Speedwell), and v. BECCABUNGA (Brooklime).

5. V. officinális (Common Speedwell).-Rough with short hairs; stem creeping; leaves elliptical, serrated; flowers in spikes.-Heaths and dry pastures, common. A hairy plant with prostrate stems and erect spike-like clusters of blue flowers; varying from 2 to 6 inches in length, according to soil. The leaves are astringent and bitter, and are sometimes made into tea.-Fl. MayAugust. Perennial.

6. V. Beccabunga (Brooklime). - Smooth; leaves elliptical, blunt, slightly serrated; clusters opposite; stem rooting at the base.-Brooks and ditches, common. A succulent plant about a foot high, with rather large, smooth leaves, and bright blue flowers, abounding in 
situations favourable to the growth of Water-cresses and 'Water-parsnep-Fl. June-August. Perennial.

7. V. Anagallis (Water Speedwell).-Smooth; leaves narrow, tapering, serrated; clusters opposite ; stem erect. - Streams and ditches, common. Resembling the last, but distinguished by its larger size, narrow leaves, erect growth, and small flesh-coloured flowers. Fl. JuneAugust. Perennial.

8. V. scutelláta (Marsh Speedwell).-Dmooth; leaves linear, slightly toothed; clusters alternate; fruit-stalks bent back; capsules of 2 flat round lobes.-Marshes, not uncommon. A weak straggling. plant, well distinguished by its very narrow leaves, and large flat capsules. Flowers pale pink.-Fl. June-August. Perennial.

\section{* * Flowers solitary, axillary.}

9. VI. hederifolia (Ivy-leaved Speedwell).-Leaves stalked, 5-7-lobed; sepals heart-shaped, fringed; capsule of two swollen lobes.-A common weed everywhere, hearing in the axil of each leaf a pale blue flower, the stalk of which is bent back when in fruit. The capsule is composed of 2 much swollen lobes, each of which contains 2 large black seeds.-Fl. all the summer. Annual.

10. V. agrestis (Field Speedwell).-Leaves stalked, heart-shaped, deeply serrated; sepals oblong, blunt; flower-stalks as long as the leaves. - A common weed, with several long prostrate stems and small blue flowers. The capsule is composed of 2 swollen, keeled lobes, and each cell contains about 6 seeds.-Fl. all the summer. Annual.

* Closely allied to the preceding are V. polita, distinguished by its small leaves, which are shorter than the flower-stalks : and V. Buxbaumii, a stouter plant, with large bright blue flowers, and sharply keeled capsules.

\section{Verbascum (Mullein).}

1. V. Thapsus (Great Mullein).-Leaves woolly on both sides, running down the stem; stem simple; 
flowers in dense spikes.-Road-sides, common. A stout herbaceous plant $2-5$ feet high, remarkable for its large

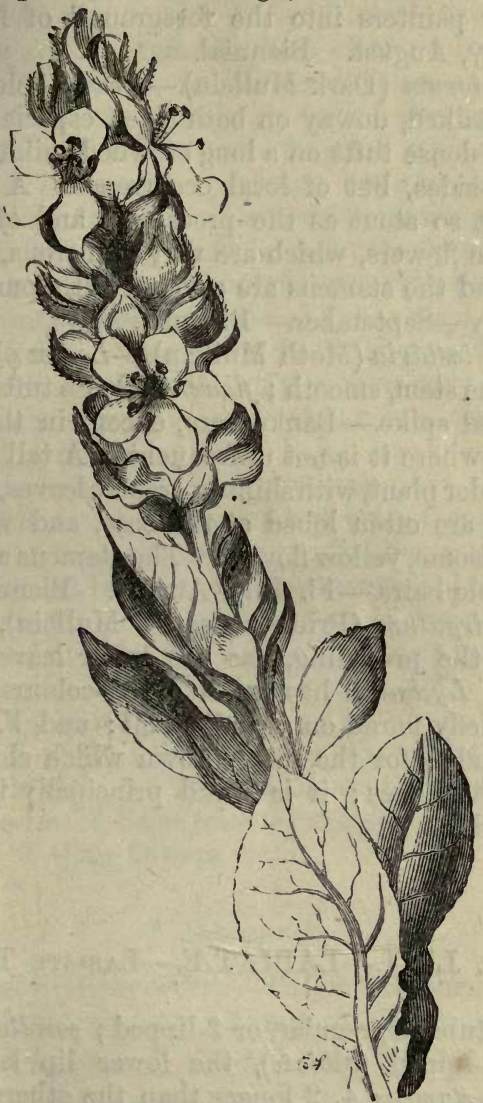

VERBASCUM THAFSUS (Great Mullein).

flannel-like leaves and club-shaped spikes of yellow flowers. Two of the 5 stamens are longer than the rest, 
and hairy, the remaining three are smooth. This plant, together with Burdock and Fox-glove, is often introduced by painters into the foreground of landscapes. -Fl. July, August. Biennial.

2. V. nigrum (Dark Mullein).-Leaves oblong, heartshaped, stalked, downy on both sides, especially below ; flowers in dense tufts on a long crowded spike.-Hedges and road-sides, but of local occurrence. A handsome plant, not so stout as the preceding, and of a darker hue. The flowers, which are very numerous, are bright yellow, and the stamens are covered with purple hairs. -Fl. July-September. Biennial.

3. V. Blattária (Moth Mullein).-Leaves oblong, embracing the stem, smooth ; flowers in loose tufts on a long interrupted spike.-Banks, rare, except in the West of England, where it is not unfrequent. A tall and somewhat slender plant, with shining, crenateleaves, the lowest of which are often lobed at the base, and with large, very handsome, yellow flowers. The stamens are covered with purple hairs.-Fl. July, August. Biennial.

* $V$. virgátum (Primrose-leaved Mullein), which is allied to the preceding, has the lower leaves downy; rare : V. Lychnitis has small cream-coloured flowers, and is chiefly found on a chalky soil : and $V$. floccósum is remarkable for the mealy down which clothes both sides of its leaves; it is found principally in Norfolk and Suffolk.

Ord. LXII.-LABIATA.-Labiate Tribe.

Calyx tubular, regular, or 2-lipped ; corolla irregular, mostly 2-lipped (labiate), the lower lip largest, and 3 -lobed; stamens 4, 2 longer than the others, or sometimes wanting; ovary deeply 4-lobed; style 1; stigma 2-cleft ; fruit of 4 seeds, each of which is enclosed within a distinct shell or rind.-A large and strongly-marked 
natural order, comprising upwards of 2,000 species, which agree in having square stems, opposite leaves, labiate, or 2-lipped flowers, and a 4-lobed ovary with a single style arising from the base of the lobes. They are most abundant in temperate climates, and are remarkable for not possessing injurious properties in any single instance. Many are fragrant and aromatic: Patchouli is a favourite perfume, both in its natural state and when distilled. Lavender contains a fragrant volatile oil, which is valued both for its fragrance, and as a medicine for its stimulant properties. Several kinds of mint, as Peppermint and Pennyroyal, are much used in medicine. Spear-mint, Basil, Thyme, Marjoram, Savory, and Sage, are commonly used as pot-herbs, furnishing both agreeable and wholesome condiments. Horehound, Ground-Ivy, and Balm, are in rural districts popular remedies for chest complaints. Rosemary is remarkable for its undoubted power of encouraging the growth of the hair, and curing baldness, and is the active ingredient in most good pomatums; an infusion of it prevents the hair from uncurling in damp weather; and it is one of the plants used in the preparation of Hungary water, and Eau de Cologne. The admired flavour of Narbonne honey is ascribed to the bees feeding on the flowers of this plant, as that of the honey of Hymettus is indebted for its flavour to Wild Thyme. Several species of Sage (Salvia) are also cultivated for the beauty of their flowers.

\section{* Stamens 2.}

1. LÝcopus (Gipsy-wort).-Calyx 5-toothed; corolla 4-cleft, nearly regular. (Name in Greek signifying a Wolf's-foot, from a fancied resemblance in the leaves.)

2. Salvia (Sage)-Calyx 2-lipped; corolla gaping ; filaments forked. (Name from the Latin salveo, to be well, from the healing properties of the genus.) 
* Stamens 4.

+ Corolla nearly regular, its tube scarcely longer than the calyx.

3. Mentha (Mint).-Calyx equal, 5-toothed; corolla 4-cleft, with a very short tube. (Name, the Latin name of the plant.)

++ Corolla 2-lipped, lips nearly equal in length.

4. Thyмus (Thyme).-Calyx 2-lipped, 10-13-ribbed, the throat hairy; corolla with the upper lip notched, the lower 3-cleft ; flowers in heads, or whorls. (Name, the Latin name of the plant.)

5. Oríganum (Marjoram).-Calyx 5-toothed, 10-13ribbed, the throat hairy ; flowers in spikes, which are imbricated with bracts. (Name from the Greek oros, a mountain, and ganos, joy, from the favourite station of the family.)

H+ Corolla with the upper lip very short, or wanting.

6. ÁJuga (Bugle).-Calyx 5-cleft; corolla with a long tube, the upper lip very short, lower 3-cleft. (Name said to be corrupted from the Latin Abiga, an allied plant.)

7. Teucrium (Germander)-Calyx 5-cleft; corolla with the upper lip deeply 2-cleft, lower 3-cleft. (Name from Teucer, who is said to have been the first to use it in medicine.)

+1+ Corolla 2-lipped, lips unequal; calyx 5-toothed; stamens langer than the tube of the corolla.

8. BaLlóta (Black Horehound).-Calyx funnelshaped, with 5 sharp equal teeth; corolla with the upper lip erect, concave; lower 3-lobed, the middle lobe largest, heart-shaped; two front stamens the longest. (Name in Greek signifying rejected, from the offensive smell of the plant.) :

9. Leonúnus (Motherwort).-Calyx with 5 prickly 
teeth ; corolla with the upper lip nearly flat, very hairy above; anthers sprinkled with hard, shining dots; two front stamens the longest. (Name in Greek signifying a Lion's tail, from some fancied resemblance in the plant.)

10. Galeóbdolon (Weasel-snout).-Caly $x$ with 5 ribs, and as many nearly equal teeth; corolla with the upper lip arched, entire; lower in 3 nearly equal acute lobes; two front stamens the longest. (Name in Greek denoting that the plant has the smell of a weasel.)

11. Galeopsis (Hemp-nettle).-Calyx bell-shaped, with 5 prickly teeth; corolla with an inflated throat; upper lip arched, lower 3-lobed, with 2 teeth on its upper side; two front stamens the longest. (Name in Greek denoting that the flower bears some resemblance to a veasel.)

12. Límium (Dead-nettle).-Calyx bell-shaped, with 10 ribs, and 5 teeth; corolla with an inflated tube; upper lip arched, lower 2 -cleft, with 1 or 2 teeth at the base on each side; two front stamens the longest. (Name from the Greek laimos, a throat, from the shape of the flower.)

13. Betónica (Betony).-Calyx egg-shaped, with 10 ribs, and 5 sharp teeth; tube of the corolla longer than the calyx; upper lip slightly arched, lower flat, of 3 unequal lobes; two front stamens the longest. ("Name altered from Bentonic, in Celtic ; ben meaning head, and ton, good, or tonic." -Sir W. J. Hooker.)

14. Stachys (Woundwort).-Calyx tubular, bellshaped, with 10 ribs, and 5 equal teeth; tube of the corolla as long as the calyx ; upper lip arched, lower 3-lobed, the side lobes bent back before withering; two front stamens the longest. (Name in Greek signifying a bunch, from the mode of flowering)

15. NEPETa (Cat-mint, Ground Ivy).--Calyx tubular, oblique, 5-toothed; tube of the corolla longer than the calyx ; upper lip flat, notched, lower 3-lobed, two front stame:rs the shortest. (Name of doubtful or igin.) 
$+1+++$ Corolla 2-lipped, lips unequal; calyx 5-10toothed; stamens shorter than the tube of the corolla.

16. MarrúBIUM (White Horehound).-Calyx with 5 or 10 teeth, the throat hairy; tube of the corolla longer than the calyx ; upper lip straight, very narrow, deeply 2-cleft, lower 3-lobed. (Name of doubtful origin.)

++++++ Corolla 2-lipped, the lips unequal; calyx 2-lipped.

17. Calamintha (Calamint, Wild Basil, Basil Thyme). -Calyx 13-nerved, tubular, swollen underneath; upper lip 3-cleft; lower 2-cleft, throat mostly hairy; tube of the corolla straight; upper lip nearly plane, lower spreading, 3-cleft. (Name, the Greek name of some allied plant.)

18. Melitis (Wild Balm).-Calyx bell-shaped, much wider than the tube of the corolla, variously lobed; upper lip of the corolla nearly flat, entire, lower with 3 rounded, nearly equal lobes. (Name from the Greek melitta, a bee, from the quantity of honey contained in the tube.)

19. Prunella (Self-heal).-Calyx flattened, and closed when in fruit; filaments 2-forked. (Name from a German word for the quinsy, for which complaint it was considered a specific.)

20. Scutellaria (Skull-cap.)-Upper lip of the calyx bulged outward about the middle, and finally closing down like a lid over the fruit; tube of the corolla much larger than the calyx. (Name from the Latin scutella, a little cup, which the calyx somewhat resembles.)

\section{LÝcopus (Gipsy-wort).}

1. I. Europaeus (Common Gipsy-wort).-The only British species.-On the banks of rivers and ditches, frequent. An aquatic plant, with erect, scarcely branched 
stems, 2 feet high, deeply cut, pointed, opposite leaves, and small, pale, flesh-coloured flowers, growing in crowded.

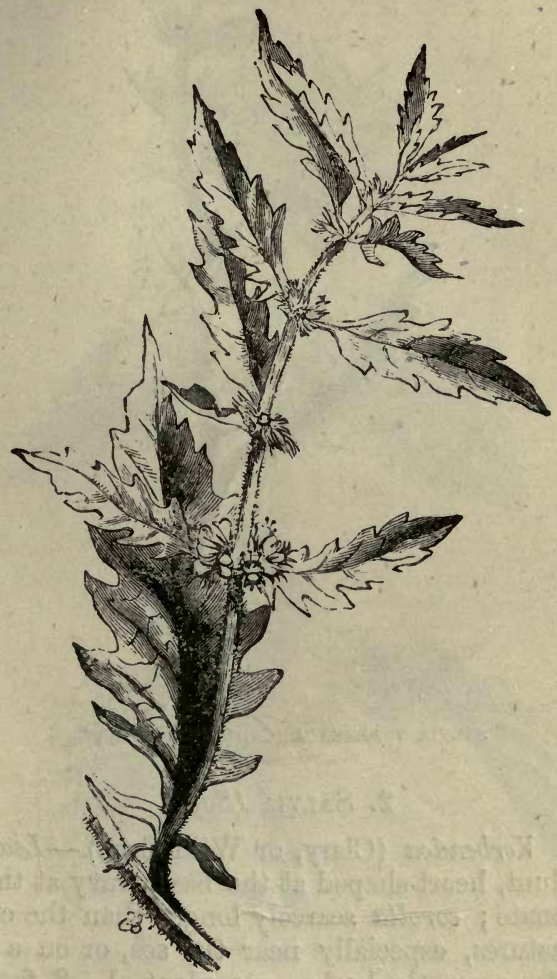

LÝCOPUS EUROPAUS (Common Gipsy-wort).

whorls in the axils of the upper leaves.-Fl. July, August. Perennial. . 


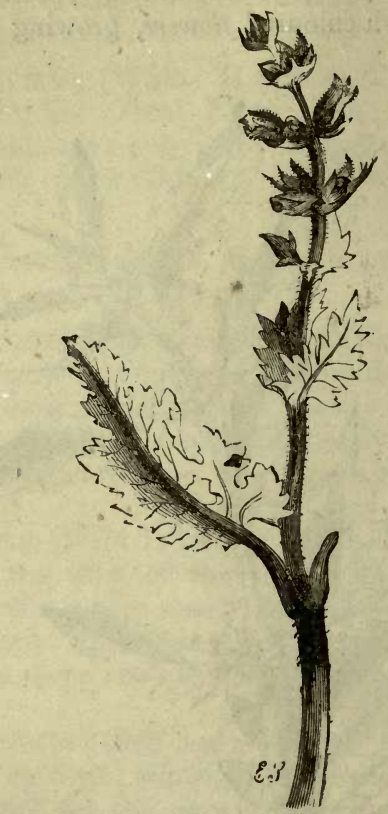

SALVIA VERBENÁCA (Clary, or Wild Sage).

2. Salvia (Sage).

1. S. Verbenáca (Clary, or Wild Sage).-Leaves oblong, blunt, heart-shaped at the base, wavy at the edge, and crenate; corolla scarcely longer than the calyx.Dry pastures, especially near the sea, or on a chalky soil. An aromatic herbaceous plant, $1-2$ feet high, rendered conspicuous by its long spikes of purple-blue flowers, the calyx of which is much larger than the corolla. The leaves are few, and much wrinkled, and at the base of each flower are 2 heart-shaped, fringed, acute bracts.-Fl. June-August. Perennial. 
* S. pratensis (Meadow Clary), which is not considered a native plant, occurs in Kent, and is distinguished by its corolla being twice as long as the calyx.

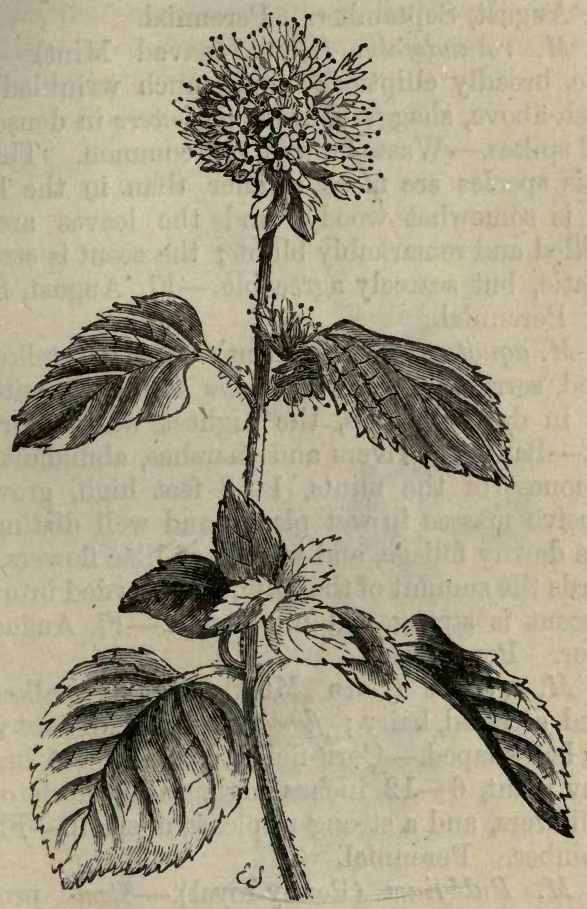

MENTHA AQUATICA. (Hairy Mint).

3. Mentha (Mint).

1. M. sylvestris (Horse Mint).-Leaves egg-shaped, tapering to a point, serrated, downy,' hoary beneath; flowers in a thick cylindrical spike; bracts awl-shaped; 
calyx very hairy.-Damp waste ground, frequent. A strong-scented plant, usually growing in masses, with downy foliage very white beneath, and rather slender spikes of lilac flowers, which are often interrupted below. -Fl. August, September. Perennial.

2. M. rotundifolia (Round-leaved Mint). - Leaves sessile, broadly elliptical, blunt, much wrinkled, nearly smooth above, shaggy beneath ; flowers in dense, cylindrical spikes.-Waste ground, not common. The spikes in this species are more slender than in the last, the stem is somewhat woody, and the leaves are much wrinkled and remarkably blunt; the scent is strong and aromatic, but scarcely agreeable.-Fl. August, September. Perennial.

3. M. aquática (Hairy Mint).-Leaves stalked, eggshaped, serrated, downy; flower's at the summit of the stem in dense whorls, the highest whorls forming a head.-Banks of rivers and marshes, abundant. The commonest of the mints, $1-2$ feet high, growing in extensive masses in wet places, and well distinguished by its downy foliage, and whorls of lilac flowers, which, towards the summit of the stem, are crowded into heads ; the scent is strong and unpleasant.-Fl. August, September. Perennial.

4. M. arvensis (Corn Mint).-Leaves stalked, eggshaped, serrated, hairy ; flowers in dense, distant whorls ; calyx bell-shaped.-Corn-fields, common. A branched, downy plant, $6-12$ inches high, with whorls of small lilac flowers, and a strong unpleasant smell.-Fl. Aug., September. Perennial.

5. M. Pulégium (Penny-royal).-Stem prostrate; leaves egg-shaped, nearly smooth; flowers in distant whorls; calyx downy, its mouth closed with hairs.Wet heathy places, not common. The smallest of the family, and very different in habit from any of the others ; the stems are prostrate, the flowers purple, and the whole plant of an agreeable perfume and flavour. It is commonly cultivated in cottage gardens for the 
sake of being made into tea, which is a favourite remedy for colds.-Fl. July, August. Perennial.

* Several other species and varieties of Mint are described by botanists, some of which are scarcely distinct from the preceding; others, such as Pepper-Mint, Spear-Mint, and Bergamot-Mint, are not really wild, but have escaped from cultivation.

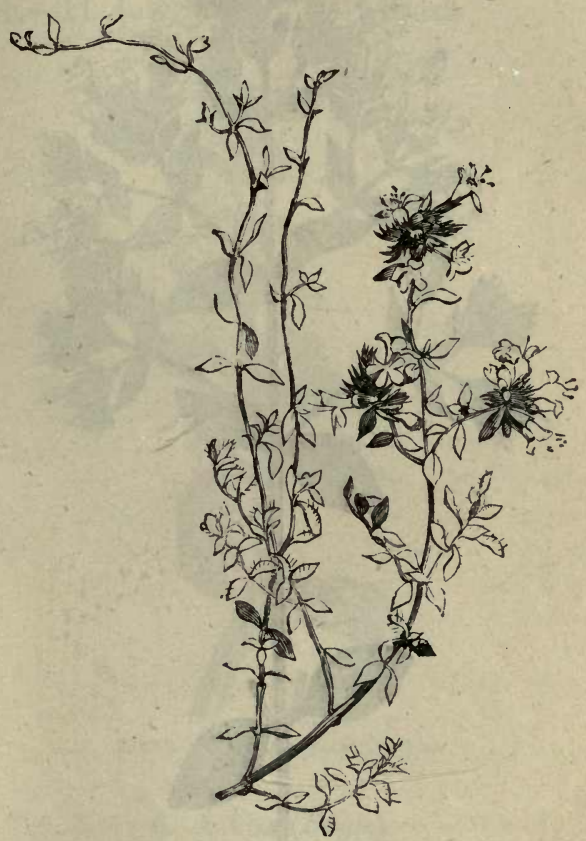

THYMUS SERPYLLUM (Wild Thyme).

\section{Thymus (Thyme).}

1. T. Serpyllum (Wild Thyme).-The only British species.-Dry heathy places, common. A well-known 
and favourite little plant, with woody stems, small fringed leaves, and heads of purple flowers. The whole plant diffuses a fragrant, aromatic perfume, which, especially in hot weather, is perceptible at some distance.

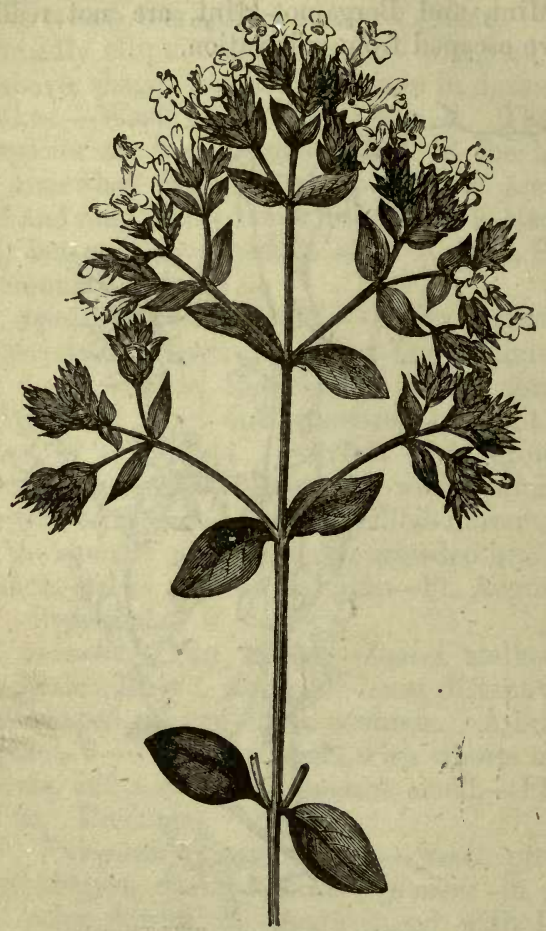

oríganum VUlgáRÉ (Common Marjoram).

5. Oríganum (Marjoram).

1. O. vulgáré (Common Marjoram).-The only British species.-Dry bushy places, especially on chalk or lime- 
stone, frequent. Growing about a fo'ot high, and distinguished by its egg-shaped downy leaves, and heads of purple flowers, which are crowded into the form of a cyme. The bracts are longer than the flowers, and tinged of the same colour, both being, while the plant is in bud, of a deep red hue. The whole plant is fragrant and aromatic, and is frequently cultivated as a pot-herb.-Fl. July, August. Perennial.

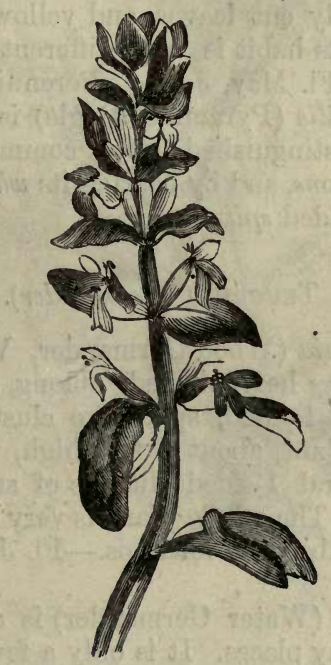

ÅJUGA REPTANS (Common Bugle).

\section{Ajuga (Bugle).}

1. A. reptans (Common Bugle).-Stem erect, with creeping scions at the base; lower leaves stalked, upper sessile; flowers whorled, crowded into a spike.-Moist meadows and woods, common. Well marked by its solitary tapering flower-stalk, 6-9 inches high, and 
creeping scions. The flowers are blue, and the upper leaves, or bracts, are tinged with the same colour. A white variety is sometimes found.-Fl. May, June. Perennial.

2. A. Chamópitys (Ground Pine).-Stem much branched, spreading; leaves hairy, deeply 3-cleft, the segments linear; flowers solitary, axillary.-Sandy fields, in Kent, Essex, and Surrey. A tufted herbaceous plant, $4-6$ inches high, with reddish-purple viscid stems, finely cut leaves, and yellow flowers spotted with red. Its habit is very different from that of the preceding.-Fl. May, June. Perennial.

* A. pyramidális (Pyramidal Bugle) is a rare Highland species, distinguished from common Bugle by being without scions, and by bearing its whorls of flowers crowded into 4 -sided spikes.

\section{Teucrium (Germander).}

1. T. Scorodónia (Wood-Germander, Wood-Sage).Stem erect; leaves heart-shaped, oblong, stalked, wrinkled; flowers in 1-sided, spike-like clusters.-A common woodland plant, about 2 feet high, with sage-like leaves, and several 1-sided clusters of small greenishyellow flowers. The whole plant is very bitter, and has been used as a substitute for hops.-Fl. June-August. Perennial.

* T. Scórdium (Water Germander) is a rare species, growing in marshy places. It is only a few inches high, and bears its flowers, which are purple, in distant whorls. This plant was formerly employed in medicine as a tonic, and a protection against infectious diseases; now, however, it is scarcely used except by rustic practitioners. $T$. Chamoedrys is a doubtful native, and is also rare; the flowers are purple, with dark lines, large and handsome, and grow 3 together in the axils of the leaves. Several other species are frequently cultivated in gardens as ornamental plants. 


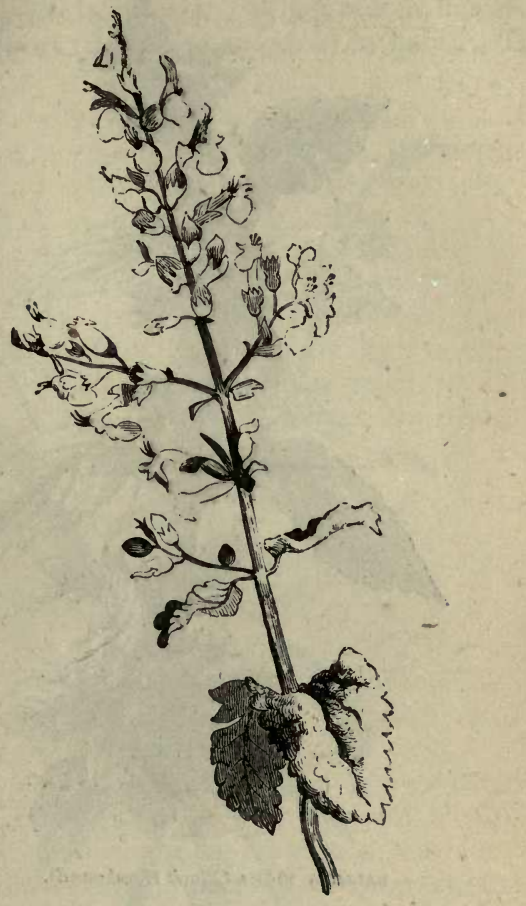

TEUCRIUM SCOROdénia (Wood Germander, Wood Sage).

\section{BaLlóta (Black Horehound).}

1. B. Nigra (Black Horehound).-The only British species.-Waste ground, common. A tall bushy plant, with downy, wrinkled, crenate leaves, and numerous purple flovers. The odour of the whole plant is pecu- 


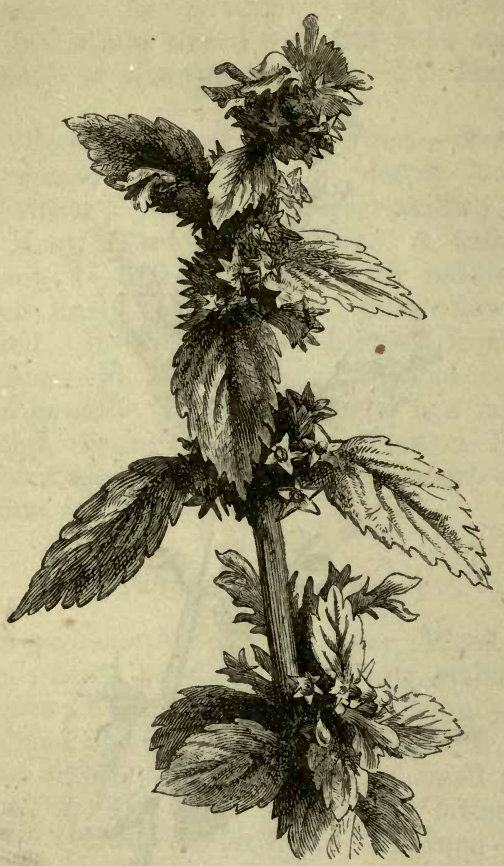

BALLÓta Nigra (Black Horehound).

liarly strong and offensive.-Fl. July, September. Perennial.

\section{Leovúnus (Motherwort).}

1. L Cardíaca (Common Motherwort).-The only British species.-Hedges and waste places, not common. Distinguished from all other British plants of the Order by its leaves, which are deeply cut into 5 or 3 narrow, 
pointed segments, and by the prickly calyx-teeth of its flowers, which grow in whorls. When not in flower it resembles Mugwort (Artemísia vulgaris) in habit. The

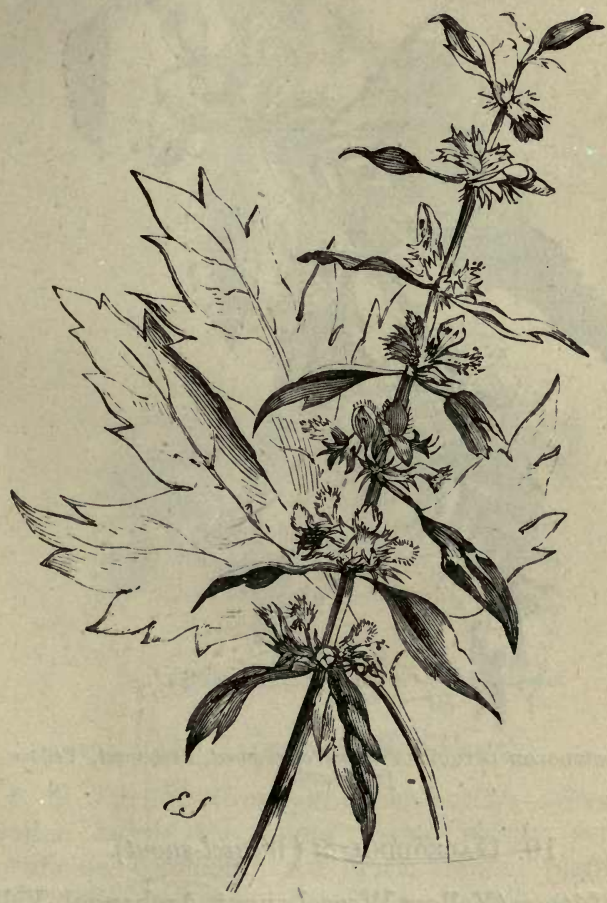

LEONÚRUS CARDIACA (Common Motherwort).

stems are 2-3 feet high, branched, principally below; the upper.leaves are very narrow and entire ; the flowers light purple.-Fl. August. Perennial. 


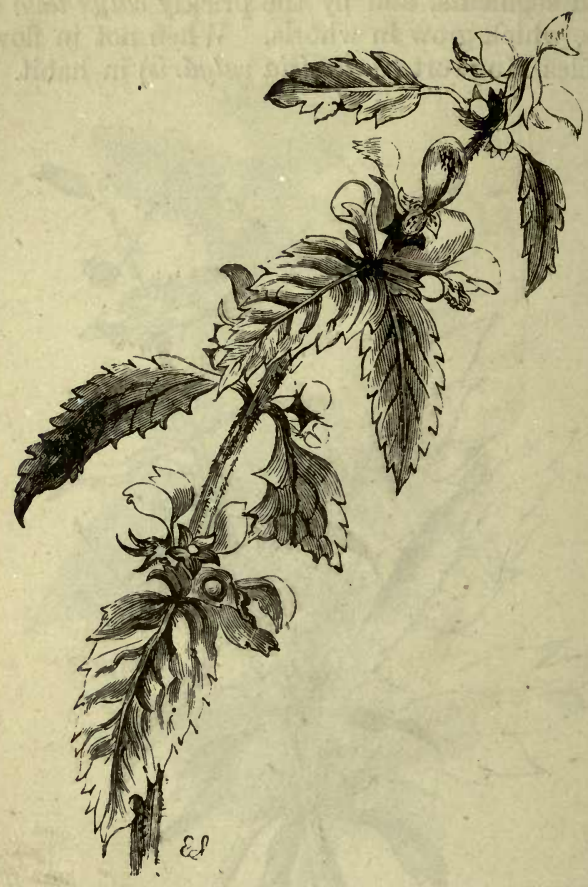

galébdolon lóteum (Yellow Weasel-snout, Archangel, Yellow Dead-nettle).

10. Galeóbdolon (Weasel-snout).

1. G. lúteum (Yellow Weasel-snout, Archangel, Yellow Dead-nettle).-The only species.-Damp woods and hedges; not unfrequent. Resembling in habit the common White Dead-nettle, but rather taller; the leaves are narrow and more pointed; the flowers, which grow in whorls, and are large and handsome, are yellow, blotched with red.-Fl. May-July. Perennial. 


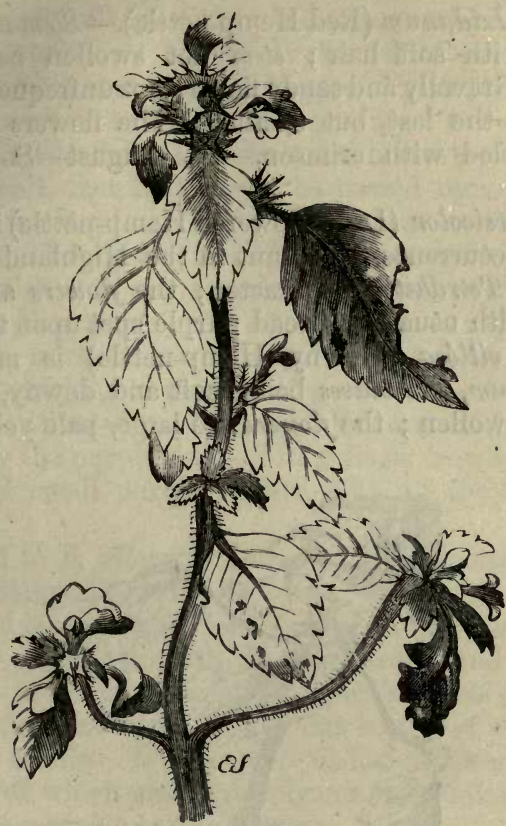

GALEOPSIS TETRÁHIT (Common Hemp-nettle).

\section{Galeopsis (Hemp-nettle).}

1. G. Tetráhit (Common Hemp-nettle). -Stem bristly, swollen below the joints; leaves bristly, serrated.Cornfields, common. An erect, slender plant, 2 feet high, with opposite spreading branches, numerous whorls of flowers which are variegated with light purple and yellow, and sometimes nearly white. The stems are remarkably swollen beneath every pair of leaves, and the whorls of flowers are rendered conspicuous by the long sharp calyx-teeth.-Fl. July-September. Annual. 
2. G. Ládanum (Red Hemp-nettle).-Stem and leaves downy with soft hair; stem not swollen below the joints.-Gravelly and sandy fields ; not unfrequent. Resembling the last, but smaller. The flowers are purple, mottled with crimson.-Fl. August-September. Annual.

* G. versícolor (Large-flowered Hemp-nettle) is a plant of local occurrence, abundant in the Highlands, resembling G. Tetráhit in character; the flowers are large, yellow, with asually a broad purple spot upon the lower lip; G. villósa (Downy Hemp-nettle) is more like G. Ládanum, the leaves being soft and downy, and the stem not swollen; the flowers are large, pale yellow.

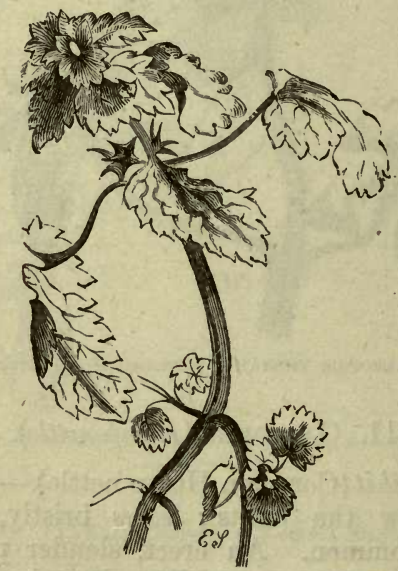

LAMIUM PURPUREUM (Purple Dead-nettle).

\section{Límium (Dead-nettle).}

1. L. album (White Dead-nettle).-Leaves heartshaped, tapering to a point, serrated, stalked.-Hedges and waste ground, abundant. A common, but not in- 
elegant weed, well marked by its large pure white flowers and black stamens. So closely does the foliage of this plant resemble that of the Stinging Nettle, that many persons are afraid to handle it, supposing it to be a Nettle in flower. The flowers of the latter, however, are green, and so small, that they would be passed unnoticed but for their growing in spiked panicles near the summit of the stem. The square stem of the Dead-nettle is enough to distinguish it at any stage of its growth.-Fl. all the summer. Perennial.

2. L. purpúreum (Purple Dead-nettle).-Leaves heart or kidney-shaped, blunt, crenate, stalked.-A common weed in cultivated ground, and by way-sides, distinguished by the purple tinge of its foliage, crowded upper leaves, and small purple fiowers.-Fl. all the summer. Perennial.

* Allied to L. album is L. maculátum (Spotted Deadnettle), distinguished by its leaves, each with a white blotch, and large purple flowers : two other species occur in similar situations with $L$. purpureum, and also resemble it in habit; namely, L. amplexicaule (Henbitnettle), which has round, deeply-cut leaves, of which the upper are sessile : L. incisum (Cut-leaved Dead-nettle), the leaves of which are all deeply cut and stalked; both of these have small purple flowers.

\section{Betónica (Betony).}

1. B. officinális (Wood Betony).-The oniy British species.-A common and very pretty woodland plant, about two feet high, bearing an interrupted head or spike of light purple flowers on a long and slender stem. There are always 2 or 3 pairs of oblong crenate sessile leaves beneath the divisions of the spike; the lower leaves are all stalked.-Fl. July, August. Perennial.

\section{Stachys (Wound-wort).}

1. S. sylvática (Hedge Wound-wort).-Flowers 6 in a whorl ; stem erect ; leaves heart-shaped, acute, stalked. - 


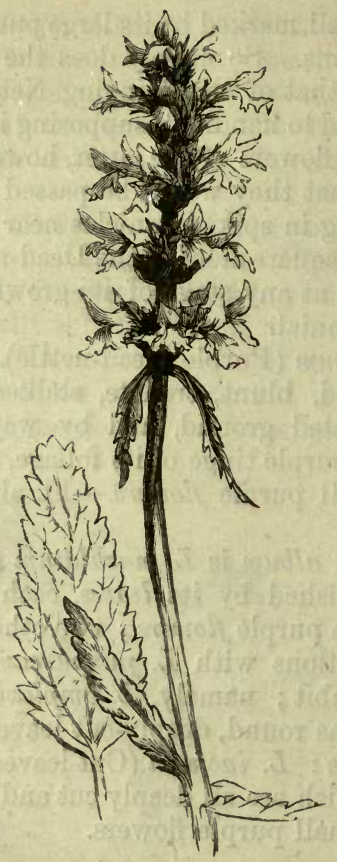

BETóNICA OfFICINÁlis (Wood Betony).

Woods and herlges, common. A branched hairy plant, $2-3$ feet high, with numerous whorls of dark but dull purple flowers, almost forming a spike. There are rarely more or less than 6 flowers in a whorl, and the outline of the leaves is not at all oblong. When in seed the calyx-teeth are rigid.-Fl. July, August. Perennial.

2. S. palustris (March Wound-wort).-Flowers 6 in a whorl ; leaves narrow-oblong, heart-shaped at the base, sessile.-Marshes, common. Taller and stouter than the last, and distinctly marked by its oblong leaves tapering to a point, and light purple flowers.-Fl. July-August. Perennial. 


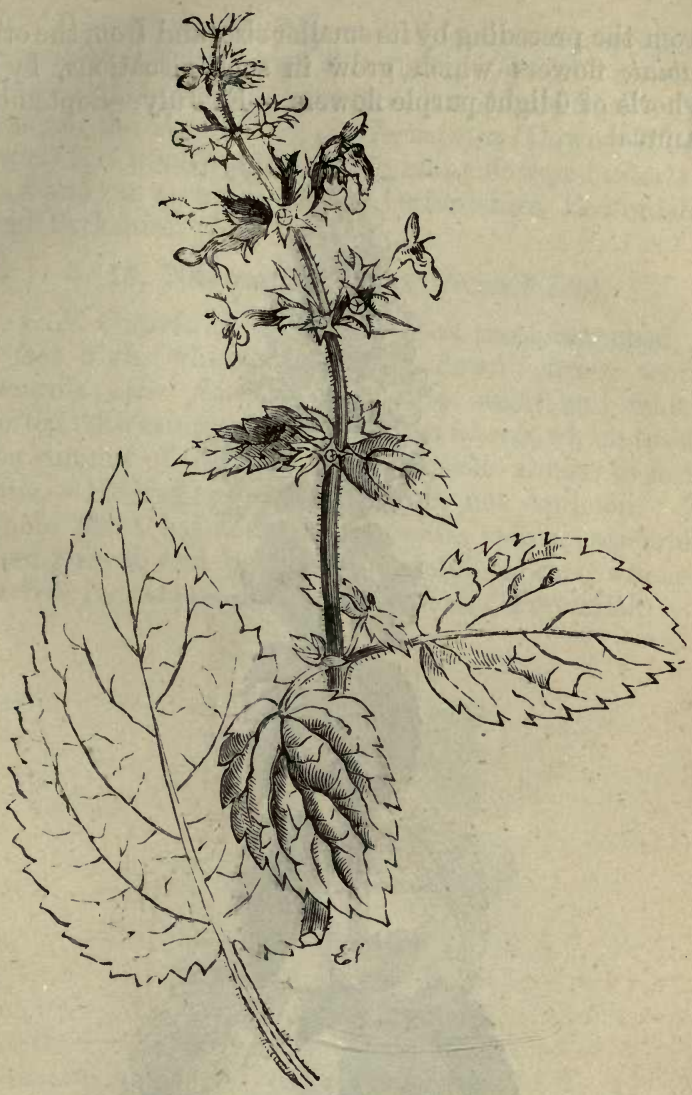

STACHYS SYLVÁtica (Hedge Wound-wort).

3. S. arvensis (Corn Wound-wort).-Flowers 6 in a whorl; stem spreading; leaves heart-shaped, obtuse; corolla scarcely longer than the calyx. - Corn-fields, common. A small plant, $6-8$ inches high, occurring abundantly as a weed in cultivated land; distinguished 
from the preceding by its smaller size, and from the other labiate flowers which grow in such situations, by its whorls of 6 light purple flowers.-Fl. July-September. Annual.

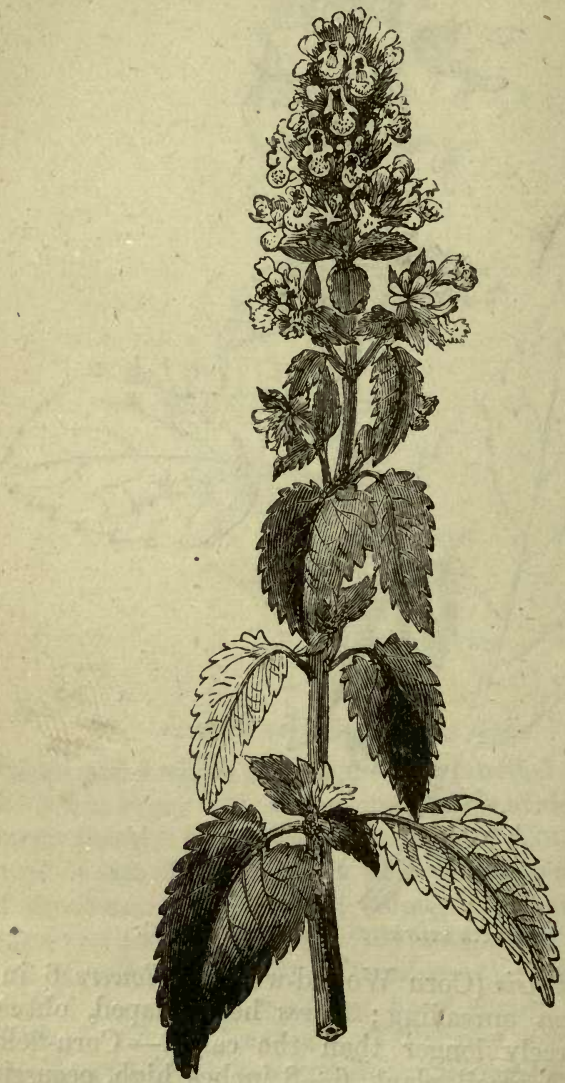

NǴPETA CATÁRIA (Cat Mint). 
* S. ambrigua (Ambiguous Wound-wort) approaches S. palustris, from which it is distinguished by its stalked leaves ; it is of local occurrence, but it is said to be abundant in the Highlands ; S. Germánica (Downy Woundwort) is a woolly plant having many flowered whorls; it is found on a chalky soil in Oxfordshire, Bedfordshire, and Berkshire.

\section{NEPETA (Cat-mint, Ground Ivy).}

1. N. Catária (Cat-mint).-Stem erect, branched, 23 feet high, white with mealy down; leaves whitish beneath; the flowers, which are small and whitish, dotted with crimson, grow in dense whorls, which towards the summit of the stem are so close as almost to form a spike.-Hedges and waste ground, not common. The whole plant has a strong aromatic odour, resembling Penny-royal, and peculiarly grateful to cats,' whence it derives its name-Fl. July, August. Perennial.

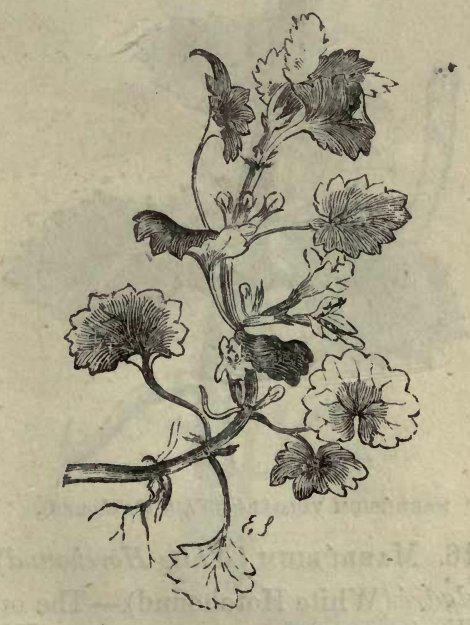

NGPETA GLECHOMA (Ground Ivy).

K. K 
2. N. Glechóma (Ground Ivy).--Stem trailing; flowers 3 or 4 together, axillary.-Hedges and waste ground, abundant. A favourite spring flower, with creeping stems, kidney-shaped, crenate, roughish leaves, and bright purple-blue flowers which grow in threes in the axils of the leaves. The whole plant has a strong aromatic odour, which, though scarcely fragrant, is far from disagreeable. In rural districts the leaves are often dried and made into tea. Described by some botanists under the name of Glechóma hederácea.-Fl. April-June. Perennial.

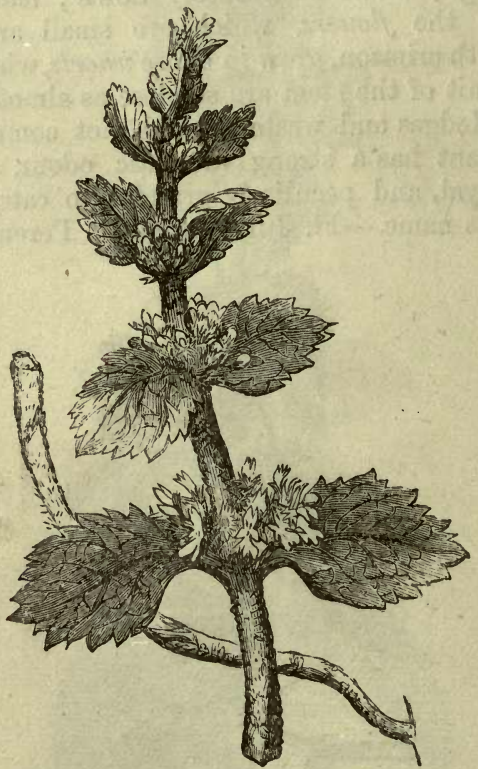

MARRÉBIUM VULGÁRÉ (White Horehound).

16. Marrúbium (White Horehound).

1. M. vulgáré (White Horehound).-The only British species.-Waste ground, not common. Well distin- 
guished by its bushy stems $1-2$ feet high, which are covered with white woolly down, by its wrinkled leaves, and its dense whorls of small white flowers, of which the calyx-teeth are sharp and hooked. The whole plant is aromatic and bitter, and is a common remedy for coughs.-Fl. August. Perennial.

17. Calamíntha (Calamint, Basil Thyme, Wild Basil).

1. C. Ácinos (Basil Thyme). - Stem ascending, branched; leaves oblong, on short stalks, serrated, acute.-Dry gravelly places, not common.-A small bushy herb $6-8$ inches high, with hairy, egg-shaped leaves and purple flowers, which grow in whorls as well as at the summit of the stem. The calyx is distinctly

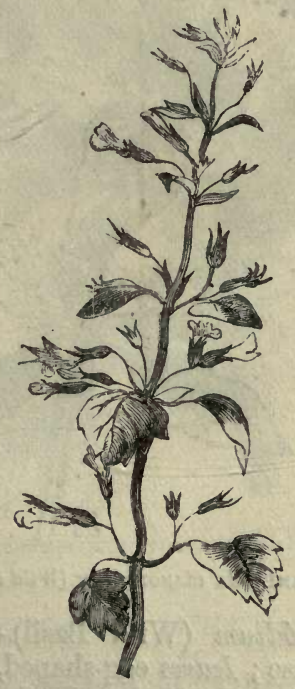

CALAMINTHA OFFICINális (Common Calamint),

K K 2 
2-lipped, the lower lip bulged at the base. Described by some botanists under the name of Ácinos vulgáris. -Fl. July, August. Perennial.

2. C. officinalis (Common Calamint).-Leaves stalked, egg-shaped, slightly serrated ; flowers stalked, in forked axillary cymes. - Way-sides and hedges, not uncommon. An erect, bushy plant, with downy stems and foliage, and numerous, light purple flowers, which have small pointed bracts in the forks of their stalks. The whole plant has a sweet aromatic flavour and makes a pleasant tea.-Fl. July, August. Perennial.

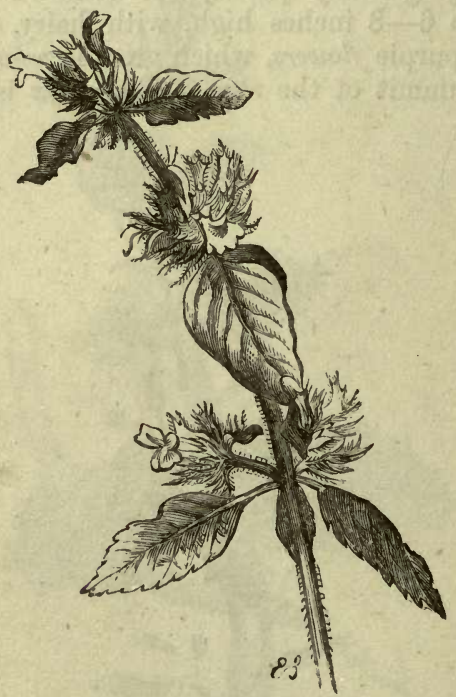

CALAMINTHA ClinóódIUM (Wild Basil).

3. C. Clinopódium (Wild Basil).-Calyx scarcely bulged at the base ; leaves egg-shaped, stalked; flowers in crowded compound whorls.-Bushy places, frequent. A straggling hairy plant, $1-2$ feet high, with egg-shaped 
leaves, several bristly whorls of stalked, purple flowers, and numerous, long, pointed bracts.-Aromatic and fragrant. Described by some botanists under the name of Clinopódium vulgáré.-Fl. July, August. Perennial. * C. Népeta (Lesser Calamint) is a smaller plant, with leaves which are more strongly serrated, and bears its flowers on longer stalks. It is perhaps scarcely distinct from $C$. officinalis.

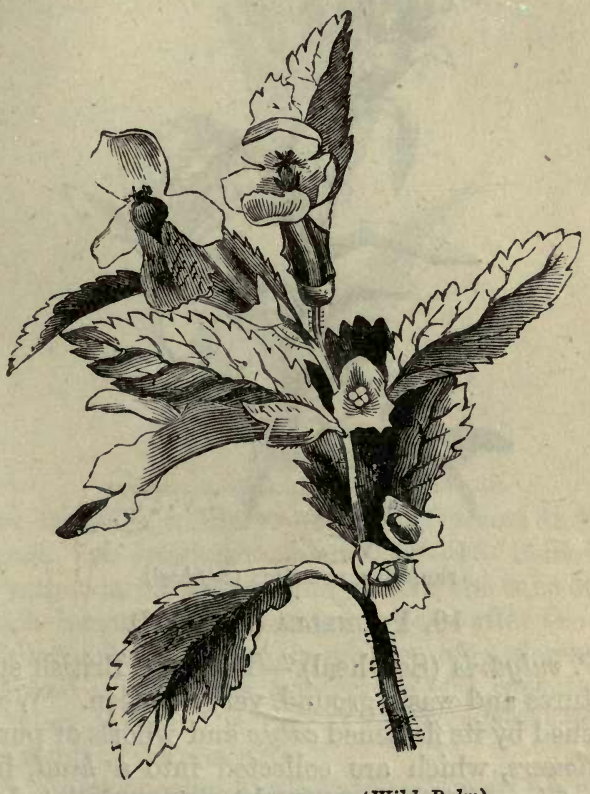

MELITTIS MELISSOPHYLLUM (Wild Balm).

\section{Meurtis (Wild Balm).}

1. M. Melissophyllum (Wild Balm).-The only British species.-Woods in the south and west of England. 
A very handsome plant, about a foot high, with large, hairy, serrated leaves and conspicuous white flowers blotched with bright rose-colour. The foliage while fresh has an offensive smell, but in drying acquires the flavour of new hay or Woodruff.-Fl. June, July. Perennial.

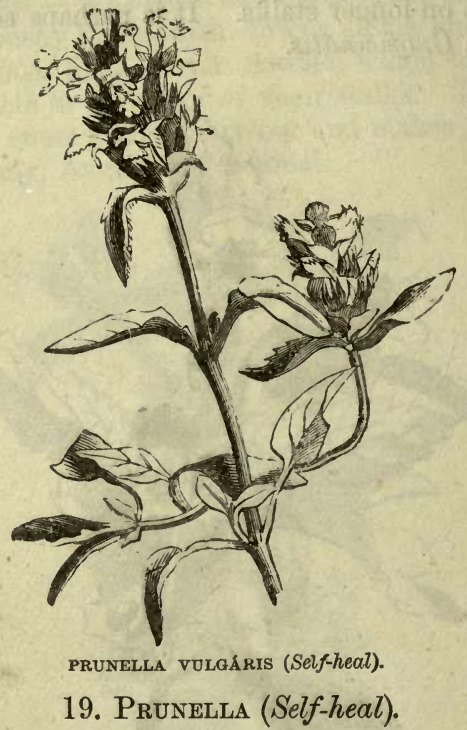

1. P. vulgáris (Self-heal).-The only British species. - Pastures and waste ground, very common. Well distinguished by its flattened caly $x$ and whorls of purplishblue flowers, which are collected into a head, having a pair of leaves at the base, and two taper-pointed bracts beneath each whorl.-Fl. July, August. Perennial.

\section{Scutellarta (Skull-Cap).}

1. S. galericuláta (Greater Skull-Cap).-Leaves oblong, tapering, heart-shaped at the base, notched; 


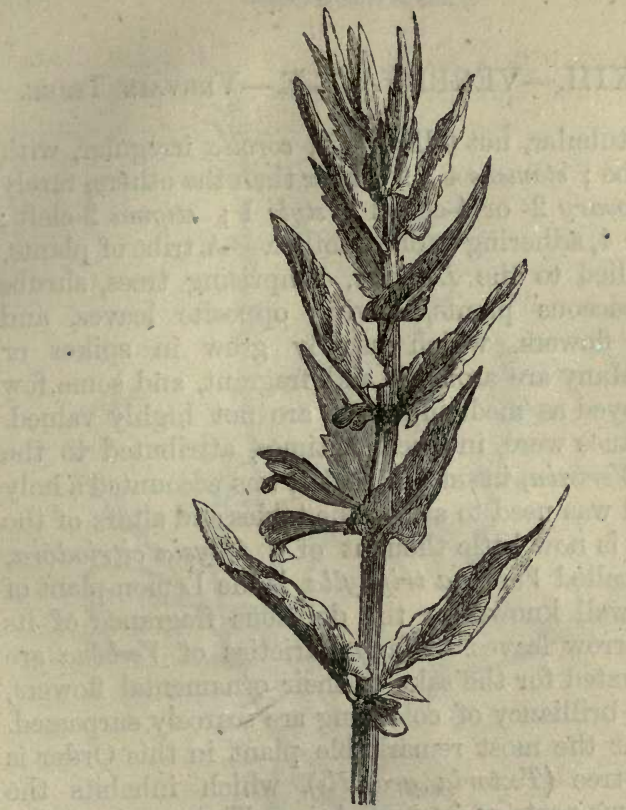

SCUTELLARIA NAJUR (Greater Skull-cap).

flowers in pairs, axillary.-Banks of rivers and ponds, frequent. A handsome plant, 12-18 inches high, with rather large, bright blue flowers, the tube of which is much longer than the calyx. Soon after the corolla has fallen off, the upper lip of the calyx closes on the lower, and gives it the appearance of a capsule with a lid; when the seed is ripe it opens again.-Fl. July -September. Perennial.

* S. minor (Lesser Skull-Cap) is a small bushy herb, 4-6 inches high, with egg-shaped leaves, of which the lower ones are often toothed at the base; the flowers are small, of a dull purple colour; the calyx is the same as in the last. It grows in bogs, but is not common, except in the West of England. 


\section{ORD. LXIII. - VERBENACEA. - VervaIN Tribe.}

Calyx tubular, not falling off ; corolla irregular, with a long tube; stamens 4 ; 2 longer than the others, rarely 2 only ; ovary 2 -or 4 -celled; style 1 ; stigma 2-cleft; seeds 2 or 4 , adhering to one another. - A tribe of plants, closely allied to the Labiáto, comprising trees, shrubs and herbaceous plants, having opposite leaves, and irregular flowers, which usually grow in spikes or heads. Many are aromatic and fragrant, and some few are employed as medicines, but are not highly valued. Great virtues were, in ancient times, attributed to the common Vervain, insomuch that it was accounted a holy plant, and was used to sweep the tables and altars of the gods. It is now little thought of. Aloysia citriodóra, formerly called Verbéna triphylla, is the Lemon-plant of gardens, well known for the delicious fragrance of its rough, narrow leaves. Many varieties of Verbéna are also cultivated for the sake of their ornamental flowers, which for brilliancy of colouring are scarcely surpassed. But by far the most remarkable plant in this Order is the Teak-tree (Tectoria grandis), which inhabits the mountainous parts of eastern Asia. The trunk of this tree sometimes attains the height of two hundred feet, and its leaves are twenty inches long by sixteen broad. The timber abounds in particles of flint, and somewhat resembles mahogany in colour, but is lighter and stronger. For ship-building it is thought to be superior to Oak.

1. Verbéna (Vervain).-Calyx 5-cleft; corolla unequally 5-cleft; stamens shorter than the tube of the corolla. (Name, the Latin name of the plant.)

\section{Verbéna (Vervain).}

1. V. officinalis(Common Vervain). - The only British species.-Waste ground,'common. A slender plant, 1- 


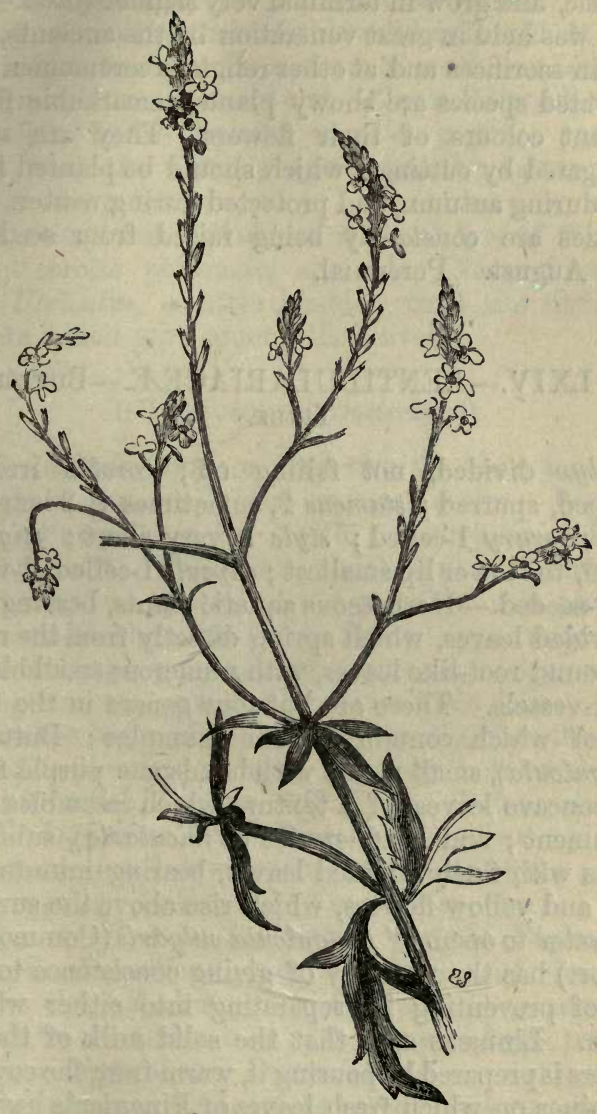

VERBÉNA OFFICINÁLIS (Common Vervain).

2 feet high, with but few leaves, which are roughish 3-cleft, or simply cut. The flowers, which are very small, 
are lilac, and grow in terminal very slender spikes.-This plant was held in great veneration by the ancients, being used in sacrifices and at other religious ceremonies. The cultivated species are showy plants, remarkable for the brilliant colours of their flowers. 'They are readily propagated by cuttings, which should be planted in fine sand during autumn, and protected during winter. New varieties are constantly being raised from seed.-Fl. July, August. Perennial.

\section{ORD. LXIV.-LENTIBULARIACEÆ.-BUTTERWORT TRIBE.}

Calyx divided, not falling off; corolla irregular, 2-lipped, spurred; stamens 2, sometimes 4, 2 long and 2 short; ovary 1-celled; style 1, very short; stigma 2lipped, the lower lip smallest ; capsule 1-celled, 2-valved, many-seeded.-Herbaceous aquatic plants, bearing either undivided leaves, which spring directly from the root, or compound root-like leaves, with numerous small bladders or air-vessels. There are but four genera in the Order, two of which contain British examples: Butterwort (Pinguícula), small plants with handsome purple flowers and concave leaves, of a texture which resembles greasy parchment ; and Bladderwort (Utricularia), submersed plants with finely divided leaves, bearing minute bladders, and yellow flowers, which rise above the surface of the water to open. "Pingurcula vulgáris (Common Butterwort) has the property of giving consistence to millk, and of preventing its separating into either whey or cream. Linnæus says that the solid milk of the Laplanders is prepared by pouring it, warm from the cow, over a strainer on which fresh leaves of Pinguicula have been laid. The milk, after passing among them, is left for a day or two to stand, until it begins to turn sour; it throws up no cream, but becomes compact and tenacious, and most delicious in taste. It is notnecessary that fresh leaves 
should be used after the milk is once turned: on the contrary, a small portion of this solid milk will act upon that which is fresh, in the manner of yeast." - (Lindley.)

1. Pinguícula (Butterwort).-Calyx 2-lipped, upper lip 3-cleft, lower 2-cleft; corolla gaping, spurred. (Name from the Latin pinguis, fat, the leaves being greasy to the touch.)

2. Utricularia (Bladderwort).-Calyx of 2 equal sepals; corolla personate, spurred. (Name from the Latin Utrículus, a little bladder, from the little airbladders which grow among the leaves.)

\section{Pinguícula (Butterwort).}

1. P. vulgáris (Common Butterwort).-Spur tapering; segments of the corolla very unequal, entire.-Bogs and heaths, principally in the North. A singular and very beautiful plant. The leaves, which spring all from the roots, have the edges rolled in; they are of a peculiar, parchment-like hue, and have a frosted appearance. The flowers are large, purple, very handsome, and grow in a nodding manner, each on the summit of a delicate stem, $3-4$ inches high, which springs directly from the root. The root is fibrous, and has a very loose hold on the soft ground in which it grows.-Fl. June. Perennial.

2. P. Lusitánica (Pale Butterwort). -Spur cylindrical, obtuse, curved downwards ; segments of the corolla nearly equal; leaves and flower-stalks covered with short hairs. - Bogs in the western parts of England, in the North of Scotland, and in Ireland. Of the same habit as the last, but much smaller. The leaves are greenish white, and veined; the flowers light pink.Fl. July-September. Perennial.

* P. grandiflóra (Large-flowered Butterwort) is a yet more beautiful plant than $P$. vulgáris. It is distinguished by its large, very irregular, purple corolla, the middle segment and spur of which are notched; it grows in bogs in the counties of Cork and Kerry, Ireland. $P$. 


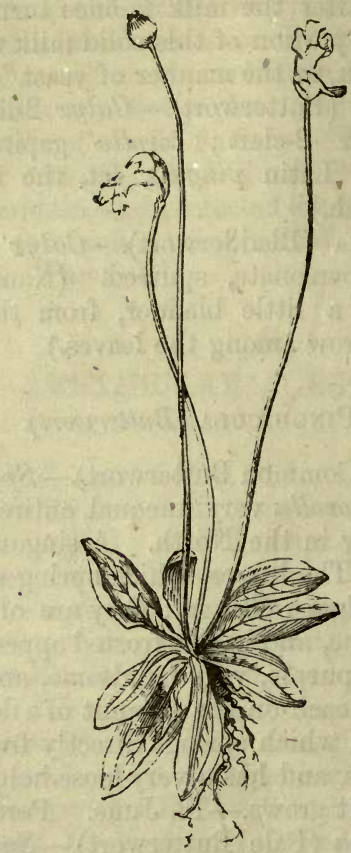

PINGUTCULA LUSITÁNICÀ (Pale Butterwort).

alpina (Alpine Butterwort) is about the size of $P$. Insitánica; the flower-stalks are smooth, and the flowers yellowish; it is very rare, being found only in bogs in Scotland and Ireland.

\section{UTRICULÁRIA (Bladderwort).}

1. U. vulgáris (Common Bladderwort).-Submersed. Leaves divided into numerous hair-like segments, and bearing small air-bladders; lips of the corolla about equal in length; spur conical.-Ditches and deep pools, not 
very common. Before flowering, the stem and leaves float in the water by help of the minute bladders,

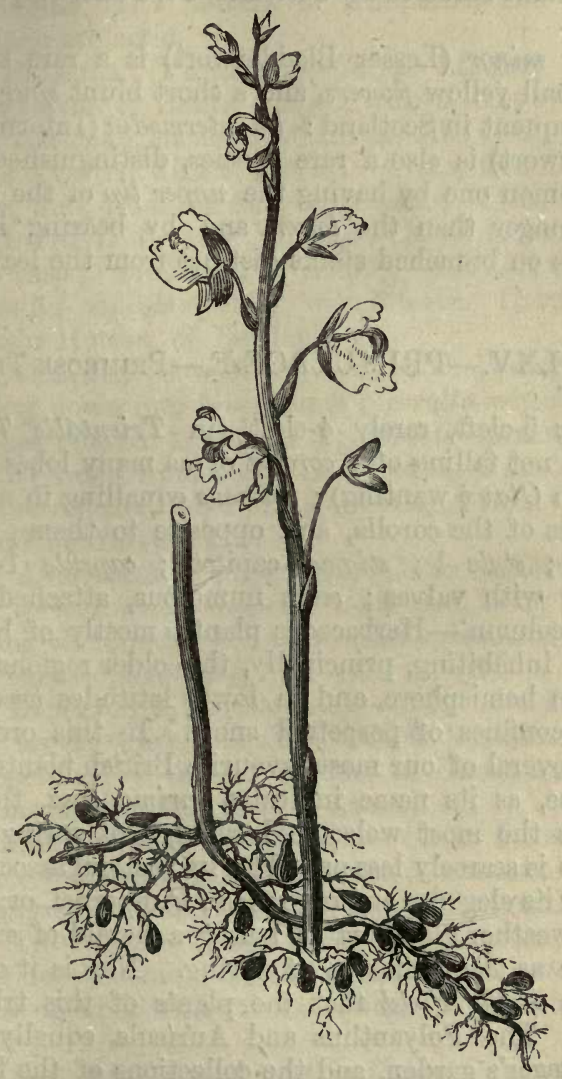

UTRICULÁRIA VULGÁRIS (Common Bladdemwort).

which are then filled with air; the flowers, which grow in clusters of $6-8$ together, are large, and bright yellow, 
and are raised several inches out of the water. After flowering the bladders become filled with water, and the whole plant sinks to the bottom.-Fl. June, July. Perennial.

* U. minor (Lesser Bladderwort) is a rare species, with small yellow flowers, and a short blunt spur; it is most frequent in Scotland: U. intermedia (Intermediate Bladderwort) is also a rare species, distinguished from the common one by having the upper lip of the corolla much longer than the lower, and by bearing its airbladders on branched stalks distinct from the leaves.

\section{ORD. LXV.-PRIMULACEÆ.-Primrose Tribe.}

Calyx 5-cleft, rarely 4-cleft (in Trientális 7-cleft), regular, not falling off ; corolla of as many lobes as the calyx (in Glaux wanting); stamens equalling in number the lobes of the corolla, and opposite to them; ovary 1-celled; style 1; stigma capitate ; capsule 1-celled, opening with valves; seeds numerous, attached to a central column.-Herbaceous plants, mostly of humble growth, inhabiting, principally, the colder regions of the northern hemisphere, and in lower latitudes ascending to the confines of perpetual snow. In this order are

- found several of our most favourite British plants. The Primrose, as its name indicates (prima rosa, the first rose), is the most welcome harbinger of spring; the Cowslip is scarcely less prized for its pastoral associations than for its elegance and fragrance ; Pimpernel, or " Poor man's weather-glass," is as trusty a herald of summer weather as the Primrose of spring. Nor is it only as Flowers of the Field that the plants of this tribe are valued. The Polyanthus and Aurícula equally grace the cottager's garden, and the collections of the florist; and several species of Cýclamen are commonly found in conservatories. Some species possess active medicinal properties; the flowers of the Cowslip are made into a 
pleasant soporific wine; and the leaves of the Aurícula (Primula Aurícula) are used in the Alps as a remedy for coughs. The flowers of Pimpernel and roots of Cýclamen are acrid.

1. Prímula (Primrose).-Calyx tubular, 5-cleft; corolla salver or funnel-shaped, with a long cylindrical tube ; stamens 5, enclosed within the tube of the corolla ; capsule 5-valved with ten teeth. (Name from the Latin primus, first, from the early appearance of the flowers.)

2. Ноттопia (Water Violet).-Calyx 5-cleft almost to the base; corolla salver-shaped, with a short tube ; stamens 5 ; capsule opening with 5 teeth. (Named after Professor Hotton, of Leyden.)

3. Cŕclamen (Sow-bread).-Calyx bell-shaped, cleft half way down into 5 segments ; corolla wheel-shaped, the lobes reflexed; stamens 5 ; capsule opening with 5 teeth. (Name from the Greek cyclos, a circle, either from the reflexed lobes of the corolla, or from the spiral form of the fruit-stalks.)

4. Anagallis (Pimpernel).-Calyx 5-cleft to the base; corolla wheel-shaped; stamens 5, hairy; capsule splitting all round. (Name in Greek denoting that the plant excites pleasure.)

5. Lysimáchia (Loosestrife).-Calyx 5-cleft to the base ; coroula wheel-shaped ; stamens 5 , not hairy ; capsule opening by valves. (Name in Greek having the same meaning as the English name.)

6. Centúnculus (Chaffweed).-Calyx 5-cleft to the base ; corolla with an inflated tube ; stamens 4 ; capsule splitting all round. (Name of doubtful etymology.)

7. Trientális (Chickweed Winter-green).-Calyx 7-cleft to the base'; corolla wheel-shaped; stamens 7 ; capsule opening with valves. (Name of doubtful etymology.)

8. Glaux (Sea-milkwort).-Calyx 0 ; corolla bellshaped, 5-lobed; stamens 5 ; capsule 5-valved, with 510 seeds. (Name in Greek denoting the sea-green colour of the foliage.) 
9. Sámolus (Brookweed).-Calyx 5-cleft, adhering to the lower half of the capsule, not falling off ; corolla salver-shaped, with 5 scales at the mouth of the tube; stamens 5; capsule opening with 5 reflexed teeth.

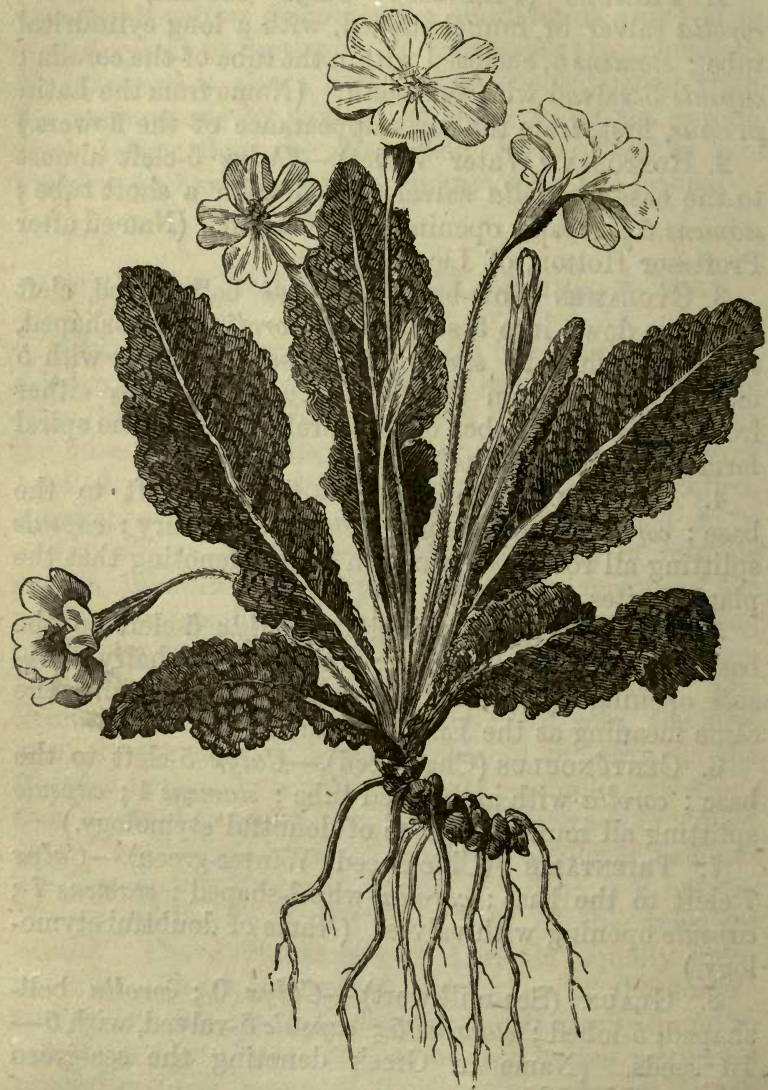

PRIMUla vulgáris (Primrose). 
("Named, some say, from the Island of Samos, where Valerandus, a botanist of the 16th century, gathered our Samolus Valerandi."-Sir W. J. Hooker.)

\section{Prímula (Primrose).}

1. P. vulgáris (Primrose).-Flowers each on a separate stalk; leaves oblong, egg-shaped.-Banks and woods, abundant. Among the most welcome of spring flowers, and too well known to need any description. The colour of the flower is so peculiar as to have a name of its own ; artists maintain that primrose-colour is a delicate green ; white, purple, and lilac varieties are not uncommon.-Fl. March-May. Perennial.

2. P. elatior (Oxlip).-Flowers in a stalked umbel, salver-shaped ; calyx tubular; leaves egg-shaped, contracted below the middle.-Woods and pastures, not common. Distinguished from the Primrose by its umbellate yellow flowers, and by its leaves, which become suddenly broader above the middle, and from the Cowslip by its tubular, not bell-shaped calyx, and flat, not concave corolla.-Fl. April, May. Perennial.

3. $P$. veris (Cowslip, Paigle).-Flowers in a stalked umbel, drooping, funnel-shaped; calyx bell-shaped; leaves egg-shaped, contracted below the middle. - Pastures, common. Among the many pleasing purposes to which these favourite flowers are applied by children, none is prettier than that of making Cowslip Balls. The method, which may not be known to all my readers, is as follows : - The umbels are picked off as close as possible to the top of the main stalk, and from fifty to sixty are made to hang across a string stretched between the backs of two chairs. The flowers are then carefully pressed together, and the string is tied tightly so as to collect them into a ball. Care should be taken to choose such heads or umbels only as have all the flowers open, or the surface of the ball will be uneven.-Fl. April, May. Perennial. 


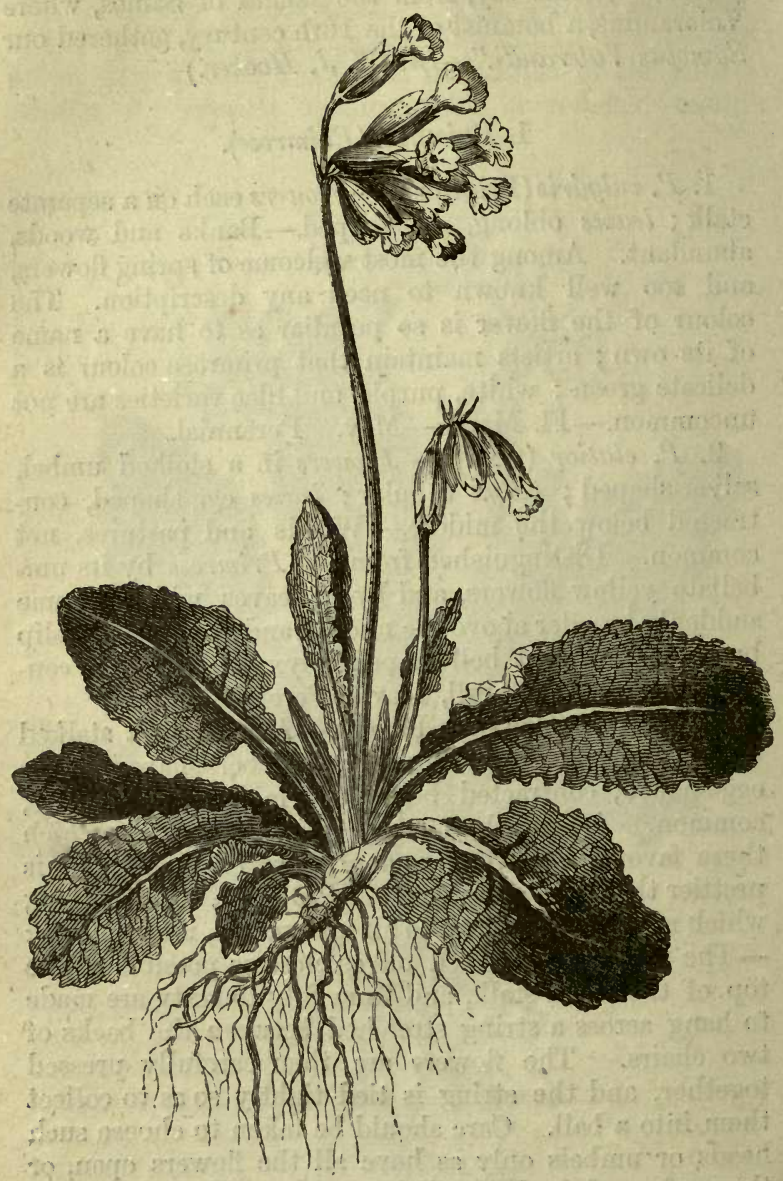

primula veris (Cowslip, Paigle). 
* P. farinósa (Bird's-eye Primrose) is found in mountainous pastures in the North of England, and South of Scotland; its leaves are thickly covered with a powdery meal, and the flowers are purple with a yellow eye : $P$. scótica (Scottish Primrose) is a rare species, growing in the Orkneys, and in a few places in the North of Scotland; it resembles the last, but is smaller. All the varieties of Primrose, Cowslip, and Auricula, may be easily propagated by dividing the roots in autumn. New varieties are raised from seed, which should be sown as soon as ripe in leaf-mould, and pricked out into beds when large enough.

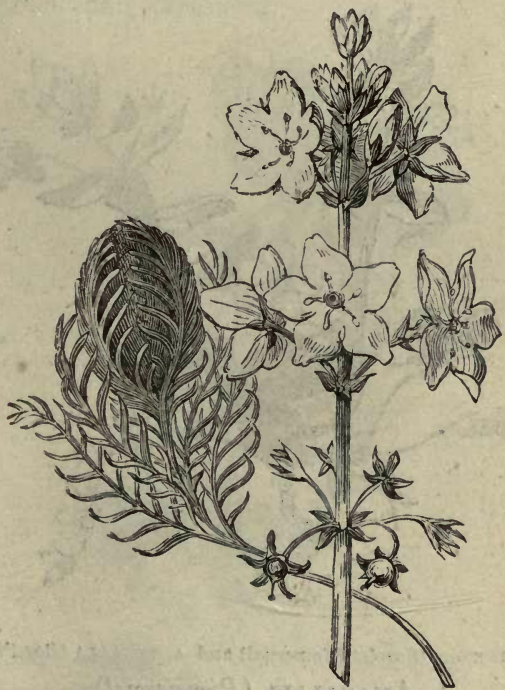

HотTб́NIA (Water Violet).

2. HotтónIA (Water Violet).

1. H. palustris. (Water Violet).-The only British species.-Ponds and ditches; common. An aquatie plant, with finely divided, submersed leaves; flowers 
large, handsome, pink and yellow, arranged in whorls around a leafless stalk, which rises several inches out of the water.

\section{Cúclamen (Sow-bread).}

1. C. hederofolium (Ivy-leaved Sow-bread).-The only species found in Britain, and probably not a native.-Remarkable for its globular, brown root, and nodding flesh-coloured flowers, the lobes of which are bent back. As the fruit ripens, the flower stalk curls spirally, and buries it in the earth. The root is intensely acrid.-Fl. April. Perennial.

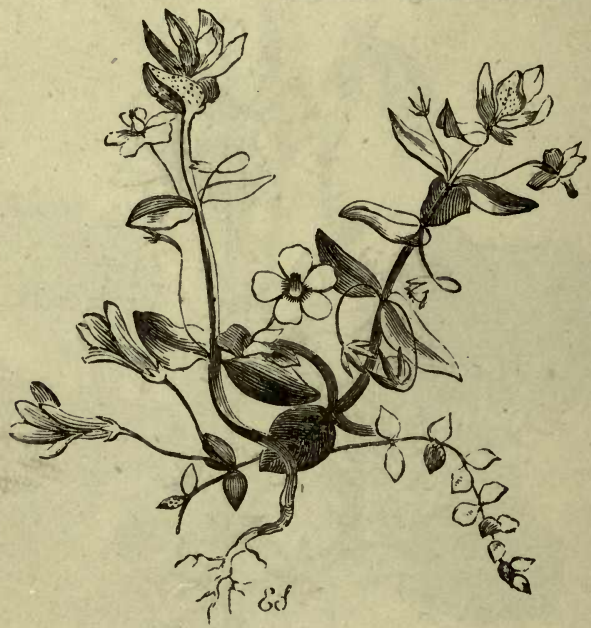

anagallis arvensis (Scarlet Pimpernel) and a. tenella (Bog Pimpernel).

\section{Anagallis (Pimpernel).}

1. A. arvensis (Scarlet Pimpernel).-Leaves eggshaped, dotted beneath, sessile ; petals crenate.-Cultivated ground, abundant. A pretty little plant; with bright scarlet flowers, which expand only in fine weather, and have consequently gained for the plant the name of 
Poor man's weather-glass. The colour of the flowers occasionally varies to flesh-coloured, or white with a red eye. A bright blue variety, which some botanists consider a distinct species, is more unfrequent.-Fl. June, July. Annual.

2. A. tenella (Bog Pimpernel).-Stem creeping; leaves roundish, stalked, shorter than the flower-stalks. - Boggy ground and sides of rivulets, common. A beautiful little plant with slender stems 4-6 inches long, small leaves which are arranged in opposite pairs, and erect rose-coloured flowers, larger than those of the Scarlet Pimpernel, and more frequently having the lobes of the corolla erect than expanded.

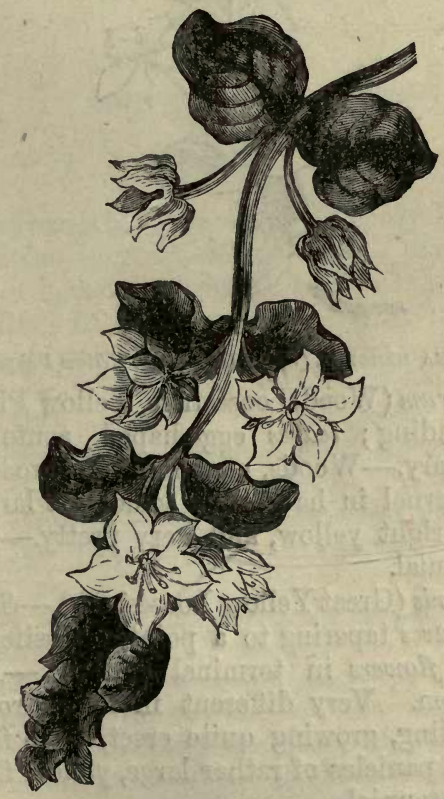

IYSIMÁCHIA NUMMULARIA (Money-wort). 


\section{Lysimáchia (Loosestrife).}

1. L. Nummularia (Money-wort, Herb-twopence).Stem creeping; leaves roundish, slightly stalked; flowers solitary, axillary.-Banks of rivers and damp woods, common. A very pretty plant, well marked by its opposite, shining leaves, and large, yellow flowers. The stems often grow a foot or more in length, and hang from the banks of rivers in a very graceful way. This plant is much used to ornament artificial rockeries.-Fl. June, July. Perennial.

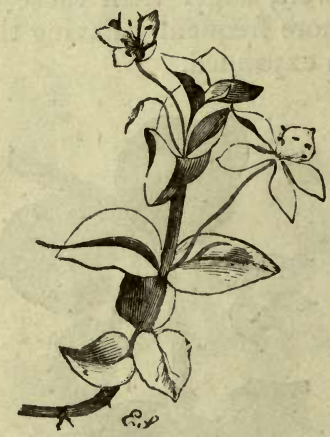

LySimachia NÉmorum (Wood.Loosestrife, Yellow Pimpernel).

2. L. némorum (Wood Loosestrife, Yellow Pimpernel). -Stem spreading; leaves egg-shaped, acute; flowers solitary, axillary.-Woods, common. Approaching the Scarlet Pimpernel in habit, but somewhat larger; the flowers are bright yellow, and very pretty.-Fl. June, July. Perennial.

3. L. vulgáris (Great Yellow Loosestrife).-Stem erect, branched; leaves tapering to a point, opposite, or 3-4 in a whorl; flowers in terminal panicles.-Banks of rivers, common. Very different in habit from either of the preceding, growing quite erect, $2-3$ feet high, with terminal panicles of rather large, yellow flowers.Fl. July. Perennial. 
* L. thyrsiflóra (Tufted Loosestrife) resembles $L$. vulgáris in habit, but bears its flowers, which are small and yellow, in numerous, dense clusters; it grows in marshes in Scotland and the North of England, but is rare.

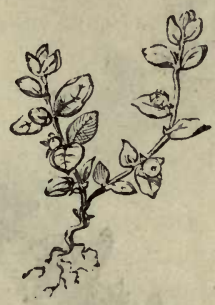

CENTÚNCULus mfNimus (Chaffweed).

\section{Centúnculus (Chaffweed).}

1. C. minimus (Chaffweed).-The only British species. -One of the smallest among British plants, rarely exceeding an inch in height, and often much less. It is nearly allied to the Pimpernel, and at the first glance might be mistaken for a stunted specimen of the common species. The leaves are egg-shaped, acute; the flowers sessile, axillary. It is sometimes branched, but very frequently consists of a single stem, 6 or 8 leaves, and as many inconspicuous flowers.-It grows in damp, gravelly places, especially where water has stood during winter.-Fl. June-August. Annual.

\section{Trientális (Chickweed Winter-green).}

1. T. Europđa (European Chickweed Winter-green). -The only British species, and the only British plant belonging to the Linnæan Class, Heptandria.-Abundant in many parts of the Highlands of Scotland, and occasionally found in the North of England. A pretty 
plant, with an unbranched stem $4-6$ inches high, bearing a few large leaves near its summit, and one or more delicate white flowers, each on a slender stalk. The number of stamens varies from $7-9 .-\mathrm{Fl}$. June. Perennial.

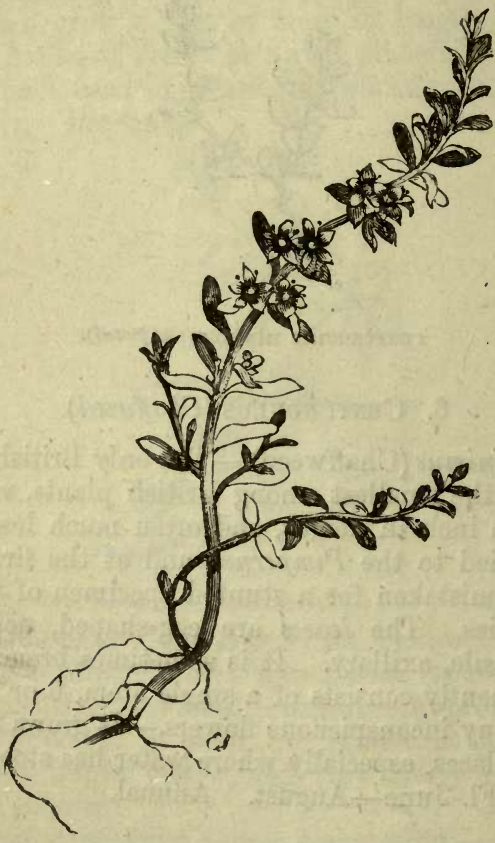

GLAUX MARítima (Sec Milk-wort).

8. Glaux (Sea-Milkwort).

1. G. maritima (Sea-Milkwort).-The only species.Sea shore and salt marshes, common. A fleshy, marine plant 3-6 inches high, growing in thick patches, with 
numerous egg-shaped, glaucous leaves, and axillary pink flowers, which are destitute of calyx. In habit it resembles Honckenya peploídes.-Fl. June-August. Perennial.

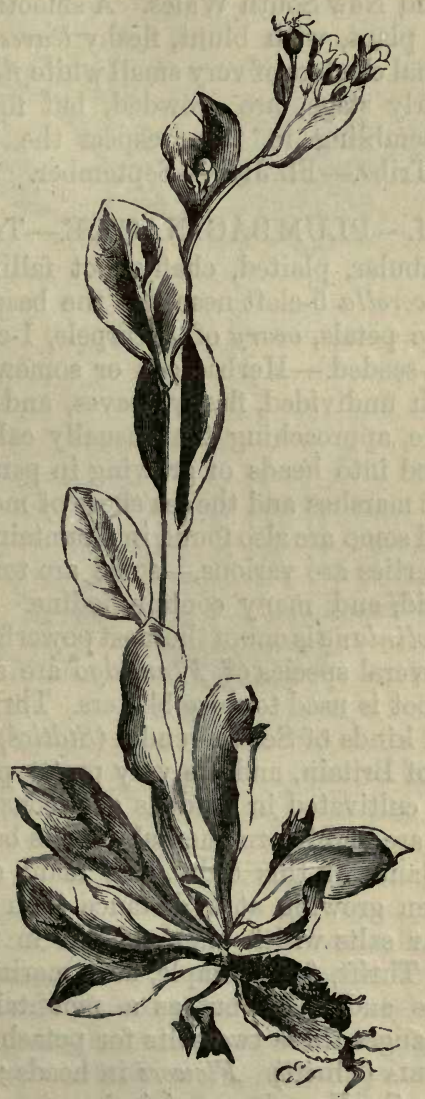

SAMOI,US VALERANDI (Brookweed). 


\section{Símolus (Brookweed).}

1. S. Valerandi (Brookweed). - The only British species.-Watery places, common, and, like many other aquatic plants, widely diffused, being found in Africa, A-merica, and New South Wales. A smooth, pale green, herbaceous plant, with blunt, fleshy leaves, and one or more terminal clusters of very small white flowers, which, in their early stage, are crowded, but finally become distant, resembling in this respect the habit of the Cruciform Tribe-Fl. July-September. Annual.

Ord. LXVI.-PLUMBAGINACEA.-Thrift Tribe.

Calyx tubular, plaited, chaffy, not falling off, often coloured; corolla 5-cleft nearly to the base ; stamens 5 opposite the petals, ovary of 5 carpels, 1 -celled; styles 5 ; fruit 1-seeded.-Herbaceous or somewhat shrubby plants, with undivided, fleshy leaves, and flowers of a thin texture, approaching that usually called Everlasting, collected into heads or growing in panicles. They inhabit salt marshes and the sea shore of most temperate regions, and some are also found in mountainous districts. Their properties are various,- - some are tonic, some intensely acrid, and many contain iodine. The root of Státicé Caroliniana is one of the most powerful astringents known ; several species of Plumbágo are so acrid that the fresh root is used to raise blisters. Thrift (Arméria) and several kinds of Sea-Lavender (Státicé) grow on the sea shores of Britain, and are very pretty plants. Other species are cultivated in gardens and conservatories, to which they are highly ormamental.' It has been remarked that the plants of this order, like many other marine plants, when growing at a distance from the sea, lose the peculiar salts which they contain in their natural localities. Thrift, for example, as a marine plant contains iodine and soda, but as a mountain or garden plant, exchanges these two salts for potash.

1. Arméria (Thrift). Flowers in heads ; styles hairy. (Name from the French armoiries.) 
2. Státicé (Sea Lavender). F'lowers panicled; styles smooth. (Name from the Greek statizo, to stop, from its supposed medicinal virtues.)

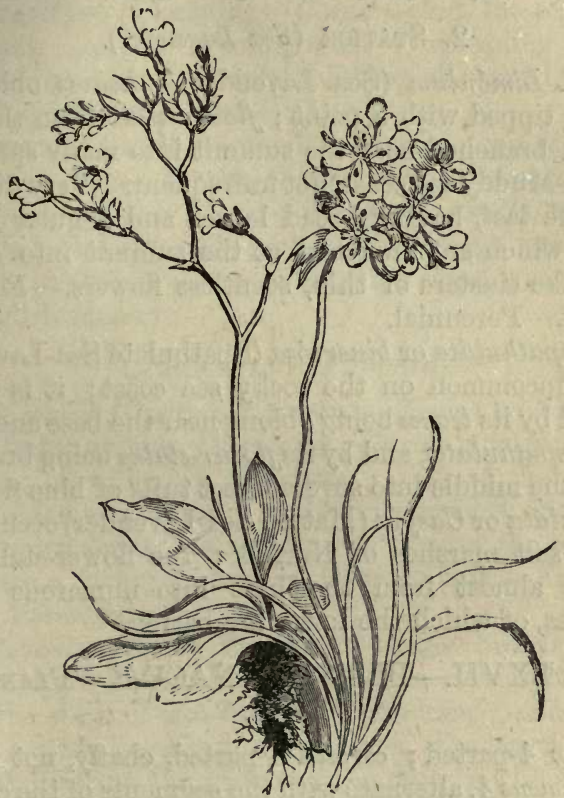

STÁtICÉ SPATHULÁta (Spathulate Sec-Lavender) and ARMÉria Marítima (Thrift).

\section{Armeria (Thrift).}

1. A. marítima (Thrift).-Leaves linear, fleshy; flowerstalks springing directly from the roots, leafless, and bearing each a roundish head of flowers.- Sea shores and the tops of mountains, common. Leaves forming dense tufts or balls ; flowers rose-coloured, in roundish heads, which are raised on downy stalks $3-6$ inches from the ground; 
the summit of the flower-stalk is cased in a brown membranous sheath, and the flowers are intermixed with ehaffy bracts, or scales; the fruit is almost winged by the dry, chaffy calyx.-Fl. July, August. Perennial.

\section{Státicê (Sea Lavender).}

1. S. Limónium (Sea Lavender).-Leaves oblong 1ribbed, tipped with a point; flower-stalk from the root, leafless, branched near the summit into many spreading tufts.-Muddy sea coast, not unfrequent. Very different from the last, having broad leaves and angular flowerstalks, which are branched at the summit into several spike-like clusters of thin, scentless flowers.-Fl. July, August. Perennial.

* S. spathuláta or binervósa (Spathulate Sea-Lavender) is not uncommon on the rocky sea coast; it is distinguished by its leaves being oblong near the base and wider above (spathulate), and by its flower-stalks being branched below the middle into several erect tufts of blue flowers : S. reticuláta or Caspia (Matted Sea-Lavender) occurs only in the salt marshes of Norfolk; the flower-stalks are divided almost from the base into numerous zigzag branches, of which the lower are barren.

\section{ORD. LXVII.-PLANTAGINACEA.-PLANTAIN TRIBE.}

Calyx 4-parted; corolla 4-parted, chaffy, not falling off ; stamens 4, alternate with the segments of the corolla, and having very long, thread-like filaments, and lightlyattached anthers; ovary 2- rarely 4-celled; style 1; stigma hairy ; capsule splitting transversely ; seeds 1, 2, or many in each cell.-Herbaceous plants of humble growth, with many ribbed or fleshy leaves spreading horizontally from the root. The flowers, which are made conspicuous by their long stamens, grow in spikes. Several species are common in great Britain as wayside, meadow, and marine plants, and many are found in almost all parts of the world. The leaves are slightly 
bitter and astringent; the seeds abound in a tasteless mucilage, which is used in medicine as a substitute for Linseed, and is said to be employed in France to stiffen muslin.

1. Plantágo (Plantain).-Calyx 4-cleft, the segments bent back; corolla tubular, with 4 spreading lobes; stamens very long; capsule splitting all round, 2-4celled. (Name of doubtful origin.)

2. Littorella (Shore-weed).-Stamens and pistils in different flowers ; barren flower stalked; stamens very long; fertile flower sessile ; bracts 3 , corolla tubular, contracted at both ends; style very long; capsule 1 seeded. (Name in Latin having the same meaning as the English name.)

\section{Plantágo (Plantain).}

1. P. major (Greater Plantain).-Leaves broadly eggshaped on long channelled stalks ; flowers in a long spike, the stem of which is cylindrical; cells of the capsule many-seeded.-Borders of fields and waysides, abundant. Well known for its spikes of green flowers, the seeds of which are a favourite food of Canary birds.-Fl. June, July. Perennial.

2. P. media (Hoary Plantain).-Leaves broadly elliptical on short flat stalks ; flowers in a close cylindrical spike, the stalk of which is also cylindrical ; cells of the capsule 1-seeded.-Meadows, common. The leaves spread horizontally from the crown of the root, and lie so close to the ground as to destroy all vegetation beneath and to leave the impression of their ribs on the ground; the spike is shorter than in $P$. major, but grows on a longer stalk, and the flowers, which are fragrant; are rendered conspicuous by their light purple anthers.-Fl. June, July. Perennial.

3. P. lanceoláta (Ribwort Plantain).-Leaves narrow, tapering; flowers in a short spike, the stalk of which is angular; cells of the capsule 1-seeded.-Meadows, abundant. Under the name of Cocks and Hens this plant 
is well known to children, who amuse themiselves by striking the heads one against another until the stalk breaks. The flowers are dark brown.-Fl. June, July. Perennial.

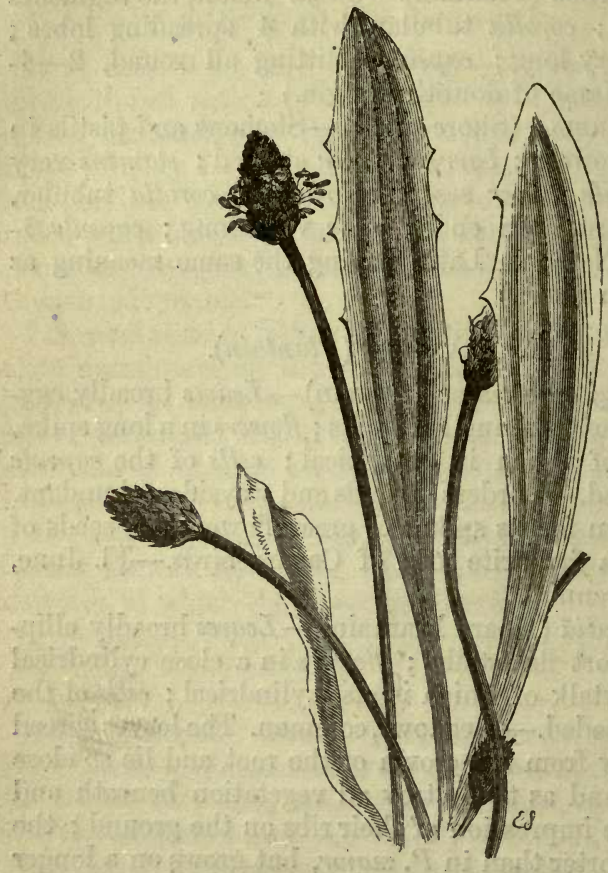

PLANTÁGo LANCEOLÁta- (Ribwort Plantain).

4. P. marítima (Sea-side Plantain).-Leaves linear, grooved, fleshy, woolly at the base. - Sea shores and tops of mountains, common. Easily distinguished from the rest of the genus by its long, fleshy leaves.-Fl. JuneSeptember. Perennial. 
5. P. Corónopus (Buck's-horn Plantain), - Leaves pinnatifid; capsule imperfectly 4-celled, 4-seeded.Waste ground, especially near the sea, common. The only British species which has divided leaves; these are more or less downy, and usually prostrate.-Fl. June, July. Annual.

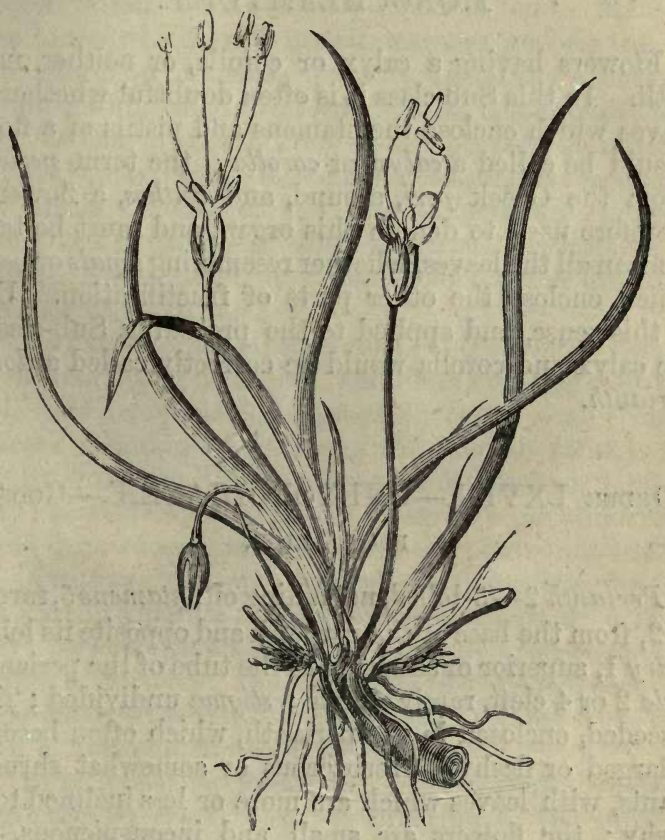

IITTORELLA LACUSTRIS (Shore-weed).

2. Littorella (Shore-weed).

1. L. lacustris (Shore-weed).-The only species.Marshes and banks of lakes. Not unlike Plantágo marítima in habit, but at once distinguished by its soli- 
tary barren flowers, raised each on a stalk 2-4 inches high ; the fertile flowers are sessile among the leaves.Fl. June-September. Perennial.

\section{SUB-CLASS IV. \\ MONOCHLAMYDEAE.}

Flowers having a calyx or corolla, or neither, never both. In this Sub-class it is often doubtful whether the leaves which enclose the stamens and pistils of a flower should be called a calyx or corolla: the term perianth (from the Greek peri, around, and anthos, a flower) is therefore used to denote this organ, and must be taken to mean all the leaves, whether resembling sepals or petals, which enclose the other parts of fructification. Used in this sense, and applied to the preceding Sub-classes, the calyx and corolla would be correctly called a double perianth.

ORDER LXVIII.-CHENOPODIACEAE-GoosEFOOT TRIBE.

Perianth 2-5-lobed, not falling off; stamens 5, rarely 1 or 2 , from the base of the perianth and opposite its lobes ; ovary 1 , superior or adhering to the tube of the perianth ; style 2 or 4 cleft, rarely simple ; stigma undivided ; fruit 1-seeded, enclosed in the perianth, which often becomes enlarged or fleshy.-Herbaceous or somewhat shrubby plants, with leaves which are more or less inclined to be fleshy; the flowers are small and inconspicuous, the perianth decidedly partaking of the characters of a calyx, which sometimes, as in Átriplex, has a tendency to become enlarged when in fruit. Some plants have flowers bearing pistils only, others stamens only, and others again both stamens and pistils. They are common weeds in many temperate climates, and are most abundant in salt marshes 
and on the sea shore. Many of the plants of this tribe are used as esculent vegetables, as Spinach, Beet, and Orache. Beet is cultivated extensively in France for making sugar, and a variety of it affords valuable food for cattle under the name of Mangold Wurzel. In Peru the leaves of Chenopodium Quinoa, a plant growing at a great elevation, are a common article of food. Many of those kinds which grow in salt marshes and on the sea shore afford an immense quantity of soda. According to some naturalists Salvadóra Pérsica, belonging to this order, is the Mustard Tree of Scripture. It bears a juicy fruit, having the flavour of cress, and its seeds are very small. Some of the species have an offensive. odour; but a variety of Chenopódium Botrys, found in Zermatt, Switzerland, is remarkable for the aromatic fragrance of its foliage.

1. Chenopódium (Goose-foot). - Perianth deeply 5-cleft, remaining unaltered, and finally closing over the single seed ; stamens 5 ; stigmas 2 ; leaves flat. (Name in Greek meaning the same as the English name.)

2. Sú́DA (Sea Blite).-Perianth deeply 5 -cleft, often fleshy; stamens 5; stigmas 2-3; leaves semicylindrical. (Name from suced, soda, in which the plants ahound.)

3. Átriplex (Orache).-Stamens and pistils for the most part in separate flowers, sometimes united; barren flower, perianth $2-5$ cleft; stamens 5; fertile flower, perianth of 2 valves; stigmas 2 ; fruit 1 -seeded, covered by the enlarged perianth; leaves flat. (Name from the Greek $a$, not, and trephein, to nourish.)

4. BeTA (Beet).-Perianth deeply 5-cleft; stamens 5 ; stigmas 2 ; fruit 1 -seeded, adhering to the tube of the fleshy perianth; leaves flat. (Name, the Latin name of the plant.)

5. Sátsola (Saltwort).-Perianth deeply 5-cleft; stamens 5; stigmas 2 ; fruit 1-seeded, crowned by the shrivelled lobes of the perianth; leaves cylindrical. (Name from the Latin sal, salt, from the alkaline salt in which it abounds.) 
6. Saliconnia (Glass-wort).-Perianth top-shaped, fleshy, undivided; stamens $1-2$; style very short; stigma 2-cleft ; fruit enclosed in the dry perianth ; stem jointed ; leaves none. (Name from the Latin sal, salt, and cornu, a horn, from the alkaline salt in which it abounds, and the horn-shaped branches.)

\section{Chenopodium (Goose-font). * Leaves undivided.}

1. C. ólidum (Stinking Goose-foot).-Stem spreading; leaves egg-shaped, with a triangular base, fleshy, mealy; flowers in dense clustered spikes.-Waste places, especially near the sea. Distinguished by its fishy smell, which is disgusting in the extreme.-Fl. August. Annual.

2. C. polyspermum (Many-seeded Goose-grass).-Stem spreading; leaves egg-shaped, sessile; flowers in branched, somewhat leafy, slender spikes ; seeds flattened horizontally, shining, minutely dotted.-Waste ground, not common. Varying in size, from 4 inches to a foot in height; the stems and leaves usually have a red tinge, and the plant, when in flower, has a not inelegant appearance from the number of shining, brown seeds, which are not concealed by the perianth.

\section{* Leaves toothed, angled, or lobed.}

3. C. Bonus-Henrícus (Good King Henry).-Leaves triangular, arrow-shaped; flowers in compound, leafless spikes.-Waste places near villages, common, A darkgreen, succulent plant, about a foot high, with large, thickish leaves, which are used as Spinach.-Fl. August. Perennial.

4. C. album (White Goose-foot).-Leaves egg-shaped, with a triangular base, bluntly toothed, upper ones narrow, entire; flowers in dense, clustering spikes.-Waste places and cultivated ground, common. Whole plant succulent; leaves more or less fleshy, and covered with 


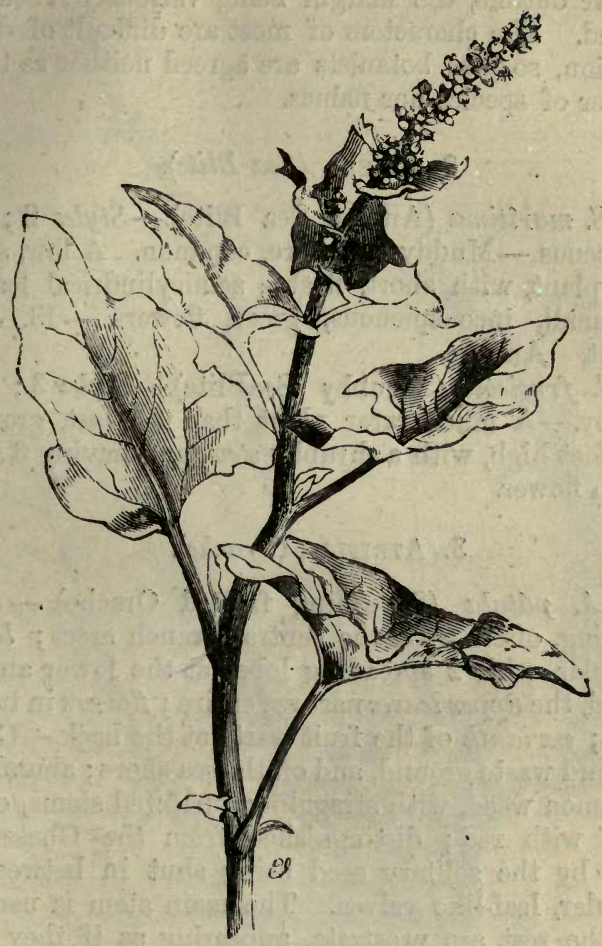

CHENOPODIUM BONUS-HENRICTS (Good King Henry),

a whitish, mealy powder. This is, perhaps, the commonest species ; it grows $1-3$ feet high.-Fl. JulySeptember. Annual.

* There are several other British species of this uninteresting family, some of which have nothing but their rarity to recommend them, and others are remarkable only for the tendency of their leaves to assume a triм м 2 
angular outline, the margin being variously lobed and toothed. The characters of most are difficult of discrimination, so that botanists are agreed neither as to the number of species nor names.

\section{Sumda (Sea Blite).}

1. S. marítima (Annual Sea Blite).-Styles 2 ; stem herbaceous.-Muddy sea-shore, common. A low, straggling plant, with short, fleshy, semicylindrical leaves; and small, inconspicuous, green flowers. - Fl. July, August. Annual.

2. S. fruticósa (Shrubby SeaBlite).-Styles 3 ; stem shrubby.-A much rarer plant than the last, growing $2-3$ feet high, with a shrubby stem, and having 3 styles in each flower.

\section{Atriplex (Orache).}

1. A. pátula (Spreading fruited Orache). - Stem spreading, often with the central branch erect; leaves triangular, with 2 spreading lobes at the lower angles, toothed, the upper leaves narrow, entire; flowers in tufted spikes; perianth of the fruit warty at the back.-Cultivated and waste ground, and on the sea shore; abundant. A common weed, with straggling, furrowed stems, often tinged with red; distinguished from the Goose-foot family by the solitary seed being shut in between 2 triangular, leaf-like valves. The main stem is usually erect, the rest are prostrate, appearing as if they had been bent down by force.-Fl. July, August. Annual.

2. A. laciniáta(Frosted Sea Orache).-Stem spreading; leaves with three angles, wavy at the edge, and toothed, mealy beneath. - Sea shore, frequent. Distinguished from the preceding by its mealy leaves, and the whitish hue of the whole plant.-Fl. July, August. Annual.

* Several other species are described by botanists, but the remark annexed to the preceding family applies equally well to this. 
GOOSE-FOOT TRIBE.

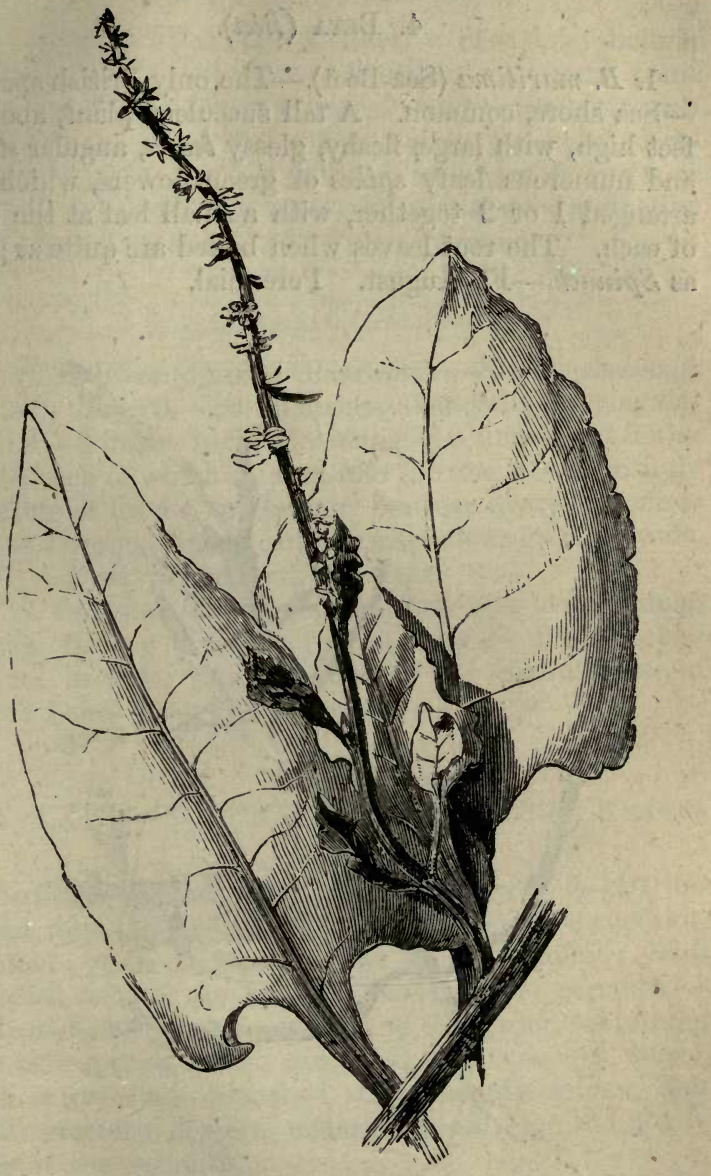

BetA Maritima (Sea-Beet). 


\section{Beta (Beet).}

1. B. maritima (Sea-Beet).-The only British species. -Sea shore, common. A tall succulent plant, about 2 feet high, with large, fleshy, glossy leaves, angular stems, and numerous leafy spikes of green flowers, which are arranged 1 or 2 together, with a small leaf at the base of each. The root leaves when boiled are quite as good as Spinach.-Fl. August. Perennial.

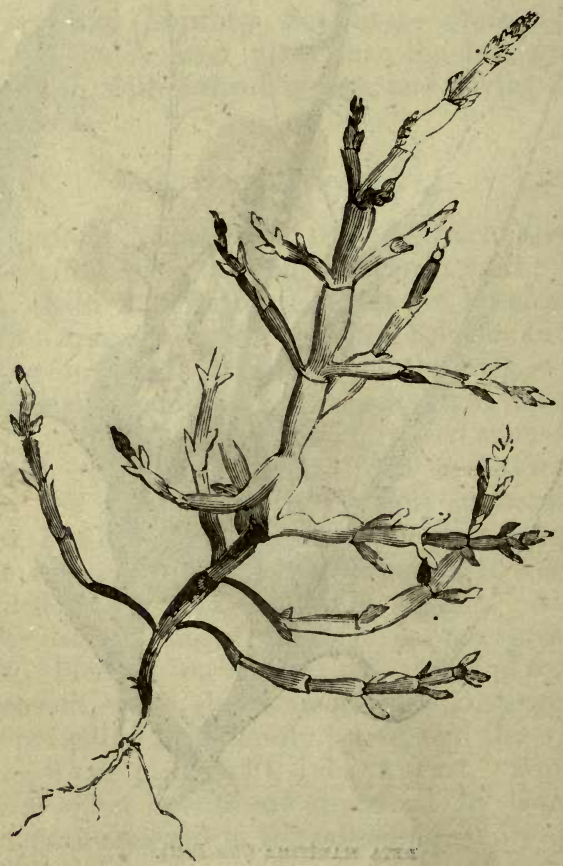

8ALICORNIA HERBẢCEA (Jointed Glass-wort). 


\section{Sálsola (Saltwort).}

1. S. Kali (Prickly Saltwort).-The only British species.-Sandy sea shore, common. A small plant with prostrate, branched stems, and succulent awlshaped leaves, each of which terminates in a sharp prickle; the flowers are solitary, and have 3 bracts at the base of each. The whole plant abounds in alkaline salt, whence its name.-Fl. July. Annual.

\section{Saliconnia (Glasswort).}

1. S. herbácea (Jointed Glasswort).-Stem herbaceous, jointed ; leaves 0.- Salt marshes, abundant. A singular plant 4-8 inches high, consisting of a number of fleshy joints, each of which is fitted into the one below, entirely destitute of leaves, and bearing between every two joints of the terminal branches 3 inconspicuous green flowers. -Fl. August, September. Annual.

* S. radícans (Rooting Glasswort) is a less common species, having prostrate, rooting stems. Both species abound in soda, which is used in the manufacture of glass; hence the name Glasswort.

\section{Ord. LXIX.-SCLERANTHACEAE-The KNAWEL Tribe.}

Perianth tubular, 4 or 5 cleft; stamens 5-10, inserted into the mouth of the tube; ovary 1 , superior, 1-celled; styles 2 or 1 notched at the summit; fruit enclosed within the hardened tube of the perianth.Only one British genus belongs to this order, containing but two species, which are small inconspicuous weeds, with wiry much branched stems, scanty foliage, and small greenish flowers, remarkable only for the chaffy edge of the perianth.

1. Solerantius (Knawel).-Calyx 5 -cleft, contracted at the mouth of the tube; petals 0 ; stamens 10 , rarely 
5 ; styles 2 ; fruit 1-seeded, covered by the hardened calyx. (Name from the Greek scléros, hard, and anthos, a flower, from the hardness of the calyx.)

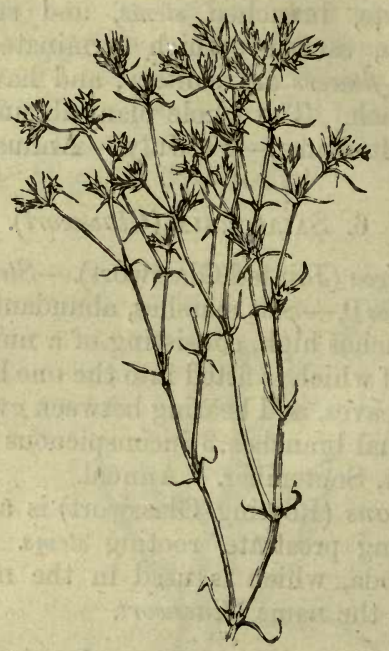

SCLERANThUS ANNUA (Annual Knavel).

-1. Scleranthus (Knawel).

1. S. annua (Annual Knawel).-Calyx, when in fruit, spreading, acute, with a narrow whitish margin; root annual.-Corn-fields, especially on a gravelly soil, common. A small plant, 2-4 inches high, with numerous tangled stems, awl-shaped leaves, and green flowers, which grow either in the forks of the stems, or in terminal tufts. - Fl. July-November. Annual.

* S. perennis (Perennial Knawel) has prostrate stems, blunt calyx-leaves, with a broad margin, and perennial roots. It grows in dry sandy fields, in Norfolk and Suffolk. 
Ord. LXX.-POLYGONACE.Æ.-The Persicaria
Tribe.

Flowers often bearing stamens only, or pistils only. Perianth deeply 3-6 parted, often in two rows ; stamens $5-8$ from the base of the perianth; ovary 1 , not attached to the perianth; styles 2 or 3 ; fruit a flattened or triangular nut.-Herbaceous plants, distinguished by the above characters and by bearing alternate leaves furnished at the base with membranous stipules, which encircle the stalk. The perianth is often coloured; and as the flowers, though not large, are numerous, and grow in spikes or panicles, many of them are handsome plants. Others, as the Dock, are unsightly weeds; they are found in all parts of the world, from the Tropics to the Poles. The properties residing in the leaves and roots are very different, the former being acid and astringent, and sometimes of an agreeable flavour; the latter nauseous and purgative. The powdered root of several species of Rhéum affords the valuable medicine Rhubarb, and the leaf-stalks of the same plants are much used for making tarts; the sharp taste is attributed to the presence of oxalic, nitric, and malic acids. Two native kinds of Sorrel, and several of Dock, belong to the genus Rumex. Sorrel ( $R$. Acetósa) is sometimes used in the same way as Rhubarb-stalks; but the species mostly employed in cookery is $R$. scutáta. To the genus Polýgonum belong P. Fagopýrum, Buck-wheat, or Beech-wheat, so called from the resemblance in shape between its seeds and the mast of the Beech-tree. In some countries the flour derived from its seeds is made into bread, but in England it is not much cultivated except as food for pheasants, which are very partial to it. $P$. tinctórum is extensively cultivated in France and Flanders for the sake of the blue dye afforded by its herbage ; and several other species are used as medicine. Triplaris Americana attains the dimensions of a tree, and is remarkable for being infested 
by ants, which excavate dwellings for themselves in its trunk and branches. (See "Forest Trees of Britain," vol. ii. p. 65.)

1. Polýgonum (Persicaria).-Perianth deeply 5-cleft, not falling off; stamens 5-8; styles 2 or 3 ; fruit a triangular or flattened nut. (Name in Greek signifying having many knees, or joints, from the numerous joints of the stem.)

2. Rumex (Dock).-Perianth deeply 6-cleft, in two rows, the interior segments large ; stamens 6 ; styles 3 ; fruit a triangular nut, covered by the enlarged inner perianth. (Name, the Latin name of the plant.)

3. OxÝRIA (Mountain-Sorrel).-Perianth deeply 4cleft, in two rows, the interior segments large; stamens 6 ; styles 2 ; fruit a flattened nut with a membranous wing. (Name from the Greek oxys, sharp, from the acid flavour of the stem and leaves.)

\section{Polýgonum (Persicaria). \\ * Styles 3 ; fruit triangular.}

1. P. Bistorta (Bistort, Snakeweed).-Stem simple, erect, bearing a single dense spike; leaves egg-shaped, the lower ones on winged stalks.-Moist meadows, not common. A rather handsome plant, with a large twisted root, and several stems $1-1 \frac{1}{2}$ foot high, each of which bears a cylindrical spike of flesh-coloured flowers. The English names Bistort (twice twisted) and Snake-weed were given in allusion to the form of the root.-Fl. June. Perennial.

2. P. vivíparum (Viviparous Bistort).-Stem simple, ereet, bearing a single loose spike which has in the lower part small bulbs in place of flowers ; leaves very narrow, their margins rolled back.-Mountain pastures, especially in the Highlands of Scotland. A slender plant, $6-8$ inches high, remarkable for its tenelency to propagate itself by small, red bulbs, which supply the place of 
flowers in the lower part of the spike; the flowers are light flesh-coloured.-Fl. June, July. Perennial.

3. P. aviculáré(Common Knot-grass).-Stem branched, prostrate; leaves narrow, elliptical ; flowers axillary.-. Waste ground and road sides, abundant. A common weed, with leaves which are furnished with chaffy stipules, and with minute flesh-coloured or greenish-white flowers. It varies greatly in size, and in rich soil often has a tendency to grow nearly erect. - Fl. all the summer. Annual.

* Closely allied to $P$. aviculáré are $P$. Roberti, a seaside plant, with stouter stems, glaucous foliage, and large shining fruit; and $P$. marítimum, also a sea-side plant, but very rare, distinguished from the preceding by its large, nerved stipules, and shrubby stem.

4. P. Fagopýrum (Buck-wheat).-Stem erect; leaves heart-arrow-shaped, acute ; flowers in spreading panicles. -A doubtful native, found only near cultivated land, where it is grown principally as food for pheasants. The stems are branched and about a foot high, the flowers light flesh-coloured.-Fl. July, August. Annual.

5. P. Convólvulus (Climbing Persicaria).-Stem twining; leaves heart-arrow-shaped; segments of the perianth bluntly keeled; fruit roughish.-Cultivated ground, abundant. A mischievous weed with the habit of the Field Convólvulus, twining round the stems of corn and other plants, and bearing them down by its weight. The flowers are greenish-white, and grow in axillary spikes about 4 together.-Fl. July, August. Annual.

* P. dumetórum (Copse Buck-wheat) is distinguished from the last by its more luxuriant growth, its winged perianth, and shining fruit. It grows in bushy places in the South of England.

\section{** Styles mostly 2 ; fruit fattened.}

6. P. amphŕbium (Amphibious Persicaria).-Stem erect, or supported in the water by the floating leaves; flowers in oblong spikes; stamens 5 ; leaves oblong, heart-shaped at the base.-Ditches and banks of pools, 


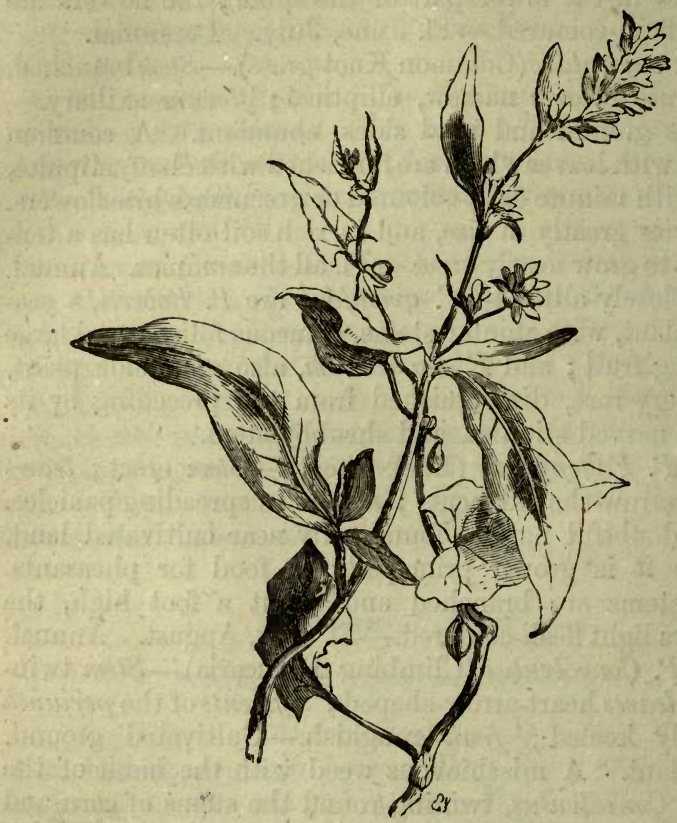

Polýgonum convólveles (Climbing Persicaria).

frequent. So different are the forms assumed by this plant when growing in the water and on land, that the varieties might well be taken for two distinct species. In the water, the stems are $2-3$ feet long, being supported by long-stalked, floating, smooth leaves; on land, the stems are about a foot high, and the leaves narrow and rough. In both forms of the plant the spikes of flowers are rose-coloured and handsome.-Fl. July-September. Perennial.

7. P. Persicária (Spotted Persicaria).-Stem erect, branched; leaves narrow, tapering, often spotted; flowers 
in spikes ; stamens 6 ; styles forked; stipules fringed.Waste and damp ground, abundant. A common weed 1-2 feet high, distinguished by its rather large leaves stained with purple, and numerous oblong spikes of greenish or pinkish-white flowers.-Fl. July, August. Annual.

* P. lappathifolium (Pale-flowered Persicaria) closely resembles the last; it is distinguished by having 2 distinct, instead of forked styles, and by not having the stipules fringed; in both species the leaves are sometimes white with silky down.

8. P. Hydropiper (Water-Pepper).-Steni erect; leaves narrow, tapering; flowers in loose, drooping spikes; stamens 6.-Ditches and places where water has stood during winter, abundant. Well distinguished by its slender, drooping spikes of greenish flowers. The fresh juice is acrid, but not of an unpleasant flavour, and is said to cure pimples on the tongue.-Fl. August, September. Annual.

* Some botanists reckon three other species of Polýgonum, besides the foregoing, but they are of rare occurrence and difficult to be distinguished, with the exception of $P$. minus, several stations for which are given; it resembles $P$. Hydropiper, but is a smaller plant with upright spikes, narrower leaves, and nearly undivided styles.

\section{Rumex (Dock, Sorrel).}

* Flowers having both stamens and pistils; herbage not acid.

1. R. Hydrolápathum (Great Water-Dock).-Leaves narrow, elliptical, tapering at both ends, the lower ones heart-shaped at the base; enlarged segments of the perianth bluntly triangular, tubercled.-River-banks, frequent. A picturesque plant $4-6$ feet high, with exceedingly large leaves, and several stems which bear 
numerous green flowers in almost leafless whorls.-Fl. July, August. Perennial.

* There are about ten other species of Dock, some of which are rarely to be met with, others far too common. The most abundant kind is $R$. obtusifólius (Broadleaved Dock), too well known to need any description: $R$. crispus (Curled Dock) has acute curled leaves, and is also common : $R$. sanguíneus (Bloody-veined Dock) has the veins of its leaves tinged of a beautiful crimson; the other specios are less frequent.

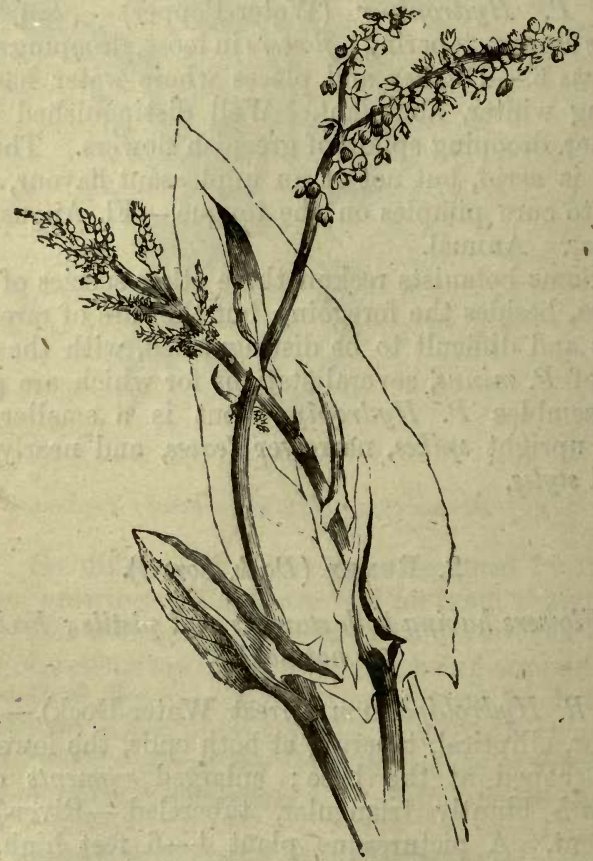

RUMEX CETOSA (Common Sorrel). 
* * Stamens and pistils on different plants; herbage acid.

2. R. Acetósa (Common Sorrel).-Leaves oblong, slightly arrow-shaped at the base.-Meadows, abundant. A slender plant about 2 feet high, with juicy stems and leaves, and whorled spikes of reddish-green flowers. Well known for the grateful acidity of its herbage.-Fl. June, July. Perennial.

3. R. Acetosella (Sheep's Sorrel).-Leaves tapering to a point, produced at the base into long arrow-shaped barbs.-Dry gravelly places, abundant. Much smaller than the last, and often tinged, especially towards the end of summer, of a deep red hue.-Fl. May-July. Perennial.

\section{OxÝria (Mountain Sorrel).}

1. O. reniformis (Mountain Sorrel).-The only species. -Damp places near the summits of high mountains, frequent. Approaching the Common Sorrel in habit, but shorter and stouter. The leaves are all from the root, fleshy, and kidney-shaped; the flowers are green, and grow in clustered spikes : the herbage has a grateful acid flavour.-Fl. June-August. Perennial.

\section{ORd. LXXI-ELAAAGNACEA.-Oleaster Tribe.}

Stamens and pistils on separate plants. Barren flowers in catkins ; perianth tubular; stamens $3-8$, sessile on the throat of the perianth; fertile flower solitary, tubular, not falling off; ovary. 1-celled; style short; stigma awl-shaped; fruit a single nut, enclosed within the fleshy perianth. - Trees or shrubs, with leaves which. have no stipules, but are covered with scurfy scales. They are found in all parts of the northern hemisphere. The fruit of several species of Elæagnus is eaten in the East, and the flowers are highly fragrant, and abound in honey, which, in some parts of Europe, is considered 
a remedy for malignant fevers. The only British species is the Sea Buckthorn (Hippophaë Rhamnoides). 1. Hrppophä̈ (Sea Buckthorn).-Stamens and pistils on separate plants; barren flowers in small catkins; perianth of 2 valves; stamens 4 , with very short filaments ; fertile flowers solitary ; perianth tubular, cloven at the summit; style short; stigma awl-shaped; fruit a 1-seeded nut, enclosed in the fleshy perianth. (Name of - doubtful etymology.)

\section{Hippophaxं (Sea Buckthorn).}

1. H. Rhamnoides (Sea Buckthorn, Sallow-Thorn).The only species.-Sand-hills and cliffs on the eastern coast of England. A thorny shrub 4-5 feet high, with very narrow, silvery leaves, small greenish flowers, which appear with the leaves in May, and numerous orangecoloured berries, which are of an acid flavour, and very juicy. The stems, roots, and foliage are said to impart a yellow dye.-Fl. May. Shrub. (See Miss Pratt's "Common Things of the Sea-side.")

\section{ORD. LXXII.-THYMELACEA-D-DAPHNE TRIBE.}

Calyx tubular, coloured, 4- rarely 5-cleft, occasionally having scales in its mouth; stamens 8,4 , or 2 , inserted in the tube of the perianth; ovary 1-celled; style 1 ; stigma undivided; fruit a 1 -seeded nut or drupe.Shrubs with undivided laurel-like leaves, remarkable for their tough bark, which is of a highly acrid nature, causing excessive pain if chewed, and raising a blister if applied to the skin. Both the bark and root of Mezéreon (Daphné Mezéreon) are used in medicine; they are of very violent effect, whether taken inwardly or applied externally. The berries of Spurge-Laurel are poisonous to all animals except birds. In the East the bark of several species is manufactured into ropes and paper. The inner bark of Lagetta lintearia, when 
macerated and cut into thin pieces, assumes a beautiful net-like appearance, whence it has received the name of Lace-bark. In the South of Europe two plants belonging to this tribe are used to dye wool yellow. The seeds of Inocarpus edullis are eaten when roasted, and have the taste of Chestnuts. Daphné Japónica, or Indica, with its varieties, is commonly cultivated in conservatories and gardens for the sake of the delicious fragrance of its flowers. The only British genus belonging to this tribe is-

1. Daphne (Spurge-Laurel).-Characters given above. (Name, the Greek for a Laurel, which it resembles in the character of its foliage.)

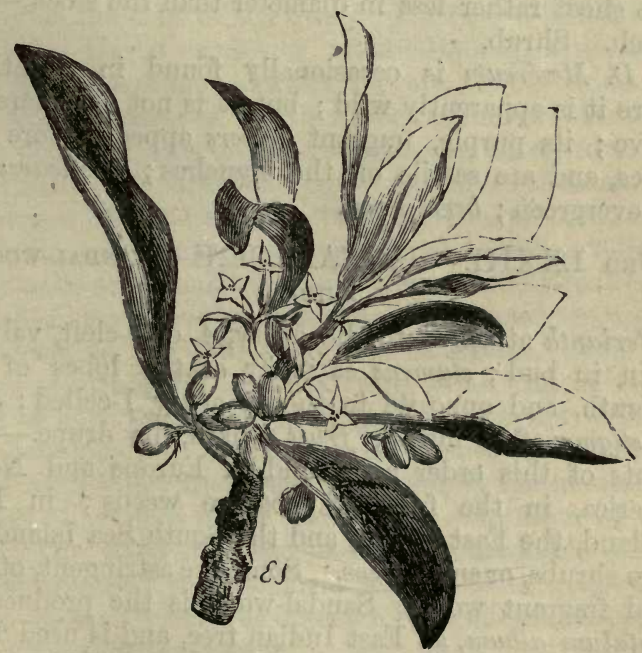

DAPHNE LaURÉola (Spurge-Laurel).

\section{Daphne (Spurge-Laurel).}

1. D. Lauréola (Spurge-Laurel).-Flowers in drooping, axillary clusters ; leaves evergreen.-Woods, not un- 
frequent. A low shrub, about 2 feet high, very little branched, and remarkable for its smooth, erect stems, which are bare of leaves except at the summit. The leaves are smooth, shining, and evergreen ; the flowers are green, and in mild weather fragrant; the berries, which are egg-shaped and nearly black, are, as has been noted above, poisonous. From the tendency of this plant to bear its proportionally large leaves only on the summit of the stem, it has some resemblance to a group of Palms. If transplanted from the woods and potted, it may be employed with advantage as a stock on which to graft the delicious $D$. Indica. The operation should be performed in Spring with the leafy extremity of a shoot rather less in diameter than the stock.-Fl. March. Shrub.

* D. Meréreum is occasionally found in situations where it is apparently wild; but it is not considered a native; its purple, fragrant flowers appear before the leaves, and are sessile on the branches; the leaves are not evergreen ; berries red.

\section{ORD. LXXIII.-SANTALACEA.-SANDAL-WOOD Tribe.}

Perianth attached to the ovary, 4- or 5-cleft, valvate when in bud; stamens as many as the lobes of the perianth, and opposite to them ; ovary 1-celled; style 1 ; stigma often lobed; fruit a hard, dry drupe.-The - plants of this order are found in Europe and North America, in the form of obscure weeds ; in New Holland, the East Indies, and the South Sea Islands as large shrubs, or small trees. Some are astringent, others yield fragrant wood. Sandal-wood is the produce of Sántalum album, an East Indian tree, and is used both medicinally and as a perfume. In New Holland and Peru the seeds of some species are eaten. The only British plant belonging to this tribe is-

1. Thésium (Bastard Toad-flax).--Characters given above. (Name of doubtful origin.) 


\section{Thésium (Bastard Toad-flax).}

1. T. linophyllum (Bastard Toad-flax).-The only British species. - Chalky hills, not common. A rather small plant, with a woody root, nearly prostrate stems, very narrow, pointed leaves, and leafy clusters of whitish flowers.-Fl. July. Perennial.

\section{ORD. LXXIV.-ARISTOLOCHIACEA.-BIRTH- WORT TRIBE.}

Perianth attached to the ovary below, tubular above, with a wide mouth; stamens 6-12 inserted on the ovary; ovary 3-6-celled; style 1; stigmas rayed, as many as the cells of the ovary ; fruit 3-6-celled, many seeded.-Herbs or shrubs, often climbing, with simple leaves, and solitary, axillary flowers, very abundant in the warmer parts of South America, but rare elsewhere. The plants of this order are generally bitter, tonic and stimulant. The dried and powdered leaves of Asarabacea (Ásarum Europoeum) are used in the preparation of cephalic snuffs, exciting sneezing, and giving relief to head-ache and weak eyes. Virginian Snake-root (Aristolóchia serpentaria) and other allied species are used as antidotes to the bite of venomous snakes. The juice extracted from the root of a South American species is said to have the power of stupifying serpents if placed in their mouths. Other African species are said to be used by the Egyptian jugglers to stupify the snakes with which they play tricks during the exhibition of their art. The wood of Aristolochia is remarkable for not being arranged in concentric layers, but in wedges. A thin slice is a beautiful object for examination under a microscope of low power.

1. Aristolóchia (Birthwort).-Perianth tubular, curved, swollen at the base, the mouth dilated on one side; anthers 6, inserted on the style; stigma 6-lobed; capsule 6-celled. (Name in Greek denoting the supposed medicinal virtues of the plant). 
2. Ásarum (Asarabacca).-Perianth bell-shaped, 3cleft; stamens 12 inserted at the base of the style; stigma 6-lobed; capsule 6-celled. (Name from the Greek $a$, not, and seira, a wreath, denoting that the plant was by the ancients excluded from garlands.)

\section{Aristolóchia (Birthwort).}

1. A. Clematitis (Birthwort).-The only species found growing in wild situations in Britain, but not considered indigenous.-Woods, and among ruins in the east and south of England, rare. A singular plant, with creeping roots, slender, unbranched, erect stems, and large heartshaped leaves; the flowers, which grow several together, are of a dull yellow colour, swollen at the base, contracted above, and expanding into an oblong lip with a short point.-Fl. July, August. Perennial.

\section{2. Ásarum (Asarabacca).}

1. A. Europoum (Asarabacca).-The only species found in Britain, and not considered indigenous.Woods in the North, rare. A curious plant, consisting of a very short stem, bearing two large shining leaves, and a solitary dull-green drooping flower.-Fl. May. Perennial.

\section{ORD. LXXV.-EMPETRACEA - CROW-BERRY TrIBE.}

Stamens and pistils on separate plants; perianth of several scales arranged in 2 rows, the inner resembling petals ; stamens equal in number to the inner scales, and alternate with them; ovary of 3,6 , or 9 cells, on a fleshy disk; style 1; stigma rayed; fruit fleshy, with long cells; seeds 1 in each cell. Small heath-like evergreen shrubs, with minute axillary flowers, chiefly inhabiting Europe and North America. The leaves and fruit are slightly acid. The berries of the Crow-berry 
(Empetrum nigrum), though of an unpleasant flavour, are eaten in the Arctic regions, and are considered as a preventive of scurvy.

1. Émpetrum (Crow-berry).-Perianth of 3 outer and 3 inner scales. (Name in Greek signifying growing on a rock.)

\section{1. Émpetrum (Crow-berry).}

1. E. nigrum (Black Crow-berry, Crake-berry).-The only British species; abundant on mountainous heaths in the North.-A small, prostrate shrub, with the habit of a Heath. The stems are much branched; the leaves are oblong, very narrow, and have their margins so much recurved as to meet at the back; the flowers are small and purplish, growing in the axils of the upper leaves. The berries, which are black, are much eaten by moorfowl.-Fl. May. Perennial.

ORD. LXXVI.-EUPHORBIACEAE.-SPURge TRIBE.

Stamens and pistils in separate flowers ; perianth lobed, with various scales or petal-like appendages; stamens varying in number and arrangement; ovary mostly 3 celled, with as many styles and stigmas; fruit generally 3 -celled and 3-seeded. - A large order, very difficult to be defined even by the experienced botanist, and, therefore, very likely to puzzle the beginner, who must not be disheartened if he is a long while in reducing to their place in the system those plants belonging to it which he first meets with. Linnæan botanists differ as to the Class in which the Spurges should be placed; nor is it agreed upon to which Sub-class in the Natural System they should be referred; for, though the European species have only a single perianth, many of the tropical genera are undoubtedly furnished with both sepals and petals. The order contains nearly 200 genera, and it is necessary to examine many of these, before the relation can be 
traced between those families which most differ. The number of species is thought to be not less than 2,500, which are distributed over most of the tropical and temperate regions of the globe, especially the warmer parts of America. They are either trees, shrubs, or herbs, and some kinds have the external habit of the cactus tribe. Among so numerous an assemblage of plants, we should expect to find a great dissimilarity of properties, which, indeed, exists to a certain extent ; yet nearly all agree in being furnished with a juice, often milky, which is highly acrid, narcotic, or corrosive, the intensity of the poisonous property being usually proportionate to the abundance of the juice. Of the genus Euphórbia, Spurge, which gives name to the order, ten or twelve species are natives of Britain. The British Spurges are all herbaceous, and remarkable for the singular structure of their green flowers, and their acrid milky juice, which exudes plentifully when either the stems or leaves are wounded. A small quantity of this placed upon the tongue produces a burning heat in the mouth and throat, which continues for many hours. The unpleasant sensation may be allayed by frequent draughts of milk. The roots of several of the common kinds enter into the composition of some of the quack fever medicines; but they are too violent in their action to be used with safety. The Irish Spurge is extensively ased by the peasants of Kerry for poisoning, or rather stupifying, fish. So powerful are its effects, that a small creel, or basket, filled with the bruised plant, suffices to poison the fish for several miles down a river. Euphórbia Láthyris is sometimes, though erroneously, called in England the Caper-plant. Its unripe seeds are pickled, and form a dangerous substitute for genuine capers, which are the unexpanded flower-buds of Cáparis spinósa, a shrub indigenous to the most southern countries of Europe. Among the foreign Spurges, some species furnish both the African and American savages with a deadly poison for their arrows. Another, 
called in India Tirucalli, furnishes an acrid juice, which is used in its fresh state for raising blisters. Other kinds are used in various parts of the world as medicines, but require to be administered with caution. The gum resin, Euphorbium, of chemists, is procured from three species growing in Africa and the Canaries, by wounding the stems, and collecting in leathern bags the sap which exudes. It is an acrid poison, highly inflammable, and so violent in its effects as to produce severe inflammation of the nostrils if those who are employed in powdering it do not guard themselves from its dust. Pliny relates that the plant was discovered by King Juba, and named by him after his physician, Euphorbus. The Manchineel tree (Hippómané Mancinella) is said to be so poisonous, that persons have died from merely sleeping beneath its shade. Its juice is pure white, and a single drop of it falling upon the skin burns like fire, forming an ulcer often difficult to heal. The fruit, which is beautiful and looks like an apple, contains a similar fluid, but in a milder form; the burning it causes in the lips of those who bite it guards the careless from the danger of eating it. Jatrópha Manihót, or Manioc, is a shrub about six feet high, indigenous to the West Indies and South America, abounding in a milky juice of so poisonous a nature, that it has been known to occasion death in a few minutes. The poisonous principle, however, may be dissipated by heat, after which process the root may be converted into the most nourishing food. It is grated into a pulp, and subjected to a heavy pressure until all the juice is drained off. The residue, called cassava, requires no further preparation, being simply baked in the form of thin cakes on a hot iron hearth. This bread is so palatable to those who are accustomed to it, as to be preferred to that made from wheaten flour; and Creole families, who have changed their residence to Europe, frequently supply themselves with it at some trouble and expense. The fresh juice is highly poison- 
ous ; but, if boiled with meat and seasoned, it makes an excellent soup, which is wholesome and nutritious. The heat of the sun even is sufficient to dissipate the noxious properties; for, if it be sliced and exposed for some hours to the direct rays of the sun, cattle may eat it with perfect safety. The roots are sometimes eaten by the Indians, simply roasted, without being previously submitted to the process of grating and expressing the juice. They also use the juice for poisoning their arrows, and were acquainted with the art of converting it into an intoxicating liquid before they were visited by Europeans. By washing the pulp in water and suffering the latter to stand, a sediment of starch is produced, which, under the name of tapioca, is extensively imported into Europe, where it is used for all the purposes to which arrow-root and sago are applied. It is light, digestible, and nourishing, so much so, indeed, that half a pound a day is said to be sufficient to support a healthy man. Caoutchouc, or India-rubber, is a wellknown elastic gum, furnished in greater or less abundance by many plants of this order, but especially by a South American tree, Siphónia or Hévea elástica.

The fragrant aromatic bark called cascarilla is produced by a shrub belonging to this order, Croton Eleutherria, a native of the Bahamas, and by other species of Croton indigenous to the West Indies and South America. Croton oil is the product of Croton Tiglium, and is so violent a medicine, as to be rarely administered until all other remedies have failed. Castor-oil is expressed from the seeds of Ricinus commuinis, an African tree, frequently to be met with in English gardens under the name of Palma-Christi, where, however, it only attains the rank of an annual herbaceous plant. The Box is the only British tree belonging to this Order, of the poisonous properties of which it partakes, though to a limited extent. In some parts of Persia it is very abundant ; and in these districts it is found impossible to keep camels, as the animals are very fond of browsing 
on the leaves, which kill them. The Dog-Mercury (Mercurialis perennis) is an herbaceous plant, common in our woods, and an active poison ; another species, $M$. апnиа, is less frequently met with, and, though poisonous, is not so virulent as the other species.

1. Euphórbia (Spurge).-Perianth or involucre bellshaped, containing 12 or more barren flowers or stamens, and 1 fertile flower or pistil; ovary 3-lobed; styles 3; stigmas 2-cleft; capsule 3-celled, 3-seeded. (Name from Euphorbus, physician to Juba, an ancient king of Mauritania, who first employed the plant as medicine.)

2. Mercuriális (Mercury).-Stamens and pistils on different plants.-Perianth 3-cleft to the base ; barren flower, stamens 9, or more; fertile flower, styles 2 ; ovary 2-lobed ; capsule 2-celled, 2-seeded. (Name in honour of the heathen god Mercury.)

3. Buxus (Box).-Stamens and pistils in separate flowers, but on the same plant.-Perianth 4-cleft to the base; barren flower with 1 bract; stamens 4 ; fertile flower with 3 bracts ; styles 3 ; capsule with three horns, 3 -celled; cells 2-seeded. (Name, the Latin name of the tree.)

\section{Euphórbia (Spurge).}

* Involucre tipped with pointed or angular glands.

1. E. amygdaloídes (Wood Spurge).-Stem branched above in an umbellate manner into about 5 rays ; rays 2 -forked ; bracts perfoliate ; leaves narrow, egg-shaped, hairy beneath ; glands of the involucre crescent-shaped. -Woods, abundant. A common woodland plant, with somewhat shrubby stems, $1-2$ feet high, conspicuous in spring and summer with its golden-green leaves and flowers, and in autumn with the red tinge of its stems and leaves.-Fl. March, April. Perennial.

* To this group belong E. Peplus (Petty Spurge), a very common garden weed, $3-4$ inches high, distinguished by its pale hue, its 3-rayed and forked umbel of numerous flowers, the involucres of which are crescent- 


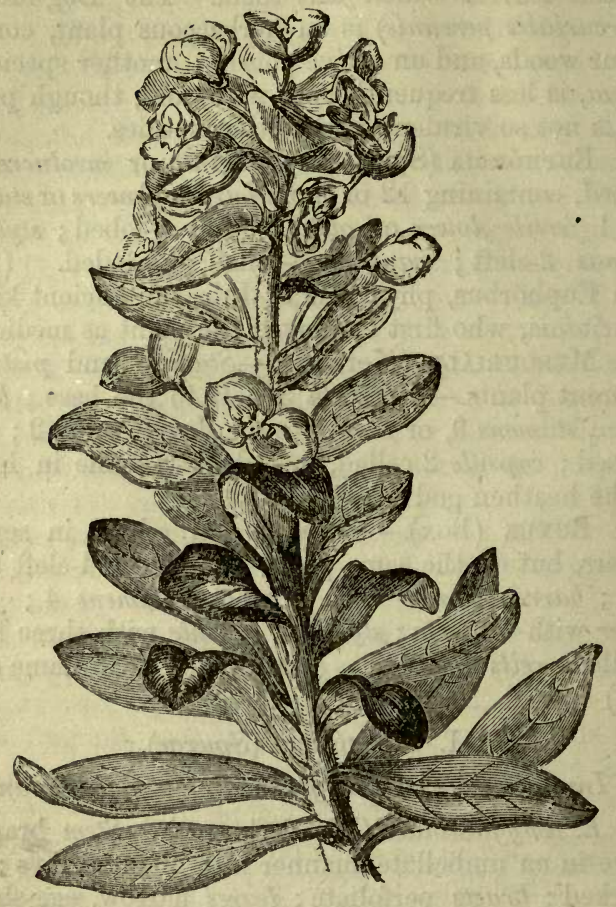

EUPHORBIA AMYGDaLof́dES (Wood Spurge).

shaped, with long horns: $E$. exigua (Dwarf Spurge), common in corn-fields, distinguished from the preceding by its narrow, glaucous leaves, and slenderer habit: $E$. Parálias (Sea Spurge), a stout, somewhat shrubby plant, growing in large masses on the sandy sea-shore, and remarkable for its numerous imbricated, glaucous leaves: and E. Portlándica (Portland Spurge), also a marine species, readily distinguished from the last by its less 
robust habit, and the red tinge of its stems and leaves : E. Láthyris (Caper Spurge), a tall herbaceous species, 2-4 feet high, common in gardens, is remarkable for the glaucous hue of its foliage, its heart-shaped, taperpointed bracts, and very large capsules, which abound to a great degree, as well as the rest of the plant, in the milky, acrid fluid found throughout the family.

\section{* Glands of the involucre not pointed.}

2. $\boldsymbol{E}$. helioscópia (Sun Spurge).-Umbel of 5 rays, which often are repeatedly forked ; leaves oblong, tapering towards the base, serrated above; capsule smooth.Cultivated ground, abundant. Varying in size from a few inches to 2 feet in height, but easily distinguished by the golden-green hue of its spreading umbel, which is large in proportion to the size of the plant, and has several serrated leaves at its base.-Fl. July, August. Annual.

* E. platyphýlla (Water Spurge) is a rare species, which might be mistaken for a small specimen of $E$. helioscópia; it is, however, well marked by having its leaves slightly hairy beneath, and its capsules rough with warts at the back: E. Peplis (Purple Spurge) is peculiar to the sandy sea-shore; it grows quite flat on the sand, sending out several branches at right angles to the root, in a circular manner ; the whole plant is of a beautiful purple hue. Several other species of Spurge are described by British botanists, but they are either very rare, or not considered indigenous.

\section{Mercuríális (Mercury).}

1. M. perennis (Dog's Mercury).-Perennial; stem simple; leaves stalked, roughish.-Woods and shady places, abundant. A common, woodland, herbaceous plant; sending up from its creeping roots numerous undivided stems about a foot high. Each stem bears several pairs of rather large, roughish leaves, and 


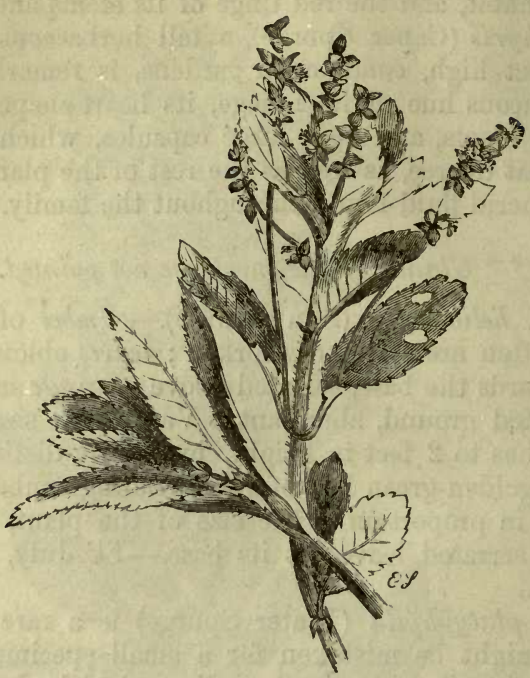

MERCURIALIS PERENNIS (Dog's Mereury).

among the upper ones grow the small, green flowers, the barren on long stalks, the fertile sessile.-Fl. April, May. Perennial.

2. $M$. annua (Annual Mercury).-Annual ; stem branched; leaves sessile, smooth.-Waste places; not common. Taller than the last, and branched. The leaves are smaller and of a light green hue. Barren and fertile flowers are sometimes found on the same plant.-Fl. August. Annual.

\section{Buxus (Box).}

1. B. sempervírens (Common Box-tree).-A small tree growing in great abundance, and apparently wild, 
on Box-hill, Surrey, where it ripens its seeds. A dwarf variety is common in gardens. For a full de-

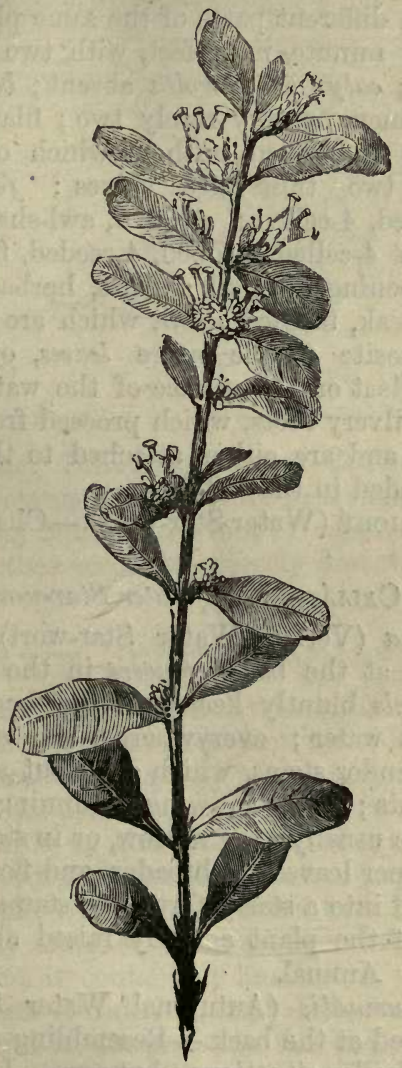

BUXUS SEMPERVIRENS (Common Box-tree).

scription of this valuable tree, see "Forest Trees of Britain."-Fl. April. Small tree. 


\section{ORD. LXXVII.-CALLITRICHACEA-W-WATER StaR-wort Tribe.}

Flowers in different parts of the same plant, axillary, solitary, very minute, imperfect, with two white bracts at the base; calyx and corolla absent; barren flower, with one stamen, or very rarely two; filament threadlike, bearing a 1-celled anther, which opens at the summit by two transverse valves; fertile flower, ovary 4-angled, 4-celled; styles 2, awl-shaped; stigma simple; fruit 4-celled, 4-lobed, 4-seeded, flattened laterally, not opening.-Small aquatic, herbaceous plants, with long, weak, tangled stems, which are usually submerged, opposite simple entire leaves, of which the upper alone float on the surface of the water, and long thread-like silvery roots, which proceed from the joints of the stem, and are either attached to the soil below or are suspended in the water.

1. Callítriché (Water Star-wort).-Characters given above.

\section{Callítriché (Water Star-wort).}

1. C. verna (Vernal Water Star-wort).-Leaves in pairs, united at the base; flowers in the axils of the leaves; carpels bluntly keeled at the back.-Streams and stagnant water; everywhere. An aquatic plant with long slender stems, which send out shining roots from the joints ; either growing in running water, when the leaves are usually very narrow, or in stagnant water, when the upper leaves are broader, and float on the surface, crowded into a starry form, the stamens being the only parts of the plant actually raised above it.-Fl. May-July. Annual.

2. C. autumnális (Autumnal Water Star-wort).Carpels winged at the back.-Resembling the last, and growing in similar situations; but rare. In this species the whole plant is submerged, all the leaves are narrow and abrupt, and of a deeper green.-Fl. June-October. Annual. 


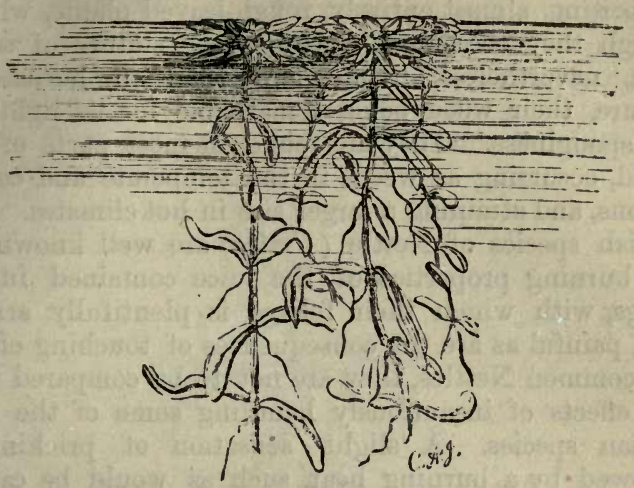

CALIf́triché VerNa (Vernal Water Star-wort).

* Two other British species of Callítriché are described by botanists, which vary in a slight degree from the preceding, but they are not of common occurrence, and are on other accounts scarcely deserving of a separate notice.

\section{ORD. LXXVIII.-URTÍCACEÆ.NETTLE TrIBE.}

Stamens and pistils generally in separate flowers, and often on different plants ; perianth divided, not falling off, sometimes wanting; stamens equal in number to the lobes of the perianth, and opposite to them ; anthers curved inwards in the bud, and often bursting with elasticity; ovary 1, simple ; fruit a hard and dry 1seeded capsule.-A difficult order, the limits of which are variously assigned by different botanists. In its widest extent it contains a number of valuable fruits, as the famous Bread-fruit, and Jack-fruit (Artocarpus incisifolia and A. integrifolia), the Fig, Mulberry, and Sycamore of the Scriptures. The Upas-tree of Java, and Palo-de-vaca or Cow-tree of Demerara, are arranged in the same Order, with many others. In its more limited extent the Nettle Tribe contains 23 families, 
comprising, almost entirely, rough-leaved plants, which, though they occasionally acquire the stature of trees, have, nevertheless, little more than an herbaceous texture, their wood being remarkable for its lightness and sponginess. They are found in most parts of the world, occurring as weeds in the temperate and colder regions, and attaining a larger size in hot climates. The British species of Nettle (Urtíca) are well known for the burning properties of the juice contained in the stings, with which their foliage is plentifully armed. But, painful as are the consequences of touching one of our common Nettles, they are not to be compared with the effects of incautiously handling some of the East Indian species. A slight sensation of pricking is followed by a burning heat, such as would be caused by rubbing the part with a hot iron: soon the pain extends, and continues for many hours, or even days, being attended by symptoms such as accompany lockjaw and influenza. A Java species produces effects which last for a whole year, and are even said to cause death. Specimens of the Tree-Nettle were measured by Backhouse, in Australia, the trunks of which were found to measure 18,20 , and 21 feet in circumference. In some species the fibre is so strong that cordage is manufactured from it. The burning property of the juice is dissipated by heat, the young shoots of the common Nettle being often boiled and eaten as a pot-herb, and the tubers of Urtica tuberósa are eaten as potatoes.

1. URTíca (Nettle).-Stamens and pistils in separate flowers, on the same or different plants ; barren flower, perianth of 4 leaves, stamens 4 ; fertile flower, perianth of 2 leaves, 1-seeded. (Name from the Latin uro, to burn, from its stinging properties.)

2. Parietaria (Pellitory).-Stamens and pistils in the same flower; perianth 4-cleft; stamens 4; flaments at first curved inwards, finally spreading with an elastic spring ; fruit 1-seeded. (Name from the Latin paries, a wall, where these plants often grow.) 
3. Húmulus (Hop).-Stamens and pistils on different plants ; barren flower, perianth of 5 leaves ; stamens 5 ; fertile flower, a catkin composed of large, concave scales, each of which has at its base two styles and 1 seed. (Name from the Latin humus, rich soil, in which the plant flourishes.)

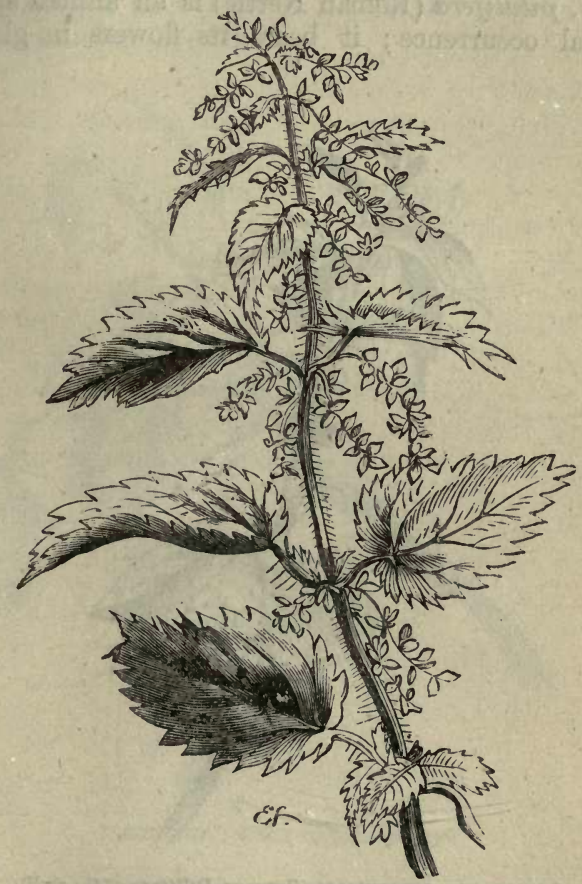

URTICA DIOfCa (Great Nettle).

1. Urtíca (Nettle).

1. U. dioíca (Great Nettle).-Leaves heart-shaped at the base, tapering to a point; flowers in long, branched 00 
clusters.-A common weed, too well known to need further description.-Fl. July, August. Perennial.

2. U. urens (Small Nettle).-Leaves elliptical ; flowers in short, nearly simple clusters. - Waste places, abundant. Smaller than the last, but closely resembling it in habit and properties.-Fl. July-October. Annual.

* U. pilulífera (Roman Nettle) is an annual species, of local occurrence; it bears its flowers in globular heads.

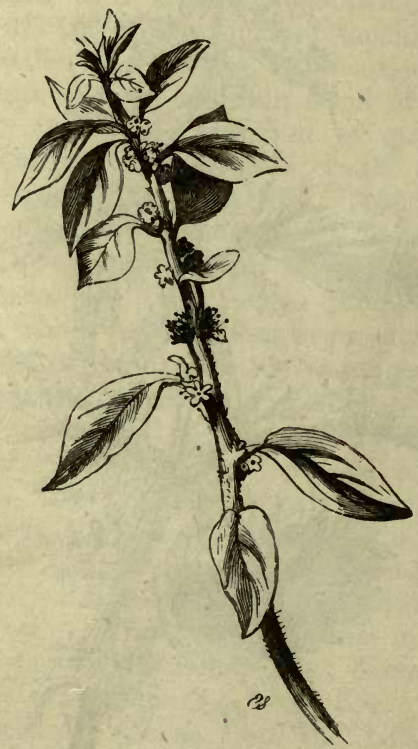

PARIETARIA officinalis (Common Pellitory-of-the-wall).

2. Parietaria (Pellitory-of-the-wall).

1. P. officinalis (Common Pellitory-of-the-wall). - The only British species.-A much-branched, bushy, herba- 
ceous plant, with narrow, hairy leaves, reddish, brittle stems, and small, hairy flowers which grow in clusters in the axils of the leaves. The filaments are curiously jointed and elastic; so that if touched before the expansion of the flower, they suddenly spring from their incurved position and shed their pollen. In rural districts an infusion of this plant is a favourite medicine.-Fl. all the summer. Perennial.

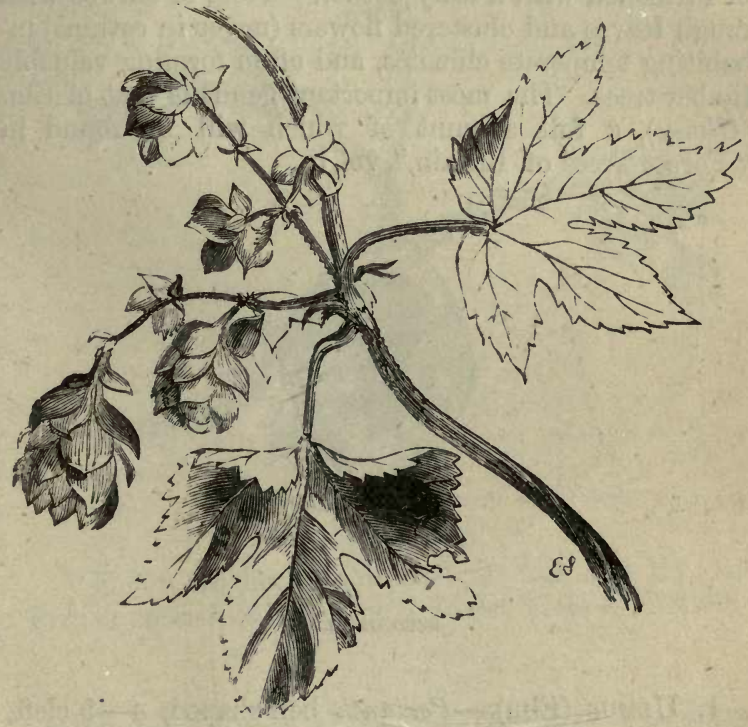

HƠMULUS LUPUI,US (Common Hop).

3. Húmulus (Hop).

1. H. Lripulus (Common Hop).-A beautiful climbing plant, commonly cultivated for the sake of its catkins, which are used to give a bitter flavour to beer, and naturalized in many places.-Fl. July. Perennial.

002 


\section{ORd. LXXIX.-ULMÁCEA-ELm TRIBE.}

Stamens and pistils in the same or different flowers; perianth bell-shaped, often irregular; stamens equalling in number, and opposite to the lobes of the perianth ; ovary not attached to the perianth, 2-celled, styles and stigmas 2 ; fruit 1 or 2 -celled, not bursting, drupe-like, or furnished with a leafy border.-Trees or shrubs with rough leaves and clustered flowers (never in catkins) inhabiting temperate climates, and often forming valuable timber-trees. The most important genus is that of Elm (Ulmus), a full account of which will be found in "Forest Trees of Britain," vol.ii.

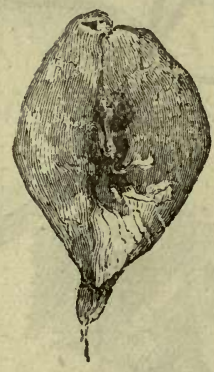

SEED OF ELM.

1. Uluus (Elm).-Perianth bell-shaped, 4-5-cleft, persistent ; stamens 5 ; styles 2 ; capsule thin and leaflike, containing a single seed. (Name, the Latin name of the tree).

\section{Ulmus $(E l m)$.}

1. U. campestris (Common small-leaved Elm).Leaves obliquely wedge-shaped at the base, tapering to 
a point ; fruit oblong, deeply cloven.-Hedge-rows and parks, abundant.-Fl. March. Tree.

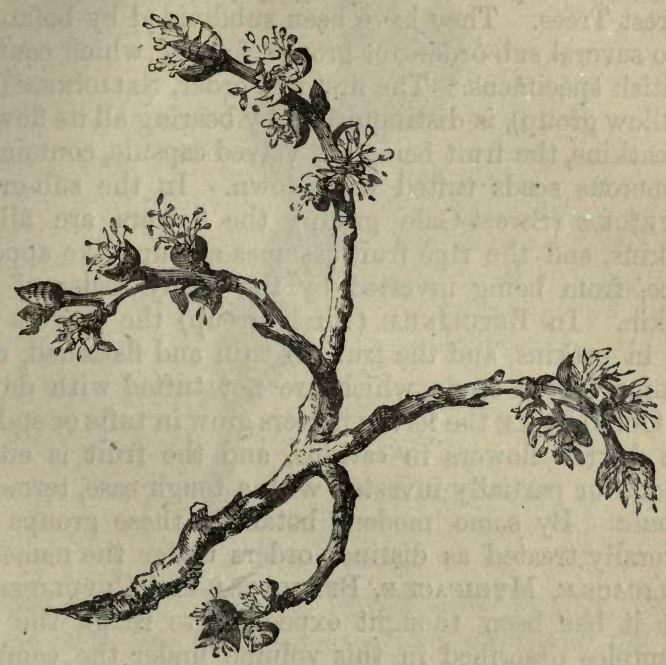

ULMUS CAMFESTFIS (Common small-leaved Elm).

* For a further description of this and the other British species of Elm, sen " Forest Trees of Britain."

\section{ORD. LXXX.-AMENTACEA.-CATKIN-BEARING TRIBE.}

Stamens and pistils in separate flowers, and often on different plants ; barren flowers in heads or catkins, composed of scales ; stamens $1-20$, inserted on the scales ; fertile flowers clustered, solitary, or in catkins ; ovary usually simple ; stigmas 1 or more.-An extensive order, containing a large number of trees which are highly 
valued for their fruit, timber, bark, and other minor productions. They are most abundant in temperate climates, comprising a large proportion of our English Forest Trees. They have been subdivided by botanists into several sub-orders, or groups, four of which contain British specimens. The first sub-order, SALICínex (the Willow group), is distinguished by bearing all its flowers in catkins, the fruit being a 2-valved capsule, containing numerous seeds tufted with down. In the sub-order Mrríces (Sweet-Gale group), the flowers are all in catkins, and the ripe fruit assumes a drupe-like appearance, from being invested by the fleshy scales of the catkin. In BeTulínese (Birch group) the flowers are all in catkins, and the fruit is thin and flattened, containing 1 or 2 seeds, which are not tufted with down. In CuPULífER the fertile flowers grow in tufts or spikes, the barren flowers in catkins, and the fruit is either wholly or partially invested with a tough case, termed a cúpula. By some modern botanists these groups are severally treated as distinct orders under the names of Salicacese, Mrricacede, Betulaces and Cupulifere; but it has been thought expedient to retain the few examples described in this volume under the comprehensive order Amentaceæ. All the British Trees belonging to the order are described at length in "Forest Trees of Britain," where mention also occurs of many foreign species, which are worthy of notice for their application to useful purposes or for their peculiar productions.

\section{Sub-order I.-SaLICínes.-Willow Group.}

1. SALIX (Willow).-Stamens and pistils on different plants (dioecious); scales of the catkin imbricated entire; stamens $1-5$; stigmas 2 ; capsule of 2 valves, 1-celled; seeds numerous, tufted with cottony down. (Name, the Latin name of the plant.)

2. Pópulus (Poplar). - Stamens and pistils on different plants; scales of the catkin jagged; stamens $8-30$; stigmas 4 or 8 ; capsule of 2 valves, obscurely 


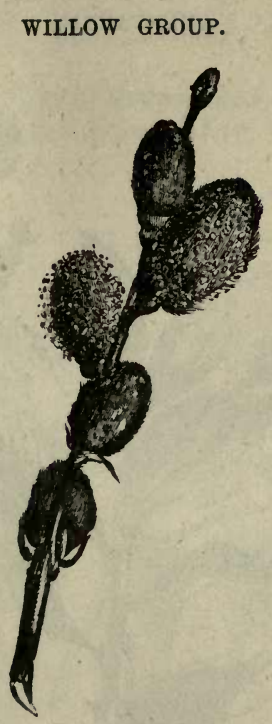

SALIX (Willow).

2-celled; seeds numerous, tufted with cottony down. (Name from the Latin pópulus, and signifying the tree

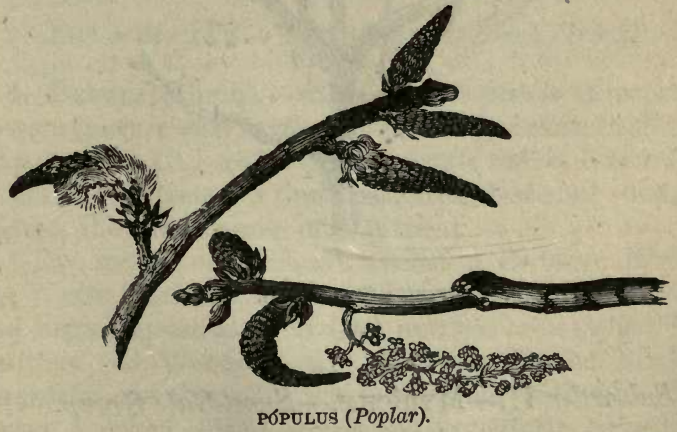

of the people, which it was considered to be at Rome and in France during the Revolutions.) 


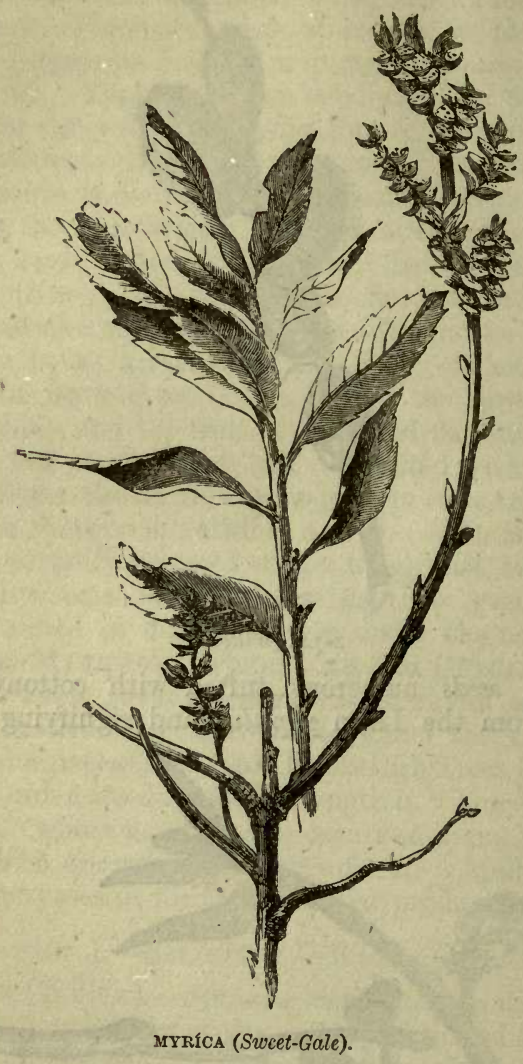

Sub-order II.-MYRÍCEs.-Sweet-Gale Group.

3. Myríca (Sweet-Gale).-Stamens and pistils on different plants; scales of the catkin concave; stamens 
$4-8$; stigmas 2 ; fruit drupe-like, 1-seeded. (Name the Greek name of the Tamarisk.)

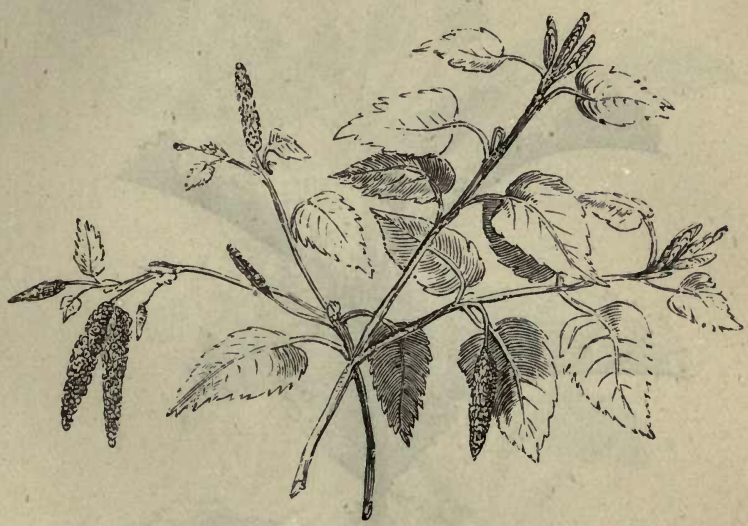

BÉTULA ALBA (White Birch).

Sub-order III.-BetulíNes.-Birch Group.

4. Bétula (Birch).-Stamens and pistils in separate flowers (monocious); scales of the barren catkin in threes ; stamens 10-12; scales of the fertile catkin 3-lobed, 3flowered ; stigmas 2 ; fruit flattened, 1-seeded, winged. (Name, the Latin name of the tree.)

* Two species of Birch are natives of Britain ; $B$. alba, the White Birch, a forest tree, which for lightness, grace, and elegance, stands unrivalled, and has been styled "the Lady of the Woods ;" and B. nana, Dwarf Birch, a mountain shrub, with wiry branches, and numerous round, notched leaves, which are beautifully veined.

5. Auvus (Alder).-Stamens and pistils in separate flowers; scales of the barren catkin 3-lobed, 3-flowered; 
stamens 4 ; scales of the fertile catkin 2 -flowered, permanent, becoming hard and dry ; stigmas 2 ; fruit flattened, not winged. (Name, the Latin name of the tree.)

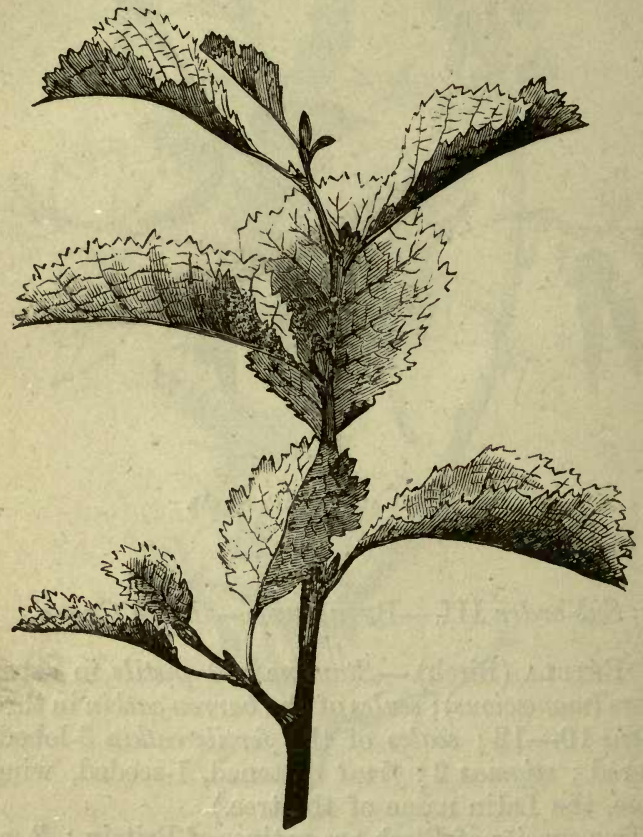

ALNUS GLUTINOSA (Common Alder).

* Alnus glutinósa (Common Alder) is the only British species belonging to this family. It is a widely diffused tree, growing in swampy ground throughout most of the temperate regions of the globe. 


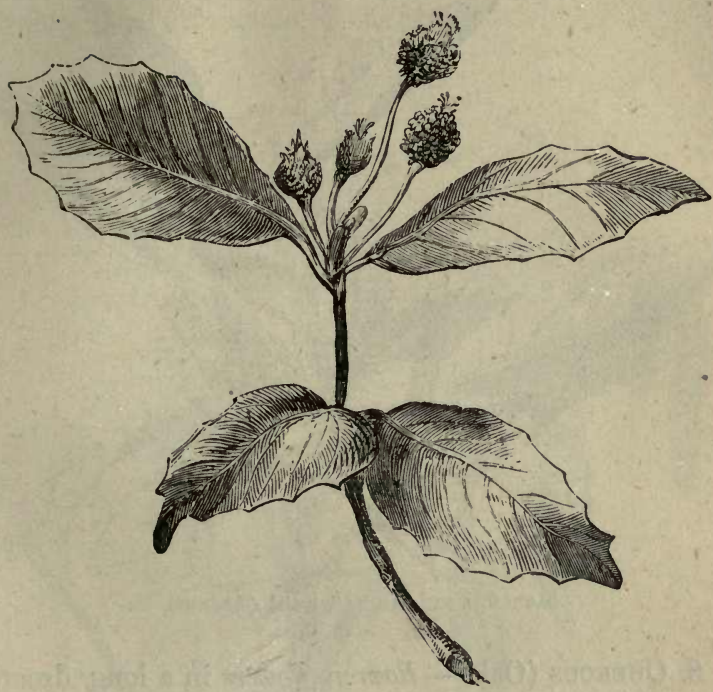

FAGUS SyLVÁtica (Common Beech).

Sub-order IV.-CupULÍfERE.-Mast-bearing Group. * Stamens and pistils in separate flowers (monoecious).

6. FAGUS (Beech).-Barren flowers in a globose catkin; stamens 5-15; fertile flowers 2 together, within a 4-lobed, prickly involucre; stigmas 3 ; nuts 3 cornered, enclosed in the enlarged involucre. (Name in Greek phegos, a species of Oak, in Latin fagus, a Beech.)

7. Castánea (Chestnut).-Barren flowers in a very long, spike-like catkin ; stamens $10-20$; fertile flowers 3 together, within a 4-lobed, very prickly involucre; stigmas 6 ; nuts not distinctly 3 -cornered, enclosed in the enlarged involucre. (Name, the Latin name of the tree.) 


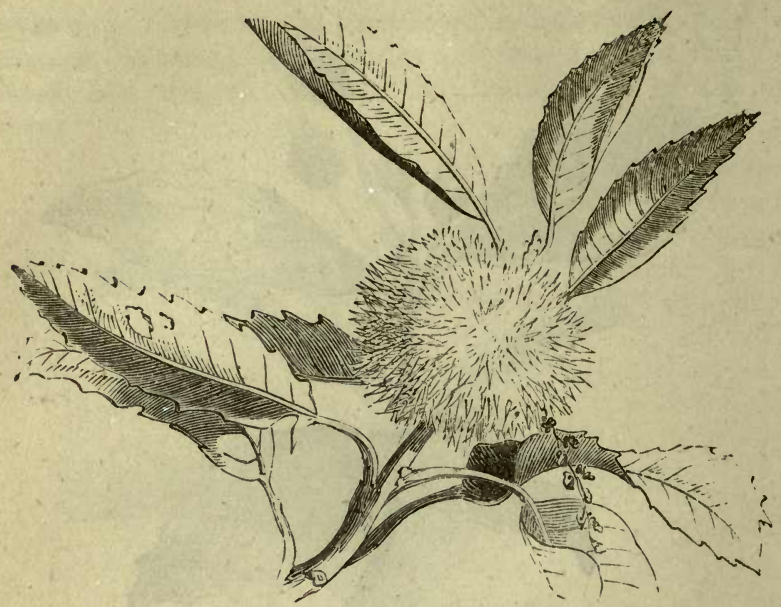

CASTÁNEA VULGÁRIS (Spanish Chestnut).

8. Quercus (Oak).-Barren flowers in a long, drooping catkin; stamens 5-10; fertile flowers with a cup-

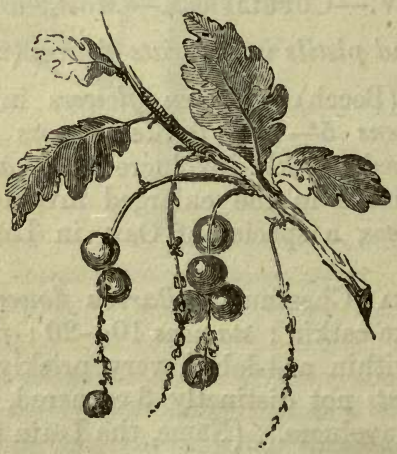

QUERCUS ROBUR (Common Oak). 
shaped sealy involucre; stigmas 3 ; fruit an acorn. (Name, the Latin name of the tree.)

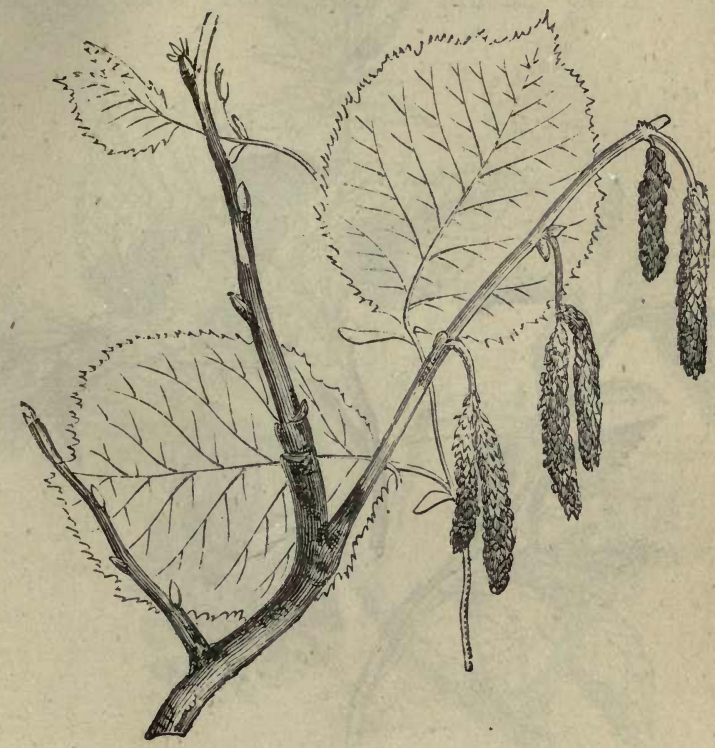

Córylus avellána (Common Hazel).

9. Córylus (Hazel).-Barren flowers in a long, drooping, cylindrical catkin; scales 3-cleft; stamens 8; fertile flowers several, enclosed in a bud-like involucre ; stigmas 2; nut enclosed in the enlarged jagged involucre. (Name, the Latin name of the tree.)

10. Carpínus (Hornbeam).-Barren flowers in a long, cylindrical catkin; scales roundish; fertile flowers in a loose catkin ; scales large and leaf-like, 3-lobed; stigmas 
2 ; nut strongly ribbed. (Name, the Latin name of the tree.)

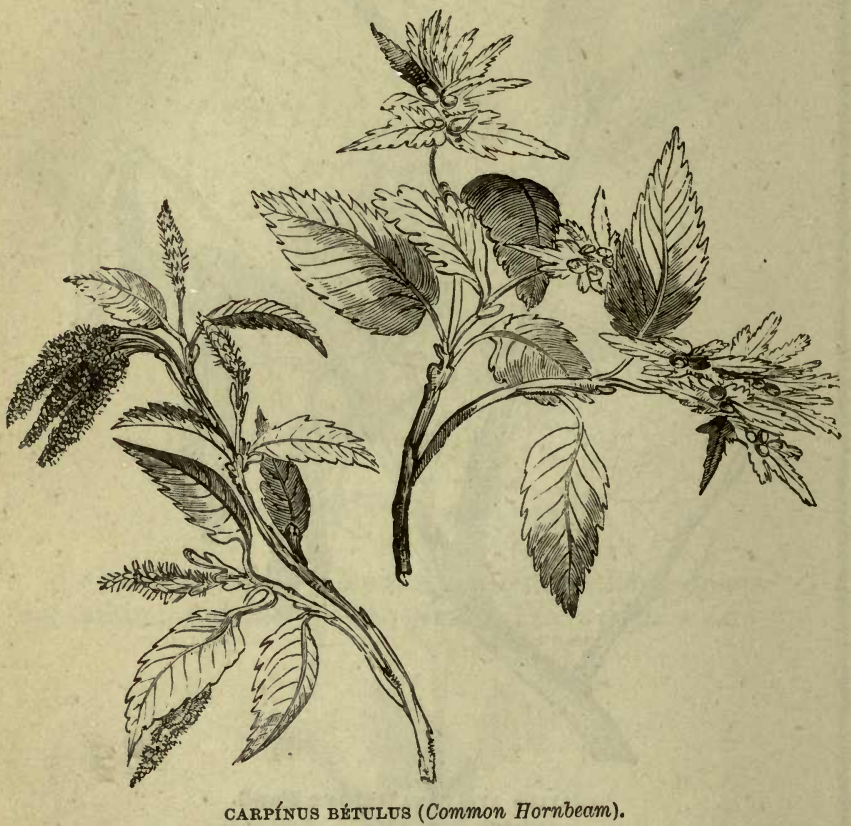

* For a full description of the trees belonging to this order, see "Forest Trees of Britain."

ORD. LXXXI.-CONIFER E.-FIR TRIBE.

Stamens and pistils in separate flowers, and often on different trees. Stamens collected in sets around a com- 
mon stalk ; fertile flowers in cones, destitute of styles and stigmas ; fruit a cone, composed of hardened scales or bracts, bearing, at the base of each, naked seeds, which are often winged. For a full description of this important Tribe, see "Forest Trees of Britain," vol. ii.

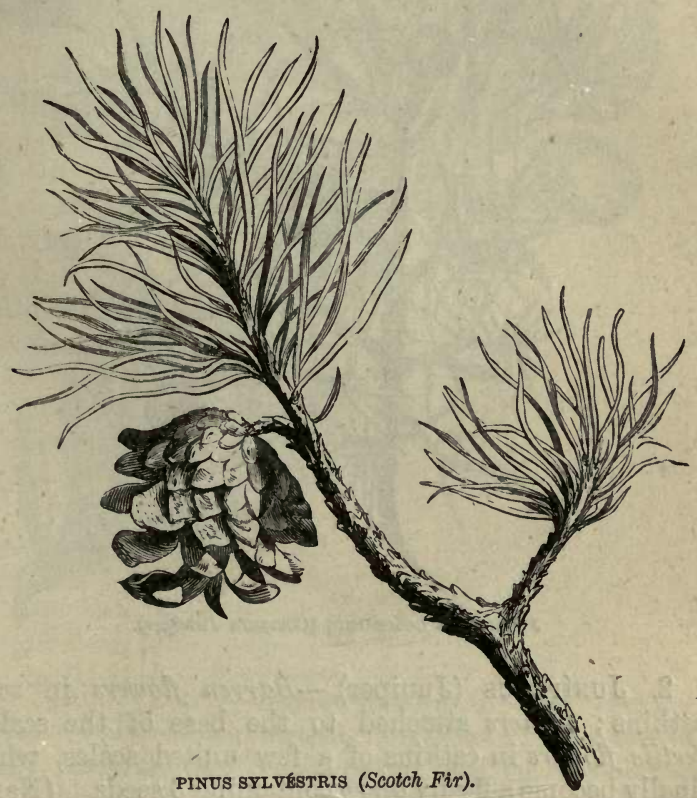

1. Pinus (Fir).-Barren flowers in clustered scaly catkins, the upper scales bearing sessile anthers; fertile flowers in an egg-shaped catkin, which finally becomes a woody cone; seeds winged. (Name, the Latin name of the tree.) 


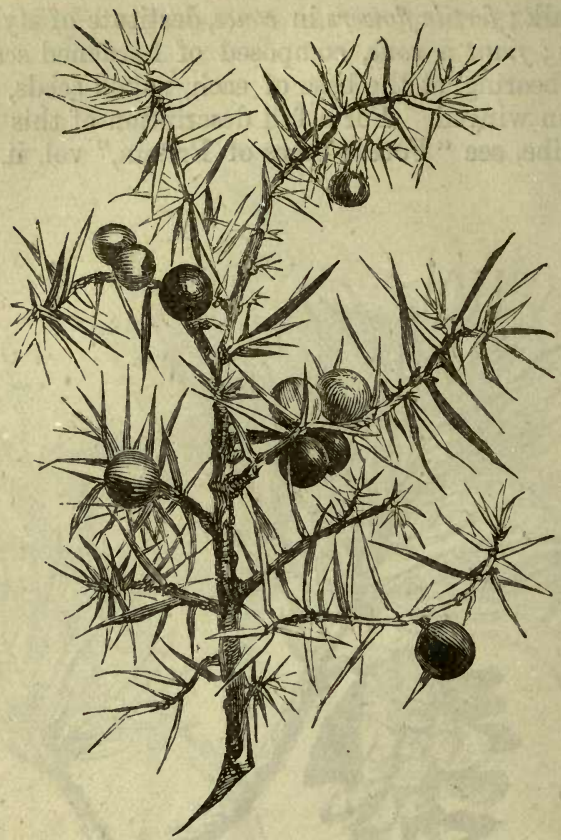

JUNipERUS COMMUNIS (Common JUniper).

2. Juníperus (Juniper).-Barren flowers in scaly catkins; anthers attached to the base of the scales; fertile flowers in catkins of a few united scales, which finally become a fleshy berry containing 3 seeds. (Name, the Latin name of the tree.)

* $J$. communis (Common Juniper) is a native of all the northern parts of Europe, and in Great Britain is generally found on hills and heathy downs, especially where the soil is chalky. The berries are much used to flavour hollands or geneva, a spirit distilled from corn. 


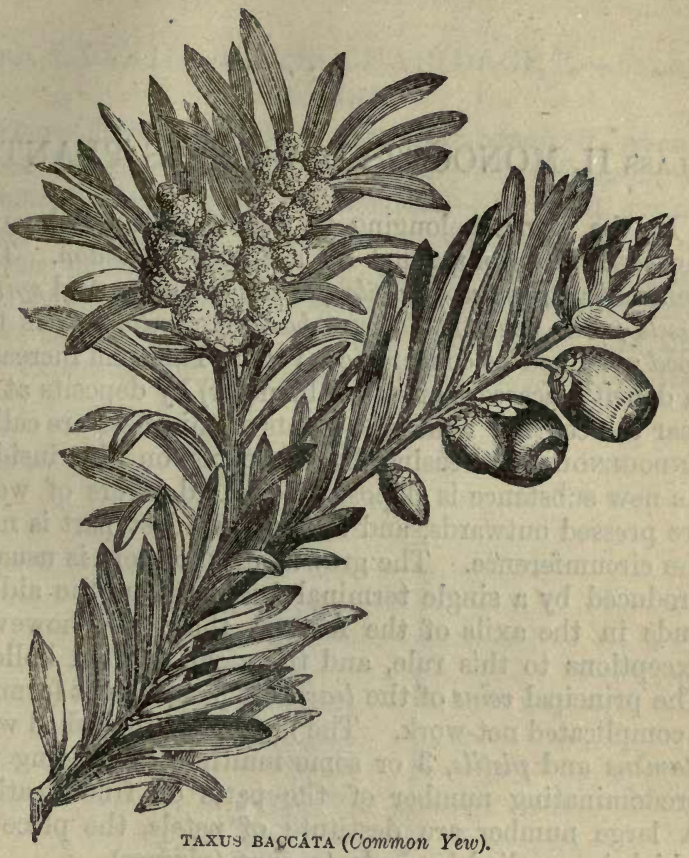

3. Taxus (Yew).-Barren flowers in oval catkins which are scaly below; stamens numerous; fertile flowers solitary, scaly below ; fruit a naked seed, surrounded at. the base by the enlarged pulpy scales. (Name, the Latin name of the tree.)

* T. baccáta (Common Yew), the only British Yew, is an evergreen tree, remarkable for its longevity. The foliage is poisonous ; but the berries are said to be innocuous, being often eaten by children without ill effect. The variety called Irish Yew has erect instead of spreading branches. 


\section{Class II. MONOCOTYLEDONOUS PLANTS.}

Is the plants belonging to this class the embryo of the seed is accompanied by a single cotylédon. The stem consists of woody fibre, cellular tissue, and spiral vessels; but there is no true bark nor pith, nor is the wood arranged in concentric layers. The stem increases in density (scarcely at all in diameter) by deposits at or near the centre; hence the plants of this class are called ENDOGENOUs (increasing by additions on the inside). As new substance is deposited, the old layers of wood are pressed outwards, and thus the hardest part is near the circumference. The growth of the stem is usually produced by a single terminal bud, without the aid of buds in the axils of the leaves; there are, however, exceptions to this rule, and the stem is often hollow. The principal veins of the leaves are parallel, not forming a complicated net-work. The flowers are furnished with stamens and pistils, 3 or some multiple of 3 being the predominating number of the parts of fructification. A large number are destitute of petals, the place of which is supplied by scales or chaff (glumes).

\section{SUB-CLASS I. \\ PETALOIDEE.}

Flowers furnished with petals, arranged in a circular order, or without petals. ${ }^{1}$

(1) Sub-class II., GLUmaces, contains plants, which have, instead of petals, chaffy scales or glumes, which are not arranged in a circular order, as is the case with the Petaloideæ, but are imbricated, such as the Grasses and SEDGES. 


\section{ORD. LXXXII.-HYDROCHARIDACEAE-FROG- BIT Tribe.}

Flower-buds enclosed in a sheath; sepals 3 , green; petals 3 ; stamens 3,9 , 12 or more ; ovary inferior, 1or many-celled; style 1 ; stigmas $3-9$; fruit dry or juicy, not bursting, 1- or many-celled.-A tribe of aquatic plants, often floating, among which the most remarkable is Valisneria spirális, the flower of which grows at the extremity of a long, spiral stalk. As the bud expands, the spire partially uncoils, allowing the

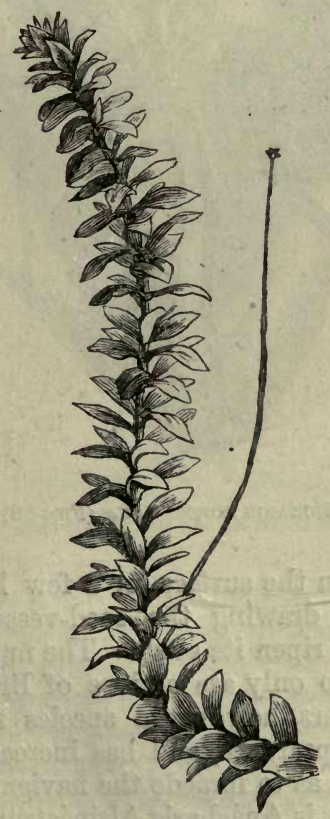

ANÁCHARIS ALSINÁSTRUM.

P P 2 


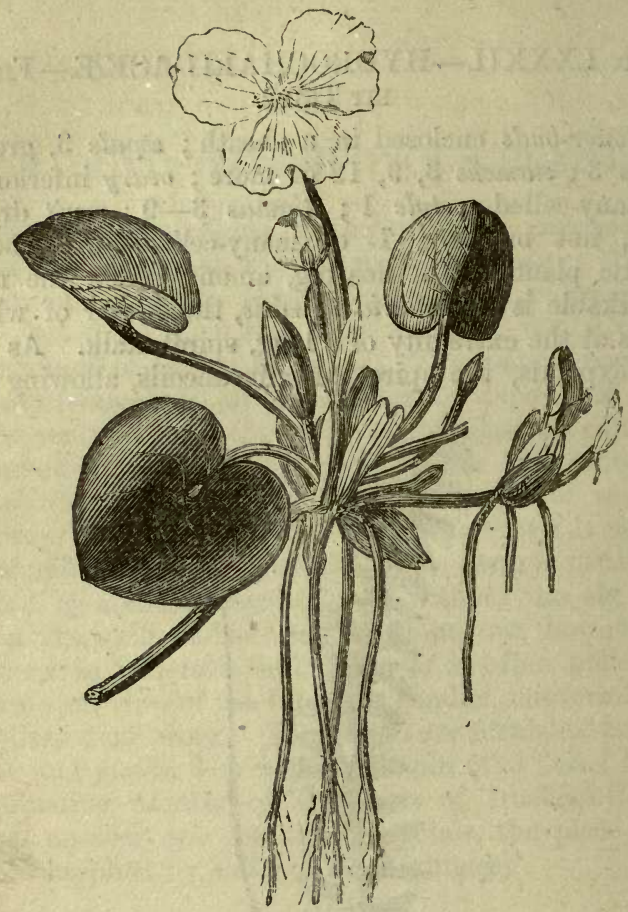

HYDROCHARIS MORSUS-RANE (Frog-bit).

flower to float on the surface for a few hours, and then contracts again, drawing the seed-vessel beneath the surface, there to ripen its seeds. The number of species is small, and two only are natives of Britain. Within the last few years, however, a species new to Britain has made its appearance, and has increased to such an alarming extent, as to impede the navigation of some of our canals. This is Anácharis Alsinástrum, a submerged aquatic, having much of the habit of Potamogéton 


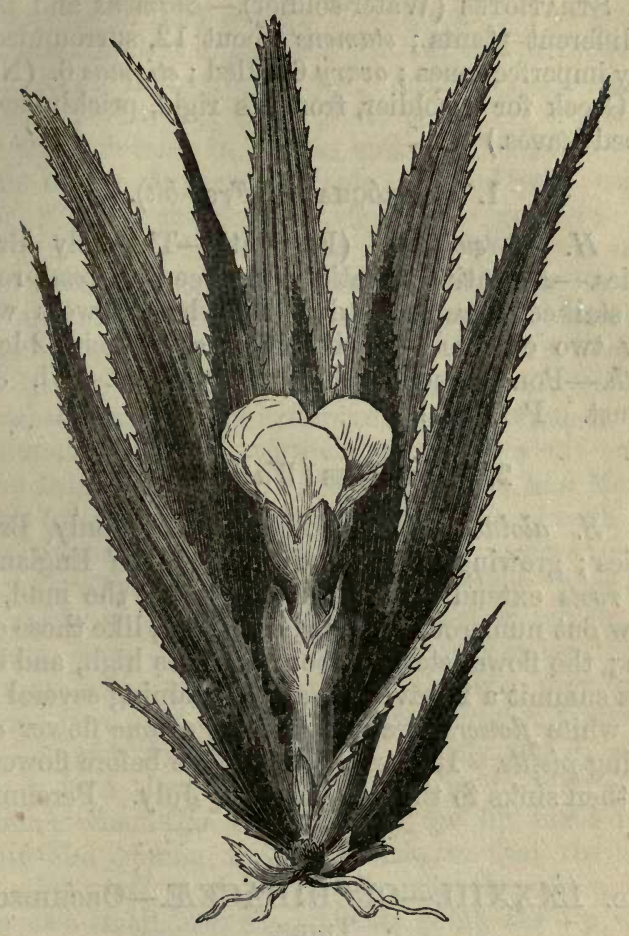

STRATIÓtES ALOIDES (Water-soldier).

densus. It is a native of North America, but since its introduction has increased to an alarming extent. It is to be found in flower in still water in September.

1. HydróchaRIS (Frog-bit). - Stamens and pistils on different plants; stamens 9-12; ovary 6 -celled; stigmas 6. (Name from the Greek hydor, water, and charis, elegance, the plants being showy aquatics.) 
2. Stratiótes (Water-soldier).-Stamens and pistils on different plants; stamens about 12 , surrounded by many imperfect ones ; ovary 6-celled ; stigmas 6 . (Name, the Greek for a soldier, from its rigid, prickly, swordshaped leaves.)

\section{HydRócharis (Frog-bit).}

1. H. Morsus-rance (Frog-bit).-The only British species.-A floating aquatic, with creeping stems, roundish, stalked leaves, and delicate, white flowers which grow two or three together from a pellucid 2-leaved sheath.-Ponds and ditches, not general.-Fl. July, August. Perennial.

\section{Stratiótes (Water-soldier).}

1. S. aloides (Water-soldier).-The only British species; growing in ditches in the East of England.The roots extend to some distance into the mud, and throw out numerous rigid prickly leaves, like those of an Aloe; the flower-stalk is about 6 inches high, and bears at its summit a 2-leaved sheath, containing several delicate white flowers, bearing stamens, or one flower only, bearing pistils. It rises to the surface before flowering, and then sinks to the bottom.-Fl. July. Perennial.

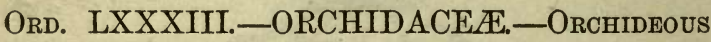 TRIBE.}

Sepals 3 , often coloured; petals 3 , the lowest unlike the rest, and frequently spurred; stamens and style united into a central column; pollen powdery or viscid, sometimes raised in masses on minute stalks; ovary 1 celled; stigma a viscid hollow in front of the column; fruit a 3-valved capsule, with 3 rows of seeds.-A very extensive tribe of perennial herbaceous plants, with fibrous or tuberous roots, fleshy or leathery leaves, all the veins of which are parallel, and flowers so variable 
in form as to defy general description, yet so peculiar that the slightest experience will enable the student to refer them to their proper tribe. British species have for the most part two or more glossy sheathing leaves, and bear their flowers in simple spikes or clusters. The colour of the flowers is purple, mottled with various other tints, flesh-coloured, white, or greenish. The structure of the lower lip of the corolla is in many cases most singular; sometimes resembling in form, size, and colour insects which naturally frequent the places where the flowers grow; such are the Bee, Fly, and Spider Orchis (Ophrys apífera, O. muscífera, and 0 . aranifera). In other instances the same organ presents a fantastic caricature of some more important subject of the animal kingdom; such are the Man, and Monkey Orchis (Áceras anthropóphora, and Orchis macra). The same mimicking extends to foreign species :- "So various are they in form," says Dr. Lindley, "that there is scarcely a common reptile or insect to which some of them have not been likened." Occasionally the structure is more complex : in Caleana nigríta the column is a boat-shaped box, resembling a lower lip; the lip itself forms a lid that exactly fits it, and is hinged on a claw, which reaches the middle of the column; when the flower opens, the lip turns round within the column and falls back, so that the flower being inverted, it stands fairly over the latter. The moment a small insect touches its point, the lip makes a sudden revolution, brings the point to the bottom of the column, and makes prisoner any insect which the box will hold. When it catches an insect, it remains shut as long as its prey continues to move about; but if no capture is made, the lid soon recovers its position. The rusty flowers of Spiculaea ciliáta, when spread open, may be compared to long-legged spiders, the lip, with a long solid plate, looking like their body, while an appendage at its point, which is apparently moveable, is not unlike the head of such a creature. Orchideous 
plants are to be found in all climates except the very coldest and driest; they are most abundant in the hot, damp regions of the tropics, where they exist in the greatest profusion, not, as in temperate countries, deriving their nourishment from the earth, but supported by the moisture that floats around them. Clinging to the trunks and branches of trees, to the stems of ferns, and even to the bare rock, they seem to adopt the habits of animals as well as to imitate their forms. In many of these the flowers only are conspicuous, the plant itself consisting of creeping, claw-like roots, and tufts of elliptical bulbs, from the summit of which spring a few tough leaves, and wiry, jointed stems, which seem incapable of producing the symmetrical and curiously-coloured flowers they are destined shortly to bear. Of late years, great attention has been paid to the cultivation of exotic Orchideous plants; and by imitating, as far as possible, their natural condition, great success has been already attained. An Orchideous house is now a common adjunct to the conservatory in the gardens of the wealthy, where, if it be well managed, some one or other of these curious air plants, as they have been called, may be seen in bloom at all seasons of the year, some clinging to broken potsherds, some to logs of wood, some to the outer fibre of the cocoa-nut, or simply suspended by wires from the roof of the house. It is somewhat remarkable that endless as are the varieties of form which the flowers of this tribe assume, their properties vary but little. They furnish few, if any, medicines of importance; to the useful arts they contribute only a kind of cement or glue, which is recommended by no particular excellence; a nutritious substance called Salep is prepared from the roots of Orchis máscula and other species, but this is not extensively used; and though the flowers of many species are very fragrant, no perfume is ever extracted from them. With the exception of Vanilla, the dried fruit of Vanilla aromática, which is much used in . 
flavouring chocolate and other sweetmeats, no plant in the Order can be said to be extensively used, either in the arts or sciences. Lindley conjectures the number of species to amount to 3000 .

The characters by which the families of this Order are distinguished are, owing to the curious structure of the flowers comprised in it, so peculiar that they require to be attentively studied by reference to fresh specimens before any description of them can be understood. It has been thought necessary, therefore, in the case of the Orchideous Tribe, to depart from the method pursued in the other parts of this work, and instead of perplexing the student with a systematic detail of generic characters, to describe such species as are of common occurrence, attention being paid only to their more obvious characters. The student will thus be enabled to ascertain the names of most, if not all, of the species which are likely to excite his attention. He may then examine them with accuracy, and when he has made himself acquainted with their structure and peculiarities, he will be in a position to compare whatever new spec:as may chance to fall in his way with the descriptions given in works of higher pretension.

The first which is likely to be presented to his notice is Orchis máscula (Early purple Orchis), a succulent plant about a foot high, flowering in May and June, and abounding in woods and pastures wherever the Wild Hyacinth flourishes. The root consists of two roundish solid tubers; the leaves are of a liliaceous texture, stained with dark purple spots, oblong and clasping the stem ; the stem is solitary, and bears an erect cluster of purple flowers, mottled with lighter and darker shades; each flower rises from a somewhat twisted ovary, and has a long spur, which turns upwards. The colour of the flower, associated as it often is with Cowslips and Wild Hyacinths, is rich and beautiful; but the odour is strong and offensive, especially in the evening.

Orchis Mório (Green-winged Meadow Orchis) comes 


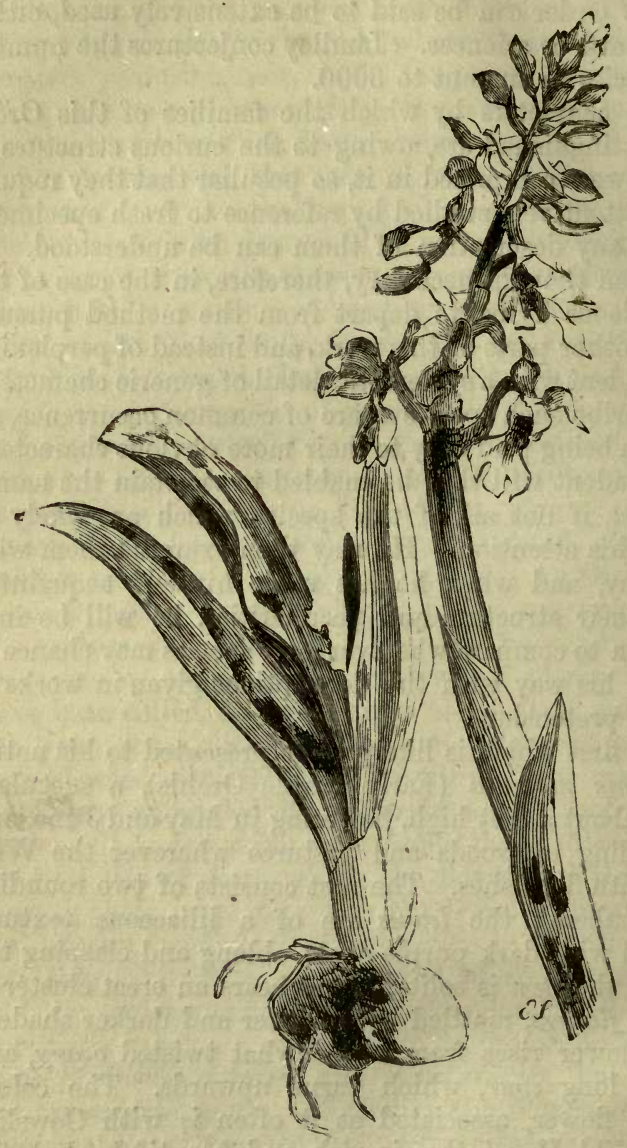

ORcers Mascula (Ẽarly purple Orchis). 
into flower about the same time with the last, and resembles it in habit. It is, however, a shorter plant, and bears fewer flowers in a cluster ; it is best distinguished by the two lateral sepals, which are strongly marked with parallel green veins, and bent upwards so as to form a kind of hood over the column. It grows in meadows, and is often very abundant.

Orchis pyramidális (Pyramidal Orchis) bears at the summit of a somewhat slender stem a dense cluster, broad at the base and tapering to a point, of small deep rose-coloured flowers, which are remarkable for the length and slenderness of the spur. It usually grows on chalk or limestone, and flowers in July.

Orchis maculáta (Spotted Orchis) may be distinguished from either of the preceding by its root, which consists of two flattened tubers, divided at the extremity into several finger-like lobes. Its leaves are spotted like those of 0 . máscula, and its flowers are light purple, curiously marked with dark lines and spots. It grows abundantly on heaths and commons, flowering in June and July.

Orchis latifólia (Marsh Orchis) is a taller plant than the last, but has, like it, palmated-roots ; the leaves are remarkably erect; flowers rose-coloured or purple ; and the bracts, which taper to a fine point, are longer than the flowers. It grows abundantly in marshes and wet pastures, and blossoms in June and July. All the above species, especially 0 . Mório, occasionally bear white flowers.

Gymnadénia conópsea (Sweet-scented Orchis) somewhat resembles Orchis maculáta; the flowers are rosepurple, but not spotted, and very fragrant; the spur is very slender, and twice as long as the ovary. It grows in dry, hilly, or mountainous pastures, and flowers in June and July.

Habenaria bifolia (Butterfly Orchis) is a singular plant, but not appropriately named, for the resemblance which its flowers bear to a butterfly is very slight. It bears 


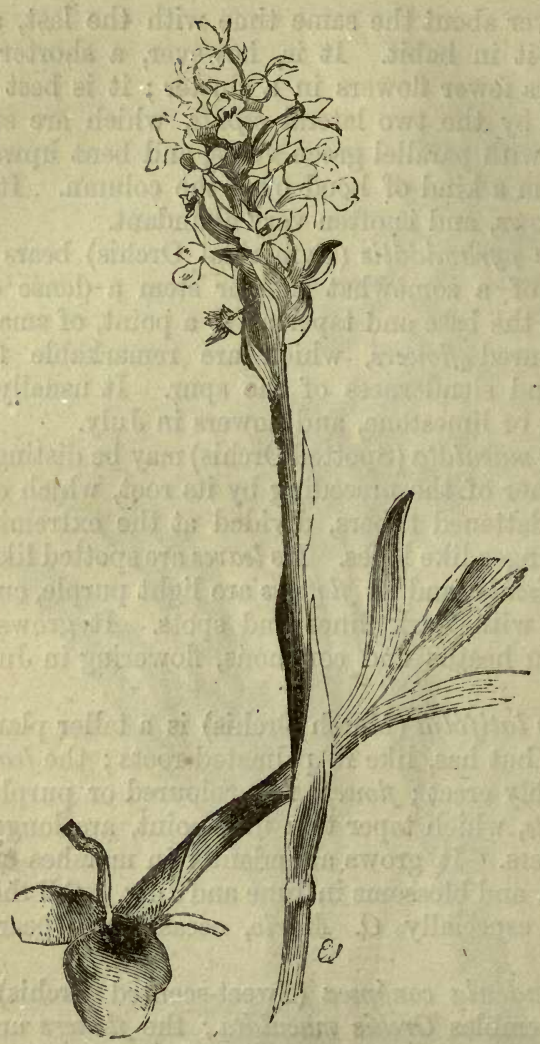

GYMNADENIA CONÓPSEA (Sweet-scented Orchis).

two broad leaves immediately above the root; the stem is slender and angular, about a foot high, and bears a loose cluster of greenish-white flowers which are remarkable for the length of the spur, and for the strap-shaped lower lip of the corolla. It grows on heaths and the borders 
of woods, blooming in June. The flowers are fragrant in the evening. $H$. viridis (Green Habenaria) and $H$. álbida (Small White Habenaria) are small plants from

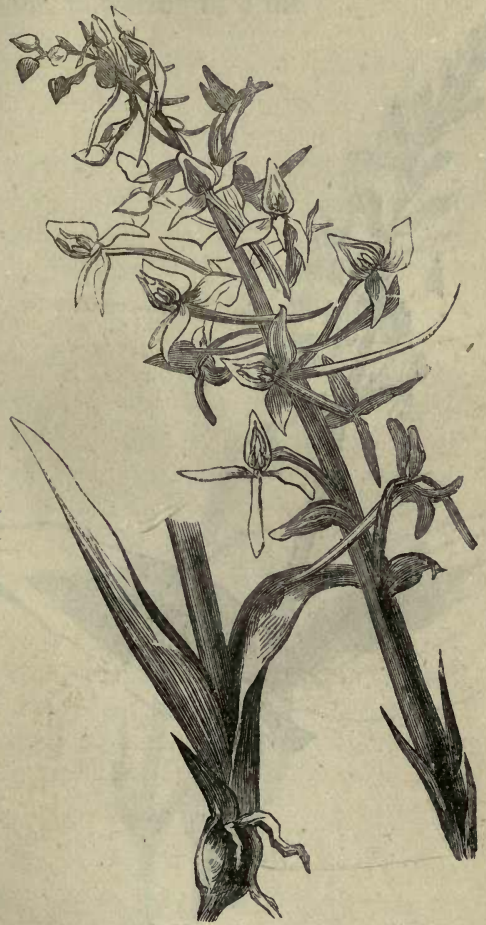

HABENARIA BIFOLIA (Butterfly Orchis).

6 to 8 inches high, the former with green flowers, the latter with flowers which are white and fragrant.

Lístera ováta (Twayblade) grows from 12 to 18 inches high, and is well marked by its bearing, about half way 
up its cylindrical stem, two opposite egg-shaped leaves; the flowers are small and green. It is not uncommon in woods and orchards, and flowers in June. Listera cor-

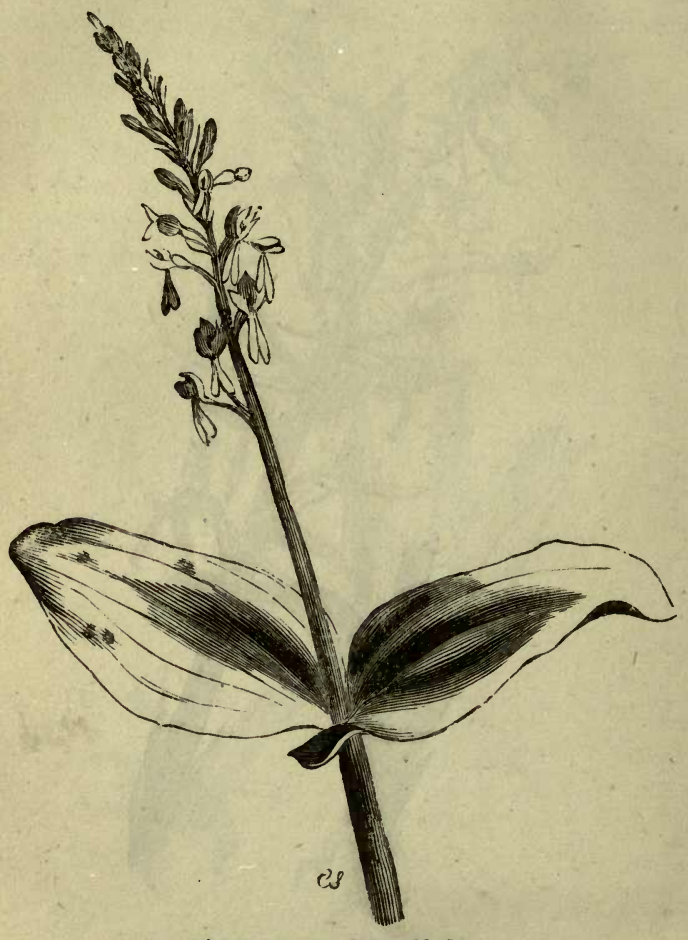

Listera ovata (Twayblade).

dáta is a much smaller plant, with two heart-shaped leaves. It occurs in mountainous districts, and flowers from June to August.

Listera Nidus-avis (Bird's-nest) is a pale reddishbrown plant, about a foot high, entirely destitute of 
leaves, the place of which is supplied by numerous sheathing, brown scales. The root eonsists of many short fleshy fibres, from the extremities of which the young plants are produced. It is found sparingly in shady woods, flowering in June.

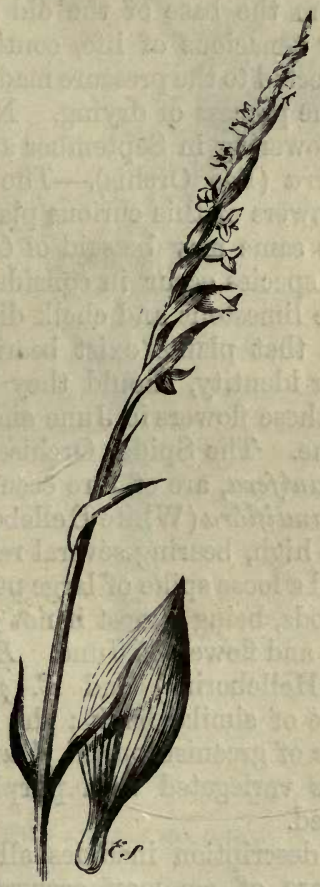

NEOTTIA SPIRÁLIS (Lady's Tresses).

Neottia spirális (Lady's Tresses) is a curious little plant, from 4 to 6 inches high, with tuberous roots and a spike of small white flowers, which are arranged in a 
single row, and in a spiral manner, in some specimens from left to right, in others from right to left, round the upper portion of the stalk. The flowers are fragrant in the evening. The leaves form a tuft just above the crown of the root, and wither before the flowers begin to expand. These are succeeded by a tuft of new leaves, which arise from the base of the old stem; the latter are remarkably tenacious of life, continuing to unfold even while subjected to the pressure made on the blottingpaper during the process of drying. Not uncommon in dry pastures, flowering in September and October.

Ophrys apifera (Bee Orchis).-The distinctive character of the flowers of this curious plant is given in its name, and the same may be said of $O$. muscifera (Fly Orchis); both species occur in considerable abundance in many of the limestone and chalk districts. No one who has heard that plants exist bearing these names, can doubt their identity, should they fall in his way. The former of these flowers in June and July, the latter in May and June. The Spider Orchises, Ophrys arachnites and $O$. aranifera, are of rare occurrence.

Epipactis grandiflóra (White Helleborine) grows from 1 foot to 2 feet high, bearing several rather broad leaves on the stem, and a loose spike of large pure white flowers. It grows in woods, being almost if not entirely confined to a chalky soil, and flowers in June. Epipactis latifolia (Broad-leaved Helleborine) and E. palustris (Marsh Helleborine) are of similar habit; the former bearing a long loose spike of greenish-purple flowers; the latter a spike of flowers variegated with purplish-green, white and rose-coloured.

The above description includes all the Orchideous plants which are of common occurrence. The rarer species indigenous to Britain are:-Orchis ustuláta (Dwarf dark-winged Orchis), 0 . fusca (Great brownwinged Orchis), O. militaris (Military Orchis), O. tephrosánthos (Monkey Orchis), and O. hircina (Lizard Orchis). -These grow only in chalk districts. 


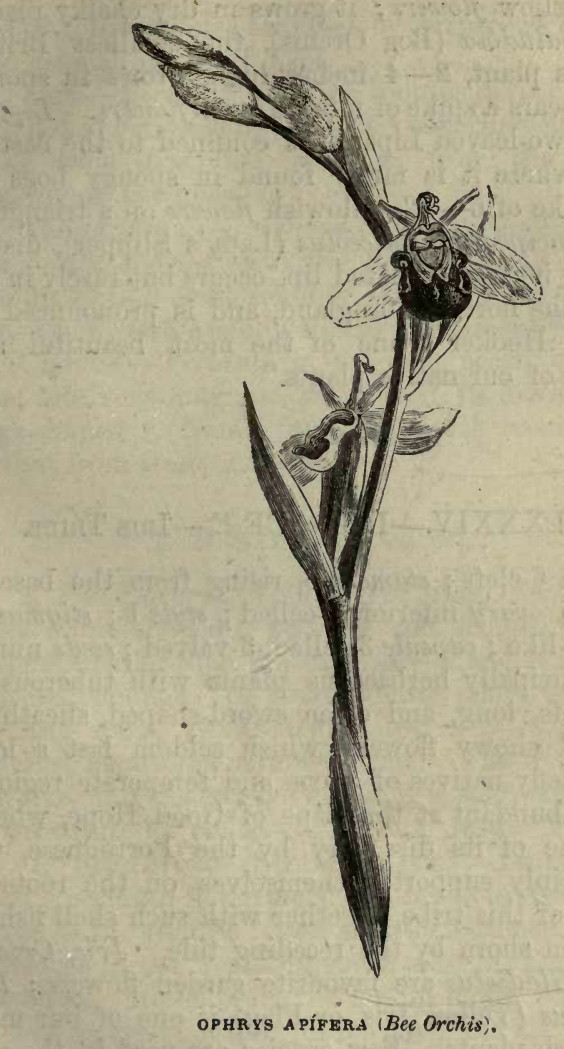

Goodyera repens (Creeping Goodyera) is a small plant with creeping roots, growing in fir woods in Scotland; Corallorhiza innáta (Coral-root) is well marked by its curiously-toothed roots, which infigure resemble branched coral; it occurs in marshy woods in Scotland. Áceras anthropóphora (Man Orchis) bears a long, loose spike of Q Q 
greenish yellow flowers; it grows in dry chalky places. Malaxis paludósa (Bog Orchis), the smallest British Orchideous plant, 2-4 inches high, grows in spongy bogs, and bears a spike of minute green flowers. Liparis Loesélii (Two-leaved Liparis) is confined to the eastern counties, where it is rarely found in spongy bogs; it bears a spike of $6-12$ yellowish flowers on a triangular stalk. Cypripédium Calcéolus (Lady's Slipper), distinguished by its large inflated lip, occurs but rarely in the woods of the north of England, and is pronounced by Sir W.' J. Hooker "one of the most beautiful and interesting of our native plants."

\section{ORD. IXXXIY.-IRIDACEA,-IRIS TRIBE.}

Perianth 6-cleft ; stamens 3, rising from the base of the sepals ; ovary inferior, 3 -celled; style 1 ; stigmas 3 , often petal-like ; capsule 3 -celled, 3-valved ; seeds numerous. Principally herbaceous plants with tuberous or fibrous roots, long, and often sword-shaped, sheathing leaves, and showy flowers, which seldom last a long time. Chiefly natives of warm and temperate regions, and most abundant at the Cape of Good Hope, where, at the time of its discovery by the Portuguese, the natives mainly supported themselves on the roots of the plants of this tribe, together with such shell-fish as were left on shore by the receding tide. Iris, Crocus, Ixia, and Gladiolus are favourite garden flowers; Iris Pseud-ácorus (Yellow Iris, or Flag) is one of our most showy marsh plants. Few species are used in the arts or sciences; the roots of Iris Florentina afford Orrisroot, which, when dried, has a perfume resembling that of Violets, and is used as an ingredient in tooth-powder; the dried stigmas of Crocus sativus, were anciently much prized as a dye, and are still employed for the same purpose, as well as in medicine and cookery; and the 
roots of a few species are used by barbarous nations as an occasional article of food.

1. IrIs.-Perianth with the 3 outer divisions longer, and reflexed ; stigmas 3 , petal-like, covering the stamens. (Name from Iris, the rainbow, from the beautiful colouring of the flowers.)

2. Trichonéma.-Perianth in 6 equal spreading divisions; tube shorter than the limb; stigma deeply 3cleft, its lobes 2-cleft, slender. (Name from the Greek thrix, a hair, and néma, a thread or filament.)

3. Crocus.-Perianth in 6 equal, nearly erect divisions ; tube very long; stigma 3 -cleft, its lobes inversely wedge-shaped. (Name from the Greek crocos, saffron, and that from crocé, a thread.)

\section{IrIS (Flower-de-luce).}

1. I. Pseud-ácorus (Yellow Iris, Flag, Corn Flag).Leaves sword-shaped; perianth not fringed, its inner divisions smaller than the stigmas.-Marshes and banks of rivers, common. A stout aquatic plant with creeping, acrid roots, sword-shaped leaves $2-3$ feet long, and large, handsome yellow flowers. The root yields a black dye, and the roasted seeds, it is said, may be used as a substitute for coffee.-Fl. June, July. Perennial.

2. I. foetidissima (Stinking Iris).-Leaves swordshaped; perianth not fringed, its inner divisions about as large as the stigmas ; stem slightly flattened.-Woods and hedges in the west and south-west of England, not uncommon. Resembling the last in habit, but smaller. The flowers are of a dull leaden hue, and the leaves so acrid as to leave a burning taste in the mouth, or even to loosen the teeth. The whole plant, when bruised, emits a disagreeable odour. Sir. W. J. Hooker states that "in Devonshire it is so frequent, that one can hardly avoid walking among it when herbalizing, and being annoyed by the smell." This, however, is an exaggeration. The berry-like seeds, which are of a 


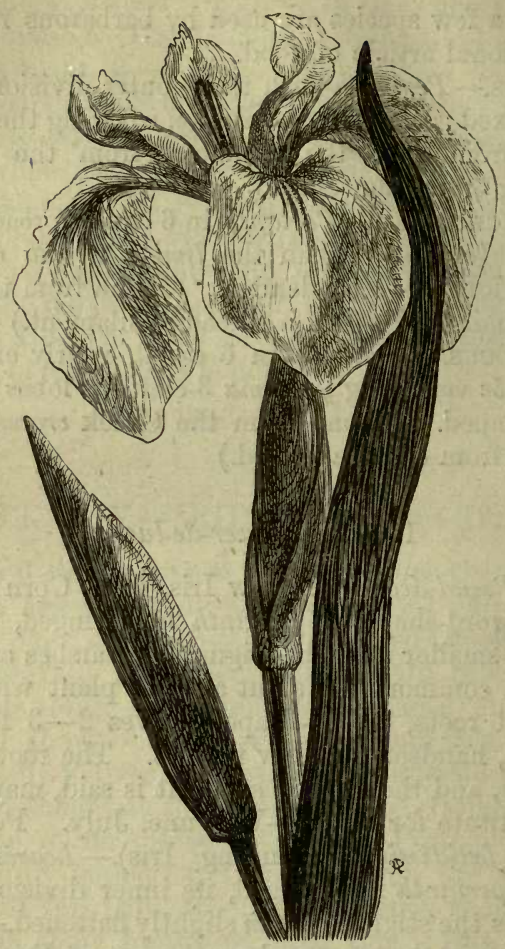

IRIS PSEUD-ACORUS (Yellow Iris, Flag, Corn Flag).

beautiful scarlet colour, remain attached to the plant all through the winter.-Fl. June-August. Perennial.

* Many speeics of Iris are cultivated for their beauty, some of which are occasionally found apparently wild, in the neighbourhood of gardens.

\section{Trichonéma.}

1. T. Columnae (Columna's Trichonéma).-The only British species.-A small bulbous plant, $3-4$ inches 
high, with very narrow leaves, and solitary purplish flowers tinged with yellow, partaking the characters of the Iris and Crocus. It grows only on a sandy pasture called the Warren, at Dawlish, Devon.-Fl. March, April. Perennial.

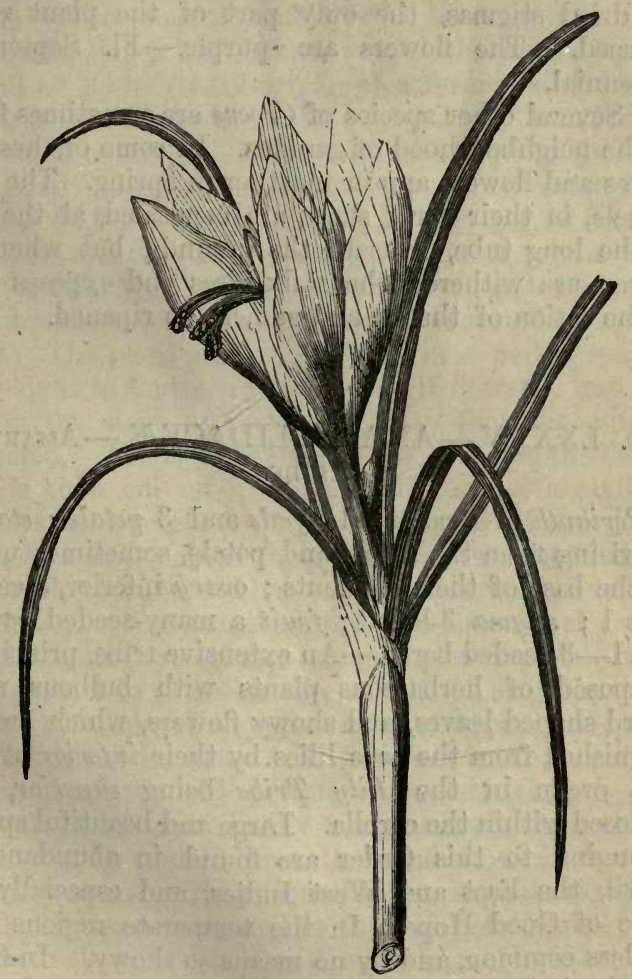

CRocus satífus (Saffron Crocus). 


\section{Crocus.}

1. C. sativus (Saffron Crocus).-Leaves appearing after the flowers, linear ; flower-stalks enveloped with a double sheath; stigma long and drooping.-Said to be naturalized at Saffron-Walden, in Essex, where it is largely cultivated for the sake of the saffron afforded by its dried stigmas, the only part of the plant which is used. The flowers are purple.-Fl. September. Perennial.

* Several other species of Crocus are sometimes found in the neighbourhood of gardens. In some of these the leaves and flowers appear together in spring. The seedvessels, in their early stage, are concealed, at the base of the long tube, beneath the ground; but when the flowers are withered, the stalk rises and exposes them to the action of the air and sun, to be ripened.

\section{ORD. LXXXV.-AMARYLLIDACEAE-AMARYLLIS TRIBE.}

Perianth of 3 coloured sepals and 3 petals; stamens 6 , arising from the sepals and petals, sometimes united by the base of their filaments ; ovary inferior, 3-celled; style 1 ; stigma 3 -lobed; fruit a many-seeded capsule or a $1-3$-seeded berry.-An extensive tribe, principally composed of herbaceous plants with bulbous roots, sword-shaped leaves, and showy flowers, which are distinguished from the true lilies by their inferior ovary; that organ in the Lily Tribe being superior, and enclosed within the corolla. Large and beautiful species belonging to this Order are found in abundance in Brazil, the East and West Indies, and especially the Cape of Good Hope. In the temperate regions they are less common, and by no means so showy. In-Great Britain, it is doubtful whether a single species is indigenous, though the number of varieties cultivated in 
gardens, both in conservatories and in the open air, is very great. The bulbous roots of many plants belonging to the Amaryllis Tribe are poisonous ; some, it is said, to such a degree that deleterious properties are communicated to weapons dipped in their juice. The roots of the Snowdrop and Daffodil are emetic, and the flowers of the last (Narcissus Pseudo-Narcissus) are a dangerous poison. The roots of some species, however, are nutritious, affording a kind of arrowroot. From the juice of a kind of Agávé (A. Americana) a fermented liquor is made, which, under the name of "pulque," is in Mexico a common beverage. This plant, called by the Mexicans " maguey," is cultivated over an extent of country embracing 50,000 square miles. In the city of Mexico alone the consumption of pulque amounts to the enormous quantity of eleven millions of gallons, and a considerable revenue from its sale is derived by government. The plant attains maturity in a period varying from eight to fourteen years, when it flowers ; and it is during the stage of flowering alone that the juice is extracted. The central stem, which encloses the flowerbud, is then cut off near the bottom, and a cavity or basin is discovered, over which the leaves are drawn close, and tied. Into this reservoir the juice distils, which otherwise would have risen to nourish and support the flower. It is removed three or four times during the 24 hours, yielding a quantity of liquor varying from a quart to a gallon and a half. The juice is extracted by means of a syphon made of a species of gourd, and deposited in bowls. It is then placed in earthen jars, and a little old pulque is added, when it soon ferments and is immediately ready for use. The fermentation occupies two or three days, and when it ceases it is in fine order. Old pulque has an unpleasant odour, which has been compared to that of putrid meat; but when fresh it is brisk and sparkling. In time even. Europeans prefer it to any other liquor. This Agave is popularly known in England by the name of American 
Aloe. It grows but slowly in this climate, and, as it rarely attains perfection, is believed by many persons to flower once in a hundred years. A fine specimen which flowered at Clowance, Cornwall, in September, 1837, is thus described:- "A sturdy stem $17 \frac{1}{2}$ inches in diameter rises from a chevaux de frise of spiked leaves to the height of 14 feet without a branch ; but copiously beset with leaves of the same character, which gradually diminish in size, and are continued to the very top, till from being four or five feet long, they become mere bracts, measuring not as many lines. The lower branches are not, as they are often represented in engravings, shorter than those above them, but extend to the length of several feet, describing a graceful curve. A short distance above, but not so close as to appear crowded, or so exactly opposite as to present a formal appearance, another branch leaves the main stalk, a very little shorter than the lower one, and is succeeded by others, in all thirty-four, the last being twenty-five feet from the ground. Each of these bears at its extremity a mass of green flowers, the summits of which form nearly a plane surface. The number of flowers on the five lower branches amounts to 911 , so that the whole, including those on the summit of the stem, must be computed, on a fair average, at no less than 5,000 perfect flowers. The quantity of honey which they contained was very great, and as it was constantly dropping, moistened the ground beneath. The plant, exhausted by the unusual effort, for which it had been for many years preparing, died the same year." The roots and leaves of the species of Agávé contain woody fibre (pita thread), useful for various purposes; this is separated by bruising and steeping in water, and afterwards beating. The Mexicans also make their paper of the fibres of Agave leaves laid in layers. The expressed juice of the leaves is also stated to be useful as a substitute for soap. 


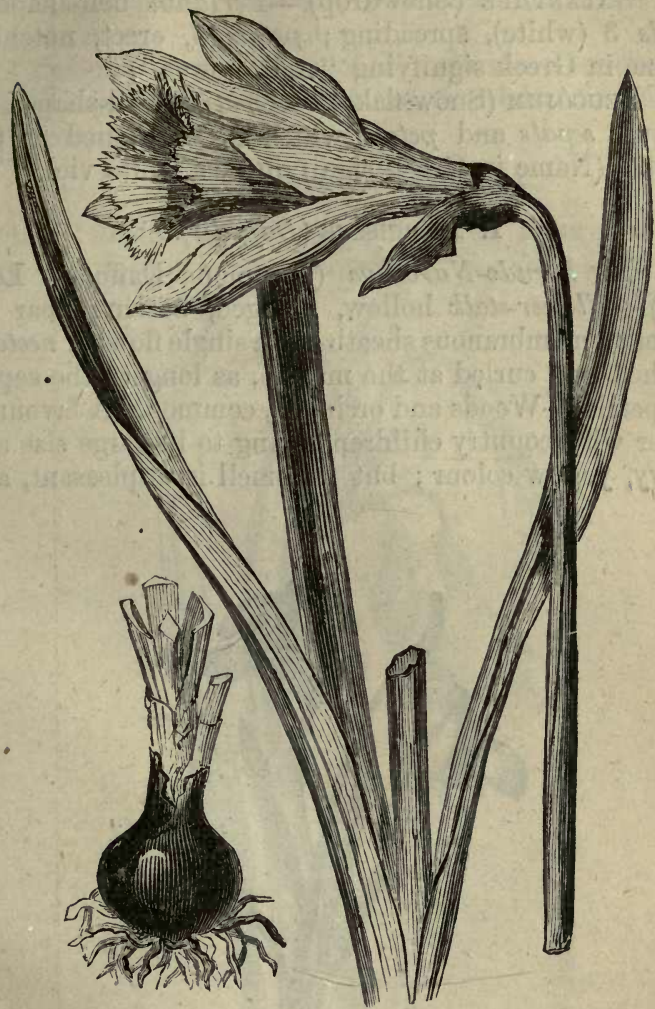

NARCISSUS PSEUDO-NARCISSUS (Common Daffodil, Lent Lily).

1. NARcissus (Daffodil).-Perianth tubular at the base, terminating in a bell-shaped crown or nectary, which has 6 equal sepals and petals at its base. (Named after Narcissus, a fabulous youth, said to have been changed into a flower.) 
2. Galanthus (Snowdrop).-Perianth bell-shaped; sepals 3 (white), spreading; petals 3, erect, notched. (Name in Greek signifying "milk-flower.")

3. Leucósum (Snow-flake).-Perianth bell-shaped, of 6 equal sepals and petals, which are thickened at the point. (Name in Greek signifying "a white violet.")

\section{Narcissus (Daffodil).}

1. N. Pseudo-Narcissus (Common Daffodil, Lent Lily)._Flower-stalk hollow, 2-edged, bearing near its summit a membranous sheath and a single flower; nectary notched and curled at the margin, as long as the sepals and petals.-Woods and orchards, common. A favourite flower with country children, owing to its large size and showy, yellow colour; but its smell is unpleasant, and

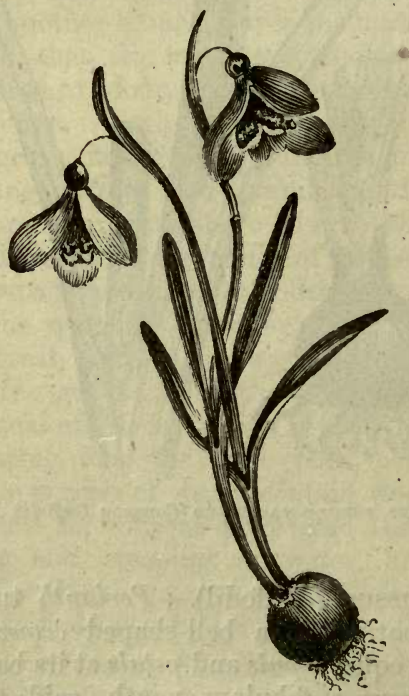


the whole plant possesses poisonous properties.-Fl. March, April. Perennial.

* Several other species of Narcissus are occasionally found near houses, but they are invariably the outcast of gardens.

2. Galanthus (Snowdrop).

1. G. nivális (Snowdrop).-Too well known to need any description. The Snowdrop, $G$. plicatus, recently

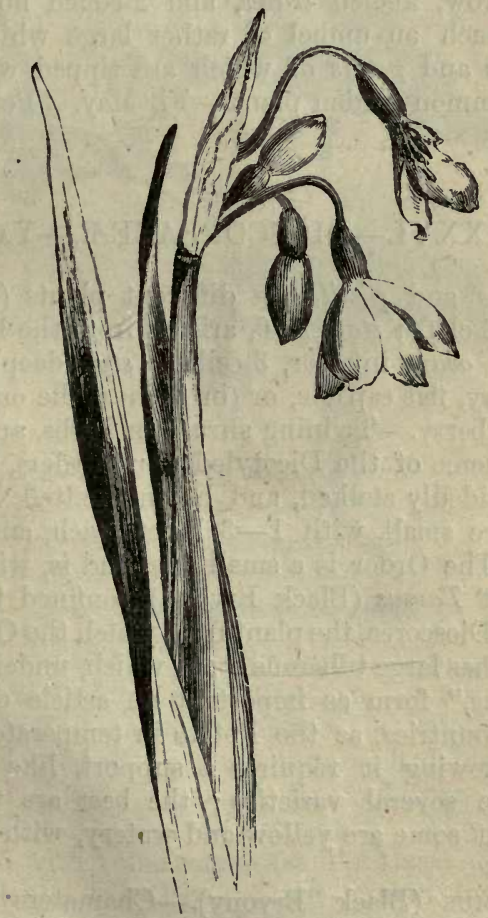


introduced from the Crimea, differs mainly from the common species in having broader, plaited leaves, and somewhat larger flowers.-Fl. January-March. Perennial.

\section{Leucójum (Snowflake).}

1. L. ostivum (Summer Snowflake).-A doubtful native, found occasionally in moist meadows in many parts of England.-A bulbous plant about 2 feet high, with narrow, keeled leaves, and 2-edged flower-stalks bearing each an umbel of rather large white flowers, the sepals and petals of which are tipped with green. It is a common garden plant.-Fl. May. Perennial.

\section{ORD. LXXXV1.-DIOSCOREACEA-YAM TRIBE.}

Stamens and pistils on different plants (dicecious); perianth 6-cleft; stamens 6 , arising from the base of the perianth ; ovary inferior, 3-celled; style deeply 3-cleft ; fruit a dry, flat capsule, or (in Tamus, the only British species) a berry.-Twining shrubs or herbs, approaching in habit some of the Dicotyledonous Orders, the leaves being decidedly stalked, and having netted veins; the flowers are small, with $1-3$ bracts each, and grow in spikes. The Order is a small one, and is, with the exception of Tamus (Black Bryony), confined to tropical regions. Dioscorea, the plant from which the Order takes its name, has large tuberous roots, which, under the name of "Yams," form as important an article of food in tropical countries, as the Potato in temperate climates. When growing it requires a support, like the Hop. There are several varieties; the best are white and mealy, but some are yellow and watery, with a slightly bitter taste.

1. Tamus (Black Bryony).-Characters - described above. (Name, the Latin name of the plant.) 


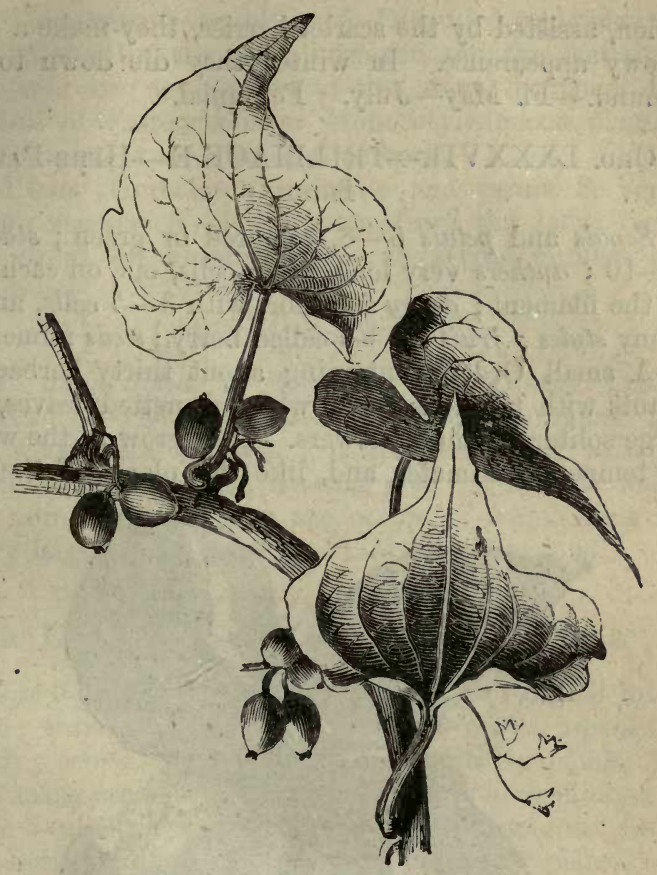

TAMUS CoMmÚNis (Black Bryony).

\section{Tamus (Black Bryony).}

1. T. comminis (Black Bryony).-The only British species.-Root a large, solid tuber, black externally; stem slender, twining among bushes to the length of many feet, and clothed with numerous varnished, heart-shaped leaves, and clusters of small, green flowers, which are succeeded by elliptical scarlet berries. The leaves are reticulated with veins somewhat like those of Dicotyledonous plants, but they are not jointed to the stem. Late in autumn they turn dark purple or bright yellow, 
when, assisted by the scarlet berries, they make a very showy appearance. In winter they die down to the ground.-Fl. May-July. Perennial.

\section{ORD. LXXXVII.-TRILLIACEAE-HERB-PARIS Tribe.}

Sepals and petals $6-8$, coloured or green; stamens 6 - 10 ; anthers very long, their cells, one on each side of the filament ; ovary superior, with $3-5$ cells, and as many styles; fruit a 3-5-celled berry; seeds numerous. -A small Order, containing about thirty herbaceous plants with tuberous roots, whorled, netted leaves, and large solitary terminal flowers. They grow in the woods of temperate climates, and, like the plants of the last

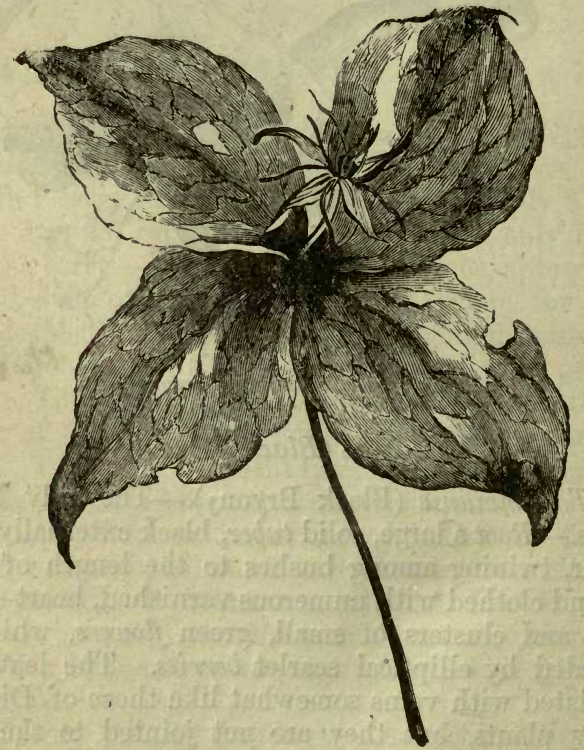

PARIS QtadRifolia (Four-leaveá Herb-Paris, True-Love-Knot). 
Order, bear some resemblance to Dicotyledonous plants. The structure of the seed, however, and the fact that the leaves are not jointed to the stem, fix them in the class of Endogenous or Monocotyledonous plants. Their properties are acrid and narcotic.

1. PÁris (Herb-Paris).- Sepals and petals 8, very narrow ; stamens 8-10. (Name from the Latin par, paris, equal, on account of the unvarying number of the leaves.)

\section{Páris (Herb-Paris).}

1. P. quadrifolia (Four-leaved Herb-Paris, TrueLove-Knot).- The only British species; growing in damp woods, not common. A singular plant, with a stem about a foot high, bearing near its summit four large, pointed leaves, from the centre of which rises a solitary large, green flower.-Fl. May. Perennial.

\section{ORD. LXXXVIII.-LILIACEA.-LILY TRIBE.}

Calyx 0 ; corolla of 6 petals, distinct, or united into a tube; stamens 6 , inserted into the petals, opening inwards ; ovary superior, not united with the petals, 3celled, many-seeded ; style 1; stigma simple or 3-lobed; capsule 3-celled, 3-valved, oblong ; seeds numerous, flattened horizontally.-An extensive family of plants, of which the majority are herbaceous, with bulbous roots, and showy flowers; some, however, attain the dimensions of shrubs, or even trees, in which case they resemble the Palms rather than exogenous trees, the trunk being destitute of true bark and pith, and the leaves being never jointed to the stem. Butcher's Broom (Ruscus) is the only British species which assumes a shrubby character; Asparagus is a branching herbaceous plant, with creeping roots, scaly stems, and bristle-like leaves; Convallaria (Lily of the Valley) has also creeping roots. These three produce a berry-like fruit. All other British species have bulbous roots, and the fruit when ripe is a 
dry capsule. Plants of the Lily tribe are most abundant in temperate climates, but attain their greatest magnitude in the tropics. Draccena Draco (Dragon's Blood) is said to grow to the height of 70 feet, with a stem upwards of 40 feet in circumference. In the Canaries one is in existence which is known to have been an ancient tree in the year 1406. The leaves of many species contain a tough fibre, which is used as a substitute for hemp or flax. Among these the most remarkable is Phormium tenax (New Zealand Flax). The genus Allium (Onion, Garlic, and Leek) supplied food to the early inhabitants of Egypt, and had divine honours paid to it. In Kamtr schatka, Tartary, and the Sandwich Islands, various species are cultivated for the same purpose. The bud and tender part of the stem of the Grass-tree, a native of Tasmania, is said to be nutritious, and of an agreeable flavour, and in our own country the young shoots of Asparagus rank among the most delicate of our esculent vegetables.: In medicine many species are of great value, among which, aloes, the condensed juice of Alóé uulgáris; \&c., and squills, an extract of Scilla maritima, are well known. As ornamental plants the beauty of the Lily Tribe has beenfor ages proverbial ; Lilium Chalcedónicum, which covers the pląins of Syria with its scarlet flowers, is said to have been the plant to which our Blessed Saviour alluded in His Sermon on the Mount, under the title of "the lilies of the field." The innumerable varieties of Hyacinth are derived from an Eastern plant, Hyacinthus Orientális ; and the Tulip (Túlipa) was long the most highly prized among florists' flowers, and furnished in Holland a subject for the most absurd speculation.

\section{Group I. AsParagex.-The Asparagus Group. Roots never bulbous; fruit, a berry.}

1. Aspáragus.-Corolla deeply 6-cleft, bell-shaped; stamens 6 , distinct ; stigmas 3 , bent back. (Name, the Greek name of the plant.) 
2. Ruscus (Butcher's Broom).-Corolla deeply 6-cleft ; stamens and pistils on different plants (dioecious); stamens connected at the base; style surrounded by a nectary. (Name, " anciently bruscus, from bruskelen; in Celtic, box-holly." -Sir W. J. Hooker.)

3. Convaluaria (Lily of the Valley).-Corolla 6cleft, bell-shaped, soon falling off, not jointed with the pedicel ; stamens 6, distinct; stigma 1. (Name from the Latin convallis, a valley, the usual locality of this family.)

4. Polygónatum (Solomon's Seal).-Corolla 6-cleft, elongated, persistent, jointed with the pedicel ; stamens 6 , distinct; stigma 1. (Name in Greek denoting "many angled," from the character of the stem.)

\section{Group II. ScilLex.-The Squill Group.}

Root bulbous; fruit a capsule; stalk leafless.

5. ÁGRaPHIS (Hyacinth).-Corolla deeply 6-cleft, tubular, bell-shaped; lobes of the corolla reflexed at the extremity. (Name, a Greek compound, which signifies "unwritten," denoting that the petals do not bear marks resembling written characters, as is the case with some species of Hyacinthus, in which genus this plant was formerly placed.)

6. ScIlla (Squill).-Corolla of 6 spreading petals; flowers blue or purple, in a cluster or corymb, not enclosed in a sheath, falling off as the seed ripens. (Name, the Latin name of the plant.)

7. Ornithógalum (Star of Bethlehem).-Like Scilla, except that the petals are white, and do not fall off. (Name from the Greek ornis, a bird, and gala, milk. 'This plant is supposed by Linnæus to be the "dove's dung" mentioned in 2 Kings vi. 25.)

8. Allium (Garlic).-Corolla of 6 spreading petals ; flowers in an umbel, at the base of which is a sheath of 1 or 2 leaves. (Name, the Latin name of the plant.) 
Group III. TULIPEE.-The Tulip Group.

Like the Squill group, except that the flower-stalk is leafy.

9. Gígea.-Flowers in an umbel or corymb; petals 6 , without a nectary; anther's erect, attached to the filaments by their bases; style conspicuous. (Named in honour of Sir Thomas Gage.)

10. Túlipa (Tulip).-Flowers solitary, rarely 2 on a stem; petals and anthers as in Gágea; style 0. (Name from toliban, the Persian name for a turban.)

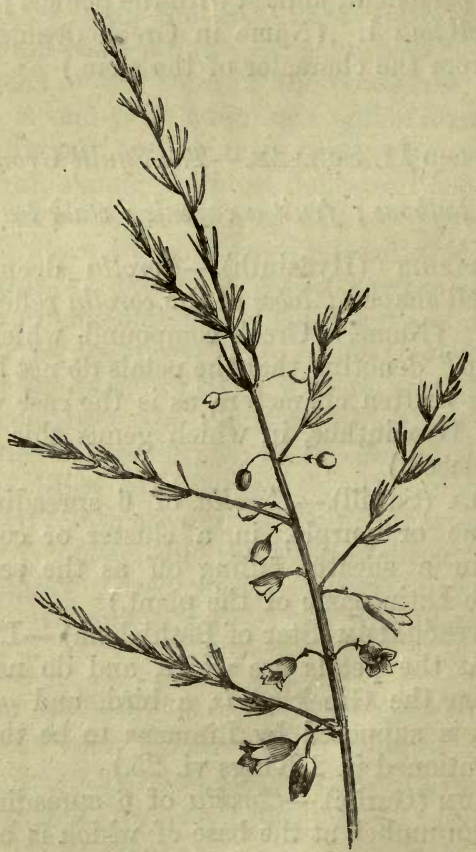


11. Fritillaria (Fritillary).-Flowers solitary; petals 6 , with a nectary at the base of each; anthers attached above their bases; style 3-cleft at the summit. (Name from the Latin fritillus, a dice-box, the common accompaniment of a chequer-board, which the marking of the flower resembles.)

* Besides the above, several other genera are described by British botanists, of which Anthéricum or Lloydia (Spider-wort) is the only real native; it is very rare, growing only near the summit of Snowdon and other mountains in Wales.

\section{Asparagus.}

1. A. officinális (Common Asparagus). - The only British species, occurring sparingly on several parts of the sea-coast, especially near the Lizard Point, Cornwall; it differs only in size from the cultivated plant. See "A Week at the Lizard."-Fl. July, August. Perennial.

\section{Ruscus (Butcher's Broom).}

1. R. aculeátus (Butcher's Broom, Knee Holly).-The only British species, and only British shrub of Endogenous growth.-Waste and bushy places, not uncommon, especially in the south of England. A low shrub 3-4 feet high, with erect green stems, which are branched and plentifully furnished with very rigid leaves terminating each in a sharp spine. The flowers are minute, greenish-white, and grow singly from the centres of the leaves; the berries are as large as marbles, round, and of a brilliant scarlet colour.-Fl. April, May. Shrub.

\section{Convaluaria (Lily of the Valley).}

1. C. majalis (Lily of the Valley).-Leaves all from the root; flowers drooping, in a long, one-sided cluster. -Woods, in a light soil, not frequent. A common, 


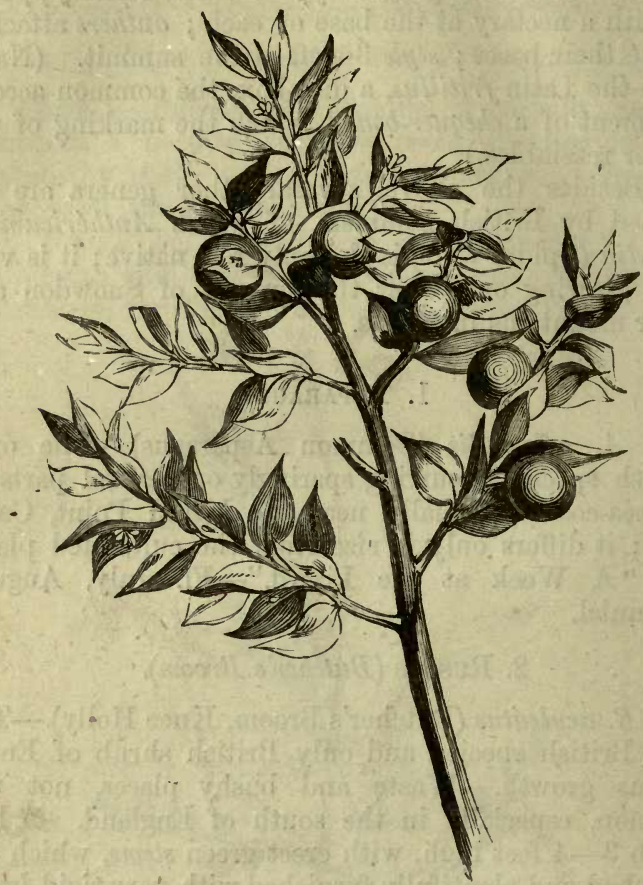

RUSCUS ACUlEÁtuS (Butcher's Broom, Knee Holly).

and universally admired garden plant, equally prized for its globular, pure white flowers, and for its delicious perfume.-Fl. May. Perennial.

\section{Polygonátum (Solomon's Seal).}

1. P. multiflórum (Solomon's Seal).-Stem roundish, bearing numerous elliptical leaves, which are all turned one way, and opposite them small clusters of drooping flowers, which are all turned the other way; filaments 
hairy.-Woods, in several parts of England and Scotland, but not frequent. A singular plant, 1-2 feet high, bearing numerous whitish flowers, with green tips, shaped like old-fashioned round seals.-Fl. June. Perennial.

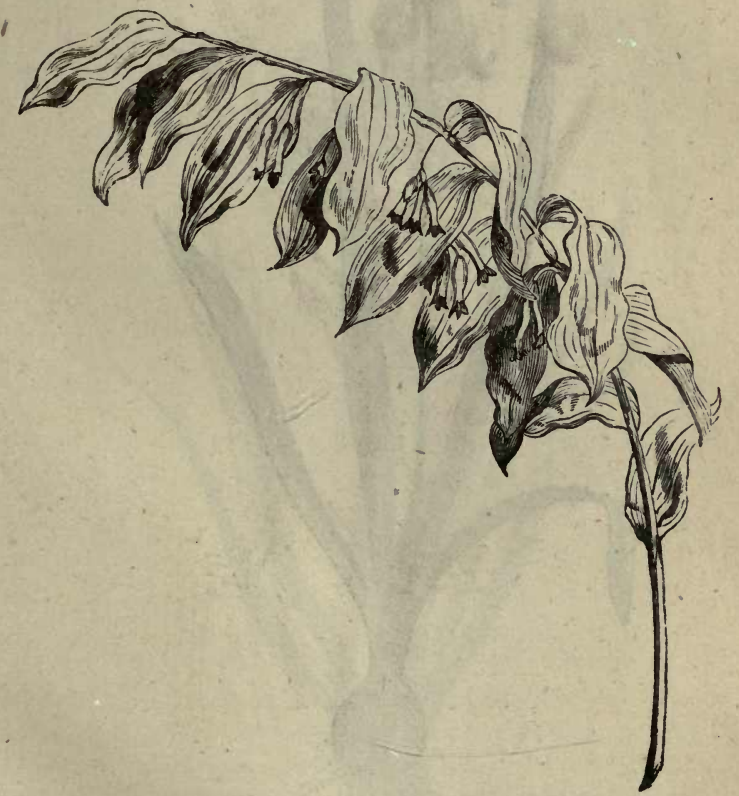

FOLYGONÁTUM MULTIFLÓRUM (Solomon's Seal).

* P. officinálé (Angular Solomon's Seal) differs from the last species in having an angular stem, mostly solitary flowers, and smooth filaments: P. verticillátum bears its leaves $3-4$ in a whorl. Both these species are rare. 


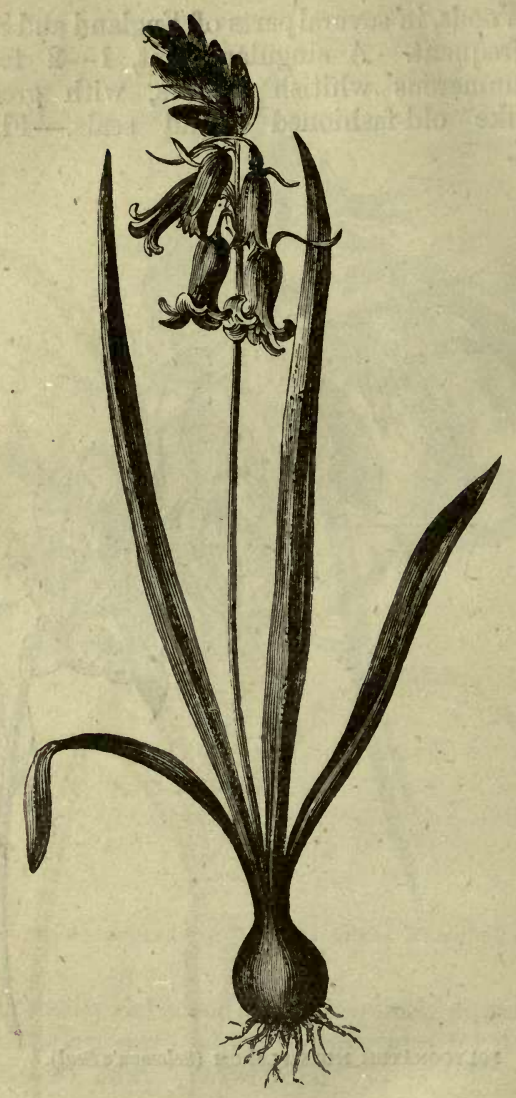

ÁGRAPHIS NUTANS (Wild Hyacinth, Blue-bell).

5. Agraphis (Hyacinth).

1. A. nutans (Wild Hyacinth, Blue-bell).-The only British species. Too abundant and well known to need 
any description. The name Hyacinthus was originally given to some species of Lily into which the youth Hyacinthus was fabled to have been changed by Apollo. The petals are marked with dark spots, arranged so as to resemble the Greek word AI, alas! The present species, however, having no such characters on its petals,

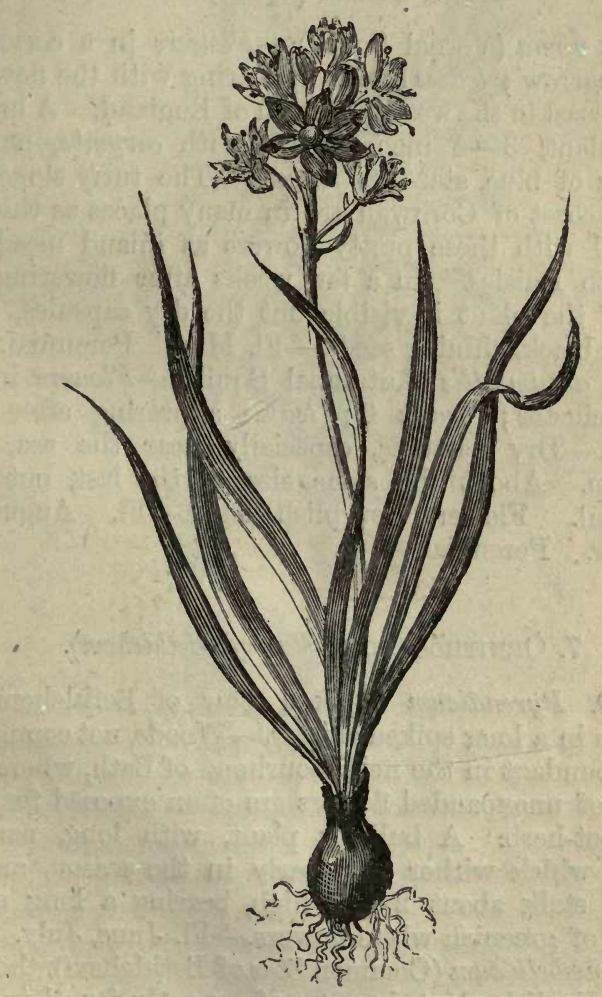

scilla verna (Vernal Squill). 
was named non-scriptus, not written. It is sometimes, though incorrectly, called Hair-bell ; the true Hair-bell being Campánula rotundifolia. Modern botanists have removed it from the genus Hyacinthus into that which it at present occupies.-Fl. May, June. Perennial.

\section{Scillua (Squill).}

1. S. verna (Vernal Squill).-Flowers in a corymb; bracts narrow ; leaves linear, appearing with the flowers. - Sea-coast in the west and north of England. A lovely little plant, 3-4 inches high, with corymbs, or flat clusters of blue, star-like flowers. The turfy slopes of the sea-coast of Cornwall are in many places as thickly studded with these pretty flowers as inland meadows are with Daisies. In a few weeks after flowering no part of the plant is visible but the dry capsules, containing black, shining seeds.-Fl. May. Perennial.

2. S. autumnális (Autumnal Squill).-Flowers in an erect cluster; bracts 0 ; leaves appearing after the flowers.-Dry pastures, especially near the sea, not common. About the same -size as the last, but less beautiful. Flowers, purplish blue.-Fl. AugustOctober. Perennial.

\section{ORnithógalum (Star of Bethlehem).}

1. O. Pyrenáicum (Spiked. Star of Bethlehem).Flowers in a long spiked cluster.-Woods, not common; very abundant in the neighbourhood of Bath, where the spikes of unexpanded flowers are often exposed for sale as a pot-herb. A bulbous plant, with long, narrow leaves, which wither very early in the season, and a leafless stalk about 2 feet high, bearing a long erect cluster of greenish-white flowers.-Fl. June, July.

* O. umbellátum (Common Star of Bethlehem), though not an English plant, is not unfrequently found in the 
neighbourhood of houses. It bears large, pure white flowers, which are green externally, and grow in umbels,

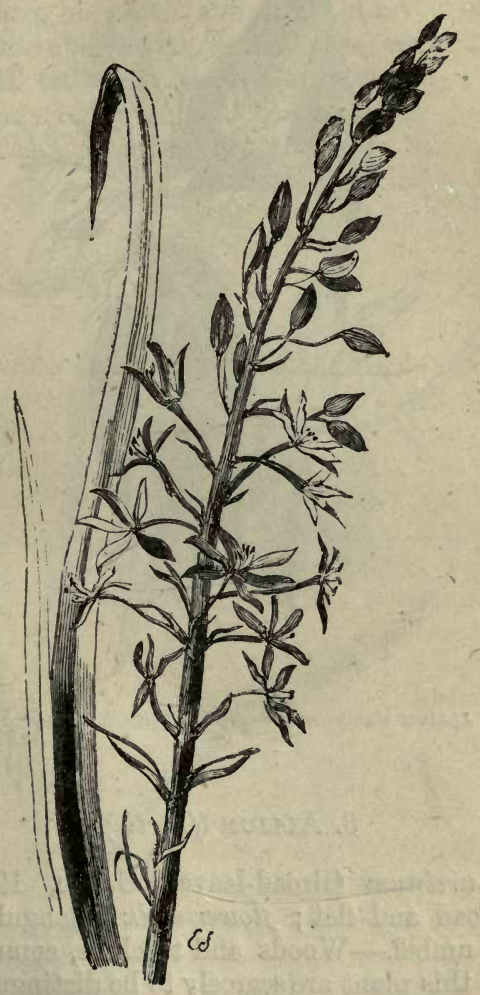

ORNITHóGALUM PYRENÁICUM (Spiked Star of Bethlehem).

or, rather, corymbs, opening only in sunny weather. It is a common garden plant. 


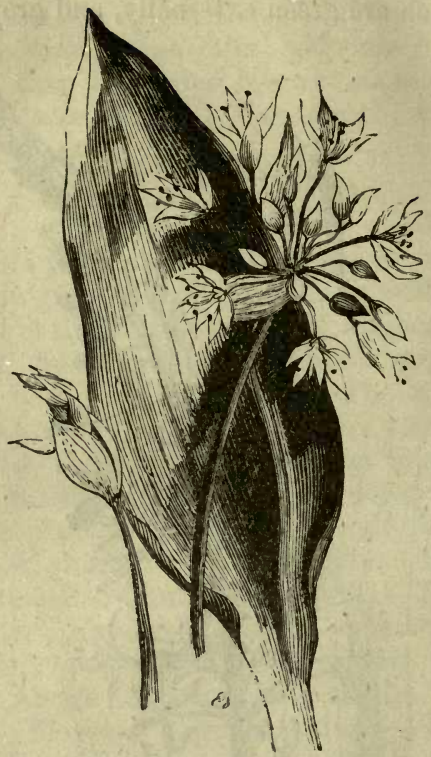

ALLIUM ORSINUM (Broud-leaved Garlic, Ramsons).

\section{Allium (Garlic).}

1. A. ursinum (Broad-leaved Garlic, Ramsons).Leaves broad and flat; flower-stalk triangular; flower in a flat umbel.-Woods and thickets, common. The leaves of this plant are scarcely to be distinguished from those of the Lily of the Valley; the flowers are white and pretty, but the stench of the whole plant is intolerable.-Fl. May, June. Perennial.

* Seven other species of Garlic are described by British botanists, but none of them are so common as 
the last. A. Schoenóprasum (Chives) is a pretty plant, with dense heads of bright purple flowers. In a wild state its foliage is scanty, but under cultivation becomes very abundant, in which state it is a favourite cottage pot-herb. Several other species are remarkable for bearing small bulbs among the flowers.

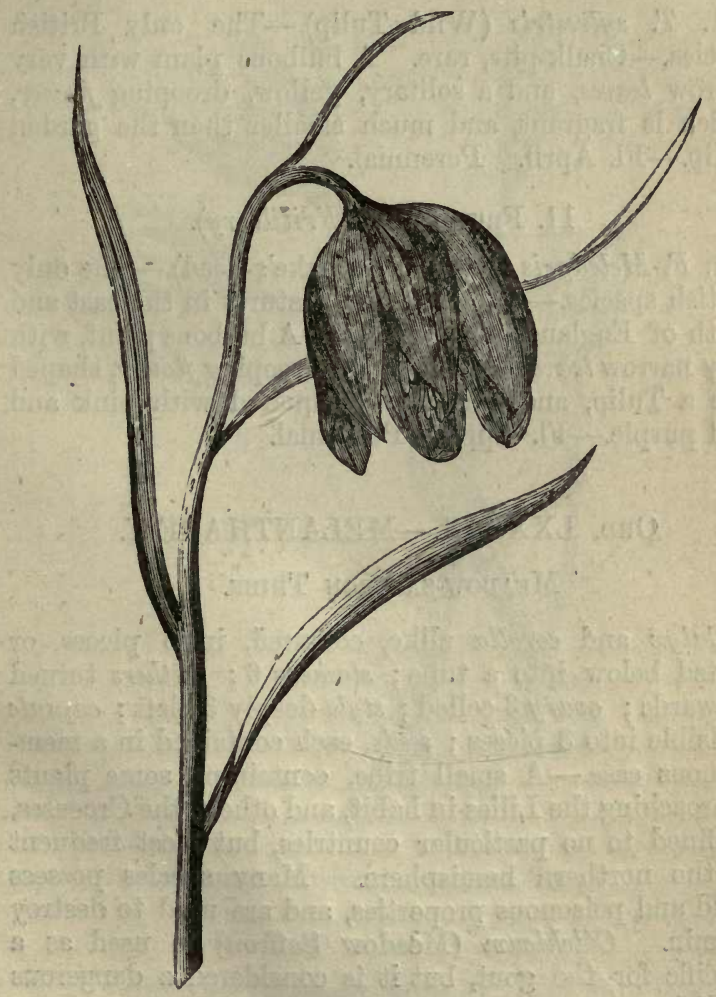

FRITILLARIA MELEAGRIs (Fritillary, Snake's-head). 
9. Gígea.

1. G. luitea (Yellow Gágea).-The only British species. -Woods and pastures, rare. A bulbous plant 6-8 inches high, with long narrow leaves, and umbels of yellow flowers.-Fl. March-May. Perennial.

\section{TúLIPa (Tulip).}

1. T. sylvestris (Wild Tulip).-The only British species.-Chalk-pits, rare. A bulbous plant with very narrow leaves, and a solitary, yellow, drooping flower, which is fragrant, and much smaller than the garden Tulip.-Fl. April. Perennial.

\section{Fritillaria (Fritillary).}

1. F. Meleágris (Fritillary, Snake's-head).-The only British species.-Meadows and pastures in the east and south of England, not common. A bulbous plant, with very narrow leaves, and a solitary drooping flower, shaped like a Tulip, and curiously chequered with pink and dull purple.-Fl. April. Perennial.

\section{ORD. LXXXIX.-MELANTHACEA.}

\section{Meadow-Saffron Tribe.}

Calyx and corolla alike, coloured, in 6 pieces, or united below into a tube; stamens 6 ; anthers turned outwards ; ovary 3 -celled; style deeply 3-cleft ; capsule divisible into 3 pieces; seeds, each contained in a membranous case.-A small tribe, containing some plants approaching the Lilies in habit, and others, the Crocuses, confined to no particular countries, but most frequent in the northern hemisphere. Many species possess acrid and poisonous properties, and are used to destroy vermin. Cólchicum (Meadow Saffron) is used as a specific for the gout, but it is considered a dangerous medicine. 
1. Cólchicum (Meadow Saffron).-Corolla with a very long tube, rising from a sheath. (Name from Colchis, a country famous for medicinal herbs.)

2. Tofieldia (Scottish Asphodel).-Corolla of 6 petals; flowers each from a small 3-lobed sheath. (Name in honour of Mr. Tofield, an English botanist.)

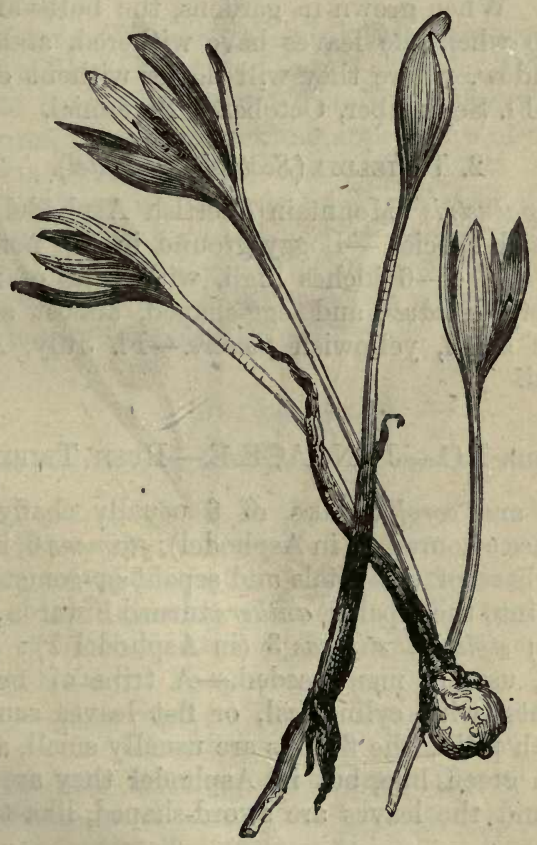

COLCHICUM AUTUMNALE (Meadow Saffron).

1. Cólchicum (Meadow Saffron).

1. C. autumnálé (Meadow Saffron).-The only British species.-Meadows, not general. A not unfrequent 
garden plant, with large broad leaves, which wither away in summer and are succeeded by several light purple, or sometimes white flowers, resembling Crocuses in all respects except that they have 6 instead of 3 stamens. At the time of flowering the seed-vessels are concealed beneath the ground, where they remain until the following spring, when they rise above the surface and are ripened. When grown in gardens, the bulbs are often taken up when the leaves have withered, and placed in a window, where they will flower without earth or water.-Fl. September, October. Perennial.

\section{Tofieldia (Scottish Asphodel).}

1. T. palustris (Mountain Scottish Asphodel).-The only British species.-Boggy ground in the north. A small plant, 4-6 inches high, with tufts of narrow, sword-shaped leaves, and egg-shaped, almost stalkless spikes of small, yellowish flowers.-Fl. July, August. Perennial.

\section{ORD. XC.-JUNCACE E.-Rush TRIBE.}

Calyx and corolla alike, of 6 usually chaffy pieces (sometimes coloured, as in Asphodel); stamens 6, inserted into the base of the petals and sepals, or sometimes 3 , inserted into the sepals ; anthers turned inwards ; 'ovary superior ; style 1; stigmas 3 (in Asphodel 1); capsule 3-valved, usually many-seeded. - A tribe of marsh or bog plants, with cylindrical, or flat leaves sometimes filled with pith; the flowers are usually small, and of a brownish green hue, but in Asphodel they are bright yellow, and the leaves are sword-shaped, like those of the Iris.

The true Rushes (Juncus) are, for the most part, social plants, and are often of considerable use in fixing the soil of marshes and bogs. The stems of the common species are used for making mats and the wicks of candles. The tall aquatic plant usually called the 
Bulrush belongs to the Sedge Tribe, the Club-rush to the Order Typhaceex, and the Flowering Rush to the Order Butomacexe.

1. Juncus (Rush). - Perianth chaffy ; filamients smooth ; stigmas 3 ; capsule 3 -celled, 3-valved; seeds numerous. (Name, the Latin name of the plant, and that from jungo, to join, the stems having been woven into cordage.)

2. Lúzula (Wood-rush).-Like Juncus, except that the capsule is 1-celled, and only 3 -seeded. (Name supposed to have been altered from the Italian lucciola, a glow-worm, from the sparkling appearance of the heads of flowers when wet with rain or dew.)

3. Narthecium (Asphodel).-Perianth of 6 coloured sepals and petals; stamens downy; stigma 1 ; capsule 3 -celled; seeds numerous. (Name from the Greek narthex, a rod, to which, however, the only British species bears little resemblance.)

\section{Juncus (Rush).}

* Stems cylindrical, tapering to a point; leaves none.

1. J. effúsus (Soft Rush).-Stems not furrowed; panicle below the summit of the stem, branched and spreading; capsule blunt.-Marshy ground, common. This and the following species are well known as the rushes of which mats and the wicks of candles are made.-Fl. July. Perennial.

2. J. conglomeratus (Common Rush).-Stems not furrowed; panicle below the summit of the stem, crowded; capsule ending in a point.-Marshy places, common. Only distinguished from the last by its dense panicle of flowers, and pointed capsule.-Fl. July. Perennial.

3. J. glaucus (Hard Rush).-Stems deeply furrowed, rigid; panicle below the summit of the stem, branched and spreading.-Marshy places, and roadsides, common. Very distinct from the two last, from which it may be distinguished by its more slender, furrowed, glaucous 


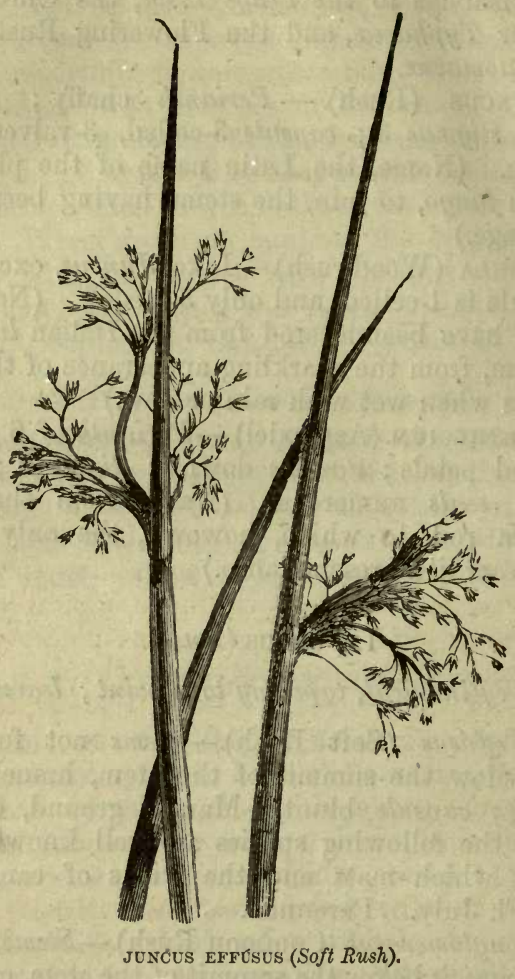

stems, and its very loose panicle of slender flowers.Fl. July. Perennial.

* $J$. maritimus (Lesser Sea-Rush) is marked by its pungent stems and bracts, which latter are dilated at the base; capsules oblong, equalling the sepals in length : $J$. acutus (Great Sea-Rush) also has dilated bracts, of which the outer, as well as the stems, are spinous ; capsules twice as long as the sepals; this, the largest 
British species, grows on the sandy sea-shore in great abundance in a few places ; it is well marked by its stout and rigid habit, and by its large, polished capsules.

$$
\text { * * Stems leafless; leaves all from the root. }
$$

4. J.squarrósus (Heath Rush).-LLeaves rigid, grooved; panicle terminal.-Moors and heaths, abundant. Well marked by its rigid stems and leaves, of which the latter have mostly one direction. The stems are about 1 foot high ; the flowers larger than in the marsh species, and variegated with glossy brown, and yellowish white.-Fl. June, July. Perennial.

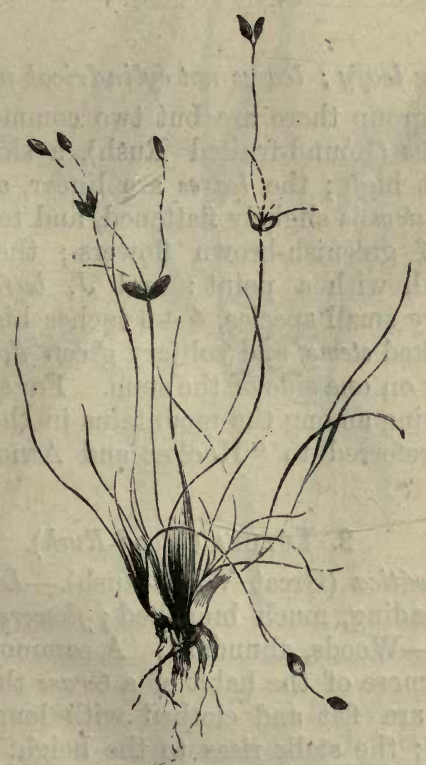

Juncus Uliginosus (Lesser Bog-jointed Rush). 
* * * Stems leafy; leaves cylindrical, or but slightly flattened, jointed internally.

* The most common species in this group are :-

J. acutiflorus (Sharp-flowered jointed Rush), a slender plant, $1-2$ feet high, with slightly flattened stems and leaves, and terminal panicles of brown sharp-pointed flowers : J. lampocarpus (Shining-fruited jointed Rush), resembling the last, but distinguished by its large, brown, glossy capsule: J. obtusiflórus (Blunt-flowered jointed Rush), rather smaller than $J$. acutiflórus, and well distinguished by its blunt flowers; and $J$. uliginosus (Lesser Bog jointed Rush), a small and very variable plant, 3-8 inches high, bearing a few clusters rather than panicles of flowers. All these are common in boggy ground.

**** Stems leafy; leaves not cylindrical nor jointed.

* In this group there are but two common species ; $J$. compressus (Round-fruited Rush), a slender plant, about a foot high; the leaves are linear, and grooved above ; the stem is slightly flattened, and terminates in a panicle of greenish-brown flowers; the capsule is nearly round, with a point: and $J$. bufonius (Toad Rush), a very small species, $4-6$ inches high, with repeatedly forked stems, and solitary green flowers, which grow mostly on one side of the stem. For several other species growing among the mountains in the north, the student is referred to "Hooker and Arnott's British Flora."

\section{Lúzula (Wood-Rush).}

1. L. sylvática (Great Wood-Rush).-Leaves hairy; - panicle spreading, much branched; flowers in clusters of about 3.-Woods, abundant. A common woodland plant, with more of the habit of a Grass than a Rush. The leaves are flat and clothed with long, scattered, white hairs; the stalk rises to the height of about 2 feet, and bears a terminal loose cluster of brownish 
flowers, with large light yellow anthers.-Fl. May, June. Perennial.

2. L. pilósa (Hairy Wood-Rush).-Leaves hairy; panicle little branched; flowers solitary.-Woods, not unfrequent. Smaller than the last, and well distinguished by its solitary flowers, the stalks of which are bent back when in fruit.-Fl. May, June. Perennial.

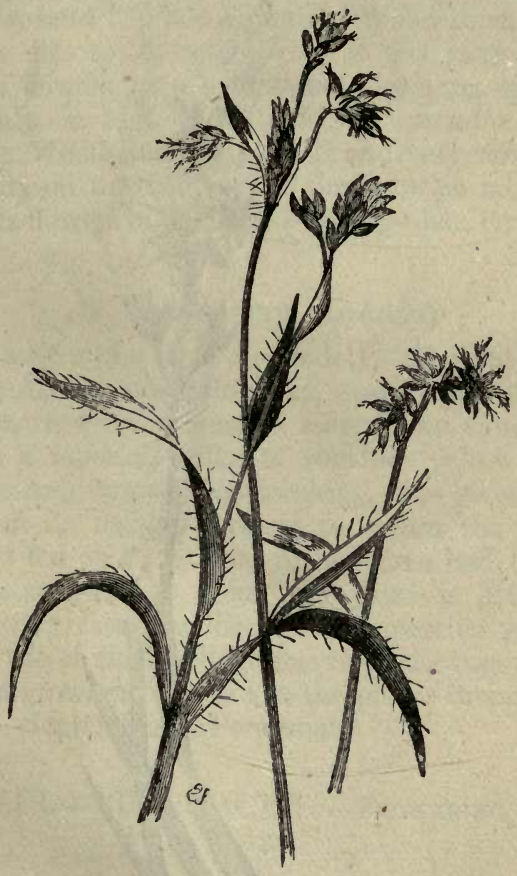

LÚZULA CAMPESTRIs (Field Wood-Rush).

3. L. campestris (Field Wood-Rush).-Leaves hairy; panicle of 3 or 4 dense, many-flowered clusters. Pastures, common. Much smaller than either of the s s 2 
preceding. This is one of the first grass-like plants to show flower in spring, when it may be distinguished from all other meadow-herbs by its dense clusters or spikes of brownish-green flowers, each of which contains 6 large, light-yellow anthers.-Fl. March-May. Perennial.

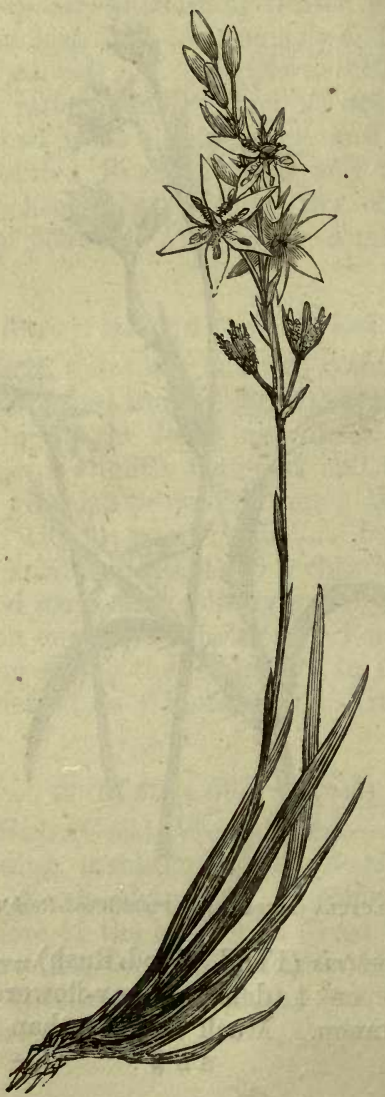

Mabthécium ossífragum (BogAsphodel). 
* Other British species of Wood-Rush are L. Fórsterí (Forster's Wood-Rush), the panicle of which is slightly branched, and bears its flowers solitary; each capsule contains 3 seeds, having a straight tail at their summits; it resembles $L$. pilosa in habit, but is much smaller; the seeds of the latter plant are furnished with a long hooked tail : L. spicátà (Spiked Mountain Wood-Rush) is about the same size as $L$. campestris; it has narrow leaves, bears its flowers in a compound, drooping spike, and grows only on high mountains : $L$. arcuáta (Curved Mountain Wood-Rush) is a small and very rare species, found only on the summit of the Scottish mountains; it bears its flowers in panicles, $3-5$ together, on drooping stalks.

\section{NARTHÉcium (Asphodel).}

1. N. ossifragum (Bog Asphodel).- The only British species.-An elegant little plant, $6-8$ inches high, with tufts of narrow sword-shaped leaves, like those of the Iris, and a tapering spike of star-like yellow flowers. The name ossifragum, bone-breaking, was given to this plant from its being supposed to soften the bones of cattle that fed on it. Other plants have had the same properties assigned to them, but there is little doubt that in every case the diseases in question are to be traced to the noxious exhalations from the bogs in which the plants grow, rather than to the plants themselves.Fl. July-September. Perennial.

\section{ORD. XCI.-BUTOMACEA.-FLOWERING RUSH TRIBE.}

Sepals 3, green; petals 3 , coloured ; stamens varying in number; ovaries superior, 3,6 , or more, distinct, or united into a mass; carpels many-seeded.-A small tribe of aquatic plants with sword-shaped leaves and conspicuous flowers. The only British example is the Flowering Rush, described below. 
1. Bútomus (Flowering Rush).-Stamens 9 ; carpels 6. (Name from the Greek bous, an ox, and temno, to cut; because cattle feeding on the leaves are liable to cut their mouths.)

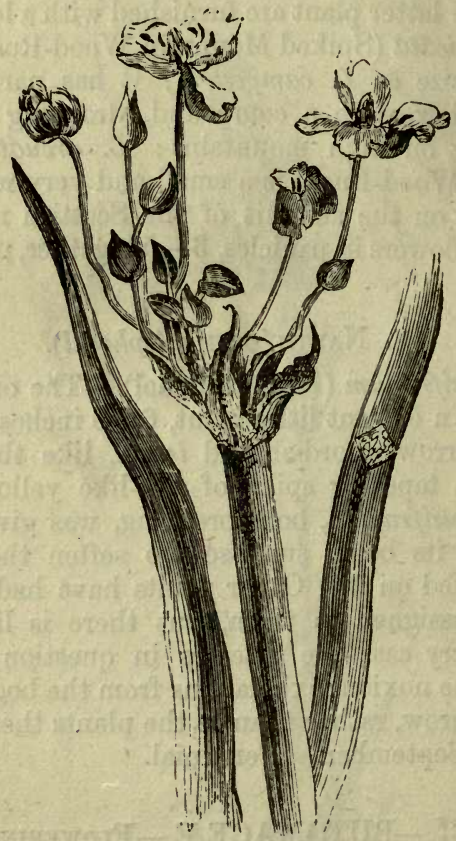

вÚtomus UMBellatus (Flowering Rush).

1. Bútomus (Flowering Rush).

1. B. umbellatus (Flowering Rush).-The only British species.-A tall, aquatic plant, growing in stagnant water and slow rivers, not uncommon. The leaves are swordshaped, 2-4 feet long, and spring all from the root; 
the flowers are large, rose-coloured, and handsome, and grow in a simple umbel at the top of a round stalk, which rises several feet above the surface of the water. -Fl. June, July. Perennial.

\section{ORder XCII.-ALISMACEAE-WATER-Plantain TRIBE.}

Sepals 3, green; petals 3, coloured; stamens varying in number; ovaries superior, numerous ; carpels numerous, 1- or 2-seeded.-A small tribe of aquatic plants, often floating, with long-stalked leaves, and flowers which in some respects resemble those of the Crowfoot Tribe. Like the Crowfoots, too, they contain an acrid juice, though the roots of some species, deprived of their acridity by drying, are said to be used as food.

1. Alisma (Water-Plantain).-Flowers containing both stamens and pistils ; stamens 6 ; carpels numerous, 1-seeded. (Name, the Greek name of the plant, and that said to be derived from the Celtic alis, water.)

2. Actínocarpus (Star-fruit).-Like Alisma, except that the carpels are 2-seeded, and spread in a radiate manner. (Name in Greek having the same meaning as the English name.)

3. SagitTaria (Arrow-head).- Stamens and pistils in separate flowers (monocious); stamens numerous ; carpels numerous, 1-seeded. (Name from the Latin sagitta, an arrow, from the shape of the leaves.)

\section{Alisma (Water-Plantain).}

1. A. Plantágo (Great Water-Plantain).-Leaves all from the root, broad below, and tapering to a point; flowers in a compound, whorled panicle.-Margins of rivers, lakes, and ponds; common. A stout, herbaceous plant, $2-3$ feet high, with large, stalked leaves, ribbed like those of a Plantain, and a leafless, whorled panicle 


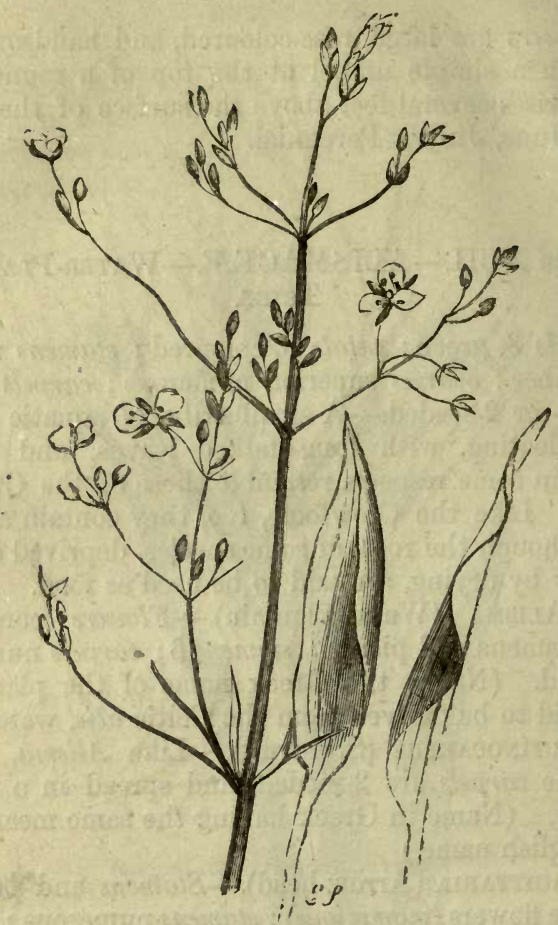

ALISMA PLANTAGo (Great Water-Plantain).

of lilac flowers, the petals of which are very delicate, and soon fall off.-Fl. June-August. Perennial.

2. A. ranunculódes (Lesser Water-Plantain).-Leaves narrow, and tapering at both ends; flowers in umbels.Peaty bogs, not uncommon. Much smaller than the last, and well marked by the above characters, as well as by its larger flowers.

* A. natans (Floating Water-Plantain) is found only in mountain lakes; it has floating leafy stems, and the 
flowers, which are solitary, are white, with a yellow spot.

2. Actínocarpus (Star-fruit).

1. A. Damasonium (Common Star-fruit). - The only British species.-Ditches in the midland counties, not common. An aquatic plant, with the habit of a WaterPlantain. The leaves grow on long stalks and float on the surface of the water; the flowers, which grow in whorls, are white, with a yellow spot at the base of each petal ; the fruit is composed of 6 pointed carpels, which are arranged in the form of a star.-Fl. June, July. Perennial.

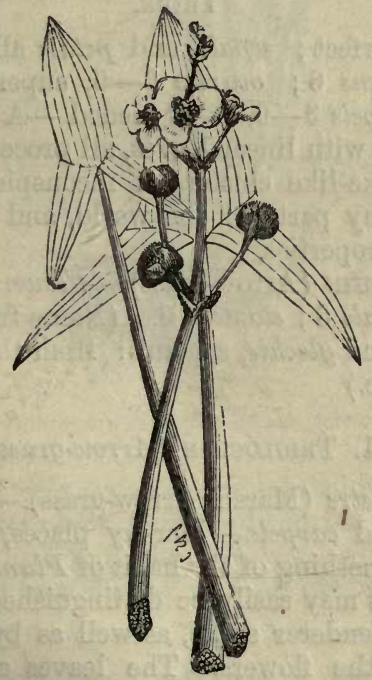

SagitTaria sagrtTifolia (Common Arrow-head).

3. SagitTária (Arrow-head).

1. S. sagittifolia (Common Arrow-head).-The only British species.-Rivers and ditches, not unfrequent. 
A pretty plant, well distinguished by its large arrowshaped leaves, and whorled panicles of delicate, fleshcoloured flowers, both of which rise $6-8$ inches out of the water. This is one of the very few plants which neither smoke nor buildings have driven out of London, there being still large beds of it in the Thames, near the Temple. Gardens and Hungerford Market, where the eager botanist may even yet gather fine specimens.-Fl. July-September. Perennial.

\section{ORD. XCIII.-JUNCAGINACEÆ.-ARROW-GRASS TRIBE.}

Flowers perfect; sepals and petals alike, green and small ; stamens 6 ; ovaries $3-6$, superior, united or distinct; carpels $3-6,1-2$ seeded. $-A$ small order of marsh plants, with linear leaves, all proceeding from the root, and spike-like clusters of inconspicuous flowers; found in many parts of the world, and possessing no remarkable properties,

1. Triglóchin (Arrow-grass).-Flowers in a spike; sepals and petals 6 ; stamens 6 . (Name from the Greek treis, three, and glochis, a point: from the three points of the capsule.)

\section{Triglóchin (Arrow-grass).}

1. T. palustre (Marsh Arrow-grass). - Fruit linear, of 3 combined carpels.-Marshy places, frequent. A plant with something of the habit of Plantago maritima, from which it may easily be distinguished by its fewer flowers and slenderer spike, as well as by the different structure of the flowers. The leaves are linear and fleshy.-Fl. June-August. Perennial.

2. T. marítimum (Sea Arrow-grass).-Fruit eggshaped, of 6 combined carpels.-Salt marshes, common. Like the last, but well marked by its rounded, not linear, capsule.-Fl. May-September. Perennial. 
TYPHACEE.-REED-MACE TRIBE.

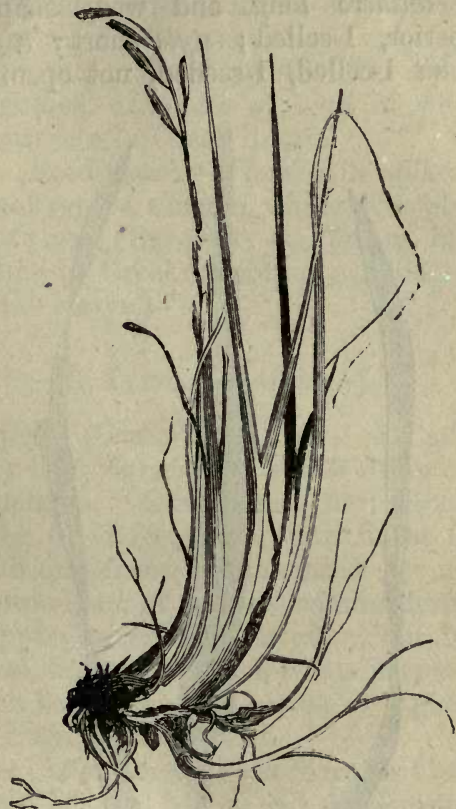

TRIGLOCHIN PALUSTRE (Marsh Arrovo-grass).

* Scheuchzeria palustris, which belongs to this order, is a very rare plant, found only in the north. It has a few semicylindrical, blunt leaves, and a leafless stalk, terminating in a cluster of $5-6$ green flowers.

\section{ORd. XCIV.-TYPHÁCEA_-REED-Mace TRIBE.}

Stamens and pistils separate, but on the same plant (monocious) ; flowers in dense spikes or heads not enclosed in a sheath; perianth composed of 3 scales or a tuft of hairs ; stamens $3-6$, distinct, or united by their 
filaments; anthers long, and wedge-shaped; ovary single, superior, 1-celled; style short; stigma linear, lateral ; fruit 1-celled, 1-seeded, not opening, angular

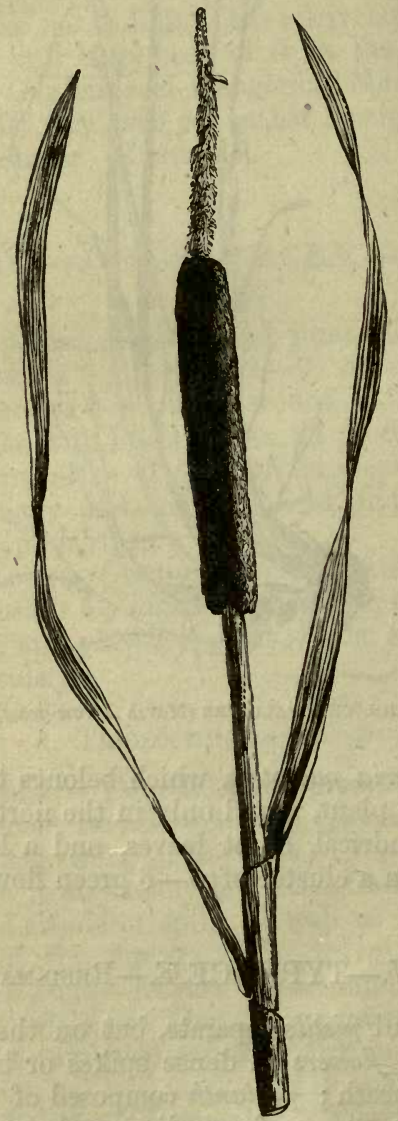

- TYPha LATIFolia (Great Reed-Mace, or Cat's Tail). 
by mutual pressure. - Herbaceous plants, growing in marshes or ditches, with jointless stems, sword-shaped leaves, and small flowers, which are only conspicuous from their compact mode of growth. The order contains only two families, examples of both of which are of common occurrence in Great Britain.

1. Trpha (Reed-mace).-Flowers in spikes. (Name from the Greek typhos, a marsh, where these plants grow.)

2. Spargánium (Bưr-reed). - Flowers in globular heads. (Name in Greek denoting a little band, from the ribbon-like leaves.)

\section{Trpha (Reed-Mace).}

1. T. latifolia (Great Reed-Mace, or Cat's Tail).Leaves nearly flat; barren and fertile spikes continuous. -Ponds, common. Our largest herbaceous aquatic, often growing $6-8$ feet high, with linear leaves, and stout, cylindrical stems, surmounted by a club-like spike, the lower part of which contains fertile flowers only, the upper barren. It is often, but incorrectly, called Bulrush, the true Bulrush being Scirpus palustris, a plant which has more of the habit of a gigantic rush. -Fl. July, August. Perennial.

2. T. angustifolia (Lesser Reed-Mace, or Cat's Tail).Leaves grooved below; barren and fertile spikes slightly interrupted.-Ponds, less frequent than the last, from which it differs by the above characters, and by its smaller size.-Fl. July, August. Perennial.

\section{Spargánium (Bur-reed).}

1. S. ramósum (Branched Bur-reed).-Leaves triangular at the base, with concave sides; stem branched. -Ditches, common. A large aquatic, which at a distance might be mistaken for a Flag (Iris Pseudacorus). The leaves are sword-shaped, and the flowers are collected into globular heads, of which the lower 
contain fertile flowers only, the upper barren.-Fl. July, August. Perennial.

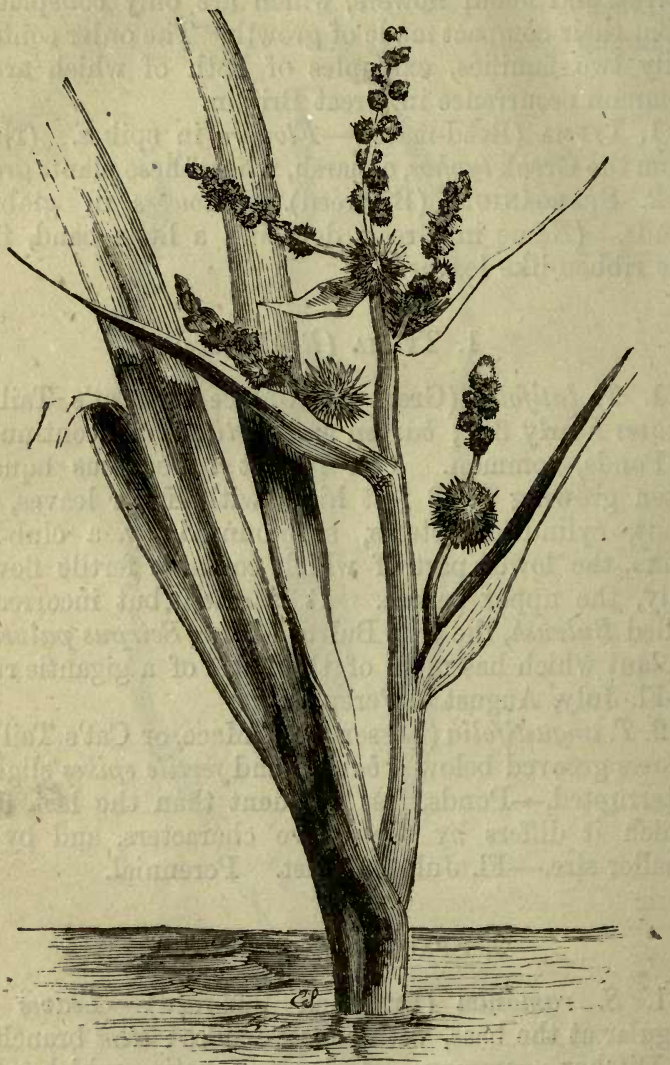

SPARGaNIUM RAMOSUM (Branchied Bur-reed).

2. S. simplex (Unbranched upright Bur-reed). Leaves triangular at the base, with flat sides; stem un- 
branched.-Ditches, common. Smaller than the last, and at once distinguished by the above characters.

* S. natans (Floating Bur-reed) is found only in the north. It has very long, pellucid, floating leaves, and flowers resembling those of the preceding species, except that the barren head is usually solitary.

\section{ORD. XCV.-ARACEÆ.-The Cuckoo-PINT TRIBE.}

Stamens and pistils separate, but on the same plant (monoecious); flowers arranged on a spadix, or central column, and enclosed in a sheath; perianth 0 ; stamens numerous, sessile on the spadix ; ovaries the same, below the stamens; stigma sessile ; fruit a berry.-A curious tribe of plants, all more or less resembling the British species, Arum maculátum, abounding in tropical countries, and possessing acrid, or even poisonous qualities, which, however, may be dissipated by heat. The most remarkable plant of the order is the Dumb-Cane of the West Indies, a species growing as high as a man, and having the property, when chewed, of swelling the tongue and destroying the power of speech. The effects continue for several days, and are accompanied with much pain. Other species, which are scarcely less noxious in their fresh state, are extensively cultivated in tropical countries, and produce tuberous roots, which, when cooked, are important articles of food. Even the British example of the order (Arum maculátum), though its juice is so intensely acrid that a single drop will cause a burning taste in the mouth and throat, which continues for hours, has roots which, when properly prepared, are wholesome and nutritious. This plant is cultivated in the Isle of Portland, and the starch procured from the roots is, under the name of Portland Sago, used as a substitute for arrow-root. Several species have 
been observed to evolve a considerable quantity of heat from the spadix at the time of the expansion of the sheath.

1. Arum (Cuckoo-pint).-Flowers on a club-shaped spadix, which is naked above, and enclosed in a convolute sheath. (Name, the Greek name of the plant.)

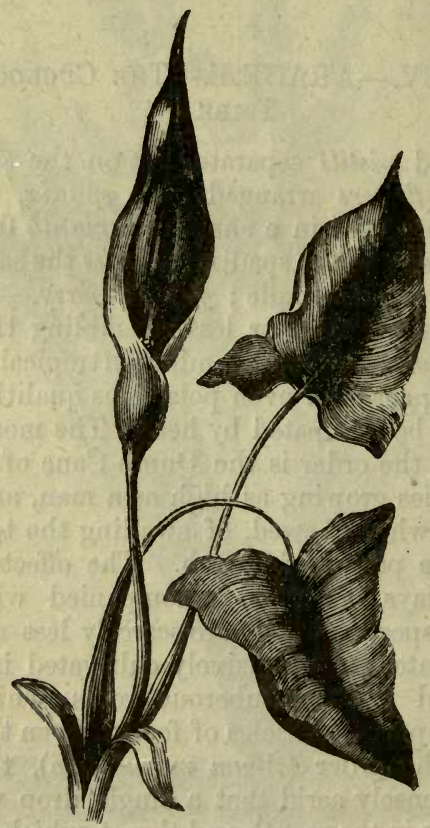

ARUM MaCulatum (Cuckoo-pint, Wake-Robin, Lords-and-Ladies).

1. Arum (Cuckoo-pint).

1. A. maculátum (Cuckoo-pint, Wake-Robin, Lordsand-Ladies).-The only British species.-Hedges and 
woods, common in most parts of England. A succulent, herbaceous plant, with large, glossy, arrow-shaped leaves, which are often spotted with dark purple. The upper part of the spadix is club-shaped, and of a light pink, dull purple, or rich crimson colour, which is easily rubbed off ; about the middle of the spadix is a ring of glands, terminating in short threads, the use of which is unknown; below this is a ring of sessile anthers, and yet lower down another row of sessile ovaries. The upper part of the spadix soon falls off, leaving the ovaries, which finally become a cylindrical mass of scarlet berries, which are conspicuous objects when all the rest of the plant has withered and disappeared. The spadix with its sheath may be discerned wrapped up in the young leaf-stalks, even before the leaves have risen above the surface of the ground.-Fl. May, June. Perennial.

\section{ORD. XCVI.-ORONTIACEA.-SWEET SEDGE TRIBE.}

Flowers perfect, arranged on a central column or spadix, at first enclosed in a sheath; perianth of $4-8$ scales ; stamens equalling the scales in number; ovary superior ; fruit a berry. - A tribe of plants nearly allied to the Araceae, and resembling them in properties. Calla Ethiópica is, under the name of Egyptian Lily, perhaps better known than the only British species, Ácorus Cálamus, or Sweet Sedge. This last plant is said to have supplied the "rushes" with which, before the use of carpets had been introduced into England, it was customary to strew the floors of the great. As it did not grow in the neighbourhood of London, but had to be fetched at considerable expense from Norfolk and Suffolk, one of the charges of extravagance brought against Cardinal Wolsey was that he caused his floors to be strewed with rushes too frequently. It is still 
used to strew the floor of the cathedral at Norwich on festival-days.

1. Áconus (Sweet Sedge). - Sheath leaf-like, not convolute, overlapping the spadix. (Name in Greek denoting that the plant has the power of curing diseases in the pupil of the eye.)

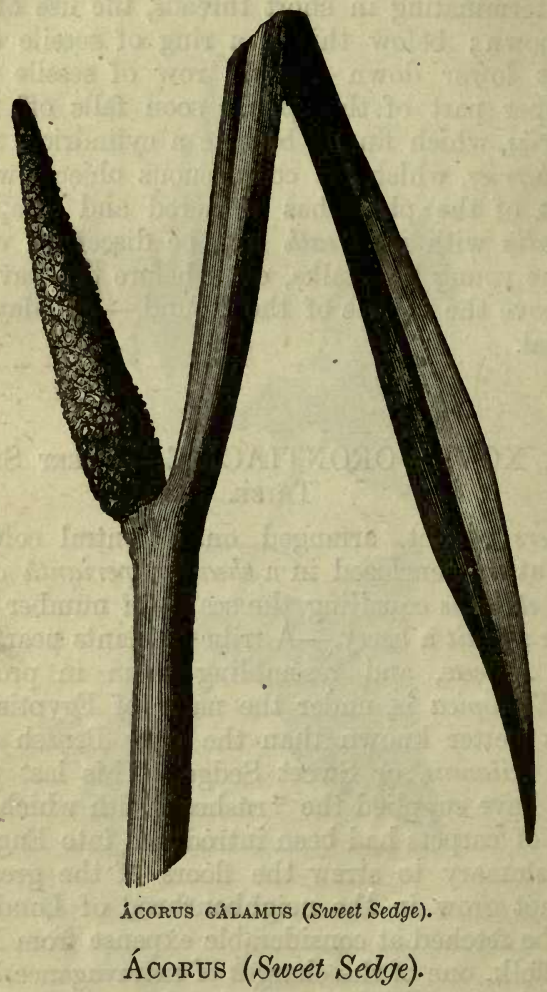

1. A. Cálamus (Sweet Sedge).-The only British species.-Watery places in Norfolk and Suffolk. An 
aquatic plant, with somewhat of the habit of a sedge or large grass. It is easily distinguished from all other British plants by its peculiar spadix, and the fragrance of its roots, stems, and leaves.-Fl. June. Perennial.

\section{ORD. XCVII.-PISTIACEA.-DUCK-WEED TRIBE.}

Minute floating plants, composed of simple or lobed leaves, and fibrous roots, which are not attached to the soil, propagating themselves principally by offsets, but sometimes producing on the edge of the leaves $1-2$ stamens, and 1-4 seeded ovaries, enclosed in small sheaths. Lemna (Duck-weed) is the only British example, and the number of foreign species is but small.

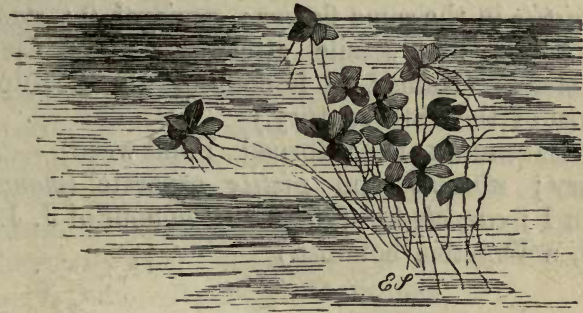

LEMNA MINOR (Lesser Duck-weed).

\section{Lemna (Duck-weed).}

1. L. minor (Lesser Duck-weed).-A minute plant, but often so abundant as to cover the surface of stagnant water, where, with the insects which it harbours, it is greedily devoured by ducks. In this species the leaves are egg-shaped, and bear each a single root. Three other species have been found in Britain, for a description of which the student is referred to "Hooker and Arnott's British Botany." 


\section{ORD. XCVIII.-NAIADACEAE-POND-WEED Tribe.}

Submersed or floating aquatics with very cellular stems and peculiar leaves, which are sometimes almost leathery, but more frequently thin and pellucid. The flowers are small, olive-green, resembling in structure the Arrow-grasses; sometimes solitary, but more frequently arranged in spikes, they inhabit ponds and slow. streams, or rarely salt marshes. One British species, Zostéra marina, grows in the sea.

1. Ротamogéton (Pond-weed).-Flowers in a spike ; stamens and pistils in the same flower; perianth of 4 sepals; stamens 4 ; carpels 4, sessile. (Name from the Greek pótamos, a river, and geíton, a neighbour.)

2. Ruppia.-Flowers about 2 on a stalk; stamens and pistils in the same flower; perianth 0 ; stamens 4 ; carpels 4 , at first sessile, afterwards raised each on a long stalk. (Named in honour of H. B. Ruppius, a botanist of the 18th century.)

3. Zannichellia (Horned Pond-weed). - Flowers axillary; stamens and pistils separate (monoecious); stamen 1 ; carpels 4 . (Named in honour of J. J. Zannichelli, a Venetian botanist.)

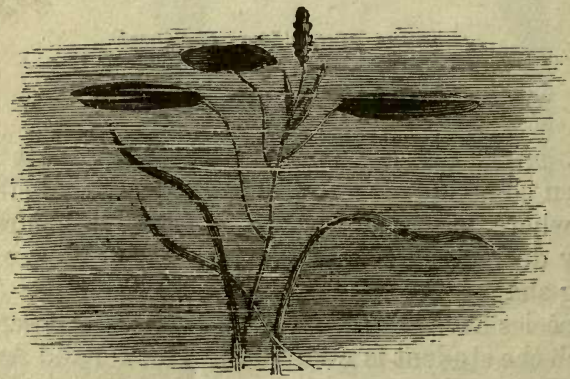

potamogéton natads (Floating Pond-weed) 
4. Zostéra (Grass-wrack).-Flowers composed of stamens and pistils alternately arranged in 2 rows in a long leaf-like sheath. (Name from the Greek zoster, a girdle, which the leaves resemble in form.)

\section{Potamogéton (Pond-weed).}

1. P. natans (Floating Pond-weed).-Upper leaves elliptical, ribbed, and cellular, lower submersed, linear. - Ponds and ditches, common. An aquatic plant, with cord-like stems, proportioned to the depth of the water in which it grows; smooth, floating leaves, on long stalks; and cylindrical spikes of small green flowers, which rise above the surface of the water. The upper, or floating leaves are $2-3$ inches in length, the lower, which are not always present, are very narrow and a foot long, or more-Fl. June-August. Perennial.

2. P. perfoliatus (Perfoliate Pond-weed).-Leaves alternate, all submersed, egg-shaped, embracing the stem, pellucid, 7-nerved.-Ponds and lakes, common. Remarkable for its brown, almost transparent leaves, $2-3$ inches long, which when dry have the appearance of gold-beaters' skin, and are so sensitive of moisture, that they will curl when laid on the palm of the hand.-Fl. June-August. Perennial.

3. P. densus (Opposite-leaved Pond-weed).-Leaves opposite, all submersed, embracing the stem, pellucid. -Ponds and rivers, common. Like the last in habit, but smaller.-Fl. June-August. Perennial.

4. P. pusillus (Small Pond-weed).-Tieaves linear, very narrow ; flowers in a long-stalked, loose spike.Ponds and lakes, common. A tangled mass of threadlike stems, and dull, olive-green leaves, with numerous spikes of brownish flowers, which are either submersed, or partially rise above the surface of the water.-Fl. June-August. Perennial.

* From 18 to 20 species of Pond-weed are described as natives of Britain; they all, more or less, resemble 
the above in habit, and as they are by no means an interesting family of plants, easy to obtain, or pleasant to examine, it is not thought necessary to describe their characters in an elementary work like this.

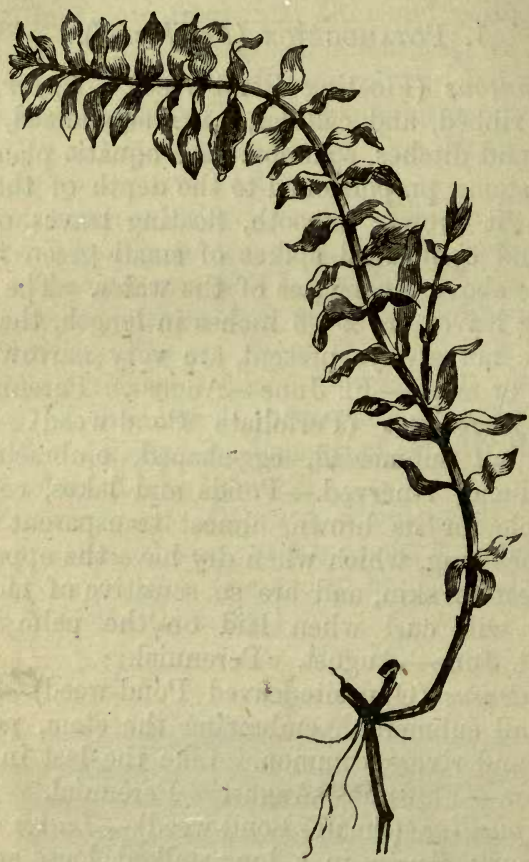

potamogḱton denscs (Opposite-leaved Pond-weed).

\section{RUPPIA.}

1. R. marituma (Sea Ruppia).-The only species, growing in salt-water ditches, distinguished from Potamogéton pusillus by its spiral flower-stalks, and longstalked fruit.-Fl. July-August. 


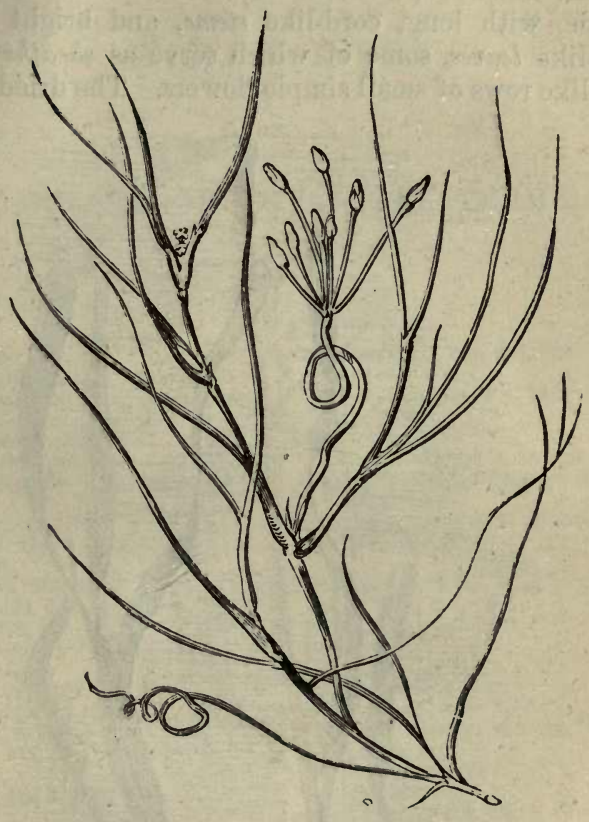

RUPPIA MARITIMA (Sea Ruppia).

3. Zannichellia (Horned Pond-weed).

1. Z. palustris (Horned Pond-weed). - The only British species. A submersed aquatic, with the habit of Potamogéton pusillus, from which it may be well-distinguished by its small, almost sessile, axillary flowers, the stigmas of which are unevenly cup-shaped.-Fl. August, September. Perennial. 
4. Zostéra (Grass-wrack).

1. Z. marina (Grass-wrack).-A submersed marine aquatic, with long, cord-like stems, and bright green, grass-like leaves, some of which serve as sheaths to the bead-like rows of small simple flowers. The dried leaves

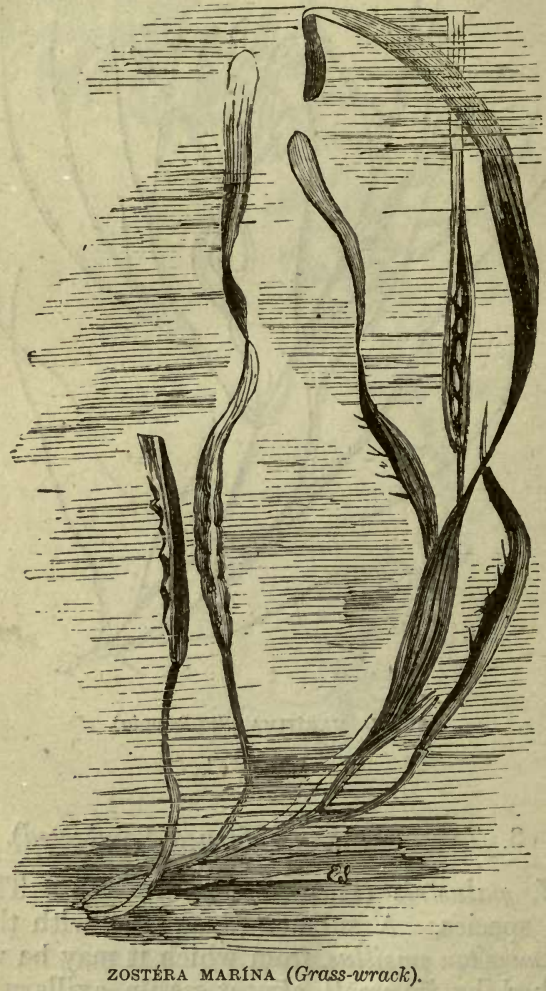

and stems are used as beds, and are also employed in packing glass. The inner fibre has been recommended as a substitute for cotton.-Fl. July, August. Perennial. 


\section{ENGLISH INDEX}

\section{AND \\ GLOSSARY OF BOTANICAL TERMS.}

Abele. See Poplar. abrupt, blunt, as if broken off. acuminate, tapering to a sharp point. acute, sharp-pointed.

Adder's-meat, 101. æstivation, the state of flowers in bud.

Agrimony, 175, 194.

Agrimony, Hemp, 326, 357.

Alder, 569.

Alexanders, 249, 257.

Alkanet, 429, 437.

Allseed, 228, 230.

ALMOND GROUP, 171. alternate, iv.

AMARYLlis TrIBE, 598.

Andromeda, 395, 400.

Anemone, 3, 7 .

Angelica, 252, 274. angular, vi. annual, lasting one year. anther, $\mathrm{x}$. apetalous, without petals.

APPLE GROUP, 177.

Apple, 203. aquatic, growing in water.

Archangel, 490. arillus, a dry covering of some seeds, as mace.

ARROW-GRASS Tribe, 634 .

Arrow-grass, 634.

Arrow-head, 631, 633. arrow-shaped, vi.

Asarabacea, 548. ascending, iv.

Ash, 408, 410 .

Asparagus Group, 608.

Asparagus, 608, 611.

Aspen. See Poplar.
Asphodel, 621, 622, 623, 629 .

Avens, 174, 184.

Avens, Mountain, 174, 183. awl-shaped, $x$.

Awl-wort, 38, 49. awn, a stiff bristle, as in barley. axil, the angle between a leaf and the stem, iv. axillary, growing in an axil.

Azalea, 394, 400 .

Bald-money, 272.

Balm, Wild, $475,501$.

Balsam Tribe, 129.

Balsam, 131.

Bane-berry, 4, 21.

BARBERry TrIBE, 22.

Barberry, 23, 24. barren, bearing stamens, but no pistils, $x i$.

Barrenwort, 23, 24.

Bartsia, 455, 466.

Basil Thyme, 478, 499.

Basil, Wild, 478, 499.

Bastard Toad-flax, 546, 547.

Beaked-Parsley, 253, 281.

Beam, White, 206.

Bean Tribe, 139.

Bear-berry, 395, 401.

Bed-straw, 303, 304.

Bee Orchis, 592.

Beech, 571.

Beet, 529, 534 .

BELL-FLOWER TRIBE, 382.

Bell-flower, 382, 383.

bell-shaped, ix. berry, xii.

Betony, 477, 493. biennial, lasting two years. bifid, two-cleft. 
Bilberry, 390.

Bindweed Tribe, 423.

Bindweed, 424.

bipinnate, twice pinnate.

bipinnatifid, twice cut in a pinnate manner.

Birch Group, 569.

Birch, 569.

Bird-cherry, 179.

Bird's-eye, 470.

Bird's-foot, 143, 168.

Bird's-foot Trefoil, 142, 157.

BIRD's-NEST TRIBE, 402.

Bird's-nest, 402, 405.

Bird's-nest Orchis, 590.

Birthwort Tribe, 547.

Birthwort, 547, 548.

Bistort, 538.

Bitter-Cress, 38, 55.

Bittersweet, 445.

Bitter-Vetch, 143, 166.

Blackberry, 192.

Black-Bryony, 604, 605.

Black-Horehound, 476, 487.

Blackthorn, 178.

Bladder Campion, 92 .

Bladder seed, 285.

Bladderwort, 507, 508.

Blinks, Water, 227.

Blite, Sea, 529, 532.

Blue-bell, 614.

Blue-bottle, 326, 354

Blue Flea-bane, 328, 367.

Bog-Asphodel, 622, 629.

Bog-Orchis, 594.

Borage Tribe, 427.

Borage, 429, 435.

border, the expanded part of the corolla, ix.

Box, 553, 556.

Bramble, 175, 192.

bracts, small leaves at the base of a flower-stalk, vii.

Brier, Sweet, 200.

bristly, xiii.

Brocoli, 69.

Brooklime, 471.

Brookweed, 512, 522.

Broom, 141, 148.

Broom-Rape Tribe, 449.

Broom-rape, 450.

Brussels-Sprouts, 69.

Bryony, Black, 604, 605.

Bryony, White, 225.

Buckbean, 414, 420.

Buckthorn Tribe, 136.

Buckthorn, 138, 139.

Buckthorn, Sea, 544.

Buckwheat, 539.

Bugle, 476, 485.

Bugloss, 429, 436.
Bugloss, Viper's, 428, 429.

bulbous, iii.

Bullace, 179.

Bur, Butter, 364.

Burdock, 325, 346.

Bur-Marigold, 326, 356.

Bur-Medick, 150.

Burnet Group, 175.

Burnet, 175, 196.

Burnet, Salad, 198.

Burnet-Saxifrage, 250, 265.

Bur-Parsley, 252, 279.

Bur-Reed, 637, 638.

Butcher's-Broom, 609, 611.

Butter-Bur, 327, 364.

Buttercup, 3, 8.

Butterfly Orchis, 587.

Butterwort Tribe, 506.

Butterwort, 507.

Cabbage, 40, 66 . caducous, falling off very early, as the sepals of the poppy.

Calamint, 478, 499. calyx, the outer case of a flower, viii.

Campion, 88, 92, 95.

capillary, hair-like, vi.

capitate, round like a head.

capsule, a dry seed-vessel, xii.

Caraway, 250, 262.

Carline-Thistle, 326, 353.

Carnation, 90. carpels, ovaries with their styles and stigmas, $x i$.

Carrot, 252, 278.

Catchfly, 88, 92. catkin, xiv.

Catkin-bearing Tribe, 565.

Catmint, 477, 497.

Cat's-ear, 324, 334.

Cat's-tail, 637.

Cauliflower, 69.

Celandine, 28, 31.

Celandine, Lesser, 3, 11.

Celery, 250, 258. cell, a vesicle, or little bladder, the simplest form of vegetable structure.

cellular, composed of cells.

Centaury, 413, 416 . cernuous, nodding.

Chaffweed, 511, 519.

chaffy, xiii.

Chamomile, 329, 379 .

Chamomile, Wild, 379.

Cherlock, 70.

Cherry Group, 179.

Cherry, 173, 178.

Chervil, 253, 284.

Chestnut, 571 . 
Chicory, 325, 344.

Chickwead Tribe, 89.

Chickweed, 101.

Chickweed, Jagged, 89, 101.

Chickweed, Mouse-ear, 89, 90, 105, 106.

Chickweed Winter-green, 511, 519.

Chives, 619.

Cicely, 253, 284.

ciliated, fringed.

Cinquefoil, 174, 185.

Cinquefoil, Marsh, 174, 189. circinate, curled, like the young frond of a fern.

Clary, 480.

claw, the base of a petal, ix.

Cleavers, 306.

Clove-Pink, 90.

Clover, 152, 153.

Clover, Spotted, 150.

Cloudberry, 194.

Clubrush, 637.

club-shaped, cylindrical, but becoming larger from the base upwards.

cluster, xiii.

Cockle, 97.

Cock's-comb, 466.

Cocks-and-Hens, 525.

Cole-seed, 69. coloured, not green, viii.

Colt's-foot, 366.

Columbine, 4, 20.

column, a name given to the united pistil and stamens in the Orchis Tribe.

Comfrey, 428, 433.

compound, iv. v. xiv.

Compound Flowers, 319.

cone, the fruit of the Fir Tribe, xii.

conical, xiii.

connate, growing together, v.

convolute, rolled together.

Coral-root, 38, 55 .

Coral-rooted Orchis, 593.

Coriander, 286.

corculum, the same as embryo.

cordate, heart-shaped.

corm, a solid bulbous root, iii.

Corn-Cockle, 89, 98.

Cornel Tribe, 289.

Cornel, 289, 291.

Corn-Flag, 595.

Cornish Money-wort, 455, 468.

Corn-Marigold, 376.

Corn-Salad, 311, 313. corolla, the inner leaves or petals of a flower, viii. corymb, xiii.

Cotton-Thistle, 351.
Cotton-weed, 327, 358.

cotyledon, a seed-lobe, xii. 1.

Cowbane, 249 ,257.

Cowberry, 392.

Cow-Parsnep, 252, 276.

Cowslip, 513.

Cow-wheat, 454, 462.

Crab-Apple, 203.

Crake-berry, 549.

Cranberry Tribe, 389.

Cranberry, 390, 392.

Crane's-bill, 124.

creeping, iii. iv.

crenate, scolloped at the edge.

Cress, Bitter, 55.

Cress, Rock, 39, 58.

Cress, Swine's, 53.

Cress, Wall or Thale, 64.

Cress, Water, 61.

Cress, Winter, 39, 59.

Cress, Wart, 38, 54.

Cress, Yellow, 48, 62.

Crimean Snowdrop, 604.

Crocus, 598.

Cross-wort, 304.

CrowberRy Tribe, 548.

Crowberry, 549.

Crowfoot Tribe, 2.

Crowfoot, 3, 8.

Cruciferous Trube, 36. cruciform, placed crosswise, $\mathbf{x}$. cryptogamous, or cryptogamic ; plants are so called which are reproduced without the aid of stamens and pistils.

Cuckoo-flower, 55.

Cuckoo-PINT Tribe, 639.

Cuckoo-pint, 640.

Cudweed, 327, 361, 362.

culm, the stalk of grasses.

Currant Trube, 239.

Currant, 239, 240. cuticle, the thin outer skin of a plant.

cyme, xiv.

eymose, growing in the form of a cyme.

Cyphel, 90, 107.

Dabeoc's, St., Heath, 399.

Daffodil, 601, 602 .

DAISY GrouP, 323, 327, 366.

Daisy, $328,376$.

Dandelion, 325, 342.

DaphNe Tribe, 544.

Deadly-Nightshade, 444, 447.

Dead-Nettle, 477, 492.

Dead-Nettle, Yellow, 490. deciduous, soon falling off: decurrent, running down the stem.

Dewberry, 192. 
dichlamydeous, having a double perianth.

dicotyledonous, composed of two seed-lobes, xii. 1.

didynamous, having four stamens, two long and two short.

diocious plants are those which have the stamens and pistils in separate flowers and on different plants.

disk, the central part of a compound flower, ix. : a flat space surrounding the ovary.

Dock, 538, 541 .

Dodder, 424, 426.

Dog-Mercury, 553.

Dog-Rose, 201.

Dog-Violet, 78 .

Dogwood, 291. dotted, xiii.

Dropwort, 173, 181.

Dropwort, Water, 251, 269. drupe, a nut enclosed in pulp, xii.

DuckWeed Tribe, 643.

Duckweed, 643. duct, an imperfectly spiral vessel.

Dutch Clover, 152.

Dwale, 447.

Dyer's-Rocket, 72 .

Earth-nut, 250, 263. egg-shaped, oval, with the base broader than the extremity, vi.

Eglantine, 200.

Elder, 295, 296.

Elder, Water, 297.

Elecamipane, 328, 373. elliptical, egg-shaped, with both ends alike, vi.

Elm Tribe, 564 .

Elm, 564 .

emarginate notched.

embryo, the bud contained in a seed.

Enchanter's Nightshade, 209, 212.

ENDOGENS, xiii. ensiform, sword-shaped. entire, not cut at the edge, $\mathbf{v}$. epidermis, the cuticle. erect, iv.

Eryngo, 249, 255.

Evening Primrose, 209, 212.

Everlasting, 327, 361.

Everlasting-Pea, 164.

Exogens, xii: exserted, protruded beyond the other parts.

Eye-bright, 455, 467.

family, xxi. farinaceous, abounding in flour. fascicled, growing in a dense tuft.

Fennel, 251, 271.

fertile, bearing pistils and producing seeds, xi.

Fenugreek, 142, 152.

Feverfew, 377 .

Field-Madder, 303, 309.

Field-Scabious, 315, 318.

FIG-WORT TRIBE, 453.

Fig-wort, 454, 460. filament, $x$.

Fir Tribe, 574.

Fir, 575.

Fir-rape, 405.

Flag, 595 .

Flax Tribe, 107.

Flax, 108.

Flax-seed, 108, 110.

Flea-bane, 328, 374.

Flea-bane, Blue, 328, 367 .

Flixweed, 63.

floret, a small flower in the Nat. Ord. CoMposita.

flower, vii.

Flower-de-Luce, 595.

Flowering-RUSh Tribe, 629.

Flowering-Rush, 630.

Flowering-Willow, 209.

Fluellen, 458.

Fly-Orchis, 592 .

Fool's-Parsley, 251, 270.

Forget-me-not, 429, 438 forked, iv.

Fowler's-Service, 204.

Foxglove, 454, 456 . free, not united, xi. fringed, $v$.

Fritillary, 611, 620.

Frog-bit Tribe, 579.

Frog-bit, 581, 582.

frond, the leaf of a fern.

fructification, the parts composing the fruit.

fruit, the seed with its covering, xii.

Fullers'-Teasel, 315.

Fumitory TRIBE, 38.

Fumitory, 33, 34 .

funnel-shaped, ix.

furcate, forked.

Furze, 141, 144.

fusiform, spindle-shaped.

Gagea, 610,620 .

GALE, SWEET, Group, 568.

Gale, Sweet, 568 .

gaping, having an open mouth, ix.

Garlic, 609, 618.

Garlic-Mustard, 39, 65.

generic narne, xxii. 
Gentian Tribe, 412.

Gentian, 413, 414.

Gentianella, 413, 418. genus, genera, xxi.

Geranium Tribe, 123. germen, or ovary, the lowest part of the pistil, xi.

Germander, 476, 486.

Germander Speedwell, 470.

gibbous, swollen at the base, as in the flowers of Snapdragon.

Gillyflower, 90.

Gipsywort, 475, 478.

glabrous, perfectly smooth.

gland, a cell containing some secretion.

Glasswort, 530, 535.

glaucous, covered with a palegreen bloom.

Globe-flower, 3, 14. glume, the chaff of the grasses.

Goat's-beard, 323, 329.

Golden-rod, 328, 368.

Golden-Samphire, 374.

Golden-Saxifrage, 241, 245.

Goldylocks, $326,358$.

Good-King-Henry, 530.

Goodyera, 593.

Gooseberry Tribe, 239.

Gooseberry, 239, 240.

Goose-FooT TrIBE, 528.

Goose-foot, 529, 530.

Goose-grass, 185, 306.

Gorse, 144.

Gout-weed, 250, 262.

Gourd TrIbE, 224.

Grass-of-Parnassus, 80, 81.

Grass-wrack, 645, 648.

Greek-Valerian, 422.

Green-weed, 141, 145.

Grey-Millet, 432.

Gromwell, 428, 432.

Ground-Ivy, 477, 498.

Ground-Pine, 486.

Groundsel, 328, 370.

Guelder-Rose, 296.

habitat, the locality in which a plant grows.

Hairbell, 384, 616.

halbert-shaped, arrow-shaped with the barbs turned outwards, vi.

Hare's-ear, 251, 268.

Hare's-foot, 154.

hastate, halbert-shaped.

Hawk-bit, 324, 332.

Hawk's-beard, 324, 338.

Hawk-weed, 324, 340.

Hawthorn, 178, 206.

Hazel, 5 73. head, xiv.

Heartsease, 78.

heart-shaped, vi.

Heath Tribe, 392.

Heath, 394, 395.

Heather, 394, 398.

Hedge-Mustard, 39, 62.

Hedge-Parsley, 252, 279.

Hellebore, 3, 17.

Helleborine, 252.

Hemlock, 249, 257.

Hemlock, Water, 249, 257, 268.

Hemp-Agrimony, 326, 357.

Hemp-Nettle, 477, 491.

Henbane, 444, 447.

herbaceous, having a succulent stem.

Herb-Bennet, 184.

Herb-Christopher, 21.

Herb-Paris Tribe, 606.

Herb-Paris, 607.

Herb-Robert, 126.

hispid, bristly.

Herb-Twopence, 518.

Hog's-Fennel, 286.

Hogweed, 276.

Holly Tribe, 405.

Holly, 406, 407.

Holly, Sea, 255.

Honewort, 285.

Honeysuckle, 296, 299.

Hop, 561, 563.

Horehound, Black, 478, 487.

Horehound, White, 478, 498.

Hornbeam, 573.

Horned-Pondweed, 644, 647.

Horned-Poppy, 28, 31.

HoRNWORT TRIBE, 218.

Hornwort, 219,

Horse-Mint, 481.

Horse-Radish, 38, 48.

Horse-shoe Vetch, 143, 168.

Hound's-tongue, 429, 442.

House-Leek, 233, 235.

Hyacinth, 609, 614.

hybrid, intermediate between two distinct species, and partaking the characters of both.

imbricated, overlapping, like the tiles of a house.

indehiscent, not opening with joints.

indigenous, native, or growing wild.

inferior, xii.

inflorescence, mode of flowering, xiii.

interruptedly pinnate, pinnate with smaller leaflets between. 
inversely egg-shaped or heartshaped, oval or heart-shaped with the base narrower than the extremity, vi.

involucre, a whorl, vii.

IrIs Tribe, 594.

Iris, 595 .

irregular, unequally divided, $\mathbf{x}$.

IVy TRIBE, 286.

Ivy, 287, 288.

Jack-by-the-Hedge, 65.

JACOB'S-LADDER TRIBE, 421.

Jacob's-ladder, 422.

Jagged-Chickweed, 89, 101.

Joint-Vetch, 168.

Juniper, 576.

Kale, Sea, 38, 53.

keel, $x$.

kidney-shaped, vi.

Kidney-Vetch, 158.

kind, xxi.

Kuapweed, 326, 354.

KNAWEL TRIBE, 535.

Knawel, 535, 536.

Knee-Holly, 611 .

KNOT-GRASS TRIBE, 228, 230.

Knot-grass, 228, 539.

labiate, lipped, ix.

Labiate Tribe, 474.

laciniated, jagged.

Lady's-fingers, 142, 158.

Lady's-mantle, 175, 194.

Lady's-slipper, 594 .

Lady's-smock, 55.

Lady's-tresses, 591.

Lamb's-Lettuce, 313.

lamina, a plate, the broad part of a leaf.

Larkspur, 4, 20.

- Lavender, Sea, 523, 524.

leaflet, a single portion of a compound leaf.

leaves, various forms of, iv.

legume, a long pod without a partition, xii.

Lent-Lily, 601.

Leopard's-bane, 328, 372.

Lesser Celandine, 3, 11.

Lettuce, 324, 337.

ligulate, strap-shaped.

Lily Tribe, 607.

Lily-of-the-Valley, 609, 611.

limb, the expanded part of a petal, ix.

LIME TrIBE, 115.

Lime, 116.

Linden, 116.

linear, very narrow, with the edges parallel, vi.
Ling, 394, 398.

Linnæa, 296, 301.

Liparis, 594.

Livelong, 236.

lobe, lobed, v.

LoBELIA TRIBE, 388.

Lobelia, 388.

London-Pride, 242.

London-Rocket, 63.

Loosestrife, 511, 518.

Loosestrife Purple, Tribe, 219.

Loosestrife, Purple, 219, 221.

Lords-and-Ladies, 640.

Lousewort, 455, 464.

Lovage, 251, 272. .

Lucerne, 150.

Lungwort, 428, 431.

lyrate leaf, a pinnatifid leaf with a rounded terminal lobe, and smaller divisions near the base.

Madder Tribe, 302.

Madder, 303.

Madder, Field, 303, 309.

Madwort, 429, 442.

MaLLOW TRIBE, 110.

Mallow, Marsh, 111, 114.

Mallow, Tree, 111, 114.

Mallow, 111.

Man-Orchis, 593.

Maple Tribe, 121.

Maple, 122, 123.

marcescent, withering.

MARE'S-TAIL TRIBE, 215.

Mare's-tail, 215.

Marigold, Corn, 376.

Marigold, Marsh, 3, 17.

Marjoram, 476, 484.

Marsh-Cinquefoil, 174, 189.

Marsh-Mallow, 111, 114.

Marsh-Marigold, 3, 17.

Marsh-Pennywort, 254.

Marsh-Trefoil, 420.

Marsh-wort, 250, 261.

MAST-BEARING GroUP, 571.

May, 206.

May-weed, 378.

Meadow-Rue, 3, 6.

MEadow-Saffron Tribe, 620.

Meadow-Saffron, 621.

Meadow-Saxifrage, 286.

MeadoW-sWeEt Group, 173.

Meadow-sweet, 173, 181.

Medick, 141, 149.

Medlar, 177, 206.

medullary, belonging to or connected with medulla, the pith.

Melilot, 142, 151.

membranous, membranaceous, having the texture of a membrane or parchment. 
Menziesia, 394, 398.

Mercury, 553, 555.

Meu, 272.

Mezereon, 544. midrib, the principal vein of a leaf.

Mignonette, 72 .

Milfoil, 381 .

Milfoil, Water, 215, 216.

Milk-Thistle, 324, 337.

Milk-Vetch, 142, 160.

MiLKWORT TRIBE, 83.

Milkwort, 83.

Milkwort, Sea, 511, 520 .

Mint, 476, 481.

Mistletoe Tribe, 292.

Mistletoe, 293, 294.

Mithridate-Mustard, 40.

Moneywort, 518.

Moneywort, Cornish, 455, 468.

moniliform, having the appearance of a necklace.

Monk's-hood, 4, 21.

monochlamydeous, having a single perianth.

monocotyledonous, xiii. 578.

monœeious plants are those which have the stamens and pistils in separate flowers, but on the same plant.

Moschatel, 287, 289.

Motherwort, 476, 488.

Mountain-Ash, 204.

Mountain-Avens, 174, 183.

Mountain-Sorrel, 538, 543.

Mouse-ear, 438.

Mouse-ear-Chickweed, 89, 105.

Mouse-tail, 3, 13.

Mudwort, 454, 461.

Mugwort, 327, 361.

Mullein, 455, 472 . muscology, the study of Mosses.

Musk-Mallow, 113.

Musk-Thistle, 348.

Mustard, 40, 70 .

Mustard, Garlic, 39.

Mustard, Hedge, 39, 62.

Mustard, Treacle, 39, 66.

Mustard, Mithridate, 40.

Mustard, Tower, 39, 59.

Narcissus, 601, 602 .

Navew, 66 . nectary, any distinct organ in a flower containing honey, xiii.

NetTle Tribe, 559.

Nettle, 560,561 .

Nettle, Dead, 477, 492.

Nettle, Hemp, 477, 491.

NightShade Tribe, 442.

Nightshade, 444,445 .

Nightshade, Deadly, 444, 447.
Nightshade, Enchanter's, 209, 212.

Nipplewort, 325, 343.

Nonsuch, 149.

Nottingham-Catchfly, 95 . nut; a seed contained in a hard dry shell, xii.

Oak, 572.

obcordate, inversely heart-shaped. oblong, vi. obovate, inversely egg-shaped.

Ol.eAster Tribe, 543.

Olive Tribe, 407. opposite, iv.

Orache, 529, 532. orbicular, round.

ORCHIDEOUS T'RIBE, 582.

Orchis, 583

Orchis, Butterfly, 587.

Orchis, Bee, Fly, Spider, Monkey, Lizard, \&c. 592.

Orehis, Man, 593.

Orchis, Sweet-scented, 587.

Orpine, 236.

Osier. See Willow.

ovary, or germen, the lower part of the pistil, xi.

ovule, the embryo seed.

Ox-eye, $329,376$.

Ox-lip, 513.

Ox-tongue, 323, 331.

Paigle, 513.

paleaceous, chaffy.

palmate, divided into five or more narrow lobes, $\mathbf{v}$. panicle, xiii.

Pansy, 78.

papilionaceous, butterfly-shaped, $\mathrm{x}$.

pappus, a feathery appendage of the seed, viii.

parasitic, growing on another living vegetable.

parenchyma, cellular tissue.

Parnassus, Grass of, 81.

Parsley, 250, 259.

Parsley, Beaked, 253, 281.

Parsley, Bur, 252, 279.

Parsley, Fool's, 251, 270.

Parsley, Hedge, 252, 279.

Parsley-Piert, 196.

Parsley, Stone, 250, 262.

Parsnep, 252, 275.

Parsnep, Cow, 252, 276.

Parsnep, Water, 250, 266. parted, deeply divided. partial, xiv.

Pasque-flower, 8. patent, spreading.

Pea Tribe, 139. 
Pea, Everlasting, 164.

Pear, 202.

Pearl-wort, 89, 98.

pectinate, divided like the teeth of a comb.

pedate, palmate with the outer lobes divided, $\mathrm{v}$.

pedicel, the stalk of a flower in eompound inflorescence.

peduncle, a flower-stalk.

Pellitory, 560, 562 .

peltate, circular, with the stalk in the centre, $v$.

Penny-Cress, 37, 40.

Penny-royal, 482.

Pennywort, 233, 234.

Pennywort, Marsh, 254.

Peony, 4, 22.

Pepper-mint, 483.

Pepper-Saxifrage, 251, 272.

Pepper, Water, 541.

Pepperwort, 37, 44.

perennial, lasting many years.

perfoliate, having a stem passing through a pair of leaves, v.

perianth, a name sometimes given to the calyx or corolla, $x$.

pericarp, or fruit, the seed with its covering, xii.

PeriwinkLe Tribe, 410.

Periwinkle, 411.

Persicaria Tribe, 537.

Persicaria, 538.

persistent, not falling off, opposed to caducous.

personate, ix.

petaloid, petal-like.

petals, the inner leaves of a flower.

Petaloidea, 578.

petiole, a leaf-stalk.

petiolate, having a leaf-stalk.

Petty-whin, 145.

phænogamous, furnished with evident stamens and pistils.

Pheasant's-Eye, $3,8$. phycolngy, the study of seaweeds.

Pig-nut, 264.

Pimpernel, 511, 516.

Pimpernel, Yellow, 518.

Pink TRIBe, 88.

Pink, 88, 90.

pinnate, divided like a feather, $v$. pinnatifid, lobed in a pinnate manner, v.

pistil, xi.

pistiliferous, bearing pistils.

Plantain Tribe, 524.

Plantain, 525.

Ploughman's-Spikenard, 328, 373.

Plum Group, 178.

Plum, 173, 178.
Plume-Thistle, 326, 349.

plumule, the bud contained in a seed, xii.

pod. See legume.

pollen, $x$.

poly, many, as polypetalous, \&c.

pome, an apple.

Pond-Weed Tribe, 644.

Pond-weed, 644.

Poor-man's Weather-glass, 517.

Poplar, 566.

Poppy Tribe, 27.

Poppy, 28.

Poppy, Horned, 28, 30.

Poppy, Welsh, 28, $3 i$.

pore, a small hole, xii.

pouch, a short pod with a partition, 36.

premorse, bitten off.

prickle, a sharp point not having a woody centre.

Primrose Tribe, 510.

Primrose, 511, 513.

Primrose, Evening, 209, 212.

Privet, 407, 408.

prostrate, iv.

pseudo, false.

pubescent, downy.

Purple-Loosfatrife Tribe, 219.

Purple-Loosestrife, 219, 221.

Purslane Tribe, 226.

Purslane, Sea, 89, 104.

Purslane, Water, 220, 221.

Queen-of-the-Meadows, 181.

Quicken-tree, 204

quinate, growing in fives, $v$.

raceme, the same as a cluster.

rachis, the stalk of a fern.

radiate, a term applied to those compound flowers the outer florets of which are larger than those of the disk.

radical, springing from the root,iv. radicle, the embryo root.

Radish, 40, 72,

Radish, Horse, or Water, 48 ,

Ragged-Robin, 95.

Ragwort, 328, 369.

Rampion, 383, 386.

Ramsons, 618.

Rape, 69.

Raspberry, 192.

ray, the outer florets of a compound flower, ix.

receptacle, xiii.

reflexed, bent back.

Red-rattle, 455, 464.

Red-Robin, 96.

REED-MACE TRiBe, 635. 
Reed-mace, 637.

regular, equally divided, ix.

Rest-harrow, 141, 149.

ringent, gaping.

Rocket Tribe, 72.

Rocket, 40, 71 .

Rocket, Dyer's, 72.

Rocket, London, 63.

Rocket, Sea, 38, 52.

Rocket, Yellow, 59.

Rock-Cress, 39, 58.

Rock-Rose, 75.

root, iii.

Rose Group, 176.

Rose Tribe, 171.

Rose, 177, 199.

Rose-Bay, 209.

Rose-root, 236.

rostrate, beaked.

rotate, the same as wheel-shaped. rounded, vi.

Rowan-tree, 204. runcinate, pinnatifid with the

lobes pointing backwards. runner, the same as a scion.

Rupture-wort, 228, 229.

Rush Tribe, 622.

Rush, 623.

Rush, Flowering, 630 .

Saffron-Crocus, 598.

Sage, 475, 480. sagittate, arrow-shaped.

Saint-foin, 144, 169.

Salad-Burnet, 198. saline, abounding in salt.

Sallow. See Willow.

Sallow-Thorn, 544.

Salsafy, 329.

Saltwort, 529, 535. salver-shaped, ix. samara, the winged seed of the Ash, Sycamore, \&c.

Samphire, 252, 272.

Samphire, Golden, 374.

SANDAL-WOOD Tribe, 546.

Sandwort-Spurrey, 228, 231.

Sandwort, 89, 104.

Sanicle, 249, 255.

sapwood, in exogenous trees the layers of wood next the bark.

Satin-flower, 101.

Sauce-alone, 65.

Saw-wort, 325, 346.

SAxifrage Tribe, 241.

Saxifrage, 241, 242.

Saxifrage, Beaked, 282.

Saxifrage, Bur, 279.

Saxifrage, Burnet, 250, 265.

Saxifrage, Golden, 241, 245.

Saxifrage, Hedge, 279.
Saxifrage, Mountain-Meadow, 286.

Saxifrage, Pepper, 251, 272.

Scabious, 315, 316.

Scabious, Sheep's, 383, 387.

scabrous, rough to the touch.

scandent, climbing.

scape, a flower-stalk springing directly from the root and bearing no leaves, xiii.

scion, a creeping shoot, iv.

Scorpion-Grass, 429, 438.

Scottish Asphodel, 621, 622.

Scotch Thistle, 326, 351.

Scurvy-Grass, 38, 46.

Sea-Blite, 529.

Sea-Buckthorn, 544.

Sea-Heath Tribe, 84 .

Sea-Heath, $85,86$.

Sea-Holly, 255.

Sea-Kale, 38, 53.

Sea-Lavender, 523, 524.

Sea-Milkwort, 511, 520.

Sea-Purslane, 89, 104.

Sea-Rocket, 38, 52.

secund, all arranged on one side. seed, xii.

Self-heal, 478, 502.

seminal, relating to the seed.

sepals, calyx-leaves.

serrate, saw-edged, v.

Service-tree, 202.

sessile, sitting, destitute of a stalk, v.

setaceous, bristly.

Shamrock, 133, 152.

Sheep's-bit, 387.

Sheep's-Scabious, 383, 387.

Sheep's-Sorrel, 543.

Shepherd's-Needle, 253, 281.

Shepherd's-Purse, 37, 41.

Shoreweed, 525, 527 .

silicle, a short pod with a partition, 36.

silique, a long pod with a partition, 36.

silver-grain, in exogenous trees, the rays communicating between the pith and bark.

Silver-weed, 185.

simple, iv. xiii.

sinuous, wavy, like the edge of an oak-leaf.

Skall-cap, 478, 502.

Sloe, 178.

Smallage, 258.

Smooth Gromwell, 428, 433.

Snake's-head, 620 .

Snakeweed, 538.

Snapdragon, 454, 457.

Sneeze-wort, 382.

Snowdrop, 602, 603. 
Snowflake, 602, 604.

Soapwort, 88, 92.

Solomon's-Seal, 609, 612.

Sorrel, 543.

Sorrel, Mountain, 538, 543.

Sorrel, Wood, 132.

Sow-bread, 511, 516.

Sow-Thistle, 324, 337.

spatliulate, oblong, but widening towards the end.

Spear-wort, 10.

species, xxi.

specific name, xxii.

Speedwell, 455, 469.

Spider-Orchis, 592.

Spider-wort, 611.

Spignel, 251, 272.

spike, xiii.

spindle-shaped, cylindrical, but tapering to a point, like a carrot, iii.

Spikenard, Ploughman's, 328, 373.

SPINDle-tree Tribe, 133.

Spindle-tree, 136.

spiral vessels, minute tubes, resembling in form the spring of a bell.

spores, the seeds of ferns, mosses, \&c.

Spotted Clover, 150.

spur, a sharp horn-shaped swenling.

Spur-Valerian, 311.

Spurge Tribe, 549.

Spurge, 553.

Spurge-Laurel, 545.

Spurrey, 229, 232.

Spurrey, Sandwort, 228, 231.

squarrose, at right angles with the stem.

Squill, 609, 616.

Squinancy-wort, 308.

stamens, $x$.

standard, $\mathrm{x}$.

St. Dabeoc's Heath, 399 ,

St. John's-wort, 117, 118.

St. Patrick's-Cabbage, 242.

Star-of-Bethlehem, 609, 617.

Star-fruit, 631, 633.

Star-Thistle, 356.

Starwort, Sea, 328, 367.

Starwort, Water, 558.

stellate, star-like.

stem, iv.

sterile, barren, having stamens but no pistils.

stigma, the summit of the pistil, xi. stipules, wings at the base of a leaf-stalk, vii.

stipe, the stem of a fern, palm, or fungus.

stipitate, stalked.
Stitchwort, 89, 101.

Stock, 39, 66.

stolon, a rooting scion.

STONECROP TRIBE, 232.

Stonecrop, 233, 236.

Stone-Parsley, 250, 262.

Stork's-bill, 124, 127.

strap-shaped, vi.

Strapwort, $228,229$.

STRA WBERry Group, 173.

Strawberry, 174, 191.

Strawberry-tree, 395, 400.

style, the middle part of the pistil, xi.

subulate, awl-shaped.

Succory, 325, 344.

Sundew, 79, 80 .

superior, xii.

suture, a seam or joint.

Sweet-Brier, 200.

Sweet-Gale Group, 568.

Sweet-Gale, 568.

Sweet-Sedge Tribe, 641.

Sweet-Sedge, 642.

Swine's-Cress, 53.

sword-shaped, vii.

Sycamore, 123.

syngenesious, united by the anthers.

TAMARISK TrIBE, 222.

Tamarisk, 222, 223.

TANSY GROUP, 323, 326, 356.

Tansy, 327, 359 . tap-root, the main vertical root.

Tare, 162.

Teasel Tribe, 315.

Teasel, 314,315 .

tendril, a twisted stalk, bearing neither leaf nor flower.

terminal, xiii.

terete, long and cylindrical.

ternate, growing in threes, v.

testa, the outer shell of a seed.

tetradynamous, having six stamens, four long and two short.

thalamus, the receptacle.

Thale-Cress, 64.

Thistle Group, 323, 325, 346.

Thistle, Carline, 326, 353.

Thistle, Cotton, 325, 351.

Thistle, Milk, 337, 349.

Thistle, Musk, 326,348 .

Thistle, Plume, 326, 349.

Thistle, Scotch, 326, 351 .

Thistle, Sow, 324, 337.

Thistle, Star, 356 .

thorn, a sharp point, having a woody centre.

thread-like, $x$.

Thrift Tribe, 522. 
Thrift, 522, 523.

throat, the upper part of a tube.

Thyme, 476, 483 .

Thyme, Basil, 478, 499.

Toad-Flax, 454, 457.

Toad-Flax, Bastard, 546. tomentose, covered with thick cotton.

toothed, v.

Tooth-wort, 450, 453.

Tormentil, 174, 188.

Tower-Mustard, 39, 59.

Traveller's-Joy, 3, 4.

Treacle-Mustard, 39, 66.

Tree-Mallow, 11i, 114.

Trefoil, 142, 152.

Trefoil, Bird's-foot, 142, 157.

Trefoil, Marsh, 420. tribe, xxiii.

Trichonema, 596 . trifid, three-cleft. trivial name, xxii.

True-Love-Knot, 607. trumpet-shaped, ix.

truncate, ending abruptly, as if cut off.

tuber, tuberous, iii.

Tulip Group, 610.

Tulip, 610, 620.

Turnip, 69.

Tutsan, 118.

Twayblade, 589.

umbel, xiv.

umbellate, growing in an umbel.

UMBELLIFEROUS Tribe, 246.

uncinate, hooked.

unilateral, one-sided.

urceolate, pitcher-shaped.

Valerian Tribe, 309.

Valerian, 311.

Valerian, Greek, 422.

valvate, opening with valves.

valves, xii.

varieties, xxii.

vascular, containing vessels.

Venus'-Comb, 281.

vermicular, worm-like.

vernation, the state of leaves in bud.

verrucose, warty.

verticillate, whorled.

Vervain TrIBE, 504.

Vervain, 504.

vesicle, a bladder.

VETCH GROUP, 143.

Vetch, 143, 161.

Vetch, Bitter, 143, 166.

Veteh, Horse-shoe, 143, 168.

Vetch, Milk, 142, 160.
Vetchling, 143, 164.

Villarsia, 414, 420.

villous, shaggy.

VIOLET TRIBE, 76.

Violet, 76.

Violet, Water, 511, 515.

Viper's-Bugloss, 428, 429.

viscous, clammy.

viviparous, producing young plants instead of seeds.

Wake-Robin, 640.

Wall-Cress, 64.

Wall-flower, 39, 66 .

Wall-Pellitory, 562.

Wall-Pepper, 238.

Wart-Cress, 38, 53.

Water-Blinks, 227.

Water-Cress, 61.

Water-Dropwort, 251, 269.

Water-Elder, 297.

Water-Hemlock, 268.

WATER-LILY Tribe, 25.

Water-Lily, 26.

Water-Milfoil, 215, 216.

Water-Plantain Tribe, 631.

Water-Plantain, 631.

Water-Parsnep, 250, 266.

Water-Pepper, 541.

Water-Purslane, 220, 221.

Water-Radish, 48.

Water-Soldier, 582.

WATER-STARWORT TrIBE, 558.

Water-Starwort, 558.

Water-Violet, 511, 515.

Watiriwort Tribe, 86.

Waterwort, 86.

wavy, v.

Wayfaring-Tree, 296.

Weasel-snout, 477, 490.

Weld, 72.

Welsh-Poppy, 28, 30.

wheel-shaped, ix.

Whin, 144.

Whinberry, 390.

Whin, Petty, 145.

White-beam Tree, 206.

White-Bryony, 225.

White-Horehound, 478, 498.

White-rot, 249, 254.

White-thorn, 206.

White Water-Lily, 26.

Whitlow-Grass, 38, 50.

Whortleberry, 390.

whorl, three or more leares springing from the same point on a stem, iv.

whorl, growing in a whorl, iv.

Wild-Balm, 475, 501.

Wild-Basil, 478, 499.

Wild-Chamomile, 329, 379. 
Wild-Sage, 475, 480 .

Wild-Succory, 344 .

Wild-Thyme, 483.

WILlow Group, 566.

Willow, 566.

Willow-herb Tribe, 208.

Willow-herb, 202.

Willow, Flowering, 209.

Willowstrife, 221.

Wind-flower, 3,7 .

wings, a name often given to any leaf-like expansion, $x$.

Winter-Cress, 39, 59.

Winter-green, 402.

Winter-green, Chickweed, 511, 519.

Woad-waxen, 146.

Wolf's-bane, 21.

Wood-Anemone, 7 .

Woodbine Tribe, 295.

Woodbine, 299.
Woodruff, 303, 307.

Woodrush, 623, 626.

Wood-Sage, 486.

WOOD-SORREL TRIBE, 131.

Wood-Sorrel, 132.

Wormseed, 66.

Wormwood, 327, 360.

Woundwort, $477,493$.

YAM TRIBE, 604.

Yarrow, 329, 381.

Yellow-Cress, 48, 62.

Yellow Dead-nettle, 490.

Yellow Pimpernel, 518.

Yellow-rattle, 455, 466.

Yellow-Rocket, 59.

Yellow Water-Lily, 26, 27.

Yellow-weed, 72.

Yellow-wort, 414, 419.

Yew, 577. 


\section{IATIN INDEX.}

Acer, 122, 123.

Aceras, 593.

ACERACE\&, 121.

Achillea, 329, 381.

Aconitum, 4, 21.

Acorus, 642 .

ACOTYLEDONES, XXi.

Actæa, 4, 21.

Actinocarpus, 631, 633.

Adonis, 3, 8 .

Adoxa, 287, 289.

Agopodium, 250, 262.

Athusa, 251, 270.

Agraphis, 609, 614.

Agrimonia, 175, 194.

Agrostemma, 89, 98.

Ajuga, 476, 485 .

Alchemilla, 175, 194.

Alisma, 631.

AlismaCfe, 631.

Alliaria, 39, 65 .

Allium, 609, 618.

Alnus, 569.

ALSINE $2,89$.

Althæa, 111, 114.

AMARYLLIDACE $\bar{*}, 598$.

AMENTACEA, 565.

AmYGDale 171.

Anacharis, 580.

Anagallis, 511, 516.

Anchusa, 429, 437.

Andromeda, 395, 400 .

Anemone, 3, 7.

Angelica, 252, 274 .

Antennaria, 327, 361.

Anthemis, 329, 379 .

Anthericum, 611.

Anthriscus, 253, 281.

Anthyllis, 142, 158.

Antirrhinum, 454, 457.

Apargia, 324, 332.

A pium, 250, 258.

A POCYNACEAE, 410.

AQUIFOLIACE AE, 405.

Aquilegia, 4, 20.
Arabis, 39, 58.

ARACEN, 639.

ARALIACEA, 286.

Arbutus, 395, 400.

Arctium, 325, 346.

Arctostaphylos, 395 , 401.

Arenaria, 89, 104.

Aristolochia, 547, 548.

ARISTOLOCHIACE E, 547 .

Armeria, 522, 523.

Armoracia, 38, 48.

Artemisia, 327, 360 .

Arthrolobium, 168.

Arum, 640.

Asarum, 548.

ASPARAGEA, 608.

Asparagus, 608, 611.

Asperugo, 429, 442.

Asperula, 303, 307.

Aster, 328, 367.

Astragalus, 142, 160.

Atriplex, 529, 532.

Atropa, 444, 447.

Azalea, 394, 400.

Ballota, 476, 487.

BALSAMINACEA, 129.

Barbarea, 39, 59.

Bartsia, 455, 466.

Bellis, 328, 375.

BerberidaceA, 22.

Berberis, 23, 24.

Beta, 529, 534 .

Betonica, 477, 493.

Betula, 569.

Betuline.4, 569.

Bidens, 326, 356.

BORAGINACEA, 427.

Borago, 429, 435.

Brassica, 40, 66 .

Bryonia, 225.

Bunium, 250, 263.

Bupleurum, 251, 268.

ButomaCe. 629 .
Butomus, 630 .

Buxus, 553, 556.

Cakile, 38, 52.

Calamintha, 478, 499.

Callitrichace 558.

Callitriche, 558.

Calluna, 394, 398.

Caltha, 3, 17.

CALYCIFLOR.E, XX. 133.

Calystegia, 424.

Campanula, 382, 383.

Campanulaceac, 382.

CAPRifoliaCe 295.

Capsella, 37, 41.

Cardamine, 38, 55.

Carduus, 326, 348.

Carlina, 326, 353.

Carpinus, 573.

Carum, 250, 262.

CARYOPHyLlaCEE, 87.

Castanea, 571.

Caucalis, 252, 279.

Celastracea, 133.

Centaurea, 326, 354.

Centrantlius, 311.

Centunculus, 511, 519.

Cerastium, 89, 105.

Ceratophyllacea, 218.

Ceratophyllum, 219.

Chærophyllum, 253, 284.

Cheiranthus, 39, 66.

Chelidonium, 28, 31.

Chenopodiacea, 528.

Chenopodium, 529,530.

Cherleria, 90, 107.

Chironia, 417.

Chlora, 414, 419.

Chrysanthemum, 329 , 376.

Chrysocoma, 326, 358.

Chrysosplenium, 241, 245. 
Cicendia, 413, 418.

Cichoraceat, 323, 329.

Cichorium, 325, 344.

Cicuta, 249, 257.

Circæa, 209, 212.

Cistace 7 , 74.

Clematis, 3, 4 .

Cnicus, 326, 349.

Cochlearia, 38, 46.

Colchicum, 621.

Comarum, 174, 189.

Composita, 319.

Conifera, 574.

Conium, 249, 257.

Convallaria, 609, 611 .

Convolvulaceas, 423.

Convolvulus, 424 .

Corallorhiza, 593.

Coriandrum, 286.

Cornacee, 289.

Cornus, 291.

Corollifloke, $\mathrm{xx}$. 292.

Corrigiola, 228, 229.

Corydalis, 33.

Corylus, 573.

Cotyledon, 233, 234.

Crambe, 38, 53.

Crassulacea, 232.

Cratægus, 178, 206.

Crepis, 324, 338.

Crithmum, 252, 272.

Crocus, 595, 598.

CructFere, 36.

CUCURBitace $\not 2,224$.

CUPUlifere, 571 .

Cuscuta, 424, 426.

Cyclainen, 511, 516.

Cynarocephalie, 323, $325,346$.

Cynoglossum, 429, 442.

Cypripedium, 594.

Daphne, 545.

Daucus, 252, 278.

Delphinium, 4, 20.

Dentaria, 38, 55 .

Dianthus, 88, 90.

DiCOTYLEDONES, $\mathrm{xx}$.

Digitalis, 454, 456.

Dioscorace 60 , 604.

Diotis, 327, 358.

Diplotaxis, 40, 71.

Dipsacese, 314.

Dipsacus, 314, 315.

Dironicum, 328, 372.

Draba, 38, 50 .

Drosera, 79, 80.

Droseracese, 79

Dryas, 174, 183.
Echium, 428, 429.

Elatine, 86.

ELATINACE $A, 86$.

EleagNACE

EMPETRACEA, 548.

Empetrum, 549.

Epilobium, 209.

Epimedium, 23, 24.

Epipactis, 592.

Eranthis, 17.

Erica, 394, 395.

ERICACE.E, 392.

Erigeron, 328, 367.

Erodium, 124, 127.

Eryngium, 249, 255.

Erysimum, 39, 66.

Erythræa, 413, 416.

Euonymus, 136.

Eupatorium, 326, 357.

Euphorbia, 553.

EUPHORBIACEA, 549.

Euphrasia, 455, 467.

Fagus, 571.

Fedia, 311, 313.

Filago, 327, 363.

Fœniculum, 251, 271.

Fragaria, 174, 191.

Frankenia, 85, 86.

Frankeniace $8,84$.

Fraxinus, 408, 410.

Fritillaria, 611, 620 .

Fumaria, 33, 34.

Fumariacese, 33.

Gagea, 610, 620.

Galanthus, 602, 603 .

Galeobdolon, 477, 490.

Galeopsis, 477, 491 .

Galium, 303, 304.

Genista, 141, 145.

Gentiana, 413, 414.

Gentlanace $A 1,412$.

Geraniace $\not$, 123.

Geranium, 124.

Geum, 174, 184.

Glaucium, 28, 31.

Glaux, 511, 520.

Glechoma, 498.

Glumace

Gnaphalium, 327, 362.

Goodyera, 593.

Grossulariace $\nsim, 239$.

Gymnadenia, 587.

Habenaria, 587.

Haloragace $A, 215$.

Hedera, 287, 288.

Hedysarea, 143.

Helianthemum, 75 .

Helleborus, 317 .
Helminthia, 323, 331.

Helosciadium, 250, 261.

Heracleum, 252, 276.

Herniaria, 228, 229.

Hieracium, 324, 340.

Hippocrepis, 143, 168.

Hippophaë, 544 .

Hippuris, 215.

Holosteum, 89, 101.

Honckenya, 89, 104

Hottonia, 511, 515.

Humulus, 561, 563.

Hutchinsia, 37, 43.

Hyacinthus, 615 .

HYDROCHARIDACEA, 579.

Hydrocharis, 581, 582.

Hydrocotyle, 249, 254.

Hyoscyamus, 444, 447.

HYPERICACE $A, 117$.

Hypericum, 117, 118.

Hypochæris, 324, 334.

Ilex, 406, 407.

Illecebrum, 228, 230.

Impatiens, 131.

Invla, 328, 373.

IRIDACEA, 594.

Iris, 595.

Isnardia, 209, 212.

Jasione, 383, 387.

JUNCAGINACE⿸尸, 634 .

JUNCACE E, 622 .

Juncus, 623.

Juniperus, 576.

Knautia, 315, 318.

LABIAT $\notin, 474$.

Lactuca, 324, 337.

Lamium, 477, 492.

Lapsana, 325, 343.

Lathræa, 450, 453.

Lathyrus, 143, 164.

Lavatera, 111, 114.

LEGUMINOSÆ, 139.

Lemna, 643.

LENTIBULARIACEE, 506.

Leontodon, 325, 342.

Leonurus, 476, 488 .

Lepidium, 37, 44.

Leucojum, 602, 604.

Ligusticum, 251, 272.

Ligustrum, 407,408 .

LILIACE $A$, 607.

Limosella, 454, 461.

Linaria, 454, 457.

LINACEA, 107.

Linnæa, 296, 301. 
Iinum, 108.

Liparis, 594.

Listera, 589 .

Lithospermum, 428, 432.

Littorella, 525, 527 .

Lobelia, 388.

LOBELIACE A, 388.

Lonicera, 296, 299.

LORANTHACEA, 292.

LOTEA, 141.

Lotus, 142, 157.

Luzula, $623,626$.

Lychnis, 88, 95.

Lycopsis, 429, 436.

Lycopus, $475,478$.

Lysimachia, 511, 518.

LYTHRACE, 219.

Lythrum, 219, 221.

Malachium, 90, 106.

Malaxis, 594.

Malva, 111.

MALVACEN, 110.

Marrubium, 478, 498.

Matricaria, 329, 377.

Matthiola, 39, 66 .

Meconopsis, 28, 30.

Medicago, 141, 149.

Melampyrum, 454, 462 .

MELANTHAOEA, 620.

Melilotus, 142, 151.

Melittis, 478,501 .

Mentha, 476, 481 .

Menyanthes, 414, 420 .

Menziesia, 394, 398.

Mercurialis, 553,555 .

Mertensia, 428, 433.

Mespilus, 177, 206.

Meum, 251, 272.

Mœnchia, 89, 100.

MONOCHLAMYDEA, xxi. 528.

MONOCOTYLEDONES, xxi. 578.

Monotropa, 402, 405.

MONOTROPACEA, 402 .

Montia, 227.

Myosotis, 429, 438.

Myosurus, 3, 13.

Myrica, 568 .

MYRICEE, 568.

Myriophyllum, 215, 216.

Myrrhis, 253, 284.

NAIADACEAE, 644.

Narcissus, 601, 602.

Narthecium, 623, 629.

Nasturtium, 39, 61.

Neottia, 591.
Nepeta, 477, 497.

Nuphar, 26, 27.

Nymphæa, 26.

NYMPGAEACEA, 25.

CEnanthe, 251, 268.

Enothera, 209, 212.

Oleacee, 407.

ONagracea, 208.

Onobrychis, 144, 169.

Ononis, 141, 148.

Onopordum, 326, 351.

Ophrys, 592.

ORCHIDACE 582.

Orchis, 585.

Origanum, 476, 484.

Ornithogalum, 609, 616.

Ornithopus, 143, 168.

OROBANCHACEÆ, 449.

Orobanche, 450.

Orobus, 143, 166.

ORONTIACEAs, 641.

OXALIDACE 131.

Oxalis, 132.

Oxyria, 538, 543.

Oxytropis, 142, 158.

Pronia, 4, 22.

Papaver, 28.

Papaveracede, 27.

Parietaria, 560, 562.

Paris, 607.

Parnassia, 80, 81.

Parnassie ae, 80.

Paronychiacee, 228.

Pastinaca, 252, 275.

Pedicularis, 455, 464.

Peplis, 220, 221.

Petaloidea, xxi. 578.

Petasites, 327, 364.

Petroselinum, 250, 259.

Peucedanum, 286.

Physospermum, 284.

Phyteuma, 383, 386.

Picris, 324, 331.

Pimpinella, 250, 265.

Pinguicula, 507.

Pinus, 575.

Pistiace 643.

Plantaginacees, 524.

Plantago, 525.

Puombaginace 522.

Polemoniacese, 421.

Polemonium, 422.

Polycarpon, 228, 230.

Polygala, 83.

Polygalaceis, 83.

Polygonacese, 537.

Polygonatum, 609, 612.

Polygonum, 538.
POMEA, 177.

Populus, 566.

Portulace 226.

Potamogeton, 644, 645 .

Potentilla, 174, 185.

Poterium, 176, 198.

Primula, 511, 513.

Primulace 510.

Prunella, 478, 502.

Prunus, 173, 178.

Pulicaria, 328, 374.

Pulmonaria, 428, 431.

Pyrethrum, 378.

Pyrola, 402.

Pyrus, 177, 202.

Quercus, 572.

Radiata, 323, 327, 366.

Radiola, 108, 110.

RANUNCULACEA, 2.

Ranunculus, 3, 8 .

Raphanus, 40, 72.

Reseda, 72.

RESEDACEA, 72.

RHAMNACE 136.

Rhamnus, 138, 139.

Rhinanthus, 455, 466.

Ribes, 239, 240.

Rosa, 177, 199.

ROSACE 171 .

Rosid $2,176$.

Rubia, 303.

RUBIACE.E, 302.

Rubus, 175, 192.

Rumex, 538, 541.

Ruppia, 644, 646.

Ruscus, 609, 611.

Sagina, 89, 98

Sagittaria, 631, 633.

Salicornia, 530, 535 .

SALICINE, 566.

Salix, 566.

Salsola, 529, 535 .

Salvia, 475,480 .

Sambucus, 295, 296.

Samolus, 512, 522.

Sanguisorba, 175, 196.

SANGUISORBIDE, 175.

Sanicula, 249, 255.

SANTALACE E, 546.

Saponaria, 88, 92.

Sarothamnus, 141, 148.

Saussurea, 325, 346.

Saxifraga, 241, 242.

SAXIFRAGACE 241.

Scabiosa, 315, 316.

Scandix, 253, 281.

Scheuzeria, 635. 
Schrophularia, 454, 460 . SCHROPHULARIACEE, 453.

Scilla, 609, 616.

SCILlede, 609.

SCleRANTHACEAE, 535.

Scleranthus, 535, 536 .

Scutellaria, 478, 502 .

Sedum, 233, 236.

Sempervivum, 233,235.

Senebiera, 38, 53.

Senecio, $328,369$.

Serratula, 325, 346.

Seseli, 286.

Sherardia, 303, 309.

Sibbaldia, 174, 189.

Sibthorpia, 455, 468.

Silaus, 251, 272.

Silene, 88, 92 .

SILENEE, 88.

Sinapis, 40, 70 .

Sison, 250, 262.

Sisymbrium, 39, 62 .

Sium, 250, 266.

Smyrnium, 249, 257.

Solatice $44,44$.

Solanum, 444, 445.

Solidago, $328,368$.

Sonchus, 324, 337.

Sparganium, 637.

Specularia, 386.

Spergula, 229, 232.

Spergularia, 228, 231.

Spiræa, 173, 181.

SPIREIDA, 173.

Stachys, 477, 493.
Statice, 523, 524.

Stellaria, 89, 101.

Stratiotes, 582.

Suæda, 529, 532.

Subularia, 38, 49.

Symphytum, 428, 433.

TAMARICACEA, 222.

Tamarix, 222. 223.

Tamus, 604, 605.

Tanacetum, 327, 359.

Taxus, 577.

Teesdalia, 37, 43.

Teucrium, 476, 486.

ThalAMIFLORA, XX. 2.

Thalictrum, 3, 6 .

Thesium, 546, 547.

Thlaspi, 37, 40.

Thrincia, 324, 333.

THYMELACE 544 .

Thymus, 476, 483.

Tilia, 116.

Tiliacea, 115.

Tillæa, 233.

Tofieldia, 621, 622.

Torilis, 252, 279.

Tormentilla, 174, 188.

Tragopogon, 323, 329.

Trichonema, 595, 596.

Trientalis, 511, 519.

Trifolium, 142, 152.

Triglochin, 634.

Trigonella, 142, 152.

Trilliace e, 606.

Trinia, 285.

Trollius, 3, 14.
TUBIFLORE, 323, 326, 356.

Tulipa, 610, 620 .

TuLIPEA, 610.

Turritis, $39,59$.

Tussilago, 327, 366 .

Typha, 637.

TYPHACEA, 635.

Ulex, 141, 144.

ULMACE $A$, 564.

Ulmus, 564.

UMBELLIFER 24 , 246.

Urtica, 560,561 .

URTICACEA, 559.

Utricularia, 507, 508.

Vaccinaceat, 389.

Vaccinium, 390.

Valeriana, 311.

VALERIANACE $E, 309$.

Verbascum, 455, 472.

Verbena, 504.

VerbenaCe.e, 504.

Veronica, 455, 469.

Viburnum, 296.

Vicia, 143, 161.

VICIEAE, 143.

Villarsia, 414, 420.

Vinca, 411.

Viola, 76.

VIOLACEA, 76 .

Viscum, 293, 294.

Zannichellia, 644, 646 .

Zostera, 645, 648 .

THE END.

Printed for the Society for Promoting Christian Knowledge, at the Clarendon Press, Oxford. 





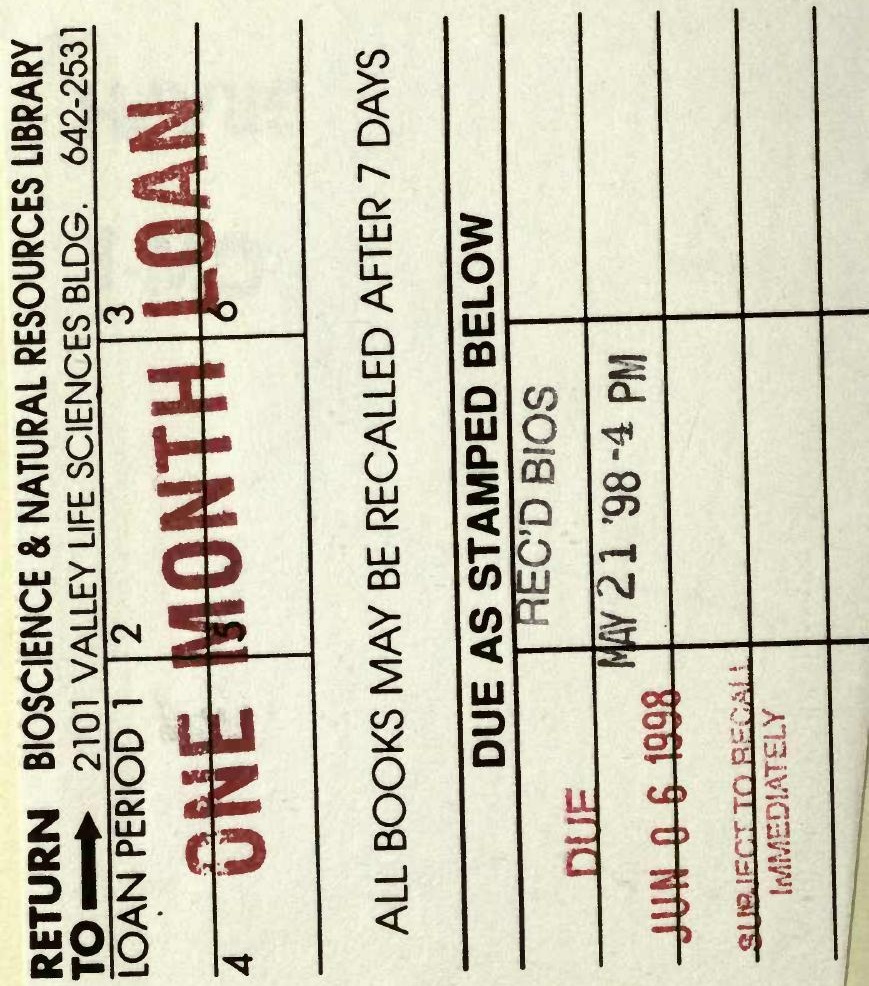
U.C. BERKELEY LIBRARIES

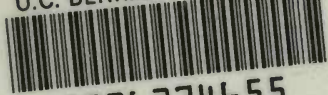

CD26274655 


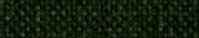

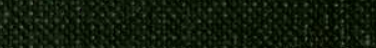

